Universidade de São Paulo

Escola de Engenharia de São Carlos

Departamento de Arquitetura

\title{
Referências europeias de arquitetura e urbanismo nas origens da produção de habitação de interesse social no Brasil (1930-1964).
}

Sálua Kairuz Manoel Poleto

Orientador: Prof. Dr. Nabil Bonduki

\begin{abstract}
Tese apresentada ao programa de
Pós-Graduação em Arquitetura e

Urbanismo do Departamento de

Arquitetura e Urbanismo da Escola de

Engenharia de São Carlos, da

Universidade de São Paulo como

requisito parcial para obtenção do

Título de Doutora em Arquitetura e

Urbanismo. "Versão corrigida."

Área de concentração: Teoria e

História da Arquitetura e do Urbanismo
\end{abstract}


AUTORIZO A REPRODUÇÃO E DIVULGAÇÃO TOTAL OU PARCIAL DESTE TRABALHO, POR QUALQUER MEIO CONVENCIONAL OU ELETRÓNICO, PARA FINS DE ESTUDO E PESQUISA, DESDE QUE CITADA A FONTE.

Ficha catalográfica preparada pela Seção de Tratamento da Informação do Serviço de Biblioteca - EESC/USP

\begin{tabular}{|c|c|}
\hline P765r & $\begin{array}{l}\text { Poleto, Sálua Kairuz Manoel } \\
\text { Referências europeias de arquitetura e urbanismo nas } \\
\text { origens da produção de habitação de interesse social no } \\
\text { Brasil ( } 1930-1964 \text { ) / Sálua Kairuz Manoel Poleto; } \\
\text { orientador Nabil Bonduki -- São Carlos, } 2011 .\end{array}$ \\
\hline & $\begin{array}{l}\text { Tese (Doutorado-Programa de Pós-Graduação em } \\
\text { Arquitetura e Urbanismo e Área de Concentração em Teoria } \\
\text { e História da Arquitetura e do Urbanismo) -- Escola de } \\
\text { Engenharia de São Carlos da Universidade de São Paulo, } \\
\text { 2011. }\end{array}$ \\
\hline & $\begin{array}{l}\text { 1. Habitação popular. 2. Política habitacional. } 3 . \\
\text { Arquitetura moderna. 4. Referências européias. I. Título. }\end{array}$ \\
\hline
\end{tabular}


FOLHA DE JULGAMENTO

Candidato(a): Arquiteto SALUA KAIRUZ MANOEL POLETO.

Tese defendida e julgada em 10/05/2011 perante a Comissão Julgadora:

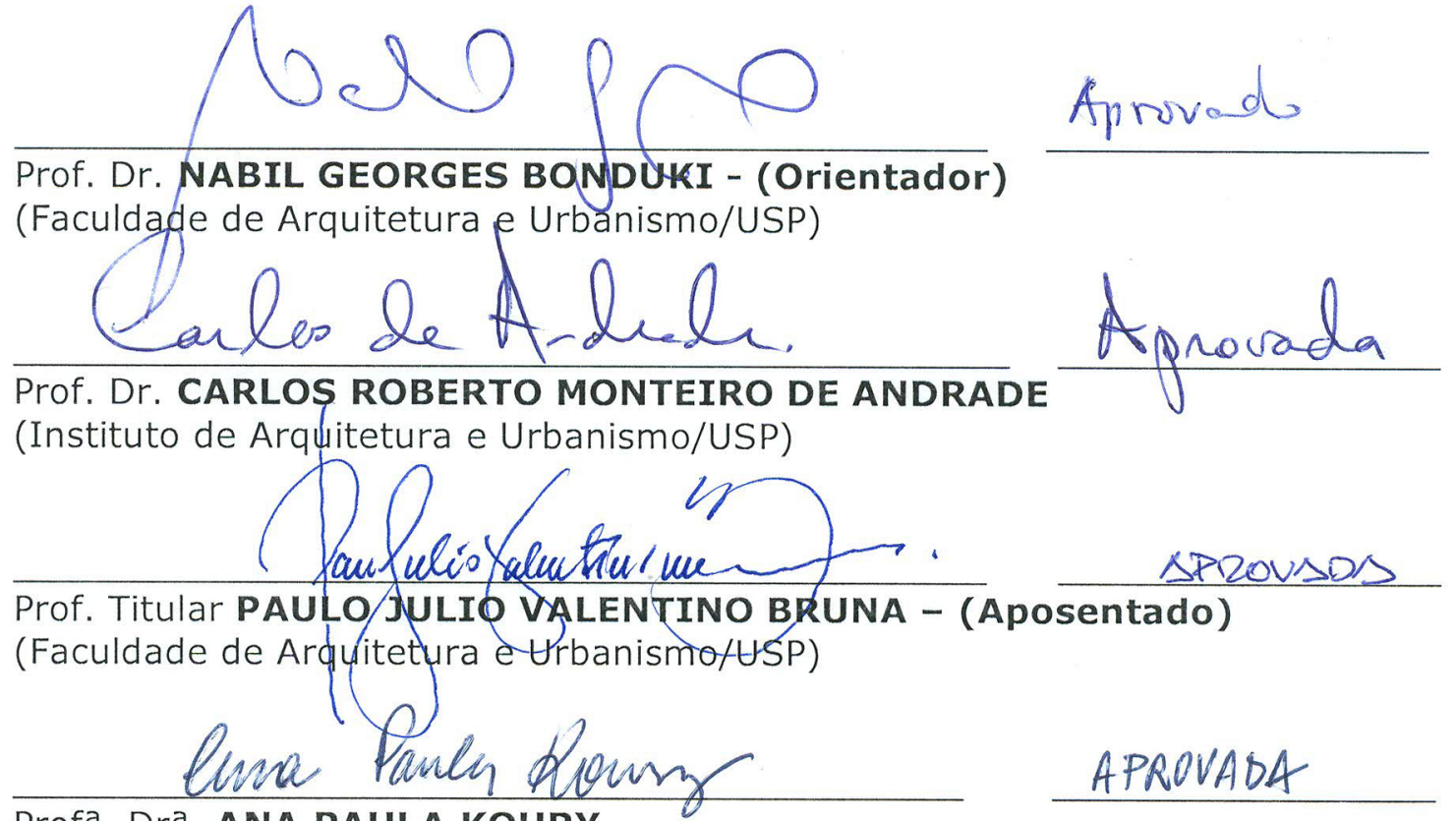

Profa. Dra. ANA PAULA KOURY

(Universidade São Judas Tadeu/USJT)

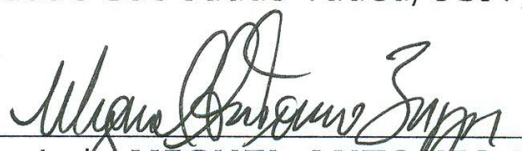

Prof. Associado MIGUEL ANTONIO BUZZAR

(Instituto de Axquitetura e Urbarnismo/USR)

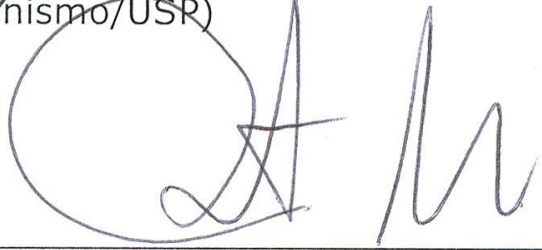

Prof. Titular RENATO LUIZ SOBRAL ANELLI

Coordenador do Pfograma de Pós-Graduação em

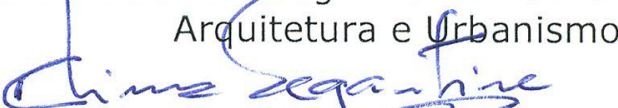

Prof. Associado PAULO CÉSAR LIMA SEGANTINE

Presidente da Comissão da Pós-Graduação da EESC 


\section{DEDICATÓRIA}

Dedico esse trabalho aos meus pais, Ivan e Idalina (in memoriam), por me incentivarem a batalhar pelos meus sonhos com dignidade; por serem meu norte. 
AGRADECIMENTOS

Seria muito difícil agradecer nominalmente a todos aqueles que me auxiliaram ao longo dessa jornada de 14 anos de pesquisa na Escola de Engenharia de São Carlos, agradecer a todas as pessoas que me acolheram nos arquivos e bibliotecas pelo Brasil afora, e fora dele, ou mesmo agradecer a todos que me incentivaram nesse processo acadêmico. Assim, tentarei elencar aqueles diretamente envolvidos na elaboração desta tese:

A CAPES, pelo apoio financeiro (2007-2009).

Em especial ao meu orientador por me mostrar a beleza de ler e aprender, escrever e ensinar; por me proporcionar a gratificação do trabalho em equipe, e pelo aprendizado de vida ao longo dos anos de pesquisa.

Aos colegas que participaram do grupo de pesquisa "Pioneiros da Habitação Social no Brasil" Ana Paula Koury, Flávia Brito, Nilce Aravecchia, Elaine Pereira, Juliana Mota, Maria Luiza, Amália, Minoru e tantos outros pelas horas de reflexão compartilhadas, trocas de experiências e trabalho duro em equipe. Ao professor Paul Meurs, do Instituto Politécnico de Delft, que prontamente me auxiliou no curto período de pesquisa na Holanda. Aos meus amigos e colegas arquitetos Maristela Siolari, Amanda Franco, Jeferson Tavares, Fernando Atique e Janice Nogueira que sempre auxiliaram com ponderações importantes.

Aos professores do Departamento de Arquitetura e Urbanismo da EESC-USP e da FAUUSP pelo aprendizado e contribuições acadêmicas valiosas, em especial aos professores Paulo Bruna e Renato Anelli pelas contribuições valiosas para conclusão do trabalho. Aos funcionários da EESC-USP que colaboraram sempre para a conclusão deste trabalho, em especial ao Marcelinho e Geraldo.

Aos colegas do programa de pós-graduação pela troca de informações, materiais e pela amizade.

A minha família, por estar sempre ao meu lado nos percalços da vida no decorrer desta longa jornada. Ao Breno, por ser meu porto seguro. A Deus, por me trazer até aqui. 
RESUMO

\section{Referências europeias de arquitetura e urbanismo nas origens da produção de habitação de interesse social no Brasil (1930-1964).}

A proposta desta tese de doutorado foi a de identificar e analisar as principais referências europeias na produção brasileira de habitação promovida pelo poder público em nível federal no período pré-BNH, a saber, pelos Institutos de Aposentadoria e Pensão (IAP's), Fundação da Casa Popular (FCP) e a principal iniciativa local à época, Departamento de Habitação Popular do Distrito Federal (DHP).

A partir de um vasto levantamento de campo iniciado pela pesquisa temática "Habitação Econômica e Arquitetura Moderna no Brasil (1930-1964)", desenvolvida pela FAU-USP e EESC-USP, concluído com a pesquisa "Pioneiros da Habitação Social no Brasil", coordenada pelo Prof. Dr. Nabil Bonduki, pudemos identificar referências e estabelecer diálogos com as diferentes linhas de arquitetura moderna na produção de moradia econômica na Europa, entre os anos 1920 e 1930, além de outras correntes concomitantes, como o movimento cidade-jardim e suas diversas interpretações.

Com a seleção das iniciativas internacionais consagradas pela literatura, foi possível analisar a produção nacional em face dessas experiências, identificando os diversos matizes da produção no Brasil, assim como foi possível entender de que forma o processo da construção da política habitacional e a produção resultante são indissociáveis na questão da habitação de interesse social. A abordagem da produção internacional também revelou outras facetas da imprecisão com que a política habitacional foi tratada pelo estado brasileiro no período, e os resultados dessa postura.

Palavras chaves: habitação social, política habitacional, arquitetura moderna, referências europeias. 


\section{European References of architecture and urbanism at the origins of the production of social housing in Brazil (1930-1964)}

The purpose of this thesis was to identify and analyze major European references in Brazilian production of housing promoted by the government at the federal level in the pre-BNH, specifically, the National Institutes of Retirement and Pension (IAP's), Popular Housing Foundation (FCP) and the main local initiatives proposed at the time, the Federal District Department of Housing (PHD).

From a wide field survey initiated by the research "Housing and Economic Modern Architecture in Brazil (1930-1964), developed by FAU-USP and USPEESC, concluded through research "Pioneers of Social Housing in Brazil" coordinated by Prof. Dr. Nabil Bonduki, we were able to identify references and establish dialogue with the different lines of modern architecture in the production of economical housing in Europe between 1920 and 1930, and other concurrent streams, as the garden city movement and its various interpretations.

With the selection of international initiatives enshrined in the literature, it was possible to analyze the national production in the face of these experiences, identifying the different facets of production in Brazil, as it was possible to understand how the process of construction of housing policy and the resulting production are inseparable the issue of social housing. The approach of international production has also revealed other facets of uncertainty with the housing issue were handled by the Brazilian state in the period, and the results of this stance.

Keywords: housing, housing policy, modern architecture, European references. 
APRESENTAÇÃO

INTRODUÇÃO

CAPÍTULO 01. CENÁRIO INTERNACIONAL

1.1. Entre guerras 5

1.1.1. Os primeiros CIAM's

1.1.2 0 pioneirismo holandês 35

1.1 .30 caso alemão $\quad 87$

1.1.4 Viena e a socialdemocracia 149

1.2. Modelos de reconstrução no pós-1945 154

1.2.1 O processo de industrialização da construção de moradia na França

1.2.2 Os novos distritos na Holanda - Amsterdam e Rotterdam 149

1.2.3 A reconstrução italiana e o INA-Casa

CAPÍTULO 02. POLÍTICA E PRODUÇÃO HABITACIONAL NO BRASIL 175

2.1. Reconhecimento da questão pelas esferas políticas e sociais 179

2.2. Principais meios de interlocução sobre o tema: o debate técnico 186

2.2.1. Barateamento da unidade habitacional 192

2.2.2 A propriedade privada e a noção de família como célula mater da 196 sociedade

2.2.3 A intervenção Estatal 203

2.3. Principais órgãos e medidas estatais destinadas ao enfrentamento da questão 210

2.3.1 As operações imobiliárias dos IAP's 210

2.3.2 A Fundação da Casa Popular e a política da propriedade unifamiliar 213

CAPÍTULO 03. PARALELOS E DISTANCIAMENTOS 219

3.1. Legados de Le Corbusier 224

3.2. As diversas referências dos CIAM's 247

3.3. Outros grupos de referências e tipologias especiais 270

3.4. Considerações gerais sobre a produção nacional 292

$\begin{array}{ll}\text { CONCLUSÃO } & 303\end{array}$

REFERÊNCIAS BIBLIOGRÁFICAS $\quad 319$ 


\section{APRESENTAÇÃO}


A investigação aqui apresentada é um dos desdobramentos da pesquisa "Pioneiros da Habitação Social no Brasil", que foi realizada com apoio da FAPESP (Projeto Temático: "Habitação Econômica e Arquitetura Moderna no Brasil", realizado na EESC-USP 1997-2000 e Projeto de Auxílio à Pesquisa: "Pioneiros da Habitação Social no Brasil", realizado na FAU-USP, 2005-2007) e do CNPQ (1997-2001), cujo objetivo geral foi:

"analisar a produção de habitação social realizada no país no período de 1930 a 1964 na perspectiva de resgatar o papel do movimento moderno e demais correntes internacionais que influenciaram a habitação social no país e identificar as transformações que ocorrem no desenvolvimento tecnológico e na legislação que interferiam na produção da moradia para os trabalhadores." (BONDUKI, 2001: 3)

Essa pesquisa envolveu uma equipe de pesquisadores, doutorandos, mestrandos e bolsistas de iniciação científica, coordenada pelo Prof. Dr. Nabil Georges Bonduki - SAP-EESC-USP, no âmbito do Grupo de Pesquisa e Assessoria em Habitação e Urbanismo (SAP-EESC-USP) e esteve articulada com o grupo de pesquisa coordenado pela Prof ${ }^{\mathrm{a}} \mathrm{Dr}^{\mathrm{a}}$. Maria Ruth Amaral de Sampaio na FAU-USP. A partir de 2003, esse trabalho teve continuidade na pesquisa "Pioneiros da Habitação Social no Brasil", coordenado pelo Prof. Dr. Nabil Bonduki, contando também com recursos do programa Petrobras Cultural para publicação de dois volumes sobre o conjunto dessa produção.

Os projetos de pesquisas mencionadas realizaram, entre 1997 e 2001, e entre 2003 e 2010, o levantamento documental da produção de habitação social no país no período de 1930 a 1964 pelo setor público, na perspectiva de resgatar o papel do movimento moderno de arquitetura na produção habitacional no Brasil.

Dentro desse projeto temático, desenvolvemos nossa Iniciação Científica, com financiamento da FAPESP, no período de 1998 a 2001, e nossa pesquisa de Mestrado, com financiamento do CNPq, no período de 2002 a 2004, sobre a produção e a política habitacional da Fundação da Casa Popular (FCP), criada 
em 1946, no Governo Dutra, e extinta em 1964, após a instalação do governo militar, dando início a uma pesquisa inédita sobre a produção da primeira instituição criada pelo poder público federal destinada à provisão habitacional.

A extensão da ação dessas instituições pode ser observada no fato de que os Institutos de Aposentadoria e Pensão (IAP's), a Fundação da Casa Popular (FCP) e os demais órgãos regionais financiaram ou construíram mais de 90.000 unidades habitacionais destinadas à baixa renda. A produção total desses órgãos, incluindo as unidades destinadas às outras classes sociais, através do Plano B dos IAP's, e a construção de Brasília somam quase 140.000 unidades. Dentro desse universo, a pesquisa temática identificou que o IAPI e a FCP foram os órgãos mais importantes nesse processo, com cerca de 20.000 unidades de moradias econômicas construídas por cada um, mas com uma grande diferença Nas tipologias habitacionais adotadas - IAPI: $70 \%$ da produção estão agenciadas em blocos habitacionais médios; FCP: praticamente a totalidade do que foi levantado e sistematizado são residências unifamiliares.

Apesar de bastante modestos, esses valores ganham expressão frente à ausência da produção estatal federal no período anterior a 1930, que estava a cargo da iniciativa privada. Por outro lado, foram criados, ao que foi possível resgatar, nada menos que dezessete órgãos estaduais ou municipais encarregados de enfrentar o problema da moradia no período, sendo que o Departamento de Habitação Popular da Prefeitura do Distrito Federal foi, do ponto de vista da arquitetura e do urbanismo, o mais importante, por contar com profissionais como a Enga. Carmen Portinho, que foi sua diretora, e dos arquitetos Affonso Eduardo Reidy e Francisco Bolonha, que projetaram os conjuntos habitacionais.

A pesquisa temática, que buscou reconhecer as origens da habitação social no Brasil (Bonduki 1998), revelou a importância da produção habitacional realizada neste período, no âmbito de uma análise das transformações do processo de provisão habitacional no país, e gerou uma primeira reflexão sobre esta produção realizada pelas instituições públicas, baseada ainda em um número restrito de conjuntos, embora de grande significado arquitetônico.

Esta análise, que buscou identificar de uma maneira geral os preceitos arquitetônicos e urbanísticos dessa produção, tentou também estabelecer o vínculo entre a questão habitacional e o modelo de desenvolvimento implantado no país no período, constituiu uma base sólida para a revisão da historiografia 
da arquitetura brasileira no que se refere aos vínculos entre arquitetura e habitação social.

As pesquisas citadas promoveram um amplo levantamento de campo e documental realizado em inúmeras cidades brasileiras, sistematizando as informações bibliográficas e iconográficas num grande banco de dados. Finalizada esta etapa, encontra-se em curso uma análise mais compreensiva e aprofundada em diversas direções, considerando o conjunto desta produção.

Nesta pesquisa de doutorado, como desdobramento desse extenso levantamento documental e de campo, procuramos identificar e analisar de maneira sistematizada as diversas referências de arquitetura moderna e outras correntes internacionais presentes na produção brasileira, estabelecendo tipologias das soluções arquitetônicas e urbanísticas utilizadas pelos vários órgãos acima citados, objetivando verificar em que medida se observa uma coerência ou não na apropriação dos pressupostos de produção de habitação em massa divulgados à época.

Utilizamos como ponto de partida para a análise as experiências europeias correntes na literatura internacional e difundidas no Brasil à época: conjuntos habitacionais em Amsterdã e Roterdã, na Holanda; produção em Berlim e Frankfurt, na Alemanha, e a experiência singular de Viena, além dos pressupostos de arquitetura e urbanismo sistematizados e difundidos pelos três primeiros CIAM's. A avaliação do período pós-segunda guerra limitou-se a apontar a difusão dos modelos racionalistas de produção em massa apenas na França e na Holanda, mas também tentamos mostrar o contraponto dessa tendência com o INA-Casa, na Itália, que tinha um enfoque mais tradicionalista. Essa escolha foi fundamentada principalmente na diferença de escala entre os projetos construído na Europa com a reconstrução a partir de 1945, que não encontra paralelos na produção em massa no Brasil, a não ser o caso específico de Brasília, que mereceria uma análise própria.

Outro fator que contribuiu para esse recorte temporal da produção internacional diz respeito ao período de maior produção dos IAP's e FCP no Brasil, que corresponde ao final do Estado Novo. A partir dos anos 1950, enquanto a Europa passava por uma reconstrução massiva, com diversas linhas de planejamento e pesquisas de racionalização da construção, o Brasil assistia ao declínio da produção dos órgãos em questão, que perduraria até a criação do 
BNH. Assim sendo, a produção que teve maior repercussão no Brasil foi aquela compreendida no período entre guerras.

A partir do entendimento dessa produção internacional, especialmente do vínculo de políticas nacionais articuladas a agentes e planejamentos locais, analisamos como a diversidade da produção nacional se deu mais por uma desvinculação entre política, planejamento e produção de habitação do que por um programa consistente e consciente de arquitetura e urbanismo dos diversos agentes envolvidos no processo, embora existam exemplos ímpares dessa produção. 
INTRODUÇÃO 
A historiografia da arquitetura brasileira, até recentemente, praticamente ignorou a produção de habitação social no período que se debruçou a pesquisa temática "Pioneiros da Habitação Social no Brasil". À exceção dos dois conjuntos de Affonso Eduardo Reidy, realizados pelo DHP-DF, Pedregulho e Gávea, muito pouco tinha se estudado sobre o assunto (Bonduki 2001).

Os estudos sobre a questão habitacional na bibliografia existente têm ressaltado o enfoque político, econômico e social, mas ainda com pouca frequência vinculando os aspectos arquitetônicos, o trabalho e a técnica a este contexto (MARICATO, 1995). Assim, salvos alguns trabalhos e publicações desenvolvidas principalmente nos últimos dez anos (BONDUKI, 1998 e 2001; SAMPAIO, 2002; GITHAY e PEREIRA, 2002), são raros os estudos que, tendo como objeto a habitação, incorporam ao tema as propostas arquitetônicas e urbanísticas e sua produção.

O trabalho de Marta Farah, a investigação mais completa sobre os Institutos de Aposentadoria e Pensões, não aprofunda o estudo dos conjuntos habitacionais por eles edificados, fornecendo apenas uma relação dos empreendimentos dos Institutos, por período e localização, o mesmo ocorrendo em relação à pesquisa desenvolvida por Varon.

Nos compêndios sobre a historiografia da arquitetura brasileira, as obras de Reidy são consideradas, geralmente, como as únicas dignas de destaque no campo da habitação social no Brasil. Bruand (1981), o apanhado mais completo da arquitetura moderna brasileira, por exemplo, apenas se refere a estes dois empreendimentos, considerados os únicos projetos desse tipo "válidos" de nota. Em outros trabalhos sobre a emergência da arquitetura moderna brasileira, as referências à produção de habitação social do período, quando existem, são sempre rápidas, sem atribuir ao tema à devida importância. Como mostra Martins (1989), esta ausência não só dos projetos de habitação econômica como de vários outros programas onde a monumentalidade não podia ser contemplada, é consequência da predominância da uma narrativa sobre a arquitetura brasileira que buscou transformar um dos projetos da arquitetura brasileira contemporânea em sua vertente dominante.

Encabeçada pela plasticidade da obra de Niemeyer e pela retórica de Costa, que estabeleceram uma forte relação entre a arquitetura tradicional brasileira e a nova arquitetura, esta visão da arquitetura brasileira se consolidou através de autores como Goodwin, Mindlin, Bruand e Lemos e tem ofuscado 
outra produção arquitetônica de grande relevância e qualidade que se desenvolveu no país entre as décadas de 1930 e 1960.

Enquanto a visão hegemônica enfatiza mormente as obras de caráter monumental e extraordinário, de grande plasticidade e que, de certa forma se distanciam dos pressupostos originais do movimento moderno, sobretudo no que se refere aos objetivos de associar economia, técnica e estética para projetar o espaço habitável de toda a cidade, uma importante produção de habitação econômica e de equipamentos públicos de grande valor arquitetônico, urbanístico e social ficou até então eclipsada pela historiografia.

$O$ destaque das obras habitacionais de Reidy pode ser entendido por elas terem exercido um papel de destaque no contexto teórico já descrito:

$$
\begin{aligned}
& \text { "a exemplar resolução plástica- } \\
& \text { construtiva-programática do bloco } \\
& \text { serpenteante e dos equipamentos } \\
& \text { sociais de Pedregulho significou a } \\
& \text { possibilidade - mais artificial do que } \\
& \text { real - de enfrentar o problema } \\
& \text { social com os mesmos elementos } \\
& \text { conceituais e plásticos que vinham } \\
& \text { dando originalidade e destaque } \\
& \text { para a arquitetura brasileira" }
\end{aligned}
$$

(Bonduki 2001).

A pesquisa iniciada por Bonduki publicada no livro Origens da Habitação Social no Brasil, e a recente publicação de Paulo Bruna (2010), Os primeiros arquitetos modernos, demonstram a necessidade de revisão da historiografia brasileira incorporando os "pioneiros" da habitação social no Brasil, especialmente o IAPI, DHP e alguns atores específicos como agentes importantes da produção de arquitetura moderna brasileira, comparando-os às vanguardas europeias dos anos 1920 e 1930.

A finalização e a sistematização da pesquisa Pioneiros da Habitação Social no Brasil, que abrangeu 77 cidades e 22 estados da federação, atestam de fato a modernidade desses órgãos e o esforço pessoal de muitos atores em introduzir a questão da produção de habitação em massa no Brasil. IAPI e DHP 
demonstram incontestavelmente esse esforço, mas estão longe de representar a totalidade da produção brasileira.

Outro aspecto importante que a pesquisa temática demonstrou, foi uma mistura de conceitos de arquitetura e urbanismo na produção no Brasil desse período nos órgãos estudados. Não é raro vermos princípios modernistas à revelia das condições técnicas das regiões ${ }^{1}$, incorporando também variantes das cidades-jardins; vemos conjuntos híbridos, com referências diversas num mesmo empreendimento, ao lado de soluções de vanguarda que antecipavam propostas e dialogavam com a produção internacional. Em casos específicos, parecia existir uma interlocução entre os diversos agentes dessa produção, promovendo modelos de intervenção específicos. O conjunto residencial Presidente Getúlio Vargas, o "Deodoro", construído pela Fundação da Casa Popular no Rio de Janeiro em 1953, é explicitamente influenciado pelas duas obras de Reidy, mas adaptando a tipologia para uma reprodução mais econômica e sistematizada (MANOEL, 2003).

Foi em face dessa diversidade que se deu a análise da produção nacional a partir de suas referências europeias primárias de produção e política partindo-se do princípio que esses elementos são indissociáveis na produção em massa de habitação.

A produção internacional, como demostra o capítulo 01 , também é extremamente diversificada, o que se deve, sobretudo, aos contornos das políticas implementadas, que privilegiavam os atores locais da produção e o planejamento municipal. Já no Brasil, essa diversidade se deu, em grande parte, em virtude da fragilidade das políticas adotadas e da desconexão com os planejamentos locais. A análise da produção e política internacional permitiu realizar outras abordagens da política que se procurava delinear no Brasil, e entender como isso se refletiu na produção do período.

\footnotetext{
${ }^{1}$ A tese de Maristela Siolari Silva (2008) demonstra o descompasso entre a industrialização da construção civil no Brasil no período estudado e as propostas de produção em massa de habitação segundo os pressupostos modernos de arquitetura, demonstrando a fragilidade do desenvolvimento do setor. Especialmente interessante é o aperfeiçoamento da indústria do vidro plano na Europa e no Brasil, demasiado tardia em relação aos pressupostos de arquitetura moderna.
} 
CAPÍTULO 01

CENÁRIO INTERNACIONAL 
Capítulo 01 
"The housing problem can only be resolved by mass production. In order to find a viable solution one has again to go back to housing blocks, but at a larger scale than previously."

H. P. Berlage 
Capítulo 01 


\subsection{Entre guerras}

A Primeira Guerra Mundial, que envolveu quase todos os países europeus $^{1}$ e outras potências não europeias, foi o episódio decisivo para o capítulo da produção em massa de habitação no mundo. Certamente, sem os nefastos resultados dos quatro anos do primeiro conflito mundial, a história da produção de habitação e mesmo a história da Arquitetura Moderna seria outra. Bem como os desdobramentos dessa nova forma de produção habitacional seriam outros não fossem a Revolução Russa em 1917, e os 31 anos de conflitos entre a declaração de guerra austríaca à Sérvia, em 28 de julho de 1914, e a rendição incondicional do Japão, em 14 de agosto de 1945 (quatro dias após a explosão da primeira bomba atômica lançada pelos EUA).

A combinação de métodos de industrialização da construção; emprego de elementos padronizados e pré-fabricados; uma nova linguagem arquitetônica primando pela racionalidade; e premissas de urbanismo pautadas em espaços comuns/coletivos abertos em detrimento dos espaços privados foram os principais ingredientes para a construção de milhares de moradias pela demanda do processo de industrialização ou em áreas devastadas pela Primeira-Guerra Mundial, em nível municipal principalmente. A utilização desses princípios elevados ao limite da capacidade de produção da construção civil levou a construção de centenas de milhares de unidades em toda a Europa no segundo Pós-Guerra, através, principalmente, de programas nacionais de reconstrução.

Ainda que as políticas habitacionais fossem distintas nos países europeus logo após a I Guerra Mundial, o estabelecimento de princípios e regras para nortear as políticas de habitação e planejamento urbano de uma forma geral parecia consenso entre os mestres europeus. Segundo Panerai (1986), "se ha mostrado que cuando se trata de frenar al desarrollo de la arquitectura, aparecen y se repiten los mismos argumentos en todos los países. Los maestros de la nueva arquitectura sentían individualmente la necesidad de unirse para ayudarse recíprocamente en el futuro, prescindiendo de las fronteras de sus países". Esse seria um dos motivos pelos quais foi bem recebido o convite de madame Hélène de Mandrot, uma

1 Exceto Espanha, Países Baixos, Suíça e os três países da Escandinávia. 
nobre franco-suíça, para realizar o primeiro encontro internacional de arquitetos de vanguarda em seu castelo La Sarraz, na Suíça.

Embora o I CIAM tenha surgido em volta às questões técnicas e estéticas propostas pelos arquitetos envolvidos, é possível avaliar a preocupação entre os arquitetos do Movimento Moderno com a profunda relação entre arquitetura e planejamento urbano observando-se os temas apresentados nos quatro primeiros CIAM's; mesmo a Declaração de La Sarraz, que é mais conhecida por tratar dos propósitos da nova arquitetura, trata do assunto.

O primeiro CIAM, em La Sarraz (1928), instigado, entre outras coisas, pela reação dos arquitetos modernos contra o resultado do concurso para o Palácio das Nações, discutiu primordialmente uma posição estética e ética em relação à forma arquitetônica; o II CIAM, em Frankfurt (1929), tratou especificamente da unidade habitacional; em Bruxelas, o terceiro congresso estendeu a questão para os loteamentos urbanos; e por fim, o IV CIAM (1933), a bordo do navio S.S. Patris II, que seguindo o percurso entre Marselha - Atenas abordou os princípios de planejamento urbano.

"The idea of modern architecture includes the link between the phenomenon of architecture and that of the general economic system. The idea of "economic efficiency" does not imply production furnishing maximum commercial profit, but production demanding a minimum working effort ... Town planning is the organization of the functions of collective life; it extends over both the urban agglomerations and the countryside ... The chaotic division of land, resulting from sales, speculations, inheritances, must be abolished but collective and methodical land policy. This redistribution of land, the indispensable preliminary basis for any town planning, must include the just division between the owners and the community of the unheard increment resulting from works of joint interest."(MUMFORD, 2000; p. xi) 
A proposta de uma nova arquitetura para os mestres da Arquitetura Moderna estava intrinsecamente relacionada a uma nova prática de urbanismo e de produção da cidade, mas não por isso existiu uma homogeneidade na produção arquitetônica e urbanística dos países envolvidos, apesar da linguagem comum de planos e superfícies depuradas, como evidenciado pela literatura específica.

\subsubsection{Os primeiros CIAM's}

A idéia de um congresso internacional de arquitetura de vanguarda foi proposta pela primeira vez pelo arquiteto soviético El Lissitzky, o qual convidou Le Corbusier para se associar a ele na realização de um congresso internacional de arquitetura em Moscou em 1924 (Mumford, 2000). Divergências políticas entre arquitetos marxistas e outros mestres europeus fizeram com que 0 Congrés Interntionaux d'Architecture Modern, CIAM, fosse fundado quatro anos depois, em 1928, na Suíça, com 24 arquitetos representando oito países europeus - Alemanha, Áustria, Bélgica, Espanha, França, Holanda, Itália e Suíça, que assinaram um documento conjunto ao final do encontro, a "Declaração de La Sarraz". Além dos signatários da Declaração, diversos outros arquitetos e convidados participaram do congresso.

O primeiro encontro para a organização do congresso foi organizado por Le Corbusier e Gabriel Guévrékian, em Paris, e pelos membros da Swiss Werkbund e pelo historiador de arte Siegfrid Giedion, em Zurique. O tema do congresso foi o documento produzido em Paris por Le Corbusier que discorria em 27 itens (na versão francesa) sobre os problemas da arquitetura moderna.

Como aponta a bibliografia especializada, vários fatores estiveram ligados à fundação de uma organização internacional que defendesse e propagasse os preceitos da nova arquitetura, entre eles o conhecido episódio do concurso para a sede da Liga das Nações, em Genebra, em que Le Corbusier e seu primo Pierre Jeanneret foram eliminados por membros do júri ligados a Ecole des Beux-Arts. Esse episódio ocorreu em 1927, mesmo ano da mostra de habitação Deutsche Werkbund Weissenhofsiedlung, em Stuttgart, que reuniu principalmente arquitetos alemães, além de convidados da Áustria, Bélgica, França e Holanda, que advogavam em favor da nova arquitetura. Ao lado 
desses eventos, vários periódicos foram criados com o intuito de promover a arquitetura de vanguarda nos países europeus nas décadas de 20 e 30 do século passado.

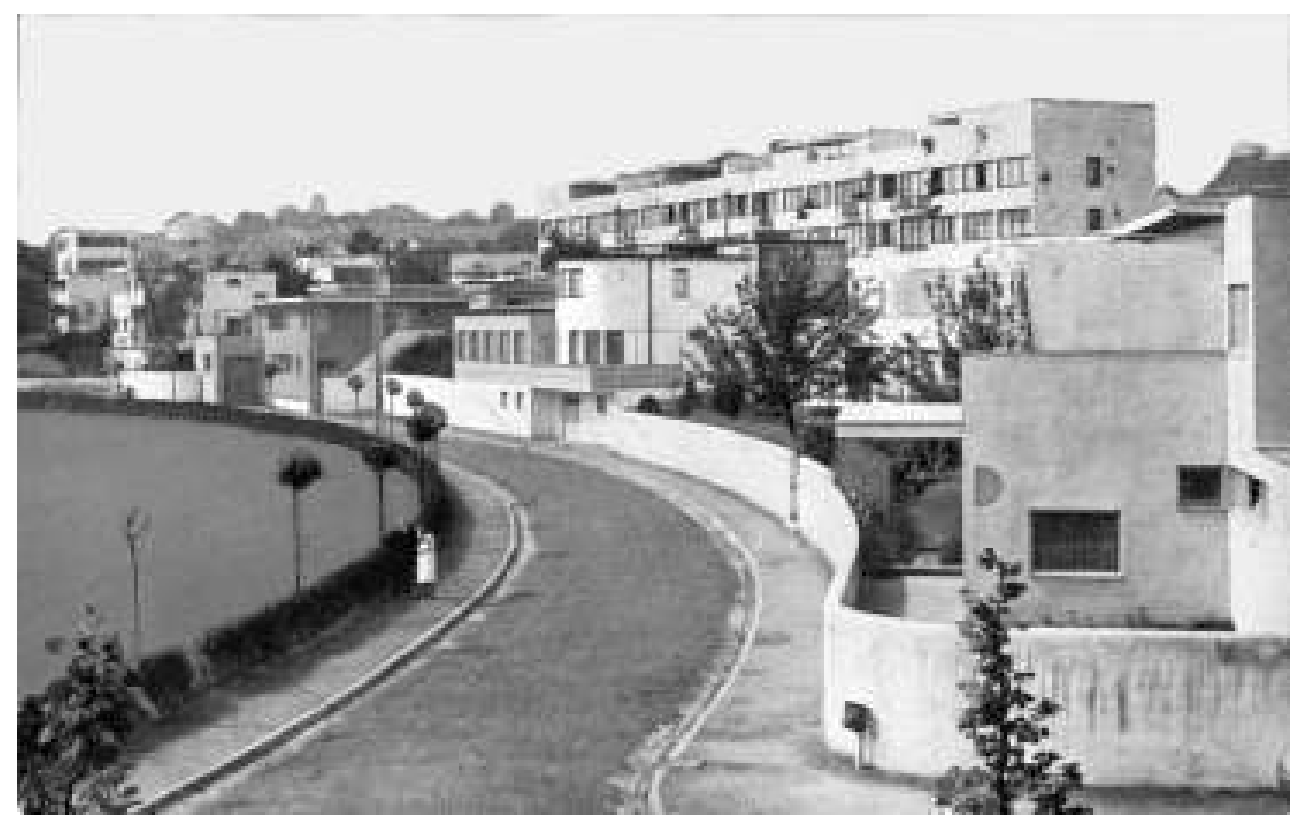

Figura 01. Deutsche Werkbund Weissenhofsiedlung, em Stuttgart, 1927. Fonte: POMMER, 1991.

Além desses fatores, podemos citar como outros exemplos de iniciativas de divulgar determinados postulados de arquitetura ou urbanismo da época, o International Federation for Housing and Planning (IFHP), criado por Ebenezer Howard em 1913, com o intuito inicial de divulgar e debater as possibilidades de aplicação dos conceitos da cidade-jardim em diversas localidades. Até o ano de 1928, O IFHP já havia realizado conferências em Paris, Londres, Bruxelas, Gothenburg, Amsterdam, Nova York e Viena, ampliando assim o número de adeptos e defensores do modelo cidade-jardim².

2 Fonte: < http://www.ifhp.org/content/about-ifhp> acessado em 20 de outubro de 2010. 


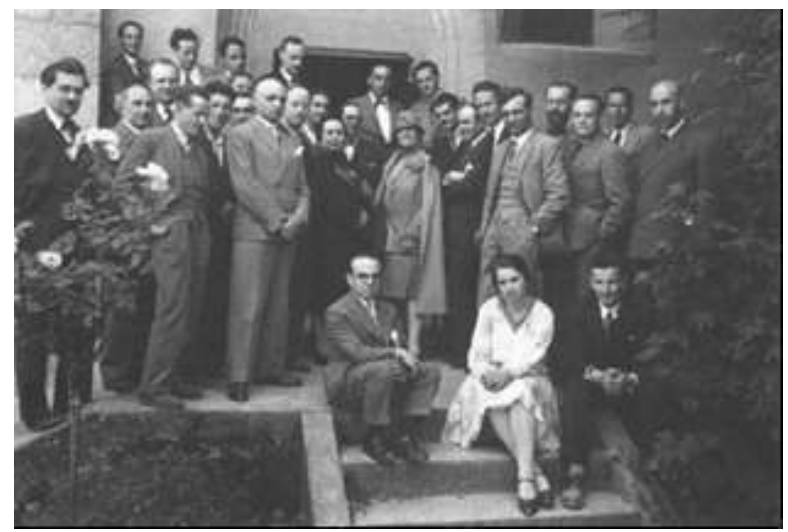

Figura 02. Foto oficial do primeiro encontro em La Sarraz. Fonte: MUNFORD, 2000.

De uma forma geral, a criação do CIAM pode ser entendida como o esforço em unir estratégias técnicas para estabelecer um programa de transformação social através da arquitetura e do planejamento urbano e regional, e de instituir um meio de promoção dessas estratégias e postulados para os clientes em potencial, como organizações estatais, iniciativa pública e clientes particulares. Mumford (2000) também aponta como objetivo indireto da criação dos CIAM os esforços para "purificar" a nova arquitetura, principalmente do Expressionismo alemão e holandês. Cabe ressaltar que nenhum dos projetos de habitação projetados por Bruno Taut e Martin Wagner em Berlim foi apresentado na exposição de habitação do II CIAM, embora tivessem projetado e edificado milhares de unidades habitacionais até $1929^{3}$.

Muito do que se discutiu em La Sarraz ocorreu em torno do programa previamente preparado por Le Corbusier e Giedion para o congresso, que era composto de seis pontos: Expressão Arquitetônica Moderna; Estandardização; Higiene; Urbanismo; Educação Primária; e Governantes e o debate da arquitetura moderna.

Entre os principias postulados de La Sarraz, são bastante conhecidos e divulgados os itens abaixo, que se referem ao novo modo de pensar e produzir arquitetura proposto no congresso:

3 Os conjuntos Hufeisensiedling Britz (1925-1930), Waldsiedlung Onkel Toms Hütte (1926-1931), Wohnstadt Carl Leigen (1928-1930) já eram bastante divulgados e conhecidos à época. Embora as pranchas não tragam os nomes dos arquitetos e dos conjuntos, foi possivel identificar, por comparação dos materiais publicados, que nenhuma planta desses conjuntos foi publicada no livro Die Wohnung für das Existenzminimum. Frankfurt: Englert and Schlosser, 1930. 
“1. General Economic System I. The idea of modern architecture includes the link between the phenomenon of architecture and that of the general economic system.

2. The idea of 'economic efficiency' does not imply production furnishing maximum commercial profit, but production demanding a minimum working effort.

3. The need for maximum economic efficiency is the inevitable result of the impoverished state of the general economy.

4. The most efficient method of production is that which arises from rationalization and standardization. Rationalization and standardization act directly on working methods both in modern architecture (conception) and in the building industry (realization).

5. Rationalization and standardization react in a threefold manner: (a) they demand of architecture conceptions leading to simplification of working methods on the site and in the factory; (b) they mean for building firms a reduction in the skilled labor force; they lead to the employment of less specialized labor working under the direction of highly skilled technicians; (c) they expect from the consumer (that is to say the customer who orders the house in which he will live) a revision of his demands in the direction of a re-adjustment to the new conditions of social life. Such a revision will be manifested in the reduction of certain individual needs henceforth devoid of real justification; the benefits of this reduction will foster the maximum satisfaction of the needs of 


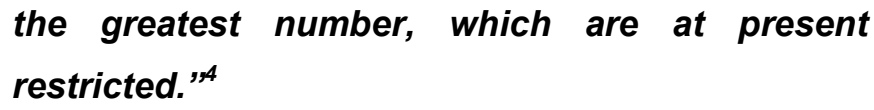

No tópico II Town Planning, foram apresentados cinco itens que se referiam ao novo modo de pensar e produzir as cidades. De forma bastante clara, a declaração colocava a necessidade de uma nova política para o solo urbano, tendo como premissa as funções básicas da cidade que se referiam à moradia, trabalho e lazer.

\section{“Il - Town Planning}

1. Town planning is the organization of the functions of collective life; it extends over both the urban agglomerations and the countryside. Town planning is the organization of life in all regions. Urbanization cannot be conditioned by the claims of a pre-existent aestheticism: its essence is of a functional order.

2. This order includes three functions: (a) dwelling, (b) producing, (c) relaxation (the maintenance of the species).

Its essential objects are: (a) division of the soil, (b) organization of traffic, (c) legislation.

3. The relationships between the inhabited areas, the cultivated areas (including sports) and the traffic areas are dictated by the economic and social environment. The fixing of population densities establishes the indispensable classification. The chaotic division of land, resulting from sales, speculations, inheritances, must be abolished by a collective and methodical land policy. This redistribution of the land, the indispensable preliminary basis for any town 
planning, must include the just division between the owners and the community of the unearned increment resulting from works of joint interest."(grifos nossos)

Ainda que não fosse 0 foco desse congresso tratar das questões urbanas, já se pode observar a essencial ligação entre pressupostos modernos de arquitetura e os novos modos de produzir a cidade para os arquitetos de vanguarda presentes no evento, através principalmente da questão da moradia. Certamente isso se deve às experiências em produção habitacional e planejamento urbano em alguns países europeus à época que só puderam ser realizadas devido a mudanças na legislação quanto às desapropriações, uso do solo, controle de aluguéis e novos padrões para habitação ${ }^{5}$.

Segundo Mumford (2000), o primeiro tópico do item Town Planning pode estar relacionado com o Manifesto Comunista, no qual Marx e Engels clamam por uma combinação de agricultura com indústria manufatureira e a gradual abolição da distinção entre campo e cidade, através de uma maior distribuição equitativa da população pelo país. Entre os integrantes do primeiro CIAM podemos apontar ao menos seis integrantes importantes com tendências socialistas explícitas: May, Meyer, Stam, Schmidt, Rietveld e Luçart.

As questões do novo agenciamento do solo podem ser entendidas também dentro deste contexto das idéias socialistas, de vida comunitária, além das reformas nas legislações urbanas nos países europeus e no zoning americano, ao lado da inclinação de Le Corbusier ${ }^{6}$ em defender edifícios com altas densidades envoltas em grandes áreas verdes. Como aponta Mumford

5Podemos citar, entre os mais significativos, o Woningwet (Ato Habitacional), 1901, na Holanda; Housing and Town Planning Act, 1909, na Inglaterra; Loi Louchier, na França; governos municipais sociais democratas na Bélgica, Áustria, Alemanha e Holanda; sequência de leis na Alemanha entre 1918 e 1930; Ato de Controle dos Aluguéis, 1922, em Viena; Revolução Russa 1917, etc.

${ }^{6}$ A Ville Contemporaine de Le Corbusier havia sido publicada em 1922. O foco central desse plano para três milhões de habitantes era um grupo de arranha-céus de dezenas de pavimentos, cruciformes, projetados em aço com panos de vidro. Os edifícios abrigariam tanto apartamentos quanto escritórios e seriam implantados num largo parque retangular, rodeados com edificações mais baixas, com tráfego de pedestres separado de autos. 
(2000), nesse primeiro congresso as tendências urbanísticas acabaram sendo convergentes por razões técnicas e políticas distintas.

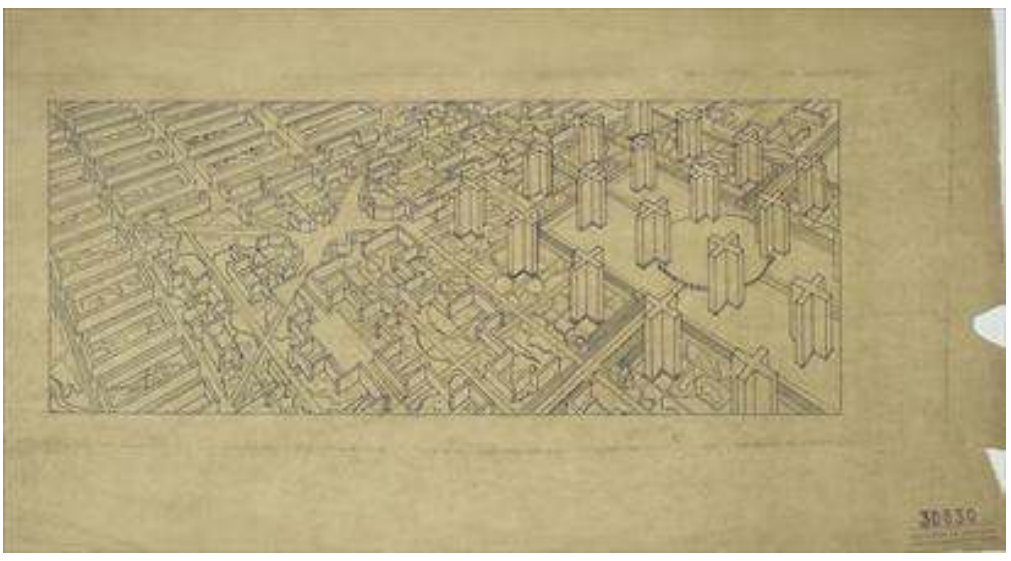

Figura 03. Ville contemporaine de trois millions d'habitants, 1922. Perspectiva geral. Fonte: http://www.fondationlecorbusier.fr

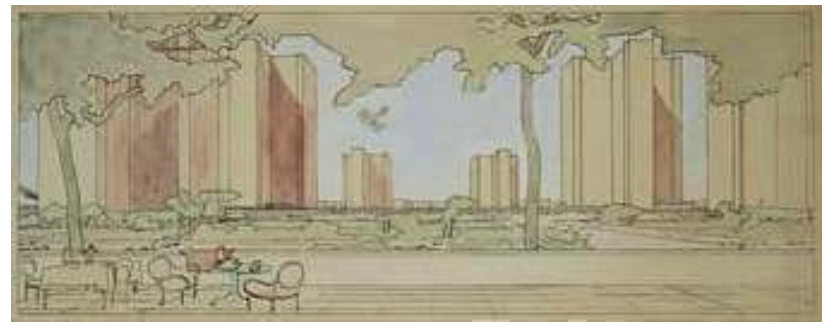

Figura 04. Ville contemporaine de trois millions d'habitants, 1922. Perspectiva das torres. Fonte: http://www.fondationlecorbusier.fr

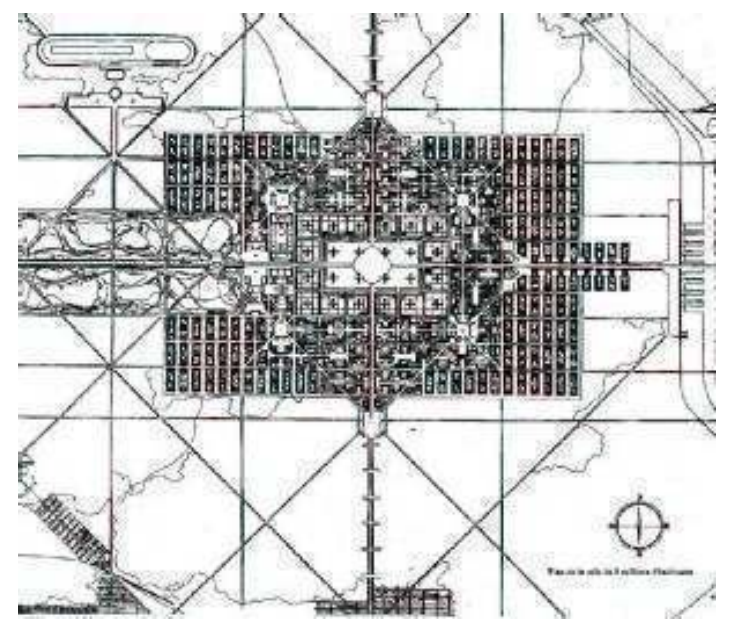

Figura 05. Ville contemporaine de trois millions d'habitants, 1922. Plano geral. Fonte: http://www.fondationlecorbusier.fr 
O II CAIM foi organizado segundo as proposições de Schmidt e Steiger em discutir as dificuldades enfrentadas pelas Neus Bauen. No encontro do primeiro CIRPAC ${ }^{7}$ na Basiléia, em 02 fevereiro de 1929, os delegados do CIAM aceitaram o convite de Ernst May em realizar o congresso em Frankfurt.

A produção alemã de habitação social após o crise inflacionária de 1923 foi um grande celeiro de experimentação na nova arquitetura. Ao lado de produções conservadores de Heimatstil, e do planejamento enraizado no Movimento de Cidade-Jardim Alemã, vemos a produção de milhares de unidades construídas dentro das concepções de racionalização e padronização dos métodos construtivos e linguagem abstrata com total ausência de adornos e referências do passado. Planejadas dentro de conceitos novos de grandes áreas verdes coletivas, separação de tráfego de pedestres e autos, preferência pela orientação solar na disposição dos edifícios, e inserção das unidades dentro de um planejamento maior de expansão urbana, esses conjuntos tinham a intenção de desafogar o centro das cidades consolidadas e promover o crescimento através de uma releitura do subúrbio-jardim.

As experiências com habitações com uma nova abordagem arquitetônica e urbanística tiveram início principalmente com a Siedlung Italienischer Garten, projetada por Otto Haesler, em 1923. Bruno Taut em Berlim, e Gropius com o projeto da Siedlung Törten em Dessau, foram outras experiências de visibilidade. Frankfurt, no entanto, foi a grande referência na qual a nova arquitetura estava fortemente ligada uma grande estratégia de planejamento urbano. Estratégia esta, que por sua vez, estava relacionada à noção de subúrbio-jardim de Raymond Unwin.

7 O CIRPARC (Comité international pour La résolution des problèmes de l'architecture contemporaine) foi reunido pela primeira vez para organizar o II CIAM; esses encontros tornaram-se tão importantes quanto os próprios CIAM's no debate da nova arquitetura e planejamento urbano entre seus idealizadores. Neste primeiro CIRPAC estavam presentes: Bourgeois, Breuer, Le Corbusier, Josef Frank, Haring, Sartoris, Schmidt, Stam, José Manuel Aizpúrua, da Espanha, e Szymon Syrkus, da Polônia. 


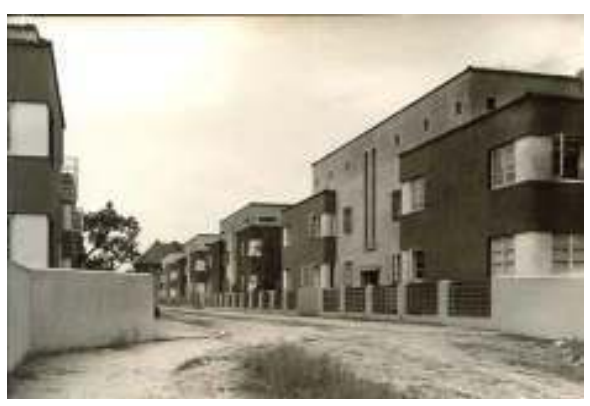

Figura 06. Die Siedlung, Italienischer Garten em Celle, Alemanha. Fonte: http://www.celle.de

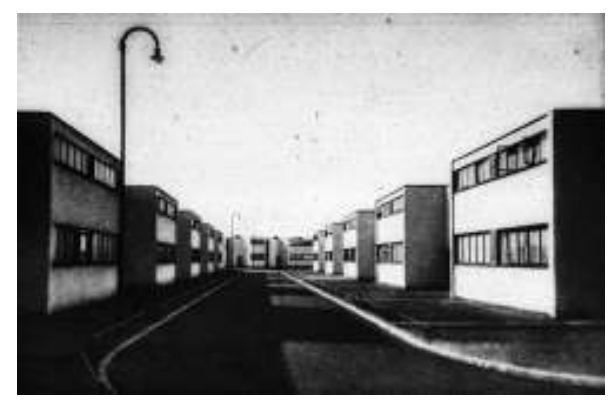

Figura 07. Walter Gropius, Törten-Dessau, 1928. Fonte: <http://tipografos.net/bauhaus/bauhausdessau.html> Foto: Baubüro Gropius.

Em vista da experiência em Frankfurt, o tema proposto para o II CIAM foi "Die Wohnung für Existenzminimum", com foco nas soluções de projeto para as unidades habitacionais, procurando resolver o problema de mínimos deslocamentos internos; condições de salubridade adequadas; formas de otimização da luz natural e ventilação; racionalização das instalações prediais; padronização dos itens construtivos; entre outros, na tentativa de achar soluções para diminuir o custo da unidade.

Para o congresso foi elaborado um questionário de 38 questões intitulado "Fundamentos econômicos e higiênicos para a moradia mínima" ${ }^{8}$ e enviado para os diversos grupos nacionais do CIAM. Contudo, a estrutura ainda insipiente do CIAM não permitiu a tabulação das questões, e no final, a moradia mínima foi assumida pelo CIRPAC como a solução universal para os problemas da habitação para a sociedade industrial.

Além do CIRPAC realizado na Basiléia para discutir o segundo congresso, em julho de 1929 foi realizado outro encontro em Frankfurt, no qual estiveram presentes Mart Stam e a equipe de May, Ferdinand Kramer, Hans Leissitkow e Josef Gantner, editor da Das Neue Frankfurt. O programa do congresso seriam palestras de Gropius, Bourgeois, Schmidt e Le Corbusier, além de uma exposição de projetos de unidades habitacionais preparadas pela

88 International Feration for Housing and Town Planing já havia realizado congressos sobre esse tema utilizando métodos similares para a abordagem do problema. Mumford, 2000; p. 31

O problema da moradia mínima já era um assunto recorrente nos esforços de resolver o problema habitacional: Na França e Inglaterra o assunto tinha sido discutido desde o século XIX, inclusive nas feiras de exposições internacionais e pelas ações filantrópicas. 
equipe de May. Projetos originários de 26 cidades europeias e dos EUA foram redesenhados pela equipe com o mesmo padrão de apresentação gráfica e layout. Cada planta foi apresentada em painéis de $1,20 \mathrm{~m} \times 2,00 \mathrm{~m}$, com informações referentes apenas a metragem quadrada, volume e área de ventilação, além de mínimas informações sobre acessos e insolação, sem o nome do autor ou localização do conjunto. Projetos construídos e estudos foram selecionados e apresentados indistintamente em três categorias: edifícios com 01 habitação, 02 habitações ou multifamiliares.
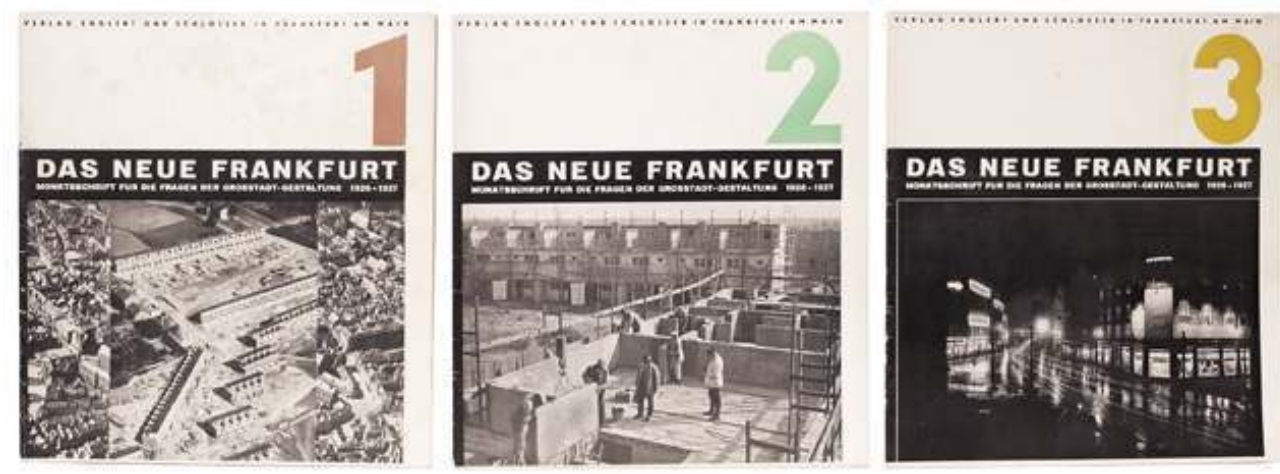

Figura 08. Capas dos primeiros números da revista Das Neue Frankfurt.

Em setembro de 1929, um mês antes da abertura do congresso, Giedion apresentou um livreto, Befreites Wohnen - o que em português seria algo parecido com Vida Liberada- o qual ilustrava projetos de diversos arquitetos comprometidos com o CIAM, como os trabalhos de Le Corbusier, Stam, arquitetos suíços, Gropius, J. P. Oud, Richard Neutra entre outros, enfatizando as possibilidades técnicas da sociedade industrial. Essas ações enfatizam o lado doutrinário e propagandista da ação dos CIAM em prol da nova arquitetura e urbanismo.

"Procuramos viviendas que, aunque pequeñas, sean sanas e y habitables $y$ ante todo facilitadlas con alquileres asequibles."

9MAY, Ernst. La vivienda para el mínimo nivel de vida. Palestra apresentada no II CIAM. In: AYMONINO, Carlo. La Vivienda Racional (1975), p.112. 
As teses apresentadas no II CIAM procuram justificar de forma cientifica, especialmente o texto de Le Corbusier, a necessidade de se adotar moradia mínimas para a solução do problema da construção em massa de grandes conjuntos habitacionais para suprir a demanda de habitação no primeiro pósguerra.

May tenta estabelecer de forma sucinta a necessidade da ação estatal para "organizar a construção de moradias para o mínimo de vida" de forma que o auxílio estatal chegasse de fato às pessoas que precisavam. Coloca ainda que a única forma de chegar a construir de maneira a atender a classe trabalhadora seria através do desenvolvimento da técnica, e clama que os arquitetos devam compreender que:

\footnotetext{
"en la construcción de viviendas, el aspecto exterior de los volúmenes y la distribución de las fachadas no deban ser considerados como las principales tareas de los arquitectos, sino que la parte más importante del problema es la construcción completa de la célula individual de vivienda según los principios de una concepción moderna de la vida y que a ellos les corresponde, además, la tarea urbanística de incorporar a la imagen de la ciudad la suma de estas células de viviendas, es decir el barrio (Siedlung), para que de este modo se creen las mismas condiciones favorables para cada elemento individual de vivienda." 10
}

A tese apresentada por Gropius, por outro lado, se atém às questões de mudanças na sociedade que implicam modificações profundas nas necessidades domésticas. O papel da mulher na sociedade industrial, como agente produtivo e com direitos iguais aos dos homens indica a necessidade de racionalização dos afazeres domésticos para que a mulher tivesse mais tempo livre. Aponta também a tendência das famílias urbanas do século XX em terem

10 Ídem. 
menos filhos; estatísticas apontadas por ele mostram que as famílias na Europa e nos EUA têm em média de 4 - 5 componentes, naquele momento.

"Con la desaparición de numerosas tareas Del hogar, que ligaban la familia a la producción de la sociedad, disminuyen las tareas de la mujer y así ahora ella busca, también fuera de la familia, la satisfacción de sus actividades naturales entrando en la vida activa. La economía, fundamentada en una nueva base gracias a la máquina, muestra a la mujer la irracionalidad de su pequeño trabajo hogareño. "11

Outro dado importante, que na verdade corresponde a tendência política de alguns países europeus no pós-guerra, a saber, Rússia, Alemanha, Áustria, Bélgica e Holanda, diz respeito à disposição da sociedade industrial ao cooperativismo e noção de comunidade:

“Así comienza hoy - partiendo de la vida
económica de los pueblos - la idea de la
racionalización para crear un gran movimiento
espiritual en el que la actuación del hombre
individual se transforma en una colaboración
beneficiosa para el bien de la comunidad total;
por encima de la rentabilidad económica en
provecho del individuo, por el camino de la
'ratio', aparece la conciencia de comunidad"12

Essa análise sociológica que faz da vida urbana do século $X X$, aliada à necessidade de alívio na carga dos afazeres domésticos levaria a proposta de

11 GROPIUS, Walter .Los Fundamentos Sociológicos de la Vivienda Mínima. Palestra apresentada no II CIAM, Frankfurt, 1929, in AYMONINO, Carlo (1975).

12 Idem. 
habitações comunitárias com serviços domésticos centralizados como alternativa correta e inevitável para os trabalhadores ${ }^{13}$.

As experiências dos soviéticos nesse campo certamente serviram de base para a construção teórica de Gropius. Em 1928 já era conhecido o projeto do edifício Narkomfin, em Moscou, projetados pelos arquitetos Moisei Ginzburg ${ }^{14}$ e Ignati Milinis, o qual adota unidades habitacionais com o mínimo de áreas individuais para as famílias, e apresenta amplo restaurante, lavanderia e salão de jogos comunitários. Outra novidade nessa edificação está na forma de circulação coletiva otimizada. As unidades são duplex ou apartamentos de 01 quarto com acesso e sanitário coletivo num pavimento intermediário. Com a possibilidade de colocar as galerias de acesso a cada três ou dois pavimentos, era possível diminuir a área dessas circulações no total da construção.

Ainda em sua apresentação no II CIAM, Gropius aborda a questão das densidades urbanas e as questões de edificações altas como solução para o problema de habitação de baixa renda, e defende a intervenção do Estado como único agente possível de empregar corretamente os fundos para ações nesse sentido, elaborar a legislação urbanística para construção no subsolo e em altura, e diminuir os custos da urbanização.

Victor Bourgeois fez uma breve explanação sobre a questão da organização da moradia mínima e aborda questões técnicas de ventilação mecânica constante do espaço, sendo as janelas utilizadas apenas para iluminação, assim como na explanação Corbusier. Também aborda a necessidade de estudo da vida doméstica para racionalização das tarefas e dos

13 Segundo Munford, (2000, p.35) Gropius se apóia nas idéias do sociólogo F. Müller-Lyer, que em texto publicado em 1921 argumenta sobre o surgimento da era das cooperativas e do direito comunitário, em contraposição ao individualismo e procura de maximização dos lucros do século XIX.

14 Ginzburg foi um dos membros da OSA (Sociedade de Arquitetos contemporâneos), fundado em 1925 e que expressou suas ideias na publicação SA (Sovremennaya Arkhitektura). Em 1928 o arquiteto foi a nomeado diretor do departamento de padronização no comitê de construção (Stroikom), e trabalhou no desenvolvimento de toda uma série de tipos de plantas padrões para uso nos novos conjuntos habitacionais. No edifício Narkomfin foi utilizado um tipo transitório de unidade de habitação para a separação total entre espaço privado e coletivo, defendido pelo grupo OSA. FRENCH, 2009, p.52.

Essas propostas de unidade mínima e serviços coletivos estavam preconizadas numa séria de competições organizadas pelo Stroikom, e publicadas pela SA em 1927 para a nova moradia coletiva do regime, ou domkommuna. FRAMPTON, 1997, p.209. 
espaços. Hans Schmidt, por sua vez, faz uma explanação sobre a necessidade de legislação mais abrangente para essa produção e o conflito existente entre as regulamentações vigentes e a produção privada que visava apenas o lucro nos construções, Defendia ainda a necessária participação dos arquitetos no processo de regulamentação e produção de moradia.
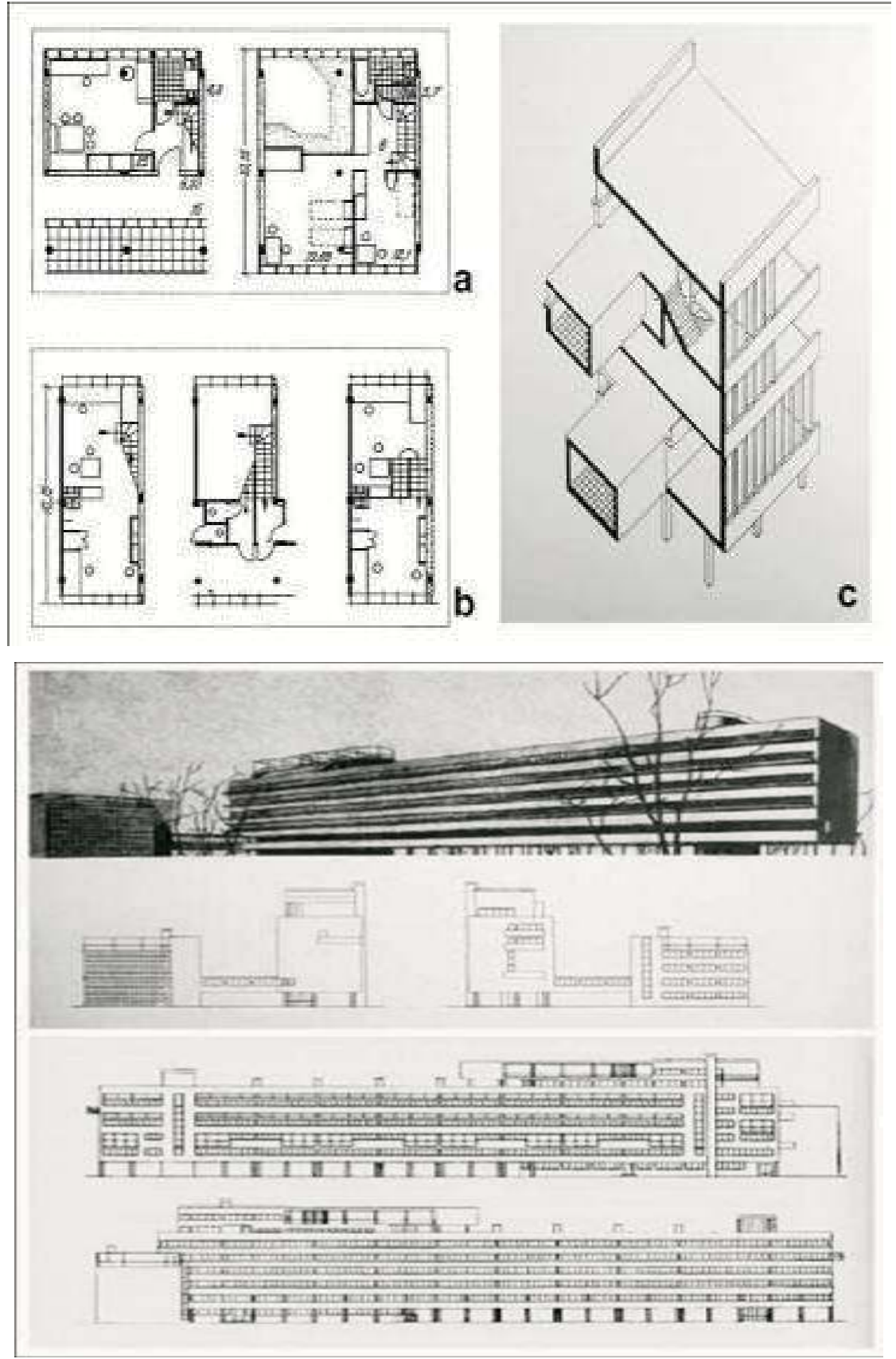

Figura 09. Edifício Narkomfin, Moscou, 1928. Planta baixa, perspectiva e fachadas. Fonte: MONICA, 2004. 
A apresentação de Le Corbusier lida por Pierre Jeanneret devido à sua viagem de Le para a América do Sul para uma sequência de palestras, tinha o tom mais científico e doutrinário em relação aos outros, além de ser o mais longo. O texto fora dividido em duas partes e abordava as questões de necessidade de industrialização e racionalização na construção de moradias; busca de uma nova linguagem na era da máquina; busca do entendimento da lógica das atividades domésticas, e invariavelmente, incorporava os cinco pontos da arquitetura em seu discurso sobre arquitetura e cidade.

"Es preciso encontrar y aplicar nuevos métodos claros y simples que nos permitan confeccionar los proyectos de vivienda y que se presten naturalmente a la estandarización, la industrialización, a la taylorización."

Le Corbusier atestava em seu discurso que seria possível estudar as funções da vida doméstica e organizá-las de modo a aperfeiçoar a circulação interna. Em sua visão, esta seria a chave para o correto projeto do espaço mínimo habitacional, organizado segundo métodos científicos e racionais, ao contrário das habitações tradicionais que são projetadas de forma mais ou menos arbitrária.

\section{"La vida doméstica consiste en una serie regular de funciones precisas. La serie regular de estas funciones organiza un fenómeno de circulación. La circulación exacta, económica, rápida, es la clave de la arquitectura contemporánea."}

A questão da industrialização fora colocada como única alternativa para se conseguir o barateamento das unidades, assim como acontecia com qualquer outro produto produzido em série. A repetição e produção em massa seriam os fatores que levariam ao barateamento da unidade. O mesmo raciocínio, levado em consideração à habitação, apontaria para a produção seriada, com elementos estandardizados e pré-fabricados, possíveis com o uso do concreto armado e do ferro. Em sua consideração, afirmava que só era possível usar o 
concreto armado de forma racional e econômica em grandes estruturas, jamais em unidades pequenas. Por isso, defendeu o arranha-céu como alternativa racional para possibilitar o processo de industrialização da construção de forma que representasse vantagens financeiras. Aplicável, portanto, à produção habitacional em massa.

Karl Moser, como presidente do CIAM eleito em La Sarraz, fez o discurso de abertura e fechamento do evento, apresentando o Estatuto de Frankfurt, que seria o estatuto e organização oficial do CIAM. A exposição preparada para o congresso contava com duzentas e sete plantas de unidades mínimas dispostas em painéis.

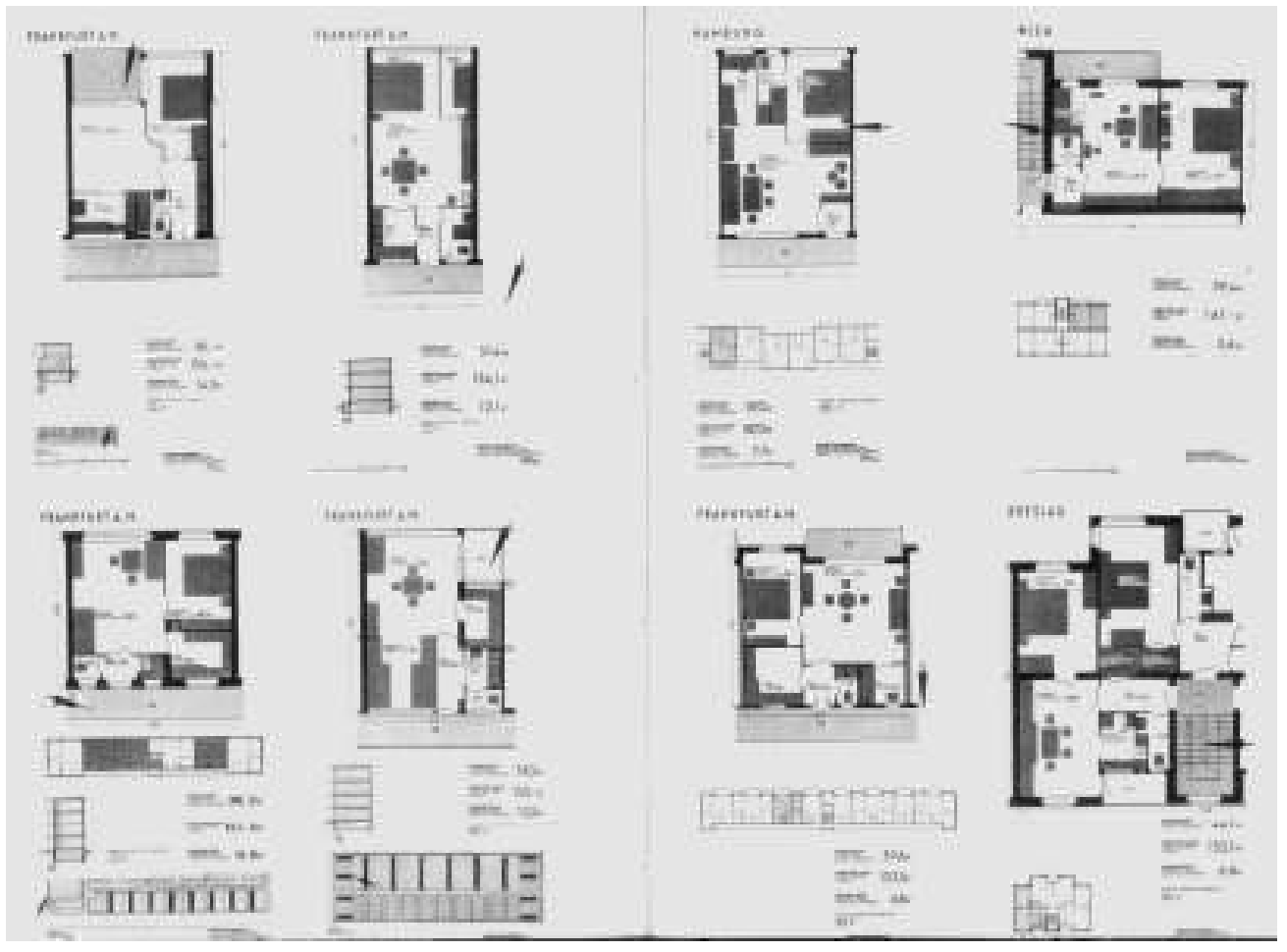

Figura 10. Exemplos dos painéis exposto durante o II CAIM, publicados em Aymonino (1979).

Nesse congresso, ficara evidente para os participantes a necessidade de discutir aspectos urbanísticos da questão habitacional, além de continuar investigando as novas possibilidades técnicas. Seria impossível chegar a conclusões assertivas sobre barateamento das unidades sem levar em consideração os custos da terra, densidade e infraestrutura urbana, como já assinalaram Gropius e Le Corbusier em suas falas, que apontavam para os edifícios altos como solução para o problema. 
Nas considerações finais do congresso, publicas em Frankfurt, por Englert e Schlosser, publicadas em Aymonino (1975), os delegados constaram que a maior parte da população das grandes cidades vivia em habitações impróprias e que essa era uma necessidade reconhecida, com exceção dos EUA e da Hungria. Assinalava a necessidade do estudo do emprego das novas tecnologias para baratear ainda mais a produção, embora as subvenções do Estado tenham conseguido algum resultado, ainda insuficiente, para barateamento da construção pelos métodos tradicionais.

Por fim, fora constatada a necessidade de pesquisa dos edifícios altos como alternativos para produção racional e acessível de moradia proletária, pois, embora fosse apontada como uma possibilidade, só existiam exemplos desse tipo de edificação nos EUA, e eram destinados para as classes mais abastadas.

O III CIAM, a convite de Bourgeois, fora realizado em Bruxelas em novembro de 1930. A preparação para o congresso iniciou-se com o CIRPAC de fevereiro de 1930, realizado no escritório de Corbusier em Paris, com a presença de Stam, Schmidt e Giedion. Segundo Mumford (2000), nesse encontro o arquiteto franco-suíço criticara o tema do II CIAM por tratar apenas da moradia e não abraçar as questões dos serviços coletivos relativos aos conjuntos habitacionais, a exemplo do que ocorria na URRS no mesmo período. ${ }^{15}$

15 Em 1928, Le Corbusier começa uma série de viagens a Moscou para tratar do projeto do Tsentroshilsoyuz, e toma ciência das diversas pesquisas para "cidades novas" e "conjuntos habitacionais" promovidas por Ginzburg e o grupo OSA. Por ocasião dessa proximidade e por seu prestígio internacional, Le Corbusier é convidado a escrever sobre a proposta para as Cidades Verdes, uma cidade socialista descentralizada, para 100.000 pessoas, que funcionaria como local para um dia de lazer e relaxamento para cada quatro dias trabalhados nas fábricas (ideal de produtividade do operariado proposto pelos médicos socialistas). As pesquisas realizadas na URRS a essa época, por diferentes tendências, se inclinavam todas para a descentralização das grandes metrópoles, e na sua corrente mais radical propunha 0 "desurbanismo". Corbusier, em texto crítico referente à Cidade Verde de Moscou, "Comentários sobre a urbanização de Moscou e das Cidades Verdes", discorre sobre a importância das grandes aglomerações urbanas, pela pujança cultural e econômica. A partir desse documento foi convidado pelos soviéticos a responder um questionário sobre o desenvolvimento de Moscou e traçou novo documento (Résponse à Moscou), com 21 desenhos para a reconstrução de Moscou, que seriam as premissas da Ville Radieuse. Sobre o assunto ver: COHEN, Jean-Louis. Le Corbusier and the Mystique of the USSR: Theories and Projects for Moscow, 1928-1936. Princeton University Press (1992) - capítulo 6; CORBUSIER. Precisões sobre um Estado Presente da Arquitetura e do Urbanismo, Cosac \& Naify, São Paulo (2004), p 255-260. 
O tema para o terceiro congresso foi um desdobramento do que foi discutido em Frankfurt, e a questão do "Desenvolvimento Racional do Lote" tem estritas ligações com a produção racional de habitação alemã apresentada no ano anterior.

A principal discussão do III CIAM acontece em torno da questão que Gropius levanta em sua palestra "Edifícios baixos, médios ou altos?" e o plano da Ville Radieuse apresentado por Le Corbusier, ambos defendendo a verticalização das edificações urbanas, apesar das vozes contrárias a essa postura. Exemplo disso é a palestra de Herbert Boehm e Eugen Kaufmann, associados de Ernst May, que demonstrava a inviabilidade financeira de edifícios altos para habitação de baixa renda pelo custo total da edificação, comparando o custo final de edificações de 2 a 12 pisos, com o auxílio das construtoras de Frankfurt Holzmann e Proesler.

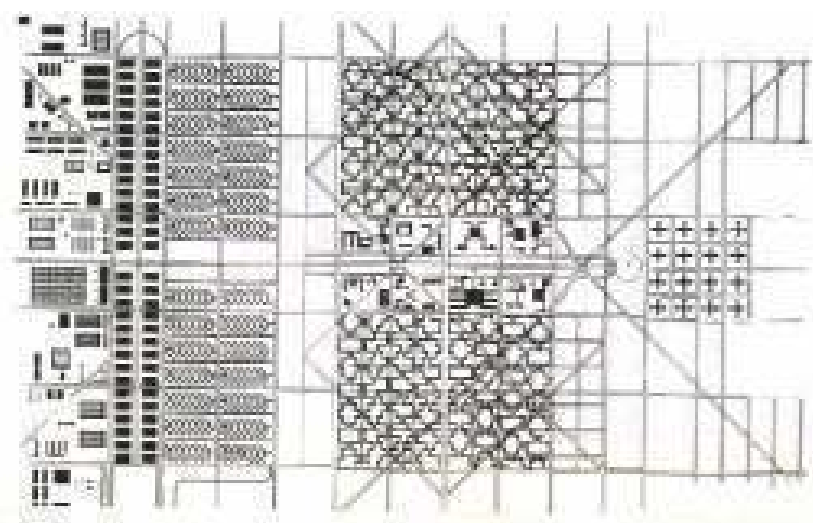

Figura 11. Esquema geral da Ville Radieuse. Le Corbusier, 1930. Fonte: http://www.fondationlecorbusier.fr

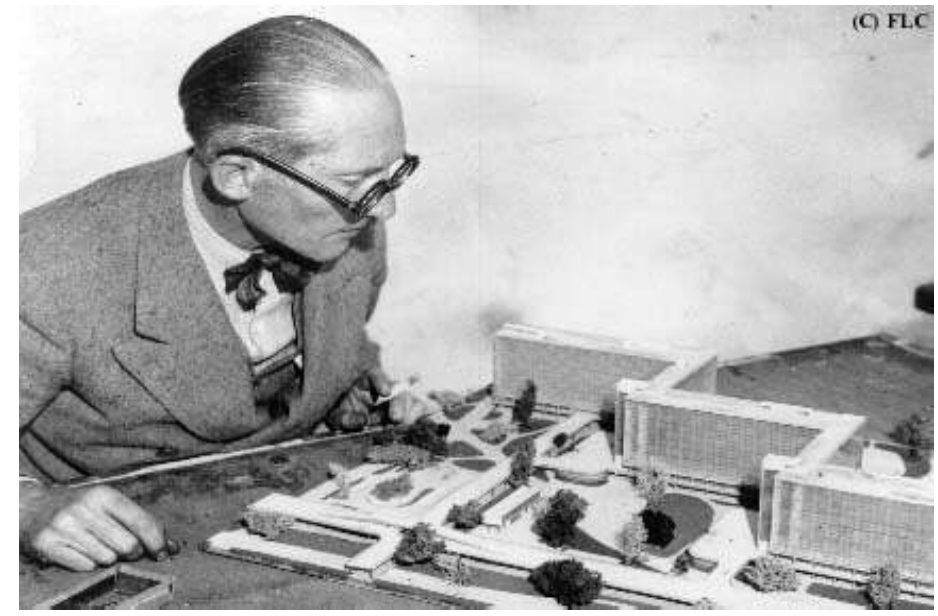

Figura 12. Maquete de parte da Ville Radieuse. Le Corbusier, 1930. Fonte: http://www.fondationlecorbusier.fr 
Richard Neutra atestava nesse congresso, na apresentação "Construções altas, médias e baixas nas condições americanas", que a experiência americana nesse tipo de edificação era sempre destinada a aluguéis altos, para famílias pequenas ou solteiros. A construção desses edifícios para a população menos favorecida deveria ser organizada por entidades oficiais ou outras organizações sociais, pois a iniciativa privada apenas conseguiria prover outras fatias da sociedade. Para o desenvolvimento de famílias maiores, a edificação de pouca altura constituía uma aspiração da sociedade americana, por isso deveria ser investigada da mesma forma.

Com vozes contrárias a construções altas para a classe operária, Gropius e Giedion tentaram desviar a análise da edificação em altura apenas pela via econômica (visto que o estudo de Frankfurt demonstrava de forma detalhada que o edifício de cinco pavimentos seria a solução mais viável), abordando as vantagens "sociais" e "psicológicas" de cada solução.

“¿Cuales son as alturas racionales para la agrupación urbanística de viviendas? Para aclarar la pregunta parece bueno empezar por acotar la significación del término "racional". El congreso debe aceptar un acuerdo sobre esta amplia acepción; racional es lo mismo que económico; textualmente es así, pero en nuestro caso comprende ante todo las necesidades psicológicas y sociales, además de las económicas. Las condiciones sociales de una política de vivienda sana son, sin duda, mucho más importantes que las económicas, pues la economía no es un fin. La racionalización sólo tiene sentido si es enriquecedora, si traduciendo al lenguaje económico - ahorra la 'mercancía' más preciosa: el esfuerzo del pueblo"16

${ }^{16}$ GROPIUS, W. (1930) ¿Construcción baja, media o alta?, in AYMONINO, C. (1975), p.211. 
Em seu texto, bastante conhecido e citado em diversos países, abordou a questão da habitação a partir da legislação alemã sobre habitação proletária, que estipulava a altura máxima das edificações em cidades grandes (04 pavimentos) e pequenas (03 pavimentos), datada de 1929. A otimização da terra, da infraestrutura urbana e dos transportes são os principais fatores que indicariam a racionalidade dos edifícios em altura para Gropius. Além do fato desse arranjo espacial, de torres em meio a grandes parques proporcionar um espaço sadio, ventilado e iluminado, e estimularem a via em comunidade, com serviços coletivos e áreas comuns de lazer, ao contrário da casinha isolada no lote da cidade-jardim.

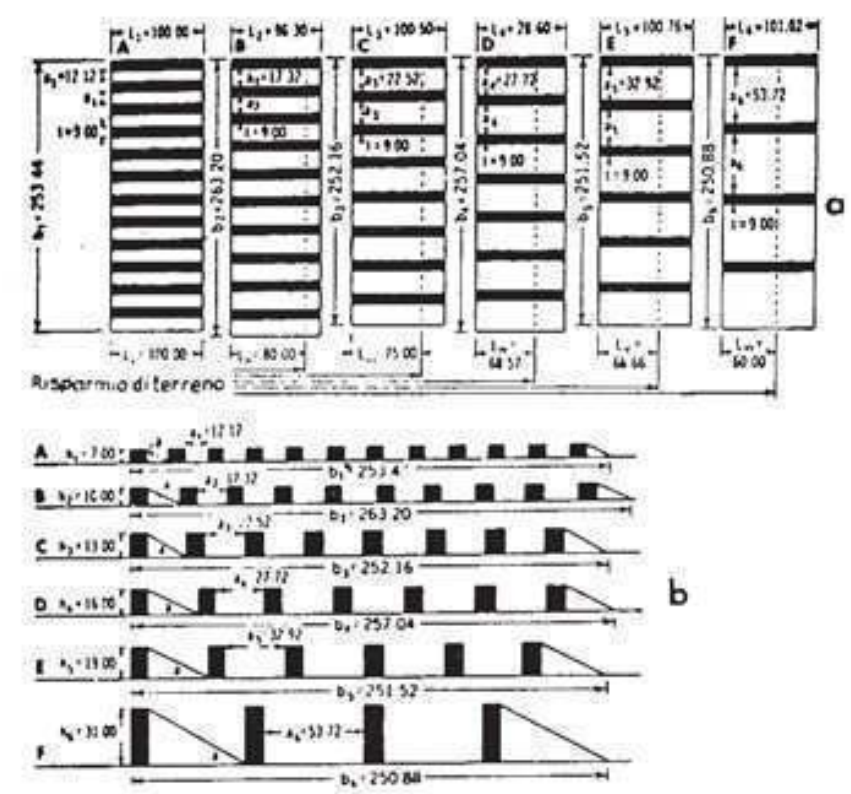

Figura 13. Esquema apresentado por Gropius demonstrando as questões de densidade e espaçamento entre as edificações baixas, médias e altas. Fonte: AYMONINO, 1979, p.217.

Na publicação do III CIAM, datada em 1931, sob o título Rationelle Bebauungsweisen, publicado por J. Hoffmann, em Stuttgart, o representante tcheco Karel Teige teceu comentários sobre o congresso no geral, e avaliou que como a iniciativa privada não poderia colaborar com a habitação proletária, seria necessário criar uma nova forma de habitação coletiva para a classe trabalhadora. Assim, como May já havia experimentado em Frankfurt, as tentativas de reduzir o custo da produção da moradia e, por conseguinte, dos 
aluguéis cobrados, iam de encontro às inevitáveis limitações do sistema econômico vigente. O problema de construção em massa das habitações deveria ser resolvido pelo planejamento em larga escala, e seria, portanto, um problema de planejamento urbano. As habitações existentes das classes trabalhadoras das cidades consolidadas serviriam apenas para serem demolidas.

Neste congresso também foram expostos 56 projetos de conjuntos habitacionais ou bairros, com diversas tendências: modelos de cidade-jardim; vilas com baixa densidade; bairros com blocos laminares dispostos ao longo das ruas, ou perpendiculares a elas, e outras variações.

Com as explanações publicadas sobre o III CIAM e os projetos apresentados durante o evento fica evidente que o pensamento dominante se voltava para novos modelos de urbanização, com habitações arranjadas em diversas tipologias, em contraposição a produção privada do século XIX. A idéia deflagrada nos congressos era a de que qualquer forma de urbanismo até aquele momento deveria ser rejeitada.

Por outro lado, a pluralidade das soluções apresentadas na exposição, especialmente aquelas edificadas, não condizem com as resoluções apontadas pela publicação do congresso, o que ratifica o caráter utópico do discurso. $\mathrm{Na}$ verdade, apenas as experiências do Middle West americano, especialmente Chicago, são em edifícios em altura, e para a classe alta. Em território Europeu, as primeiras realizações desse tipo datam de meados de 1930, com o edifício Bergpolder, em Rotterdam, e Nirvana, em Haia. Somente no segundo pós-guerra essa solução seria largamente explorada, orientada pelo III e IV CIAM.

$\mathrm{Na}$ exposição do III CAIM, as principais experiências com modelos urbanísticos voltados para grandes zonas de áreas verdes, novo parcelamento do solo e nova relação das unidades com a rua foram realizadas com edificações baixas e médias, em muitos casos com uma arquitetura bastante tradicional, embora despojada de adornos. Exemplos disso são os bairros de Transvaalburt (1918-1930) e Buiksloot (1930), em Amsterdam; Pixmore Hill, Letchworth (1903), na Inglaterra; Radburn (1929), nos EUA; Neubühl (1930), em Zurique; e outros. 


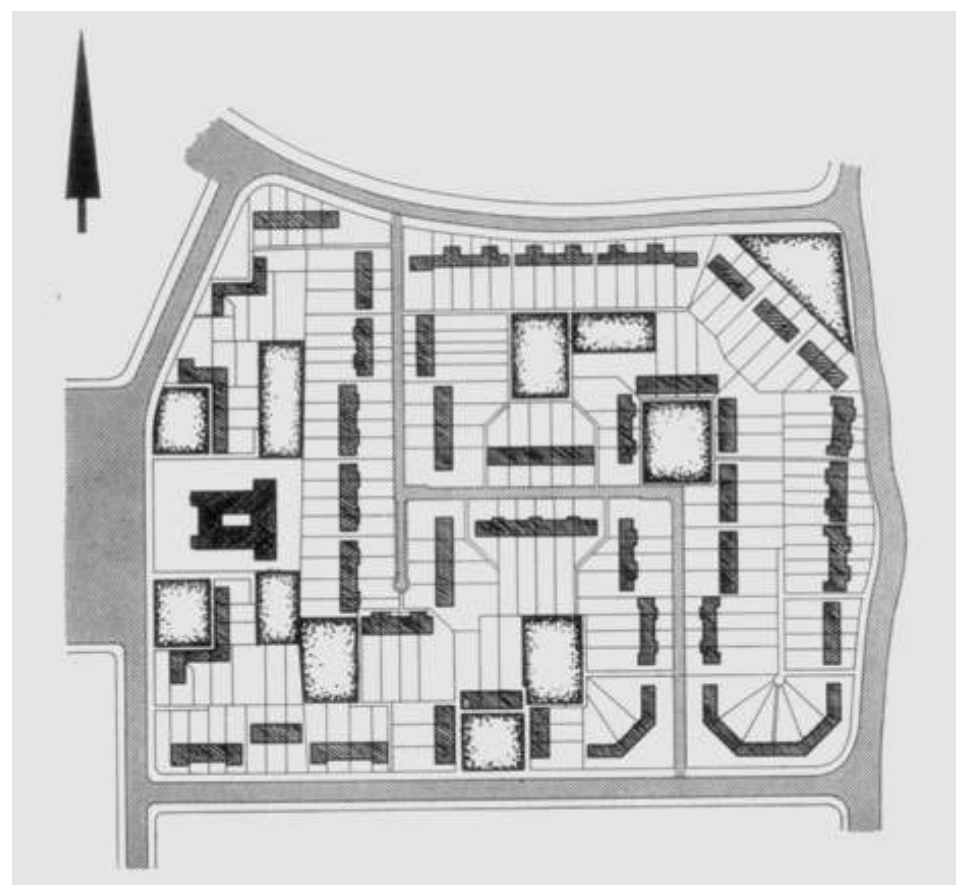

Figura 14. Lechtworth. Pixmore Hill, 1903. Fonte: Aymonino, 1979, p.263.

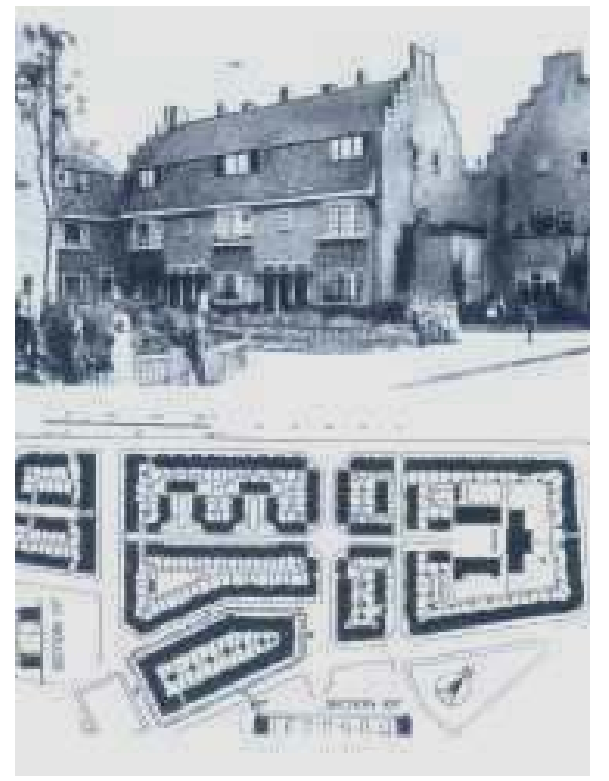

Figura 15. Transvaalbuurt, Amsterdam. 1918-1930. Arquiteto: H. Berlage. Fonte: idem, p.

Embora com vários exemplos que discordassem do discurso teórico da grande cidade verde com arranha-céus, Gropius, Le Corbusier e Giedion 
conseguiram imprimir, através da publicação Rationelle Bebauungsweisen ${ }^{17}$, a idéia de que o III CIAM tinha um discurso claro contra a cidade-jardim, as belasartes, os métodos de Berlage, e contra qualquer idéia de formalismo explícito.

De uma forma ou de outra, a pluralidade da produção habitacional da época acabou sendo exposta nestas exposições e publicações dos CIAM, e para o bem ou para o mal acabaram dando um panorama bastante abrangente das diversas formas de enfrentamento do problema produzidas e debatidas à época. E mais, evidenciaram as autoridades locais como principais atores do processo de provisão habitacional, com suporte de políticas públicas em âmbito nacional (financeiro e legislativo), pois a todo o momento a provisão habitacional é atrelada à necessidade de planejamento urbano. A discussão de descentralização ou adensamento urbano pela produção em massa de moradia traz em si a necessidade do planejamento das cidades, especialmente para as expansões urbanas e cidades novas, ou o arrasamento total, como pregava Le Corbusier, já que a reabilitação e renovação não eram temas discutidos tanto nos primeiros CIAM, como nos seminários do IFHP.

Após Bruxelas, devido à grande quantidade de trabalhos preparatórios envolvidos, o CIAM tinha começado a planejar a realização de seus congressos a cada dois anos, com o IV Congresso planejado para Moscou em 1932. A ausência de qualquer convite oficial em 1931 do Tsentroshilsoyuz, o Conselho Central de Cooperativas de Habitação da União Soviética, no entanto, fez com que o grupo realizasse uma reunião da CIRPAC em 1931, em Barcelona, em vez do Congresso "Cidade Funcional" em Moscou, como se pretendia. Sugerida por Victor Bourgeois, a escolha de Barcelona foi, em si significativa; pela primeira vez o CIAM tinha se reunido fora da Suíça, Alemanha, Bélgica e França, na região do Mediterrâneo pela qual Le Corbusier tinha sido fascinado e onde começou a preparar planos para Argel em 1931 (MUMFORD, 2000).

Em Barcelona, um grupo de jovens arquitetos estava extremamente interessado nas idéias sendo desenvolvidas pelo CIAM, e a reunião coincidiu com o convite do novo governo espanhol Republicano à Le Corbusier para participar da criação de um novo plano diretor para Barcelona. A proclamação no ano anterior da Segunda República Espanhola, que adotou uma constituição

17 Com introdução de Giedion e artigo de Teige ratificando as idéias de Corbusier e Gropius, e os comentários contrários a diversos projetos apresentados na exposição feitos a posteriore. 
semelhante a da República de Weimar, possibilitou que um regionalismo Catalão reprimido, centrado em Barcelona, pudesse florescer. Embora a figura pioneira do Movimento Moderno na Espanha na década de 1920 fosse o arquiteto madrileno, Fernando Garcia Mercadal, que tinha participado do primeiro Congresso de La Sarraz, em 1932, Barcelona havia se tornado o local mais fervilhante das atividades relacionadas ao CIAM, com diversos adeptos à nova arquitetura. Muito disso se deveu a Josep Lluis Sert, que havia sido convidado para participar da segunda conferência CIAM em Frankfurt, e que havia se juntado a Garcia Mercadal como representante espanhol no CIAM.

Sert e Josep Torres Clavé assumiram a liderança na organização do Grup d'Arquitectes i Tècnics Catalans per AL Progrès de l'Arquitectura Contemporània, ou GATCPAC, que havia se desenvolvido a partir de um primeiro grupo fundado em 1929 (sem muitas mudanças nos seus membros compostos na maioria por catalães, GATCPAC foi renomeada para GATEPAC- o E significando Espanoles - na reunião do CIRPAC de Março de 1932 em Barcelona, e depois foi aceito como o grupo CIAM Espanhol). Desde a década de 1920, grandes interesses industriais em Barcelona haviam apoiado vultosas melhorias urbanas, como melhorias na infraestrutura urbana, a renovação do centro histórico, e a ampliação das instalações portuárias. O ponto culminante desses esforços foi a Exposição Internacional de Barcelona de 1929, na qual a maior parte dos trabalhos de arquitetos locais ainda foram nos estilos das Beaux-Arts, assim como o projeto vencedor da competição da Liga das Nações dois anos antes. Nenhum projeto dos membros do GATCPAC foi exposto, mas o esforço para a modernização e o planejamento de Barcelona, dos quais era o símbolo principal, estava prestes a ser tomado por eles de uma forma diferente.

O grupo GATCPAC apoiou entusiasticamente a Segunda República Espanhola, e estava intimamente ligado à nova liderança e era simpático aos sindicatos locais, embora estes não o apoiassem. No dia da proclamação da República em 1931, o GATCPAC abriu seu escritório e espaço para exposições na rua comercial mais elitizada de Barcelona, o Passeig de Gracia, e um periódico, AC (Documentos de Actividad Contemporanea) foi iniciado. O novo governo da República tentou abordar os problemas urbanos através da conversão de edifícios privados e as estruturas do Parque de Exposições de 1929 para uso público, mas os membros do GATCPAC, que receberam uma variedade de pequenas escolas e pequenas instalações hospitalares neste 
processo, agitaram por mudanças mais radicais. Inspirados pelos CIAM's e pelo programa dos sindicatos locais pressionaram por uma redistribuição da terra urbana e pela racionalização do transporte e toda infraestrutura de comunicações, incluindo a provisão de habitação padronizada e acessível, ao lado de grandes melhorias no sistema de saneamento urbano.

Foi nesse contexto político que em 1932, Le Corbusier e o GATCPAC, sob a liderança de Sert e Torres Clavé, foram incumbidos pelo governo de realizar em um plano diretor para Barcelona. Eventualmente chamado de Macià em homenagem ao presidente, que morreu repentinamente em 1932, o Plan Macià estava ligado à tentativa do novo governo de oferecer sua própria versão de melhoria urbana para contrastar com a anterior e mais conservadora modernização, expressa na Exposição de 1929. O plano de Macià sintetizou as idéias que Le Corbusier tinha desenvolvido em sua "Resposta a Moscou", com as categorias funcionais desenvolvidas por Van Eesteren em Amsterdam, a partir de 1928. Como na Ville Radieuse, a metrópole centralizada ainda era o foco de atenção. O programa de projeto foi definido como a necessidade de substituir ou modificar a estrutura existente "caótica" e substituí-la por uma mais de acordo com as necessidades técnicas e as aspirações populares. O plano previa a adição de um "centro de negócios" novo à beira-rio, em frente à cidade velha, composto de três novos arranha-céus - essa foi a primeira aparição dos edifícios em "Y" que figuram em muitos dos planos de Le Corbusier nos anos 1930, notadamente para Argel. Estas torres, recortadas contra as montanhas atrás da cidade, imprimiram uma nova imagem de modernidade monumental para Barcelona.

No plano, o restante da cidade era dividido em três zonas de habitação: a cidade existente, que consistia do bairro medieval Gótico e os blocos do século dezenove de Cerdá, e dois novos bairros de habitações com edifícios em forma de redan. Essas áreas deveriam ser ligadas a uma nova autoestrada que atravessaria a cidade ligando-as às instalações portuárias e áreas de expansão industrial, bem como a um novo "Ciutat de Repos" (cidade do lazer) na costa do Mediterrâneo, ao sul da cidade. Como no plano de Van Eesteren para Amsterdam, o plano Macià foi baseado em zoneamento da cidade em termos das quatro funções primordiais da cidade - habitação, lazer, trabalho e circulação - e tinha por intuito modernizar suas instalações portuárias e de trânsito. Ao mesmo tempo, como nas versões anteriores dos planos de Le Corbusier para 
Argel, desenvolvidos ao mesmo tempo, grande parte da cidade existente deveria ser preservada no plano Macià. Muitas das estreitas ruas medievais e as Ramblas deveriam ser mantidas, demolindo áreas apenas nos interiores dos blocos e de algumas áreas pontuais identificadas como cortiços. As áreas que seriam demolidas, que aparecem de maneira diferente nas apresentações dos planos Le Corbusier e Sert, seriam transformadas em praças ajardinadas contendo pequenas instalações comunitárias, como bibliotecas de bairros e jardins de infância. As ruas e edifícios antigos remanescentes eram descritos como formando uma "promenade arqueológica".

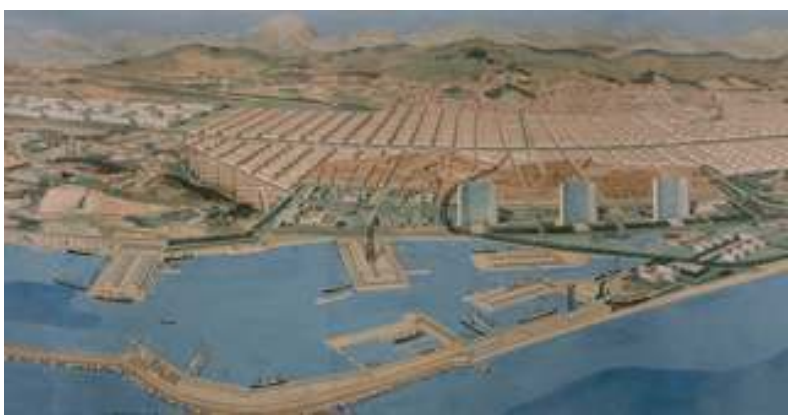

Figura 16. Plan Macià para Barcelona, 1932-33, Le Corbusier e GATEPAC.

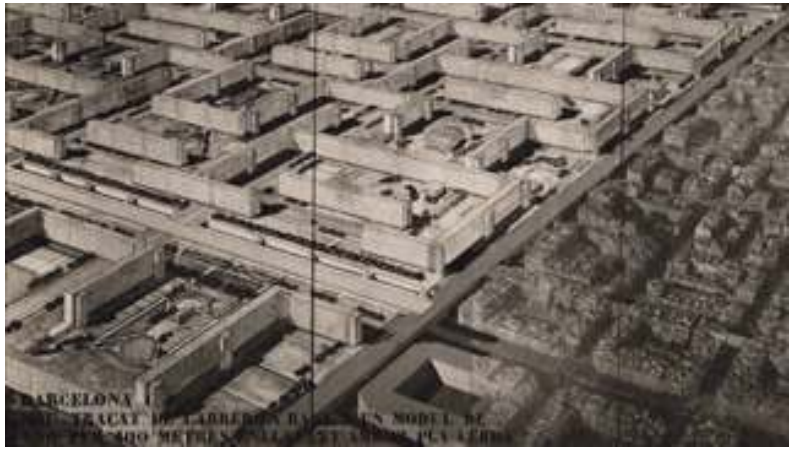

Figura 17. Plan Macià e Eixample.

As novas moradias, portos e instalações industriais melhoradas, e a Ciutat de Repos do plano Macià eram todos os elementos defendidos pelos sindicalistas. A "cidade do lazer" foi o elemento mais popular do plano Macià; em 1933 a Associação Ciutat de Repos tinha mais de 800.000 membros, incluindo associações de grupos esportivos, cooperativas de saúde, de professores e empresários. No entanto, a única parte do plano Macià realmente construída foi a Casa Bloc, um bloco redan de habitação que seria um protótipo dos novos blocos residenciais. Desenhado por Sert, Torres Clavé e Joan Subirana em 1932, e situada na Paseo de Torras i Bages, consistia de 200 unidades 
dispostas em três fileiras de apartamentos duplex com terraços individuais ligados por galerias aéreas. A construção era de estrutura de aço, com elevadores posicionados nos cantos. O programa incluía uma biblioteca pública, um clube do trabalhador, uma creche, uma biblioteca infantil, e grandes áreas projetadas para lojas cooperativas e oficinas. O projeto foi concebido para ser um grandioso protótipo, de quatrocentos metros quadrados, das novas áreas residenciais do Plan Maciá.

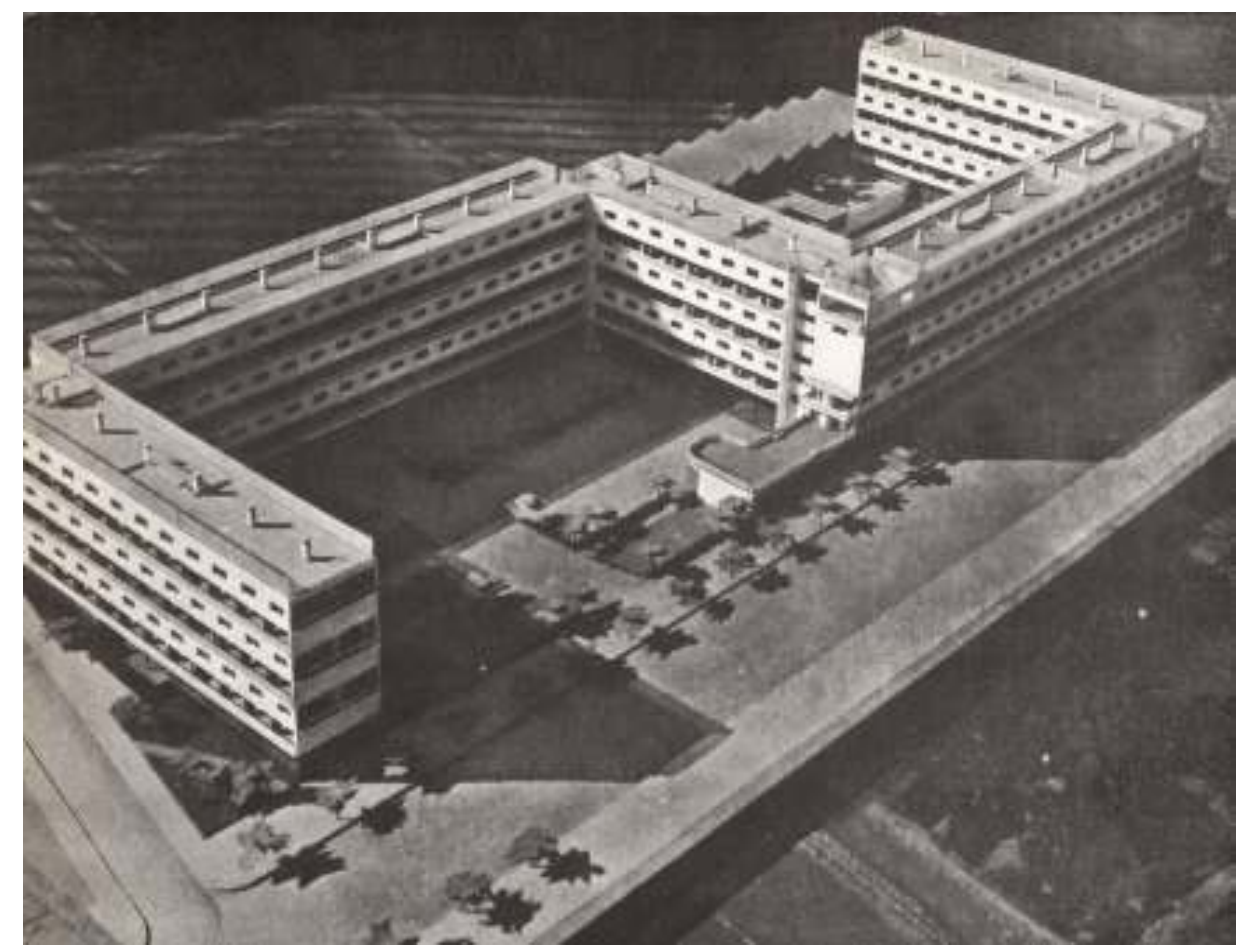

Figura 18. Casa Bloc, 1933, Barcelona. Fonte: capa do livro de Rubens Porto (1938).

A agenda da CIRPAC de Barcelona, assim como o Congresso Especial de Berlim de 1931, foram os preparativos para o futuro Congresso de Moscou. Durante o processo, foi anunciado que o convite oficial de Moscou tinha sido finalmente publicado em Março de 1932. Participaram das reuniões: Le Corbusier, Van Eesteren, Giedion, Gropius, Breuer, Bourgeois, Steiger, Gino Pollini (Milão) e Ernest Weissmann (Zagreb, lugoslávia). Os representantes espanhóis foram García Mercadal (Madrid) e Sert, Torres Clavé, Alzamora, Aizpúrua, Rodriguez-Arias, Perales, Subirana e Churruca do grupo GATCPAC (MUNFORD, 2000). Dois projetos foram apresentados na ocasião: o projeto de Weissmann para o Hospital ZIKBZ em Zagreb e o projeto de Le Corbusier para a 
competição do Palácio dos Soviéticos. A ata observou que os mapas de mesma escala e estatísticas baseadas em respostas de questionários estavam sendo preparadas para 28 cidades, de acordo com as normas elaboradas pelo grupo holandês.

Além de discussões sobre as apresentações para o próximo Congresso, durante a reunião do CIRPAC os esforços foram concentrados no sentido de apresentar as ideias do CIAM para os líderes políticos e o público em geral em Barcelona. Van Eesteren falou sobre o plano de Amsterdam em andamento para a Associação de Arquitetos da Catalunha; Le Corbusier apresentou uma palestra sobre urbanismo para funcionários do governo; Gropius se encontrou com clubes de elite sociais para falar sobre "Arquitectura funcional", e Giedion palestrou para a associação Ateneu Enciclopedic Popular sobre "A Revolução Ótica do Século XX”. Até 1934, entretanto, o plano Macià parecia estar à beira da execução, o que para Le Corbusier ajudaria a sublinhar sua importância no CIAM, uma vez que a URSS tornou-se cada vez mais inóspita a agenda da arquitetura Moderna. O cenário político e os eventos que se seguiram até a deflagração da Guerra Civil Espanhola, em 1936, mudaram o curso do planejamento urbano para Barcelona.

Apesar das tentativas do grupo CIAM da URSS - composto a essa altura também por Ernst May, Hans Schmidt, e Fred Forbat - em realizar o congresso sobre a Cidade Funcional em Moscou, e dos esforços pessoas de Le Corbusier, Giedion e Van Eesteren, o ambiente político da União Soviética com a ascensão de Stalin não possibilitou que tal evento ocorresse em território soviético.

O IV CIAM, cujas resoluções foram publicadas na Carta de Atenas, tentava abordar as questões urbanas que ficaram pendentes nos II e III congressos, analisando 33 cidades europeias e americanas. Mais uma vez, o discurso reinante gira em torno das ponderações de Le Corbusier sobre as questões urbanas, construídas ao longo de uma década. 


\subsubsection{O pioneirismo holandês}

É notório o fato de que a revolução industrial marcou um ponto de inversão na história da humanidade, desencadeando uma vertiginosa desarticulação e reestruturação social, concomitante ao desenvolvimento econômico.

Alguns autores, como Polanyi (2000), destacam que as cidades fabris; péssimas condições de moradia; trabalho infantil; longas jornadas de trabalho; baixos salários para o operariado; aumento da taxa populacional, especialmente a urbana; e a aglomeração industrial, em suma, tudo aquilo que se costumeiramente se observa com a Revolução Industrial, se tratava das incidências para uma mudança básica: o estabelecimento de uma economia de mercado em uma sociedade comercial, regida pela idéia de mercado auto regulável. Nessas condições, isso equivaleria a dirigir uma sociedade como um acessório de mercado, com as relações sociais embutidas no sistema econômico, e não o inverso.

Com a auto regulação, todos os componentes da indústria tinham uma definição de mercado, agregando bens e serviços, além de outros elementos essenciais: o trabalho, através do salário; a terra com aluguel, e o dinheiro, com os juros. Como esses elementos não poderiam ser considerados como mercadoria para o autor, pois não podem ser produzidos e reproduzidos para compra e venda, gerariam assim uma contradição.

A ficção do trabalho e da terra como mercadoria, nos termos de Polanyi (2000), com auto regulação do mercado, significaria a redenção da subsistência humana e de seu ambiente natural.

"Os mercados de trabalho, terra e dinheiro são sem dúvida, essenciais para uma economia de mercado. Entretanto, nenhuma sociedade suportaria os efeitos de tal grosseiras ficções, mesmo por um período de tempo muito curto, a menos que sua substância humana natural, assim como a sua organização de 
negócios, fosse protegida contra os assaltos desse moinho satânico". ${ }^{1}$

Segundo o novo contexto que a Revolução Industrial colocava, parecia evidente que a sociedade precisava se proteger, ou pelo menos, grande parte dela. A organização do trabalho era baseada em leis e decretos mal estruturados, que acabavam prejudicando ainda mais o trabalhador, como a Speenhanland Law ${ }^{2}$ (1795-1834), na Inglaterra. Apesar da assistência social promovida pelo Estado e pelas paróquias não ser algo estranho à época, sendo conhecida desde o século XVI na Inglaterra, por exemplo, ela não era capaz, pela sua própria essência, de enfrentar as condições terríveis de sobrevivência a que os trabalhadores eram submetidos. A organização moderna da classe trabalhadora era imprescindível para isso e teve início ainda na primeira metade do século XIX.

Após 1870, diversas medidas protecionistas conquistadas por classe e grupos de trabalhadores na Europa correspondiam em parte às necessidades de uma sociedade industrial, e se referiam à saúde, moradia, transporte, trabalho, etc.; dando início a uma nova realidade.

A era das máquinas, ou a primeira revolução industrial, promoveu a concentração da população nas áreas urbanas, que por sua vez, depois de décadas de sofrimento das classes mais pobres, passou a reivindicar novas posturas para a organização das cidades, necessárias à sua própria sobrevivência.

Em relação às condições de moradia, dado a impossibilidade do mercado privado de suprir a demanda por habitações acessíveis para a classe trabalhadora, a intervenção estatal iniciou-se em relação às legislações, subsídios e produção estatal ao lado da produção filantrópica, mas ainda de forma muito pontual e tímida.

\footnotetext{
1 POLANYI, Karl (2000). A grande transformação: As origens de nossa época. Rio de Janeiro: Campus, p.95.

2 Essa lei determinava que os trabalhadores recebessem auxílios financeiros estando ou não empregados. Essa legislação foi maléfica por dois aspectos: se por um lado os trabalhadores não tinham incentivos para trabalhar, pois eram assistidos de qualquer maneira, por outro, os patrões poderiam manter os salários em níveis escandalosamente baixos, pois os trabalhadores teriam seu padrão mínimo de sobrevivência mantido.
} 
$\mathrm{Na}$ Holanda, essas primeiras intervenções se deram principalmente devido às crises de cólera em meados do século XIX, que acometiam principalmente as regiões com habitações mais pobres, atrelando dessa forma a condição de moradia a uma questão de saúde pública.

Tem-se notícia de ações filantrópicas nos Países Baixos trabalhando a questão da moradia desde 1852. Em 1868, já existiam cooperativas operárias agindo conjuntamente com as administrações locais. Assim como em outros países, essas primeiras intervenções foram quantitativamente insuficientes face às dimensões do problema.

A partir de 1896, a prefeitura da cidade de Amsterdam implantou programas de doação de terrenos assim como de prestação de assistência técnica para a elaboração de projetos. Na verdade, os Países Baixos, dada a sua própria circunstância geológica, sempre apresentou singularidades institucionais no que diz respeito à gestão do território e dos recursos naturais de uma forma mais geral. Podemos citar, por exemplo, a gestão dos recursos hídricos, na qual a necessidade de construção e de manutenção de sistemas de diques e drenagens para a conquista de terras férteis e urbanizáveis engendrou a necessidade do desenvolvimento de formas associativas e relações públicoprivado diferenciadas e avançadas. Em relação ao desenvolvimento urbano, os altos investimentos necessários para tornar urbanizáveis áreas geologicamente impróprias induziu o desenvolvimento de um particular esquema institucional, segundo o qual os proprietários se organizavam em consórcios e se faziam desapropriar; o Estado executava os investimentos e retornava ao consórcio a terra beneficiada por um preço bem superior (SILVA, 2008). Segundo Tafuri (1985), a produção das cidades nesse país teve um caráter bem menos especulativo (relativo ao mercado de terras) que em outras localidades.

As primeiras legislações sobre habitações proletárias, ao lado de operações de saneamento urbano, diziam respeito ao arranjo interno das unidades e suas condições de salubridade em diversos países europeus. A produção, tanto por industriais como por sociedades filantrópicas eram quase insignificantes no quadro geral de carência de habitações "sãs" e da demanda pelo aumento da população urbana. Devido à visibilidade que a situação habitacional ganhou com as epidemias de cóleras, o assunto foi defendido no campo político, principalmente pelo Partido Liberal (Liberale Partij), pelo Sindicato Geral de Trabalhadores Holandeses (Algemeen Nederlands 
Werklieden Verbond), socialista, e pelo Patrimoniumo, sindicato dos trabahadores cirstãos-protestantes. Os sindicatos holandeses não eram conhecidos como organizações revolucionárias; tinham o própósito, segunfo Noud de Vreeze (2007) de trabalhar em prol da classe trabalhadora dentro das condições sociais contemporâneas.

O Ato Habitacional (Woningwet), elaborado em 1901, na Holanda, foi a primeira legislação no sentido de regulamentar e incentivar a produção de habitação atrelada à planejamentos municipais, sendo um marco para a gestão, planejamento e produção habitacional e da cidade na história ocidental. Segundo Stieber (2000, p.22), as propostas para o Ato Habitacional, ou Lei de Habitação, fizeram parte de um movimento da sociedade no sentido da intervenção e controle estatal de toda a infraestrutura urbana. Entre os anos de 1888 e 1895, grupos progressistas do conselho municipal de Amsterdam conseguiram que a municipalidade assumisse o controle dos sistemas de gás, água, telefonia e concessões de bondes. Assim, quando o Partido Social Democrata ganhara força nas esferas municipais, o terreno para uma verdadeira reforma habitacional estava preparado.

As bases para a construção da Lei de Habitação foram traçadas segundo dois estudos sobre a situação habitacional na Holanda. Em 1887, a Sociedade Para o Bem-Estar Geral (Maatschappij tot nut van 't algemeen) realizou uma pesquisa sobre as condições da habitação da classe trabalhadora; este documento seria mais um diagnóstico da situação no país. A mesma comissão realizou outro estudo em 1894, cujos resultados foram publicados no documento "A Questão da Habitação Social" (Het vraagstuk der Volkshuisvesting), o qual recomendava o empréstimo de capital a juros baixos para as associações de interesse público; o estabelecimento de regulamentações para as edificações; e o uso da legislação para expropriação de terras para facilitar a extinção dos cortiços. Segundo Grinberg (1982), essas propostas tiveram como base outros estudos realizados na Holanda e a lei inglesa "The Housing of the Working Classes Act", de 1890.

O Ato Habitacional não tem precedentes legais na história dos Países Baixos em escala nacional, mas em nível municipal existe um extenso desenvolvimento de regulamentações, endereçadas, contudo, às características físicas da construção, e não à natureza da sua produção. Essa era uma 
consequência do laissez-faire que tendia a manter as municipalidades relutantes em interferir no mercado privado.

A lei nacional aprovada pela coroa em $1902^{3}$, atribuiu às administrações locais o direito, dever e meios financeiros para o estabelecimento de planos de extensão, para desapropriar imóveis considerados insalubres pelo urbanismo sanitarista, adquirir áreas e para construir diretamente ou para oferecer empréstimos para cooperativas ou sociedades de promoção de moradias populares.

Antes da Lei de Habitação muitas autoridades locais tinham tratado a questão da habitação. Os municípios foram capazes de fazê-lo de acordo com o estado geral de poderes legislativos, que eram de um caráter mais extenso que os das autoridades locais Inglesas à época ${ }^{4}$.

Sob a Lei de Governo Local, presente na Lei de Habitação, as autoridades municipais estavam autorizadas a aprovar regulamentos em nome da ordem pública, dos bons costumes e da saúde, além de outros regulamentos relativos à gestão da comunidade ${ }^{5}$. Em linhas gerais, isso significava que os municípios tinham poder para lidar com todas as questões que não estavam especialmente reservadas ao poder legislativo do Parlamento.

Esta situação não foi alterada pela Lei de Habitação (Woningwet). As autoridades locais eram, com algumas exceções, capazes de tomar tais medidas, em nome da melhoria da habitação que julgassem convenientes, independentemente da Lei de Habitação. Assim, por exemplo, os municípios podiam comprar e vender terras, construir casas, emprestar dinheiro a construtoras privadas ou sociedades de utilidade pública de habitação da mesma forma como poderiam ter feito (e fizeram) antes da aprovação da Lei de Habitação.

O principal significado da Lei pode ser visto nos seguintes itens:

\footnotetext{
${ }^{3}$ Em 1901 a Lei foi aprovada pelas Segunda e Primeira Câmaras; em 1902 foi aprovada pela coroa.

${ }^{4}$ A Lei de Governo Local holandesa (Local Goverment Act ) não faz uma distinção entre bairros, distritos urbanos e rurais, etc., estando todos na mesma situação jurídica. No tocante a palavra "município", é entendida como abrangendo todos eles.

5 Fonte: Nederlands Instituut voor Volkshuisvesting (1920?). Dutch Housing Legislation. Printed by Drukkerij en Uitgevérij J. H. de BUSSY, AMSTERDAM.
} 
"1. Ela obrigava as autoridades locais a tomar algumas medidas que antes eram somente opcionais;

2. A nova lei conferia alguns novos poderes municipais;

3. Algumas medidas tomadas pelas autoridades locais estariam sujeitas à aprovação do Governo Provincial (Conselho Municipal),

4. O auxílio financeiro para fins de moradia poderia ser concedido pelo Estado. "6

O Woningwet tratava a questão da habitação em seu sentido amplo, somente deixando de incluir alguns itens (modificações de habitações, inspeções dos sítios das habitações).

A primeira parte da lei tornava um dever das autoridades locais expedirem leis municipais sobre construções que dispusessem sobre:

“1. A implantação dos edifícios em relação às vias públicas e a distância entre eles;

2. O nível dos pisos dos ambientes debaixo da escada e da altura dos edifícios;

3. Os tamanhos mínimos de cômodos habitáveis, escadarias e passagens;

4. Os Armários;

5. O abastecimento de água;

6. A prevenção de incêndios;

7. A prevenção da umidade;

8. A estrutura de fundações, paredes, pisos, tetos e telhados;

9. A remoção de fumaça, águas pluviais, lixo e esgoto;

10. Iluminação e ventilação. "7

6 Idem, p.04

7 Idem, p.05 
Esta enumeração não tinha caráter restritivo, as autoridades locais podiam aprovar novas leis, de acordo com suas competências gerais, relativas a outras questões em matéria de construção, e incluí-las nas leis municipais de construções.

Considerando que os referidos regulamentos lidavam com edifícios a serem construídos, as provisões para as habitações existentes deviam ser dadas em relação às matérias referidas nos números de 05 a $10^{8}$.

O Woningwet previa que As Leis Municipais de Construções estavam sujeitas à aprovação do Governo Provincial; se no prazo de três anos após a aprovação do Ato, as autoridades locais não têm tivessem aprovado leis municipais sobre construções, o Governo Provincial deveria fazê-lo.

Em cerca de um quarto de todos os municípios isto se revelou necessário. Para construir ou reformar um prédio, uma autorização devia ser obtida à partir da autarquia local. A autorização só podia ser recusada se as instalações não estivessem em conformidade com as leis municipais. Planos de construção deviam ser submetidos à aprovação da autoridade local antes do início da obra. Nenhuma casa nova ou edifício podiam ser ocupados até um certificado de aptidão para ocupação ser dada pela mesma autoridade.

A segunda parte da Lei era uma tentativa de lidar com a superlotação, pois impunha aos proprietários o dever de notificar à autoridade local o número de ocupantes da casa e as eventuais mudanças nesse número.

Esta parte foi rapidamente revogada e substituída por um artigo afirmando o dever das autoridades locais em estabelecer uma "troca de moradias", ou seja, providenciar habitações novas.

A terceira parte da Lei incidia sobre as melhorias das habitações. Comitês de Saúde tinham que fazer avaliações nas habitações nos municípios de sua área e notificar as autoridades locais sobre as suas condições, se estavam aptas para a habitação humana ou não, se precisavam de melhorias ou se estavam superlotadas. Se fossem encontrados indícios que indicavam a necessidade de reparos, uma notificação era enviada ao proprietário para executar todos os trabalhos necessários, e se superlotadas, para impedir a superlotação; o proprietário tinha o direito de enviar um recurso para o Conselho

8 Idem, p.05. 
da Cidade. Em caso de não cumprimento da notificação, uma penalidade podia ser imposta pela bancada do conselho; as autoridades locais podiam executar as obras necessárias ou declarar as instalações impróprias para a habitação humana e emitir uma ordem proibindo a uso da casa como tal.

A emissão das ordens de proibição do uso de uma casa para a habitação humana foi tratada na quarta parte da Lei. Os pedidos podiam ser emitidos pela Câmara Municipal, quer no caso mencionado acima, ou se uma casa fosse considerada imprópria para habitação humana e não pudesse voltar a ser apta mesmo com a realização de reparos. O proprietário tinha o direito de apelar contra a ordem ao Governo Provincial.

A ordem especificava um prazo, não superior a seis meses, no qual a casa deveria ser desocupa por seus ocupantes, sendo permitido o uso como uma oficina, loja, etc. Uma placa era afixada em cada casa declarada imprópria para a habitação humana. Se necessário, as autoridades locais podiam emitir uma ordem de fechamento e, em caso de perigo, demolir a habitação.

Em conformidade com as partes acima mencionadas da Lei Habitacional, cada município do país deveria ter as suas próprias Leis Municipais de Construções, a fim de garantir boas construções que ofereciam um nível de requisitos mínimos, os quais as casas existentes também deviam respeitar. Ao mesmo tempo, o caminho para lidar com instalações consideradas ruins era previsto no Woningwet ${ }^{9}$.

Segundo o documento editado em 1920 pelo Nederlands Instituut voor Volkshuisvesting, (Instituto Holandês para o Desenvolvimento Habitacional), em todo o país, tanto nas cidades, como nas zonas rurais, as piores casas desapareceram e muitas foram melhoradas, mas o estudo não oferece estatísticas sobre os casos de demolição, melhorias realizadas pelos proprietários ou pelo município. O documento indica ainda que áreas de grande extensão devessem ser demolidas devido ao excesso de habitações e construções malsãs. Coloca ainda que nos distritos rurais o padrão de habitação deveria ser elevado.

Desde que o Woningwet tornou-se lei, até o final de 1914, 12.918 casas foram condenadas como impróprias para a habitação humana, dos quais 3.739

9 Nos casos em que um regulamento era estipulado pela Woningwet, o mesmo prevalecia sobre a competência geral das autoridades locais. 
em Amsterdam, 180 em Roterdã, e 586 em Haia. Desde a guerra não havia tido praticamente nenhum aumento nesses números.

No que diz respeito à melhoria das habitações, uma boa parte do trabalho, especialmente nas zonas rurais, era feito pelas Comissões de Saúde. Essas comissões foram instituídas em todo o país, sendo que cada cidade com mais de 20.000 habitantes tinha a sua própria comissão. Seus membros, nomeados pelo Governo Provincial, não eram remunerados, com exceção do Secretário. As Comissões de Saúde deviam ser consultadas pelas autoridades locais, sempre que medidas em matéria de habitação fossem ser tomadas.

Durante os primeiros anos após a aprovação do Woningwet, foram feitas investigações aprofundadas sobre as condições de habitação em cada área, que serviram de base para medidas destinadas a melhorar ou remover habitações impróprias. Nos anos posteriores, as Comissões agiram sobre as queixas, na maioria dos casos, fazendo inspeções e propondo reparos ou emitindo ordens de fechamento. Embora fossem dificultadas pelo fato de que seu trabalho não era remunerado (em alguns casos excepcionais, apenas um funcionário assalariado estava a sua disposição), nos distritos rurais, sem sua interferência pouco teria sido feito.

Via de regra, a inspeção da habitação nestes distritos rurais não era costumeira. Mesmo a inspeção das habitações muitas vezes foi muito mal gerida, tendo um carpinteiro local agindo como inspetor, faltando habilidade técnica para tal. Além disso, muitas autoridades locais das zonas rurais, tendo sido forçadas a aprovar regulamentos aos quais não davam muita importância, não estavam preocupadas com a sua aplicação, e muitas casas foram construídas com total desprezo pelos regulamentos de construção. Somente em alguns casos excepcionais, as Comissões de Saúde fizeram um acordo pelo qual o funcionário assalariado a seu serviço, não só agia como um inspetor de habitações, mas também como um inspetor de obras para os municípios em sua área.

Nas cidades de maior importância, a supervisão de habitação e construção estava nas mãos do Departamento de Obras Públicas, que em cidades maiores possuía um Departamento de Inspeção de Habitações e Construções; em Amsterdam, Roterdã, Haia e Schiedam existia também um Departamento de Habitação. Nesses casos, as ordens para melhoria e de 
fechamento eram, em regra, preparados pelos funcionários dos departamentos e as Comissões de Saúde seriam acionadas somente para conselhos.

Um projeto de lei foi apresentado ao Parlamento na prima década do século $X X$ tornando obrigatória a nomeação dos inspetores de construções e de habitação por parte das autoridades locais de tal forma que os municípios de menor importância teriam de agir conjuntamente.

Segundo o documento do Instituto Holandês para o Desenvolvimento Habitacional (1920?), até a o final da primeira guerra a melhoria das habitações praticamente havia chegado ao fim. A falta de habitações cresceu rapidamente, e por isso nenhuma habitação poderia ser desperdiçada. Assim, as autoridades locais não emitiam ordens de fechamento. Mesmo as notificações para reparos e melhorias dificilmente poderiam ser enviadas, pois os preços dos materiais de construção aumentavam constantemente e muitos materiais se tornaram escassos.

A quinta parte da Lei Habitacional de 1902 tratava da desapropriação de terras pelos municípios e pelas sociedades de utilização de habitação pública (sociedades e cooperativas), primeiro com a finalidade de remoção das slums e segundo para a realização de um conjunto de habitações ou de um plano de extensão para os já existentes. Essa parte do Woningwet, na avaliação do Instituto Holandês, era de menor importância, pois apenas dava extensão à Lei de 1851, relativa a Aquisição Compulsória de Terras. Algumas partes foram alteradas do texto original a fim de facilitar o uso da lei para fins de habitação, e foram criados mecanismos para dar uma regulação satisfatória para a fixação da indenização a ser paga pelas casas e terrenos, se estes não pudessem ser comprados por um acordo voluntário.

No caso de remoção de favelas, a remuneração era baseada no valor do terreno e nos materiais de construção; se as casas a serem demolidas necessitavam de reparos, os custos deveriam ser deduzidos do valor a ser indenizado. Em outros casos, o preço justo de mercado dos terrenos seria obtido pelo valor de venda de todas as habitações do local no período de 18-06 meses antes da elaboração do plano.

Em alguns casos, o Woningwet foi utilizado para a remoção de favelas. Contudo, era usado mais frequentemente para a aquisição de terrenos incluídos em um planejamento urbano municipal; por exemplo, em Amsterdam, onde 
todas as terras incluídas no plano de Berlage ${ }^{10}$ para o plano de expansão "Amsterdam Sul" foram adquiridas pelo município, quer por acordos voluntários ou por via do Ato Habitacional.

Um dos Atos Emergenciais previstos na lei principal se referia diretamente à desapropriação das terras, uma vez que autorizava as autoridades locais a entrar e tomar posse de terras antes da compensação ser fixada.

A sexta parte do Woningwet regulamentava o Planejamento Urbano. Duas seções tratavam do assunto. A primeira atribuía poderes à autoridade local de proibir a construção em locais onde, de acordo com uma ordem da Câmara Municipal, uma rua deveria ser construída. A ordem estava sujeita à aprovação do Governo Provincial, que poderia rejeitá-la se a propriedade fosse afetada negativamente pela mesma. A segunda seção tinha como objetivo o mesmo fim de algumas outras partes da Lei, qual seja, forçar as autoridades locais a cumprir o que eles já tinham poder para fazer, e submeter algumas medidas à aprovação do Governo Provincial. Esta seção obrigava os municípios com mais de 10.000 habitantes, ou cuja população tivesse aumentado mais de um quinto nos últimos cinco anos, a fazer um plano de expansão. O plano devia ser revisto a cada dez anos pelo menos, e a aprovação do Governo Provincial era obrigatória.

Antes da aprovação dos planos, os mapas seriam expostos para inspeção pública, para que os proprietários de terrenos incluídos no plano que se sentissem prejudicados tivessem a oportunidade de se opor.

Um plano de expansão, tal como especificado pelo Ato Habitacional, seria um conjunto de diretrizes de construção sintetizado num mapa ou não, as quais a Câmara Municipal deveria considerar e desenvolver na extensão do município. Também dependia dos proprietários dos terrenos incluídos no plano se o que foi planejado seria realmente realizado. Mas, a observação ao plano podia ser imposta aos proprietários por uma disposição introduzida em quase todas as leis municipais, que as autorizava a proibirem quaisquer construções, a não ser nos casos das ruas que já existiam antes da lei municipal ser aprovada.

Esta disposição permitia às autoridades locais forçar todos os proprietários a observar o plano quando fora planejado construir em suas terras, porque o consentimento para a abertura de novas ruas só podia ser dado se

10 Berlage realizou importantes planos de expansão também para Haia e Utrecht devido ao Ato Habitacional. Segundo Grinberg (1982), a necessidade desses planos significou uma modificação profunda na escala de trabalho dos arquitetos, e deu à questão habitacional um papel fundamental na construção das cidades. 
elas fossem projetadas em conformidade com o mesmo. Nos distritos rurais, entretanto, tal consentimento era dado muitas vezes sem a observância do plano. ${ }^{11}$ Caso o Conselho Provincial autorizasse construção próximas a estradas ou parques planejados, o impedimento da construção só poderia ser conseguido pelas autoridades locais através de acordo voluntário ou desapropriações.

Como não havia obrigação para os proprietários dos terrenos para a realização das obras, tais como previstas no plano, a realização de ações só podia ser garantida por acordos especiais entre a autarquia e o proprietário. Se, por exemplo, um parque fosse projetado no plano de extensão, os locais necessários tinham de ser comprados e o parque construído pela autoridade local.

Em relação às cidades pequenas, não havia razão para muitos conflitos entre município e proprietários, pois existia um grande estoque de terras dentro e fora dos planos de expansão, e o crescimento moderado não exigia desapropriações imediatas. Em cidades maiores ou em com crescimento rápido, no entanto, onde havia uma premente falta de áreas para construção, a única maneira pela qual uma execução efetiva do plano pudesse ser garantida, seria pela posse de todos os terrenos incluídos no planejamento municipal. As grandes cidades holandesas tinham, seja por acordo voluntário ou por desapropriações, se tornado proprietárias de vastas áreas de terra ${ }^{12}$, que outrora foram vendidas aos construtores, mas agora na maioria dos casos, eram arrendadas.

De qualquer maneira, apesar das autoridades locais possuírem mecanismos para implementarem seus planos de extensão, as questões relacionadas ao desenho das edificações, bairros, espaços públicos locais e gerais passaram a fazer parte do processo de estudo e tomada de decisões dentro da administração e da política local.

As duas partes seguintes da Lei Habitacional, Partes VII e VIII, que regulamentavam os subsídios estatais à habitação, revelaram-se de grande importância no primeiro pós-guerra uma vez que permitiram as sociedades de

11 Fonte: Dutch Housing Legislation (1920?). p.09

12 Haia, em 1920, possuía uma área de 962 ha (2405 acres), dos quais 12 ha (30 acres) foram arrendados para sociedades de utilidade pública de habitação. Em Amsterdam 148 ha (370 acres) foram destinados para construções habitacionais. Fonte: Dutch Housing Legislation (1920?), p.11 
utilidade pública de habitação e as autoridades locais a construírem habitações baratas, não obstante o aumento dos preços de materiais e aumento da taxa de juros.

Segundo o documento do Instituto Holandês analisado, os auxílios estatais à habitação já eram adotados em outros países europeus de maneiras diferentes. A legislação belga, adotada pelos franceses, incentivava a construção de casas por pessoas físicas, para as quais algumas instituições públicas estavam autorizados à emprestar uma parte dos seus fundos. Tornaram-se necessários um intrincado sistema de sociedades que tinham de agir como intermediários, em parte para ter o controle sobre o devido uso do dinheiro pela pessoa a quem é emprestado, e em parte para diminuir o risco para as instituições públicas. $\mathrm{Na}$ Alemanha e na Áustria algumas instituições públicas também emprestavam dinheiro para as sociedades, não, porém, para repassá-lo à indivíduos isoladamente, mas a fim de permitir que essas sociedades construíssem moradias, para aluguel ou venda.

De acordo com a regulamentação holandesa, o próprio Estado concedia empréstimos, um recurso que regulamentos Holandeses e Ingleses tinham em comum. $\mathrm{O}$ empréstimo era concedido apenas às autoridades locais, jamais às associações de construção, às sociedades de habitação de utilidade pública ou diretamente aos indivíduos. Na maioria dos casos, as autoridades locais não construíam, mas concediam empréstimos a sociedades públicas de utilização de habitação que os requisitavam. As autoridades locais, em seguida, requisitavam ao Estado, que então concedia o empréstimo. Esse sistema oferecia a oportunidade de um controle mais eficiente sobre as sociedades pelas autoridades locais do que poderia ser exercida por um departamento apenas que centralizaria essas funções. O dinheiro era concedido através de hipotecas, reembolsáveis em cinquenta anos ${ }^{13}$ em frações anuais iguais, sendo os juros fixados à taxa indicada pela cotação de mercado das debêntures do Estado na Bolsa de Amsterdam. As autoridades locais eram responsáveis pelo pagamento dos juros e das parcelas do empréstimo, de modo que não havia risco financeiro para o Estado. O Governo poderia conceder 100 por cento do custo total da obra, e as autoridades locais, ao conceder o empréstimo, podiam impor

13 Desde 1915, esse período podia ser de 75 anos. Como regra, 50 anos era o período em que os empréstimos para fins de construção são concedidos, e 75 anos era o prazo para a compra de terra. 
condições que julgassem convenientes sobre a sociedade, para assegurar uma gestão eficaz, adequada reparação, etc. Às vezes era solicitado como requisito uma pequena quantidade de capital privado, formando uma parte variável do custo do terreno e da construção (raramente superior a cinco por cento). A situação mais frequente era a de que a sociedade ou cooperativa possuía um pequeno capital, como o capital social dos membros, que não tinha relação alguma com o custo de construção das habitações. Apenas algumas sociedades maiores nas cidades mais importantes tinham uma maior concentração de capital à sua disposição.

As sociedades de serviços públicos tinham um caráter semi-público e deviam ser autorizados pelo governo. Os juros sobre suas ações eram limitados a quatro por cento; o capital e o lucro só deveriam ser aplicados no melhoramento das habitações; e aos membros não podia ser dado o direito de comprar suas casas. Mais de 1300 sociedades de utilidade foram autorizadas até 1922. Cerca de 250 foram organizadas no Nationals Woningraad (Conselho Nacional de Habitação), que seria uma federação exclusiva das sociedades de habitação de utilidade pública e de autoridades locais de construção.

Além dos empréstimos, subsídios anuais podiam ser concedidos nos casos de remoção de favelas, ou se os habitantes fossem muito pobres. $O$ subsídio era concedido para as taxas do empréstimo, incluindo juros e os pagamentos das parcelas do empréstimo do capital emprestado. Como regra, metade do subsídio deveria ser pago por fundos das autoridades locais, a outra metade seria paga pelo Estado.

Até o final de 1.914, 461 empréstimos foram concedidos, 371 em nome de sociedades de utilidade pública, 90 em nome das autoridades locais de construção; 9.900 casas foram construídas e, no total, haviam sido aprovados empréstimos para a construção de 16.251 casas $^{14}$.

As organizações que contribuíram para a chegada da Lei de Habitação usaram amplamente essas novas possibilidades para construção de moradia. Entretanto, demorou até 1915 para as possibilidades que a Lei de Habitação oferecia pudessem ser desenvolvidas de forma eficaz por parte do Governo Central. À partir deste ano, que coincide com o aumento do preço dos materias pelas dificuldades que a guerra acarretava, o Governo Central forneceu

14 Dutch Housing Legislation (1920?), p.15 
contribuições substanciais para a construção de habitação social. Em Amsterdam já tinham começado as principais mudanças políticas, incluindo aquelas que levaram à fundação do Conselho Municipal de Habitação (Gemeentelijk Woningdienst) e a empresa municipal territorial, encarregada de fazer possível a execução de planos de expansão através de uma política ativa de municipalização do solo.Todo este sistema serviu, entre 1920 e 1930, de base para o desenvolvimento profissional (arquitetos, urbanistas, engenheiros) de forte conotação social no seio destas organizações: departamentos municipais para controle e desenvolvimento da construção e da habitação (Bouw-en woningtoezicht); departamento de urbanismo; empresas de habitação, seus líderes e as organizações nacionais (Vreeze, 2007).

Desde o início da guerra a iniciativa privada esteve praticamente fora da provisão habitacional, acarretando que as habitações da classe trabalhadora só eram construídas por sociedades de utilidade pública (cooperativas e associações) e algumas autoridades locais. O déficit habitacional crescia a cada dia e pelo menos 100 mil unidades eram necessárias. Em Amsterdam e Roterdã, cerca de metade das pessoas recém-casadas não conseguiam encontrar moradia, e para suprir a demanda, deveriam ser construídas 250 mil unidades até 1920 , segundo esse documento.

As administrações locais holandesas foram de fato capazes de produzir um significativo número de unidades habiacionais, no período entre guerras, para os diversos setores da sociedade. Amsterdam, entre 1920 e 1940, através da Lei de Habitação, construiu cerca de 80.000 unidades habitacionais que se somaram às 140.000 existente nas primeiras décadas daquele século. Apesar dessa produção ser conhecida à época pela dramaticidade, às vezes extravagância dos tijolos coloridos da Escola de Amsterdam - o que a afastou dos princípios da vanguarda moderna dos CIAM's - a política habitacional local foi capaz de produzir e equacionar o problema habitacional entre as duas guerras, e instituir uma cultura de projeto arquitetônico e urbanístico, com a participação dos setores envolvidos na produção da cidade. Ao lado da aura fantástica do expressionismo holandês, exisitiram em paralelo, pesquisas sobre o subúrbio-jardim e construções habitacionais em concreto, demonstrando o comprometimento da cidade em achar soluções para o desenvolvimento urbano e provisão habitacional. Amsterdam era um verdadeiro laboratório de experimentação em habitação. 
Berlage, segundo Grinberg (1982) e Stieber (2000), foi uma engrenagem fundamental nesse processo de desenvolvimento da produção habitacional na Holanda, pois acreditava, como viria a acontecer com os arquitetos do Nieuwe Zakelijkheid (Nova Objetividade), que a habitação proletária poderia simbolizar valores culturais - no caso dos arquitos da Nova Objetividade, esses valores seriam universais, e não locais, como na Escola de Amsterdam. A vanguarda moderna, alguns anos depois, viria a acreditar que a habitação poderia de fato mudar a sociedade, e não apenas simbolizá-la. Seu famoso Plano para Amsterdam Sul serviu, até meados de 1930, de base para a construção de 12.000 moradias. Largas avenidas situadas de leste a oeste formam a estrutura principal de uma rede hierarquizada de ruas e bairros sutilmente construída, no qual o bloco fechado formava, por assim dizer, a pedra fundamental sobre a qual toda a estrutra foi montada. A volumetria do conjunto foi finalizada com as edificações plasticamente trabalhadas, em volumetria e fachada, com a sensibilidade de Michel de Klerk.

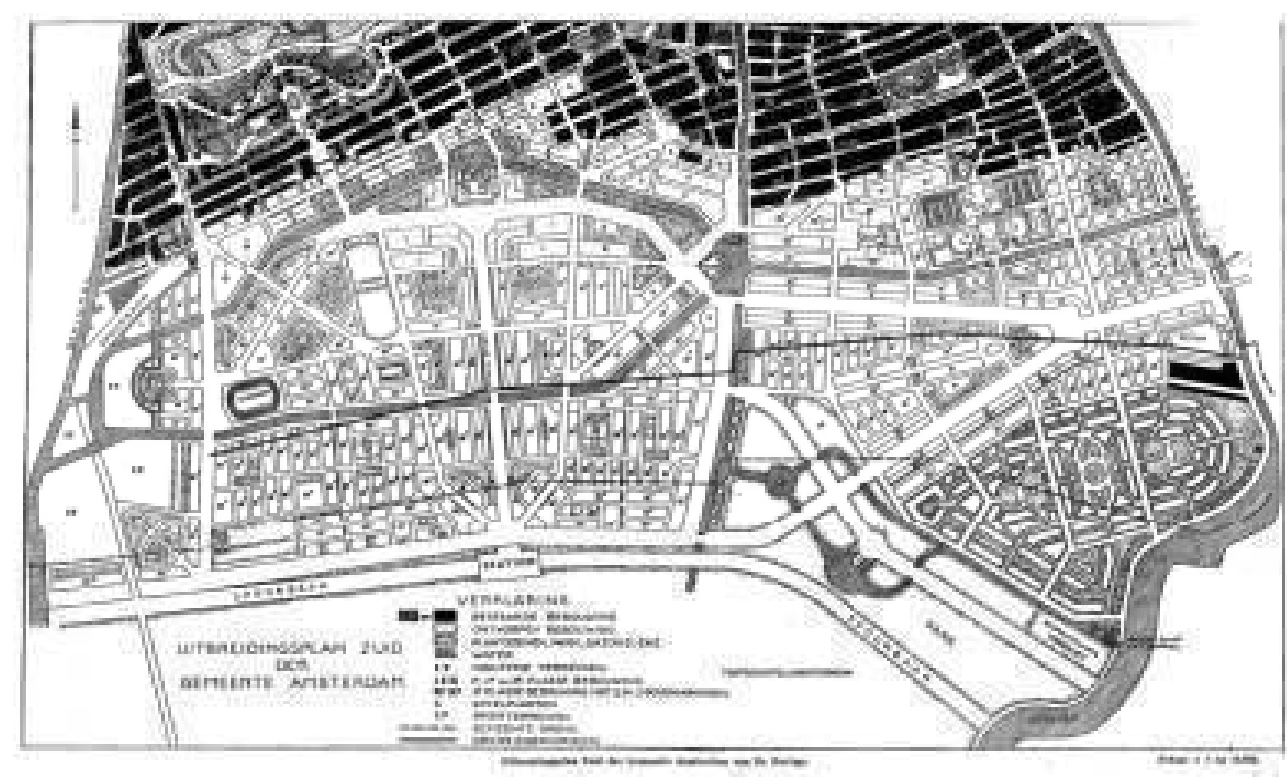

Figura 19. Plano Amsterdam Sul, H. Berlage. 1915. Fonte: PANERAI, 2004.

A "Cidade-Jardim" Vreewijk (1913-1919; 1933) foi a primeira iniciativa de subúrbio-jardim autossustentável nos arredores de Roterdã. Contudo, no ano de 1921, esse complexo foi incorporado ao Plano de Expansão de Roterdã por Granpé Molière, arquiteto responsável pela extensão da cidade. 
O projeto inicial de Berlage era menos geometrizante que a incorporação do subúrbio ao plano de extensão de Molière, que acabou adotando a direção norte-sul para as fileiras de casas a fim de conseguir melhor desempenho econômico de ocupação do terreno e de conforto. Longe de ser uma aplicação das idéias sociais de Howard, Vreewijk reflete a diluição dos princípios da cidade-jardim, que na Holanda e, em diversas outras localidades, significou simplesmente a idéia de casas unifamiliares em contato com a "natureza".

Berlage foi mais que um simpatizante dos princípios de cidade-jardim, adotando parte de um projeto vencedor de um concurso em 1915 para seu plano de Amsterdam Sul. Ele acreditava que através da difusão dos princípios de Howard, um mínimo de áreas verdes poderia ser incorporado no espaço urbano. Outro defensor desses princípios na Holanda foi Keppler, amigo de Barry Parker, que possibilitou a construção de quatro subúrbios-jardins em Amsterdam Blauwe Zand, Nieuwendam, Oostzaan e Watergraafsmeer (Betondorp) (Grinberg, 1982, p.63).

A preferência holandesa pelas habitações "baixas" foi um dos fatores que permitiu a influência do movimento cidade-jardim. Ao lado do conceito de "planejamento aberto", a idéia de cada família ter uma pequena área exterior particular, o contato da habitação direto com a natureza e o novo reconhecimento da habitação com áreas coletivas estavam presentes na cidadejardim. No Holanda, a grande escala de intervenção para esses subúrbiosjardins levou as comissões de habitação a pensarem em protótipos e produção seriada para viabilizar a construção em larga escala, tendo em consideração o tempo de obra e barateamento pela racionalização. Essa combinação é bastante evidente no projeto para Betondorp (1922-1924), para o qual foram testados diversos sistemas construtivos em concreto armado - blocos de concreto; painéis de aglomerado de concreto; painéis de concreto pré-moldados in loco; planos de fachadas inteiras moldadas in loco; paredes internas com todas as instalações embutidas; etc. Segundo entrevista com morador do conjunto, os maiores problemas enfrentados nas construções foram em relação ao combate à umidade nas juntas de dilatação e calefação das unidades.

A tendência a criação de espaços abertos na Holanda tem raízes mais profundas que qualquer relação com o movimento de cidade-jardim. Apesar do Ato Habitacional não fazer menção a qualquer forma espacial, existiam exigências quanto às distâncias entre as edificações baseadas na idéia de que 
densidade e saúde pública estavam relacionadas. Em 1909, o Conselho Habitacional de Amsterdam (Amsterdam Woningraad) recomendava que os encontros dos blocos fechados não fossem construídos e dessem lugar a jardins públicos.

\begin{abstract}
"If the northern and southern of the building blocks (of course by designing, as much as possible with this orientation) were not built up or provide with through passages, then this inner courts would become accessible oases amidst the crowdedness of the big city for every pedestrian. The oases would have great significance both as 'city lungs' and as recreation places for children, old people, and adults after work."15
\end{abstract}

Berlage utiliza a noção de bloco aberto em um dos lados, em forma de "U”, no projeto para Transvaaltbuurt, 1919, para Amsterdam, numa referência explícita ao subúrbio-jardim de Hampstead, mas com menos comprometimento com a estética e ideologia da cidade-jardim, uma vez que as aberturas nas esquinas e entre as habitações eram apenas passagens entre elas, não revelando jardins internos amplos. A preocupação com o arranjo das esquinas de modo a criar espaços mais abertos foi tratado de outra forma no quarteirão de acesso à escola do complexo: os blocos foram desalinhados de modo a não formar o cruzamento tradicional. A lição aprendida com Unwin, segundo Grinberg (1982), foi a de que a manipulação do arranjo das habitações possibilitava a formação de espaços urbanos diferenciados.

A noção de jardins rodeados por edificações, conferindo a esses espaços um caráter mais doméstico, também é uma referência direta das idéias de Camillo Sitte, que esteve bastante presente na concepção urbanística de Berlage. O plano de Amsterdam Sul pode ser visto como uma síntese das diferentes referências do arquiteto à época - Brinkmann, Sitte, Unwin - com as

15 Amsterdams Woningraad (1909). Rapport over de Volkshuisvesting in de Nieuwe Stad te Amsterdam, p.41. in: Grinberg, 1982, p.67. 
ruas, blocos de habitação, edificações especiais destacando algumas áreas e modelos de cidade-jardim como as diretrizes gerais do plano. De maneira geral, o plano de extensão foi pensado como um todo autônomo, conectado com a cidade antiga através dos quarteirões do século XIX. Berlage, deliberadamente havia ignorado o plano ortogonal anterior de Kalf, a subdivisão rural, e o organizado os novos quarteirões como uma nova cidade, com sua estrutura bem definida pelas ruas largas, procurando uma ordem visual similar à dos canais do século XVII (PANERAI, 2004).

Stieber (1998) faz uma análise sobre a cidade de Amsterdam bastante interessante sob o três aspectos de modernidade que foram responsáveis por catalisar as ações filantrópicas de habitação em uma ação de "welfare" na cidade, e no território holandês como um todo: a intervenção pública na questão, participando inclusive da discussão pública quanto ao estabelecimento de critérios estéticos, higiênicos e Standards sobre habitação; novos campos profissionais; e o aumento da representação política das massas. Procura demonstrar a construção do processo de regulamentação da profissão de arquitetura na Holanda e a intervenção estatal até mesmo nos critérios estéticos das operações urbanas e das edificações em si. As lideranças políticas, de ambas as tendências, determinadas a apagar a produção privada do século XIX de baixa qualidade, e retomar os tempos áureos do século $\mathrm{XVII}{ }^{16}$, criaram comissões para analisar os projetos, urbanísticos e arquitetônicos, submetidos ao Escritório de Inspeção de Habitação e de Construção. A formação de uma Comisaão Estética na cidade de Amsterdam, para avaliar os projetos, com o intuito de resgatar e garantir a beleza da cidade, levou a uma interessante discussão sobre atribuições profissionais e deflagrou as tensões entre grupos de arquitetos com diferentes tendências. Contra o historicismo reinante na prática arquitetônica no século XIX, a discussão tentava apontar quais os caminhos da arquitetura no novo seculo, tendo Berlage e a Escola de Amsterdam como as figuras mais expoentes nessa arena de interesses.

A adoção de planos urbanísticos com volumes de massas definidos, como nos planos de Berlage, levou a uma desarticulação no processo de projeto entre implantação e desenvolvimento das edificações, que seriam feitas a

16 Período da expansão da cidade e abertura dos três canais principais, Herengracht (Canal dos Lordes), Keizersgracht (Canal dos Imperadores), Prinsengracht (Canal dos Prínipes). 
posteriori (umas das razões pelas quais se extendeu a análise da Comissõa Estética para as fachadas das edificações, e não apenas dos planos urbanísticos). Além disso, a planta baixa das habitações e a implantação eram vistas como questão técnica de diversas áreas, como higisnistas, engenheiros sanitaristas, médicos, etc., muitas vezes estabelecidas pelas próprias sociedades públicas de construção de habitação, ao passo que a fachada era uma questão exclusiva da arquitetura. A Escola de Amsterdam era taxada pelos modernistas como simples "arquitetura de fachada", pois muitas vezes se envolvia mais com a fachada frontal das edificações, porque era frequente os outros critérios de habitação já estarem resolvidos. Contudo, Stieber (2000) demonstra que essa era uma questão social mais profunda que envolvia todos os agentes da produção de habitação naquele momento. Apesar desse conflito entre planta e fahcda, a questão habitacional mais uma vez esteve sob as luzes dos refletores, pois o entendimento geral era o de que a escala e a visibilidade dessa intervenção era impactante demais no tecido urbano, por isso deveria estar a cargo dos melhores arquitetos de Amsterdam, como de fato aconteceu à partir de 1915 (ano em que Berlage apresentou sua segunda versão, então definitiva, para o plano de Amsterdam Sul).

Outras importantes experiências habitacionais holandesas que contribuíram para uma nova cultura de reformas habitacionais no mundo aconteceram na cidade de Roterdã.

Brikmann projetou o emblemático conjunto Spangen (1919-1921), no qual a tradição dos quarteirões fechados com edificações nos perímetros recebeu diversos pontos de penetração; uma grande área de jardins; circulações internas, e uma inversão do bloco em relação à rua. Os acessos para as unidades eram feitos por galerias de circulações externas aos blocos e internas à quadra, funcionando como verdadeiras ruas aéreas. Embora não abordado pela historiografia especializada sob esse aspecto, consideramos que outra importante inovação na articulação desse conjunto sejam os blocos implantados no meio do complexo, perpendiculares à rua e articulados com as áreas comuns. Esses blocos são acessíveis apenas pelas áreas comuns no meio da quadra, preconizando assim o agenciamento de edificações descoladas do alinhamento da rua, como posteriormente seria tão debatido por Le Corbusier e outros mestres da Arquitetura Moderna - tal como definida e difundida pelos CIAM's. 
Outra abordagem da questão habitacional se deu nos projetos realizados por J. P. Oud, um dos expoentes do movimento De Stijl até 1921. Em muitos aspectos suas idéias se assemelhavam com alguns princípios de Berlage, como por exemplo, construção em massa de habitação como principal elemento componente da construção das cidades. Em artigo publicado em 1918, Oud tenta demonstrar como as noções do neoplasticismo ${ }^{17}$ se encaixavam com a estandardização proposta pelo diretor do Escritório de Inspeção de Construção e Habitação de Amsterdam, Jan van der Waeder. Nesse mesmo ano, Weader havia realizado a Convenção Nacional do Conselho de Habitação em Amsterdam, e proposto estandardização em escala nacional como solução para o problema da crise de moradia no primeiro pós-guerra. Como aponta Stieber (2000, p. 192), muitos arquitetos e associações públicas de construção foram contra a noção de standard por questões estéticas; a monotonia das construções iguais, sem a possibilidade de regionalismo ou expressões individuais, era algo negativo para os arquitetos em Amsterdam à época. Surpreendentemente, Berlage foi um dos defensores da idéia de produção estandardizada por não concordar com idéia de que esse fosse um entrave para a liberdade de expressão dos arquitetos. Berlage, ligado ao Partido SocialDemocrata, argumentava que o individualismo era uma herança burguesa que deveria ser superada pela noção de coletividade da sociedade. Nesse sentido, a produção em massa de habitação representaria essa nova aspiração social. $A$ produção em larga escala e a padronização da construção da moradia era uma necessidade econômica que também catalisava uma expressão cultural.

Oud compartilhava com Berlage essas noções de arquitetura e urbanismo, e colocava o arquiteto no papel de mestre no sentido de dar a justa forma e proporção para essa produção em massa, de forma a criar uma imagem de cidade $^{18}$. Sua primeira contribuição concreta no campo habitacional foi o pequeno conjunto de moradias em Hoek van Holland (1924-1927), amplamente divulgado nos periódicos de arquitetura à época. Esteticamente revolucionário em relação ao que se produzia no século XIX e à Escola de Amsterdam, esse projeto é constituído de duas fileiras de casas sobrepostas de dois quartos, com

17 Em 1924, Van Doesburg escreveu sobre a incompatibilidade do movimento De Stijl com a produção em massa e as noções de estandardização, colocando o movimento fora das questões da habitação social.

${ }^{18}$ A preocupação com a imagem da cidade não se restringia à cidade de Amsterdam, embora não se tenha um estudo sobre Roterdã tão profundo nos termos realizados por Stieber para Amsterdam. 
balcões contínuos marcando a fachada principal e arrematando as esquinas com forma curva. Os planos de tijolos e as paredes brancas fazem um jogo de cores e profundidade que evitam a monotonia da construção. As unidades térreas possuem quintais privativos, separados apenas por uma cerca viva baixa; esses quintais estão justapostos a uma área púbica de lazer, o que exigiu alguns cuidados nessa área de intersecção, como uma passagem de pedestres após os quintais e uma separação com cerca viva baixa da área pública desse caminho, delimitando assim os limites do público e privado de forma sutil. As unidades sobrepostas possuem balcões para as duas fachadas, garantido um pequeno espaço ao ar livre para cada unidade. Entre as duas fileiras de casas existe uma passagem para a área pública marcando o eixo da composição simétrica.

Após a crise habitacional de 1918 e a tentativa de Weader em estabelecer protótipos e estandardização para a produção holandesa, essa forma de abordagem da produção habitacional ganha atenção e diversas pesquisas para sua efetivação, com o estabelecimento de um protótipo mínimo de habitação. A experiência de Hoek van Holland foi uma das tentativas nesse sentido, e Kiefhoek pode ser entendido como de fato uma experiência no conceito de habitação mínima, apresentada e discutido no II CIAM.

O conjunto Kiefhoek foi destinado às famílias de operários com renda menos favorecida na cidade de Rotterdam. O conjunto inteiro foi construído com uma tipologia habitacional padrão, possibilitando assim um alto grau de padronização nos elementos construtivos e gerando uma economia significativa na construção. Recursos limitados fizeram que facilidades como chuveiro e cuba no banheiro não fossem previstos no projeto. Contudo, Oud se utilizou dos espaços e recursos limitados para o aproveitamento de cada centímetro quadrado da unidade, e para criar uma alternativa para o problema habitacional aclamada internacionalmente.

Quanto às edificações de vários pavimentos - altas, nos termos do CIAM - a tipologia pode ser entendida como "importada" ou estranha ao território holandês, devido às dificuldades técnicas relativas à geologia da região, à industrialização relativamente tardia da Holanda, e as características específicas da situação econômica de Chicago e Nova York intrínsecas à esse tipo de edificação (Grinberg, 1982, p.112). Presente na proposta de torres para a reconstrução do Vondelpark em Amsterdam, em projeto de $\mathrm{H}$. Th. Wijdeveld em 1919; na publicação "Arranha-céus como solução para escritórios e problema de 
moradia", do periódico Wendingene, em 1923, e em outras propostas e publicações, a idéia do arranha-céu apareceu no discurso sobre produção habitacional na terceira década do século passado na Holanda. Uma das primeiras experiências desse tipo de construção foi o edifício de 12 pavimentos (1929-1932) de J. F. Staal, para famílias de classe média, construído na área de expansão de Amsterdam Sul, Victorienplein, aprovado por razões estéticas (pois a área comportava edifícios monumentais, segundo o Plano de Berlage).

Outros exemplos dessa tipologia habitacional edificados e bastante conhecidos foram o edifício Nirvana (1927-1930), em Haia, e Bergpolder (19331934), em Roterdã, ambos considerados um fracasso imobiliário pelas associações construtoras.

O conhecido e bastante estudado "Concurso para moradia proletária barata", organizado pela Comissão de Moradias Baratas ${ }^{19}$ em 1934, na Holanda, foi a oportunidade para os racionalistas holandeses apresentarem soluções para habitação com uma linguagem moderna, explorando edificações com diversos pavimentos ${ }^{20}$. De uma forma geral, os edifícios altos foram rejeitados no concurso por seu alto custo, mas também por questão enraizada na sociedade holandesa de preferência pelas unidades médias e baixas. A comissão julgadora do concurso alegara que a nenhum edifício com mais de 04 pavimentos poderia ser destinado à habitação de baixa renda pelo alto custo da obra e pela necessidade do uso de elevadores.

De uma forma geral, a produção holandesa até a terceira década do século XX tem a especificidade de ser bastante diversificada e defender uma posição urbanística muito clara de baixas e médias densidades, com edificações que não ferissem a paisagem das cidades existentes. Sob diversas abordagens, seja da Escola de Amsterdam, do urbanismo modernista e pluralista de Berlage, seja com a racionalização de Roterdã, a reforma habitacional foi o ponto de

${ }^{19}$ Essa comissão era ligada ao Nationale Woningraad (Conselho Nacional de Habitação) e ao Nederlandsh Instituut voor Volkshuisvesting em Stendebouw (Instituto Nacional de Pesquisa em Habitação e Desenvolvimento Urbano).

${ }^{20}$ A proposta de Van de Broek, com edifícios em altura, foi a única selecionada entre os premiados. Com forte influência do edifício Bergpolderflat (bloco laminar de vários pavimentos, com galeria de circulação comum e caixa de escada localizada numa das extremidades). Van de Broek utilizou edifícios médios e altos, alinhados segundo a orientação solar, descolados do alinhamento do sistema viário, soluções que seriam muito utilizadas no segundo pós-guerra. 
partida para a modificação do espaço urbano e construção de lugares para a tendência de vida em comunidade da sociedade holandesa. Os projetos procuravam abraçar esses anseios modernos da sociedade, mas tinham também uma preocupação muito forte com a construção da imagem da cidade, como afirmaram Oud e Berlage em diferentes momentos.

Os aspectos de modernidade dessa produção são extremamente variados, como sugere Stieber (2000), e se esquivam às tentativas dos primeiros historiadores da arquitetura do século XX em abordarem a questão habitacional como um processo muito claro de reforma da sociedade por uma forma específica de arquitetura e urbanismo, qual seja o modernismo. A mesma pergunta - reforma habitacional - teria muitas respostas pertinentes, como demonstra o caso holandês.

Após meados de 1920, e o falecimento de M. de Klerk em 1923, os movimentos de vanguarda ganham força no cenário holandês, inclusive Amsterdam. Diversos arquitetos dos grupos 'De $8^{121}$, em Amsterdam, e 'De Opbouw'22 participaram dos primeiros CIAM e contribuíram para novas discussões na construção de distritos industriais.

Cornelis Van Eesteren foi uma das figuras mais importantes dentro do CIAM, assumindo sua presidência de 1930 à 1947, após a saída voluntária de Karl Moser. Sua principal contribuição para o desenvolvimento habitacional de Amsterdam foi o Plano Geral de Expansão para Amsterdam, de 1934, que englobava toda a parte Oeste da cidade, constituído de vários distritos. Logo após a criação, em 1928, do Departamento de Planejamento Físico, como parte das Obras Públicas, deu-se início o trabalho do Plano de Extensão para

21 "De 8" era formado por Ben Merkelbach, J. H. Groenwegen, Charles Karsten (1904-79), Hans van den Bosch, Henri E. van de Pauwert (1895-1981) and Pieter Jan Verschuyl (1902-83). Após 1928, Albert Boeken, Johannes Duiker and Jan Gerko Wiebenga (1886-1974), se juntaram ao grupo, além de Cornelis van Eesteren. Em 1934, Mart Stam, Gerrit Rietveld e Sybold van Ravesteyn também aderiram ao grupo, que teve suas atividades encerradas com a invasão alemã em 1942.

220 grupo Opbouw era formado por Marinus Jan Granpré Molière, Josephus Klijnen (1887-1973), L. Bolle, Alphonsus Siebers (1893-1978), Pieter Verhagen (1882-1950), Leendert Cornelis van der Vlugt, Jaap Gidding (1887-1955), Jacob Jongert, Willem Hendrik Gispen (1890-1981) e J. J. P. Oud. Posteriormente, juntaram-se ao grupo Mart Stam, Johannes Bernardus Van Logehm, Cornelis van Eesteren, Willem van Tijen, W. van Gelderen, Piet Zwart, Paul Schuitema (1897-1973) e Theodor Karel van Lohuizen (18901956). Em 1932, os dois grupos uniram forças e criaram a publicação "De 8 en Opbouw". 
Amesterdão (AUP), de Van Eesteren. Lançado em 1934, o AUP pode ser considerado como o primeiro Plano Diretor de Amsterdam, e perdurou até meados de 1960. Ele fixava as linhas gerais da política municipal de desenvolvimento espacial com uma declarada visão moderna sobre a cidade. Seu Plano, como afirma Gideon (2004), não se pauta nas questões de traçados de rua ou da aparência da arquitetura, mas nas questões de densidade, tipos e necessidades diferente de habitaçoes, território, extremamanente importante no caso holandês, e das conexões entre as áreas residenciais e as outras regiões da cidade, dividida segunda critérios funcionais.

Por algum tempo, as exigências do programa para bairros residenciais modernos já estavam sob discussão por arquitetos e urbanistas holandeses. Em Amsterdam, o grupo ' 8 ' desempenhou um papel importante no debate sobre a modernização dos distritos residenciais. Com seus colegas do Opbouw, em Roterdã, também parte do movimento de vanguarda, os membros do ' 8 ' elaboraram um manifesto em 1932, no qual as abordagens dos fundamentos do novo planejamento urbano para bairros residenciais foram estabelecidas com bases nas discussões dos CIAM's. Ben Merkelbach e Wim van Tijen foram os principais autores e o manifesto foi intitulado De Organische Woonwijk in Open Bebouwing (O distrito residencial orgânico em construção aberta).

O uso do termo orgânico se destina a indicar que todas as funções no distrito devem ser conciliadas para criação de um todo social harmônico. Diferentes tipos de escolas para diversas idades, instalações desportivas e áreas verdes públicas para recreação ao ar livre, lojas e infraestruturas sociais e religiosas, deviam todas ser levadas em consideração, de modo que os distritos residenciais poderiam satisfazer todas as necessidades sociais. Entende-se aqui a noção de expansão através de distritos independentes, com a noção de unidade de vizinhança, agenciados ao redor das cidades existentes.

O conceito de "construções abertas" foi uma inovadora, mas já preconizada, modificação no layout dos distritos residenciais. Os arquitetos da vanguarda marcaram a construção de edifícios no perímetro da quadra como imprópria para o planejamento urbano, pois argumentavam que a orientação das habitações não era adequada com esse agenciamento; quando o clima estava quente não existia ventilação, pois o bloco era um espaço abafado cercado por ruas empoeiradas, enquanto do ponto de vista da arquitetura, a aparência da face interna da quadra era pouco inspiradora. A alternativa para o bloco com 
construções perimetrais foi a construção de linhas de moradias (apresentadas e defendidas nos CIAM's): blocos implantados no eixo norte-sul com portiekflats (apartamentos com halls de entrada) com habitações construídas na orientação Leste-Oeste rodeadas por espaços verdes.

Dentro desse Plano de Expansão, a região Western Garden Cities abrigaria mais de 45.000 unidades habitacionais. Fazia parte dessa região os distritos Harry Koningsbergerstraat, Slotermeer, Geuzenveld, Overtoomseveld e Slotervaart, construídos após 1950.

Slotermeer Gargen City, uma das partes mais importantes do complexo, foi aprovado pelo Conselho Municipal em 1939 e configura umas das realizações mais importantes da arquitetura de vanguarda no período entre guerras em Amsterdam. Embora outros planos distritais anteriores tenham sido aprovados, Slotermeer Garden City, marcou o início de uma nova era em Amsterdam. Foi o primeiro bairro residencial fora da Ringbaan (via férrea circular) desenhado pelo Departamento de Planejamento Urbano. Como a Companhia de Propriedade Municipal fora capaz de comprar terras fora da Ringbaan por preços de área rural, foi possível introduzir idéias novas para habitação pública nesse distrito. $O$ objetivo era ter densidades mais baixas, maior número de moradias unifamiliares, mais espaços verdes comuns e edifícios "abertos".

O projeto, que foi publicado em 07 de julho de 1939 com um explicação abrangente e detalhada na publicação municipal (Gemeenteblad), constitui um capítulo de uma longa da história. O primeiro projeto data de junho de 1936. A redistribuição da terra foi, então, pouco mais que um esboço; o Burgemeester Vening Meineszlaan e o Eliasstraat Burgemeester formavam uma faixa verde que também funcionava como um percurso pedestre entre Bos e Lommer e o Sloterplas (lago). O Gerbrandypark também foi mostrado no plano desde o início. A Burgemeester de Vlugtlaan, conectando o Bos e Lommerweg e o Hoofdweg, foi considerada uma importante rota de trânsito secundário e provavelmente também uma rua comercial. As construções sobre o lado sul da Burgemeester de Vlugtlaan consistem de um a série de linhas de edifícios de quatro andares, perpendiculares à rua, em conformidade com os princípios do manifesto De Organische Woonwijk in Open Bebouwing.

Em um "plano de projeto provisório" de 1937, a redistribuição de lotes foi mais detalhada. A série abstrata de faixas com blocos de construções de quatro andares no lado sul da Burgemeester de Vlugtlaan assumiu um caráter mais 
convencional, com pátios interiores e fachadas externas voltadas para a rua, possivelmente para comércio. Os blocos de quatro andares no lado norte deram lugar para faixas de edifícios baixos paralelos ao eixo da via. Essas mudanças indicavam que a busca pela aparência futura de Burgemeester de Vlugtlaan ainda não tinha acabado.

Após a guerra, o projeto de 1939 foi construído de maneira modificada, mas sem nenhuma revisão formal ao plano de zoneamento aprovado. O layout do distrito com construções baixas não foi mudado, mas os edifícios baixos com lojas ao longo do lado norte da Burgemeester de Vlugtlaan desapareceram totalmente do plano. Estes tiveram que dar lugar a uma série de portiekflats em edifícios modulares desenhados por J. F. Berghoef.

Nesse período do segundo pós-guerra, o governo estimulou o uso do sistema de construção modular por meio de subsídios extras. A disposição do tráfego também foi melhorada com a redução do número de cruzamentos das ruas residenciais no Burgemeester de Vlugtlaan. O sistema de construção modular também formou um elemento estético novo na paisagem das ruas. Os elementos de fachada de concreto, os caixilhos de aço, e as dimensões fixadas pela modulação deram a esses blocos residenciais um caráter racionalista, contrastando com a linguagem formal mais tradicional dos edifícios baixos atrás deles.

As contruções na zona sul de Burgemeester de Vlugtlaan também finalmente assumiram sua forma definitiva. A composição da série de linhas com lojas na rua lateral foi refinada, com maior variação no comprimento das sequências de construção. Assim, uma composição mais simétrica foi criada, que, embora projetada por arquitetos diferentes, podem ser consideradas como um grande conjunto: um super bloco de construção, com ruas e jardins interiores, aberto para o lado do parque e fechado no lado norte.

As diferentes fases de concepção do conjunto que compõem esse distrito demostram que Van Eesteren tinha procurado por muito tempo uma composição equilibrada. O esboço de 1936, foi o primeiro confronto entre os programas de necessidades e os princípios racionais de redistribuição da terra. Sua imagem abstrata causou certa agitação nos círculos oficiais, mas com o tempo ela se tornou mais equilibrada. Assim, foi criado um bairro residencial que nos permite uma imagem representativa da evolução do planejamento da cidade entre 1920 e 1950. Os esforços para habitações unifamiliares em uma grande 
área verde, que foi de fundamental importância para o Departamento de Habitação, acabou transformada em uma visão mais urbana, com edifícios de vários andares e lojas ao longo uma rua principal.

As obras para os distritos que compunham o Plano Geral de Expansão de Amstedam se iniciaram em 1941 e se extederam até o final de 1960, mostrando claramente a ampliação da aplicação dos preceitos da arquitetura moderna na cidade.

A região composta por esses distritos diferem totalmente em paisagem e escala dos conjuntos habitacionais construídos até o plano de Van Eesterem. Em nossa análise, a principal contribuição dos planos de Berlage e Van Eesterem, e das demais experiências holandesas aqui elencadas, por mais que sejam contraditórios em seus propósitos e resultados à luz das diversas abordagens historiográfica, foi a introdução da questão habitacional, em seu sentido mais amplo, como principal elemento de planejamento urbano, como ponto de partida e chegada do exercício do planejamento da cidade. Esses planos nortearam toda a produção habitacional, inclusive a de baixa renda, por mais de cinco décadas. Ora, tal fato só é possível se toda a sociedade reconhecesse (e de fato reconheceu com a Lei de Habitação de 1901) que a produção de habitação tem o poder de causar impactos benéficos ou maléficos no tecido urbano - como bem demonstra a produção do laisse-faire do século XIX. 
Vreewijk (Garden Village)

Ano: 1916-19; 1933

Localização: Amsterdam, Holanda

Rua: Watergraafsmeer

Arquiteto: H. P. Berlage (parte inicial); De Roos; Overeynder (segunda parte)

Projeto urbano: Granpé Moliére; Verhagen; Kok (segunda parte)

Tipos: Sobrados em fileira.

Equipamentos: Escolas; biblioteca; cinema; teatro; escola de música; 58 pontos comercias e pequena estação de ônibus no centro do conjunto.

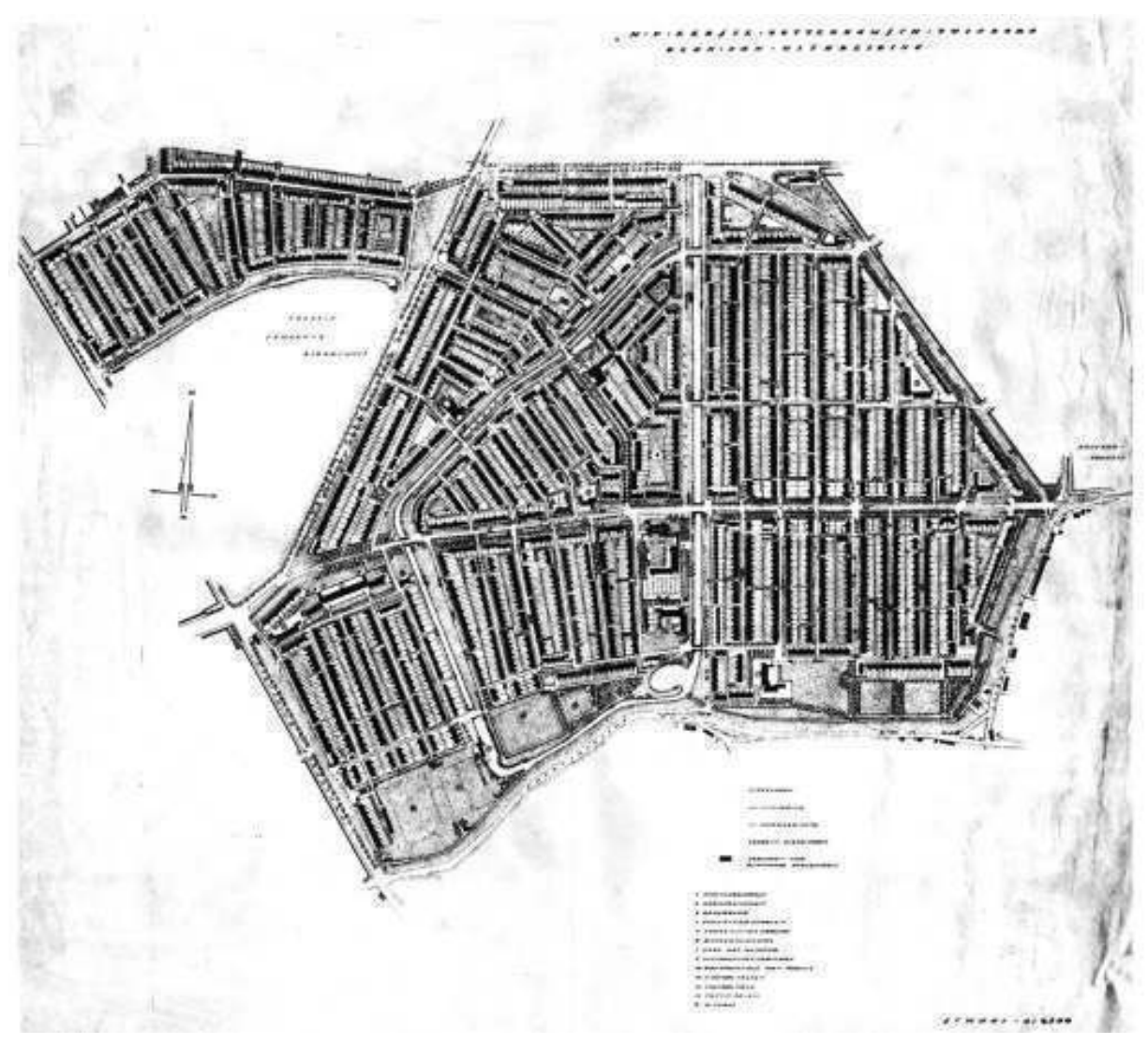

Figura 20. Implantação geral de Vreewijk. 

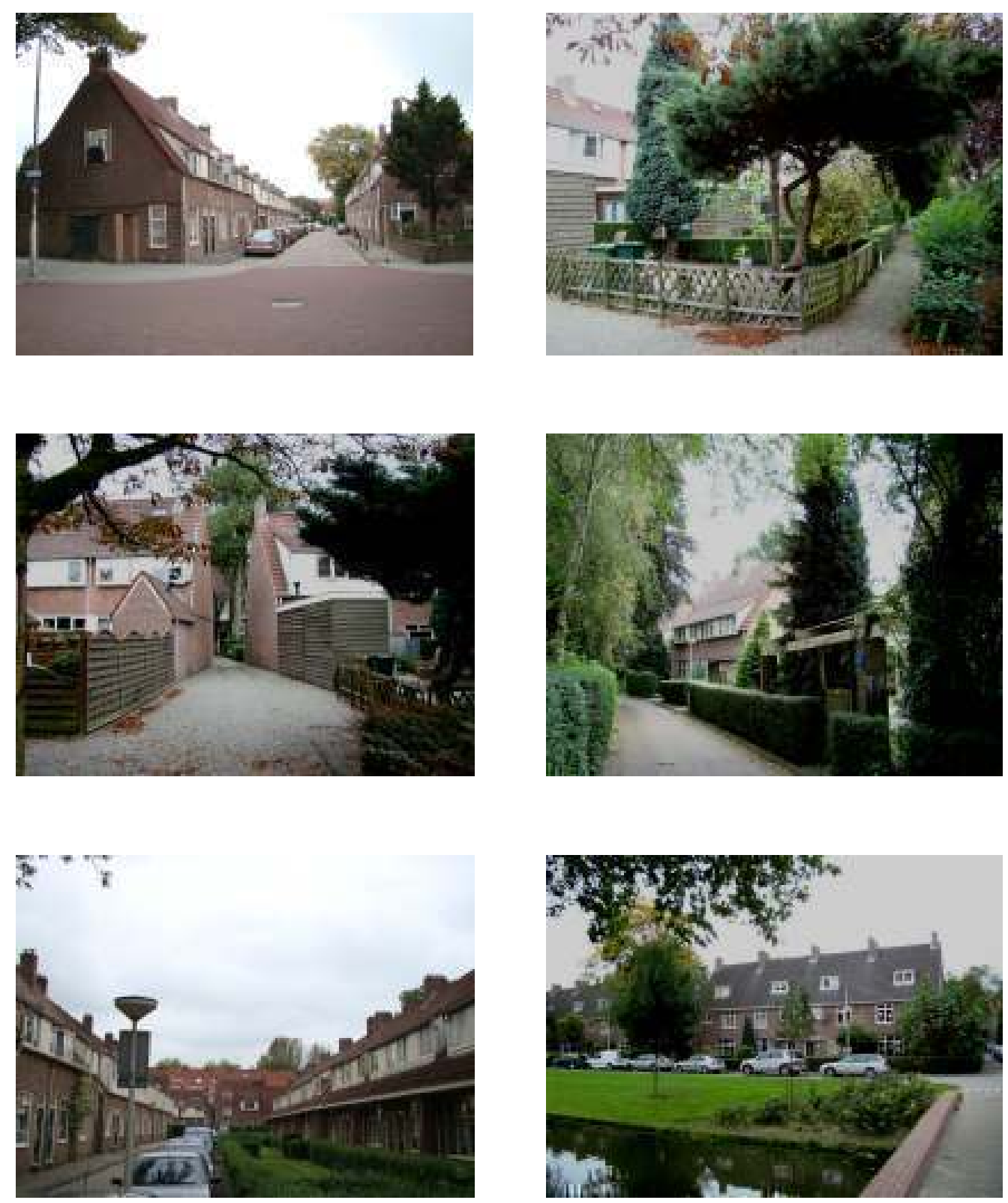

Figuras 21 - 26. Fotos atuais do bairro. Notam-se diferentes larguras de ruas, com jardins coletivos e individuais, dependendo do nível econômico das casas; abertura das quadras para passagem de pedestres em meio aos quintais privativos. $O$ bairro atende a diversas camadas sociais e é mercado pela presença massiva de áreas verdes, tanto nas ruas e jardins, como no parque previsto no projeto. Fotos da autora, 2008. 
Eigen Haard

Ano: $1917-1920$

Localização: Amsterdam, Holanda

Rua: Zaanstraat; Oostzanstraat

Arquiteto: M. de Klerk

Tipos: Bloco de habitação com 05 pavimentos e sótão. Esquinas ocupadas com equipamentos.

Equipamentos: Escola; agência de correios.

Mesmo que a industrialização e a urbanização tivessem sido tardias na Holanda, em relação a outras nações imperialistas europeias, o Ato Habitacional de 1901 foi a resposta oficial às péssimas condições de moradias da população de baixa renda e à necessidade de planejamento organizado em um país pequeno. O Ato Habitacional forneceu possibilidades de financiamento e condições para a criação de associações e cooperativas para a construção de moradias. Estas cooperativas foram responsáveis por uma grande porcentagem da habitação construída na Holanda neste século.

Uma destas corporações, Eigen Haard (Nossa lareira), desenvolveu muitos projetos de moradia na região do distrito de Spaarndammerbuurt, a oeste da região central de Amsterdã, ao longo do rio de IJ. Esta área desenvolveu-se durante o período 1915-1920 e foi palco de diversos edifícios de Michael De Klerk, que inclui o "Het Schip" (O navio), talvez o mais famoso edifício da escola de Amsterdã. "Het Schip" é o carro-chefe da Escola de Amsterdã, que estabelece De Klerk como o mais conhecido dos arquitetos desta escola.

O distrito de Spaarndammer consiste em um padrão irregular de blocos de apartamento no perímetro da quadra, numa área entre os trilhos da principal estrada de ferro da região oeste de Amsterdam, e as docas ao longo do rio.

O projeto de De Klerk para Eigen Haard, respectivamente os segundo e terceiro blocos de habitação de sua autoria para área, consiste de uma bloco de apartamentos delimitando o perímetro do quarteirão triangular, mantendo seu interior aberto, com jardins comunitários. As unidades possuem acesso pela rua, com caixas de escada ao longo da fachada, e sacadas voltadas para o jardim interno. No vértice do triangulo voltado para o parque, foi projetada uma agencia de correio com três pavimentos, ao invés dos cinco pavimentos da parte residencial da quadra. No lado norte do bloco, ao longo da Oostzaanstraat foi 
construída uma escola pública com dois pavimentos, interrompendo a fachada neste lado do triângulo. A ênfase horizontal na fachada das habitações é conseguida com as esquadrias de madeira e saliências horizontais na alvenaria, interrompidas apenas pela demarcação da caixa de escada.

A Escola de Amsterdam foi bastante criticada, pois seu repertório arquitetônico e soluções construtivas eram considerados muito luxuosos para serem promovidos pela municipalidade para a classe operária. Se por um lado existem diferentes plantas devido às particularidades da arquitetura proposta, com diferentes sacadas, coberturas diferenciadas e volumes sobressalentes, por outro lado, os blocos habitacionais são constituídos de unidades bastante compactas de 02 e 03 quartos, seguindo a uma padronização na maioria dos casos.

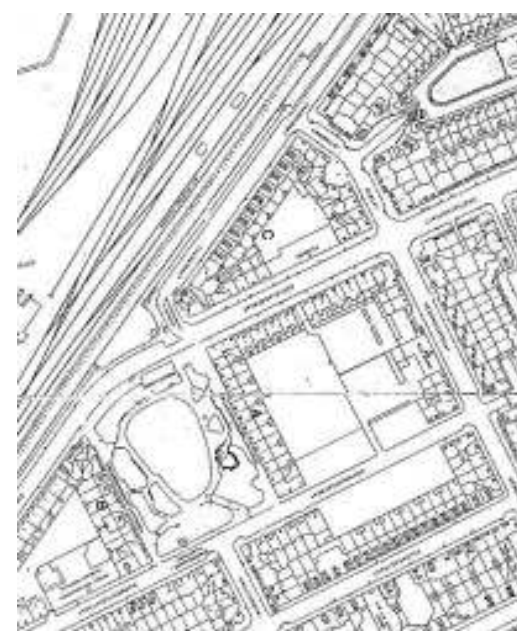

Figura 27. Localização do conjunto em quarteirão triangular.

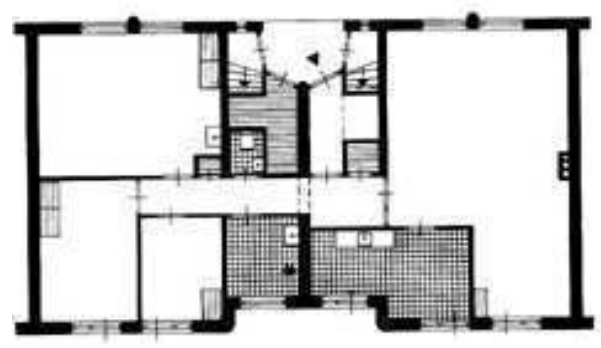

Figura 28. Planta de dois apartamentos. 

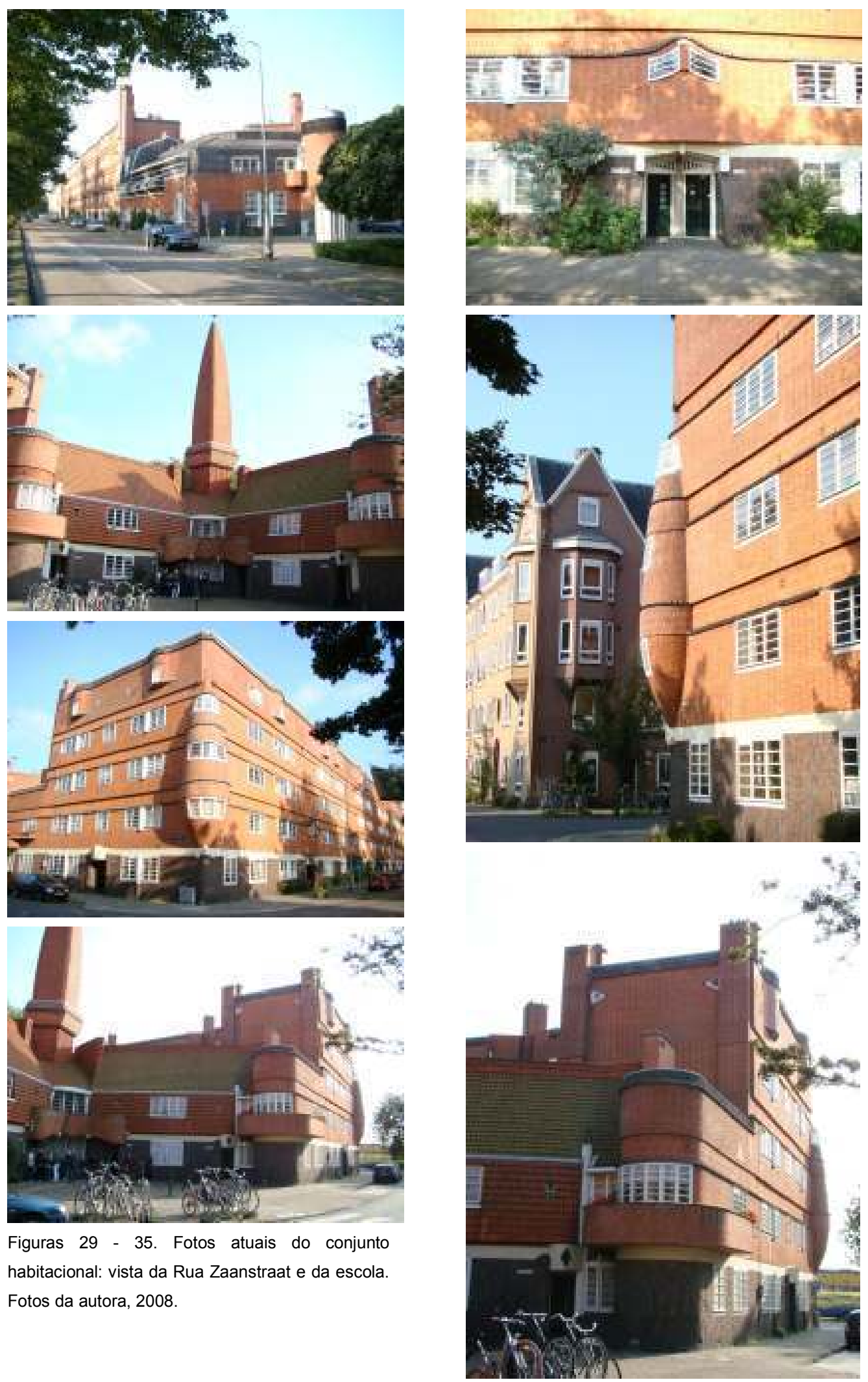
Spangen

Ano: 1918 - 1921

Localização: Rotterdam, Holanda

Ruas: Spaansebocht, Bilderdijkstraat.

Arquitetos: J. P. Oud; Michiel Brinkman

Tipos: Blocos de apartamentos com 03 e 04 andares; corredores e galerias de circulação coletivas.
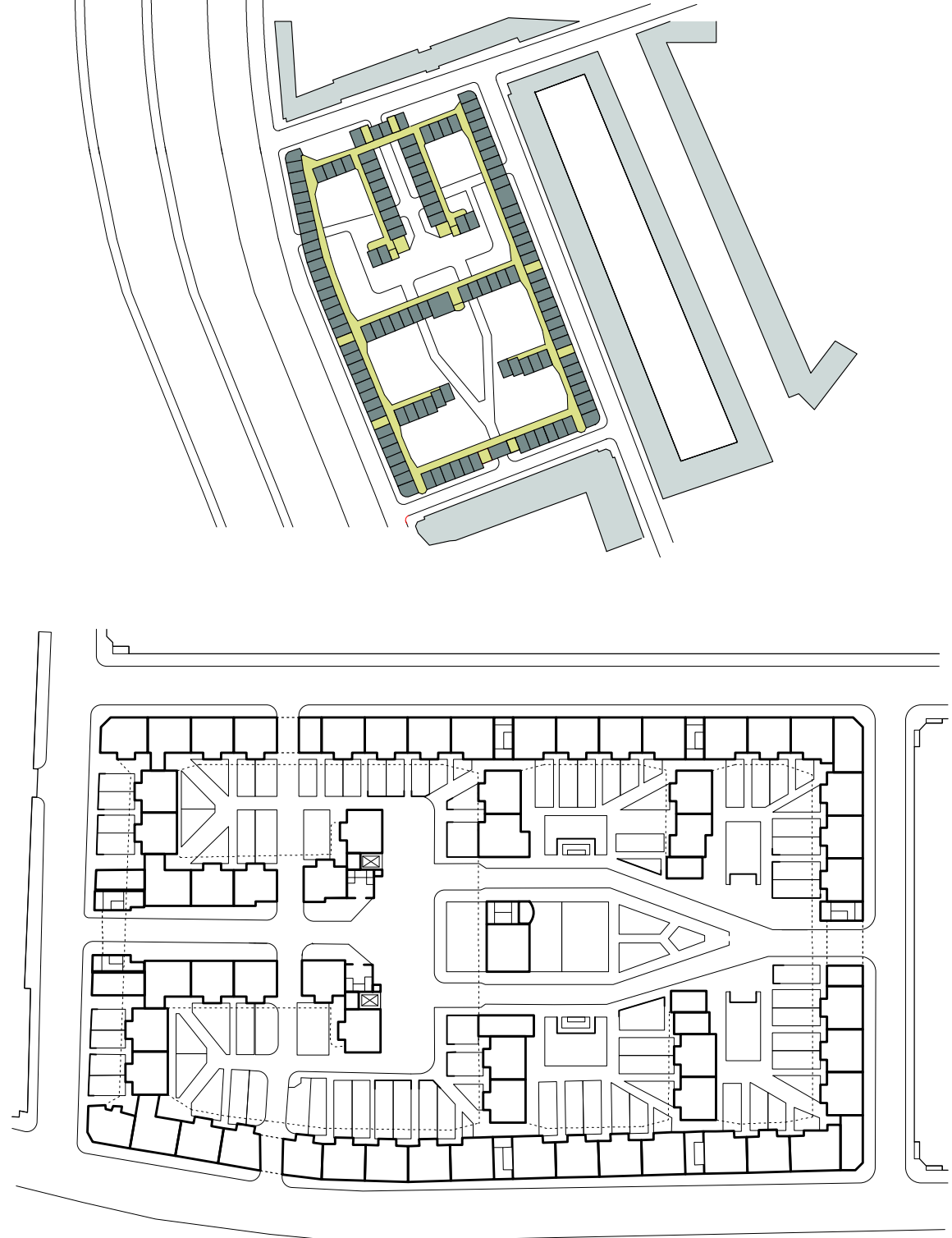

Figuras 36-37. Situação e Implantação do Spangen. Fonte: FRENCH, 2009, CD-ROM. 

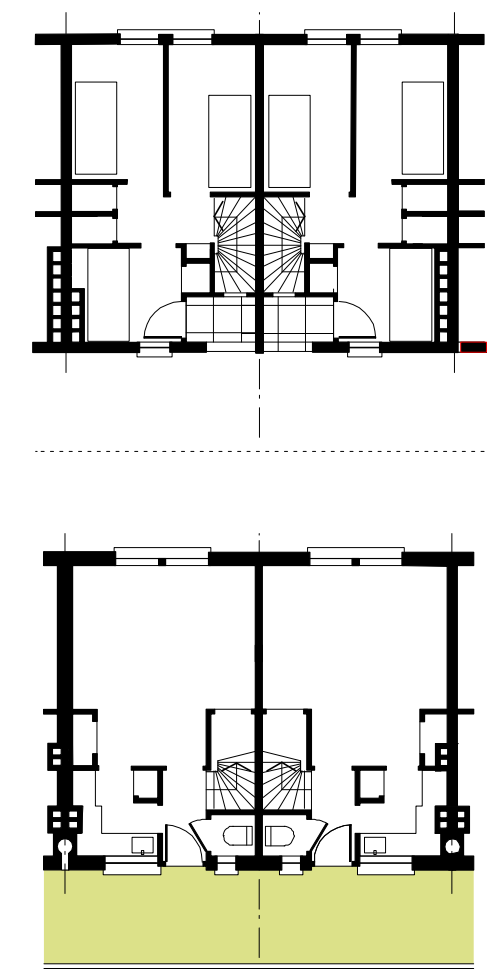

Figuras 38-39. Plantas de um apartamento duplex de 03 quartos com acesso pela "rua externa" em Spangen. Fonte: FRENCH, 2009, CD-ROM.
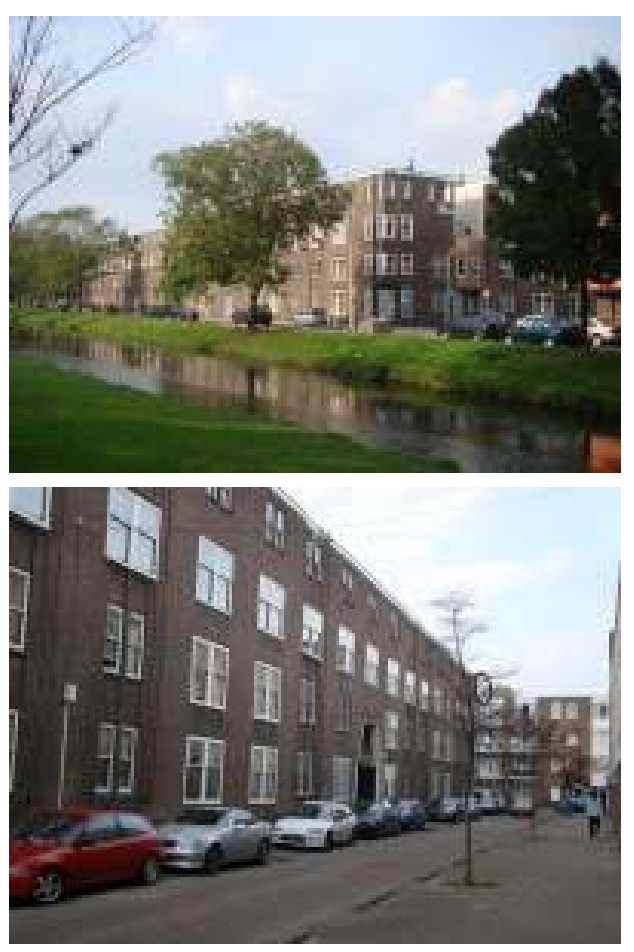
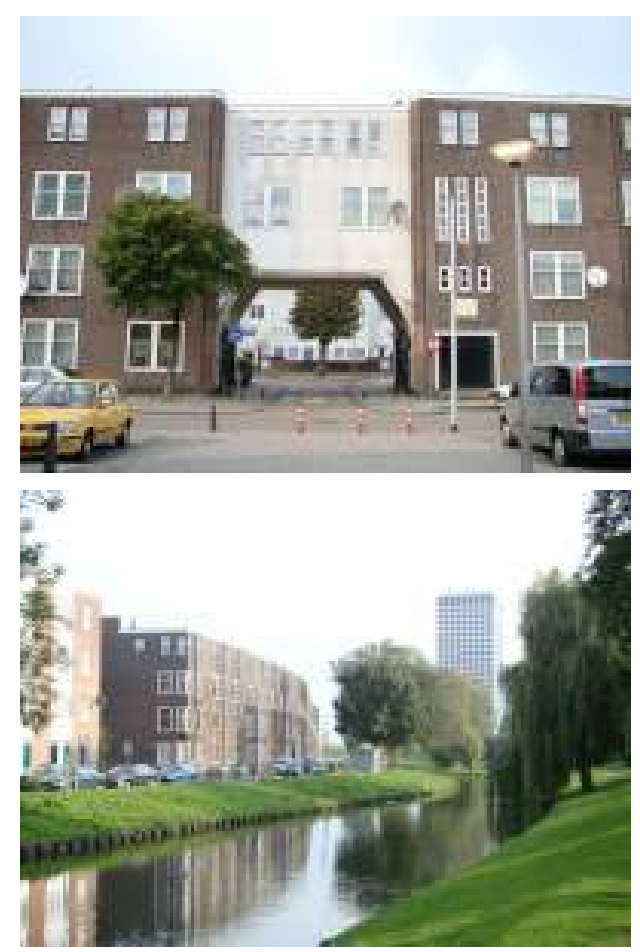

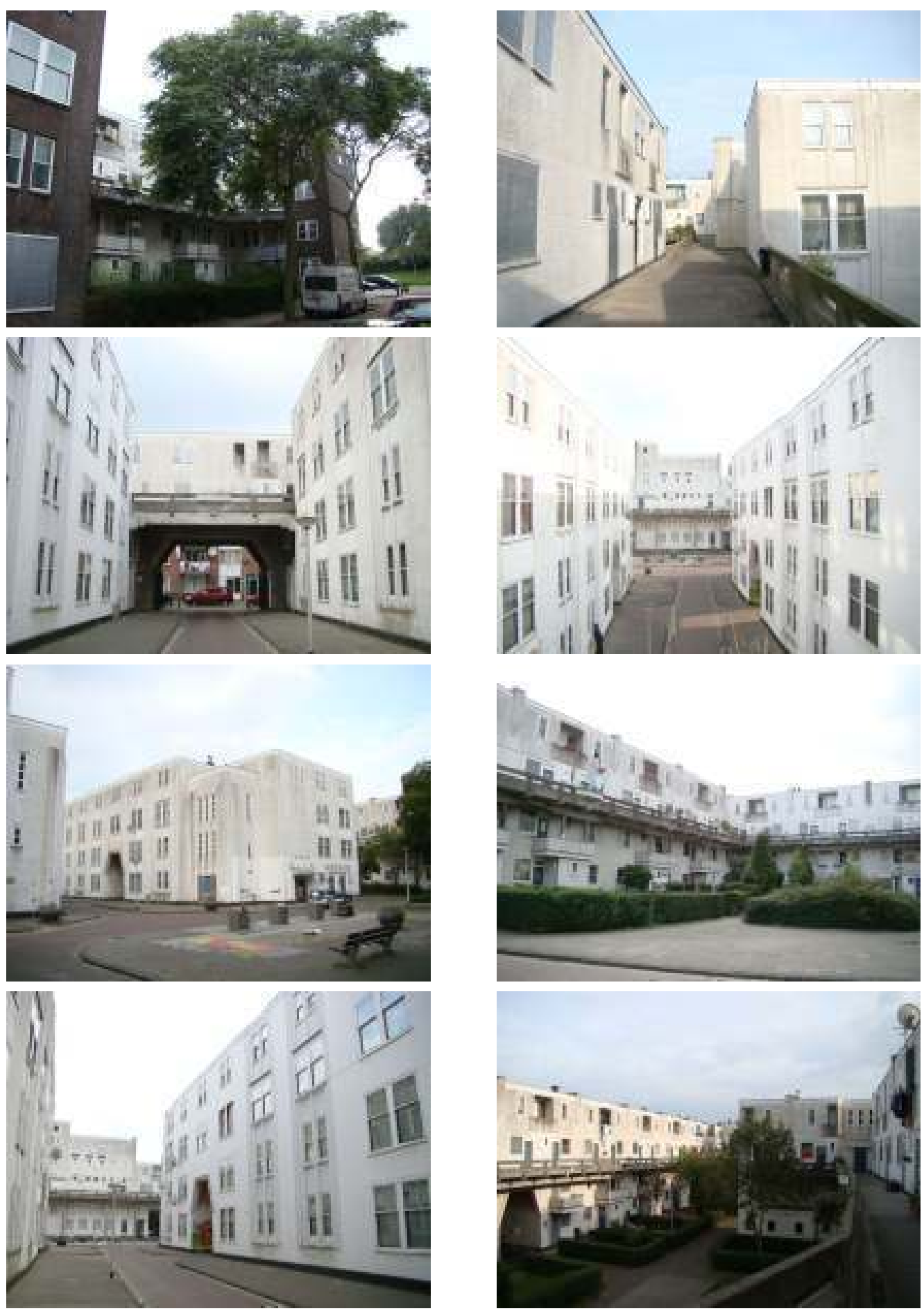

Figuras 40-51. Vistas das ruas externas e internas do conjunto. Fotos da autora (2008). 
Papaverhof

Ano: 1919 - 1922

Localização: Haia, Holanda

Rua: Papaverhof

Arquitetos: Jan Wils

Tipos: sobrados dispostos back to back

O conjunto Papaverhof consiste de duas fileiras de sobrados dispostas em $U$, configurando um grande jardim central comum. Os sobrados estão dispostos back to back e possuem jardim frontal, mas não dispõem de quintais. As unidades foram construídas seguindo os preceitos do movimento "De Stijp". Hoje o conjunto é listado como monumento e foi restaurado em 1989.
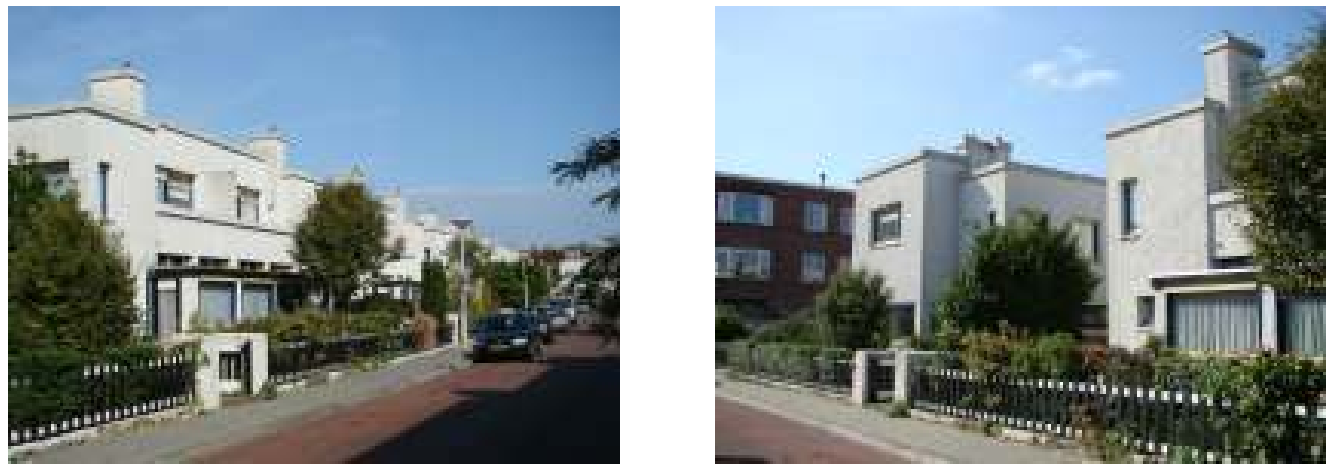

Figuras 52 - 53. Vistas externas do conjunto. Fotos da autora (2008).

Escola de Amsterdã - área sul da cidade

Ano: 1920-1923

Localização: Amsterdã, Holanda

Rua: P.L. Takstraat - Arquitetos: P.L. Kramer/M. de Klerk

Rua: Lutmastraat - Arquitetos: T. Kuipers/A. Ingwersen

Rua: Josef Israëlskade - Arquiteto: A.W. Weissman

Rua: Talmastraat - Arquiteto: J.H.Rijnja

Rua: Burgemeester Tellegenstraat - Arquiitetos: P. L. Kramer; De Degeraad

Rua: Henriette Ronnerplein

Tipos: Blocos de apartamentos com 03 e 04 andares.

Equipamentos: Escola, comércio, praças, jardins. 

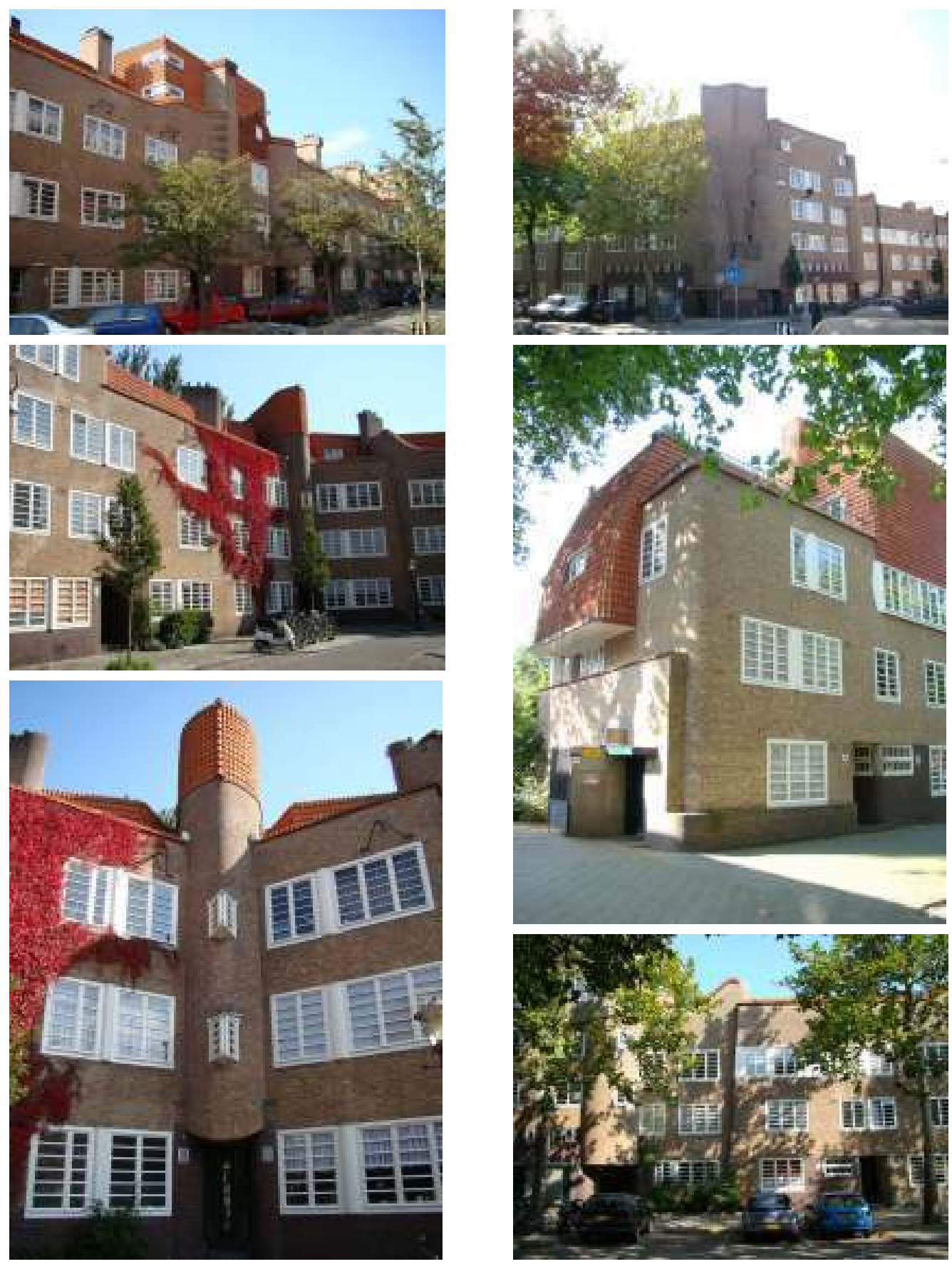

Figuras 54 - 59. Vistas externas de conjuntos da Escola de Amsterdã nas ruas Henriette Ronnerplein, Burgemeester Tellegenstraat e P.L. Takstraat. Fotos da autora (2008). 
Betondorp

Ano: 1925-1929

Localização: Amsterdam, Holanda

Rua: Watergraafsmeer

Arquiteto: D. Greiner

Número de unidades:

Tipos: Sobrados em fileira.

Equipamentos: Escolas; biblioteca; cinema; teatro; escola de música; 58 pontos comercias e pequena estação de ônibus no centro do conjunto.

O conjunto habitacional Betondorp (Vila de concreto) em Amsterdam foi um grande laboratório para construção em massa de casas em concreto, em suas diversas modalidades. Foram utilizados diversos sistemas construtivos com base no concreto armado: sistema com placas duplas de concreto pré-fabricadas e resíduos de construção civil entre elas (painel sanduíche); blocos de concreto; grandes placas de concreto pré-fabricadas (fachadas e paredes inteiras) e a combinação de dois ou mais sistemas.

Projetado nos arredores da cidade, com baixa densidade e grandes áreas de jardins, Betondorp seria uma alternativa de moradia sadia e higiênica para a classe trabalhadora. O conjunto contava com duas escolas, pequeno teatro, cinema, escola de música e biblioteca, com a intenção de criar um sentido de comunidade e suprir as necessidades de lazer e cultura para a população local, sem que essa precisasse se deslocar até a cidade; contava ainda com pequenos pontos de comércio em algumas esquinas do conjunto e uma pequena estação de ônibus.

Segundo entrevista com o Sr. Hans Bethlehen, antigo morador do conjunto, as regras para admissão de uma família na seleção das casas eram extremamente rígidas e pautadas em questões de higiene, hábitos "sadios", número de filhos, renda, etc. A seleção era feita por assistentes sociais e até os anos de 1960 existiram inspetores para verificar a condição de moradia dos inquilinos. Segundo o Sr. Hans, essas inspeções eram constantes e bastante severas. O nome original do conjunto era Cidade-Jardim (Garden Village). 


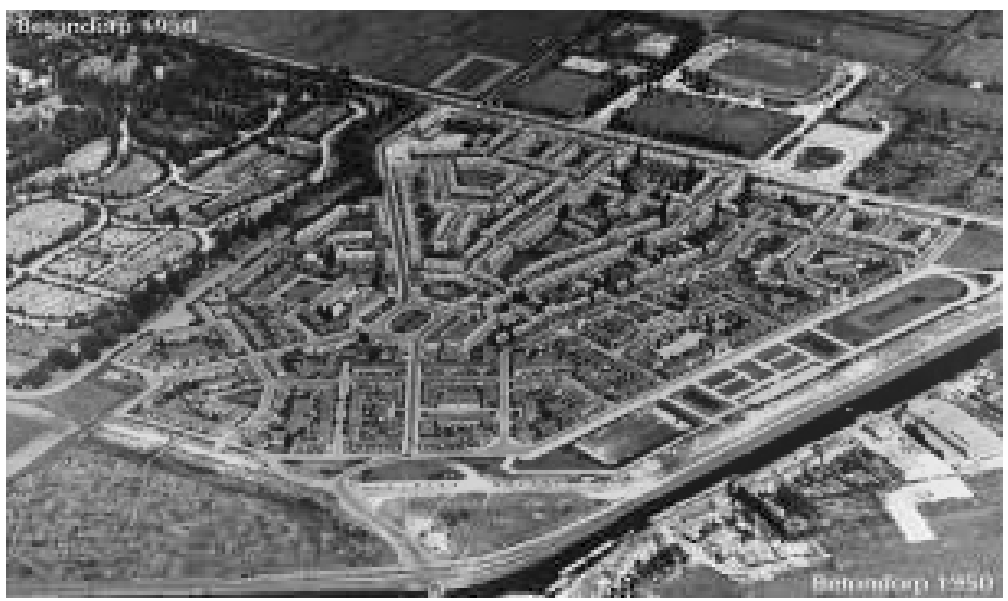

Figura 60. Vista aérea de Betondorp. Fonte: http://www.atlanticsoftware.nl/otto/history/betondorp.jpg
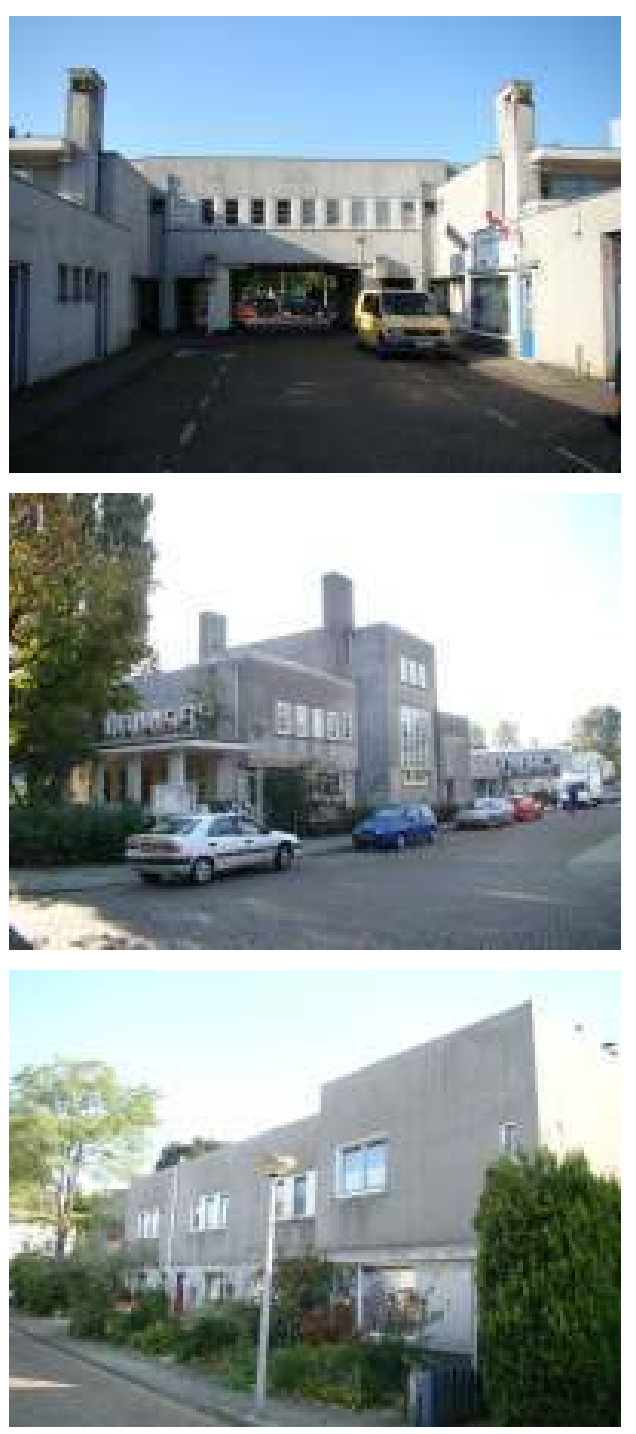

Figuras 61-66. Entrada da vila de concreto; vistas das diversas tipologias. Fotos da autora (2008).
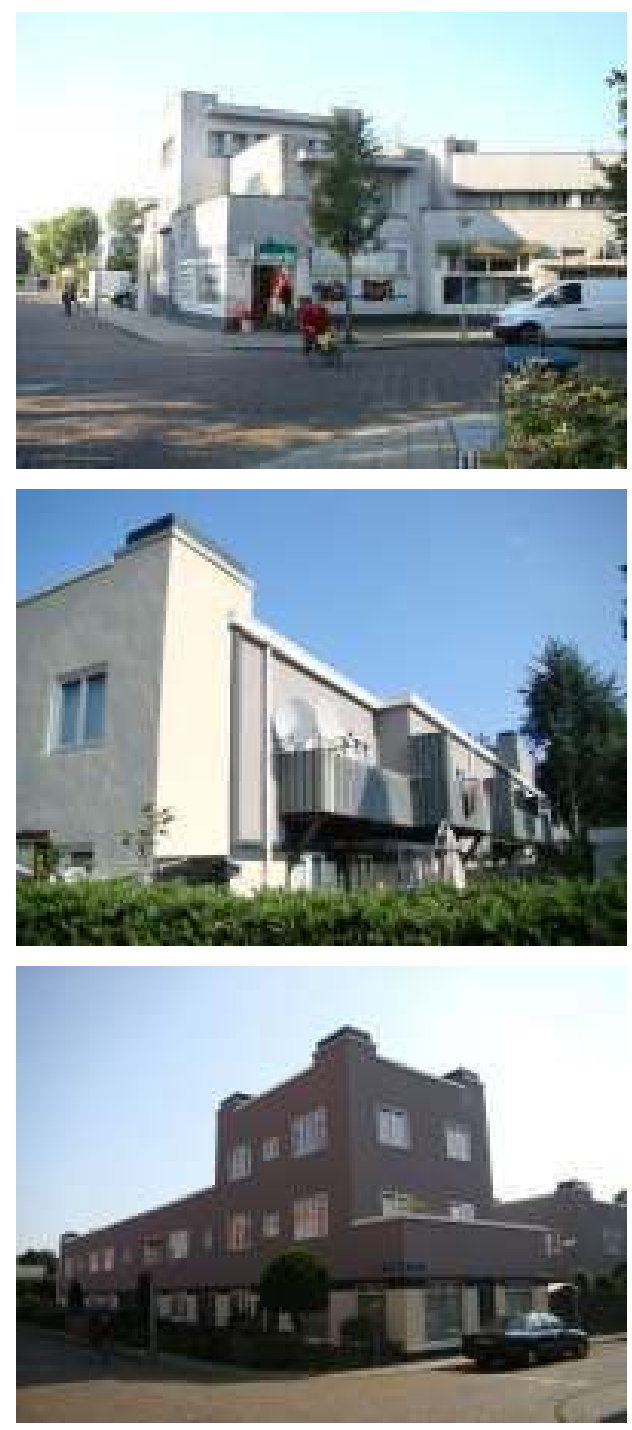

. Fotos da autora (2008). 
Kiefhoek

Ano: $1925-1930$

Localização: Rotterdam, Holanda

Ruas: Kiefhoekstraat; Lindtstraat; Eemstein

Arquitetos: J. P. Oud

Número de unidades: 294 unidades

Tipos: Sobrados em fileira

Serviços: duas lojas; serviço de água- quente; dois playgrounds; uma igreja.
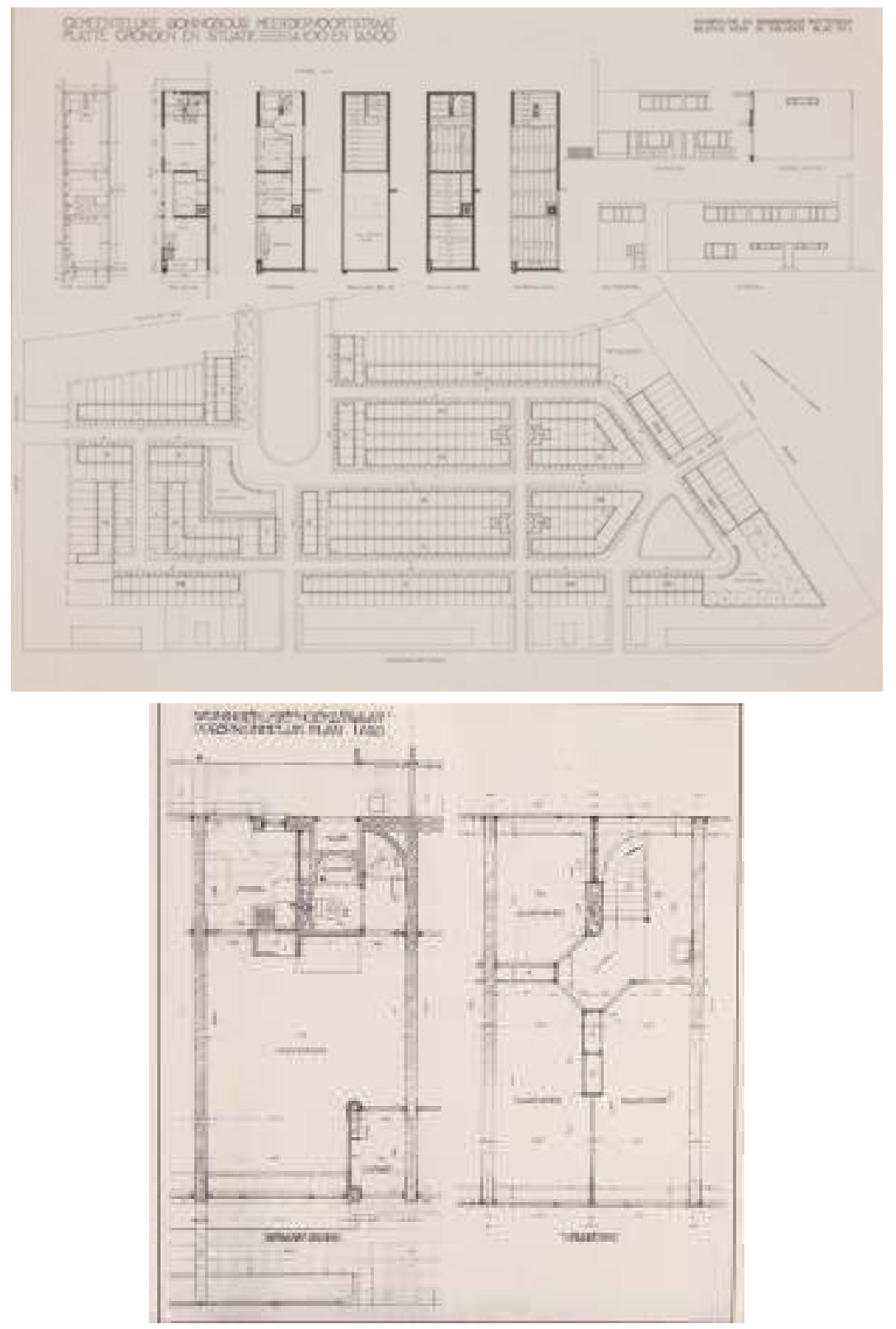

Figuras 67-68. Implantação, elevações e plantas baixas da unidade tipo do conjunto. 

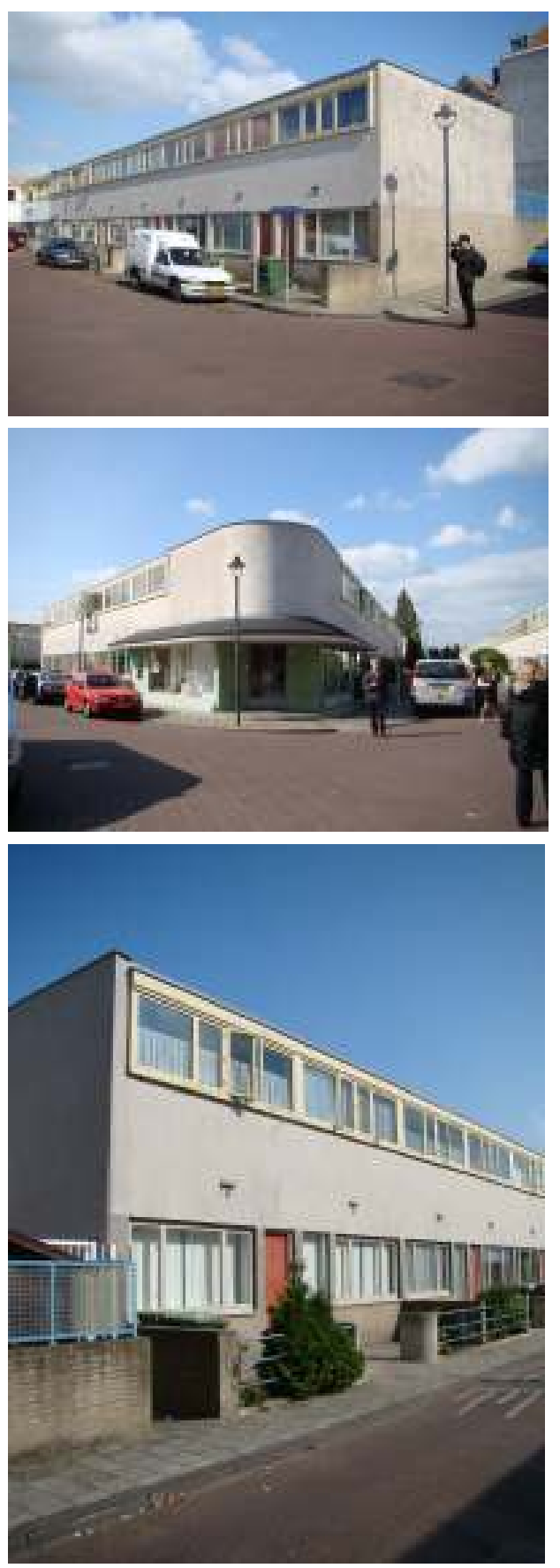

Figuras 69 -75. Vistas externas do conjunto. Fotos da autora (2008).
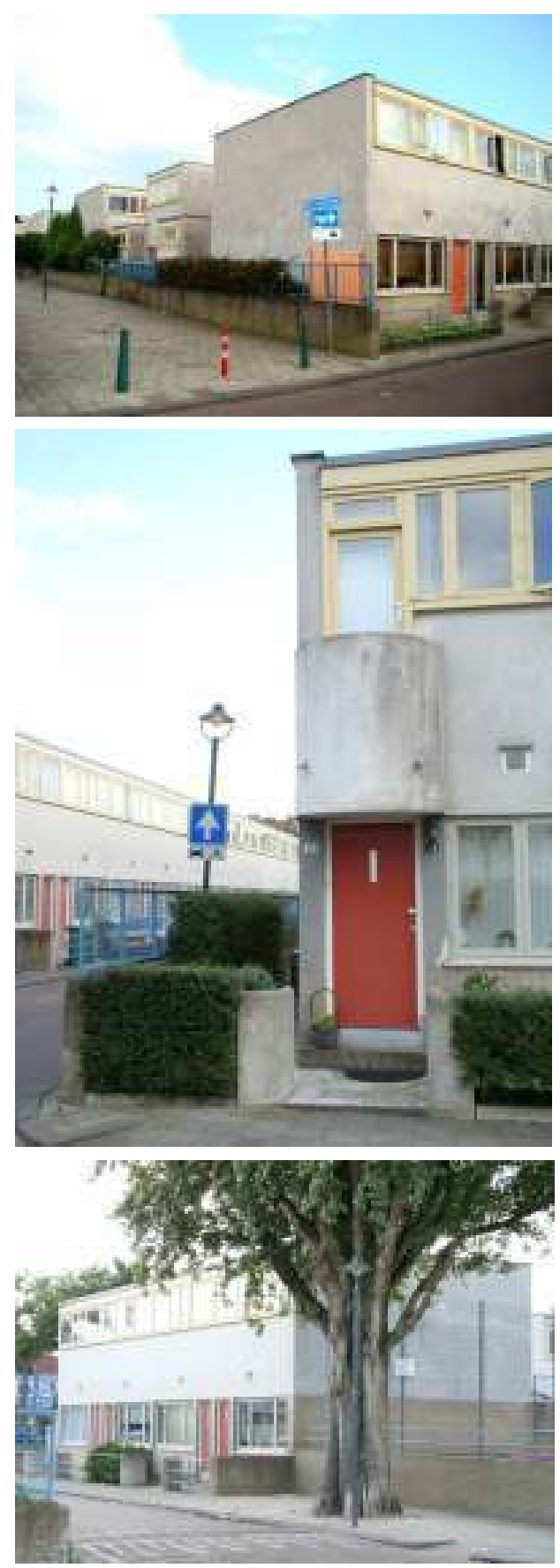

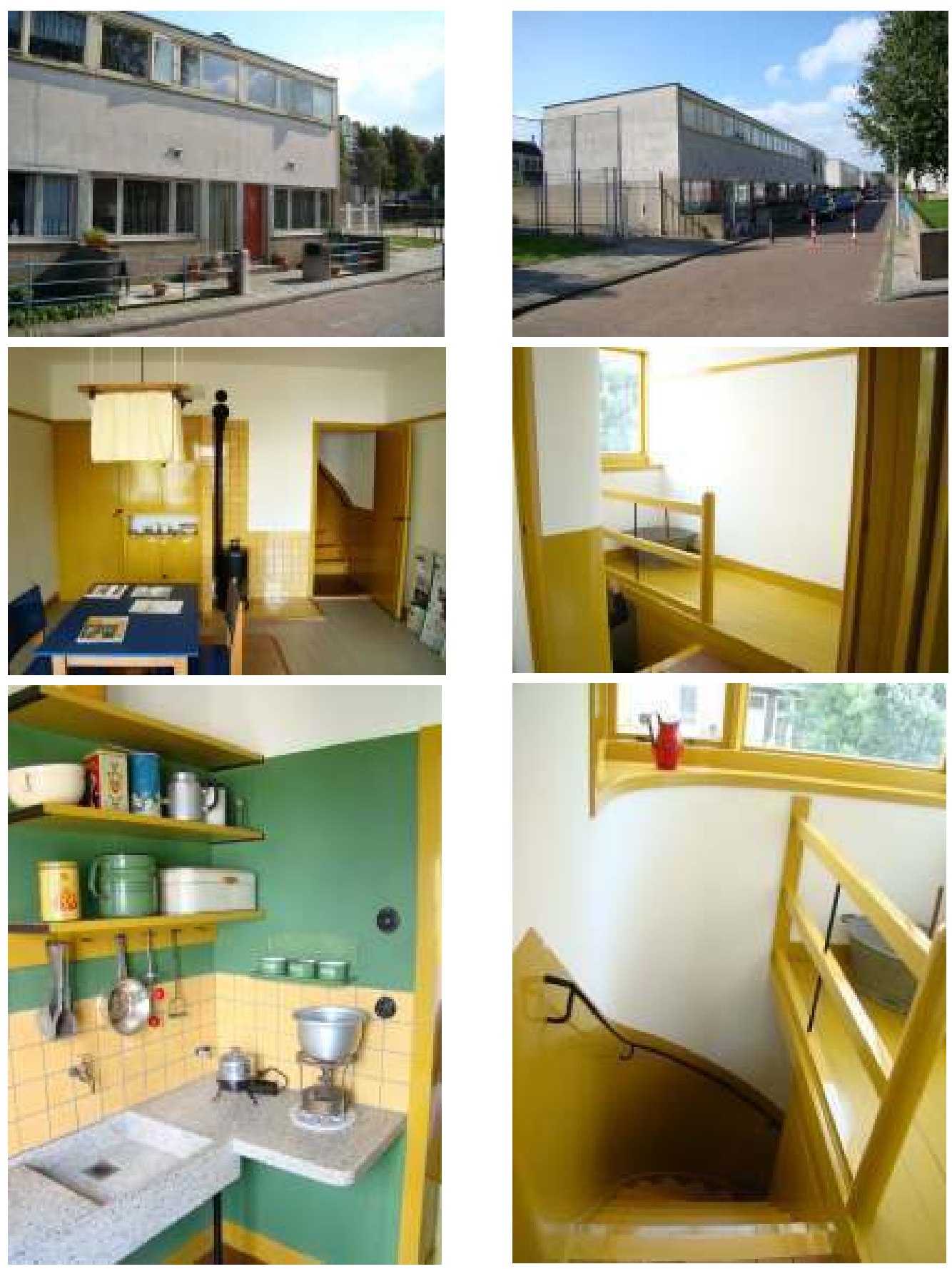

Figuras 76-81. Fotos externas do conjunto e internas do Museum Dewelling De Kiefhoek - unidade preservada e restaurada com móveis e acabamentos originais. Fotos da autora (2008). 
Transvaalbuurt

Ano: 1925-1929

Localização: Amsterdam, Holanda

Rua: Transvaalkade; Kraaipanstraat

Arquiteto: H. P. Berlage; J. Gratama; G. Versteeg

Tipos: Sobrados em fileira.

A influência de Raymond Unwin é evidente no plano de Amsterdam Sul de Berlage, mas neste conjunto residencial a referência ao trabalho de Unwin é mais explícita. Similar à aplicação geral dos ideais de cidade-jardim na Holanda, os princípios de Unwin foram aplicados aqui em um contexto mais urbano do que aqueles adotados na Inglaterra. Para Berlage, este projeto representa um movimento no sentido de liberação da rua corredor em direção a espaços mais abertos no território urbano.

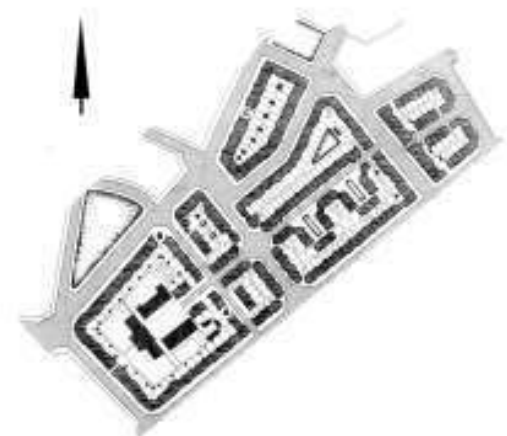

Figura 82. Implantação do conjunto. Fonte: Aymonino (1979) p.
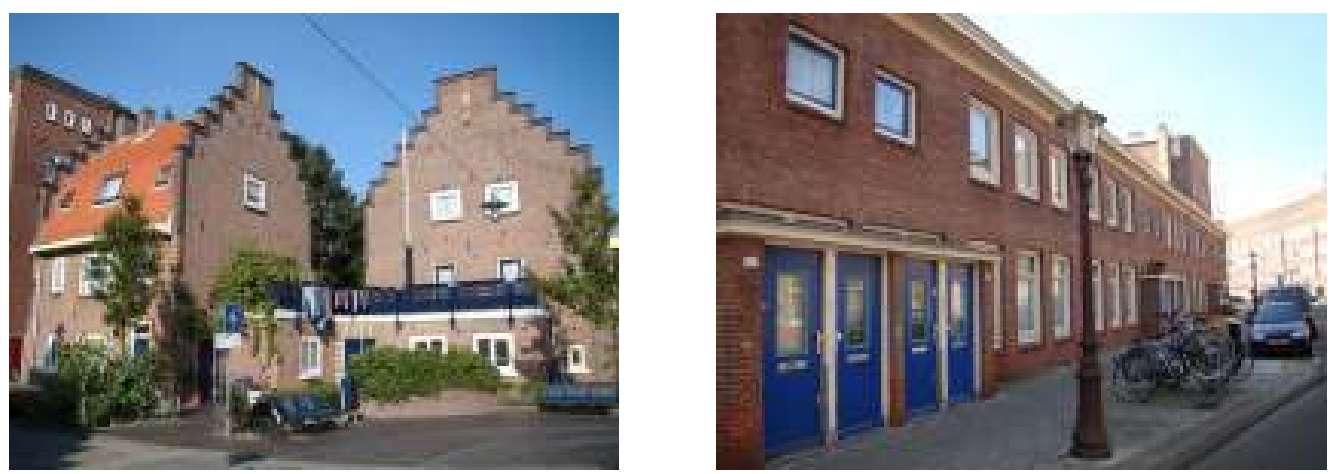

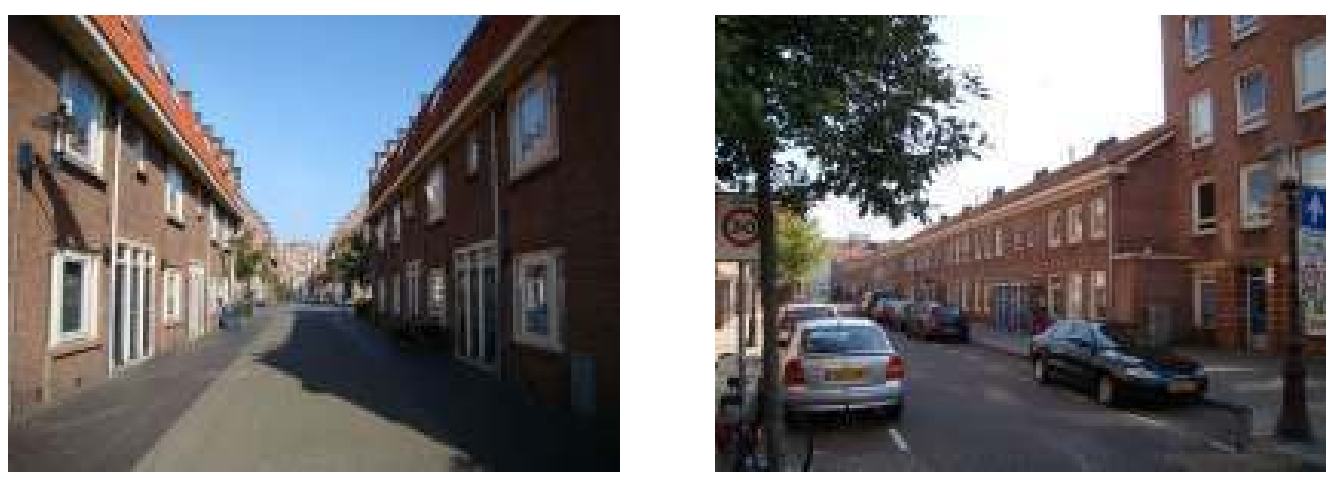

Figuras 83-86. Fotos externas do conjunto a partir da De La Reijstraat. Fotos da autora (2008).

Nirvana

Ano: $1927-1930$

Localização: Haia, Holanda

Ruas: Bernoordenhoutseweg; Wilen Witsenplein

Arquitetos: Jan Duiker; Jan Gerko Wiebenga

Número de unidades: 24

Tipos: Bloco de apartamentos com 07 andares; térreo com comércio.

Nirvana foi um dos primeiros edifícios altos de apartamentos da Holanda. Com sua construção, os arquitetos clamavam ter solucionado o problema de produção em massa de habitação, pois consideravam os edifícios em altura uma solução barata, higiênica, confortável e eficiente para a questão da moradia, assim apregoava o III CAIM. Originalmente, foram projetadas cinco torres com sete pavimentos, com quatro apartamentos por andar, com a circulação centralizada, e balcões conectando as cinco torres.

Contudo, devido ao fracasso imobiliário do empreendimento, somente uma torre foi construída e os balcões externos deram lugar no projeto à estocagem nas unidades menores (armários e prateleiras). Assim, edifício perdeu a leveza da fachada do desenho original. 


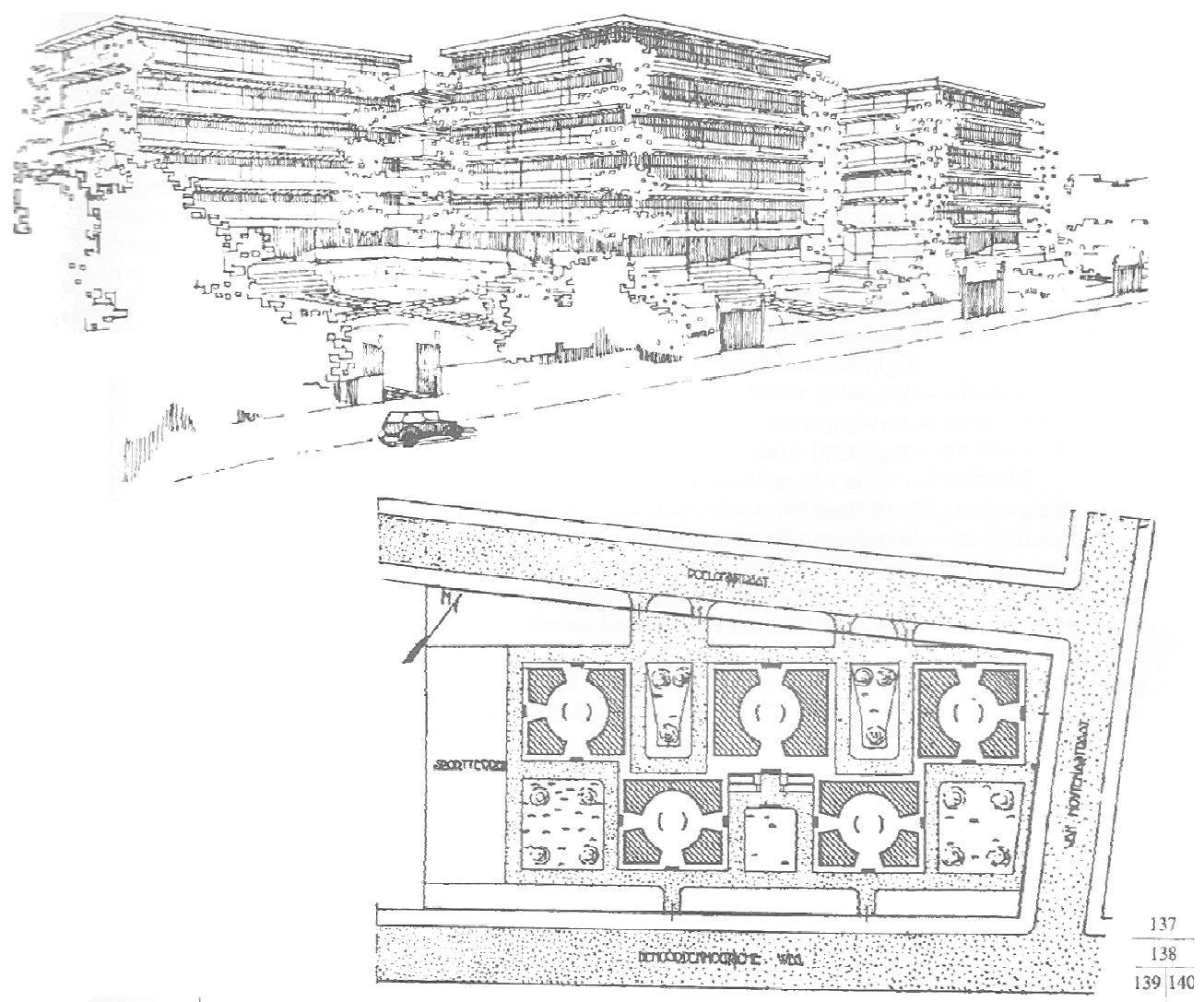

Figuras 87-88. Perspectiva e implantação do conjunto. Fonte: Grinberg, 1982, p.121.
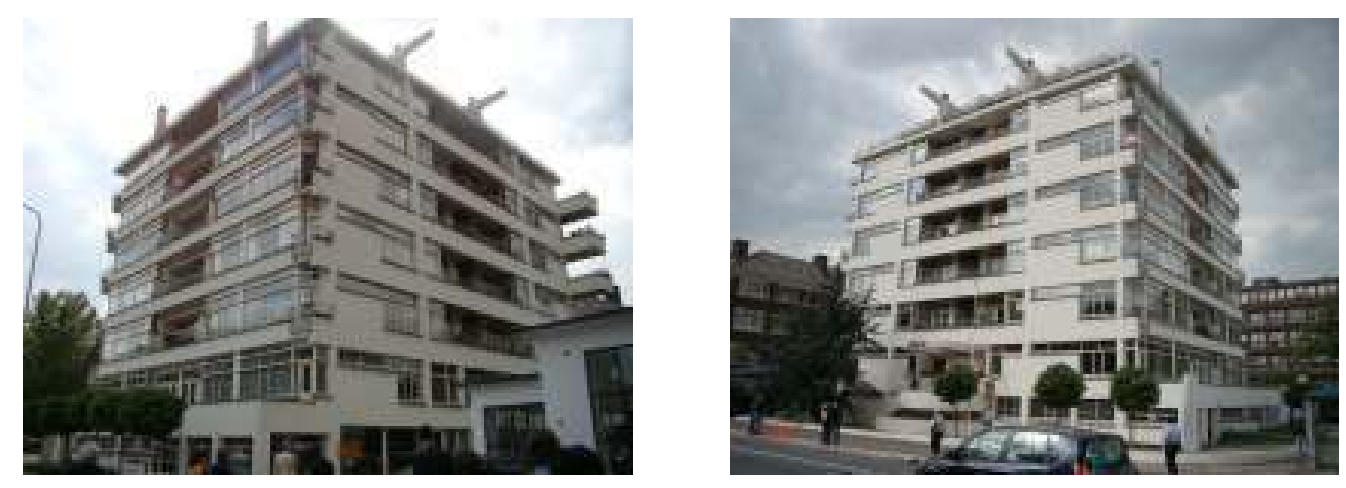

Figuras 89-90. Fotos externas do edifício. Notar as modificações do projeto original com o fechamento dos balcões com alvenaria e caixilhos. Fotos da autora (2008). 
Bergpolderflat

Ano: 1933-1934

Localização: Rotterdam, Holanda

Ruas: Borgesiusstraat

Arquitetos: W. Van Tijen; A. Briknman; L. C. Van der Vlugt

Número de unidades: 72 unidades

Área da unidade: $50,00 \mathrm{~m}^{2}$

Tipos: Bloco de apartamentos com 09 andares, corredor coletivo.

O edifício de apartamentos Bergpolder possui 09 andares com 08 apartamentos por andar. Esses apartamentos com apenas $50,00 \mathrm{~m}^{2}$ eram destinados para casais sem filhos ou famílias muito pequenas. A flexibilidade do apartamento é consegui com a criação de uma sala-dormitório com as dimensões mínimas permitidas. A entrada dos apartamentos se encontra na galeria de circulação coletiva que transpassa o lado leste do edifício.

Este foi o primeiro edifício com galeria de circulação externa construído na Holanda, demonstrando a possibilidade de uma edificação alta com qualidade, com uma implantação livre na quadra, desalinhada dos limites das quadras, tão característico da vizinhança.
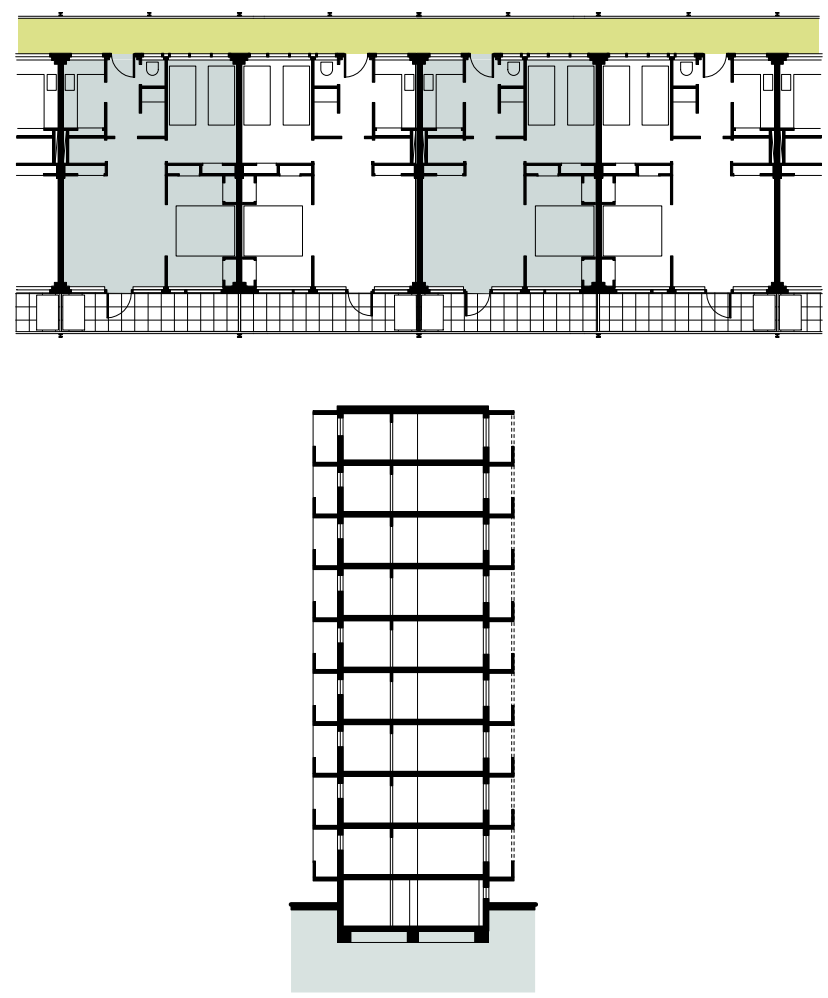

Figuras 91-92. Planta baixa das unidades e corte transversal do edifício. Fonte: FRENCH, 2009, CD-ROM. 

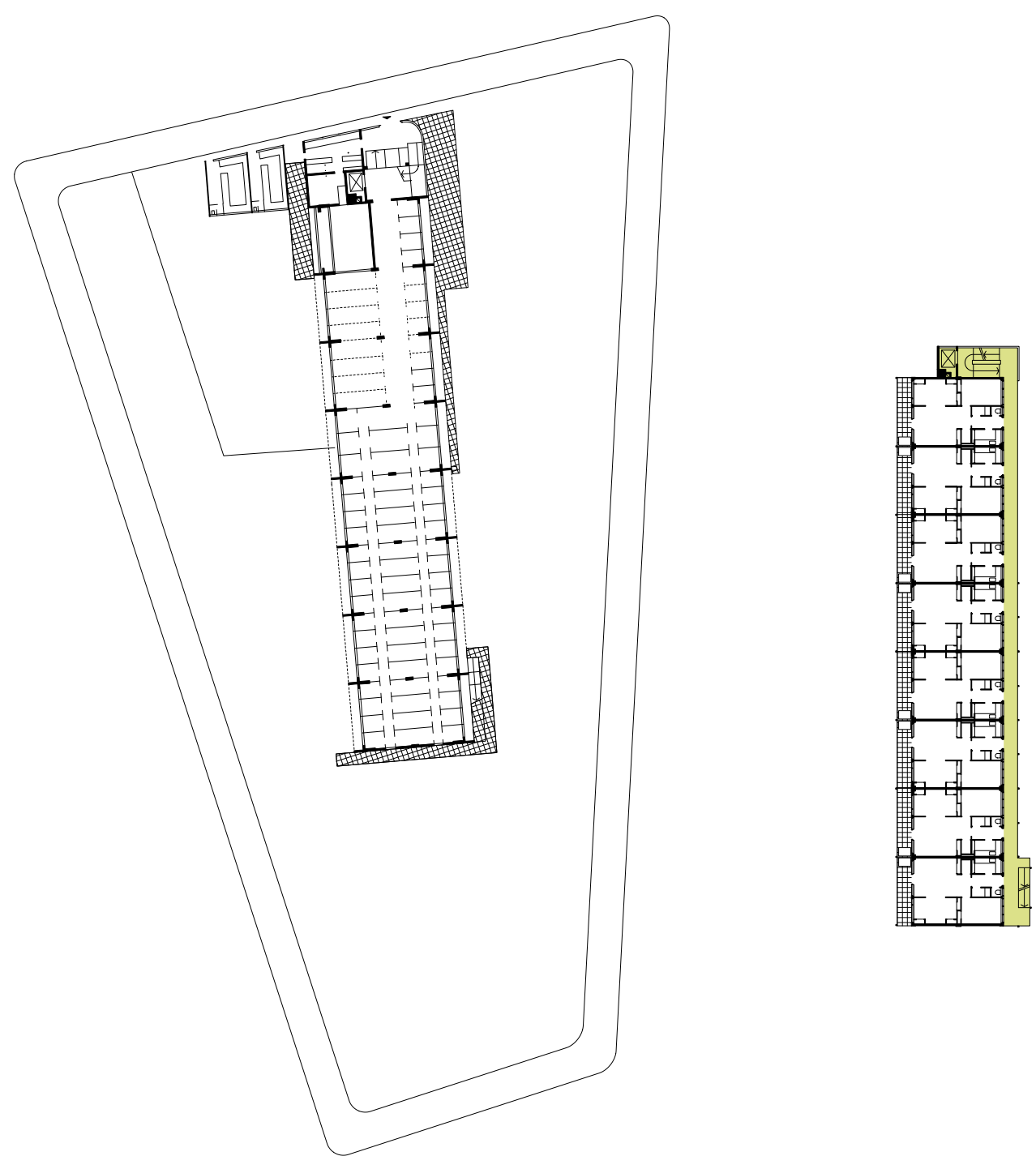

Figuras 93-94. Implantação e Pavimento tipo. Fonte: FRENCH, 2009, CD-ROM.
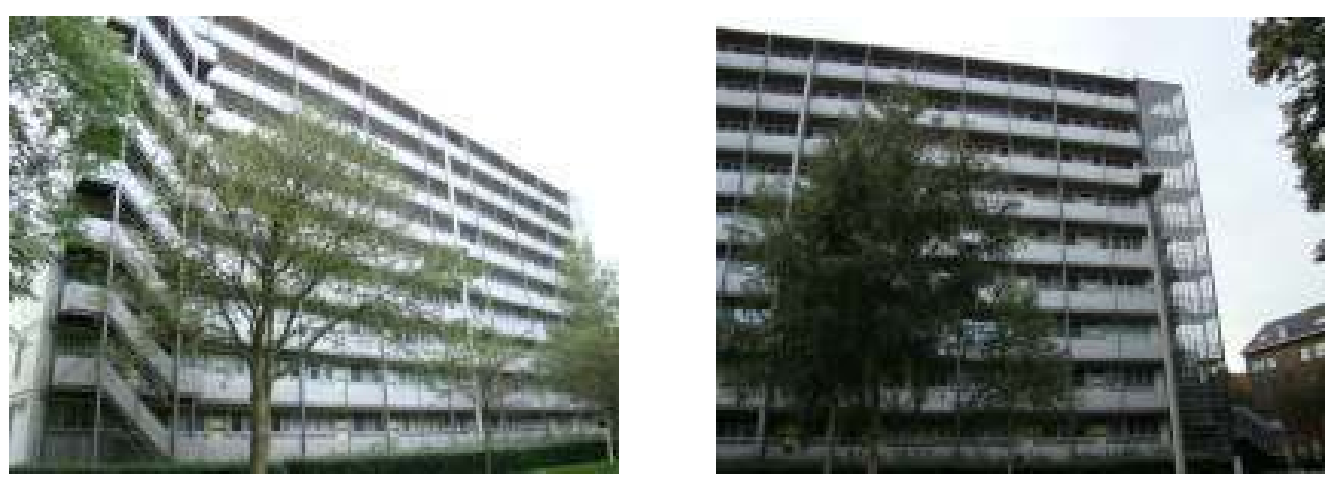

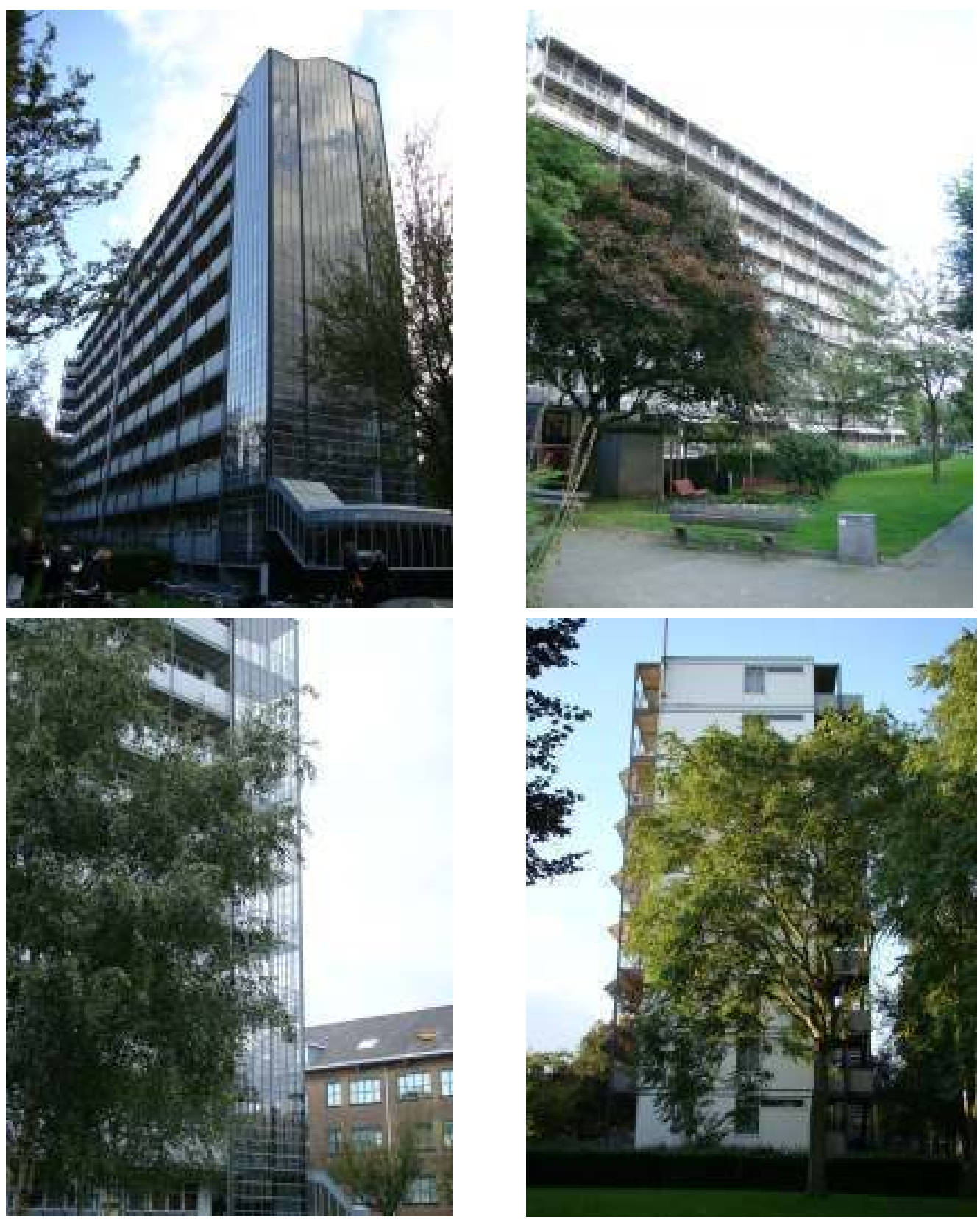

Figuras 95-100. Vistas externas do edifício. Detalhes da circulação vertical e horizontal que são os principais elementos da fachada. Fotos da autora (2008). 
Plano Geral de Expansão, Amsterdam (AUP) - Western Gargen City

Ano: 1934-1937

Localização: Amsterdam, Holanda

Planejamento urbano: Cornelis Van Eesteren

Arquitetos: vários (1928 -1935)

As cidades-jardins da área oeste de Amsterdam são partes do Plano Geral de Expansão para Amsterdam, elaborado por Cornelis Van Eesteren em 1934

Van Eesteren foi diretor do CIAM de 1930 até 1947, professor de planejamento urbano da Bauhaus e um dos criadores do conceito de "cidade funcional".

Neste Plano de Expansão, reconhecido internacionalmente, a primeira unidade de vizinhança construída foi Bos em Lommer. Uma das principais características do Plano foi a separação das funções: tráfego, moradia e trabalho, recreação e natureza. As moradias foram organizadas em blocos habitacionais baixos, médios e altos. Todo o complexo que abrange o AUP é um grande exercício de planejamento urbano, com os princípios da cidade-jardim como pano de fundo para a área de extensão a oeste de Amsterdã. Fazem parte desse plano de expansão os distritos de Harry Koningsbergerstraat, Slotermeer, Geuzenveld, Overtoomseveld e Slotervaart, desenvolvidos nos anos 50.

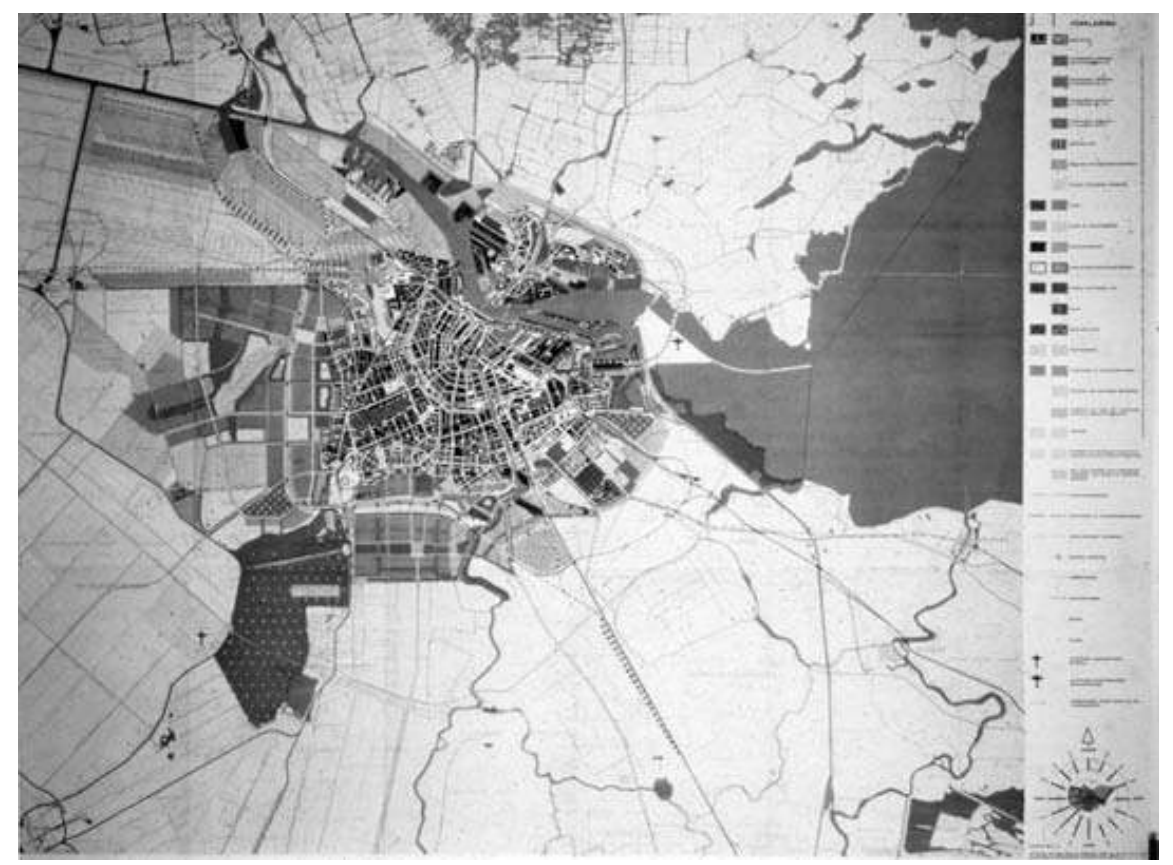

Figura 101. Plano Geral de Expansão para Amsterdam. Fonte: PANERAI, 2004. 
Landlust

Ano: 1932 - 1936

Localização: Amsterdam, Holanda

Ruas: Bestevaerstraat; Willen de Zwijgerlaan

Arquitetos: B. Merkelbach; C. J. Kasrten; P. Vorkink; G. Versteeg

Tipos: Blocos de apartamentos com 04 pavimentos.

Equipamentos: comércio, escola.
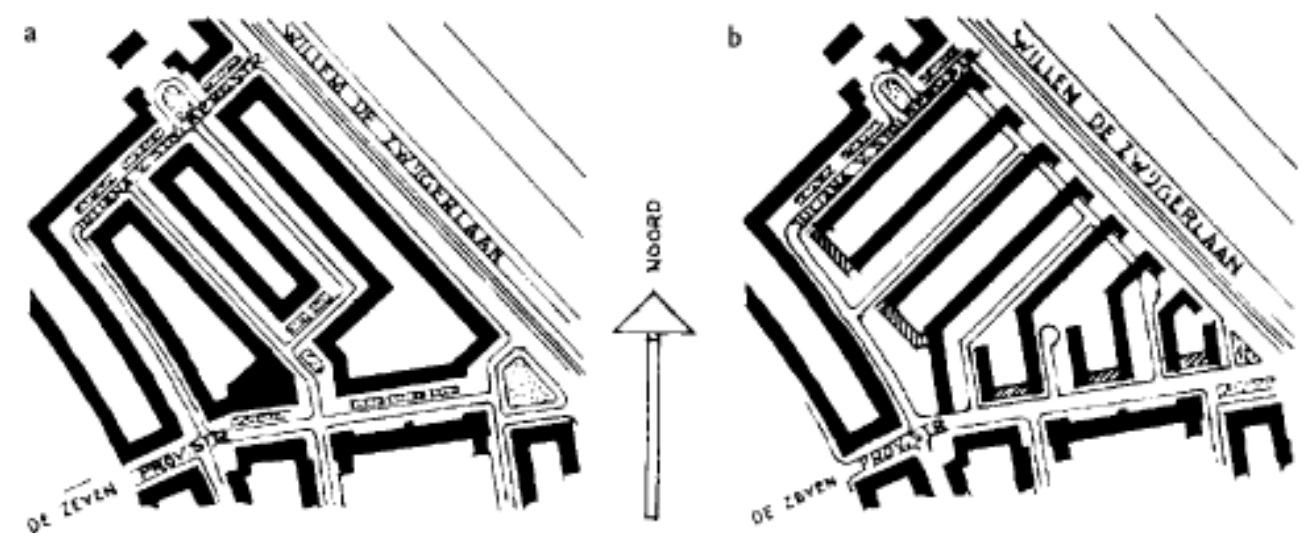

Figuras 102-3. Modificações na implantação do conjunto Landlust para atender aos preceitos racionalistas de abertura das quadras através de lâminas transversais a rua:

a. Projeto de Berlage (detalhe de plano geral de expansão oeste, 1925-6).

b. Projeto executado de Karsten, Merkelbach e colaboradores (1932-36). Segundo Panerai (2004:166), Giedion considerava esse projeto um progresso no planejamento de Amsterdam.
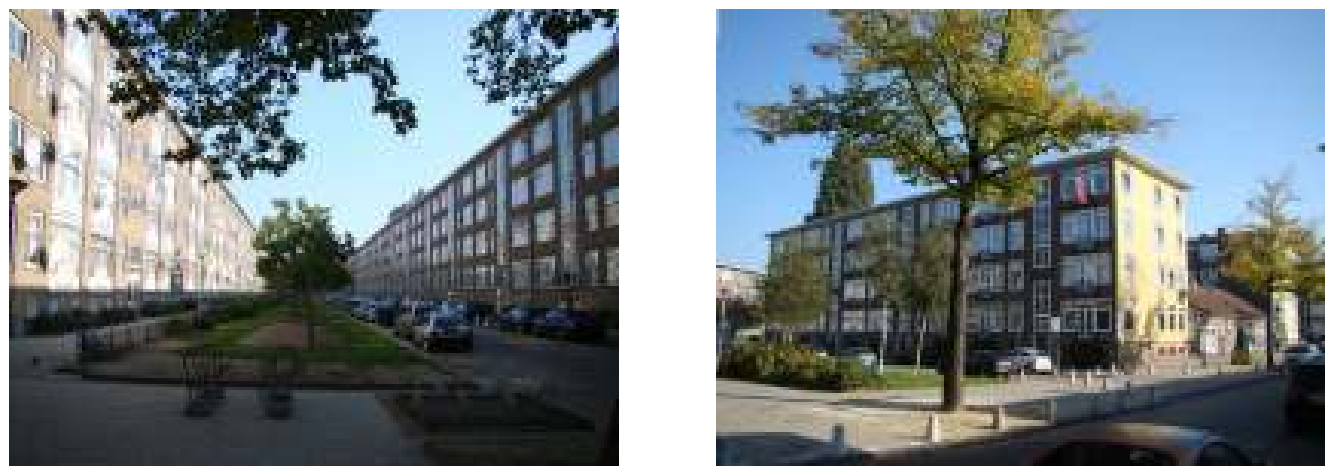

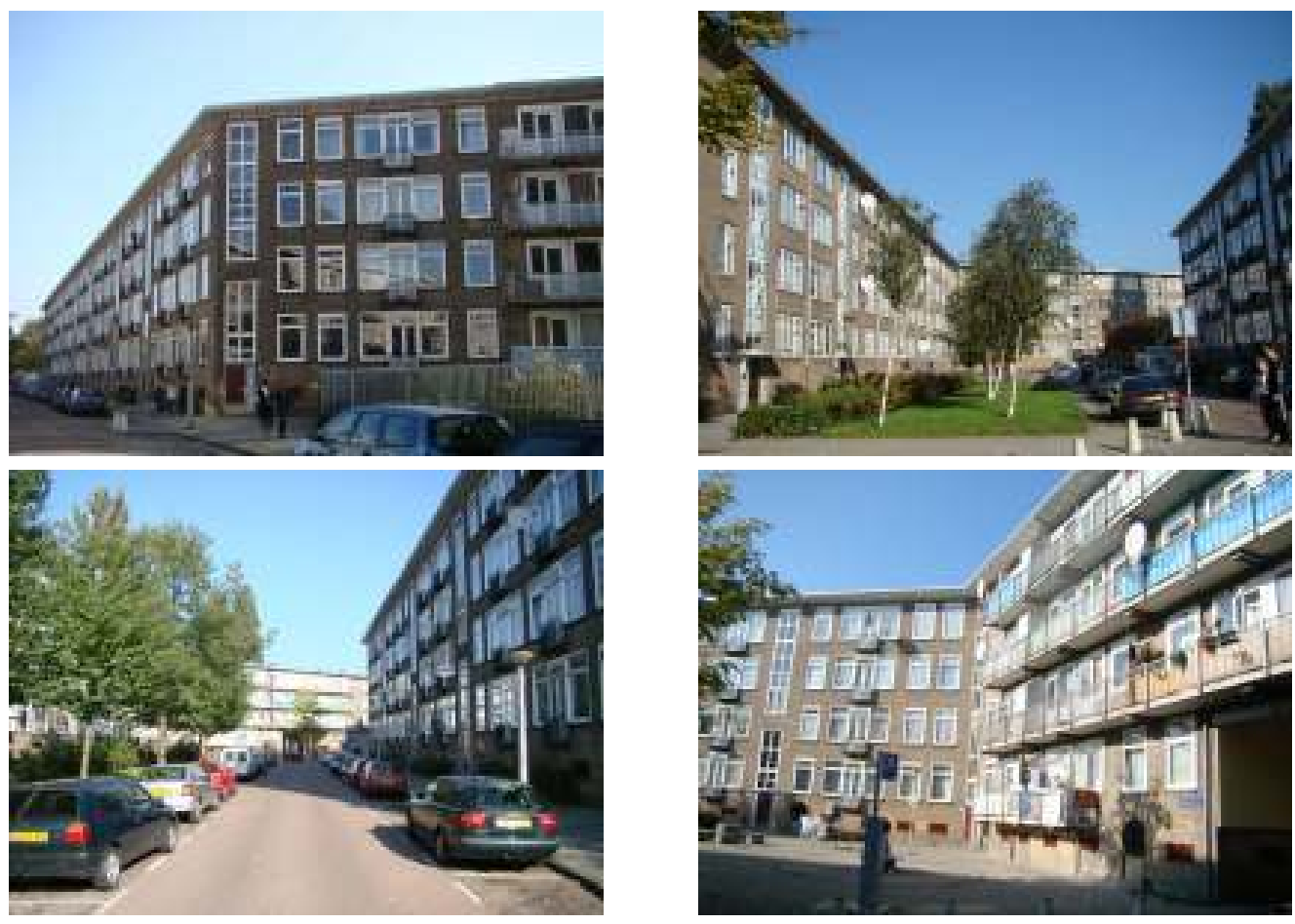

Figuras 104-9. Vistas externas do conjunto: ruas e áreas de lazer entre os blocos. Fotos da autora (2008). 


\subsubsection{O caso alemão}

Entre as cidades metropolitanas dos anos de 1920, a reforma habitacional de Berlim foi caracterizada pelo seu alto padrão arquitetônico e pela experimentação formal e morfológica da habitação social. Casas "descentes" e "higiênicas" foram construídas em larga escala para amplos setores da população.

No período entre o final da Primeira Guerra Mundial e a ascensão ao poder pela Nacional Socialista, em janeiro de 1933, Berlin se transformou em um centro metropolitano de arte moderna.

Depois da incorporação dos distritos mais afastados do centro urbano consolidado em 1920, a Grande Berlim se tornou umas maiores cidades do mundo com uma área de $876 \mathrm{~km}^{2}$; e com uma população de 3.86 milhões de habitantes, a terceira cidade mais populosa do mundo, atrás apenas de Nova lorque e Londres. Berlim era considerada a cidade industrial mais importante do continente europeu e o centro financeiro da Europa Central. A "cidade proeminente" de Martin Wagner (world-class city), na República de Weimar, foi um dos cenários mais importantes dos movimentos de vanguarda nas artes e do discurso cultural entre modernidade e tradição. Inúmeros artistas, pintores, músicos e atores viviam e trabalhavam na cidade.

Arquitetura e Urbanismo eram pontos chaves nesse movimento de reforma artística e cultural. "A Nova Berlim" - nome tirado de um periódico mensal "Monatsheft für die Probleme der Grossstadt" (Periódico Mensal dos problemas das grandes cidades) que foi fundado pelo diretor municipal de construção Martin Wagner, seguindo uma publicação similar de Ernst May em Frankfurt - considerava-se a capital da nova cultura construtiva. Mais do que qualquer outra região, Berlim ganhou a reputação de centro de vanguarda do mundo em arquitetura e planejamento urbano. Projetos Utópicos e Expressionistas, como as experiências sonhadoras de Bruno Taut (City Crown, Arquitetura Alpina, etc.) e a casa do povo de Hans Sharoun (Volkshaus-Entwurf), contribuíram para esta reputação, que foi também estimulada pelos projetos não construídos de concursos e ideias de projetos, como o arranha-céu de Mies van der Rohe e a radical proposta de reorganização urbana de Ludwig Hilberseimer "Grossstadtarchitektur" (arquitetura da grande cidade). 
Mas a reputação de Berlim como cidade como disseminadora da arquitetura e do urbanismo modernos foi estabelecida principalmente devido aos projetos de fato construídos. Alguns dos principais exemplos de arquitetura de vanguarda no mundo estão em Berlim, como a fábrica de turbinas AEG de Peter Behrens (1909), Fábrica Fagus de Gropius (1911), Exposição da Werkbund de Colonia (1914, obras de Bruno Taut, Max Taut, Erich Mendelson, Hans Poelzig e Henrich Straumer, depois da Primeira Guerra Mundial. Eles representavam uma ala estética radical da arquitetura alemã, e provocaram uma guinada funcional nos novos paradigmas para a construção de programas de edifícios de escritórios, fábricas e habitações. Juntamente com novos projetos programáticos para edifício escolares e outros equipamentos sociais como o "Strandbad Wannsee" (edificações à beira do lago) de Martin Wagner e Richard Ermisch, eles acentuaram a identidade visual da cidade com um aspecto cosmopolita e moderno.

Contudo, a maior contribuição de nova arquitetura para a criação de uma modernidade urbana e uma identidade social estava na construção de conjuntos habitacionais. Apesar da construção de casas de campo e mansões para a classe abastada, a ampla construção de conjuntos habitacionais para grande parte da população foi o principal resultado das reformas sociais e da arquitetura que tiveram lugar no período entre guerras. A dimensão e intenção do debate de arquitetura e urbanismo proposto naquele período eram mais apropriadamente expressadas nas construções cooperativas de conjuntos habitacionais.

A construção residencial teve um rápido crescimento em Berlim à partir de meados de 1920, especialmente sob o regime Social Democrata e do diretor municipal de planejamento Martin Wagner, atuante entre os anos de 1925 e1933 - um extraordinário organizador e advogado das reformas políticas. Estas importantes realizações foram o resultado da combinação sistemática da criação de instrumentos para intervenção estatal e subsídios na construção habitacional, ao lado de uma nova legislação para a habitação. A criação de companhias habitacionais privadas e companhias sem fins lucrativos de habitação foram amplamente incentivadas pelas municipalidades, não apenas em Berlim, e isto tornou possível a implementação e execução de um programa habitacional sem precedentes na Alemanha.

O fim da crise inflacionária que assolou a Alemanha em 1923, e a estabilização do mercado, propiciou o financiamento estatal (através de uma 
diversidade de agências federais, estaduais e municiais) de diversos serviços públicos, como escolas, equipamento de saúde, infraestrutura urbana e habitação, principalmente.

A demanda por habitação na Alemanha, como aponta Müller (1968), foi fruto da migração do campo para a cidade provocada pelo crescimento da indústria armamentista e outros setores, além da modificação da estrutura familiar urbana: famílias menores em maior número. Segundo a autora, o controle dos aluguéis imposto entre os anos de 1917 e 1922, afastou a iniciativa privada da produção habitacional, como ocorreu em todas as partes do mundo em que o controle foi imposto, gerando assim mais um agravante para a falta de moradia nas cidades. Como resposta, o governo foi obrigado a assumir a responsabilidade pela construção de moradia: entre os poucos anos de pico de construção da República de Weimar, fundos públicos foram usados na construção de $70 \%$ de todas as habitações edificadas na Alemanha.

A origem desse programa de habitação tem raízes no regime prussiano, que em face da crise habitacional no período pós guerra, promulgou uma lei no ano de 1918 baseada no "direito de cada cidadão de usufruir de uma habitação por seus próprios meios" 1 . A lei estabelecia um programa de empréstimos estatais para as cooperativas de construção, conhecidas como gemeinnützige Baugesellschaften $^{2}$ e exigia o estabelecimento de agências municipais e estatais (Wohnungsfüsorgegesellschaften) com o intuito de planejar e fiscalizar o auxílio para construção de moradias. Após a Revolução, o direito à moradia foi incorporado à nova Constituição e um standard mínimo para habitações financiadas com recursos públicos foi estabelecido por legislações específicas.

No ano de 1924 , após a estabilização da economia, uma taxa de $15 \%$ foi instituída, não sem grandes embates políticos, sobre os aluguéis das habitações já construídas. Essa taxa alavancou fundos federais para a construção habitacional via empréstimo para as cooperativas. Grande parte desses empréstimos era realizada a juros baixos, caracterizando um subsídio estatal.

1 LANE, 1968, p.88.

2 As cooperativas, operantes desde o século XIX, eram organizações do tipo limited-profits, que tentaram conter os efeitos da especulação privada no mercado imobiliário através da compra de grandes porções de terras além dos limites urbanos para a construção de moradia para venda ou aluguel aos seus associados. Idem, p.89 
A legislação sobre a provisão habitacional imposta logo após a I Guerra Mundial fomentava o crescimento das cooperativas de habitação e o seu estreito relacionamento com as administrações municipais:

“Municipal building administration of course had to work closely within the building societies on questions of land purchase and general planning, but in addition many cities won almost completely control over their local building societies by buying shares in them or by founding their own. In such cases it was the municipal administration which took the initiative in matter of design.",3

Somente 9.000 unidades habitacionais subsidiadas de aluguel foram construídas no período mais crítico após a primeira guerra mundial, de 1919 à 1923, enquanto que 130.000 unidades foram concluídas entre 1924 e 1930.

Em Berlim, Martin Wagner, diretor municipal de planejamento, desenvolveu um moderno conceito de desenho urbano para a produção em massa de habitação, baseado no modelo de segregação funcional, apontado por ele como solução para superar os contrastes entre a parte central da cidade e a periferia, que eram bastante marcantes na configuração da cidade. Distritos residenciais altamente densos com uma estrutura aberta e amplas áreas verdes foram construídos para preencher os vazios da estrutura urbana existente da Berlim expandida (Schillerpark Estate, Carl Leigen Estate), e na periferia foram construídos grandes conjuntos habitacionais numa configuração de "parques" urbanos (Hufeisensiedlung, Weisse Stadt, Siemensstadt) (HASPEL \& JAEGGI, 2007).

Os conjuntos habitacionais de Berlim foram amplamente divulgados e reconhecidos nos meios arquitetônicos entre seus contemporâneos, a também adquiriram um valor emblemático na discussão sobre a história da arquitetura do século XX. Em todas as principais publicações sobre a arquitetura eles aparecem ao lado da Bauhaus e da Das Neue Frankfurt como principais

\footnotetext{
3 Idem, ibidem.
} 
exemplos do modernismo em arquitetura e planejamento urbano, apesar das tentativas de Le Corbusier, Gledson e Gropius de anularem essas experiências nos Cimas. É marcante a ausência desses projetos nas publicações referentes aos II e III Cimas, como demonstrado no item anterior. 
Siedlung Schillerpark

Ano: 1924-1930

Localização: Berlim

Ruas: Barfusstrasse, Bristolstrasse, Corker Strasse, Dubliner Strasse, Oxforder Strasse, Windsorer Strasse

Área: 4,6 ha

Planejamento urbano: Bruno Taut

Arquitetos: Bruno Taut, Wiederaufbau/Komplettierung durch Max Taut (1951) und Hans Hoffmann (1953 bis 1957)

Projeto áreas livres: provavelmente Bruno Taut, mas iniciado em 1954 por Walter Rossow

Número de unidades: 303

Tipos: blocos de quatro pavimentos, com escadas para cada 02 apartamentos por andar.

O conjunto Schillerpark foi o primeiro projeto de apartamentos construídos por uma cooperativa em Berlim que incorporou características da Nova Arquitetura.

Os blocos entre as Dubliner Strasse e a Oxford Strasse são exemplos mais pertinentes desse novo arranjo habitacional. A segunda etapa do conjunto, á sudeste da Oxford Strasse, permaneceu inacabada devido à grande depressão econômica de 1929.

Os blocos da primeira etapa foram agenciados pelo arquiteto sem seguir necessariamente os ângulos retos do bloco laminar, procurando antes se acomodar aos limites do terreno. Grandes jardins foram deixados entre os blocos, que foram implantados distanciados entre si, como numa quadra aberta com o centro destinado aos moradores. A circulação de carros ocorre apenas já existente quando da construção do conjunto.

Taut utilizou detalhes expressionistas, como pilares de concreto que ultrapassam os limites da volumetria, e aberturas horizontais e balanços pronunciados nos balcões. Estes elementos contrastam com os blocos perfeitamente prismáticos e geometrizados. Outro efeito plástico notável na composição do edifício está no uso de alvenaria aparente em contraste com o vidro e as esquadrias e detalhes brancos nas fachadas.

Avariado pela II Guerra Mundial, o conjunto apenas foi restaurado, como monumento, em 1991. 


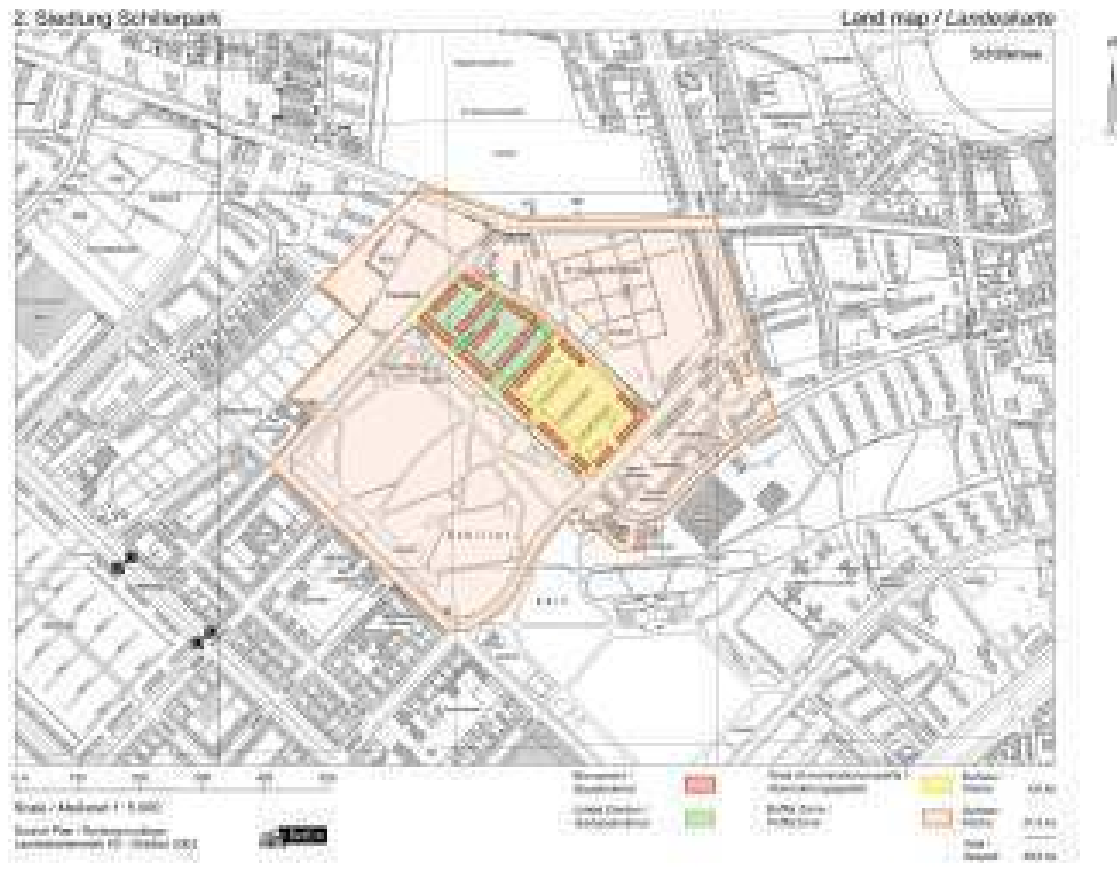

Figura 110. Mapa de situação do conjunto. Fonte: http://www.stadtentwicklung.berlin.de
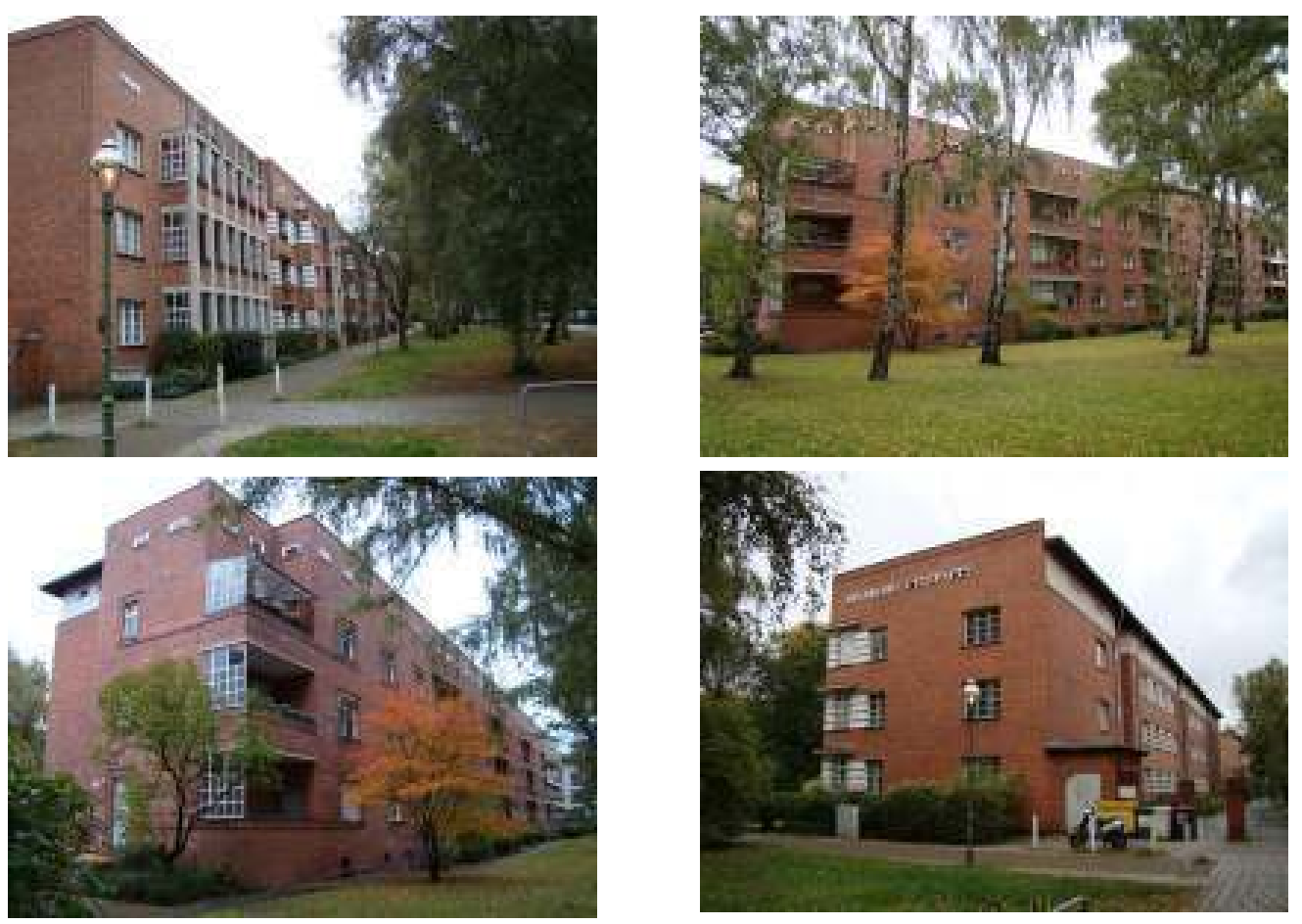

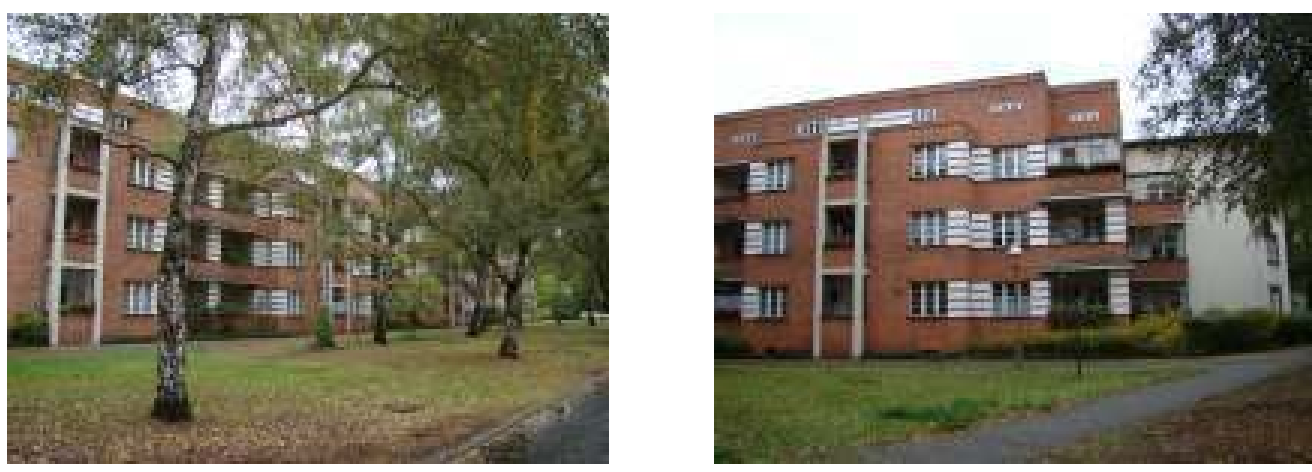

Figuras 111-16. Vistas externas do conjunto: ruas e áreas verdes entre os blocos. Fotos da autora (2008).

Hufeisensiedlung - Britz

Ano: $1925-1930$

Localização: Berlim

Ruas: Buschkrugallee, Dörchläuchtingstrasse, Fritz-Reuter-Allee,Gielower Strasse, Grüner Weg, Hüsung,Jochen-Nüssler-Strasse, Liningstrasse, LowiseReuter-Ring, Miningstrasse, Parchimer Allee, Paster-Behrens-Strasse, Stavenhagener Strasse, Talberger Strasse.

Área: 37,1 ha

Planejamento urbano: Bruno Taut, Martin Wagner

Arquitetos: Bruno Taut, Martin Wagner

Paisagistas: Leberecht Migge, Ottokar Wagler

Número de unidades: 1.963 , sendo 472 unidades unifamiliares

Tipos: blocos de três pavimentos com escadas para cada dois apartamentos; sobrados em fileira.

Durante a crítica falta de moradia enfrentada pela Alemanha depois de I Guerra Mundial, várias cooperativas e associações de habitação, associações de comércio e associações públicas de moradia foram formadas para a construção de habitação econômica em Berlim.

Uma das maiores destas associações, Gehag (Serviço público de moradia, economia e construção civil), foi fundada em 1.919 para construir moradia barata para seus membros.

Encarregada de um programa progressivo para habitação moderna, a instituição procurou a colaboração de arquitetos na nova escola moderna e, em 1924, Bruno Taut foi apontado como seu arquiteto principal. 
Taut, conhecido mundialmente por seus ensaios conceituais e por seu Pavilhão de Vidro Expressionista na mostra da Werkbund, Colônia, 1914, esteve envolvido no desenvolvimento da ideia de Gross-Siedlungen (grande comunidade residencial) como conceito para a construção de grandes complexos residências do tipo cidades-jardim, e teve também envolvimento na construção do complexo tipo cidade-jardim em Magdeburg, em 1912-15.

Construído na região sul da cidade, afastada do centro de Berlim, BritzHufeisensiedlung - literalmente "conjunto ferradura", nomeado assim devido à forma de ferradura do bloco interno de apartamentos que foi construído em torno de uma lagoa natural - foi um dos primeiros Gross-siedlungs a serem construídos em Berlim.

Junto com outro conjunto de Taut, Onkel-Toms Hutte, construído em 1926, este é considerado um dos grandes exemplos da aplicação das ideias do movimento cidade-jardim (Gartenstadtgesellschaft) associadas à arquitetura funcionalista.

A ferradura, que é o centro urbano do complexo residencial Britz, é um famoso ícone das construções residenciais dos anos 20. O complexo foi projetado em 1925 por Bruno Taut e Martin Wagner e foi o primeiro grande conjunto residencial da Alemanha, com mais de 1.000 habitações. Sob o nome expressivo de Horseshoe Estate, ela se tornou uma referência para o novo desenvolvimento social urbano, que objetivava criar habitações decentes, salutares e atraentes para amplos setores da população.

O Horseshoe Estate foi o primeiro conjunto habitacional modelo da associação beneficente de moradias "Gemcinnutzigen Heimstatten, Spar- und Bau-Aktiengesellschaft" (GEHAG), que foi fundada por Social-Democratas e associações de livre comércio. A GEHAG era parte de uma rede de organizações beneficentes de moradia, iniciada por Martin Wagner, que em trabalho em equipe muito próximo com seu arquiteto chefe, Bruno Taut, tornouse a maior desenvolvedora de um amplo modelo residencial em Berlim. Com a Horseshoe Estate, as cooperativas e empresas da associação de comércio associadas objetivavam criar uma alternativa ao empreendimento privado e um sistema que viesse a ser mais eficiente que as políticas de construções residenciais do Estado.

A implantação do conjunto, projetada por Taut e Wagner constitui-se num desenho urbano bastante marcante. Nela, Taut refinou o método de projeto que 
ele havia testado em outro conjunto bastante conhecido, Falkenberg: a interação da simetria e assimetria nos conjuntos de prédios e o estabelecimento das ruas, os deslocamentos axiais imperceptíveis e o uso fundamental da cor como elemento espacial de projeto. A inovação política e organizacional desse grande complexo residencial cooperativo foi fortemente expressada na arquitetura da forma definida de ferradura ao centro do conjunto. Isso marcou a racionalidade e a crença no progresso, inerentes ao novo estilo de construção e a coletividade e solidariedade do ideal cooperativo. Do lado leste aberto da ferradura, Taut criou uma entrada impressionante para o complexo, com uma larga escadaria que leva à área verde, que é abraçada pelos prédios. Esse é o desenho urbano chave do conjunto todo.

Enquanto Bruno Taut e Martin Wagner usavam a padronização na tentativa de racionalizar a construção de conjuntos residenciais, diminuindo, assim, os custos de construção, Leberecht Migge defendia que esse modelo moderno de trabalho deveria também ser aplicado também à criação de jardins no complexo. Ele propôs que os jardins deveriam ser padronizados em tantas partes quanto possível, e então ser construídos utilizando-se métodos de produção em massa, usando metodologias organizacionais otimizadas no processo de trabalho (HASPEL\&JAEGGI, 2007, p.52).

No Horseshoe Estate, Taut criou uma combinação artística da ideia dos jardins na história do desenho urbano, e o novo conceito de um grande complexo residencial. Ao passo que a ferradura, um prédio residencial curvo de 360 metros de comprimento e teto, com uma planta baixa replicada em série, representa a imagem do amplo conjunto com um conceito de paisagem natural incorporado, a praça em formato de losango ao oeste ("Hiisung"), com seus telhados, cumeeiras, e árvores ao centro, representa um motivo característico de jardim na cidade. Ela pode ser relacionada ao Akazienhof, em Falkenberg Garden City de Taut, e também aos vilarejos no leste da Alemanha, que estão agrupadas ao redor de uma quadra central (HASPEL\&JAEGGI, 2007, p.54).

Taut introduziu as vantagens e facilidades da cidade-jardim aos padrões mais abstratos de grandes conjuntos residenciais, e utilizou um arranjo entre blocos, marquises e recuos de tal modo a criar uma distinção clara entre áreas privadas, semiprivadas e públicas. Em Britz, longe dos distritos populosos e de cortiços apinhados, Taut foi capaz de implementar sua visão de projeto urbano aberto com muita vegetação numa escala maior quem em Falkenberg. A 
demanda artística para a modernidade e racionalidade das formas e a demanda social por iluminação, ar e luz do sol foram igualmente satisfeitas aqui.

O conjunto residencial de Britz foi construído em seis fases, de 1925 a 1930, num terreno medindo mais de 29 hectares na antiga zona rural de Britz, e forneceu 1.963 novas unidades residenciais. O paisagista Lebe-recht Migge projetou os jardins públicos e privados, e todos os espaços abertos.

A integração entre arquitetura e topografia é mais óbvia no símbolo central do complexo: a ferradura. Ao redor do lago, situado numa cavidade central do terreno, Taut colocou um prédio de três andares com 360 metros de comprimento, em forma de ferradura, formando um amplo espaço verde comunitário aberto. As salas sociais e varandas/sacadas se abrem para o lago, e todas as entradas principais estão do outro lado da ferradura. Existe outro complexo com formato simbólico a oeste: sobrados com marquises agrupadas ao redor de um jardim residencial em forma de losango. As duas estruturas estão dispostas uma próxima à outra, e elas formam os arranjos centrais das duas primeiras fases da construção do conjunto.

Ruas residenciais estreitas levam da ferradura ao sul e ao norte com casas simples e baixas com terraços que possuem longos jardins projetados. Taut posicionou cada fileira de casas em um sistema delicadamente estruturado com desvios no eixo do alinhamento da rua, layouts assimétricos e vazios. Seu projeto é uma demonstração clara de que a limitação a dois tipos de construção, totalizando 472 sobrados, não leva automaticamente à repetição monótona. Cada rua tem sua característica própria, criada pela projeção ou afastamento de grupos de sobrados, o que cria uma sensação espacial de alargamento ou estreitamento bastante dinâmica.

Mais ainda que em Falkenberg, as cores definem a disposição espacial e o projeto urbano no conjunto de Britz. Por exemplo: o branco e o azul marcam a forma fechada da ferradura, mas dentro dos prédios somente as paredes internas das varandas, os parapeitos e nichos de escadarias são azuis. Nas fileiras dos sobrados com marquises, Taut não manteve uma coloração uniforme nos blocos. Usando texturas numa variação de cores fortes, como vermelho, amarelo, branco ou azul, ele deu uma identidade visual ao contexto urbano e espacial. Assim, cada fileira ou grupo de casas teria suas próprias cores e cada rua teria sua própria identidade de cores. 
Do outro lado do conjunto residencial DeGeWo (Deutsche Gesellschaft zur Forderung des Wohnungsbaues), mais tradicional, construído ao longo da Fntz-Reuter-Allee segundo projetos dos arquitetos Engelmann \& Fangmeyer, Taut construiu uma estrutura contrastante consistindo em dois blocos alongados ao longo da rua, contendo 30 prédios idênticos de três andares com nichos de escadas projetados tipo torres. Esses prédios possuem suas fachadas vermelhosangue, que lhes renderam o nome de "Red Front" (Fronte Vermelho) (HASPEL \& JAEGGI, 2007).

A porção norte do conjunto é formada pela longa construção residencial ao longo da Stavenhagener Strasse, projetada por Martin Wagner. Do outro lado, reservatórios duplos azuis contrastam com a fachada branca defronte à vegetação das florestas de acácias e existem longos jardins frontais que levam da rua às escadarias em semicírculo. A longa fachada frontal branca é emoldurada por edificações amarelas.

Longe da ferradura, as fases III a $\mathrm{V}$ da construção foram erguidas ao longo da Buschkrugallee e da Parchimer Allee de 1927-29. Consistindo totalmente de blocos laminares, e a última fase da construção, fase $\mathrm{VI}$, foi construída em 1929/30 - novamente como um desenvolvimento misto da pequenas casas e blocos de apartamentos. As novas fases de construção refletem os problemas econômicos no final dos anos 20 .

Inicialmente, a área destinada foi generosamente mensurada, mas à partir de 1926 ela foi ficando progressivamente menor. Como consequência, as fileiras de casas da última fase, dos anos 30 , são relativamente mais próximas umas das outras, sem nenhum espaço amplo entre as ruas. Isso significou que o plano visionário de Taut para a expansão do complexo depois da fase VI não seria mais possível - ele vislumbrava um jardim independente com 2.000 residências. Assim, o amplo conjunto de Britz não possui um padrão homogêneo de habitações, ele consiste de três grandes seções espaciais do conjunto "autocontidas" (HASPEL\&JAEGGI, 2007, p.56).

$\mathrm{Na}$ última fase da construção que foi erguida ao sul da Parchimer Allee em 1929/30, Taut tinha menos terreno à sua disposição. A alternativa foi colocar sobrados e blocos em dois grupos de sete prédios alongados paralelos ao longo de ambos os lados da Gielower Strasse. Aqui, como nas duas primeiras fases da construção, prédios de apartamento mais altos, de três andares englobam uma área interna consistindo de edificações mais baixas, de dois andares, com 
marquises. Na In Parchimer Allee e na Gielower Strasse, Taut adicionou um prédio final que se originava no final da fileira e se estendia para dentro das áreas de vegetação e ruas, evitando, assim, os vazios abertos que são geralmente vistos ao final das fileiras nos conjuntos de casas ou prédios. Os blocos finais do lado mais largo e movimentado da Parchimer Allee são prédios de três andares, e seu colorido de um vermelho profundo cria uma separação sólida entre a rua pública e o interior dessa área do complexo.

Num período de apenas cinco anos, um distrito residencial com 1.963 unidades residenciais para mais de 5000 pessoas foi criado e concluído. Nenhum material ou método moderno de construção foi utilizado em Britz. Ao contrário, o objetivo foi o de se utilizar métodos convencionais de construção e reduzir os custos por meio da limitação à pouquíssimos tipos de plantas baixas usando componentes padronizados, e, ao mesmo tempo, coordenação da obra sem interrupções pelo uso de organização sistemática, e o uso de máquinas modernas.

O desenho urbano de Bruno Taut levou em conta a interação da arquitetura residencial e os espaços verdes públicos e privados, de uma maneira exemplar, além da integração de um lago existente como elemento de definição para a parte central do complexo. O projeto procurou criar condições de vida iguais para todos os seus moradores; cada habitação tem uma escada ou sacada, e cada escada ou sacada fica de frente para os jardins e funciona como um elo entre o interior e o exterior. Cada unidade unifamiliar conta com jardins acompanhando toda a testada da unidade, e o espaço de áreas verdes (quintais) entre as fileiras de casas têm sempre entre 40 e 60 metros de largura.

O espaço verde dentro da ferradura é subdividido em uma área pública no centro e jardins privados próximo ao prédio. Essas áreas são separadas por uma cerca viva e um caminho público em volta do lago ao centro do complexo. Taut e Mige vislumbraram um lago estritamente fechado com largos degraus ao ar livre. Em suas plantas originais ele deveria ser sem árvores e fechado por arbustos floridos, mas hoje o lago é dominado por árvores maduras (HASPEL\&JAEGGI, 2007, p.56). Para assegurar a uniformidade máxima dos jardins, que são mantidos pelos próprios moradores, jardins-modelo foram fornecidos pelos paisagistas.

Elementos importantes, tais como os jardins frontais, os jardins cultivados privados e as avenidas de árvores ao longo das ruas foram, em sua maior parte, 
uniformes no desenho. Espaços para lazer comunitários estão harmoniosamente integrados à estrutura geral do complexo.

O complexo de Britz sofreu apenas pequenos danos na Guerra, e por isso todos os setores do conjunto ainda guardam uma grande proporção de seu tecido original. A estrutura misturada característica do complexo, com blocos e sobrados foi preservada, sem ampliações ou novos prédios.

As unidades unifamiliares, com seus longos e estreitos jardins, também foram preservados com sua aparência original. A fachada original com molduras de tijolos, portas-janela e os planos dos telhados estão preservados por toda parte como as características principais do projeto. Hoje o conjunto é tombado pela UNESCO, ao lado de outros seis exemplares do programa habitacional da República de Weimar.

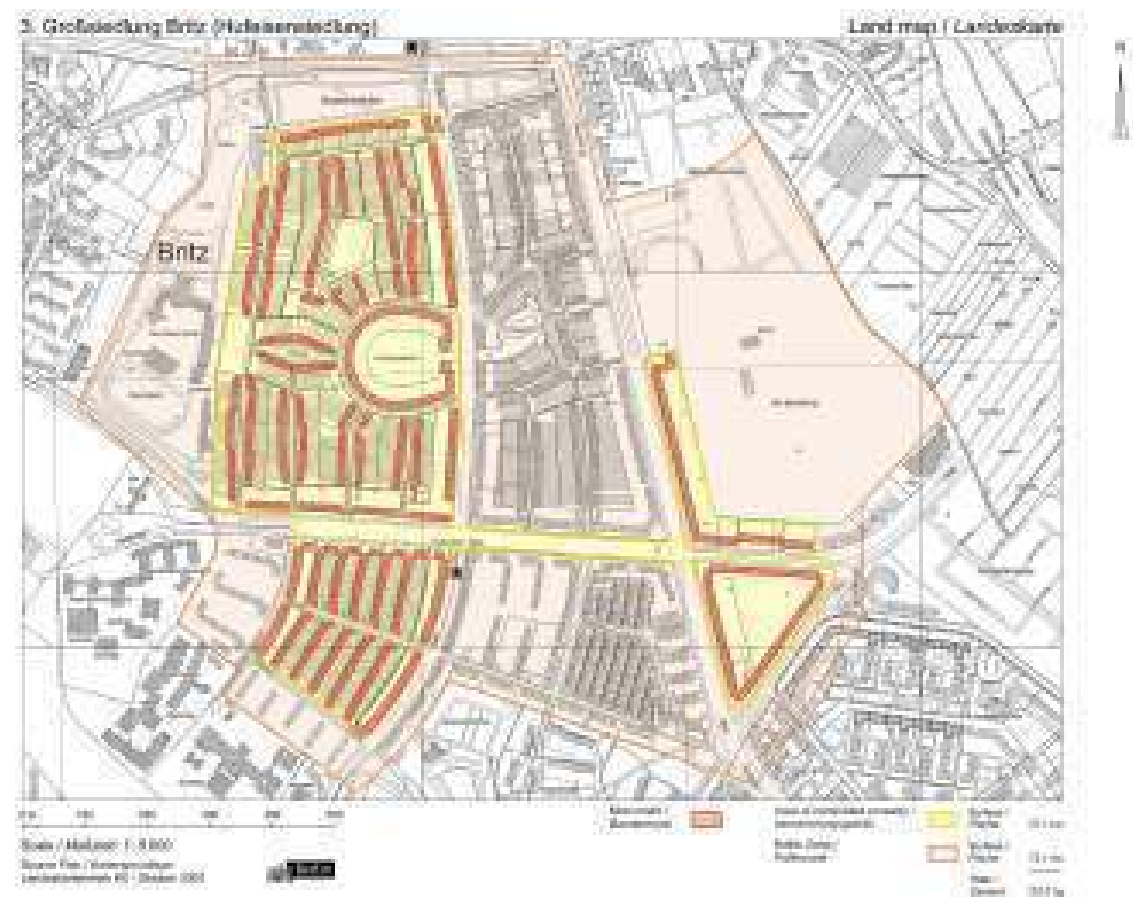

Figura 117. Mapa de situação da área tombada pela UNESCO. Fonte: http://www.stadtentwicklung.berlin.de 

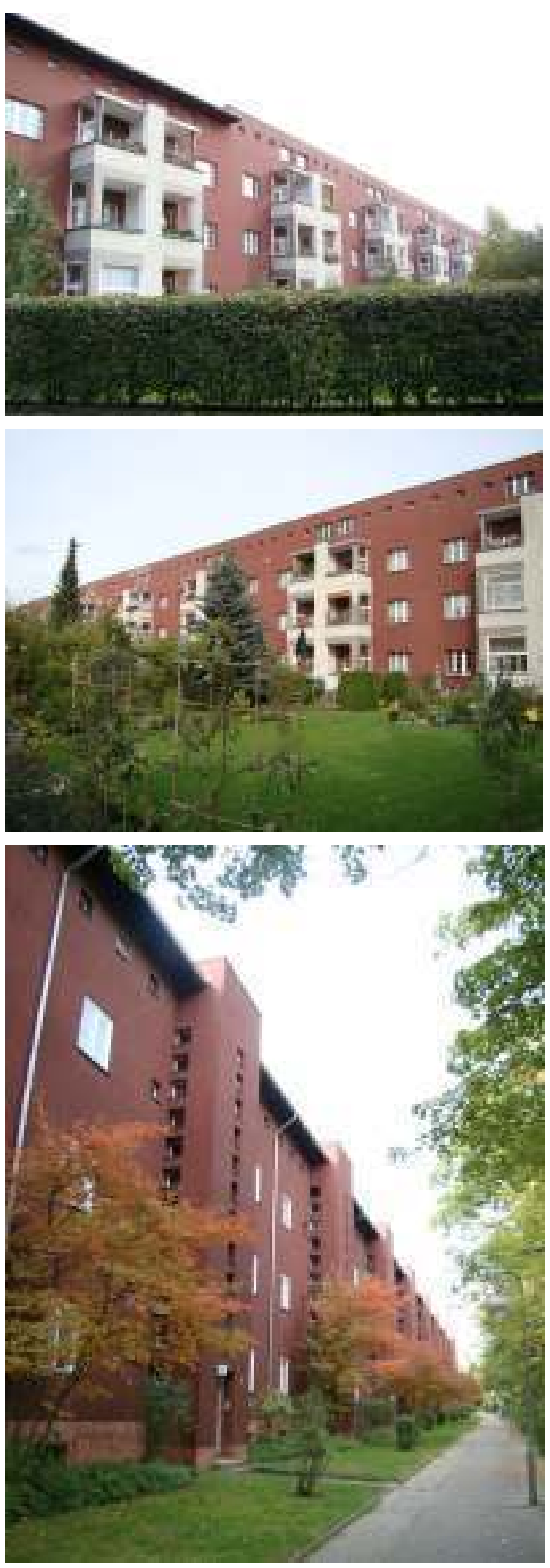

Figuras 118-23. Vista externa do Rot Front e dos sobrados. Fotos da autora (2008).
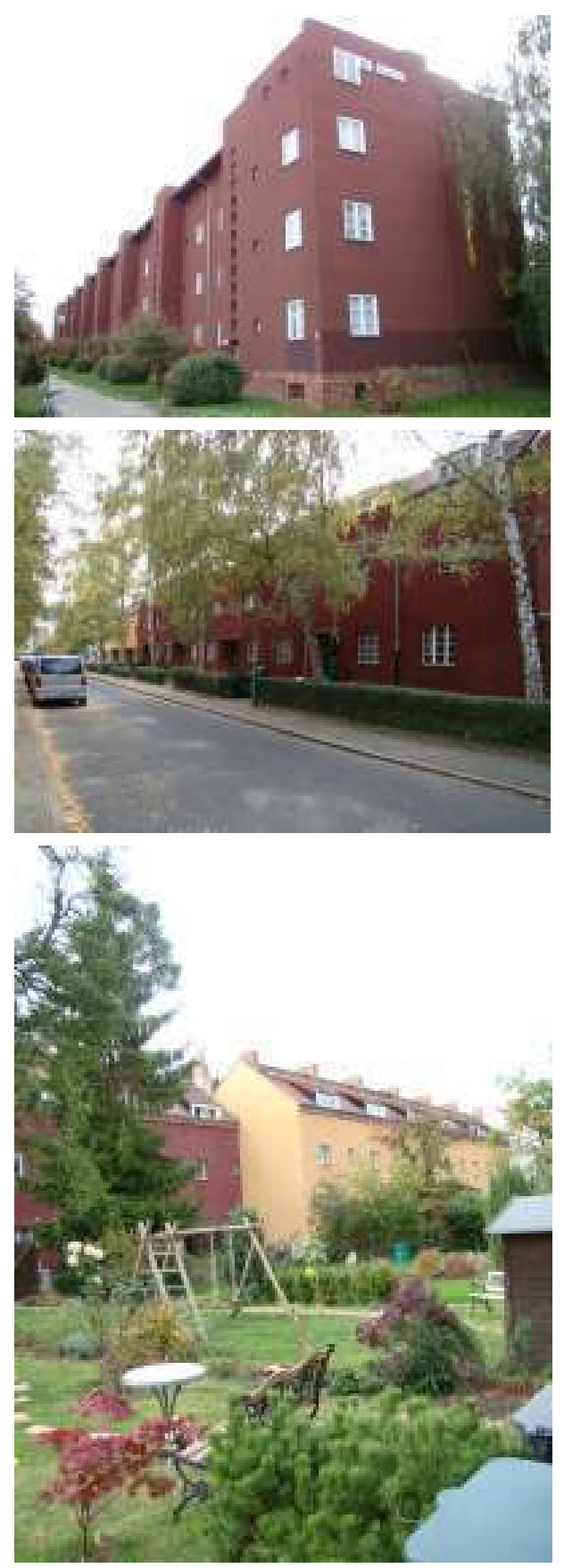

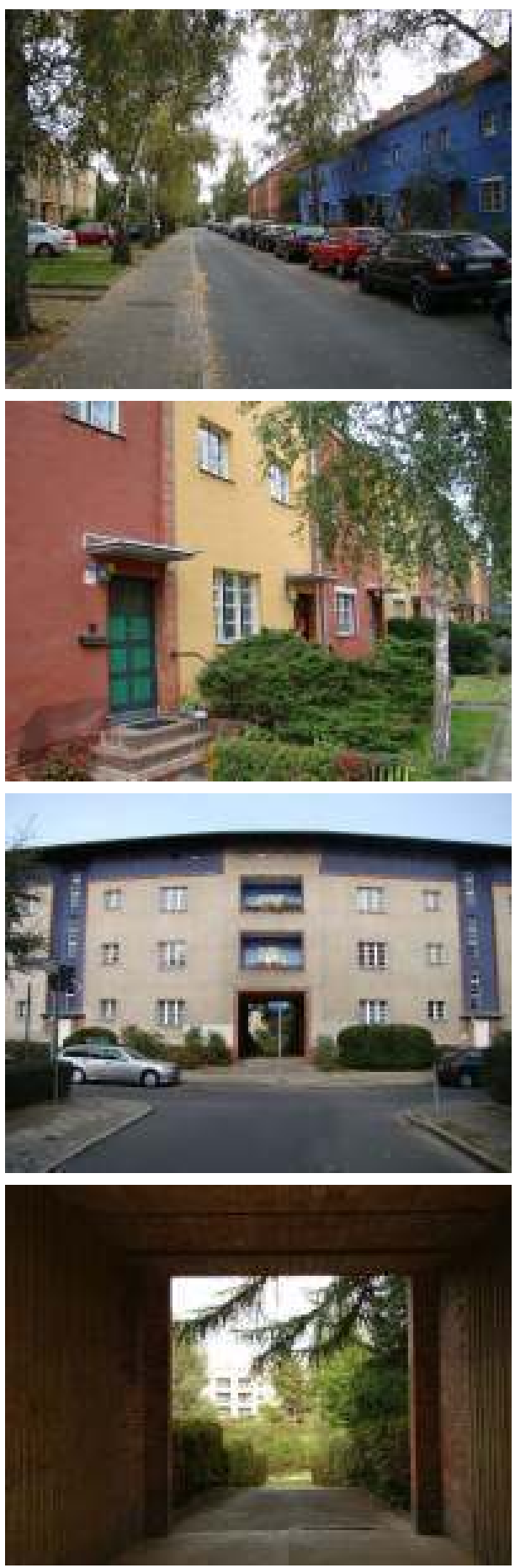

Figuras 124-31. Vista externa das ruas com sobrados e do bloco ferradura. Fotos da autora (2008).
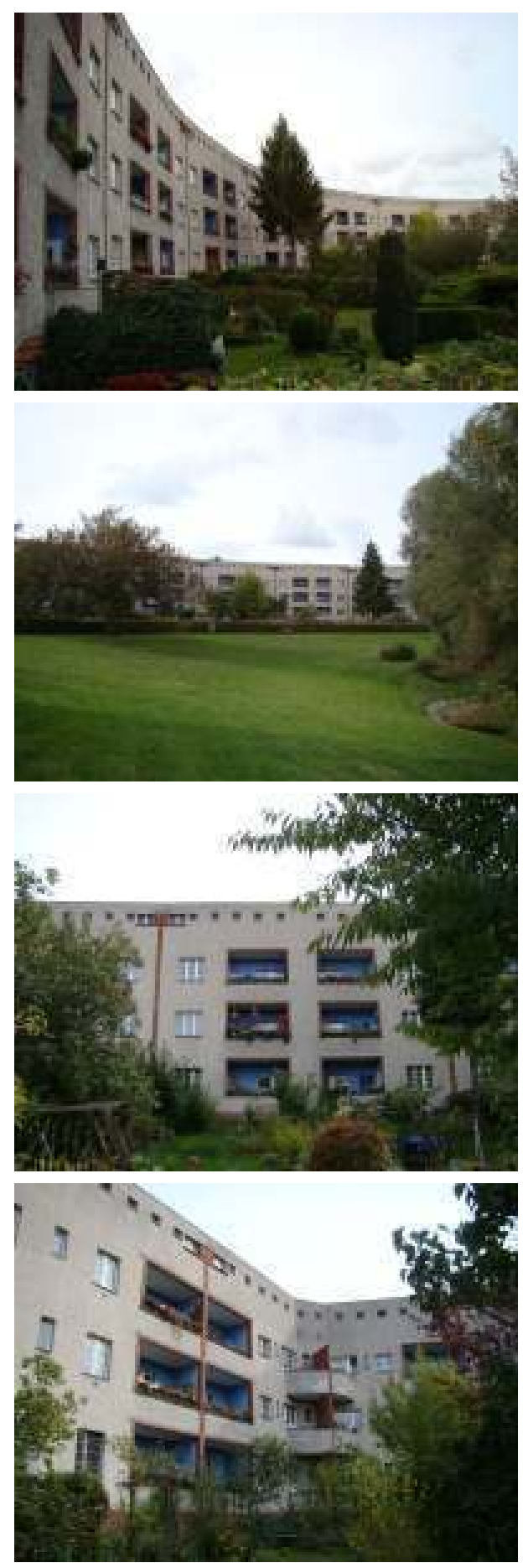

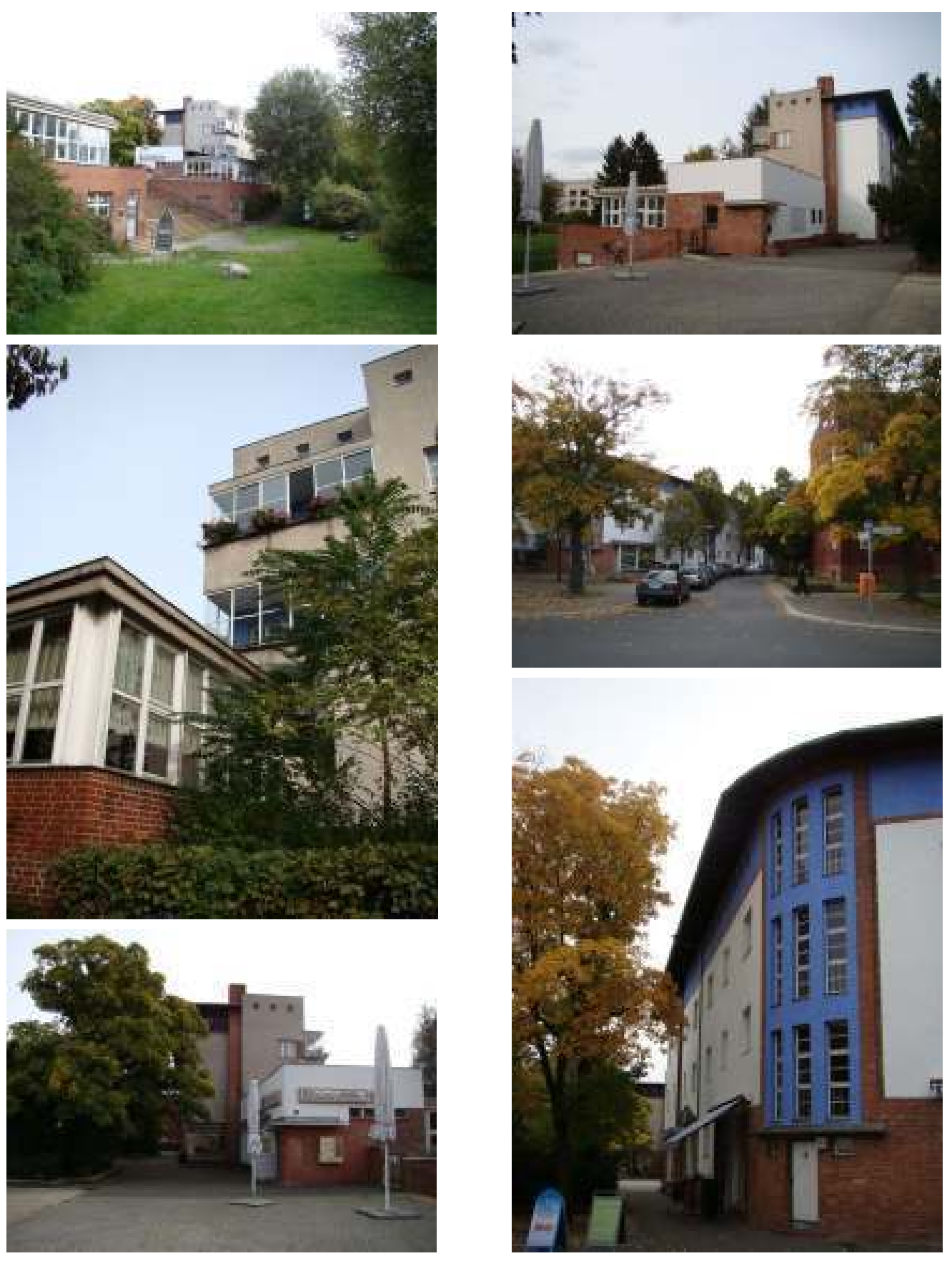

Figuras 132-37. Edifício Ferradura; serviços coletivos na entrada da ferradura. 


\section{Wohnstadt Carl Leigen}

O conjunto Wohnstadt Carl Leigen ocupa um lugar especial na produção de Bruno Taut: é o seu mais racional e denso complexo habitacional: 1.149 unidades de um a quatro quartos cada ( $80 \%$ com dois quartos), numa área urbana de 8,4 hectares. Apesar da implantação do centro da cidade, o conjunto tem infraestrutura própria.

Taut definiu o modelo cidade-jardim para as áreas coletivas como um ponto fundamental de modo de vida, pois acreditava que morar perto das ruas era um fator que desqualificava a habitação. Para tanto, ele combinou o modelo de casas em fileira com os blocos-lâminas para configurar blocos de 5-4 pavimentos em forma de "U", abertos para a Erich-Weinert-Strasse. Taut tentou deixar as principais aberturas das casas foram voltadas para a grande área ajardinada entre os blocos, como salas, quartos e sacadas, enquanto que as aberturas de serviço estão voltadas para as áreas de circulação de autos.

Embora as fachada fossem uniformemente desenvolvidas, e o conjunto apresente uma grande homogeneidade, o uso de cores, marca registrada de Taut, foi imprescindível na composição plástica das saliências e reentrâncias dos blocos habitacionais.

Fechado para o exterior e aberto para o interior - este é o princípio ordenador do conjunto em termos de agenciamento urbano. Respeitando esse princípio, os equipamentos de apoio, como comércio, foram locados na ErichWeinert-Strasse, na "entrada" dos blocos, no limiar entre o público (rua) e o coletivo (interior do "U").

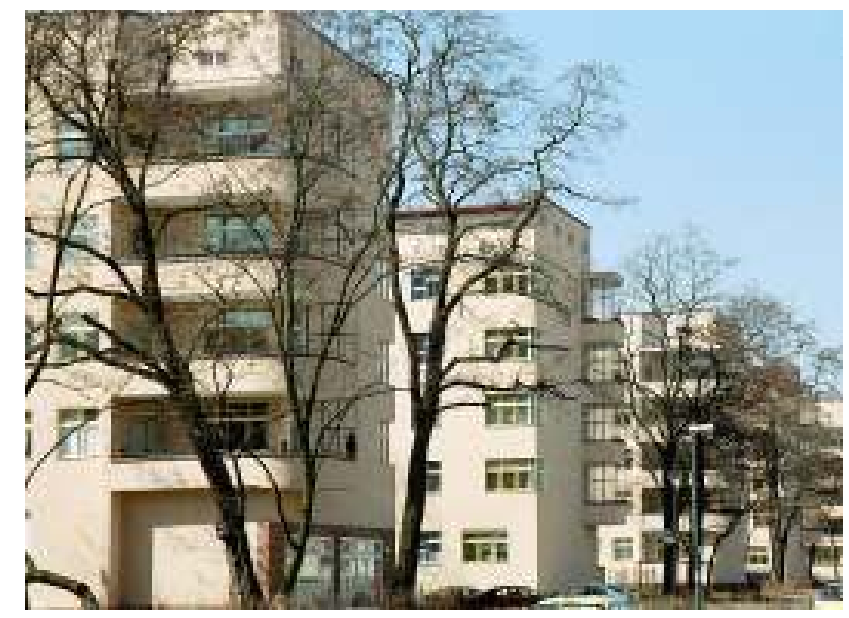

Figura 138. Sequência de edifícios ao longo da Erich-Weinert-Strasse. Fonte: http://www.stadtentwicklung.berlin.de 


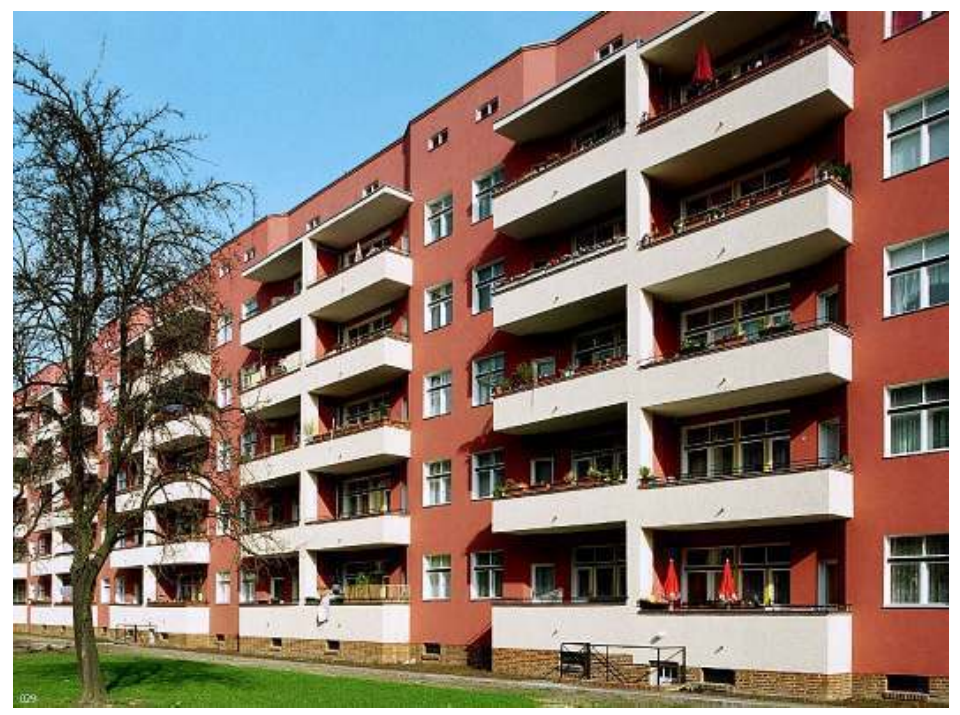

Figura 139. Área comum entre blocos. Fonte: http://www.stadtentwicklung.berlin.de

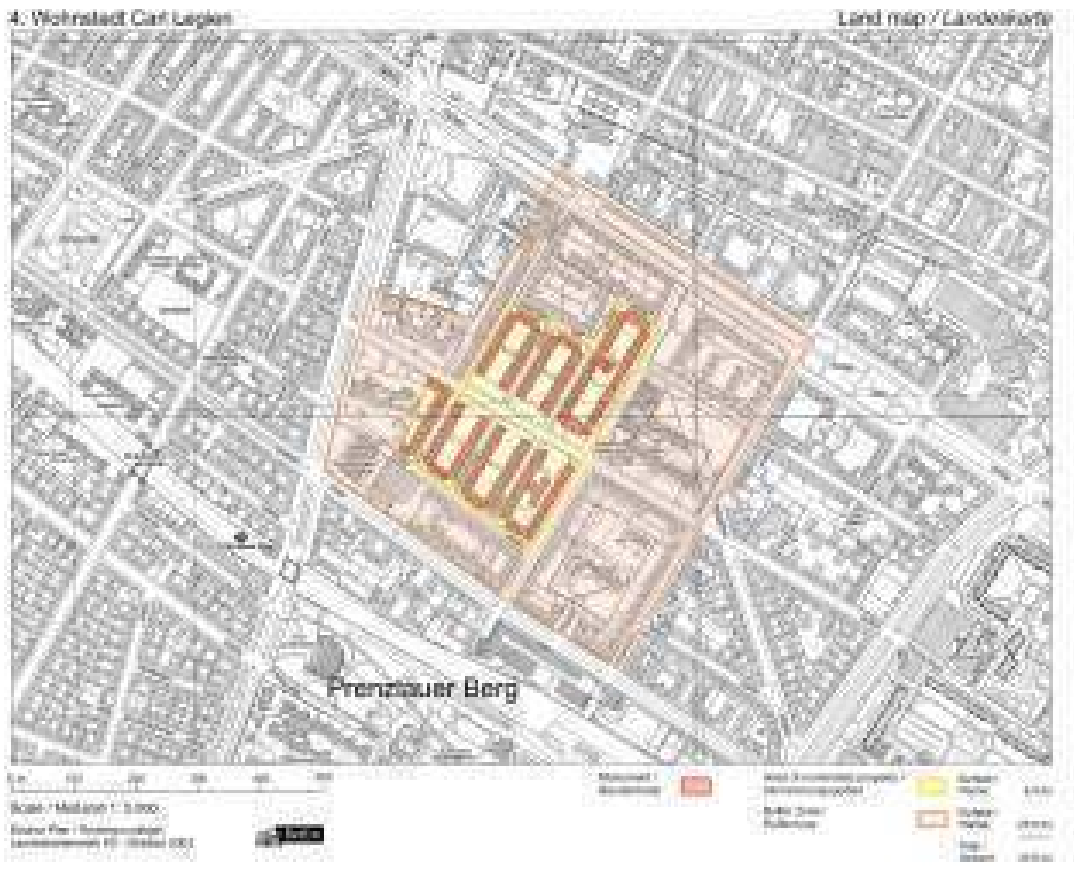

Figura 140. Mapa de situação da área tombada pela UNESCO. Fonte: http://www.stadtentwicklung.berlin.de 


\section{Gross-siedlung Siemensstadt - Ringsiedlung}

Período de construção: 1929-1931, 1933/34

Localização: Berlim

Ruas: Geisslerpfad, Goebelstrasse, Heckerdamm, Jungfernheideweg, Mäckeritzstrasse

Área: 19,3 ha

Planejamento urbano: Hans Scharoun

Arquitetos: Hans Scharoun, Walter Gropius, Otto Bartning, Fred Forbat, Hugo Häring, Paul R. Henning

Projeto áreas livres: Leberecht Migge

Número de unidades: 1.370

Tipos: blocos de quatro pavimentos com escadas para cada 02 apartamentos

Desde o princípio, o Gross-siedlung Siemensstadt, que foi construído entre1929-31, teve a reputação de ser uma exposição de arquitetura em escala ampliada. No entanto, ela foi limitada a um único tipo de construção: prédios alongados, tipo bloco laminar, embora o conjunto também demonstrasse uma variedade de layouts, plantas, métodos de acesso e projetos. Arquitetos famosos estabeleceram suas reputações internacionais aqui. Otto Bartning, Fred Forbat, Walter Gropius, Hugo Häring. Paul-Rudolf Henning e Hans Scharoun estiveram envolvidos no trabalho de design. O grupo foi gerenciado pelo diretor municipal de obras, Martin Wagner, que deu a cada arquiteto a oportunidade de implementar sua interpretação individual do novo estilo de construção social sob as condições de uma grande cidade.

Siemenssiadt, segundo a bibliografia, foi um marco para o desenho urbano internacional moderno, com subdivisões que eram composições abstratas, e não retrocediam aos motivos de desenho urbano do século XIX. modelo dominante para o planejamento urbano na Europa após a Segunda Guerra Mundial, qual seja, uma cidade com uma estrutura solta, habitações coletivas com área verde em abundância é antecipado nesse conjunto. O Siemensstadt é uma paisagem urbana moderna, que se adere ao conceito de reconstrução de Hans Scharoun de 1946.

Com suas funções sociais e sanitárias, os espaços abertos de Siemensstadt foram considerados como uma compensação para as condições difíceis de vida e trabalho. $O$ desenho que lembra um parque e a criação de uma 
área central comunitária para o lazer também serviram a esse propósito. Os primeiros objetivos foram a criação de espaços verdes contínuos e a integração das árvores já existentes. Jardins projetados foram criados somente em uma parte pequena da área. Leberecht Migge criou uma diferenciação clara entre as áreas funcionais individuais e espaços de jardins para atingir um desenho plano e racional dos espaços abertos, e assim reduzir os custos de construção e os futuros custos de manutenção dos jardins. Outro elemento importante do projeto em Siemensstadt foi a integração dos espaços públicos da rua. Árvores comuns na Alemanha foram plantadas ao longo das ruas e caminhos mais importantes para criar uma conexão espacial e funcional entre os espaços abertos criados e o sistema de vegetação geral.

Hoje, Siemensstadt é parte de uma das mais importantes áreas residenciais de Berlim. Uma faixa de complexos residenciais se estende de oeste a leste ao longo das fronteiras municipais, a partir da porção Spandau de Siemensstadt, com suas fábricas e moradias para trabalhadores, ao sul e oeste, o parque Jungfernheide, ao norte, e as áreas residenciais do pós-guerra de Hans Scharoun, ao leste, chegando ao Kurt Schuma-cher-Damm.

Para a elaboração desse projeto, simultâneo ao de Reinickendorf, foi constituído um grupo de trabalho com arquitetos sob a liderança do diretor municipal de obras, Martin Wagner. A maioria deles era membro do grupo Der Ring. O papel dos arquitetos era projetar 1.370 apartamentos por encomenda da associação beneficente "Gemeinnutzige Baugcsellschaft Berlin-Heerstrasse $m b H^{\prime \prime}$, controlada pelo município. Cada arquiteto foi designado para projetar seu próprio bloco de construção, o que conferiu uma grande diversidade ao conjunto. O complexo apresenta de novos modelos de construção, da funcionalidade de Gropius à arte espacial de Scharoun, ao lado da riqueza de detalhes das formas orgânicas de Häring. A tarefa de Scharoun foi a integração do todo o projeto urbano. Neste conjunto, pela primeira vez, ele desenvolveu seu princípio de 'vizinhança. O projeto de urbanização da gleba teve como base uma subdivisão espacial fundamentada nos recursos naturais do local. Devido à total liberdade de composição, a orientação tradicional norte-sul foi mantida para assegurar ventilação e luz natural em quantidade nos apartamentos. As árvores existentes reforçaram o caráter de parque do local desde o princípio.

Scharoun projetou os edifícios na "entrada" do conjunto, ao sul do trilho do trem da Siemens, os quais tiveram que se relacionar com as edificações 
vizinhas. Scharoun criou um tipo de "funil" constituído de três prédios de cinco andares em ambos os lados da via, afunilando para passar sob a linha S-Bahn.

A parte interna compreendia por esses três edifícios foi ocupado por um jardim contendo árvores antigas. Scharoun criou um projeto texturizado especial para a última construção, ao lado oeste de Jungfernheideweg, que ficou popularmente conhecido como o "Panzerkreuzer" (encouraçado), por utilizar motivos da arquitetura naval, tais como alturas escalonadas, cortes profundos para terraços de coberturas, sacadas tipo gôndolas e janelas redondas. As bordas das sacadas pintadas em ocre e amarelo destacam o branco dominante das paredes. Ao leste, opondo-se a essa dinâmica construção, há uma fachada uniforme, com um padrão sutil de segmentos de loggia (HASPEL \& JAEGGI, 2007).

A parte principal do conjunto começa atrás do embarque do trem urbano e termina em Heckerdamm. O bloco alongado de 338 metros de Bart Ning, que segue a curvatura do Goebelstrasse, forma uma barreira física ao sul, protegendo o conjunto da linha Siemens de trem, tanto visual como acusticamente. Ao mesmo tempo, ele define uma fronteira espacial oposta aos blocos alongados de Häring, do outro lado da Goebelstrasse, delimitando a área do conjunto.

Os dois longos blocos projetados por Gropius são formas racionais bem marcadas e elegantes nas formas abstratas e rítmicas das aberturas e esquadrias. Mais que os demais prédios do complexo, eles incorporam a racionalidade programática de um empreendimento de moradias proposto pela nova arquitetura. Esses blocos estão situados na extremidade oeste do complexo, e possuem uma curta passarela coberta na Goebelstrasse, ligando-o ao trabalho Helmat adjacente da Siemens, de Hans Hertlein, que o construiu ao mesmo tempo em que o conjunto. As formas depuradas e ortogonais de Gropius se manifestam na redução das cores de sua construção ao cinza e preto. As esquadrias de ferro nas caixas de escada, o glaze loggia, todas as janelas dos apartamentos e as grades protetoras em frente aos jardins do teto plano são pintados de cinza, de modo que essas estruturas em forma de faixas escuras contrastem claramente com o branco brilhante das fachadas.

Entre Jungfernheideweg e Geisslerpfad, os blocos norte-sul de Häring, ao sul e os seis blocos deslocados de Henning, ao norte, ficam frente a frente separados por uma larga faixa de vegetação - um passeio projetado para 
acomodar playgrounds, um jardim-de-infância e áreas de contemplação. $\mathrm{O}$ projeto de Migges para o "centro verde" do complexo, onde os jardins entre os dois longos blocos se encontram, parece ser um espaço verde aberto que viabiliza a convivência comunitária - em consonância com o conceito de vizinhança de Scharoun. Os três prédios residenciais longos de Forbat então seguem ao leste em Geisslerpfad. Materiais de construção com aparência natural e coloridos, e especialmente as formas suaves das sacadas em forma nefróide, projetando-se em frente ao prédio, são características da arquitetura funcional orgânica de Häring. Ele foi o único arquiteto a colocar sacadas e nichos de escadas no lado oeste dos prédios. Häring justificou a forma inusitada das sacadas com uma intenção funcional. Por um lado, ele desejou que as sacadas fossem estendidas ao máximo para aumentar o espaço de convivência dos apartamentos, mas, ao mesmo tempo, ele desejou reduzir a sombra resultante disso. Os tijolos claros, o reboco bege liso, a pintura branca por todas as janelas, e as portas principais marrom-escuras com suas cores quentes dialogam com o verde da redondeza criando uma aparência geral que contrasta claramente com a austeridade e racionalidade das construções projetadas por Gropius.

Como os prédios de Harting, as seis longas construções projetadas por Henning também apresentam nuances de cores naturais. A versão amarelada com sua superfície rústica, os tijolos coloridos de face amarela e as janelas e portas-balcão pintadas de amarelo brilhante dão ao grupo de prédios a aparência lúdica de uma colônia de férias, em vez de uma longa estrutura de blocos. Essa impressão é reforçada pelo fato de que os andares térreos dos três blocos do leste abrem-se para o verde com terraços que se estendem à largura total do prédio.

Os três longos blocos de Forbat na extremidade leste do complexo imobiliário em Geisslerpfad mostram designs variados. Como os prédios projetados por Gropius, a estrutura claramente geométrica das construções é definida por um estilo formal racionalista, com fachadas brancas e elementos de tijolo pintados de amarelo deliberadamente colocados. A arquitetura de Forbat é baseada na simplicidade, e uma ênfase em contornos fechados é acentuada por elementos assimétricos. O prédio norte, particularmente longo, mostra uma surpreendente solução de fachada em construções residenciais de massa. As entradas e as laterais verticais da janela da caixa da escada são fechadas e 
projetam-se, com paredes em linhas de tijolos protuberantes, com elementos redondos achatados. Isso propicia à fachada uma textura completamente incomum que lembra ondas.

As construções em Siemensstadt, que são situadas próximas a um complexo extensivo de indústrias em Siemens, sofreram extensivos danos em algumas áreas durante a Segunda Guerra Mundial. Setores inteiros de prédios projetados por Scharoun e Gropius em Jungfernheideweg um e 21, o prédio da divisa de Bartning e os longos blocos de Häring na Goe-belstrasse 21/25 e 24 foram perdidos. Mas a destruição não causou nenhuma alteração fundamental na aparência autêntica do complexo. O trabalho de reconstrução no início dos anos 50 nem sempre recuperou completamente a condição original. Para o prédio de Scharoun em Jungfernheideweg um, ele próprio projetou uma nova construção final que foi erguida em 1949-50. E o prédio do canto com a fileira de lojas no térreo, na esquina do Jungfernheideweg com a Goebelstrasse, projetado por Gropius foi substituído, em 1955, por um prédio que se desviou do original, e em 1988/89 foi redesenhado pelos arquitetos Hilmer \& Sattler, baseado no estilo racional e funcional de Gropius. Mas os prédios da Mackentzstrasse 18/22, que haviam sido projetados por Scharoun foram reconstruídos nos moldes dos prédios originais (HASPEL \& JAEGGI, 2007).

A extremidade leste do bloco desenhado por Banning foi ampliada em 1955-56, adicionando-se os prédios No. 11 -19, mas a extensão foi projetada pelo próprio arquiteto. Nessa época, a última construção na Goebelstrasse 1-9 foi erguida, a qual Hans Scharoun desenhou como um prédio de corredores cobertos. Com uma planta-baixa em forma de serra e a estrutura da fachada em degraus, ela contrasta fortemente com o estilo racional do Ring Estate. Após essa primeira fase de reformas dos prédios, completada em 1955, novo esboço e nova pintura foram aplicados em todos os prédios, nos anos 1960 e 1970, mas não seguiram a condição original.

A renovação baseada em princípios de conservação, começou no início dos anos de 1980. Restaurações e conservações importantes começaram em 1982, com a reforma dos longos prédios de Häring. Em 1984 a maioria dos prédios de Scharoun foi restaurada, e então se seguiram os prédios de Henning. Elementos danificados foram consertados e especialmente os esboços e pinturas foram restaurados à sua condição original. Mudanças somente foram aceitas onde foi inevitável, por motivos técnicos, por exemplo, no reparo das 
sacadas em forma nefróide nos prédios de Hugo Härings. Ficou decidido que se manteria a construção final de Hans Scharoun, o encouraçado, em sua versão do pós-guerra (HASPEL \& JAEGGI, 2007).

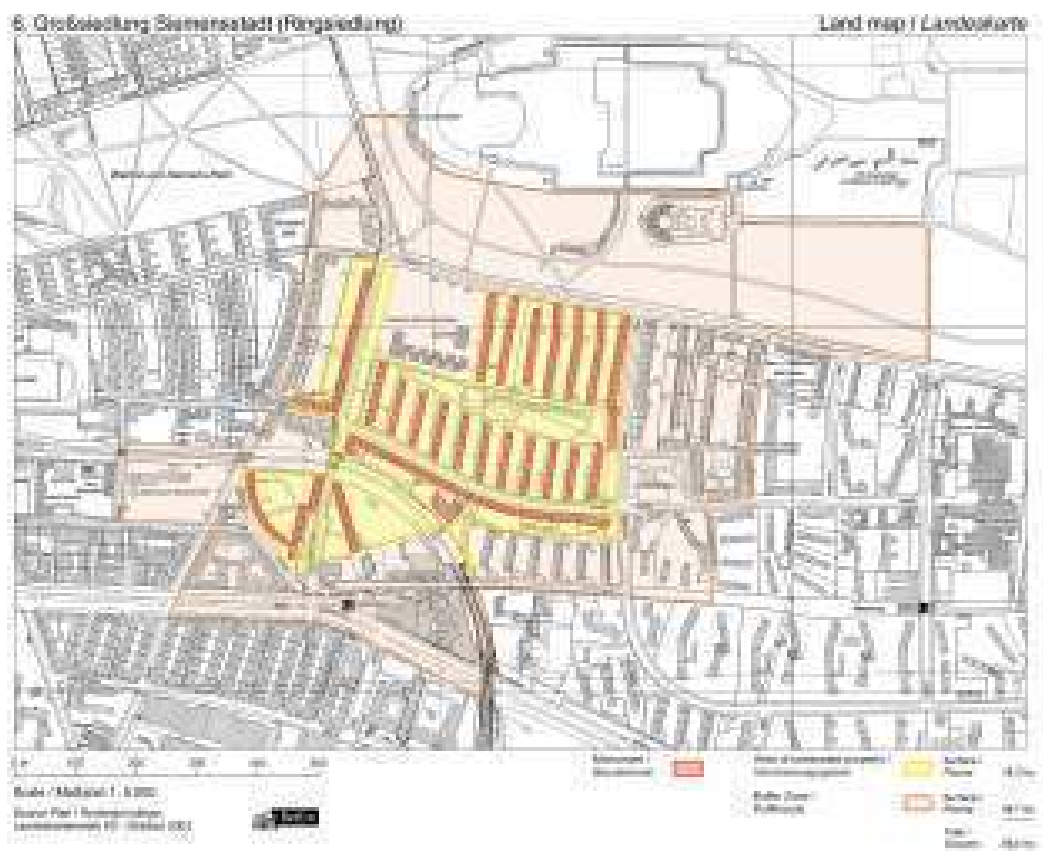

Figura 141. Mapa de situação da área tombada pela UNESCO. Fonte: http://www.stadtentwicklung.berlin.de
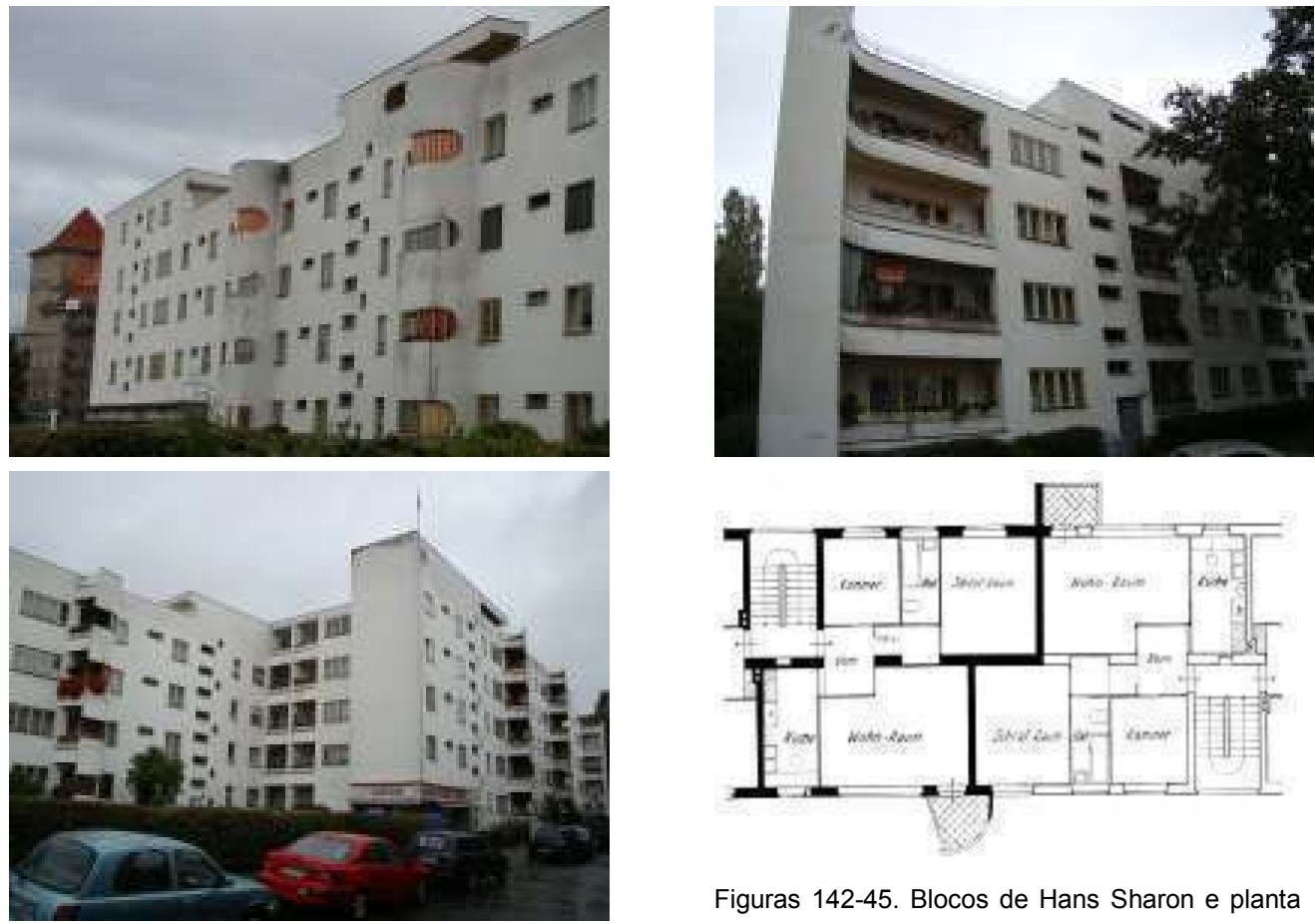

Figuras 142-45. Blocos de Hans Sharon e planta tipo de um dos blocos.

Fotos da autora (2008) 

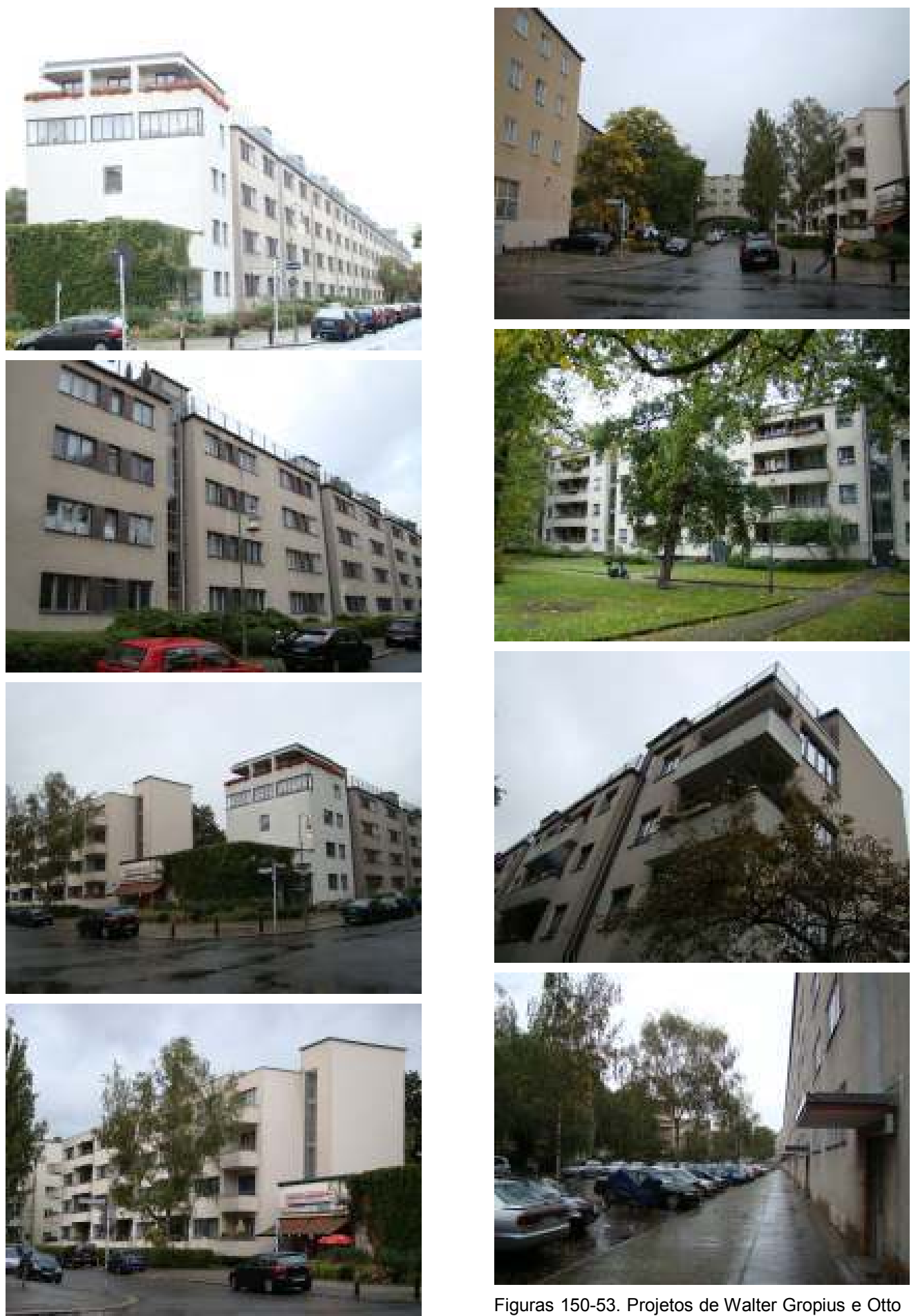

Figuras 145-49. Projetos de Walter Gropius. Fotos Figuras 150-53. Projetos de Walter Gropius e Otto Bartning. Fotos da autora (2008). da autora (2008) 

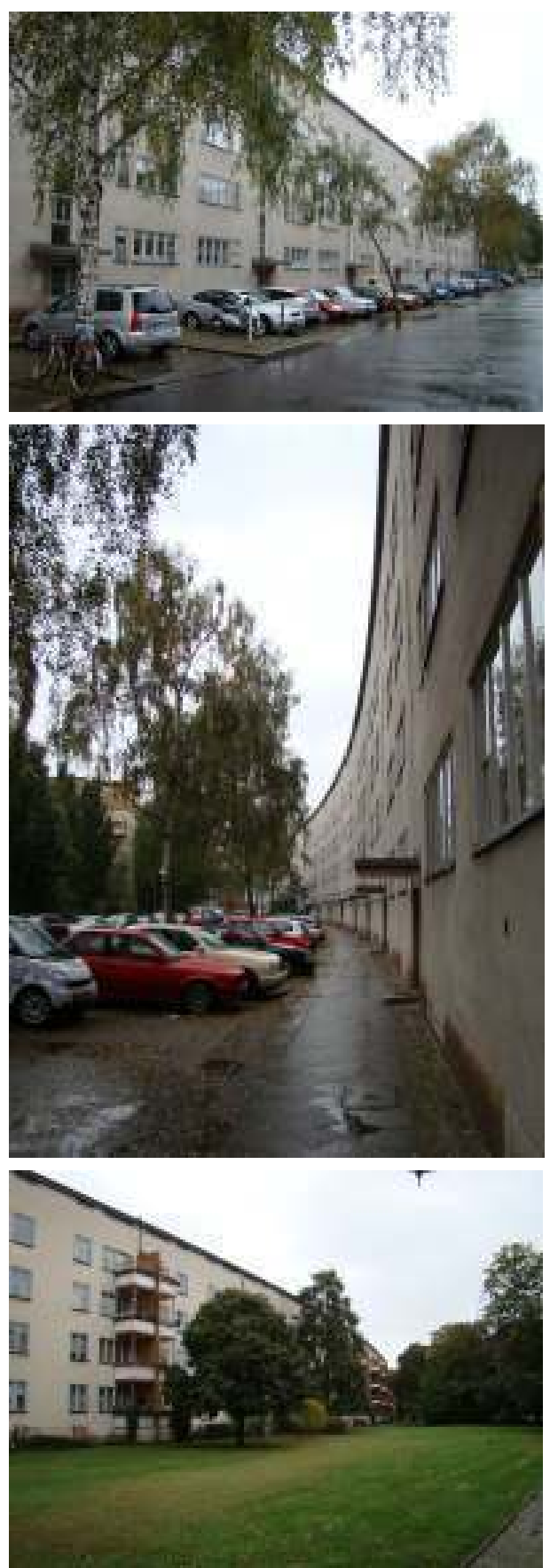

Figuras 154-56. Projeto de Otto Bartning. Fotos da autora (2008).
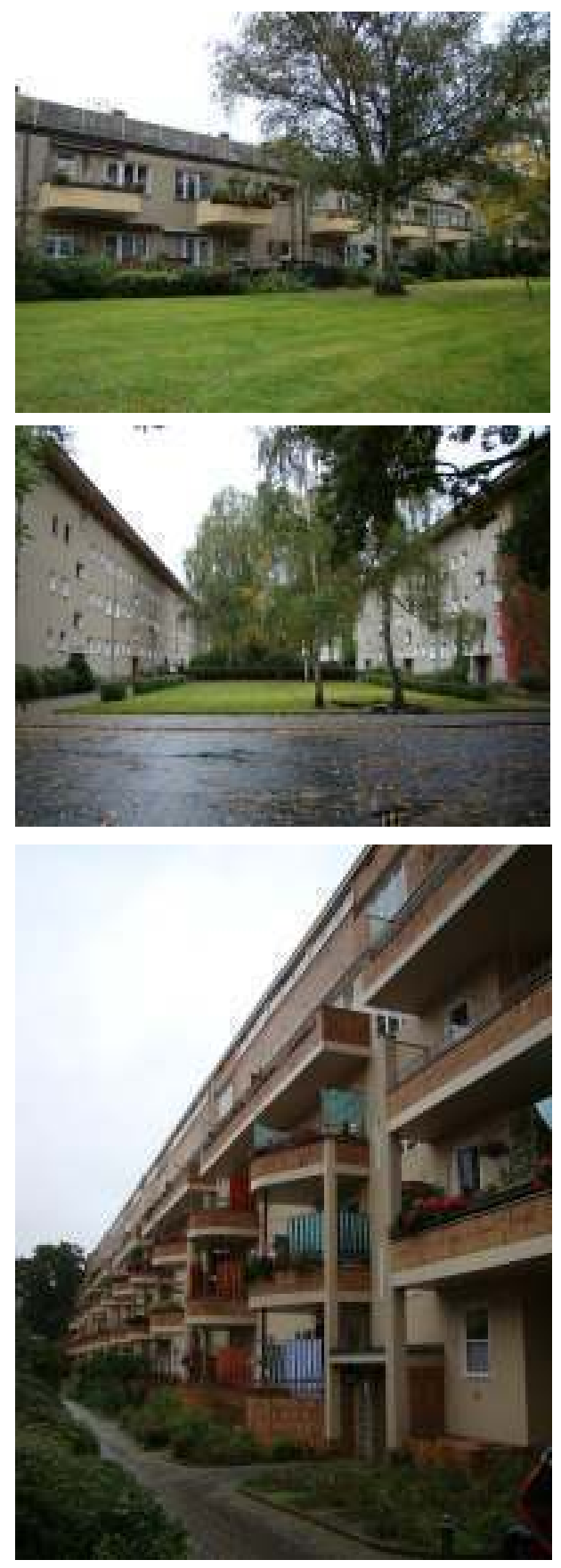

Figuras 157-59. Projeto de Paul Rudolf Henning e Hugo Häring. Fotos da autora (2008). 


\section{Weisse Stadt (White city)}

Ano: 1929-1931

Ruas: Aroser Allee, Baseler Strasse, Bieler Strasse, Emmentaler Strasse, Genfer Strasse, Gotthardstrasse, Romanshorner Weg, Schillerring, Sankt-GallerStrasse.

Área: 14,3 ha

Planejamento urbano: Otto Rudolf Salvisberg

Arquitetos: Otto Rudolf Salvisberg, Bruno Ahrends, Wilhem Büning

Projeto áreas livres: Ludwig Lesser

Número de unidades: 1.268

Tipos: blocos de quatro e cinco pavimentos, com escadas para cada dois apartamentos por andar.

O grande conjunto residencial Schillerpromenade foi completado em 1931. Logo após sua construção tornou-se conhecido como "A Cidade Branca" e foi um símbolo da construção de conjuntos residenciais modernos. O conjunto foi destaque em debates em publicações sobre arquitetura e na sequência exagerada de fotos de construções brancas que apareceram em livros e periódicos em todo o mundo por volta e 1930, que imprimiu a marca dos grandes blocos laminares brancos da arquitetura moderna alemã.

Sob a direção de construções municipal de Martin Wagner, o conjunto residencial foi projetado pelos arquitetos Wilhelm Büning, Bruno Ahends and Otto Rudolf Salvisber, e os jardins projetados por Ludwig Lesser.

O projeto urbano de O.R.Salvisberg habilmente combina vários motivos tradicionais da orientação e estrutura urbana com novas características que surgiram na construção de conjuntos residenciais na década de 1920. Ele concebeu a Aroser Alle (ex-Schillerpromenade), com seu layout e comprimento definidos, como uma rua principal com prédios ao logo dos limites do bloco, e efetivamente destacou a estrada sul com a construção de dois prédios altos como portais, delimitando assim os limites do complexo habitacional. No meio da avenida implantou um bloco transverso que age como uma ponte abrangendo a largura total da Aroser Allee. A construção ponte marca o centro do conjunto e serve como um destaque quando visto de ambas as direções; um grande relógio montado no centro da parede no andar mais alto mostra as horas em cada lado da construção. 
As construções que servem como portais, o eixo delimitado pela avenida e os blocos no seu alinhamento, e a construção em ponte são elementos com alto impacto visual que definem o arranjo espacial de forma hierárquica, imprimindo uma identidade ao conjunto. Em ambos os lados deste impressionante complexo, Salvisberg criou diferentes padrões visuais usando linhas radiais de construções e blocos transversos. A "Cidade Branca" como um todo, representa um conceito que começou com os objetivos sanitários e sociais do "novo estilo de construção" e conceitos espaciais desenvolvidos que estão tão distantes do padrão de blocos nos limites das quadras, com alta densidade, quanto dos padrões de cidades-jardim, de características rurais ou estruturas tradicionais de pequenas cidades. Em contraste aos os grandes conjuntos residenciais GEHAG em Britz e Zehlendorf, um tipo moderno de conjuntos residenciais de grandes cidades foi criado nesse complexo, que teve foco exclusivamente na criação de apartamentos em prédios de vários andares.

Ludwig Lesser, responsável pelo planejamento dos espaços abertos, criou uma estrutura de espaços abertos que satisfez a demanda do novo estilo de construção e encontrou correspondência no programa de arquitetura e projeto urbano do conjunto. Os espaços abertos no conjunto eram admiravelmente equipados com diversas áreas comunitárias e essa configuração virou padrão para projetos de conjuntos posteriores. Em vez de pequenos jardins individuais, o conjunto possuía jardins residenciais, projetados para uso comunitário - áreas verdes funcionais com lugares para se sentar e playgrounds para as crianças.

Quando as taxa de juros da construção começaram a diminuir no final da década de 1920, a cidade de Berlin começou um programa especial de construção sob a iniciativa do diretor municipal de construção Martin Wagner, que reservou 15 milhões de Reichmarks para a construção de 2.080 habitações em SchillerPromenade (hoje Aroser Allee), em Reinickendorf e em Siemnsstadt. Pela primeira vez, a cidade financiou grandes conjuntos residenciais de seu próprio orçamento, facilitando assim um planejamento experimental e um projeto e construção livre das limitações associadas às hipotecas e taxa de juros altas. A construção dos 1.268 apartamentos distribuídos principalmente em prédios de três andares, com telhado plano, foi assumido pela associação municipal benevolente "Gemeinnützige Heimstätengesellschaft Primus mbH". 
O projeto de urbanismo, os pavimentos tipos e o paisagismo foram determinados pela racionalidade e economia. Para atender a demanda por pequenos apartamentos baratos, a proporção de apartamentos de um a dois quartos/cômodos foi muito alto, perto de $80 \%$. Mas o conceito de finanças municipais, ou subsídios, permitiu experiências no layout dos apartamentos de ambos os conjuntos. Por exemplo, quatro tipos de cozinha com equipamentos idênticos foram desenvolvidas. Além disso, cálculos de rentabilidade foram feitos para as dimensões do prédio e acessos de serviço, que levaram a uma profundidade uniforme no prédio e a utilização de componentes pré-fabricados (HASPEL \& JAEGGI, 2007.

Com seus telhados planos, com a impressionante subdivisão cúbica dos prédios e especialmente as delicadas fachadas brancas, os prédios no conjunto agora se destacam da mistura de velhos e novos prédios no ambiente suburbano. Salvisberg, Ahrends e Büning usaram cores lívidas para os elementos arquitetônicos que se projetam do telhado, canos de escoamento de chuva, portas frontais e molduras de janelas.

O alinhamento norte-sul do conjunto com sua espinha dorsal na rua principal existente Aroser Allee, subdivide as três seções projetadas pelos arquitetos. A seção ao sul foi projetada por Ahrends, os blocos radiais no meio por Büning e a construção ponte e os prédios ao noroeste em Aroser Allee foram projetadas por Salvisberg. O elemento comum às três seções é a estrutura interior aberta no arranjo dos blocos, com um grande jardim coletivo.

Bruno Ahrends projetou os prédios portais na entrada sul que se projetam no pavimento superior, visualmente constringindo Aroser Allee e direcionamento a visão do espectador para o eixo principal e para o edifício ponte de Salvisberg. Esses edifícios tem dois andares mais altos que os adjacentes, e o último andar, que tem somente uma fileira de pequenas janelas, Ihe dá um ar de solidez que parece ser quase de uma fortificação. Os mastros de bandeira que se projetam do centro das estreitas fachadas e alcançam muito acima da borda do telhado, enfatizam ainda mais o portão de entrada do conjunto, que se tornou um símbolo da comunidade residente no conjunto.

Os edifícios de Ahrend no conjunto são longas linhas que seguem a curvatura da Aroser Allee e a linha paralela da Romanshorner Weg. A área em forma de pás de ventilador entre a Aroser Allee, Schillerring e Emmentaler Strasse é circundada por pequenos edifícios dispostos em torno das bordas do 
bloco. Dentro do conjunto existem dois prédios posicionados de norte a sul, entre os quais há um jardim da infância que também foi projetado por Ahrends. $O$ arquiteto demonstrou sua individualidade no desenho das janelas das escadas e na entrada das moradias, que tem molduras de tijolos Expressionistas que dramaticamente as separa das superfícies brancas racionais das fachadas de entrada.

Prédios alongados dominam a seção projetada por Büning. Mas seus prédios de três andares são arranjados em um padrão radial em vez do arranjo norte-sul que foi convencionado para blocos lâminas. Eles formam o anel exterior da área em forma de ventilador entre a Aroser Allee e Emmentaler Strasse. O espaço trapezoidal entre esses prédios foi projetado como áreas verdes que são abertas no lado mais estreito, de frente para a Schillering, mas fechados com prédios curtos de três andares no lado mais largo, de frente para a Genfer Strasse. Assim, os limites entre os arranjos das ruas e da área verde coletiva são claramente marcados nas bordas, mas anulados dentro do conjunto.

O edifício ponte de O.R. Salvisberg é uma construção de concreto armado de 40 metros, que se apóia em quatro fileiras de estreitos pilares, inserido entre os prédios de cinco andares contíguos a ele.

A grande variedade de comércios locais uma solução única na época. O conjunto tem 24 lojas situadas em vários pontos urbanos dominantes, um jardim de infância e um consultório médico, ressaltando o alto padrão social do conjunto habitacional. Infelizmente, o aquecimento central, juntamente com a lavanderia coletiva, foram demolidos em 1968 e 1969, antes do conjunto ser tombado (HASPEL \& JAEGGI, 2007).

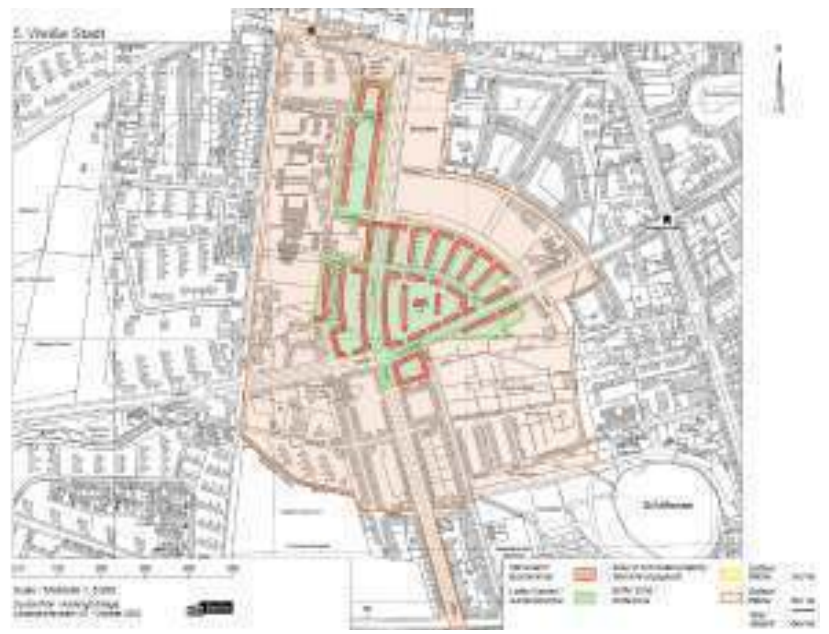

Figura 150. Mapa de situação da área tombada pela UNESCO. Fonte: http://www.stadtentwicklung.berlin.de 

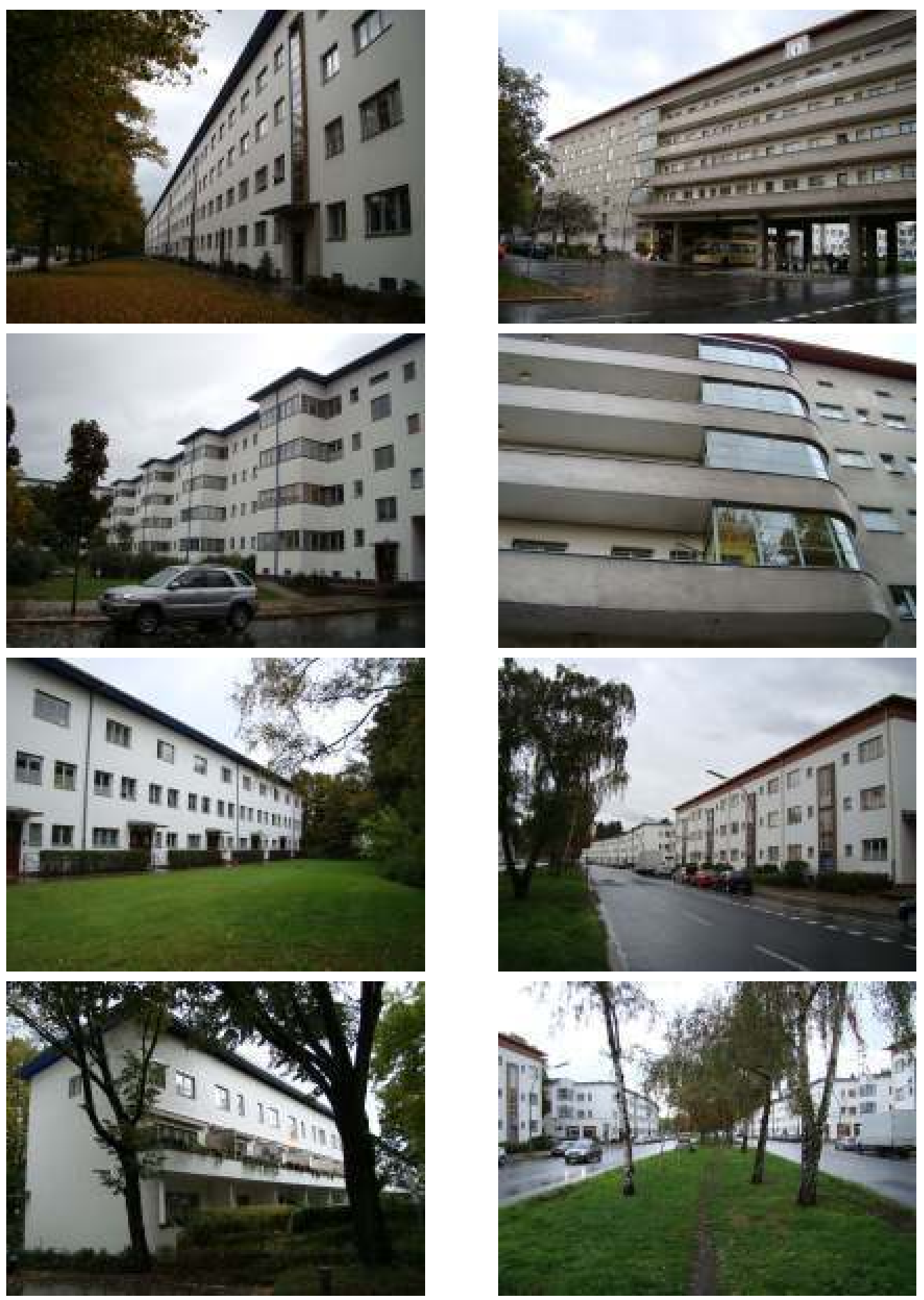

Figuras 151-58. Edifícios ao longo da Aroser

Allee. Fotos da autora (2008). 

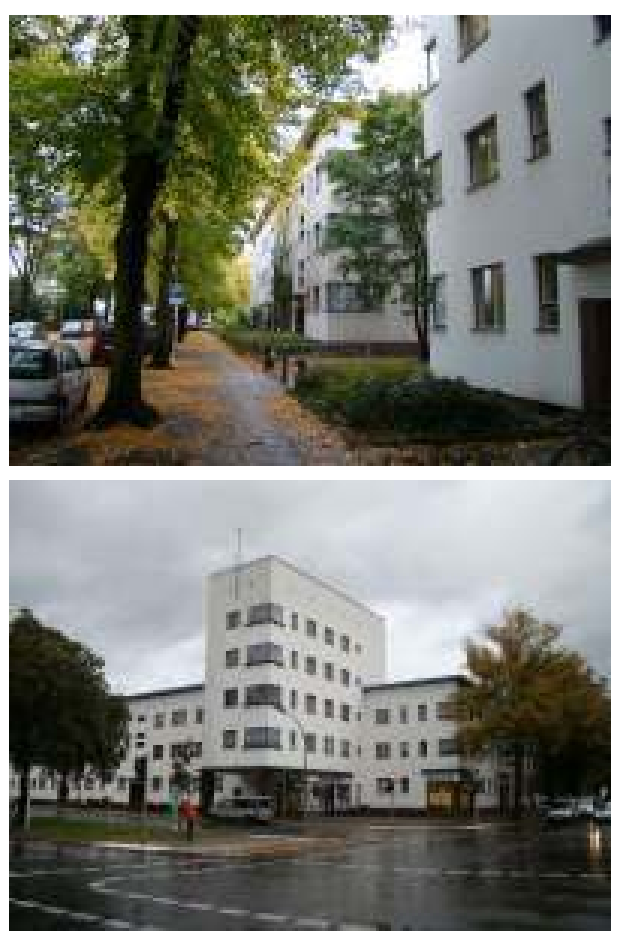

Figuras 159-62. Edifícios ao longo da Aroser Allee. Fotos da autora (2008).
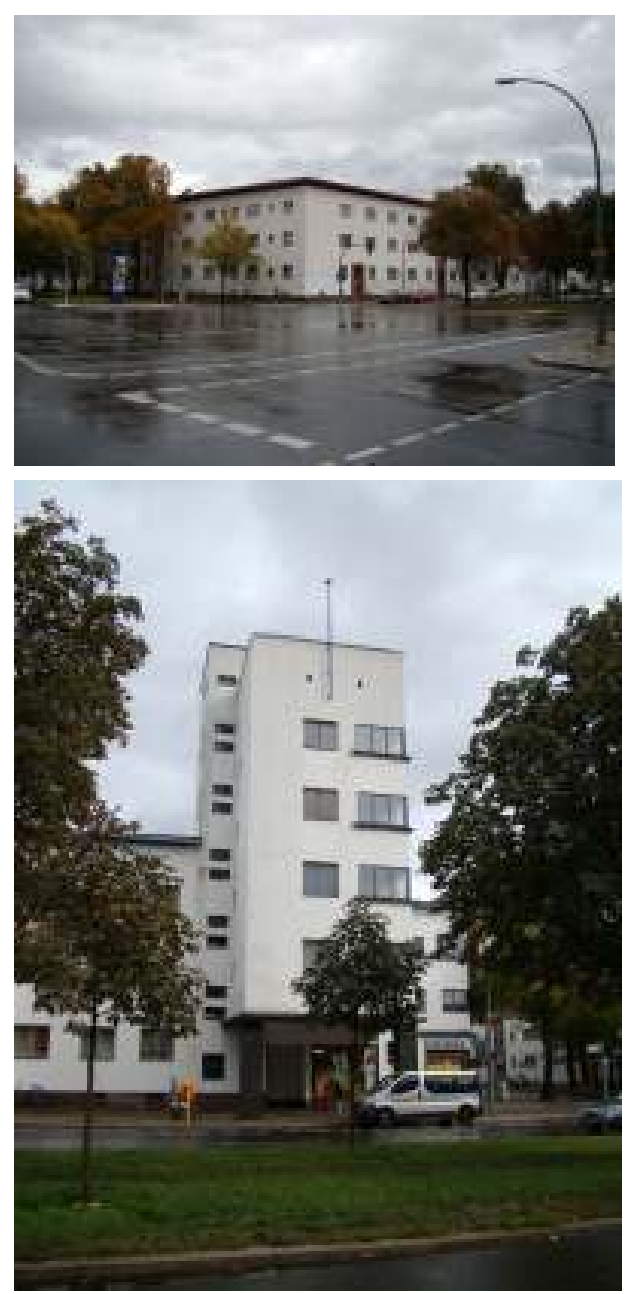
Capítulo 01 
A relação entre racionalização da construção, primeiramente da habitação proletária, através de pesquisas tecnológicas sobre métodos e materiais construtivos, e novo modo de produzir arquitetura fazia parte, como aponta Kopp (1990), da definição do que seria a arquitetura moderna.

Desde a primeira década do século $X X$, na Alemanha, podemos encontrar uma confluência interessante de técnicos e políticos para incrementar a produção industrial, inclusive dos componentes da construção civil. Bruna (2010) nos mostra que, para muitos pensadores da época, a Alemanha só teria oportunidade de competir no mercado internacional com produtos de excepcional qualidade por não possuir fontes baratas de matéria-prima, tampouco uma produção de bens de consumo ampla e barata. Era consenso entre intelectuais que apenas uma profunda transformação no desenvolvimento das artes e ofícios no país poderia promover alguma prosperidade. É com esse comprometimento que a Deutcher Werckbund, fundada em 1907, e alguns arquitetos, como Hermann Muthesius, se concentram na necessidade de aprimorar e refinar a produção de objetos tipo. Quando apresentou seu programa com dez pontos na exposição da Deutcher Werckbund o arquiteto:

“... argumenta que a arquitetura e o desenho industrial só poderão alcançar uma verdadeira importância através do desenvolvimento e aperfeiçoamento de tipos [Typisierun]; nos pontos 310 apresenta a necessidade nacional de produção de alto padrão de maneira a poder vendê-los facilmente no mercado mundial. O ponto nove trata da produção em massa nos seguintes termos: a pré-condição para a exportação é a existência de empresas grandes, eficientes, cujo gosto seja impecável. Objetos singulares [únicos] elaborados por artistas não cobrirão as necessidades da Alemanha" 1

\footnotetext{
1 Kenneth Frampton, "A Deutch Werckbund 1898-1927", em História Crítica da Arquitetura Moderna. (1997), p.112
} 
Esse ambiente de transformação das artes e ofícios, como aponta diversos autores, preparou o terreno para a elaboração das padronizações necessárias para a produção em série dos componentes destinados à construção civil. Como coloca Müller (1968), até a deflagração da Primeira Guerra existia um consenso entre os arquitetos da Deutcher Werckbund, tramitando principalmente em torno dos preceitos de Peter Berhens e Muthesius.

A bibliografia aponta duas revoluções importantes na concepção da arquitetura alemã antes da primeira guerra. A primeira foi a partir de 1900, quando arquitetos como Alfred Messel, Peter Behrens e Paul Bonatz começaram a rejeitar o ecletismo vitoriano em voga e a buscar formas mais simples, num processo de depuração da forma. A primeira grande demonstração coletiva dessas novas pesquisas foi exposição da Deutcher Werkbund em Colônia, em 1914, considerada um importante campo de experimentação de novas formas e matérias para uma arquitetura "industrializável". Exemplos disso foram: o teatro de Henri Van de Velde; o prédio administrativo para uma fábrica, apresentado por Walter Gropius, e o Pavilhão de Vidro apresentado por Bruno Taut.

Em 1918, um grupo de arquitetos ligados a Gropius declarou que estaria formulando uma arquitetura nova e socialmente consciente, que faria parte de uma revolução política que estava em curso na Alemanha². Para Argan (1993, p. 264), Gropius foi o líder de uma das diversas orientações da arquitetura moderna, aquela que defende o racionalismo metodológico-didático.

Um ano depois, em $1919^{3}$, Walter Gropius assumiu a direção da Escola de Arte de Weimar, inaugurando-a com o nome de Das Staatliches Bauhaus. A nova escola tinha como objetivo principal aproximar a arte à produção industrial. Concentrava-se nos projetos das estruturas das construções, de todo e qualquer objeto, e não em seus ornamentos, defendendo principalmente a funcionalidade e utilidade da arquitetura. Os professores e alunos ligados a Bauhaus tinham em seu discurso tendências e referências ao grupo holandês de De Stijl e ao construtivismo russo.

\footnotetext{
2 Entre 1918 e 1919, diversos eventos marcaram o final da Primeira Guerra, que culminaram na derrubada do Kaiser, fim do movimento pela revolução socialista e o estabelecimento de uma república democrática, a República de Weimar.

3 Após a derrota da Revolução Espartaquista em 1919 e a instauração da República de Weimar, sob 0 regime de parlamentarismo.
} 
A escola agrupou artistas e artesãos de diversas áreas, como arquitetura, pintura e escultura, marcenaria, tapeçaria, teatro, dança e fotografia. A Bauhaus tornou-se o ponto de encontro de todas as artes e ideias inovadoras da época. Uma das filosofias da escola era manter-se aberta para todos os movimentos de vanguarda, tendo aglutinado expoentes do cubismo, do construtivismo e da arte abstrata. Foram mestres da escola alguns dos maiores artistas do século $X X$, entre eles Laszlo Moholy-Nagy, Vassily Kandinsky, Paul Klee, Lyonel Feininger, Josef Albers, Marcel Breuer, Oskar Schlemmer, Marianne Brandt, Johannes Itten, Gerhard Marks, Georg Muche, Gunda Stölzl, Omar Akbar, Hinnerk Scheper, Joost Schmidt, Lothar Schreyer, Dietmar Starke e Magdalena Droste.

No campo habitacional, O Weissenhofsiedlung (exposição de arquitetura na forma de um novo bairro em Stuttgart), em 1927, foi sem dúvida a maior contribuição da Deutcher Werkbund no sentido de promover a vanguarda alemã em nível internacional, além de explicitar a confluência de intenções e proposições em outros países europeus. Quanto a Bauhaus, o Törten Siedlung, em Dessau (1926-1928), de Gropius, foi outro exercício importante de desenho urbano e racionalização da construção.

A tentativa de aproximação de arte e produção industrial propiciou o estudo de tipos para diversos objetos da vida cotidiana e de componentes da construção civil no país todo.

Em Frankfurt, foram elaborados detalhes padrões para produção e montagem de janelas de ferro ou madeira; batentes metálicos e ferragens para portas; tetos planos; ferragens para mobiliário, desenho de cozinha, etc. Os esforços para a padronização não se restringiram aos componentes da construção civil isoladamente, mas incorporou também o mobiliário. No escritório de May, em Frankfurt, existia uma lista de produtos aprovados para habitação proletária, como camas, cadeiras, luminárias e uma infinidade de itens, muitos deles projetados pela própria equipe de May ${ }^{4}$.

Ernst May foi outro dos arquitetos e planejadores urbanos mais expoentes durantes os anos da República de Weimar. Estudou em Londres, Darmstadt e Munique, e trabalhou por alguns anos no escritório de planejamento urbano de Raymond Unwin. Depois da primeira guerra, esteve envolvido no planejamento de Breslau. Em 1924, foi indicado pelo prefeito democrata Ludwing

4 "Housing in Frankfurt 1925-1931 and the new Wonhnkultur", em The Architectural Review, jun. 1978, p.338. 
Landamann como diretor de todas as construções da sua cidade natal, Frankfurt. Como chefe do departamento de habitação e de planejamento da cidade, May tinha amplos poderes, sem precedentes na história do município, para combater a crescente e desesperante carência de habitação em Frankfurt. May e sua equipe foram encarregados de supervisionar todos os projetos de construção municipal, além de preparar um plano geral para o município que iria controlar e direcionar toda a futura expansão da cidade. Seu escritório também controlava as inscrições para os empréstimos concedidos às cooperativas de construção; May também fora nomeado diretor da maior cooperativa de construção da cidade, à época pertencente à municipalidade. Juntamente com seus colaboradores, o arquiteto conseguiu atingir a impressionante marca de 15.000 unidades habitacionais em apenas poucos anos de gestão. A tradição da cidade em planejamento urbano e habitacional preparou o terreno no período préguerra para a execução de tal feito. Na gestão do Prefeito Franz Aideks (18901912), o município havia preparado leis que permitiam a aquisição de grandes porções de terras pela gestão pública para programar parques e empreendimentos habitacionais.

May foi uma das mais importantes figuras dos primeiros anos dos CIAM's, como já visto anteriormente. Fez parte do grupo de fundadores que se encontraram em La Sarraz em 1928 e foi responsável pela proposta de sediar o segundo congresso em Frankfurt em 1929. Frankfurt era na verdade a cidade mais apropriada para a discussão da habitação para o 'Existenz-minimum', tema do segundo congresso. As novas habitações, apartamentos ou casas, projetadas e planejadas durante sua gestão, foram desenhadas procurando o mínimo de espaço possível, o que, graças ao seu projeto funcional e seus equipamentos planejados, como cozinhas e banheiros, ofereceriam condições agradáveis de moradia para a população que até então era forçada a viver condições de cortiços.

Logo após a crise econômica de 1929, os recursos financeiros da República de Weimar para os programas habitacionais diminuíram significativamente, e embora o arquiteto tentasse por todo meio técnico diminuir o preço da unidade, a escassez de materiais e a crise financeira após o Crash de 1929, aumentavam o valor da construção a cada dia. May aceitara então a oferta de deixar a Alemanha e parte para a URSS, tornando-se o diretor de umas 
das brigadas de construção que deveriam planejar as novas cidades indústrias da União Soviética, as quais seriam o coração da nova sociedade comunista.

Essas brigadas teriam que enfrentar as condições climáticas adversas, a administração local, más condições de trabalho e principalmente contra a falta de material de construção. Até onde se sabe, poucos desses projetos foram levados a cabo, e em poucos anos a existência dessas brigadas tornou-se embaraçosa para as regiões que as abrigavam, uma vez que a proposta oficial de arquitetura da antiga URSS tornou-se avessa às ideias modernistas com a ascensão de Stalin ao poder.

May foi planejador e arquiteto ativo também no leste da África, trabalhando principalmente para as classes média e alta. Depois de muitos anos May, retornou a Alemanha, onde esteve envolvido com o planejamento de novos assentamentos, como em Neu-Alona. Estes assentamentos habitacionais foram muito menos expressivos do que aqueles que ele construiu para Frankfurt nos anos de 1920. Para conseguir maiores densidades nos assentamentos, May priorizou a construção de edifícios em altura ao invés das casas unifamiliares e dos blocos de apartamentos. As áreas residenciais se tornaram monótonas e foram projetadas privilegiando principalmente o sistema viário.

May é mais conhecido, contudo, pelo programa ambicioso de habitação popular que conduziu em Frankfurt entre os anos de 1924 e 1930. Um a cada onze residentes do perímetro urbano de Frankfurt foi contemplado com uma moradia de aluguel deste programa. O plano geral para a expansão da cidade de 1926, foi desenhado como uma série de anéis abraçando a cidade existente, separando cada um deles por faixas de terras cultiváveis ou parques. Os novos conjuntos projetados por May e sua equipe estavam situados nesses anéis ao redor da antiga cidade.

O planejamento de Frankfurt foi desenvolvido segundo o princípio do Trabanten-stadt (cidade-satélite), interpretação de May sobre os princípios de cidade-jardim de Howard e Unwin. Ao contrário dos exemplos ingleses, contudo, que tendiam a serem situadas a uma distância considerável dos centros urbanos consolidados, as áreas satélites de May estavam integradas ao complexo urbano de Frankfurt. A cidade se mantinha como um todo, com as áreas verdes funcionando como um complexo de parques urbanos. Seu vasto programa de construção foi publicado na revista mensal voltada para o público internacional, intitulada Das Neue Frankfurt (1925-1931; A Nova Frankfurt). Nesta revista, May 
anunciara a emergência de uma nova, unificada e homogênea cultura metropolitana. Racionalidade e funcionalidade foram qualidades consideradas prioridade em seus projetos. A nova Frankfurt - o nome da revista acabou se estendendo para o programa habitacional em si - antecipava uma visai de sociedade futura, organizada racionalmente e sem conflitos, de pessoas com direitos iguais e interesses comuns. Este ideal distante, quase utópico, e as necessidades reais de habitação em Frankfurt, combinados, formaram a base da política habitacional da cidade. Neste ambiente, os arquitetos da Nova Frankfurt deram prioridade para a industrialização do processo construtivo e para a utilização dos princípios tayloristas para a utilização do espaço. Eles experimentaram diversas formas de pré-fabricação e de painéis construtivos (Plattenbau), e a famosa cozinha de Frankfurt, projetada por Margarete SchütteLihotzky em 1926, tornou-se padrão em todas as unidades habitacionais.

Politicamente falando, nas intervenções de Ernst May não há nenhuma ruptura entre as decisões e as realizações. A capacidade de organização e competência dos serviços técnicos permitiram intervenções realizadas em todas as escalas, incluindo:

- "Aquisição de terrenos;

- Planejamento de detalhes: os planos das Siedlungen principais eram o trabalho de grupos de arquitetos municipais, que eram por vezes arquitetos independentes associados;

- Construção: o município estabeleceu fábricas de pré-fabricação e realizou experimentos com materiais como concreto leve;

- Financiamento da construção;

- Gerenciamento de execução: assistência técnica e controle de qualidade para as Siedlungen que foram construídas por empresas privadas e de gestão direta de projetos de cooperativas municipais,

- Informação para o público: como em Breslau, mas em uma escala maior, com a revista Das 
Neue Frankfurt, que regularmente apresentava os projetos e as realizações em Frankfurt, mas também as experiências da arquitetura moderna das cidades alemãs e estrangeiras, e muitas outras dedicadas a cultura internacional, incluindo as experiências artísticas, teatro, cinema, pedagogia e esportes." (PANERAI, 2004, p.105)

Além de pareceres técnicos, os serviços imobiliários e financeiros ajudaram na construção de habitação social de muitas outras formas:

- "Pelas políticas de terra. Na época do lançamento do projeto Nidda, a cidade já possuía 45 por cento da terra e começou a adquirir o restante através de expropriação ou troca. Os terrenos adquiridos desta forma, em que a especulação já não podia acontecer, foram alocados para a habitação de modo que os custos do terreno (incluindo serviços e uma série de infra-estruturas públicas), representariam menos de $25 \%$ do custo total da habitação;

- Financiamento e gestão. Embora ela nunca tenha chegado a 100 por cento, a participação do município foi muito grande, pois atuou diretamente na questão, seja por meio da agência municipal de sociedades cooperativas ou através de empréstimos a sociedades cooperativas particulares, que muitas vezes eram geridas pelos sindicatos. O apoio público foi fornecida na forma de empréstimos do governo a juros baixos (3 por cento, às vezes até um por cento), por meio 
de empréstimos de bancos de poupança, através de subsídios e através de garantias de empréstimo." (PANERAI, 2004, p.106)

Assim, o município conseguiu fazer com que planejamento e execução andassem pari passu, articulando técnica e decisões políticas, sendo interrompido apenas pela crise de 1929 e pela ascensão do regime nazista.

Em termos urbanísticos, ao mesmo tempo em que May e seus associados seguiam a linha moderna de planejamento e arquitetura, a equipe tinha uma grande estima pela cidade existente. Como resultado, várias situações de diálogo entre a cidade moderna e a existente foram orientações mestras no desenvolvimento de alguns projetos. Contudo, é possível estabelecer uma transformação na morfologia urbana das Siedlungen. Os conjuntos de antes de 1929 mostram uma influência mais marcante de sua interpretação dos princípios da cidade-jardim. Os projetos depois dessa data, como Westhausen e Hellerhofsiedlung, são baseados estritamente sob os princípios das habitações em fileiras "abertas" (Zeilenbau) que é muito mais racionalista.

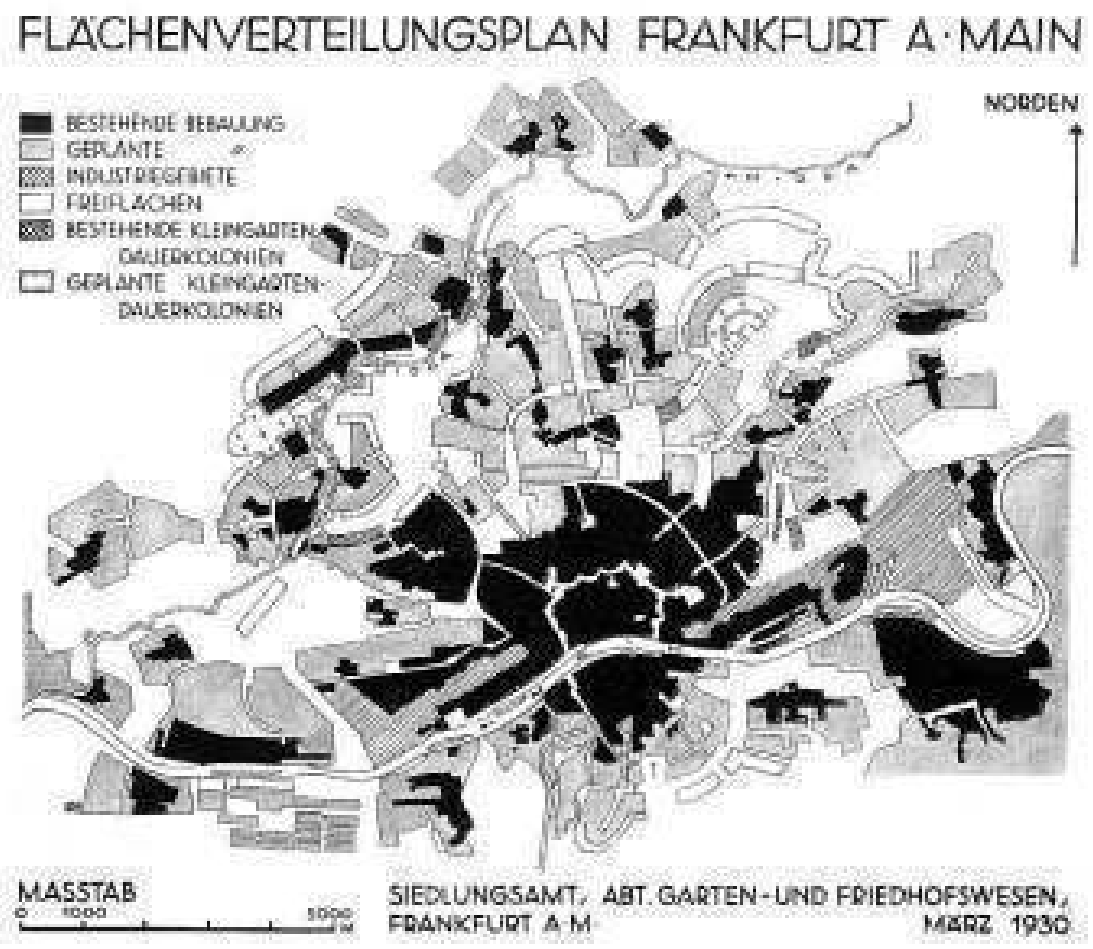

Figura 163. Ernst May, Plano de Frankfurt (Das neue Frankfurt, n. 2/3, 1930). A antiga cidade se torna o centro do sistema urbano que integra vilas vizinhas e novas áreas de habitação social. 
Os primeiros projetos construídos por May em Frankfurt foram dois conjuntos habitacionais nas porções sudoeste e norte da cidade: Bruchfeldstrasse (conhecido como Niederrad) e Hohenblick. Devido à sua ousada ocupação da quadra, com edifícios em ziguezague no perímetro da rua, conformando um grande pátio interno aberto, Niederrad foi bastante publicado à época da construção. O conjunto apresenta teto-plano, superfícies planas, padrão abstrato para modulação das aberturas e uma faixa colorida na altura do térreo, conferindo assim maior horizontalidade à construção. A utilização do grande pátio interno confere ao conjunto um ar de subúrbio, reforçado pela pouca altura dos blocos (três pavimentos). May colocou um centro comunitário na entrada do pátio interno do bloco principal, simbolizando dessa forma seu uso coletivo.

Com a localização desses dois pequenos conjuntos na borda da cidade, May de imediato demostrou a intenção em construir subúrbios satélites ao redor da cidade consolidada. Locais em que se poderia exercitar nos parâmetros de urbanismo e arranjos habitacionais sem as amarras do tecido consolidado da cidade antiga. Uma nova forma de urbanismo que possibilitaria a vida comunitária e saudável poderia se desenvolver plenamente nessas novas regiões, conectadas à cidade existente pelos meios de transporte existente (trens e ruas). As áreas adquiridas pelo município para execução da reforma habitacional até então, por serem recortadas por edificações existentes, não permitiram que o plano de expansão em anéis fosse realizado plenamente, além, é claro, da paralisação das obras após 1933. Antes dessa data, apenas na região do Vale do Nidda foi possível a construção de três grandes conjuntos que completavam parte do anel: Prauhein, Römerstadt e Westhausen - somando quase 4.000 unidades habitacionais. Os três projetos estão localizados num longo adunco a nordeste de uma curva do Rio Nidda e foram concebidos com uma concepção de subúrbios de baixas densidades; todos possuem edificações para comércios locais, e Römerstadt e Prauhein possuem também escolas e restaurantes. Esses dois últimos possuem apartamentos voltados para as avenidas principais, mas as fileiras de sobrados ou blocos estão separados entre si, destacados do viário existente, com grandes jardins entre as filas.

Em relação à paisagem urbana desses conjuntos, de fato eles constituem uma Nova Frankfurt, totalmente distinta da cidade existente. A linguagem dos 
tetos planos e planos lisos das fileiras de sobrados em Prauhein, por exemplo, somado às poucas aberturas das fachadas, conferem ao espaço uma horizontalidade pesada, suavizada pelos quintais-jardins, ao passo que os edifícios com galerias externas têm uma aspecto mais leve pelos cheios e vazios formados pelos balcões e caixas de escada. O longo edifício em curva de Römerstadt constitui um ponto focal em meio aos blocos laminares dispostos ao longo da rua, quebrando a monotonia do conjunto, configurando uma "entrada" do complexo.

Römerstadt é o mais famoso e mais convincente exemplo do planejamento urbano de May. A ideia básica de Römerstatd era tirar partido das qualidades da paisagem local: o empreendimento segue o contorno da encosta em forma de terraços, incorporando a paisagem do vale do Nida pela utilização de postos de observação distribuídos ao longo do muro de contenção entre o vale e o conjunto. Existe uma clara hierarquia entre a rua principal (Hadrianstrasse), ruas residenciais e caminhos entre os blocos, que a própria arquitetura acentua; a diferença entre a "frente" pública e as "costas" privada das habitações é enfatizada pelo desenho alinhado do acesso na parte frontal, com uma marquise sobre a porta de acesso. Nesse conjunto, as edificações não mais são alinhadas no perímetro do bloco, como no século 19 , e a monotonia do conjunto é quebrada pelas longas ruas escalonadas e curvas ao longo da encosta. Nesse projeto, May propõem uma nova relação entre as áreas de fundo de vale e as zonas habitacionais, tirando partido da paisagem e topografia para a disposição das fileiras de sobrados nas curvas de nível. Os edifícios mais altos e dispostos perpendicularmente aos blocos e casas em fileiras na última "curva" do fundo de vale pontuam os mirantes projetados e quebram a monotonia da paisagem.

Podemos observar que no desenvolvimento desses projetos May explorou amplamente o repertório da nova arquitetura difundida nos 1920. Formas puras, ortogonais ou orgânicas, fachadas austeras com poucas esquadrias (especialmente projetadas para a produção em série no programa de Frankfurt), ou grandes galerias externas de circulação demonstram o comprometimento com essa nova linguagem arquitetônica, embora May nunca a tivesse utilizado antes de sua atuação em Frankfurt. Cores fortes e contrastantes também são utilizadas para amenizar a paisagem árida da sequência de blocos 
iguais, o que evidência uma forte apropriação de outras experiências concomitantes na Alemanha, como o colorido de Bruno Taut em Berlim.

As unidades habitacionais propostas para esses conjuntos eram bastante compactas, como resultado das pesquisas de racionalização dos fluxos e funções dentro do próprio espaço de morar, bem como da possibilidade de coletivização de algumas atividades. Possuíam aquecedor central e facilidades comuns com lavanderias coletivas nos blocos de apartamentos. As condições econômicas na Alemanha que reflitam no custo da terra e aumento dos custos dos materiais de construção levaram a soluções de projetos mais radicais: utilização de camas dobráveis, cozinhas tipo com área bastante reduzida, dormitórios cada vez menores, etc. Em Praunheim, May adota a solução de espaços íntimos mínimos (quartos) e tenta ampliar a sensação de espaço pelo projeto de uma sala de estar-jantar combinada, conectada a uma cozinha "alcova", com ventilação mecânica; dessa forma, as atividades da família acabavam se concentrando na sala comum (LANE, 1968, p.104). De uma forma geral, essas experiências não primavam pela flexibilidade da planta, mas propunham usos sobrepostos no mesmo ambiente, remodelando as formas de convivência familiar.

Para o barateamento da obra, May empregou a racionalização dos elementos construtivos, como já vimos, e tentou implementar o uso de novo maquinário no canteiro de obras. Experiências com painéis de concreto leve e lajes de concreto pré-moldadas foram bastante avançadas para época, utilizadas em Praunheim e Hohenblick. Na Holanda esses processos foram testados em experiências como Betondorp e Papaverhof. 


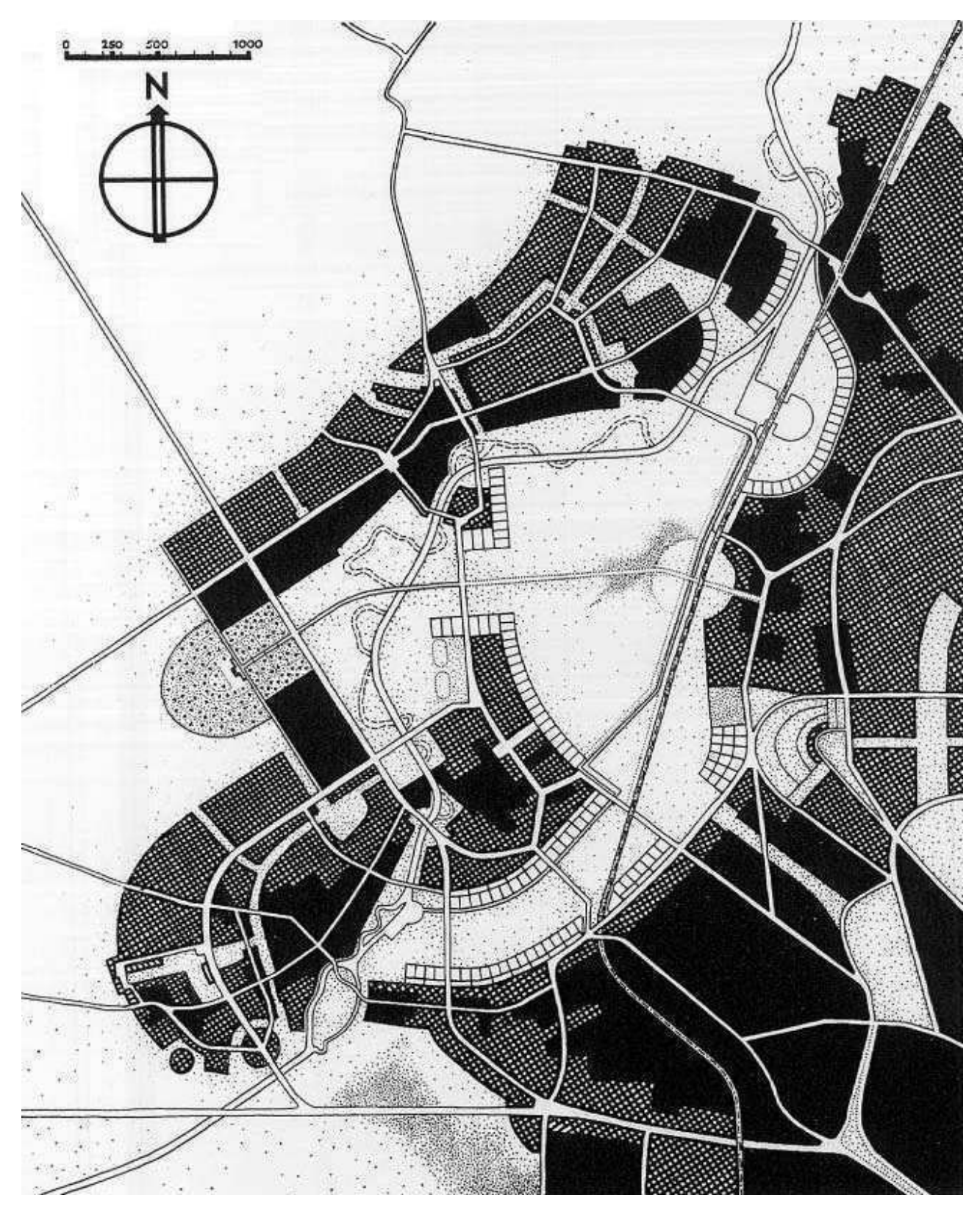

Figura 164. Plano para o Nidda Valley (Das neue Frankfurt, n. 2/3, 1930).

Em preto: áreas já edificadas; Siedlungs construídas conforme as intervenções previstas.

1. Hedderheim (village).

2. Römerstadt (siedlung).

3. Alt Praunheim (village).

4. Praunheim (siedlung).

5. Westhausen (siedlung)

6. Hausen (siedlung).

7. Rödelheim (village and siedlung).

8. Botanical Garden. 


\section{Niederrad - Bruchfeldstrasse estate ('Zickzackhausen/zigzag estate')}

Ano: $1925-27$

Localização: Frankfurt, Alemanha.

Ruas: Breubergstrasse; Bruchfeldstrasse

Arquitetos: E. May, H. Boehm, C. H. Rudloff

Número de unidades: 643

Tipos: Blocos de apartamentos com 03 pavimentos, dispostos de forma linear, ou em ziguezague; sobrados unifamiliares.

Equipamentos: Lojas, serviços, escola.

O conjunto Niederrad foi construído entre os anos de 1926-27 pela companhia especializada em moradia econômica "AG für kleine Wohnungen". Devido à disposição dos blocos principais, o conjunto é popularmente conhecido como "conjunto ziguezague". Este layout foi elaborado na tentativa de se garantir as melhores condições de ventilação e iluminação para todas as moradias; mas também pode ser entendido como uma influência das formas derivadas do movimento Expressionista. Ainda que o conjunto possua sobrados, a maioria das unidades está disposta em blocos de três pavimentos. Os blocos foram construídos em alvenaria, com estrutura de concreto, e possuem em geral um total de 06 apartamentos.

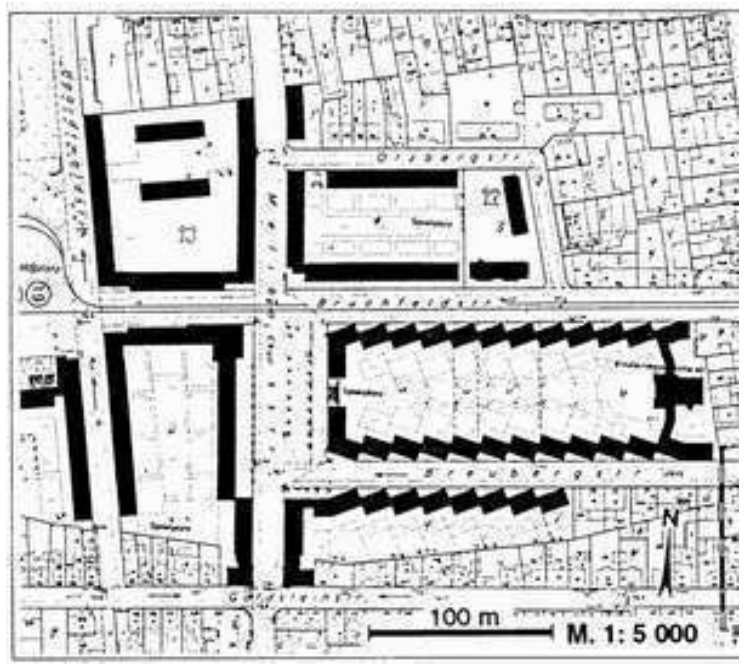

Figura 165. Implantação Niederrad. 
Capítulo 01

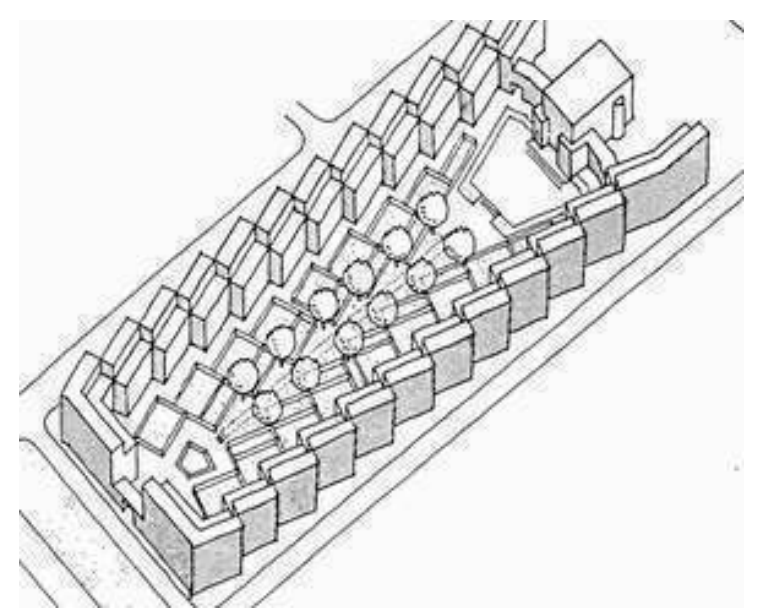

Figura 166. Perspectiva geral do bloco principal.
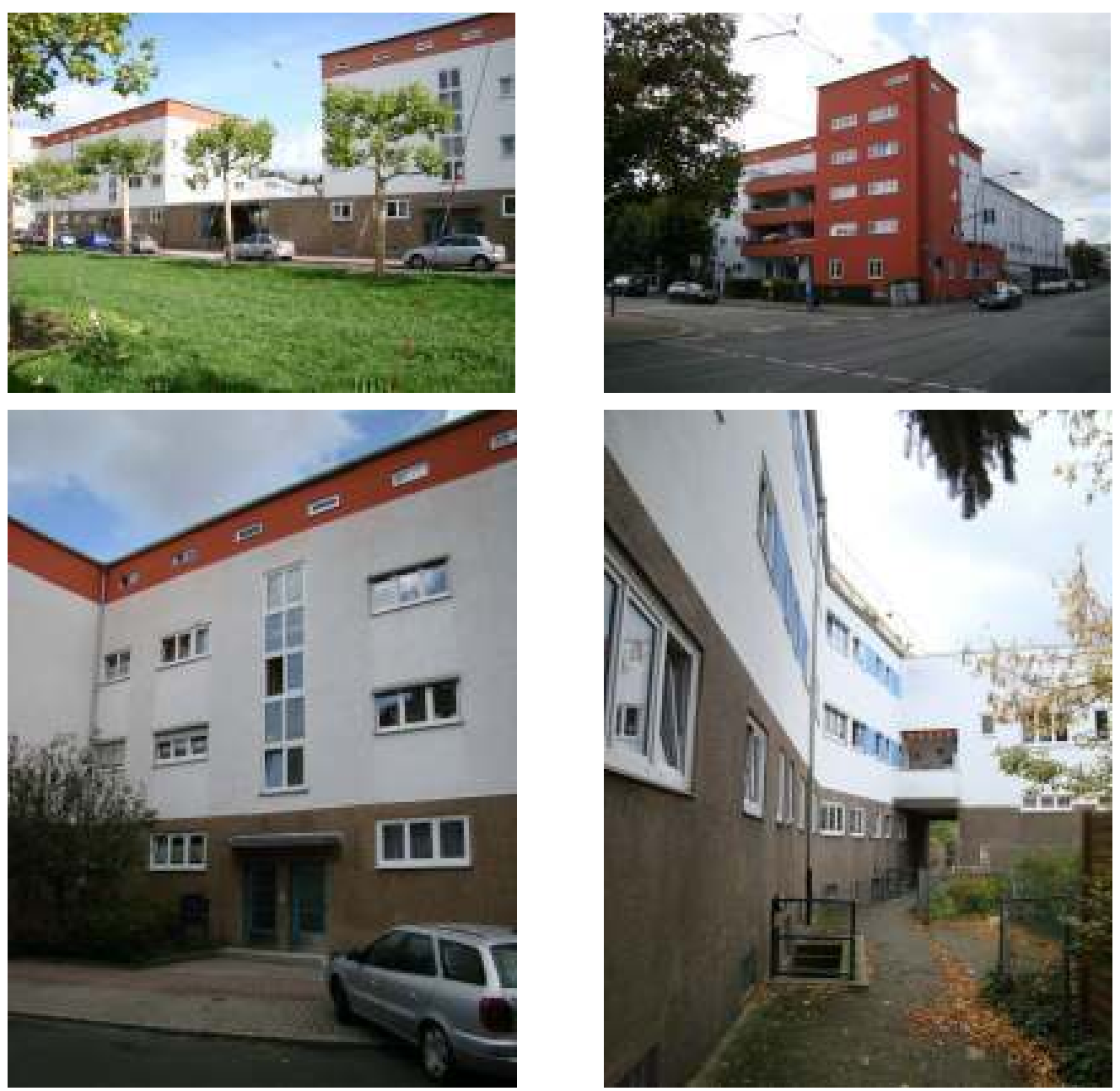

Figura 167-170. Fotos e internas do bloco principal. Fotos da autora (2008). 

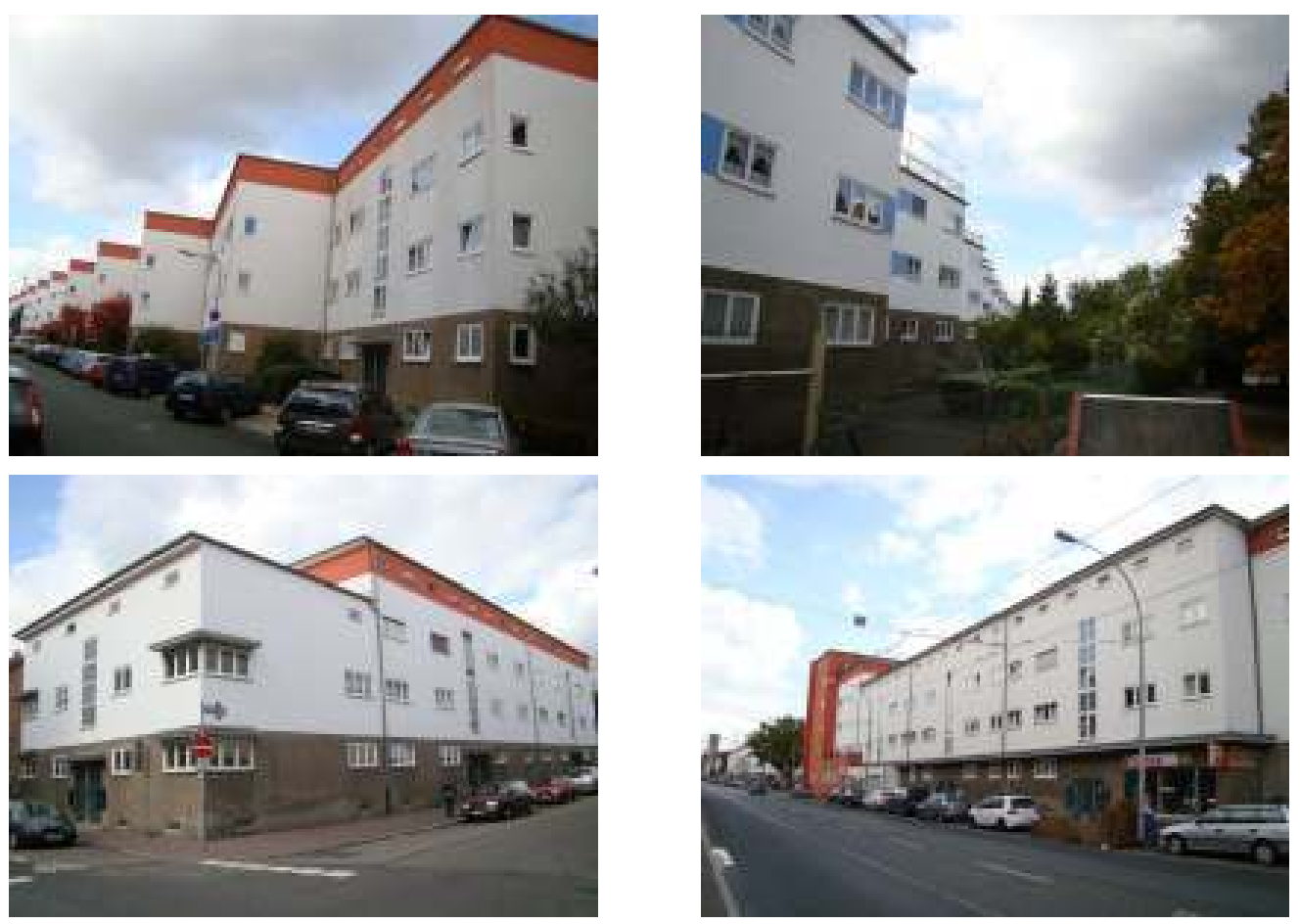

Figura 171-74. Edifícios de uso misto. Fotos da autora (2008).

\section{Praunheim}

Ano: 1926-1930

Localização: Frankfurt, Alemanha.

Ruas: Fritz Schumacher-Weg; Theodor-Fischer-Weg; Heinrich-Tessenow-Weg; Camillo-Sitte-Weg; Messelweg; Muthesius-Weg; Ludwig-Landmann-Strasse; Ludwig- Gehm-Weg; Am Ebelfeld; Pützerstrasse; Olbrichstrasse; Eberstadtstrasse; Heerstrasse; Sandplackenstrasse; Damaschkeanger; Am Hofgut.

Arquitetos: Ernst May, Emil Kaufmann, Anton Brenner Planejamento urbano: Ernst May, Herbert Boehm, Wolfgang Bangert Área do conjunto: 29,9 ha Número de unidades: 1.500; população prevista: 6.215 habitantes Tipos: Sobrados em fileira; blocos de apartamentos de 03 e 04 pavimentos, com galeria de circulação. Foram projetadas 15 unidades diferentes, todas acomodadas da forma anteriormente descrita. 


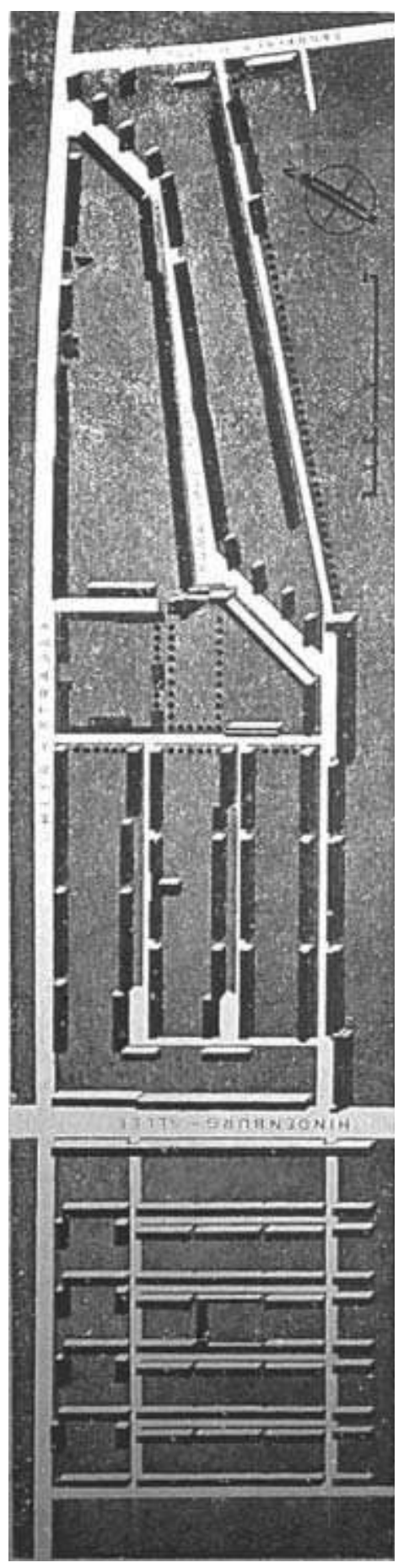

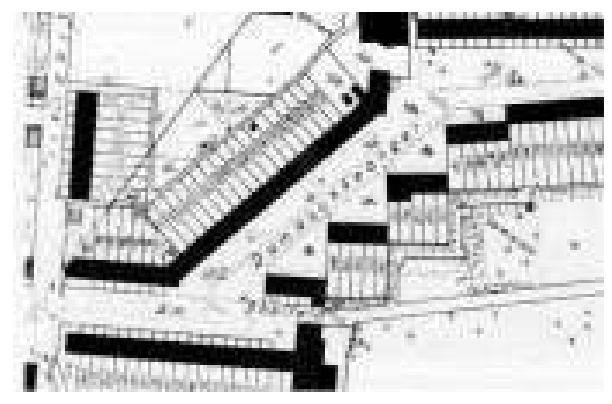
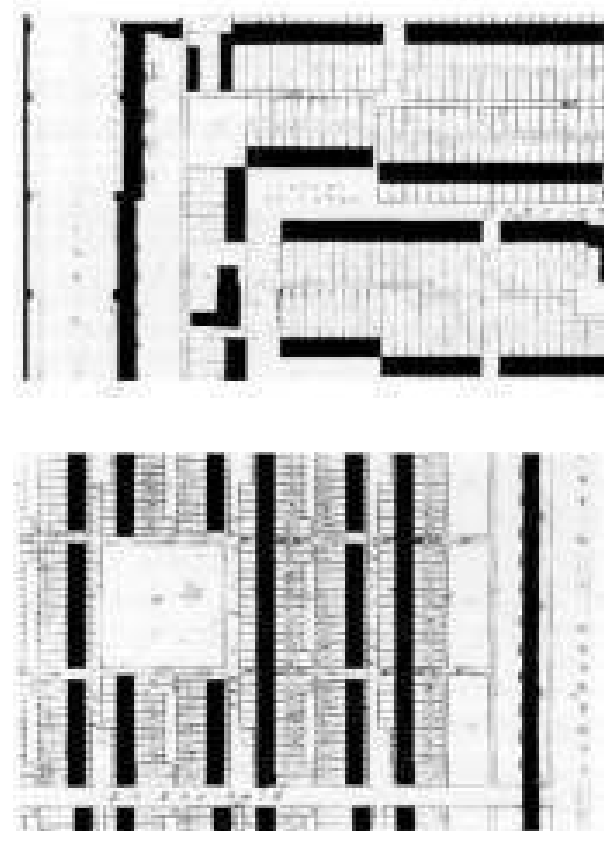

Figuras 175-178. Ernst May: Praunheim Siedlung.

As três fases deste projecto, apesar de serem parte de um mesmo conceito, marcam a passagem progressiva da fase 'pitoresca', a qual pode ser incluída Niederrad, ao "racionalismo". Fonte: PANERAI, 2004, p.109. 

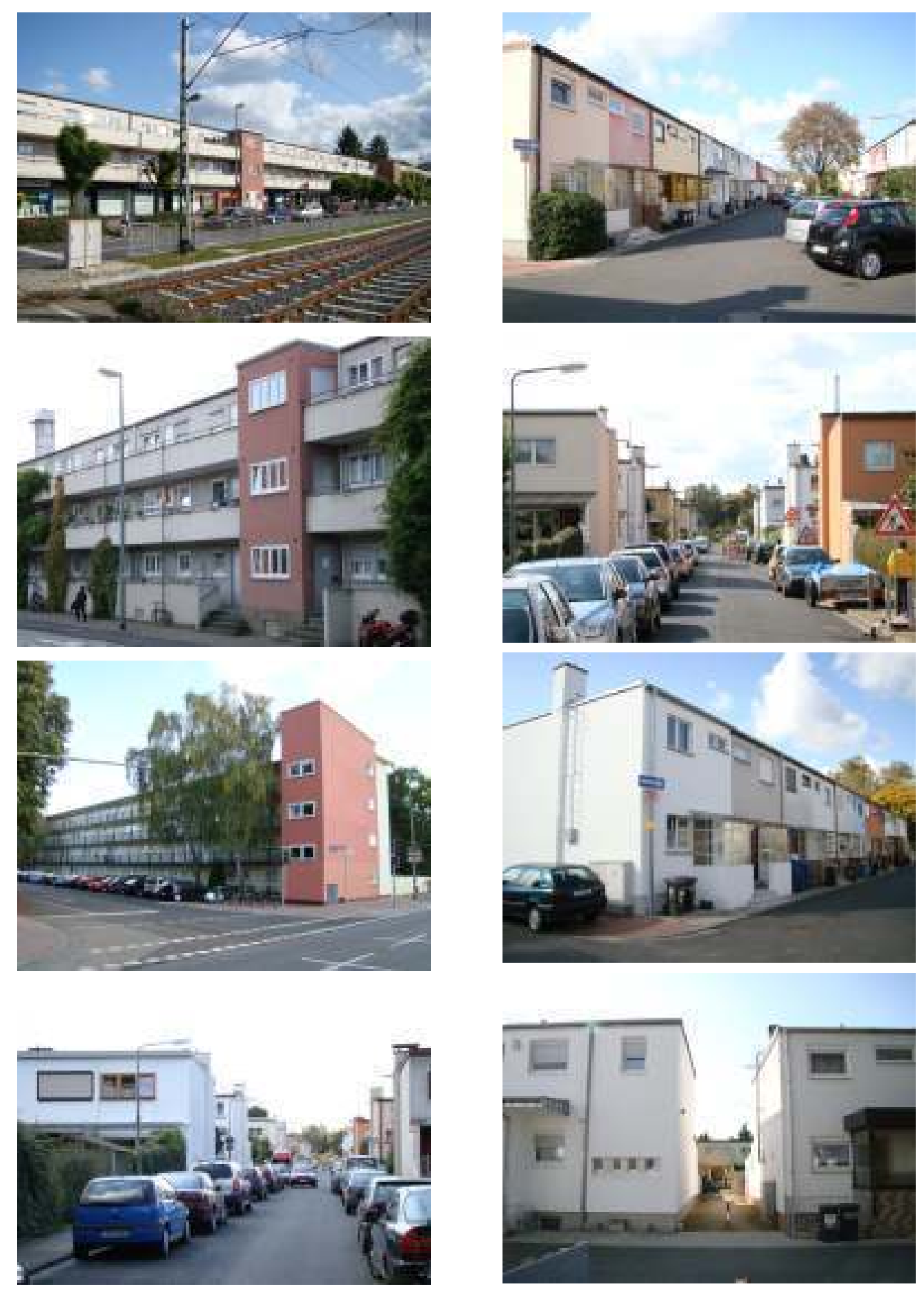

Figuras 179-86. Blocos laminares com galerias externas de circulação e fileiras de sobrados. Fotos da autora (2008). 

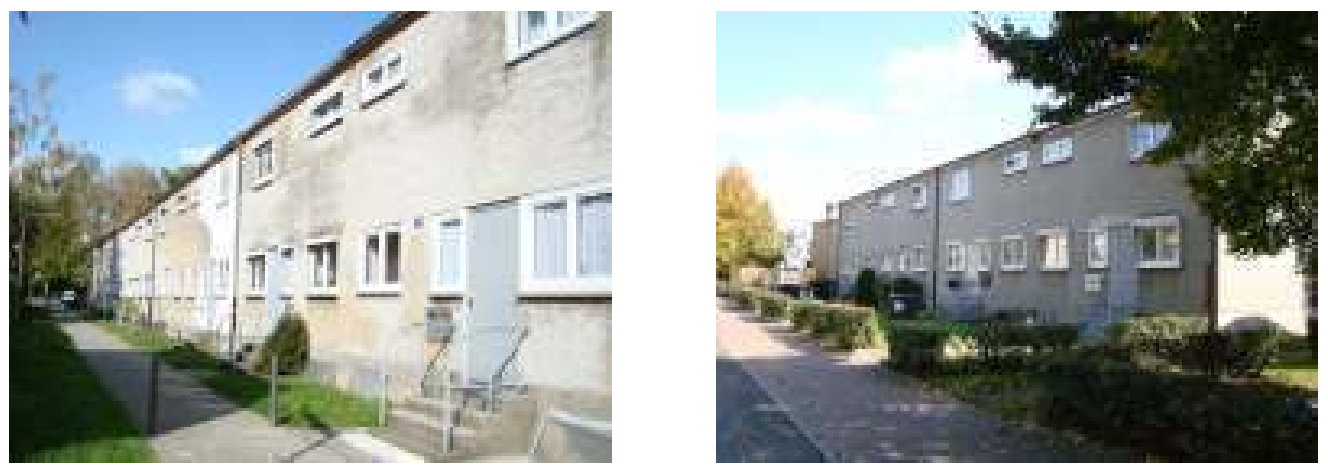

Figuras $187-88$. Fase racionalista do programa de May. Fotos da autora (2008).

\section{Römerstadt}

Ano: 1927- 28

Localização: Frankfurt, Alemanha.

Ruas: Hadrianstrasse; Mithrastrasse; Im Heidenfeld

Arquitetos: E. May, H. Boehm, W. Bangert (planning); E. May, C. H. Rudloff, K.

Blattner, G. Schaup, F. Schuster

Número de unidades: 1.220

Tipos: sobrados em fileira; blocos de apartamentos com 03 e 04 pavimentos.

Equipamentos: Lojas, serviços.

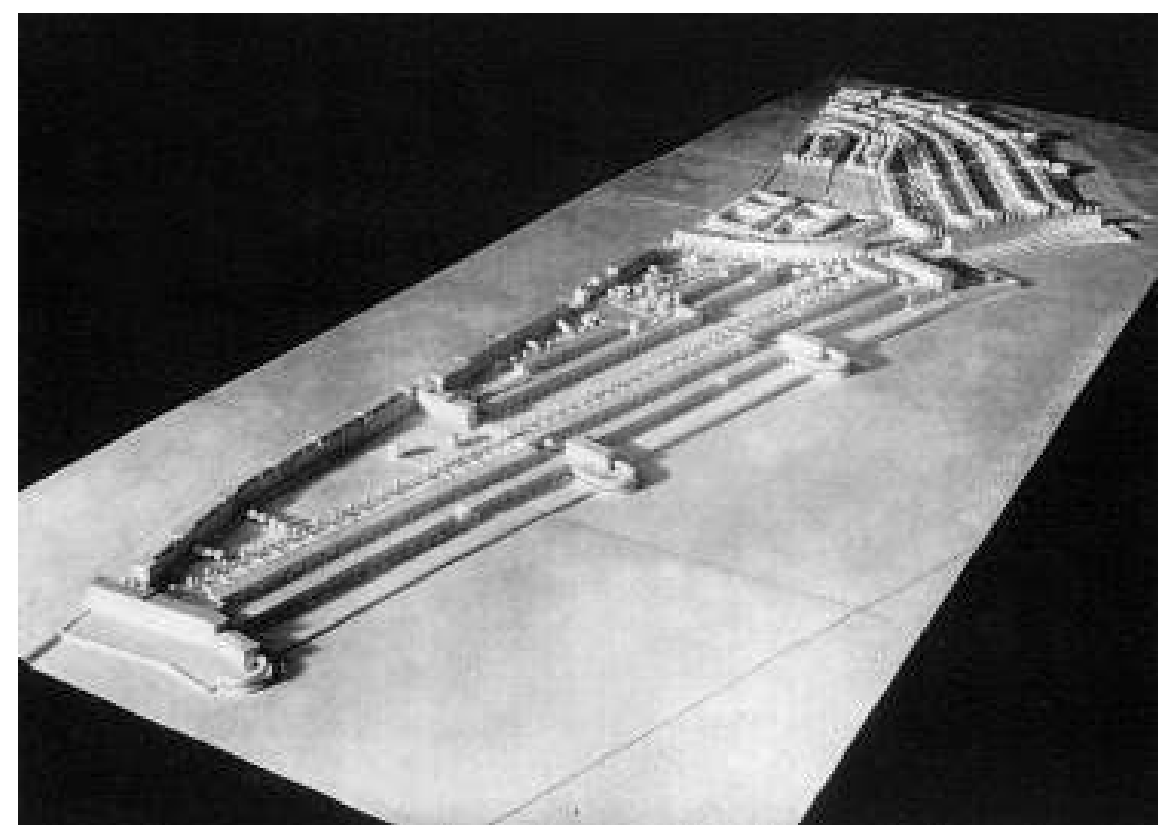

Figura 189. Maquete do conjunto. Fonte: PANERAI, 2004, p.99 
Construído entre os anos de 1927 a 1929, o conjunto habitacional de Romerstadt se estende aproximadamente 1,5 quilômetros ao longo da parte alta do vale do Nidda. O conjunto é constituído parte por sobrados com longas hortas (projetados pelo arquiteto paisagista Leberecht Migge), e parte por blocos de apartamentos. Os equipamentos construídos na época foram: um centro de compras na Hadriantrasse e uma escola, projetada por Martin Elsaesser em 1928-29.

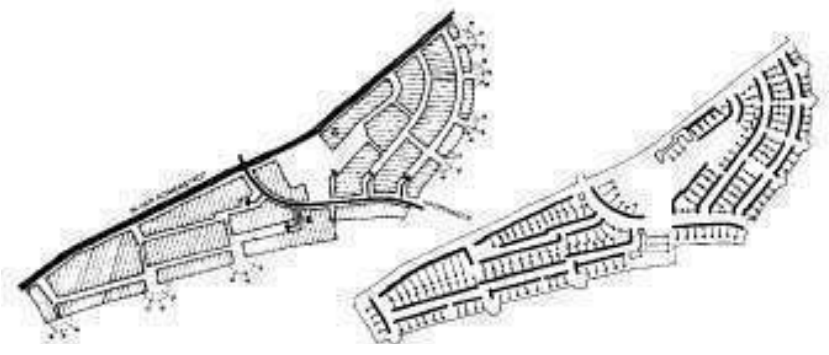

Figura 190. Implantação do conjunto.
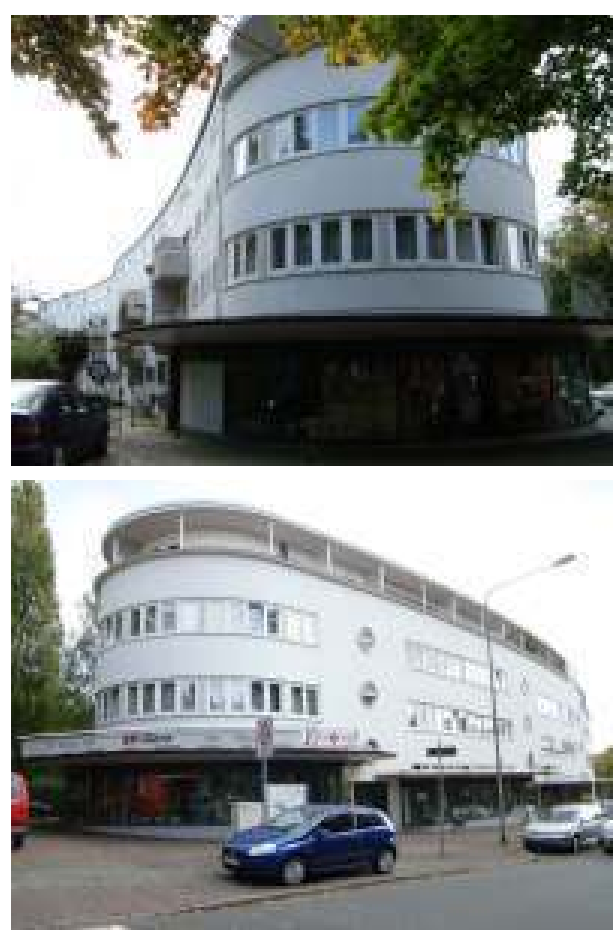

Figuras 191-94. Edifício de uso misto. Fotos da autora (2008)
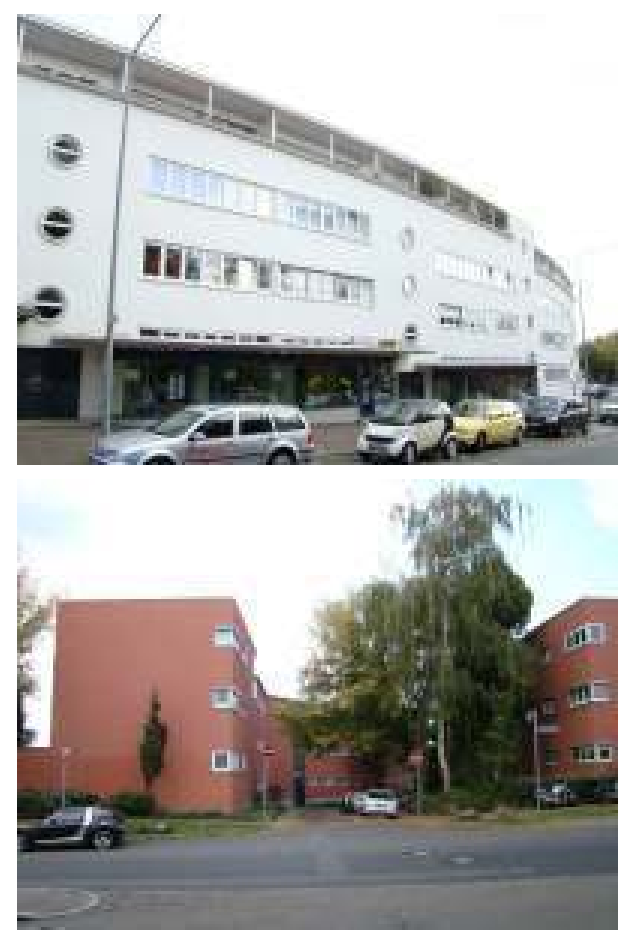

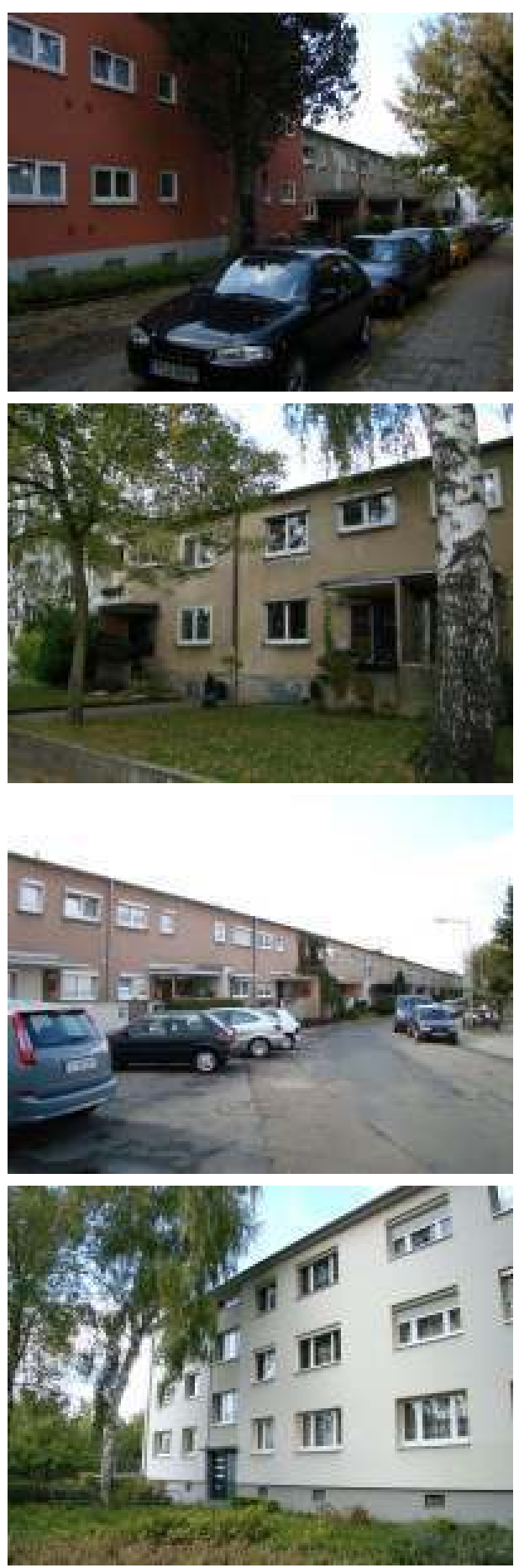

Figuras 195-202. Sobrados em fileira e blocos de habitação. Fotos da autora (2008).
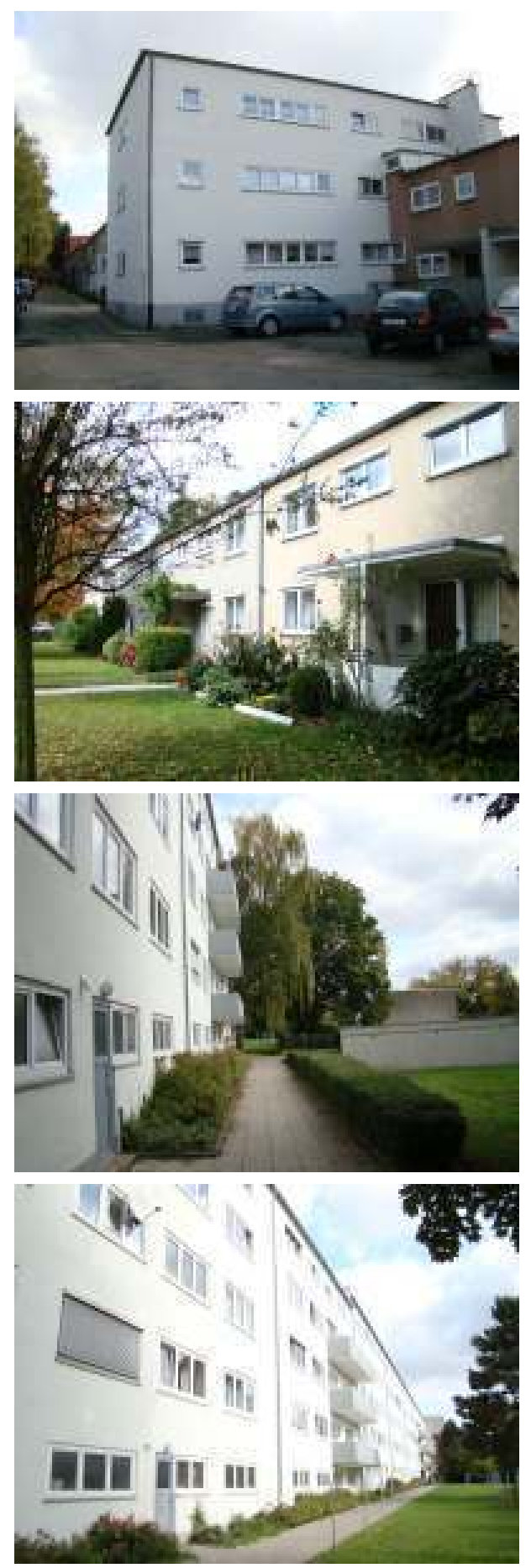

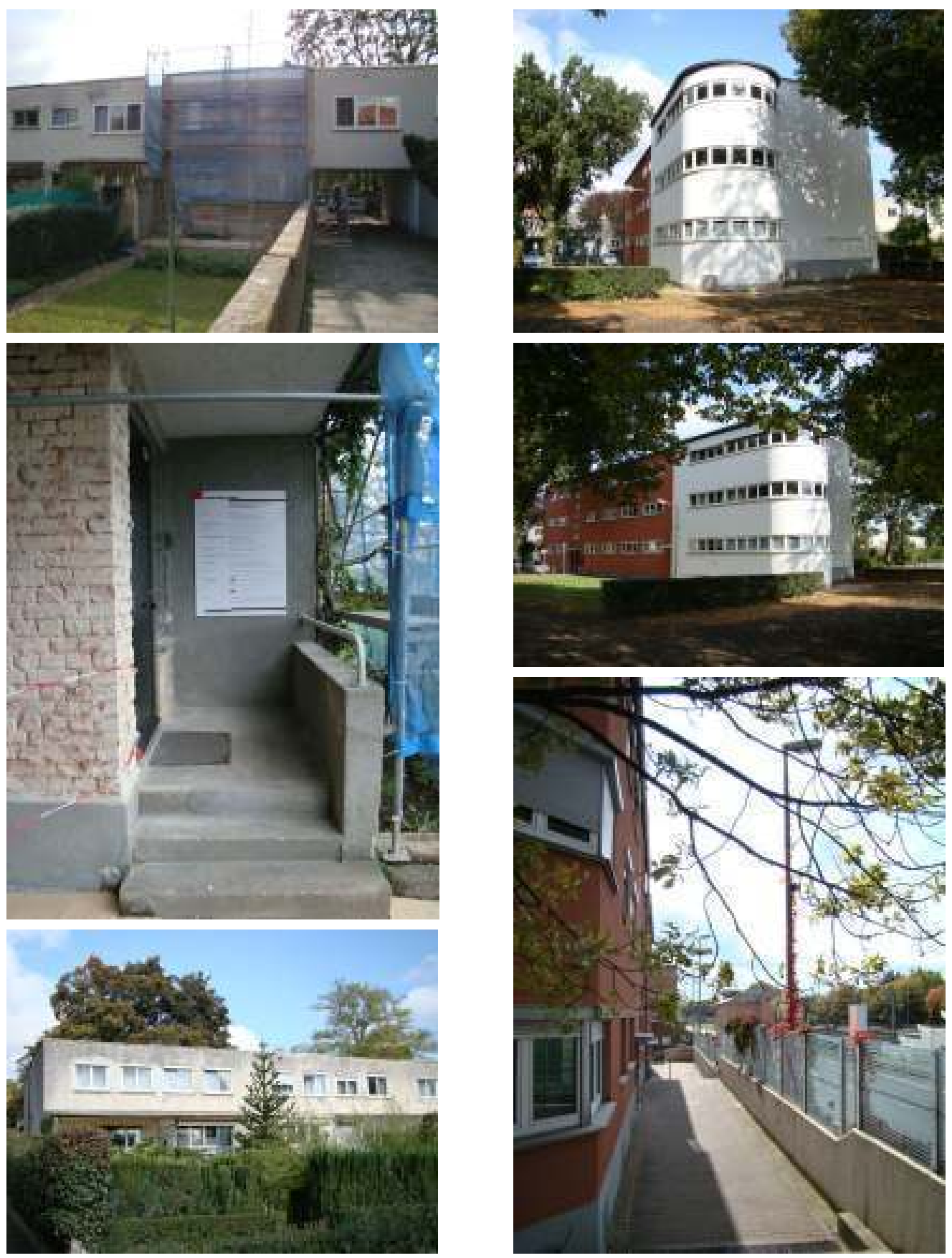

Figuras 203-208. Sobrados em fileira e blocos de habitação co vista para o vale do Nida. Ao lado, edifício próximo a linha do trem urbano. Fotos da autora (2008). 

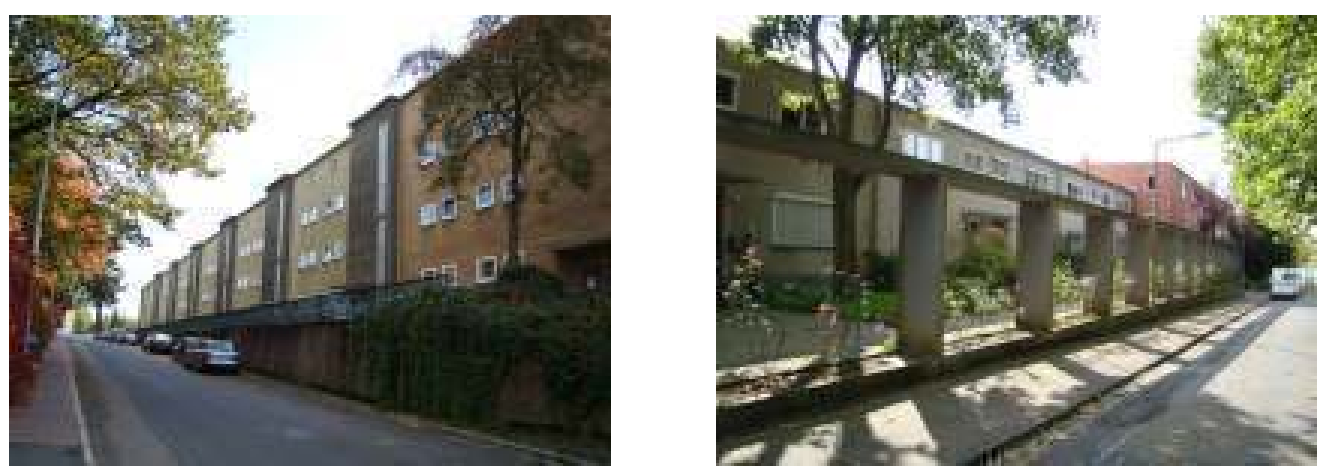

Figuras 209-210. Blocos de três andares e sobrados em fileiras. Detalhes para elementos arquitetônicos demarcando as mais privadas. Fotos da autora (2008).

\section{Riedhof West}

Ano: 1927-1934

Localização: Frankfurt, Alemanha.

Ruas: Stresemannallee; Unter den Buchen; Unter den Briken; Unter den Eichen; Unter den Eschen; Unter den Platanen; Unter den Liden; Unter den Azakien; Unter den Kastanien; Heimatring;

Arquitetos: E. May; Franz Roeckle

Planejamento urbano: Ernst May

Área do conjunto: 10,4 ha

Número de unidades: 1.072

Tipos: Blocos de apartamentos com 03 e 04 pavimentos; caixa de escada a cada duas unidades por andar.

Equipamentos: lojas

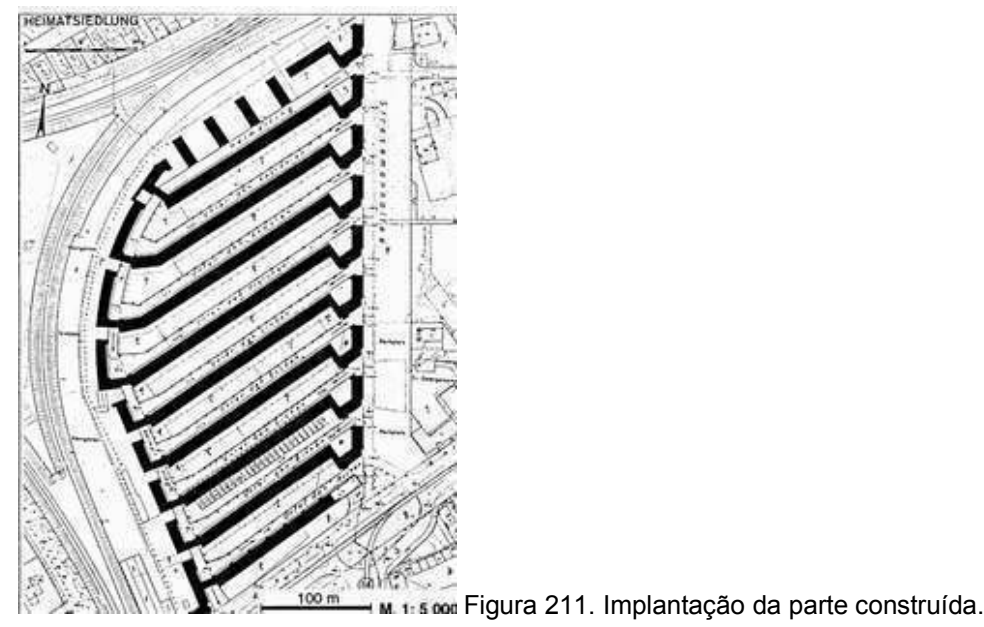




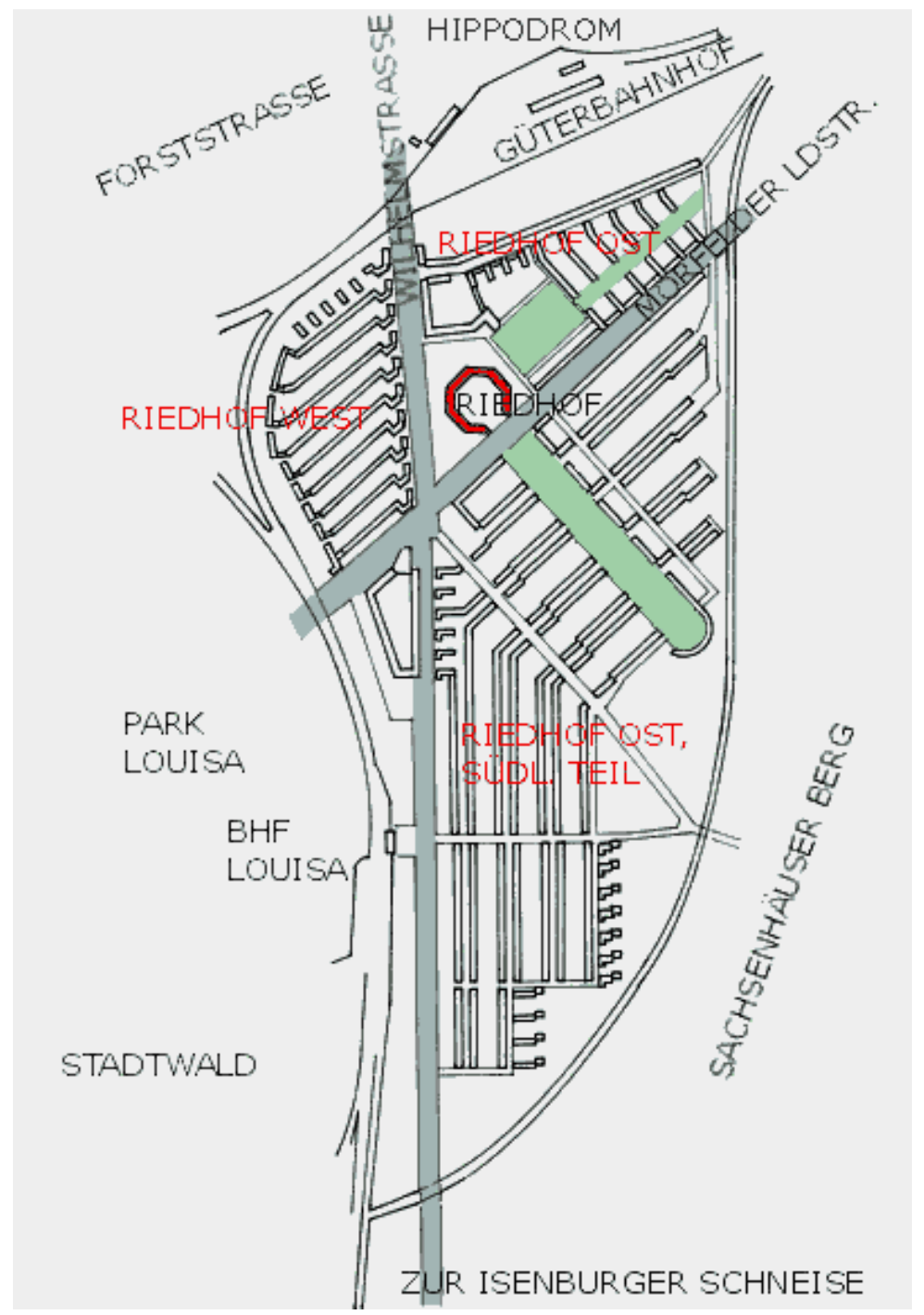

Figura 212. Planejamento para a área inteira.
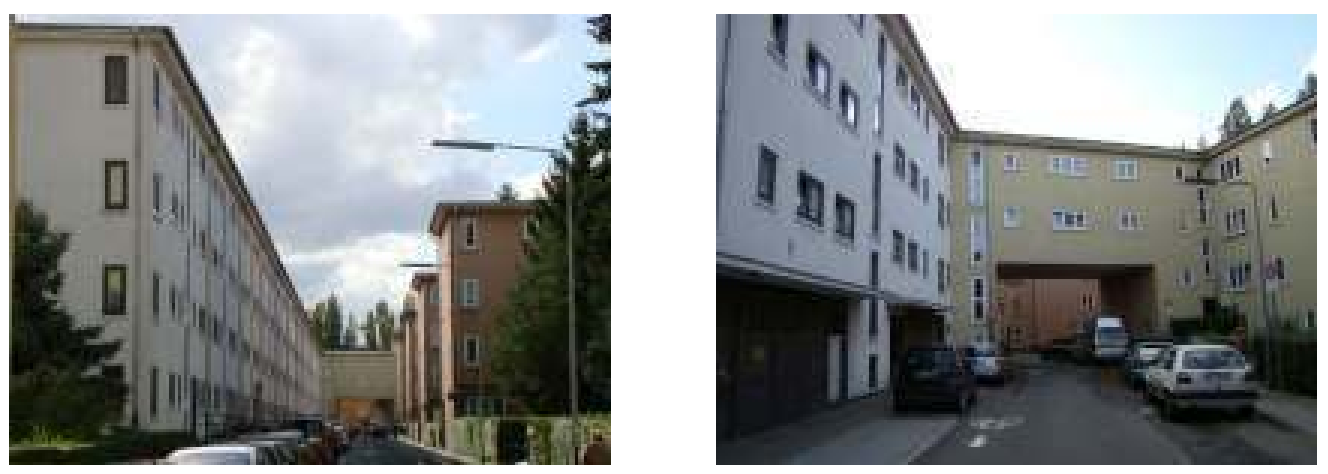

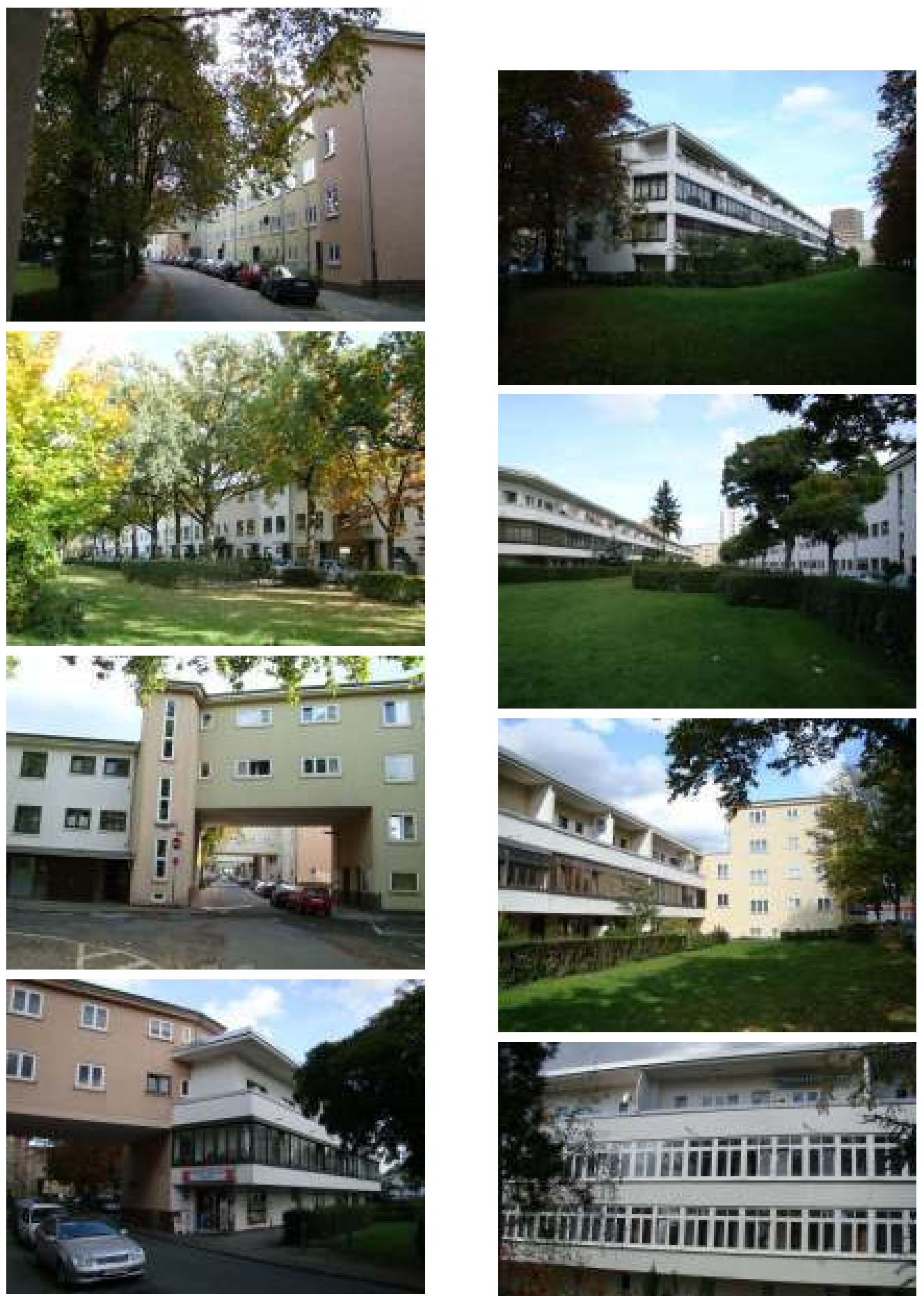

Figura 213-222. Ruas internas ao conjunto; edifícios pontes e jardins comuns. Fotos da autora (2008)
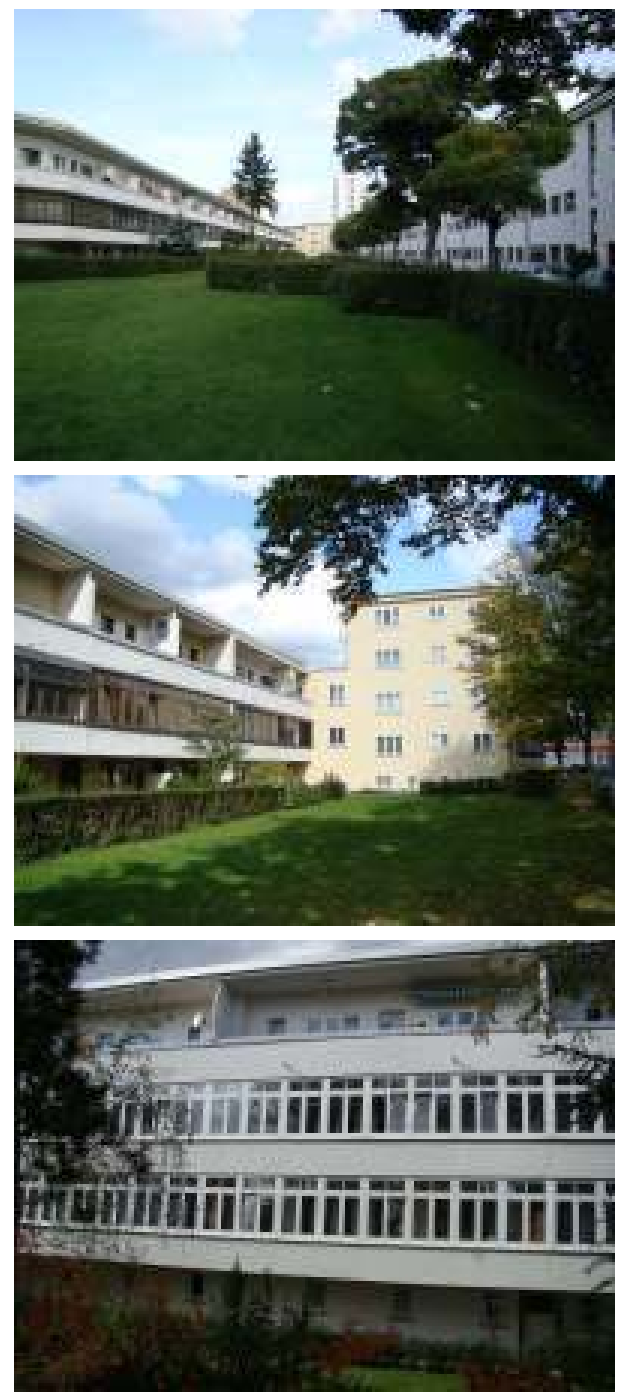


\section{Westhausen}

Ano: 1929 - 1931

Localização: Frankfurt, Alemanha.

Ruas: Ludwig-Landmann-Strasse; Stephan-Heise-Strasse; Johanna-KirchnerStrasse; Geschwister Scholl-Strasse; Egestrasse; Kollwitzstrasse; Westring; Zillestrasse.

Arquitetos: Ernst May; Ferdinand Kramer; Franz Schuster e outros.

Planejamento urbano: Ernst May

Área do conjunto: 20,1 ha

Número de unidades: 1.116

Tipos: Sobrados em fileira; blocos de apartamentos de 03 e 04 pavimentos. Todas as unidades foram equipadas com a cozinha de Frankfurt (projetada pela arquiteta vienense Margarete Schütte-Lihotzky em 1926).

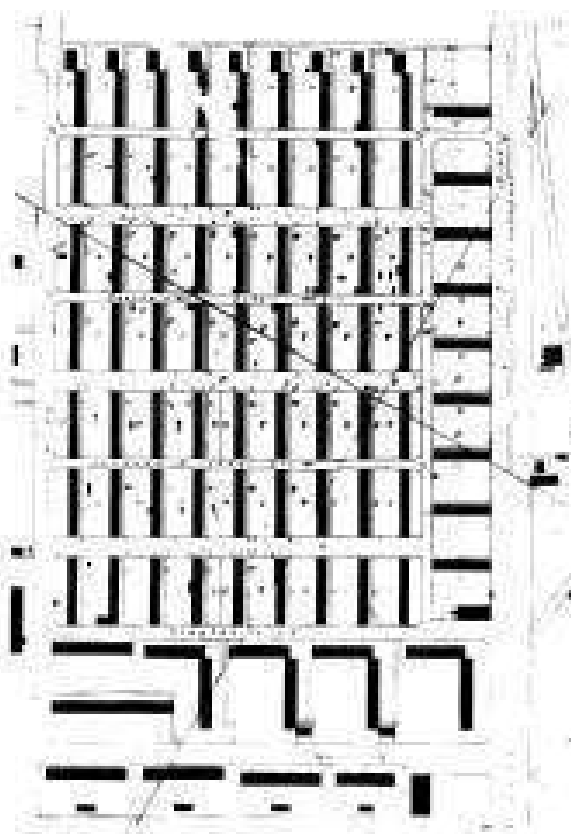

Figura 223. Maquete do conjunto. Fonte: PANERAI, 2004, p.99 

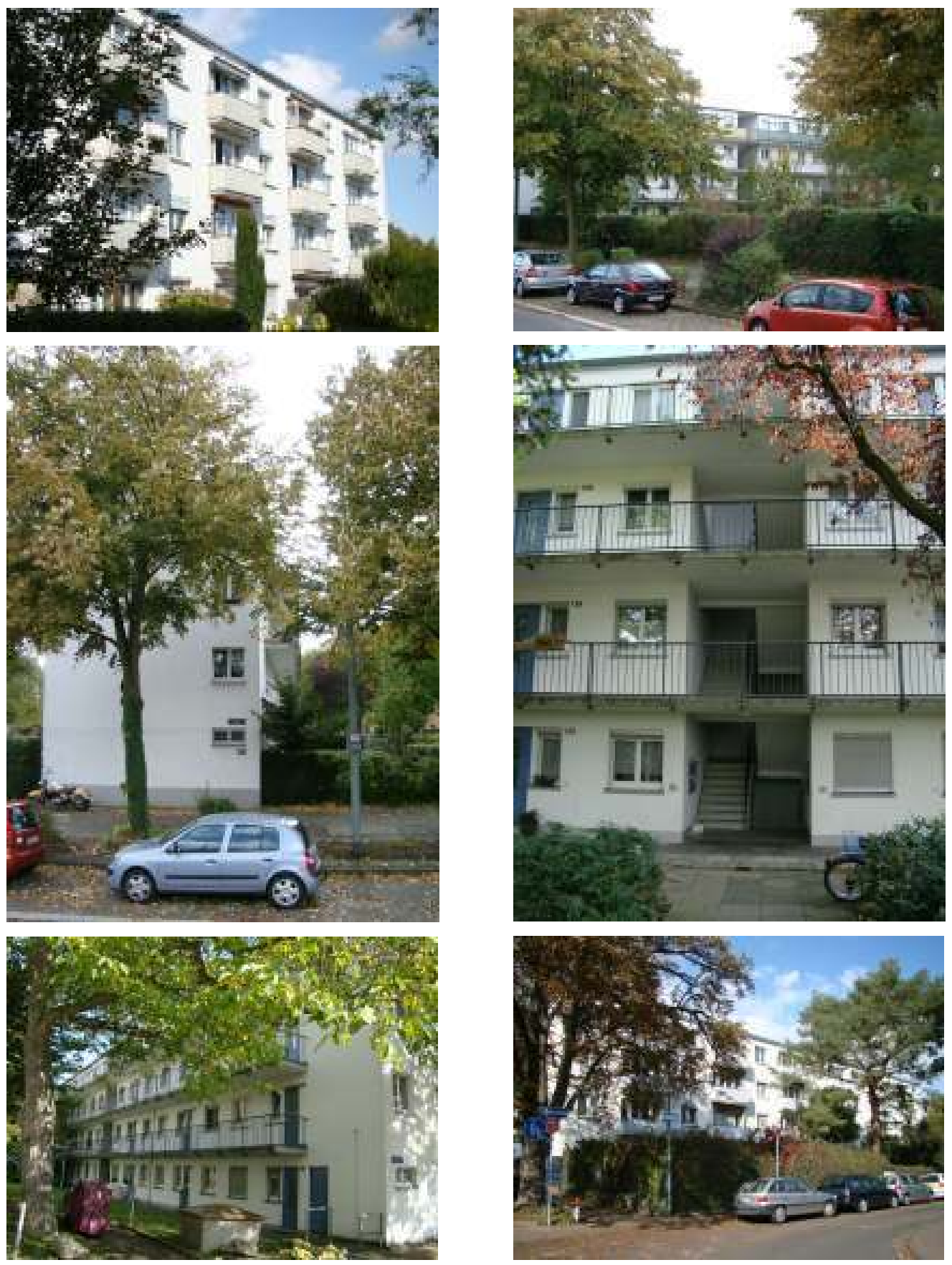

Figura 224-29. Blocos de habitação com galerias externas, perpendiculares a Ludwig-LandmannStrasse. Fotos da autora (2008). 

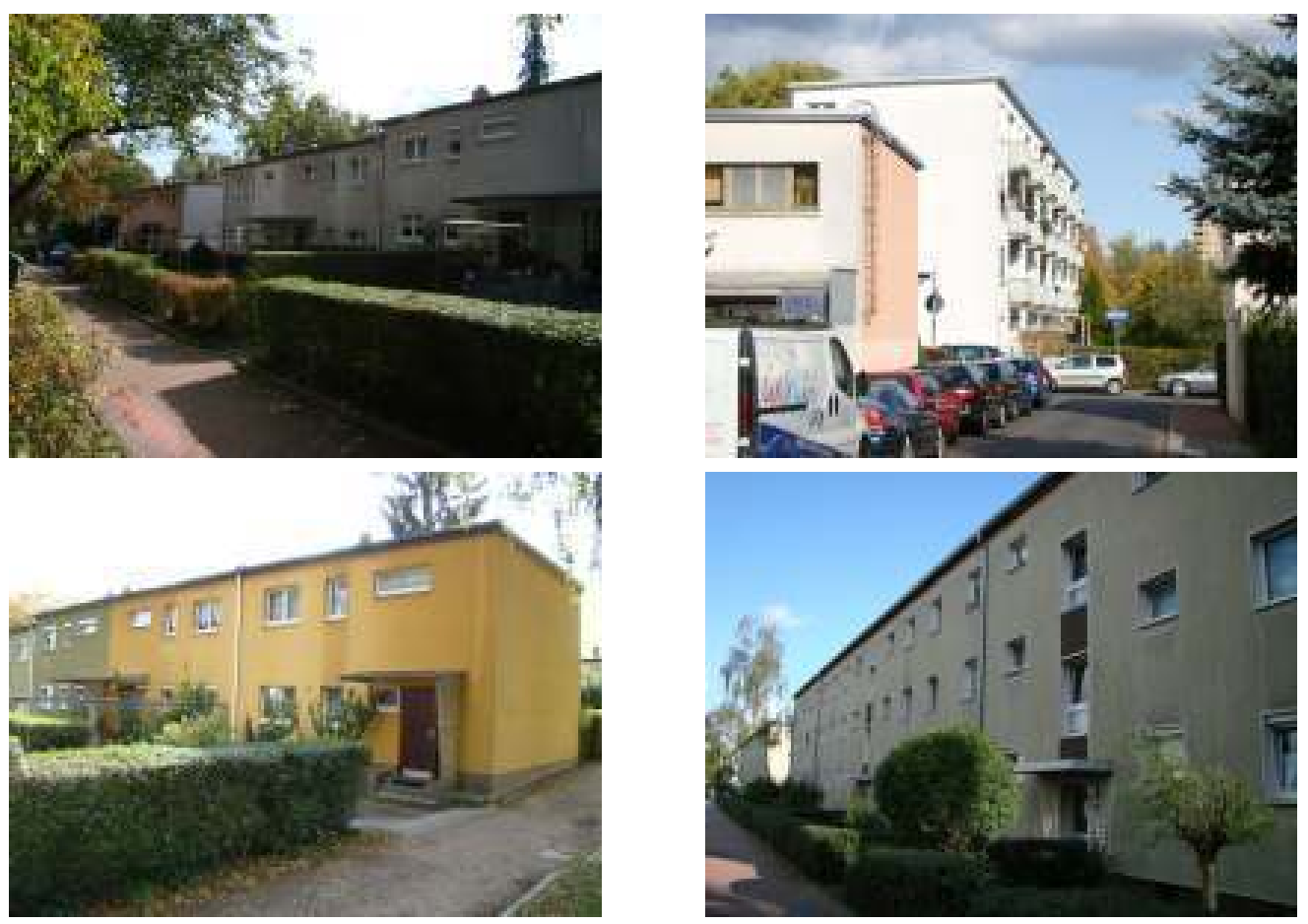

Figuras 230-33. Sobrados em fileira e blocos de três pavimentos em forma de L. Fotos da autora (2008)

\section{Hellerhofsiedlung}

Ano: 1929 -1932; 1934-1938.

Localização: Frankfurt, Alemanha.

Ruas: Frankenallee; Idsteiner Straas; Schneidhainer Straas

Arquiteto: Mart Stam.

Número de unidades: 1.194

Área da unidade: $43,00 m^{2}-48,00 m^{2}$

Tipos: blocos de apartamentos de 03 pavimentos.

Equipamentos: 20 lojas.

O conjunto habitacional de Hellerhof faz parte do programa habitacional "Das Neue Frankfurt" (nome da revista dirigida por May inicialmente, mas que se estendeu para toda a empreitada capitaneada pelo arquiteto), iniciativa do prefeito socialdemocrata Ludwig Landman e do "Baustadtrates" (arquiteto da cidade) Ernst May. Foi construído em diversas etapas durante aos anos de 1929 a 1932, e de 1934 a 1938. 
Projetadas pelo arquiteto holandês Mart Stam, que trabalhou em Frankfurt de 1928 a 1929, as quase 1.200 unidades são predominantemente equipadas com 02 quartos, sala, cozinha, banheiro e sacada, com 43,00 a 48,00 $\mathrm{m}^{2}$. Durante aos anos de 1934 a1938 a construção do conjunto esteve a cargo do arquiteto Karl Blattner.

Atualmente o conjunto é listado como monumento e pertence a uma companhia habitacional de Frankfurt.
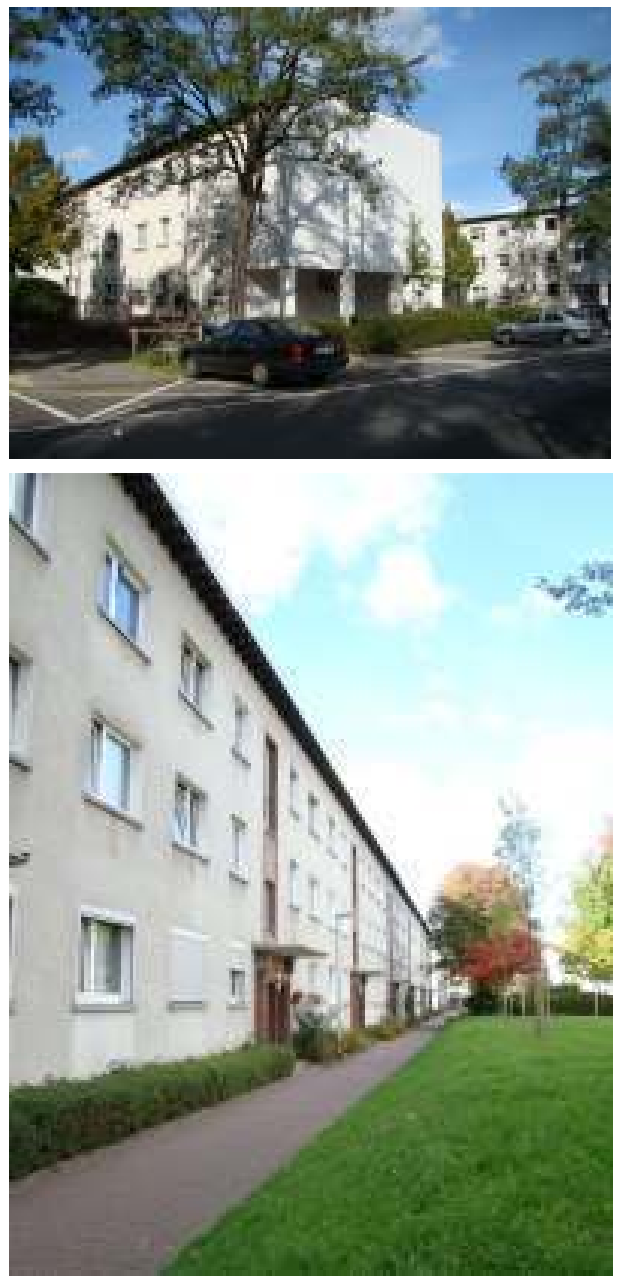

Figuras 234-37. Blocos de três pavimentos perpendiculares às ruas do conjunto. Fotos da autora (2008)
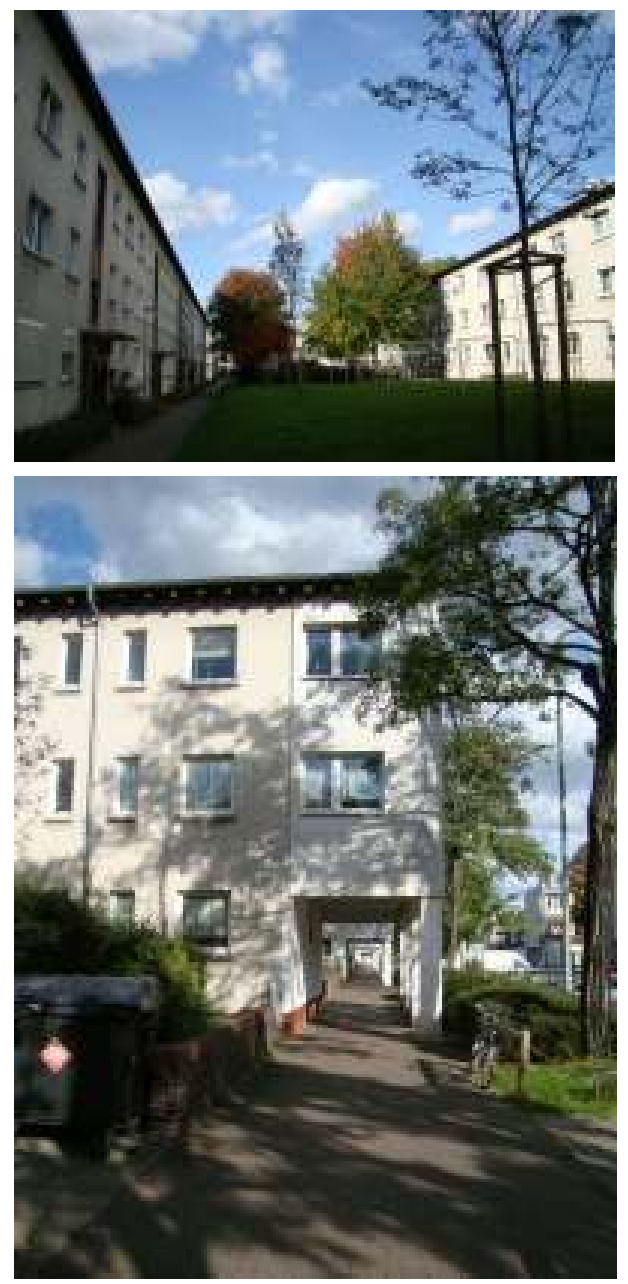

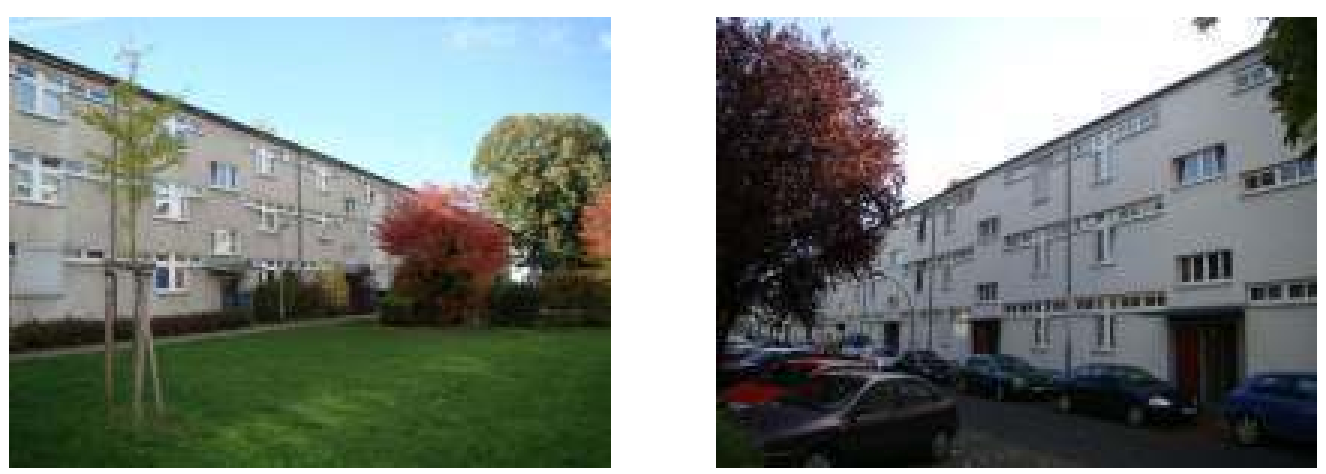

Figuras 238-39. Do lado direito, blocos paralelos às vias de acesso. Fotos da autora (2008).

\subsubsection{Viena e a socialdemocracia}

No século 19, preocupações com a saúde pública incentivaram as tentativas de melhorar a infraestrutura técnica. Como outras metrópoles da época, Viena recebeu os seus principais aquedutos, sua principal rede de esgotos, a sua proteção básica contra as inundações, o seu matadouro, a sua primeira rede de transportes públicos, linhas de gás e iluminação pública bem antes da Primeira Guerra Mundial. Simultaneamente, os profissionais de design urbano se concentraram no embelezamento de partes selecionadas da cidade permanecendo como atrações ainda para os dias atuais.

Em comparação com a Grã-Bretanha, a industrialização chegou tarde à capital do Império Habsburgo. Mas quando veio, veio com toda velocidade, e a população de Viena explodiu, ultrapassando um milhão nos anos de 1870, e chegando a 2,2 milhões durante a Primeira Guerra Mundial, superando outras capitais europeias, como Amsterdam. Até 1890, o Partido Liberal, radicais defensores do mercado livre, dominou a Câmara Municipal. Sabendo sobre os perigos do mau saneamento, e o considerando um bom negócio, os investimentos em infraestrutura técnica foram prioridade na agenda da cidade, bem à frente da construção de novas moradias. O primeiro código de construção de Viena, que regula a altura dos edifícios e a largura das ruas, é de 1829. Já em 1830 uma linha de esgoto principal foi construída, apropriadamente chamada de "Cholerakanal". A partir de 1857, a fortificações da cidade foram finalmente demolidas para dar lugar a um prolongamento da cidade interior, o Ring de Viena. Seu layout foi o resultado de um concurso internacional, o primeiro 
organizado mundialmente. O segundo código de construção de Viena, em 1859, preparou o cenário para a cidade mais generosa que Viena queria ser, com telhados mais altos, os edifícios mais altos, e ruas mais amplas do que antes com o adendo: quanto mais em linha reta possíveis.

Em 1873, o primeiro aqueduto de Viena foi aberto, trazendo água em abundância a partir de fontes Alpinas. Em 1875, o rio Danúbio foi desviado para a sua nova forma retificada abrindo vastas áreas de desenvolvimento urbano. Outro código de construção entrou em vigor em 1883, arredondando para cima os valores limites para a métrica, tornando escadas de pedras obrigatórias, e confinando o edifício a $85 \%$ da parcela total do terreno. Não se deve esquecer que eram os liberais, defensores mais vigorosos de um Estado minimalista, que decidiram sobre todos estes investimentos e regulamentos.

Quando o Partido Social-Cristão conquistou a maioria em 1895, a cidade iniciou um processo muito mais proativo no planejamento e desenvolvimento urbano. A maioria dos serviços públicos foi assumida pelo conselho da cidade: as obras de gás, energia elétrica, a rede de bondes e outros. Em torno de 1900, uma ferrovia metropolitana foi construída pelas autoridades do Estado. Os grandes hospitais também foram construídos nestes anos, em locais salubres dos subúrbios. O espaço público foi bem tratado: pavimentação de ruas era algo comum, garis varriam as calçadas e a iluminação publica era suficiente.

Atrás dos muros, dentro das casas, as condições de vida variavam enormemente. Um mercado irrestrito de aluguéis, servidos por uma sociedade altamente polarizada, de quartos com suítes de 200 metros quadrados no Ring, até uma sala de apartamento sem banheiro e sem água encanada. Todas essas moradias estavam em conformidade com o código de construção, e nenhuma política de habitação interveio até o fim do Império pré-democrático.

Nos anos que se seguiram a primeira guerra mundial, o crescimento da cidade de Viena assumiu contornos extraordinários devido principalmente a imigrações de camponeses e pesoas de outros países. A desarticulação do império austro-húngaro implicou um rearranjo político-territorial e demográfico de grandes proporções. No âmbito econômico, a metrópole foi esvaziada da função administrativa do extinto grande império. Com o novo recorte territorial, Viena estava então isolada inclusive das regiões que anteriormente a abasteciam em ítens de subsistência básica. O cenário do pós-guerra era de flagelo e penúria. 
Em 1919, o partido social-democrata, de orientação socialista, assumiu a administração municipal. Em nível nacional, isso aconteceu paralelamente à tomada de poder pelos socialistas cristãos (1920), nitidamente conservadores. A orientação política dos social-democratas austríacos era de comprometimento com as transformações sociais, numa posição bem mais progressista e radical que a da maioria dos social-democratas europeus. Esses últimos, desde a cisão da Segunda Internacional (1914), assumiam abertamente posições "reformistas" em oposição à "ortodoxia" dos comunistas.

O socialismo municipal de Viena era então uma vitrine observada pela direita e pela esquerda. O modelo de passagem para o socialismo diferia em muito da opção revolucionária russa. O programa de habitação social da Viena Vermelha era, na verdade, não apenas um programa social setorial, mas sim o ponto central de articulação de todo um projeto de desenvolvimento de uma cultura da classe trabalhadora socializada. E isso ocorria fisicamente na construção dos conjuntos habitacionais, que abrigavam todos os elementos necessários para a habitação plena: centros educativos, unidades de prestação de serviço de saúde, creches, atividades culturais, centros esportivos assim como centros comunitários. Esses conjuntos se chamavam Gemeinde- Hof, edifícios com programas habitacionasi específicos e com os tradiocinais quintaispátios abertos (Hof-haus) coletivizados (BLAU, 1998, p.226).

$\mathrm{Na}$ verdade, o programa habitacional da Viena Vermelha teve início sob uma forma bastante diferente. Durante o período de guerra, uma parte significativa da população mudou-se para a periferia da cidade. Em assentamentos ilegais, na literatura internacional conhecidos como wild settlements, era possível a produção de víveres que permitiram a essa população sobreviver à miséria que acompanhou os tempos de guerra. Com o fim do conflito, uma parte dessa população voltou para a cidade consolidada, mas outra parte se organizou em cooperativas para a construção de moradias segundo o modelo das cidades-jardins. É importante ressaltar que, na Áustria, esse modelo assumia contornos e características bastante diferentes tanto da formulação original de Howard, quanto das experiências existentes na Alemanha. A cidade-jardim vienense não tinha nada da visão ruralista presente nos conceitos originais: era relativamente densa, e os jardins freqüentemente produtivos (para subsistência de uma população devastada com a guerra). 
Em 1923, houve uma inversão de diretrizes e o programa abandonou o modelo dos GartenSiedlungen pela construção dos Gemeinbauten (blocos de habitação), totalmente inseridos na cidade existente $\mathrm{e}$, portanto, de características totalmente urbanas. De aspecto denso e monumental, esses conjuntos são bastante heterogêneos, ocupando pequenas ou grandes áreas, variando de 20 a 2.000 unidades habitacionais. Eles não seguiam a soluções arquitetônicas únicas, pois cento e noventa arquitetos, ligados a escritórios particulares, foram responsáveis pelo desenvolvimento dos projetos. Num quadro de grande desemprego, a prioridade não foi a industrialização nem as inovações tecnológicas, mas sim o engajamento de mão-de-obra, como podemos observar também na Itália no segundo Pós-Guerra, com o programa INA-Casa.

Não dispondo do instrumento da desapropirção, os terrenos eram negociados pela prefeitura, eventualmente, com o uso de intermediários com a finalidade de escapar da majoração dos preços, de certa forma inevitável se o vendedor soubesse que o comprador seria o poder público. Na verdade, a prefeitura beneficiou-se de um grande estoque de terras pré-existentes, fruto de políticas de aquisição anteriores. Em 1918, portanto antes da administração social-democrata, a prefeitura já era proprietária de 4.690 hectares, perfazendo $18 \%$ da superfície do município. O período de crise financeira facilitou a queda dos preços e ofereceu à prefeitura oportunidades bastante vantajosas para a aquisição de terras. Em 1922, o "Ato de Controle dos Aluguéis" foi outro fator a contribuir para a depreciação do custo dos terrenos. Em 1928, a prefeitura já era proprietária de 8.000 ha, perfazendo um quarto da superfície municipal. Em 1931, a adminstração possuía um terço da área do município. Em termos de recursos financeiros, a principal fonte foi a taxa sobre os aluguéis estabelecida pelo Ato de Controle dos Aluguéis de 1922, cobrada dos inquilinos. A maior parte do total arrecadado provinha dos inquilinos das propriedades luxuosas, pois as taxas tinham alíquotas progressivas.

O êxito do programa de habitação da Viena Vermelha, em grande parte, deve-se ao fato dele estar muito bem articulado e inserido em uma política mais ampla de gestão do solo. Outros instrumentos garantiam o rebaixamento do preço da terra e o controle da valorização imobiliária: o imposto sobre a terra urbanizável e não-ocupada; a taxação da valorização imobiliária; o direito de recompra pela prefeitura pelo valor declarado; a manipulação do zoneamento; 
assim como uma lei de 1929 que possibilitava a desapropriação de imóveis insalubres e de sobras de terrenos (BLAU, 1998).

O resultado desse programa (1923-1934) foi a construção de 64.000 moradias que abrigaram 200.000 moradores, num universo de 2 milhões de habitantes. Além do mais, a população beneficiada era efetivamente a necessitada, uma das premissas políticas do partido social democrata. $O$ sistema financeiro funcionava de forma que o valor dos aluguéis não excedia a uma pequeníssima parcela do salário do morador.
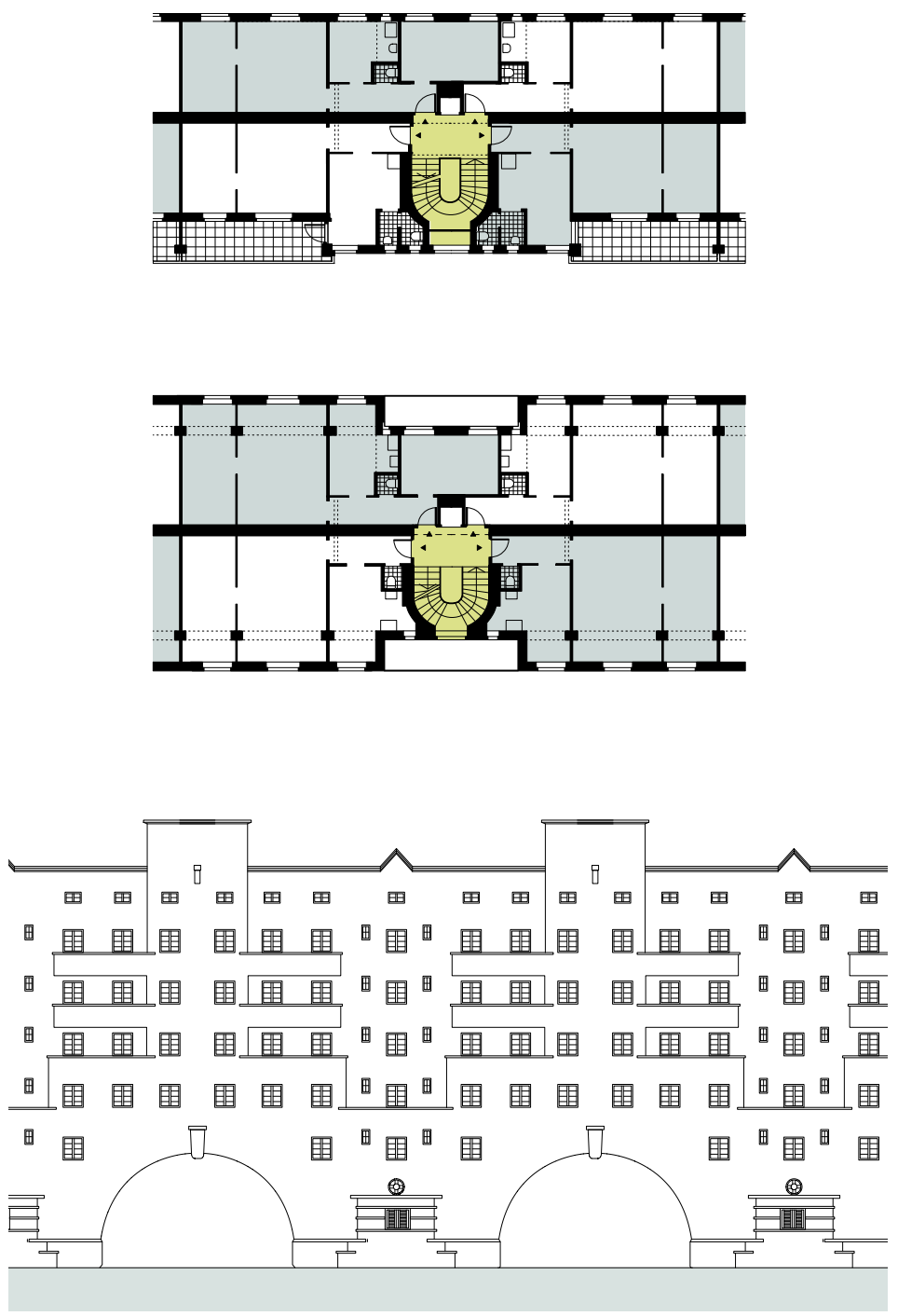

Figuras 240-242. Apartamentos tipos: térreo e demais pavimentos.

Detalhe da fachada com varandas, caixas de escada e passagens de pedestres.

Fonte: FRENCH, 2009, CD-ROM. 


\subsection{Modelos de reconstrução pós-1945}

\subsubsection{O processo de industrialização da construção de moradia na França}

Após a II Guerra Mundial, a reconstrução da França possibilitou a utilização das novas ideias do movimento moderno de arquitetura em grande escala. Ajudados pelo plano Marshall - financiamento dos EUA para a reconstrução de seus aliados e alguns inimigos da guerra - os primeiros programas experimentais de habitação de baixa renda, geralmente materializadas em vastos conjuntos habitacionais, avivaram-se.

A crise habitacional se agrava tanto pelas consequências da guerra, que deixou 450 mil unidades habitacionais destruídas (5\% das existentes em 1939), e aproximadamente um milhão de unidades danificadas, tanto pelo contínuo processo de industrialização e urbanização que intensificava o êxodo rural. A situação foi agravada também pela política contínua de controle dos aluguéis, que afugentou investidores privados do setor, como nos diversos países no qual foram adotados, levando a uma situação crítica: provisão insuficiente e inapropriada, deterioração do estoque existente.

No ano de 1944 é criado o Ministério da Reconstrução e da Urbanística, que teria a incumbência de planejar áreas urbanas e rurais, bem como cuidar das construções subsidiadas. As medidas tomadas em 1945, no âmbito político, resultaram em dispositivos legais para o reparo de cerca de um milhão de habitações parcialmente danificadas, criando certos conflitos nos campo urbanístico e planejamento da cidade a longo prazo, pois a reconstrução não acontecia sem um planejamento de longo prazo.

O governo francês criou, em 26 de outubro de 1945, um imposto sobre os aluguéis com o intuito de constituir um fundo nacional para o melhoramento das habitações rurais e urbanas, o qual logo depois se estabeleceu como o Fonds National de l'Amélioration de l'Habitat (FNAH), cuja gestão foi confiada ao Crédit Foncier de France. Em 1971, o FNAH deu lugar à Agence Nationale pour l'Amélioration de l'Habitat (ANAH).

Em 1948, o governo aprovou uma lei que estabelecia aumentos regulares e razoáveis nos aluguéis, compatíveis com a renda dos ocupantes, em troca de melhorias nas unidades, incentivando assim que o proprietários fizessem 
melhoramentos nas habitações. Esta lei era limitada às habitações construídas até aquela data.

A injeção de capital via Plano Marshal para a reconstrução territorial tornou a intervenção do Estado necessária, uma vez que a iniciativa privada não tinha condições técnicas e mesmo financeiras para a solução do problema.

Pierre Courant, que assume o Ministério da Reconstrução e da Urbanística, propôs por meio de lei em 1953, uma série de intervenções que facilitavam a construção de novas habitações, com melhoramentos urbanos e financiamento da tecnologia industrial. No mesmo ano, a criação de uma contribuição compulsória a ser paga pelas empresas de construção ( $1 \%$ do total da folha de salários para empresas com mais de 10 funcionários) trouxe recursos adicionais para a criação e desenvolvimento da habitação proletária.

Como resultado dessa lei, 50.000 alojamentos foram construídos por ano fazendo uso de industrialização e racionalização do setor construtivo. Contudo, era mais importante produzir unidades habitacionais a preocupar-se com as consequências destes conjuntos, como infraestrutura ou serviços básicos.

Em 1954, novas pressões de setores socais fizeram o governo adotar um programa para construir 12 mil novas unidades habitacionais em áreas consideradas carentes, para população de baixíssima renda.

Em 1957, cinco anos após o Plano Courant, foram institucionalizadas as Zones d'Urbanisme Prioritaire (ZUP's), constituindo uma política que levava em conta a necessidade da construção não só de unidades habitacionais, mas também da infraestrutura urbana necessária para o desenvolvimento dessas áreas.

Um programa de construção de HLM (habitation à loyer modere) foi iniciado, com duração prevista de cinco anos, e com uma meta de produção de 200 mil unidades por ano, demonstrando a ênfase do governo na habitação de aluguel.

Esse período fez parte inicialmente das tentativas de reconstrução do segundo pós-guerra; de meados de 1950 em diante, o programa contribuiu para a renovação das construções de caráter social, dando início a "Era HLM", cuja produção evoluiu de 70 mil unidades concluídas em 1948 para 320 mil unidades em 1958.

Simultaneamente, o debate sobre o desenvolvimento das cidades e planejamento urbano trouxe novas propostas para a renovação dos centros 
urbanos. Foi durante o terceiro plano instituído após o término da II guerra (1958-61) que as ações de renovação urbana tiveram início, e em 1963 a Lei Malraux criou áreas protegidas e promoveu a renovação de edifícios de boa qualidade.

Como se pode observar pelo caso Francês, uma das consequências mais prementes do após II Guerra Mundial no âmbito do planejamento urbano, foi a necessidade de gigantescos programas de reabilitação ou construções de novas moradias em condições favoráveis, com alta qualidade e preços baixos.

No âmbito técnico, foi necessário buscar a experiência anterior acumulada e agregar a contribuição de profissionais (arquitetos, engenheiros e técnicos) e laboratórios para através da industrialização da construção conseguir resultados rápidos e eficientes:

"Isto foi viável graças à existência de dois fatores distintos: de um lado, contar com uma experiência acumulada já altamente qualificada e, de outro, uma política habitacional objetiva e atuante, capacitada a criar os esquemas necessários à superação dos problemas existentes, representados principalmente pelo enorme déficit habitacional acumulado, pela carência de materiais de construção, pela dificuldade na obtenção de recursos financeiros e, sobretudo, pela escassez de mão de obra." (Bruna, 1985, p.72).

A busca por materiais novos para a construção de modo a agilizar o processo construtivo e baixar os custos é uma constante, particularmente desde a segunda metade do século XIX. Entretanto, essas pesquisas tinham mais um caráter de ensaio. É o caso das experiências de Jean Prouvè, na França, em colaboração com Lods, Berdouin e Oscar Niemeyer, que não tiveram continuidade:

\footnotetext{
"As possibilidades técnicas das estruturas leves revestidas em chapa de ferro galvanizado e produzidas industrialmente, sempre fascinaram os
} 
arquitetos, mas raramente os projetos deixaram as pranchetas para as usinas." (Bruna, 1985, p.73).

Outros materiais, embora em estudos e experiências, ainda não se apresentavam, nem se apresentam, em condições para uso em larga escala, e menos ainda no período imediatamente pós II Guerra.

Dos materiais já existentes e bastante testados em empregados, o concreto se mostrava o mais viável para o programa de reconstrução: "Trata-se de um material totalmente plástico que permite a produção em máquinas e usinas sob a forma de reprodução em moldes icásticos ou analógicos”... (Bruna, 1985, p.74).

Além disso, por ser resistente ao fogo, não apresentar significativas variações de volume em face das variações de temperatura, ser durável e não exigir muita manutenção, o concreto se apresentava vantajoso. Entretanto, por ser pesado, difícil e caro de transportar, não ser bom isolante acústico, etc. se mostrava em desvantagem em relação a materiais que, hipoteticamente, seriam ideais naquele programa de construção.

Considerando-se, porém, as suas vantagens, estudos destinados a resolver os problemas de peso, aceleração do processo de cura e isolamento acústicos estão sendo, desde há algum tempo, realizados com bastante avanço.

Além desses estudos, desde os meados do século XIX, experiências foram feitas com o concreto armado indicando ser possível a pré-fabricação, condição sem a qual não é possível pensar em produção de habitações em escala industrial. Entretanto, talvez pela condição histórica daquele momento, em que não havia a necessidade de produção em larga escala, esses experiências permaneceram apenas como experiência.

Foi na Europa, notadamente Alemanha e Inglaterra que se desenvolveram... "obras de pioneiros e de caráter francamente teórico experimental, mas que marcaram os caminhos trilhados a partir de 1945 ”... "A maior parte das obras que se executaram nesse período empregando sistemas de pré-fabricação ao pé do canteiro apresentaram um caráter peculiar, isto é, foram construções que pelas duas próprias dimensões (hangares, fábricas...) justificaram estruturas especiais que eram fundidas no chão, em geral por economia." (Bruna, 1985, p.77. 
Não era ainda a industrialização da construção. Isso porque essas experiências não se propunham à produção em série.

Várias experiências foram realizadas buscando já a industrialização, isto, e pré-fabricação, mas a eclosão da II Guerra Mundial interrompeu esse processo.

São exemplos dessas experiências, na França, as obras de Perret, ao longo dos anos de 1920, mas ele não chegou a criar um sistema próprio para a pré-fabricação de lajes ou painéis para fachadas.

Em 1930, um projeto de um edifício totalmente pré-fabricado, de autoria de H. Sauvage foi apresentado. Entretanto, o edifício não foi construído por dificuldades técnicas para o levantamento das peças de concreto. Naquele mesmo ano de 1930, Beaudoin e Lods iniciaram a construção de vários conjuntos habitacionais H.B.M (habitações de preços módicos) que, pelo seu volume, justificavam a criação de sistemas de pré-fabricação. (79).

Nos anos seguintes, Beaudoin e Lods, juntamente com os arquitetos, Bondiansky e Prouvè, se dedicaram a vários projetos experimentais com o objetivo de construírem um sistema totalmente pré-fabricado, cujo maior exemplo é o mercado e a casa do povo, em Clichy.

Essas experiências, congregando arquitetos, engenheiros, técnicos e laboratórios, permitiram que a Europa pós-guerras enfrentasse a carências de habitação, carências de recursos, de materiais e de mão-de-obra.

O processo francês é um ótimo exemplo, talvez o mais precioso exemplo de como essas experiências forma importantes no equacionamento do problema da habitação na Europa.

"O exemplo francês que pode ser considerado o paradigma de uma política de reconstrução coerentemente orientada para o desenvolvimento de uma tecnologia para a produção em massa de habitações, merece um destaque e uma análise acurada, principalmente pela continuidade dos esforços desenvolvidos com o mesmo objetivo." (Bruna, 1985, p.83). 
A resolução do problema para gigantesco déficit habitacional francês após a II Guerra Mundial seria o barateamento dos custos da construção, tanto para aumentar a disponibilidade de habitações, quanto para tornar novamente atrativo o mercado imobiliário, conforme se lê no Relatório da Agence Européenne du Productivité: "Parece que a única maneira de resolver esse problema urgente seja introduzir métodos e técnicas novas que permitam industrializar uma produção que até aqui revestiu-se de um caráter artesanal." (Bruna, 1985, p.85).

Para resolver o problema da habitação, a França tinha que enfrentar e resolver outros dois. Primeiro, a falta de materiais e equipamentos, uma vez que o parque industrial francês fora severamente danificado durante o período de guerra. Esse problema foi rapidamente equacionado de modo que, a partir do início dos anos de 1950, já estava sanado em grande parte. O segundo problema era a falta de mão de obra, particularmente a especializada, como ferreiro, encanador, eletricista, marceneiro, pintos, etc.

Chegou-se à conclusão que o melhor caminho não era formar esses profissionais especializados, tanto pelo custo de formação, quanto pela demora nesse preparo de mão-de-obra, seja também porque representaria a manutenção de um sistema de construção artesanal, incompatível com o volume de habitações que se deveriam construir. A melhor solução encontrada foi a mecanização da construção, a produção em série.

Essa solução, como aponta Bruna (1985), tinha dois objetivos: primeiro, tirar do canteiro de obras tudo quanto pudesse ser feito em uma usina, com produção industrial e controle de qualidade. Segundo, reduzir no canteiro as operações à simples operação de montagem, feita por poucos homens e equipamentos adequados.

Onde havia necessidade de mão de obra qualifica, por se tratar de uma construção artesanal (hospitais, edifícios públicos, indústrias, etc.) recorreu-se à mão de obra especializada francesa, que conseguia assim o pleno emprego. No restante, onde não havia necessidade de qualificação da mão de obra, recorreuse à mão de obra do imigrante.

Conjugava-se, assim, a economia, pela mecanização e absorção da mão de obra desqualificada do imigrante, com a diminuição das tensões sociais com o pleno emprego. 
Muito embora a industrialização da construção de habitações fosse uma necessidade no pós II Guerra Mundial, nem todos os países europeus seguiram esse caminho. Na França e na Dinamarca a industrialização ocorreu "como resultado de uma política habitacional lúcida e firme, baseada na clara consciência do papel estimulador da ação estatal, e no empenho e capacidade dos grupos técnicos chamados a colaborar." (Bruna, 1985, p.90).

Para o sucesso da política habitacional foi necessária a articulação de algumas tomadas de posições, sendo a primeira a "racionalização máxima da estrutura técnico-industrial existente." (Bruna, 1985, p.90). Isto é, buscou-se dar uma racionalização de todo o processo produtivo existente, desde o planejamento até a entrega da obra, a fim de se evitar desperdício de materiais, emprego desnecessário de atividades de mão de obra e conseguir manter a qualidade.

A racionalização, na França, envolveu dois momentos distintos. Primeiro, a racionalização do mercado, no espaço e no tempo, de modo a distribuir de modo o mais homogêneo possível os recursos por todo o território francês e a concentração de programas importantes, de modo a permitir o emprego do mesmo método de construção, mas dentro de um acordo com as empreiteiras para que não se pressionasse a procura por mão-de-obra gerando o seu encarecimento.

O segundo momento foi a racionalização dos projetos. Projetos mais simples e eficientes, sem muitos adornos e complicações, são mais rápidos e mais baratos para serem construídos. "Procurou-se, portanto, empregar projetos normalizados, compostos por algumas plantas modelos, suscetíveis de serem industrializadas eficazmente." (Bruna, 1985, p.91).

A segunda tomada de posição foi quanto à mecanização do processo. Inicialmente a mecanização foi apenas a substituição da força humana pela máquina no transporte dos materiais, levantamento, estocagem, etc. Em seguida o trabalho produtivo propriamente dito foi substituído. O homo faber como produtor de objetos foi substituído pela máquina: grandes moldes de aço, formas deslizantes, baterias para concretagem múltiplas. Como disse Blachère ..." 0 setor da indústria que não se mecaniza permanece um setor de produção 'feito à mão' quer dizer, um artesanato de luxo... E seria impensável que a habitação se tornasse amanhã um artigo de luxo. Certos edifícios especiais poderão estar nessa categoria, mas nunca a habitação, por exemplo, artigo de demanda 
corrente, de uma demanda que tende a crescer com o aumento do nível de vida e, portanto, com o encarecimento da mão de obra."(Bruna, 1985, p.95).

Contudo, como aponta o autor, em fins de 1953, quando foi assinado com a empresa Raymond Camus um contrato para a construção de 4.000 habitações, é que existiu condições para que o primeiro sistema de construções completamente industrializado fosse instalado.

Foi, portanto, somente a partir desta data que a intervenção de sistemas totalmente mecanizados nos canteiros aumentou em quantidade, espalhando-se por toda a Europa. Em 1956, um concurso em âmbito nacional denominado Concurso de Economia de Mão-de-Obra, generalizou por toda a França o conceito de construção industrializada e provocou a elaboração de projetos e processos de construção visando àquela economia. "Em dezembro de 1958, haviam sido homologados 144 processos para a fabricação de paredes portantes e 170 processos diferentes para a fabricação de lajes para pisos." (Bruna, 1985, p.97).

No âmbito da discussão sobre a reconstrução francesa do segundo pósguerra, Le Corbusier foi uma dos grandes debatedores do assunto e apresentou diversas propostas que nunca chegaram a ser concluídas ${ }^{5}$, ao lado de uma produção teórica intensa.

A primeira proposta de unidade de habitação de Le Corbusier surge do estudo de um novo sistema de alojamento de emergência, de 1944, com dois pavimentos e uma rua interna proposto para ser construído e demolido com facilidade; eram as unités d'habitacion transitories. A ideia evoluiu para as unités d'habitacion de grandeur conforme, de caráter permanente, com capacidade de 400 moradias aproximadamente e abrigando numa única edificação os serviços necessários para uma comunidade: lojas, creches, lavanderias, espaços para lazer e exercícios e estacionamento. Segundo as concepções urbanísticas e arquitetônicas de Le Corbusier, essa seria a forma ideal para resolver o problema de alojamento moderno, pois aperfeiçoaria a circulação e a infraestrutura urbana, propiciaria grandes áreas verdes pela alta densidade do edifício com vários pavimentos, permitiria o solo livre e o uso do teto-jardim, além de fomentar a necessária racionalização para a construção de tal envergadura. A

\footnotetext{
5 Como exemplo disso, têm-se as casas montadas a seco, as construções murondins, os logis provisoires transitoires; etc. Fonte: Le Corbusier. Ouéuvre Complete 1946-1952.
} 
Unidade de Habitação pode ser vista assim, como um grande condensador das teorias e práticas de Le Corbusier nas três décadas anteriores à proposta.

Após tentativas junto ao governo francês de programar a proposta em diversos planos de reconstrução, Le Corbusier consegue aprovação do Ministério para construir uma unidade experimental em Marselha, em 1946. Embora concluído em 1952, depois de muitas dificuldades e percalços construtivos, o edifício foi apenas parcialmente ocupado durante muitos anos e as facilidades comunitárias demoraram muito a serem concluídas (BENÉVOLO, 2006:682).

A Unidade de Habitação de Marselha, como mencionado anteriormente, representa mais de três décadas de pesquisa de Le Corbusier sobre habitação. Uma das poucas obras de grande porte construídas pelo arquiteto franco-suíço, este trabalho incorpora pesquisas de protótipos unifamiliares, como casas Domino e Citroham (1912-1921), bem como a relação entre a célula habitacional e o ambiente urbano nas propostas de planejamento de cidade do arquiteto (ex: cidade de Três milhões de habitantes - 1922; Cidade Radiosa - 1935).

A unidade de habitação, primeira de uma série ${ }^{6}$, consiste num bloco de 18 pavimentos sobre pilotis, com 337 apartamentos de 23 tipos diferentes. Seu sistema de acesso diferenciado utiliza corredores apenas nos pavimentos 2,5,7,8,10, 13 e 16, diminuindo assim a quantidade de corredores para acesso às moradias.

Além das habitações, em sua maioria duplex que atendem solteiros e famílias numerosas, o prédio foi equipado com terraço-jardim (paisagismo, parque infantil, piscina infantil, pista de corrida e uma academia de ginástica ao ar livre); lavanderia (equipada com máquinas de lavar elétricas); creche, jardimde-infância e um restaurante. O complexo possui ainda com um hotel de 18 apartamentos para os eventuais hóspedes dos moradores, permitindo a redução do espaço doméstico, eliminando a necessidade de um quarto extra. Lojas, uma farmácia, uma enfermaria e um bar também foram previstos dentro do edifício, nas famosas ruas-corredores.

Para minimizar o desconforto térmico nas unidades habitacionais muito estreitas e compridas, todas foram projetadas como duplex (à exceção das quitinetes de solteiros) com pé direito duplo na sala de estar, com aberturas nos

${ }^{6}$ Nantes-Rezé (1955); Berlim (1958); Briey-em-Forêt (1963); Fiminy (1965). 
dois pavimentos e brises para controle da insolação. A ventilação nas áreas molhadas foi resolvida com dutos de ventilação e ar-condicionado parcial, além de dutos para lixo nas cozinhas, que vinham equipadas com geladeiras.

As experiências com redução da circulação coletiva em edifícios pode ser observada em edifícios anteriores a esse, como o Narkomfin, em Moscou (19281930), de Moisei Ginzburg ${ }^{7}$, e outras experiências soviéticas. Esse projeto habitacional previa equipamentos de uso comum, mas numa edificação adjacente, conectada em ângulo reto ao bloco de habitação.

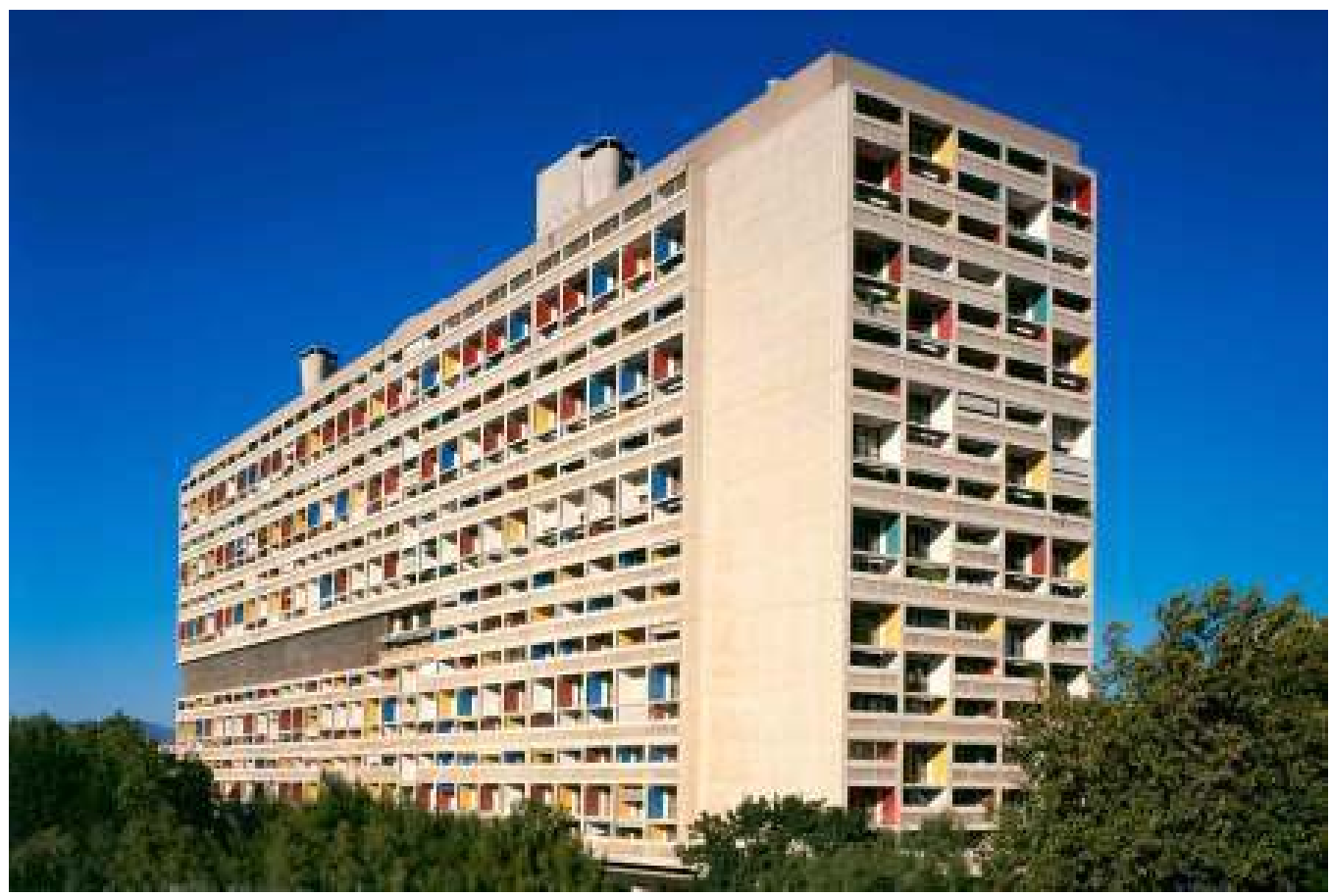

Figuras 243. Unidade de Habitação de Marselha. Fonte: http://www.fondationlecorbusier.fr

${ }^{7}$ Ginzburg fazia parte, desde 1925, do OSA (Sociedade de Arquitetos Contemporâneos), que defendiam a separação entre o coletivo e 0 individual, e propunham projetos de moradias eficientes que permitiam 0 desenvolvimento de espaços coletivos nos conjuntos, como creches, refeitórios e salas de ginástica. 

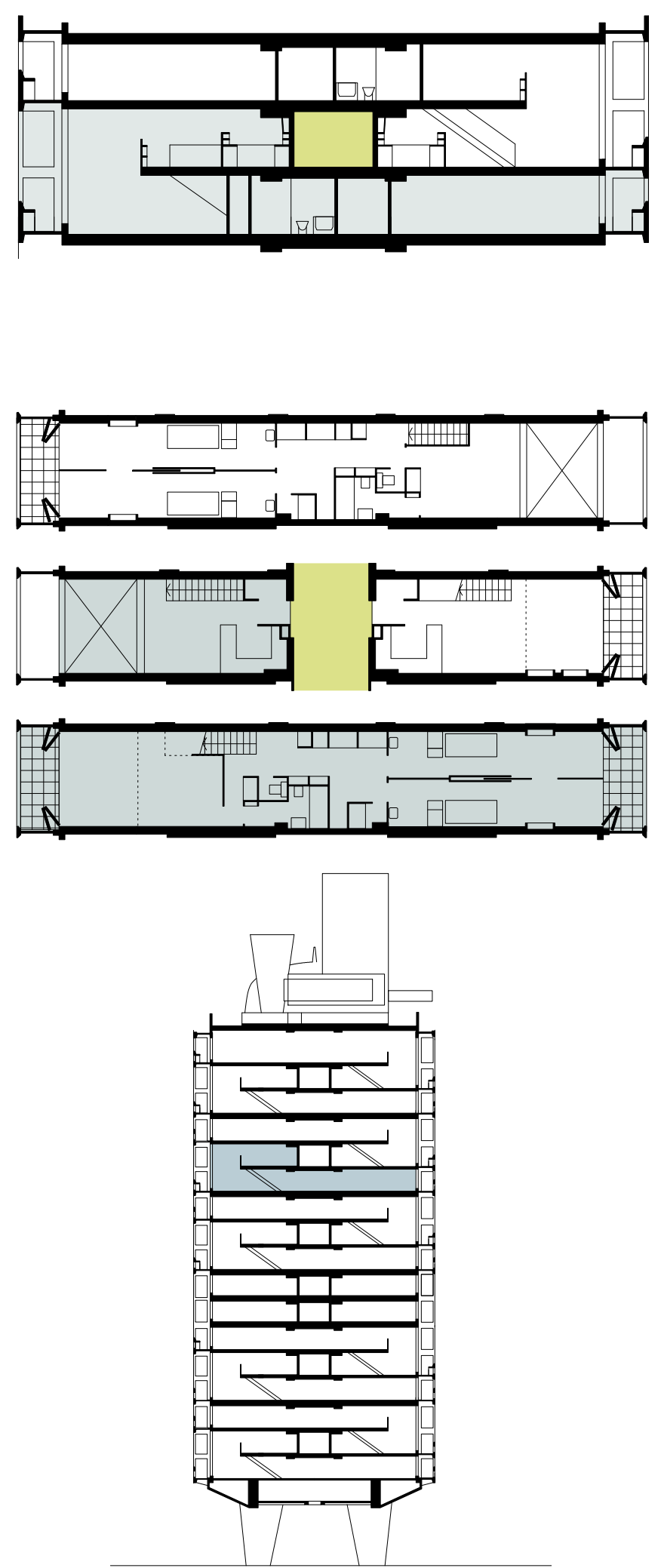

Figuras 244-46. Corte esquemático; Plantas dos três pavimentos tipos; Corte transversal. Fonte: FRENCH, 2009, CD-ROM 


\subsubsection{Os novos distritos na Holanda - Amsterdam e Rotterdam}

Além do Plano de Van Eesterem para Amsterdam, que norteou a construção de moradias para suprir a demanda do pós-guerra, podemos citar a reconstrução do centro de Roterdã, com o famoso conjunto de moradias e comércio Lijnbaan, de Van den Broek e Bakema, o conjunto Pendrecht, e caso de Hoogvliet, iniciado na segunda metade do século XIX, como exemplo da provisão de moradias em larga escala com preceitos racionalistas em território holandês.

A vila de Hoogvliet, com previsão para 60.000 unidades, foi construída para minimizar os danos causados pela destruição da guerra e para abrigar os trabalhadores da nova de área de expansão do porto de Rotterdam, nas proximidades das refinarias de petróleo da Shell. A vila medieval de Hoogvliet deu lugar, no final dos anos 40, a modernas habitações organizadas pelo princípio das neighborhood unit; composição racional e homogênea; tráfego de pedestres, ciclistas e autos separados; grandes áreas verdes e jardins comuns compensados por unidades habitacionais pequenas.

Projetada pata atingir uma população de 60.000 habitantes, a vila nunca passou a marca de 37.000 pessoas, devido principalmente à rejeição das pessoas em morarem numa área tão perigosa como a de refinaria de petróleo.

A realidade de Hoogvliet também pode ser considerada lugar comum: o cinturão verde que rodeia o núcleo e o isola de outros núcleos habitacionais está comprometido e abandonado; a população que habita as unidades de menor área são os excluídos da sociedade holandesa: imigrantes das Antilhas, população de renda baixíssima; alguns ghettos de criminalidade e tráfico foram conformados nas áreas mais pobres; o sistema de tráfego separado de pedestres, autos e bicicletas, foi remodelado e unificado; grandes áreas livres deram lugar a estacionamentos; o projeto original acabou não sendo integralmente implementado, o que gerou grandes áreas abandonadas e sem uso. 


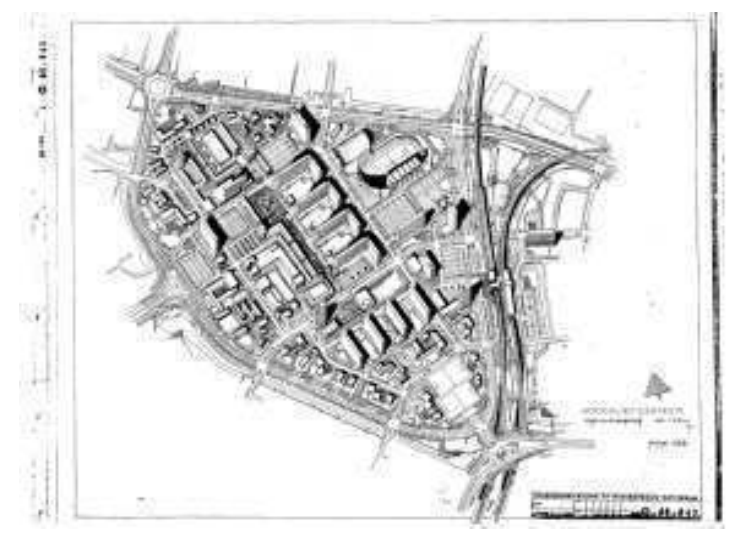

Figura 247: Perspectiva da área central de Hoogvliet. Fonte: $<$ http://www.wimby.nl/modules.php?set_albumName=album86\&op=modload\&name=beeldbank\&file=index\&incl ude=view_album.php>

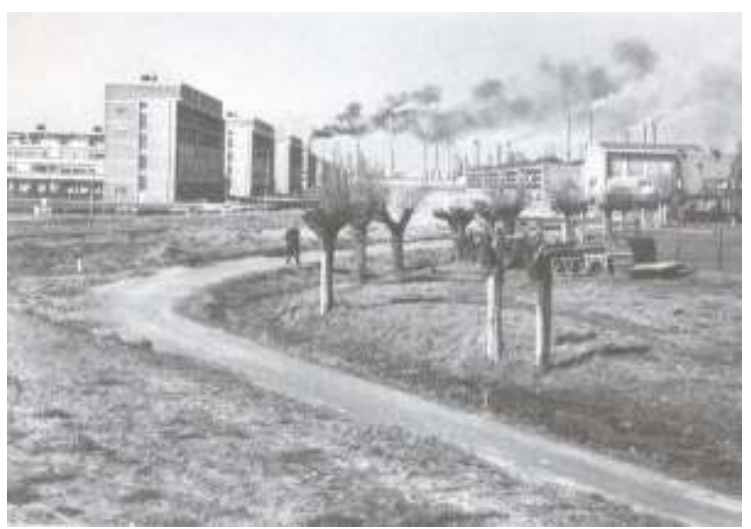

Figura 248: Hoogvliet; região próxima á área da refinaria da Shell. Fonte: Idem.

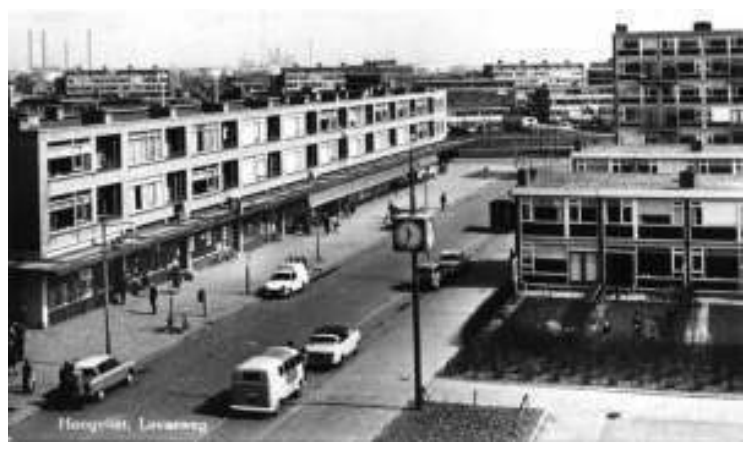

Figura 249: Vista de Hoogvliet. Fonte: Idem. 


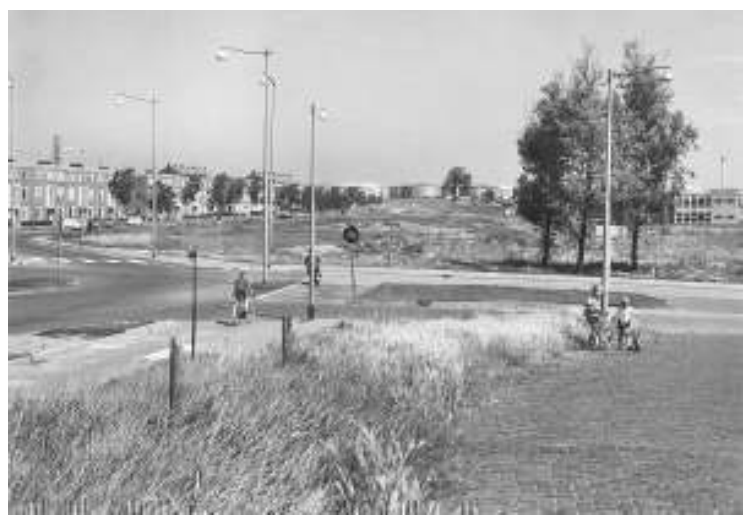

Figura: 250. Vista de área residencial recreio de Hoogvliet. Fonte: Idem.

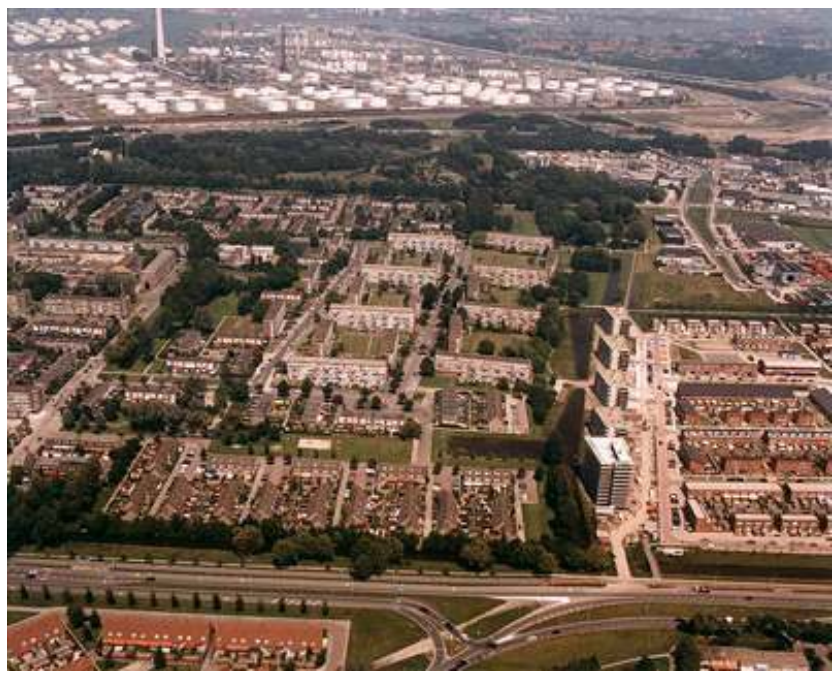

Figura: 251. Vista aérea atual de Hoogvliet. Fonte: idem. 


\section{Pendrecht}

Ano: 1949-1953

Localização: Rotterdam, Holanda

Ruas: Slinge; Zuiderparkweg; Groene Kruisweg

Arquitetos: Lotte Stam-Beese

Tipos: blocos de apartamentos com 04 e 02 pavimentos; casas em fileira.

Pendrecht, um dos distritos construídos após a Segunda Guerra Mundial, foi originalmente destinado a abrigar os trabalhadores das docas da redondeza. O distrito é constituído de 04 unidades de vizinhança ao redor de uma praça livre de tráfego de carros. Estes enclaves também formariam uma conexão espacial e social entre as habitações e a vizinhança. Cada um dos 04 enclaves é constituído de uma grande variedade de tipos habitacionais para atender a grande parte da população local. Esta diversidade social é refletida no layout espacial do conjunto, com blocos de diferentes alturas dispostos de forma livre no terreno, sem relação formal com a cidade existente.
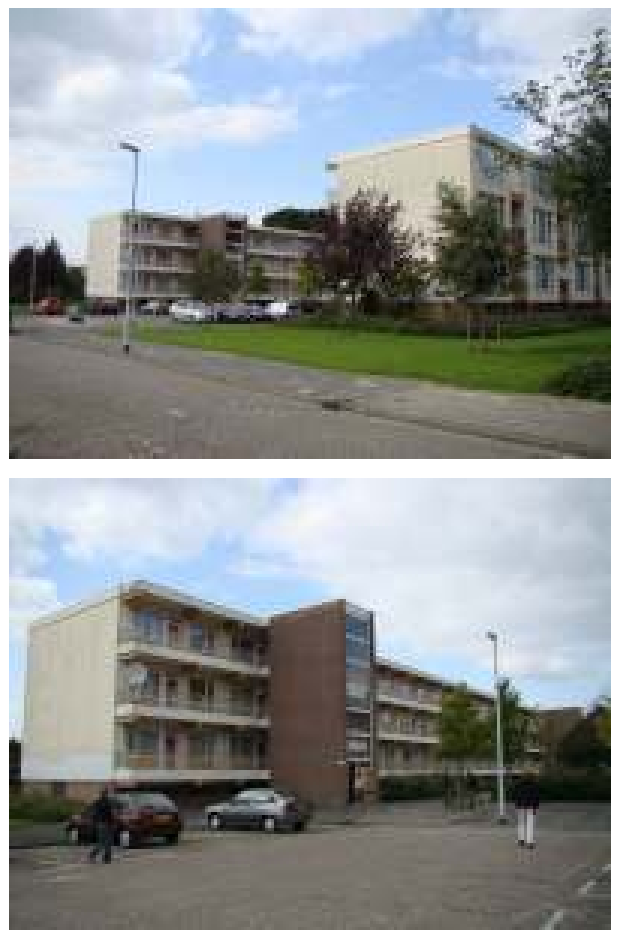
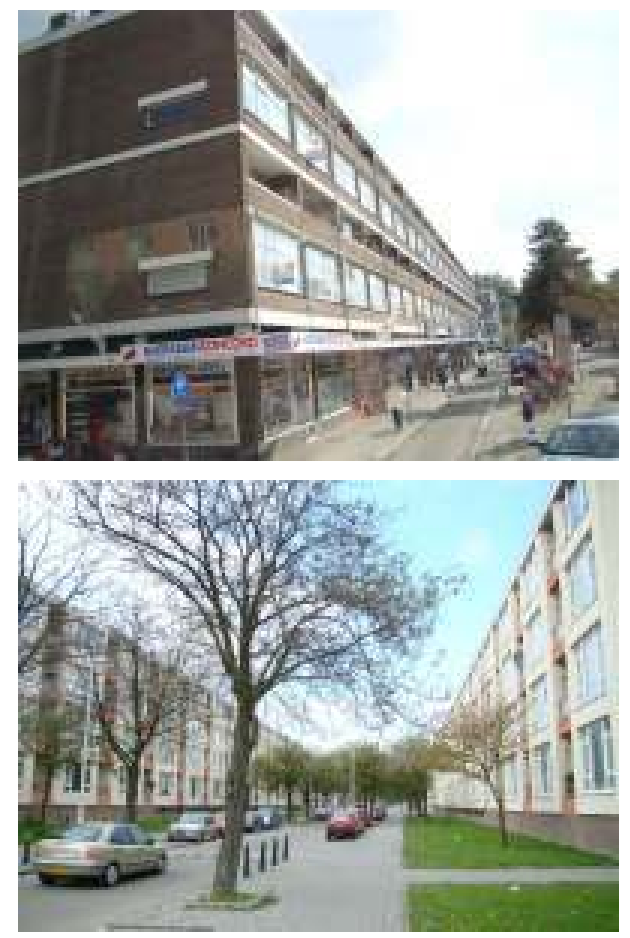

Figuras 252-55. Comércio e blocos com circulação externa, tipo galeria. Fotos da autora (2008). 


\section{Lijnbaan}

Ano: 1949-1955

Localização: Rotterdam, Holanda

Arquitetos: Van den Broek e Bakema

Área da unidade: $50,00 \mathrm{~m}^{2}$

Tipos: Bloco de apartamentos com 04; 08 e 12 pavimentos; sobrados em fileira.

Equipamentos: ruas comerciais para pedestres.

A reconstrução do centro de Rotterdam, devastado pela segunda guerra, trouxe novas feições para essa cidade tradicional holandesa. Edifícios altos, bastante espaçados entre e si, desalinhados do arruamento principal constituem hoje a paisagem central da cidade antes dominada pelos blocos habitacionais médios e de aspecto compacto. Em Lijnbaan, Van den Broek e Bakema foram contratados para a construção de 65 lojas, que foram implantadas em dois níveis ao longo de duas ruas de pedestres. Os perfis das ruas foram projetados para serem largos e baixos, criando uma nova forma para as ruas comerciais, apesar dos edifícios de vários pisos ao redor da área. Espaços para pedestres, acesso de carro para serviços e edifícios habitacionais em altura com quintais foram o resultado de uma experiência bastante rica para uma nova acomodação urbana.
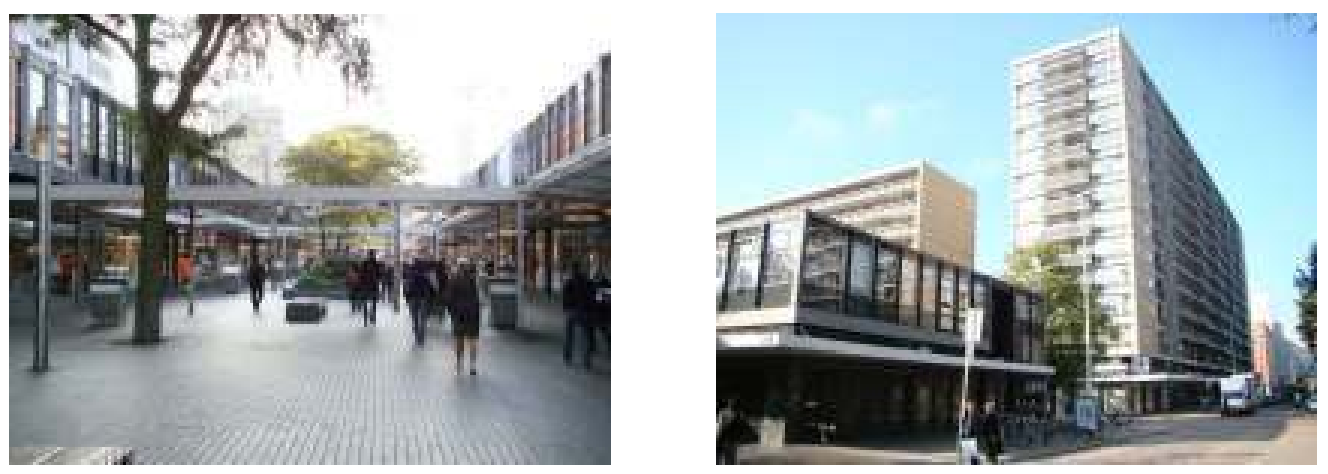

Figuras 256-57. Comércio e edifícios de habitação no coração de Roterdã. Fotos da autora (2008). 


\subsubsection{A reconstrução italiana e o INA-Casa}

Outro exemplo de reconstrução em grande escala, bastante diversa da racionalidade do caso francês e holandês, foi a experiência do INA-CASA na Itália, mas com uma tendência bastante pluralista que pretendia mais atender 0 equilíbrio econômico do país através da construção civil, do que criar uma nova sociedade através de novas pesquisas urbanísticas e arquitetônicas.

Imediatamente após a vitória eleitoral da direita na Itália e aos anos de intenso debate arquitetônico ao término da II Guerra Mundial, em 1949, o Ministro do Trabalho da Itália, Amintori Fanfani, elaborou o Piano incremento occupazione operaria. Case per lavoratori, com o objetivo de solucionar uma grande parte do problema de desemprego e de moradia da população italiana.

Para a administração do Plano foi instituída o INA-Casa (Instituto Nazionale de Assicurazione - Casa) que planejou e construiu de 1949 a 1963, envolvendo um vasto contingente de arquitetos, urbanistas e planejadores, diversos "quartieri" de habitação popular e outras intervenções menores em habitações em toda a Itália.

Este Plano de atuação foi a primeira grande intervenção pública na área habitacional que se ocupou do território italiano inteiro no segundo pós-guerra. Seu "inventor", Fanfani, era um componente do grupo "dossettiano" que, na Itália, eram os maiores partidários das teorias econômicas de Keynes, e tinha como modelo de intervenção o plano Beveridge inglês.

Nos anos imediatamente após o conflito mundial, o debate entre este grupo e a ala liberalista da Democracia Cristã acerca das políticas econômicas do país e a função e dos gastos públicos se acirrou; Fanfani, nomeado Ministro do Trabalho em 1947, foi o primeiro político a ter oportunidade de implementar os pressuposto de intervenção estatal defendida por seu grupo. O Plano foi inspirado nas políticas econômicas opostas àquela deflacionista trazida à tona pelo Ministro Einaudi: nasceu na realidade como uma intervenção moderna de welfare state, enfrentando o problema de alojamento, dramaticamente agravado depois da guerra, mas também absorvendo uma camada considerável da massa de desempregados na Itália através de um grande investimento de dinheiro público. Para dar forma e capacidade de atuação ao Plano, foi criada uma instituição ad hoc, o Ina-casa, que garantiria a eficiência e rapidez na construção das habitações populares. Entre os anos 1949 e 1963, o INA-Casa construiu 
355.000 unidades habitacionais distribuídas por toda a península, absorvendo $10 \%$ da mão-de-obra operária daquele período ${ }^{8}$.

O Plano foi lançado segundo duas premissas: a garantia de uma linha tradicionalista e artesanal, ou pré-industrial, nos projetos e construção das habitações, e da presença de um sistema articulado de controle e verificação do caráter de homogeneidade dos empreendimentos e do envolvimento de empreendedores locais e de empresários pequenos de forma a favorecer a ocupação e o aquecimento econômico do País.

Se essas premissas favoreceram em muitos casos, principalmente nos canteiros romanos, o nascimento de fenômenos como o neorrealismo arquitetônico, assim como garantiu a presença nos canteiros italianos de força de trabalho pouco especializada de origem artesão, elas foram decisivas, na verdade, em todo o contexto da reconstrução italiana: a chamada constante para as praticas construtivas tradicionais, a proibição de experimentação, a escassez de mecanização no canteiro e a forte interferência dos empreendimentos privados foram elementos que, indubitavelmente, resultaram num atraso da arquitetura italiana em relação às demais experiências europeias de reconstrução, principalmente em relação à francesa e à russa. ${ }^{9}$

Nos estudos de Benévolo e Tafuri ${ }^{10}$, o projeto para quartieri Tiburtino, na cidade de Roma, de autoria doa arquitetos Mario Ridolfi e Ludovico Quaroni e equipe (Mario Fiorentino, Federico Gorio, Maurizio Lanza, Piero Maria Lugli, Giuliuo Rinaldi, Michele Valori, Carlo Aymonino, Carlo Chiarini, Sergio Lenci, Carlo Melograni, Gian Carlo Menichetti) foi a expressão máxima tanto dos preceitos da arquitetura neorrealista, como do "atraso" ou caráter artesanal do canteiro e da falta de entrosamento com um planejamento urbanístico na cidade de Roma.

8 PORETTI, S. L'INA Casa. II cantiere e la costruzione. Ed. Gangemi, Roma, 2001.

DI BAGGI, Paola. La grande ricostruzione. Roma, 2001.

${ }^{9}$ Essa é a tese defendida por Benévolo no capítulo XIX, La segunda pós-guerra em Europa, do livro Historia de la Arquitectura Moderna, publicado em 1974, Barcelona. Segundo o autor, as experiências francesas e russas seriam exemplos positivos no sentido de se procurar conciliar a produção de habitacional nos pós-guerra com os planos urbanísticos desenvolvidos contemporaneamente e em constante diálogo com essa produção. Na Itália, a reforma urbanística, que é retomada em 1958, ocorreu de forma separada do Plano de Fanfani.

10 TAFURI, Manfredo. History of Italian Architecture, 1944-1985. 


\section{Quartiere di Forte Quezzi - INA Casa}

Período: 1956-1968

Número de unidades: 865 apartamentos

População média: 4.500 habitantes

Arquitetos Coordenadores: Luigi Carlo Daneri e Eugenio Fuselli

O Quartieri Quezzi Forte foi construído sob o plano de habitação INACasa com financiamento público. O desenho urbano do complexo foi confiado a um amplo grupo de arquitetos e remonta a 1956, e o edifício foi concluído em 1968. O projeto arquitetônico foi dividido em edifícios da seguinte forma:

- $\quad$ edifício A: Luigi Carlo Daneri e Eugenio Fuselli;

- $\quad$ edifício B: Robaldo Morozzo della Rocca;

- $\quad$ edifício C: Angelo Sibilla e Mario Pateri

- $\quad$ edifício D: Gustavo Pulitzer Finali

- $\quad$ edifício E: Claudio Andreani

Os vários edifícios que compõem todo o complexo distinguem-se pela presença de duas circulações horizontais principais, uma no térreo, sob pilotis, e a outra ao nível do quarto andar, como uma rua interna que funcionaria de área de lazer para as crianças. Apenas os edifícios maiores, de sete e seis pavimentos possuem essa circulação intermediária, os demais blocos possuem quatro pavimentos cada. A orientação geral das fachadas é a face sul, com a máxima utilização da luz natural. As construções seguem o contorno da área com declividade acentuada e cada edifício está numa cota mais baixa que o outro; o prédio mais alto, que se destaca na paisagem montanhosa tem cerca de 550 metros de comprimento. A composição dos edifícios serpenteantes é feita através de segmentos de retas e curvas, e não curvas plenas como no caso de Pedregulho, Gávea ou Deodoro, o que confere ao conjunto um aspecto deselegante.

A implantação do projeto conforma um parque urbano, e várias residências foram construídas ao redor do complexo aproveitando a urbanização da área, mas com características que destoam do conjunto. Embora vários equipamentos tenham sido previsto para a área, como creche, escola primária, igreja e um conjunto de lojas no edifício principal, eles só foram construídos após anos da conclusão do conjunto. 

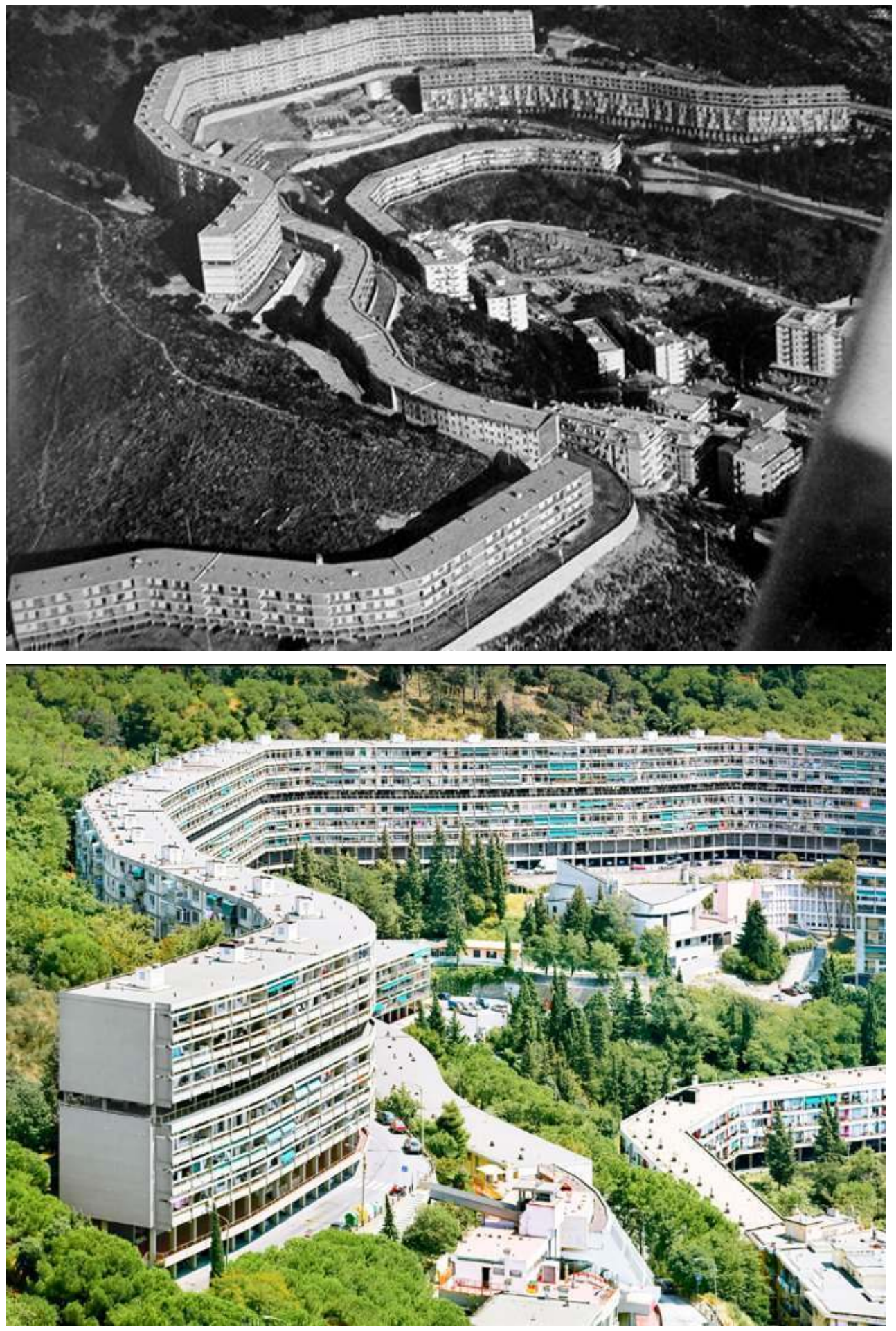

Figuras 258-259. Vista aérea do Forte Quezzi, nas quais podemos observar a composição das curvas com segmentos de retas. 

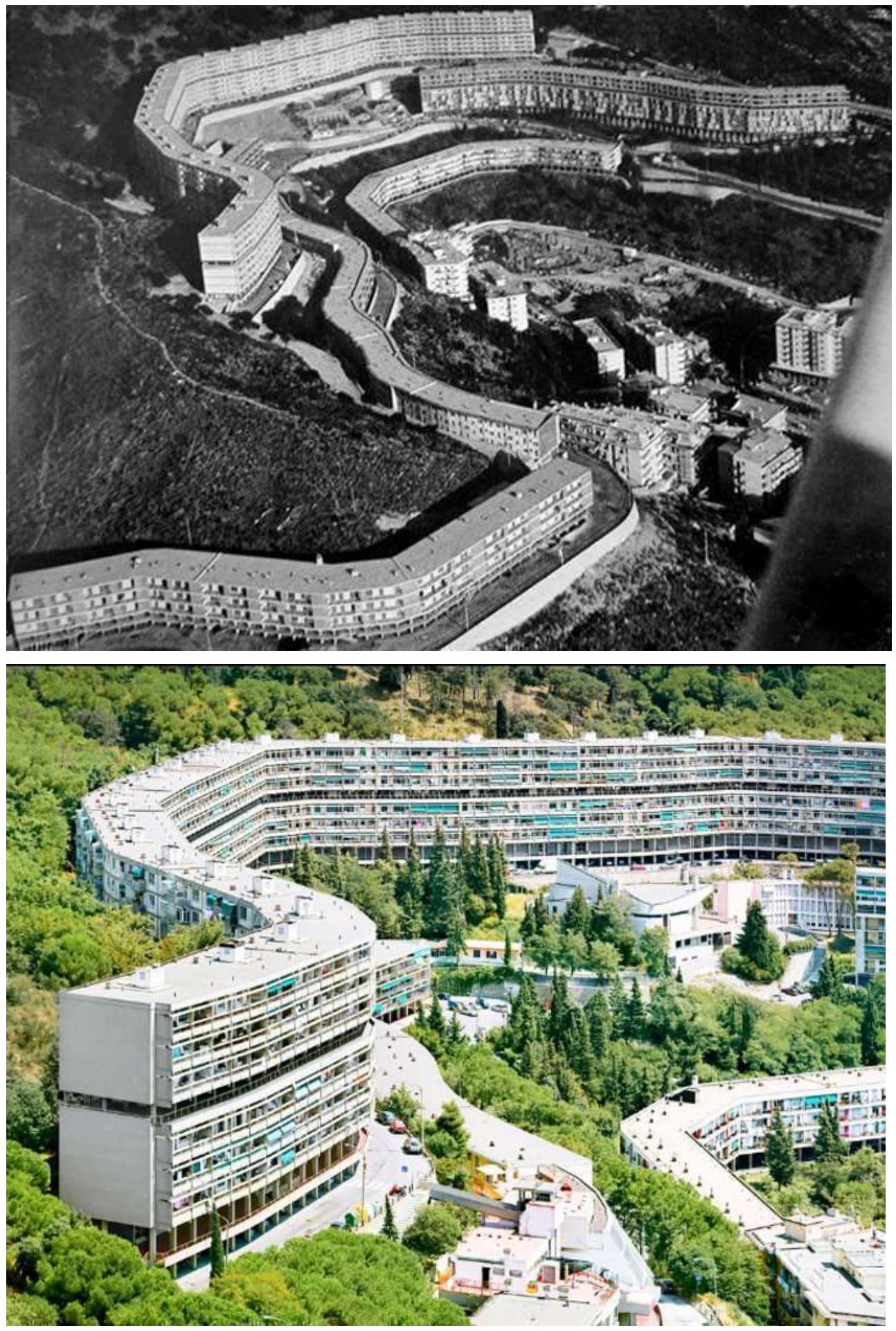

Figuras 258-259. Vista aérea do Forte Quezzi, nas quais podemos observar a composição das curvas com segmentos de retas. 
Capítulo 01 
CAPÍTULO 02

A CONSTRUÇÃO DA POLÍTICA HABITACIONAL NO BRASIL 
CAPÍTULO 02 
"Nos países adiantados tem isso (a habitação operária) merecido grande atenção e já compreenderam os fatos e os fatores. Já compreenderam que os humildes operários não devem ser tratados como máquinas ou como animais. Compreenderam que a grande instabilidade no emprego, a constante mudança de operários com a consequente perda da eficiência, não somente estiveram prejudicando a classe, mas era ainda uma mancha na sociedade, uma ameaça a paz no país, e um obstáculo a produtividade nacional. Compreenderam enfim, que um homem descontente é um mal trabalhador, enquanto que um satisfeito, com boa saúde e possuindo um lar moralizado, é um a homem capaz. (BRUHNS, 1921, p.51)" 
CAPÍTULO 02 


\subsection{Reconhecimento da questão pelas esferas políticas e sociais (1886- 1946)}

As discussões sobre habitação proletária no Brasil remontam a meados do século XIX. Diversos estudos (CORREIA, 2004; CARPINTÉRO, 1997; BLAY, 1985) demonstram que as ideias higienistas divulgadas e defendidas naquele momento histórico - muitas delas de raízes positivistas - aliadas às preocupações de ordem moral, quase sempre de fundamentos religiosos, levou à noção de que o combate às doenças físicas e os comportamentos indesejáveis dos operários e dos pobres em geral passaria, necessariamente, pela solução do problema de sua moradia.

As preocupações quanto à moradia dos operários, no Brasil, seguiam as mesmas preocupações existentes na Europa. Na Inglaterra e na França, em face do rápido e intenso processo de urbanização, a situação dos proletários era de tal monta que atraiu as atenções do Estado e de pensadores e políticos de todos os matizes ideológicos, cabendo destacar as análises feitas por Marx e Engels sobre a questão da habitação.

Apoiados em estudos realizados na Europa ${ }^{1}$, intelectuais, políticos e homens públicos e empresários brasileiros vislumbravam a possibilidade de transformar a casa num espaço modelar capaz de edificar um novo trabalhador, sadio, moralizado, e produtivo. O higienismo daquele momento histórico, em particular o de raízes positivistas, criando um modelo fisiológico de abordagem e análises social, estabeleceu a ideia de sanidade e doença - trabalhador doente igual a cidade doente. Portanto, reformas se faziam necessárias tanto na urbe, quanto na moradia do proletário.

Nessa direção, algumas publicações voltadas para a construção civil, na passagem do século XIX para o século $X X$, mesmo antes da abolição da

1 A discussão em torno das condições da moradia proletária nos países pioneiros do processo de industrialização ganha tamanho destaque no cenário internacional que modelos de habitações salubres ganham espaço nas Exposições Universais no século XIX. A Exposição de Londres de 1851 foi a primeira a lançar modelos de casas para os trabalhadores; evento que foi repetido nas exposições de 1867, 1889 e 1900 em Paris. Na exposição de 1889, cinco seções foram criadas para expor modelos de moradia: casas construídas por patrões; casas para venda construídas por sociedades comerciais ou filantrópicas; casas construídas por essas sociedades para aluguel; casas construídas por sociedades constituídas por trabalhadores; casas construídas de forma autônoma pelo próprio trabalhador (Correia, 2004, p. 27) 
escravatura, por exemplo, os Pareceres sobre os meios de melhorar as condições das habitações destinadas às classes pobres (Conselho Superior de Saúde Pública, 1886) assinalavam as vantagens de uma moradia salubre para o operário:

"Construir casas para a pobreza, construir casas para os operários é reduzir o necrológio da cidade, é aproveitar braços úteis, revigorá-los para o trabalho, dando-Ihes a comodidade do lar doméstico, e alentando-os no caminho da honestidade (Souto, 1886, 33)".

"Da casa depende a saúde, e da saúde do operário depende a qualidade e a quantidade de trabalho que ele pode produzir. O bem-estar e a saúde das classes operárias interessam a todo o país, porque representam a base da prosperidade nacional. Trabalhadores enfermos não só fazem diminuir a produção, como aumentam o numero de indigentes que tem de ser socorridos pela caridade oficial. Proporcionar ao homem do trabalho uma casa cômoda, que satisfaça a todas as condições higiênicas, que robusteça as suas forças, prolongue a sua vida e favoreça o desenvolvimento físico seu e de sua prole, é ao mesmo tempo uma missão de interesse social e de humanidade. Mas, posto que seja de grande importância a obtenção destes fins, 0 melhoramento das casas de operários satisfaz a outros de ordem ainda mais elevada, porque influi também poderosamente sobre a moral e sobre a boa organização da família (Revista dos Constructores, 20 de junho de 1886, p.70)

Como aponta Correia, uma série de artigos publicados na Revista dos Constructores, relativas ao tema da habitação das classes pobres, demonstra 
orientações e estudos dos engenheiros na modificação dos materiais e técnicas de construção no sentido de se combater a umidade e garantir ventilação nos ambientes domésticos. A impermeabilização das paredes de cozinhas e sanitários para impedir a absorção de água pelos tijolos de barro; a proposta de utilização de porões para isolar o solo do assoalho de madeira; utilização de candeeiros a gás ou energia elétrica em lugar de azeite ou querosene (por causa da fumaça e consumo de oxigênio); a necessidade de aberturas para arejamento em todos em cômodos - eliminando assim as usuais alcovas; e instalações de chaminés, claraboias e lanternas foram algumas das medidas difundidas entre 1886 e 1888 na referida revista.

Durante a República Velha (1889 - 1930), as questões de salubridade e higiene do lar, como principal meio de edificação de hábitos morais e de higiene dos trabalhadores, estavam presentes no discurso, sobretudo, dos médicos sanitaristas e dos engenheiros. Por outro lado, a discussão sobre as formas de produção da habitação barata e higiênica para a população pobre esteve na pauta do debate entre os engenheiros por muito tempo.

No início do século $\mathrm{XX}$ a proposta de produção de habitações em conjuntos para baratear o custo da construção; a isenção de impostos para compra de materiais de construção e outras formas de apoio governamental; preocupações em estabelecer as dimensões mínimas para uma casa saneada; redução dos adornos na fachada; abastecimento de água e canalização do esgoto eram assuntos presentes nos artigos publicados pelo engenheiro Everardo Backheuser e também no Relatório sobre Habitações Populares, elaborado por ele em 1906. Outro aspecto bastante importante quanto à questão habitacional, presente no seu relatório, diz respeito à necessidade de proximidade entre as casas proletárias e o local de trabalho, por causa da ineficiência dos meios de transporte, público e privado. Segundo Correia (2004), em relação a esse aspecto, o construtor, Antônio Januzzi, em artigo publicado em 1909, apontava a necessidade de se disponibilizar meios de transporte econômicos, rápidos e frequentes para os subúrbios, como medida imprescindível para viabilizar a construção de casas baratas em locais afastados dos centros de trabalho (Correia, 2004, p.21).

Embora o equacionamento da questão habitacional das camadas mais pobres fosse objeto de estudo e diagnósticos mesmo antes da abolição da escravatura no Brasil, o enfrentamento da questão antes da Era Vargas esteve 
ligado a ações da iniciativa privada de alguns industriais, com o modelo das vilas operárias; dos rentistas (particulares que investiam em moradias baratas para aluguel) e atuação direta do Estado em questões pontuais, como diminuição da carga tributária para essa modalidade de empreendimento.

As desvantagens desse modelo de atuação foram bastante debatidas nos trabalhos de Bonduki (1998), Carpintéro (1997) e Blay (1985), que demonstram a impossibilidade de a iniciativa privada equacionar e solucionar o problema da habitação.

O período da história do Brasil, que muitos autores denominam democracia populista, correspondente aos Governos Dutra, Segundo Governo Vargas, Juscelino Kubitschek, Jânio Quadros e João Goulart, também denominado como período da política nacional desenvolvimentista (1930-1964), teve como uma de suas características a pioneira intervenção direta do Estado na questão habitacional.

O problema posto na agenda de discussões, certamente desde o século anterior, era a construção de moradias operárias que atendessem a um mínimo que fosse de condições de higiene, segurança e tranquilidade, de modo que o trabalhador pudesse produzir e reproduzir sua força de trabalho com saúde, evitando, portanto, a indigência, e que conseguisse criar seus filhos em um ambiente salubre e moralizado, propiciando a eles uma vida mais digna e promissora. A partir do Estado Novo e do crescente processo de urbanização e industrialização do Brasil, o problema assumiu proporções calamitosas.

Os debates e a busca de projetos que atendessem a essas necessidades se colocavam exatamente porque, até então, o existente era a omissão do Estado, seja o Imperial, seja o Republicano mais tarde, tanto nas propostas de construção de casas para “... a pobreza...", quanto frente ao problema do rentismo, ou seja, a construção de casas para aluguel que, no mais das vezes se resumia na construção de "cortiços" completamente destituídos de quaisquer condições de habitabilidade.

A grandiosidade e a importância do problema posto pela falta de uma política habitacional eficiente e barata, dado importantíssimo de uma perspectiva econômica, seja para o trabalhador, seja para o projeto de desenvolvimento nacional, explica porque, historicamente forças sociais e políticas que tradicionalmente se encontravam em campos opostos, se uniram em torno das propostas para a resolução do problema da moradia operária. Foram intelectuais 
de várias tendências, empresários, políticos, interpretes da realidade nacional, de filiação ideológica a mais variada, liberais alguns, outros positivistas, muitos comunistas, mas todos claramente conscientes de que o desenvolvimento nacional, seja estritamente econômico, seja moral, político e social, não se daria sem o oferecimento ao operário das condições minimamente ideais de moradia.

O que mais chama a atenção nos estudos sobre o período não são as muitas presenças e algumas ausências de profissionais, intelectuais e políticos à mesa dos debates, mas a natureza mesma das discussões e propostas com que se abordaram o objeto, a moradia operária a partir dos anos 1930. A marca indelével daquele período e daquelas discussões foi que, tanto os grupos que se acercaram das propostas de Vargas, quanto seus opositores ideológicos, os comunistas, por exemplo, defendiam a tese de ser a intervenção do Estado o único modo de se resolver a flagelante situação da moradia operária no Brasil.

Tanto o getulismo e os getulistas, de perfil muito semelhante ao de Mussolini e Hitler, quanto os comunistas, de perfil stalinista, não podiam, por razões de sua ideologia e de seus objetivos, aceitar as teses e as propostas da liberal democracia - modelos rentistas ou paternalista das vilas operárias. entre guerras foi um período ideológica e politicamente marcado pela ascensão das ideologias totalitárias, de direita e de esquerda, no fulcro do fascismo, nazismo e comunismo, de modo que ideais como os de Getúlio Vargas, de Salazar, Franco, Perón, ou dos totalitaristas de esquerda, nos países do Bloco Comunistas, não eram apanágio do ditador brasileiro.

Para os seguidores desses ideais, o liberalismo era o instrumento empregado pelos donos do capital, e no caso particular, pelos rentistas para justificarem a exploração incontrolada o mercado dos aluguéis das moradias operárias e da criação de mais e maiores cortiços sem nenhuma fiscalização e penalizações.

As descrições verbais e iconográficas dos cortiços, particularmente em São Paulo, encontradas na abundante literatura sobre o tema ${ }^{2}$, mostram as condições de vida subumana a que eram relegados os trabalhadores e suas famílias, sem a menor intervenção eficaz do Estado, que se amparava na tese

2 Sobre vilas operárias ver:

BLAY, Eva A. Eu não tenho onde morar. Vilas operárias na cidade de São Paulo, São Paulo, Nobel, 1985.

CARPINTÉRO, Marisa Varanda T. (1997). A construção de um sonho: os engenheiros-arquitetos e a formulação da política habitacional no Brasil. Ed. da UNICAMP, Campinas, SP. (Capítulo II). 
da lei da oferta e da procura para desculpar sua omissão. Até Lei do Inquilinato de 1942, que "congelou" os aluguéis, as poucas intervenções diretas do Estado nessa esfera, como a isenção de impostos que incidiam sobre a construção de casas residenciais, acabaram por beneficiar apenas os proprietários e não os inquilinos.

Esse ambiente de discussões e propostas foi propiciado pelo Estado brasileiro que, a partir da Revolução de 1930, assumiu um papel relevante no processo de elaboração da legislação social, de modo a assegurar as necessidades dos trabalhadores urbanos e de criar as condições necessárias para a industrialização do país.

A produção industrial que se solidificou a partir desse período, marcada primeiramente pela substituição de importação de produtos não duráveis, foi também acompanhada pela consolidação de um mercado interno, provocando o processo de acumulação urbano-industrial no país ${ }^{3}$. A passagem da economia baseada no processo de produção agrário-exportadora para a sociedade urbano-industrial provocou mudanças profundas nos principais centros urbanos do país. No período de 1920 a 1950, a migração interna foi responsável por, pelo menos, $60 \%$ do aumento da população urbana nas principais cidades brasileiras (Melo, 1987, p.46).

Frente à emergência de novas questões sociais, o primeiro Governo Vargas estabeleceu um tipo de relação sociedade-estado que pode ser mais bem conceituada como um autoritarismo orgânico por meio do que os interesses sociais e econômicos foram incorporados numa rede de estruturas centrais controladas pelo Estado.

A criação do Ministério do Trabalho, Indústria e Comércio, em 1930, estabeleceu um corporativismo institucionalizado na área social e nas relações de trabalho. A nova estrutura englobava os diversos sindicatos, as agências de seguro social e a justiça do trabalho, constituindo-se como uma das principais estratégias estatais no sentido de regulamentar as condições da reprodução da força de trabalho urbano. Essa regulamentação se dava em termos das condições de trabalho (honorários, férias, trabalho feminino e de menores), em termos dos mecanismos institucionais para o enfrentamento dos conflitos do trabalho (Justiça do Trabalho, Comissões e Juntas de Reconciliação) e em

${ }^{3} A$ produção industrial de bens não duráveis no país nesse período cresce $60 \%$ (Melo, 1987, p.43). 
termos das compensações sociais para quem fazia parte da produção aposentadoria e pensão (Gomes, 1988). O regime de Vargas legitimou as questões sociais convertendo-as em uma área privilegiada de políticas públicas.

Por outro lado, organizando as relações de trabalho e promovendo reformas sociais de "cima para baixo" e reprimindo grupos militantes e uniões independentes das estruturas estatais, o Estado esvaziou as demandas dos grupos sociais menos mobilizados. A sindicalização e o corporativismo, além de deixar várias ocupações sem uma categoria específica reconhecida pelo Estado e, portanto, sem os benefícios estabelecidos e gerenciados pelo MTIC, tinha o intuito de desmobilizar e controlar o proletariado urbano.

O conjunto das ações intervencionistas do Estado no sentido de se industrializar o país e melhorar as condições do trabalho urbano provocou, consequentemente, um crescente processo de urbanização (aumento da população urbana), agravando as condições de moradia nos centros urbanos. Segundo Oliveira (1988), a regulamentação das relações entre trabalho e capital foi um dos principais fatores da passagem da estrutura produtiva baseada na hegemonia agrário-exportadora para a urbano-industrial no país à partir da revolução de 1930.

Num contexto em que todas as questões econômicas tornam-se preocupações do poder público e das entidades empresariais envolvidas na estratégia do desenvolvimento nacional, pautado na industrialização, o problema da moradia emergiu como um dos aspectos primordiais das condições de reprodução da força de trabalho, pois consumia uma parcela significativa dos salários e influía no modo de vida e na formação moral e ideológica dos trabalhadores (Bonduki 1998).

A questão habitacional é reconhecida nesse contexto como um dos aspectos primordiais no amparo ao trabalhador brasileiro e como um dos problemas emergenciais da nova realidade urbana no Brasil pós-1930.

Abandonando a política do liberalismo da República Velha, em que a construção de moradias estava a cargo da iniciativa privada, o governo passou a interferir diretamente na produção habitacional, abordando-a como parte do conjunto das novas questões sociais e econômicas emergentes com a industrialização brasileira.

Nesse período (1930-1964), em que vemos a pioneira intervenção estatal na questão, o problema habitacional foi enfrentado pelos Institutos de 
Aposentadoria e Pensão (IAP's) e pelas Leis do Inquilinato, instituídos no Estado Novo, ao lado da Fundação da Casa Popular, criada no Governo Dutra. Outras iniciativas em âmbito estadual e municipal ganharam destaque, como a Liga Social Contra os Mocambos; em Pernambuco; a CECAP, em São Paulo, e o Departamento de Habitação Popular do Distrito Federal (Rio de Janeiro).

\subsection{Principais meios de interlocução sobre o tema: o debate técnico}

Segundo Bonduki (1998), embora as questões sanitárias ainda estivessem presentes como pano de fundo no debate da política habitacional do pós 1930 , os dois principais temas que se colocavam no discurso sobre a questão da moradia foram a habitação entendida como condição básica de sobrevivência na reprodução da força de trabalho, ou seja, como fator econômico de influência na estratégia de desenvolvimento do país, e a moradia como um dos elementos fundamentais na formação ideológica, política e moral do trabalhador, do "homem novo" (Gomes, 1988) e do trabalhador padrão que o regime queria forjar. A habitação representava uma das condições da formação da classe trabalhadora no Brasil naquele período, tanto sob o aspecto econômico-político como social.

Dentre os principais aspectos do enfrentamento da questão habitacional discutidos durante a primeira Era Vargas, vemos a defesa da viabilização da propriedade e da moradia isolada como a base da intervenção estatal.

Ainda que o enfoque em relação à habitação operária não fosse mais as questões sanitárias de desinfecção dos espaços públicos e privados, controle de epidemias, circulação e separação dos corpos, a imposição de normas de conduta para o trabalhador e a separação das classes sociais em diferentes locais no espaço urbano permaneceu nos anos 1930 e 1940.

Outro aspecto importante que diferencia a abordagem nesses períodos está nos atores que focam a questão da moradia. Enquanto na República Velha eram principalmente os médicos sanitaristas e engenheiros que debatiam o problema da habitação operária, a partir dos anos 1930 outros profissionais se incorporaram no debate com peso, como engenheiros, arquitetos, advogados, assistentes sociais, economistas, empresários, advogados, etc. (Bonduki, 1998, cap. 2), estabelecendo-se assim, um outro regime disciplinar sobre o objeto "habitação operária” (Rago, 1985). Por isso, diz Cantanhede que o “... problema 
da habitação popular vem constituindo nos últimos tempos, um dos pontos em que sociólogos, estadistas, economistas, financistas e urbanistas se debatem no entrechoque das ideias, dos projetos e das realizações". (CANTANHEDE, 1942 p.135)

Diferentemente da estratégia disciplinar das vilas operárias do ideal sanitarista de habitação proletária, que visava disciplinar e higienizar o trabalhador de forma direta, no confinamento da fábrica sob o olhar atento do patrão, a partir de meados de 1920 outra forma de poder disciplinador começa a se esboçar, diluído nos saberes específicos, como na fábrica taylorizada; saberes esses "únicos autorizados para solucionarem os problemas de uma classe infantilizada e pouco civilizada" (Rago, 1985, p.189).

A problematização da moradia popular pelo saber médico-higienista incorporada pelos saberes, técnicos e "objetivos" da engenharia, da arquitetura e sociologia, deslocou a abordagem higiênico-moral da habitação para o âmbito econômico - político, contudo ainda apoiado em aspectos morais: a degeneração da raça, a degradação do espírito, a corrupção do trabalhador, o que acarretaria sua pouca produtividade. A moradia do trabalhador passa a ser, assim, uma questão de ordem pública, de estabilidade política e econômica.

Dessa forma, o combate à pobreza, à imoralidade, à doença e à subversão associa-se a um objetivo eminentemente econômico: era preciso recuperar o trabalhador degenerado e corrompido pelo meio promíscuo em que habitava para se promover o progresso nacional, pautado na industrialização e modernização dos meios produtivos. Era preciso adaptar o trabalhador para a nova realidade econômica.

A importância que o tema da habitação assumiu no governo Vargas pode ser identificada na quantidade de artigos, investigações, congressos e jornadas de habitação que ocorreram nos anos 30 e início da década de 1940, que revelam também novas formas de abordagem do problema habitacional.

Esses eventos se deram pela criação de novas entidades públicas e privadas que tinham como pauta a nova política de industrialização do país com todos os seus desdobramentos e necessidades. Bonduki (1998, cap. 2) destaca a criação do Instituto de Engenharia, que realizou o / Congresso de Habitação em São Paulo, em 1931, e do IDORT (Instituto de Organização Racional do Trabalho) que, em 1941, promoveu as Jornadas de Habitação Econômica. 
Publicações especializadas em diferentes áreas do conhecimento também se debruçam sobre o tem da habitação: Digesto Econômico e Observador Econômico e Financeiro, revistas na área de economia; Revista do Serviço Social, de assistência social; Sociologia, revista de sociologia; Boletim do Ministério do Trabalho Indústria e Comércio, Revista do Arquivo Municipal, na área de administração pública; Revista Cultura Política, revista editada pelo DIP, Departamento de Imprensa e Propaganda do Estado Novo. Além das revistas de arquitetura e de engenharia, Arquitetura e Urbanismo, do IAB, Arquitetura e Engenharia, de Belo Horizonte, Habitat, Acrópole, Módulo e Revista Municipal de Engenharia.

Nos anos de 1940, os arquitetos passaram a ter espaços próprios organizados, sobretudo o Instituto dos Arquitetos do Brasil (IAB), e os Congressos Brasileiros de Arquitetos foram importantes espaços de debate sobre a questão habitacional.

Diversas pesquisas quantitativas que ajudaram a traçar as condições de vida e de habitação do trabalhador brasileiro foram realizadas pela recém criada Escola Livre de Sociologia e Política em São Paulo (influenciada pela sociologia norte americana), por pesquisas realizadas em esferas pertencentes ao Ministério do Trabalho, e por outras fontes. Essas pesquisas promovidas segundo os novos pressupostos ideológicos e políticos ajudaram a diagnosticar e equacionar o problema da habitação no país.

No debate sobre habitação que se estabeleceu nesses meios, observamos algumas ideias centrais no sentido de se praticar uma política habitacional pautada em três pontos fundamentais: a orientação para criação de uma agencia nacional responsável pelo setor habitacional; a defesa da viabilização da propriedade para as classes laboriosas e a orientação para construção de unidades unifamiliares, em contraposição às habitações coletivas, tão combatidas principalmente na República Velha. Essas premissas culminaram na criação da Fundação da Casa Popular, órgão do Banco Nacional de Habitação.

O I Congresso de Habitação, realizado em São Paulo em 1931 pelo Instituto de Engenharia em parceria com a Prefeitura Municipal de São Paulo, reuniu arquitetos, engenheiros, higienistas e sociólogos com o objetivo de buscar soluções para os problemas de urbanismo e das questões habitacionais de classe operária. 
Nesse congresso, que tinha como um dos propósitos propor linhas de ação para o "momento de franca reconstrução econômica e social de após revolução" (Dória, 1931), as conferências estavam dividas em seis sessões, a saber:

I - Habitação econômica - programmas. Loteamento do terreno. Districtos.

II - Habitações colletivas. Casas de apartamentos. Inquilinos e proprietários.

III - Racionalização dos materiais de construção processos de construção - padronização. Condições de conforto.

IV - Codificação - códigos estaduaes e municipaes. Exames de resistência e recepção de materiaes.

$V$ - Financiamento de construções - Problemas de capital nas construções.

VI - Livre - Assumptos não contemplados nas theses anteriores. (Anais do I Congresso de habitação, 1931, p. 15)

As teses apresentadas nesse congresso se debruçaram principalmente sobre as questões tecnológicas - área de iluminação e ventilação, pé-direito, espessura de paredes, materiais, etc. - para uma produção em larga escala de habitação social em todo o território nacional, a necessidade de estabelecimento da habitação mínima ${ }^{4}$, o combate à habitação coletiva, que seria um dos meios de subversão dos trabalhadores, e a defesa da viabilização da propriedade para a classe operária.

O I Congresso Panamericano de Vivenda Popular, realizado em Buenos Aires em 1939, reuniu arquitetos, engenheiros e profissionais ligados à produção habitacional de seus países de origem para debater a habitação em seus

\footnotetext{
${ }^{4}$ Nesse Congresso vemos a presença de algumas ideias do II Congresso Internacional de Arquitetura Moderna (CIAM), realizado em Frankfurt em 1929. O engenheiro - arquiteto Bruno Simões Magro, em sua conferência Habitações Econômico, cita a tese apresentada por Ernest May apresentada no II CIAM.
} 
aspectos higiênico, econômico e social. Os temas das discussões no evento foram:

\author{
Aspecto Econômico; \\ Aspecto Higiênico; \\ Aspecto Social; \\ O Urbanismo e a Habitação Popular; \\ Aspecto Financeiro; \\ Aspecto Arquitetônico e Construtivo; \\ A Casa e a Educação Popular; \\ Aspecto Jurídico e Legislativo, \\ Estado atual da Habitação na América.
}

A equipe brasileira enviada ao Congresso era composta pelo arquiteto Rubens Porto, pelos engenheiros Paulo Acioli de Sá e Plínio Cantanhede - que integravam a delegação oficial do ministério do trabalho - e pelo engenheiro Francisco Batista de Oliveira, nomeado pela pasta do Exterior por indicação do Sindicato Nacional de Engenheiros e do Clube de Engenharia.

No contexto das discussões o problema da moradia operária e da proposta intervencionista da Era Vargas, foi realizada simultaneamente em São Paulo e no Rio de Janeiro, em 1941, pelo IDORT (Instituto de Organização Racional do Trabalho), a Jornada de Habitação Econômica. O Instituto de Organização Racional do Trabalho surgiu a partir do trabalho de uma comissão instituída no ano de 1929 pela Associação Comercial de São Paulo, que gerou o Instituto Paulista de Eficiência, transformado em junho de 1931 em IDORT. Entre as muitas contribuições para a reforma da habitação no Brasil, situa-se a ação desse Instituto, órgão que se empenhou em difundir métodos de "gerenciamento científico" na organização da construção e do uso da moradia no país. (CORREIA, Telma de B. 2004).

O IDORT era uma instituição de fundamentos positivistas, criada para discutir e encaminhar propostas "científicas", tanto para a questão da moradia social, quanto para outras questões como, racionalização da administração, transportes, alimentação, etc. consideradas fundamentais para o projeto de desenvolvimento racional da Nação, razão pela qual mantinha estreitas ligações com os empresários envolvidos com o projeto de desenvolvimento industrial. 
Significativas e reveladoras as palavras de seu Presidente quando da inauguração das Jornadas de Habitação Econômica, quando afirmava que o Idort organizara as jornadas de acordo com os princípios cartesianos porque era um instituto que se propunha difundir ideias que se fundamentavam em princípios de organização científica. (Álvaro, 1942, p. 9).

A habilidade getulista de incluir em seu projeto mesmo os adversários ideológicos, como os comunistas, por exemplo, resultou no envolvimento de acadêmicos e profissionais liberais que, antes, ficam ao largo dessas discussões. Por isso, nas Jornadas de Habitação Econômica 35 profissionais foram envolvidos, num espectro que envolvia higienistas, engenheiros, advogados, assistentes sociais, urbanistas, sociólogos, economistas, demógrafos, geógrafos, literatos além de empresários convidados a participarem dos debates, conforme nos informa Bonduki (BONDUKI, 1998, p. 74).

Em outras palavras, esse novo ambiente de discussão iniciou um processo de afastamento de preconceitos morais, de propostas assistencialistas ou da ideia de que as soluções técnicas, por si, seriam capazes de resolver os problemas da habitação. Dória sintetizou esse novo momento nas seguintes palavras: "Precisamos criar entre nós a preocupação, essencialmente americana, da Social Engineering" (DÓRIA, 1931).

Convém salientar o fato de que essas jornadas repercutiram as teses apresentadas nos II Congresso Internacional de Arquitetura Moderna (II CIAM), realizado em Frankfurt, em 1929. Por exemplo, a conferência de Bruno Simões Magro, engenheiro e arquiteto, cita, aceitando, as teses de Ernest May, apresentadas no II CIAM.

Entretanto, mesmo com a intensa participação de diversos profissionais, de várias áreas do conhecimento naquelas Jornadas de Habitação Econômica, algumas ausências importantes foram notadas, como Carlos Frederico Ferreira e Rubens Porto, arquitetos ligados ao Ministério do Trabalho e aos Institutos de Aposentadoria e Pensões. Cabe notar, primeiro, que os IAP's desenvolveram projetos importantes de habitação social, de modo que já em 1941, executavam obras importantes, como o conjunto residencial do Realengo, um dos mais importantes a ser construído.

Fizeram parte do evento conferências, a exposição "Casa Popular" (no edifício da $\mathrm{ABI}$ ), além de trabalhos apresentados em revistas especializadas, 
crônicas publicadas em jornais ou lidas em programas de rádios e entrevistas foram veiculadas.

\subsubsection{Barateamento da unidade habitacional}

Reduzir o custo de produção da habitação se tornou um dos grandes desafios dos técnicos envolvidos com a questão. Vários enfoques foram dados para a redução do custo da unidade habitacional, como a racionalização e simplificação dos sistemas construtivos, redução de dimensões (pés-direitos e largura dos cômodos), mudança no código de obras, estandardização das unidades, normatização dos materiais, combate à especulação imobiliária e a viabilização do acesso à periferia (Bonduki, 1998).

Com a análise dos congressos e publicações supracitados, pudemos verificar que as questões construtivas e de projeto das habitações, embora frequentemente resultando em soluções convencionais, estavam pautadas sobretudo em fórmulas para ventilação e insolação, dimensionamento dos cômodos, materiais e soluções construtivas que garantissem o conforto das habitações. As preocupações de caráter higienistas se refletem na orientação de se procurar o bom desempenho técnico dos materiais utilizados nas habitações, bem como no justo e calculado dimensionamento dos cômodos para garantia de ventilação, insolação e asseio dos ambientes.

O Eng. Attilio Fugulin, em tese apresentada à Jornada de Habitação Econômica, propunha a redução do custo total da obra pela redução das dimensões da moradia operária, sem diminuir a circulação interna do ar, o que seria conseguido por meio de aberturas nas paredes que se comunicassem com o exterior. Sua proposta era reduzir o pé direito de 3,0 $\mathrm{mts}$ para 2,60 mts, e para 2,20 mts na cozinha e no banheiro, em uma área total construída de 56,225 m².

A ideia era, no entanto, chegar à metragem total construída por etapas, de modo que, em "um lote de $7 \times 25$, onde, por etapas, poderíamos construir inicialmente uma casa com : um quarto, um sala, chuveiro e cozinha. A seguir, aumentar-se-ia um cômodo. Futuramente, mais um cômodo, ficando a casa com três quartos, sala, chuveiro e cozinha." (FUGULIN, 1942, p. 196).

O Eng. Bruno Rudolf, no mesmo congresso, concordava em ser possível esse aumento gradativo nos cômodos das moradias, o que resultaria em destinação distintas às suas dependências. Conforme sua tese, "à medida que 
aumentam as dimensões da morada, diminui o emprego da cozinha como sala de estar. $O$ arquiteto pode utilizar informações como essas que Ihe indicam quais os cômodos onde a família de preferência se reúne e como variam esses hábitos de grupo social para grupo social." (RUDOLF, 1942, p. 29)

Entretanto, no que diz respeito aos materiais de construção, o Eng. Antônio dos Santos Oliveira alertava, no mesmo congresso, que, embora houvessem pesquisas "relativamente a novos materiais ainda hoje não temos substitutivo melhor e mais barato dos que usamos; não há dúvida de que estão em estudos: ensaios, projetos e experiências, para ver se é possível a substituição dos altamente usados por outros mais econômicos." (OLIVEIRA,1942, p. 196).

A orientação de se estudar os materiais e sistemas construtivos utilizados em cada região do país para sua adequação para a produção em série pode ser entendida com o sentido duplo de se garantir melhores condições de conforto térmico nas moradias, e como um fator de barateamento das habitações.

Essa, sem dúvidas, a tese defendida, dentre outros, pelo Eng. Henrique Dória e também pelo Eng. e Arq. Bruno Simões Magro. Para dória, a questão da habitação de baixio custo não estava resolvida e dependia da análise de “... nossas condições mesológicas, da escolha dos materiais e de processo construtivos mais eficientes e econômicos, do desenvolvimento do nosso incipiente espírito de associação e auxílio mútuo (...)” (DÓRIA, 1931, p. 53)

Na mesma linha de raciocínio, Bruno Simões Magro sustentava a tese de que se deveriam estabelecer princípios gerais básicos para a nação toda, mas que as questões de aplicação prática deveria se ater aos “...factores regionaes decisivos, meio cosmico e social, materiaes de construção e clima, elementos tão dispersos em paiz como o nosso, de grande extensão territorial" (MAGRO, 1931, p. 56).

Com essa preocupação e com o intuito de encaminhar soluções para o problema, a Comissão de Aspecto Arquitetônico e Construtivo do I Congresso Panamericano de Vivenda Popular apresentou as seguintes conclusões:

"1 - Construção da moradia popular individual, urbana e rural - à parte das condições higiênicas previstas nos outros aspectos - para sua disposição 
mais acertada, deve seguir as seguintes

características:

A individual mínima: $1^{\circ}$, não deve possuir dimensões dos compartimentos tão mínimas que contrariem o mínimo indispensável para satisfazer as necessidades biológicas, espirituais e morais do trabalhador e da sua família; $2^{\circ}$, toda vivenda popular deve ter uma superfície máxima coberta de $85,00 \mathrm{~m}^{2}$.

A coletiva: deve $1^{\circ}$, estar circundada em todos os lados por ruas, pateos ou jardins; $2^{\circ}$, assegurar luz e ar diretos em todas as habitações.

A rural: deve $-1^{\circ}$, prever varandas que as resguardem das inclemências do tempo; $2^{\circ}$, possuir camaral depuradores para a drenagem cloacal e depósito de água potável com bomba.

$2^{\circ}$ - Recomenda para cada paiz a utilização das matérias primas regionais que produzam, e por motivos econômicos, um bom entendimento entre as nações americanas no sentindo de estabelecer $o$ intercâmbio dos materiais e produtos, tendo em vista favorecer o barateamento da construção." (Conclusões da Comissão de Aspecto Arquitetônico e Construtivo 1939, p.56).

Em nenhum momento essas questões mesológicas ou de adequação local aparecem como uma preocupação arquitetônica de procura do caráter nacional nas construções, ou mesmo como um discurso regionalista de defesa e valorização das culturas locais (Manoel, 2004). As pesquisas de materiais regionais e das condições locais de projeto e construção era filtrada por questões de conforto corporal, fácil aquisição de material e criação de sistemas de produção de modo a garantir a construção de habitação barata e higiênica nas regiões mais distantes e com maiores intempéries.

Essa postura revela também uma preocupação com a possibilidade de povoamento e desenvolvimento de todas as regiões do país, e não apenas dos 
centros urbanos mais importantes, preconizando uma política habitacional para todo o território. Sob esse aspecto, o dado local é viável econômica e tecnicamente, o local é universalmente válido.

A discussão em torno da padronização de elementos construtivos, regionais ou não, traz em si a preocupação com o projeto arquitetônico, com formas de se evitar a monotonia dos conjuntos residenciais pela utilização de elementos produzidos em série:

\begin{abstract}
"Ainda como aspecto econômico há a estudar a padronização dos elementos construtivos, para que justamente com a construção em larga série, essas unidades residenciais possam ficar a um preço compatível com o salário. Essa padronização não quer dizer uma rigorosa semelhança entre todas as unidades e refiro-me aos elementos construtivos: esquadrias, telhados, madeiramento, etc. Sem que isso crie monotonia no conjunto, a padronização não afasta a possibilidade de variação no aspecto das unidades, quer de fachada, quer de planta, dando a cada futuro habitante a impressão de que a sua casa é algo diferente das demais." (CANTANHEDE, 1942, p. 134)
\end{abstract}

Quanto à produção em massa de habitação, que envolve a questão da habitação coletiva como uma das formas de barateamento da unidade, existe uma divergência quanto à melhor alternativa. Se por um lado a habitação coletiva representa um melhor aproveitamento do terreno e redução no custo da unidade devido à economia de materiais e racionalização dos meios construtivos, por outro representa a insalubridade e promiscuidade combatidas pelos higienistas na República Velha. Essa solução aparece no discurso dominante como alternativa nos casos em que não fosse viável a construção de casas isoladas, como um mal necessário em situações específicas, como poderemos verificar no próximo item. Em poucos casos as questões urbanas que cada modalidade implica foram profundamente debatidas pelos técnicos, que se ativeram mais ao caráter social e moral da questão. Embora fosse 
fundamental no planejamento da ação governamental no campo da habitação, a questão urbana e da cidade que se pretendia construir no Brasil esteve descolada do discurso sobre a habitação desde o início da intervenção estatal no Brasil. As questões pertinentes a esse tema em nosso país eram outras naquele momento.

\title{
1.2.2. Propriedade privada e a noção de família como célula mater da sociedade
}

\author{
"O problema é nacional e não de classe. É público e \\ não privado. Precisamos criar o nosso "Órgão \\ nacional de casas operárias" para apressar a \\ transformação desejada - do casebre em casa \\ higiênica." \\ OLIVEIRA, Francisco B. A Casa Proletária Brasileira
}

O apelo nacionalista na questão habitacional aparece no caráter social, econômico e político da abordagem do problema. Como salientamos anteriormente, a produção habitacional ganhava o papel principal no combate à pobreza, à imoralidade, à doença e à subversão, associando-se assim ao objetivo econômico de recuperar o trabalhador degenerado e corrompido pelo meio promíscuo em que habita para se promover o progresso nacional.

Esse exatamente o sentido das palavras do empresário Roberto Simonsen na Conferência Inaugural da Jornada da Habitação Econômica, em 1941, quando enfatizava que

"Iniciativas como esta nos permitem como que seccionar toda a estrutura nacional, sob um de seus aspectos mais interessantes, qual seja, o da habitação de nossas populações, inventariando o que existe, comparando com o que se processa alhures e acendendo marcos luminosos de orientação para os nossos governos e para a nossa gente. O programa da Jornada foi elaborado tendo em vista a inter-relação existente entre o problema da habitação e os demais relacionados com a nossa 
vida econômica, social e política." (SIMONSEN, 1942, p. 30)

O progresso nacional não seria alcançado, portanto, pela luta de classes (burguesia $\mathrm{x}$ proletariado), mas pela harmonia entre elas, pelo corporativismo e pela cooperação entre as diversas categorias de trabalhadores tendo o poder público, o Estado, como mediador e promotor dessa harmonia através das políticas sociais. Tal a ideologia oficial daquele momento, como revela a epígrafe acima.

Sob esse aspecto, o reconhecimento da questão habitacional como de caráter social, como o meio de proteção da família (dentro do ideal cristão e, curiosamente, também burguês) e, dessa forma, como meio de manutenção da reserva de mão-de-obra no país propiciou um discurso pautado na defesa da propriedade e da casa isolada.

Embora no I Congresso Pan-Americano de Habitação a delegação brasileira tivesse sido constituída de arquitetos e engenheiros ligados aos IAP's, uma das conclusões mais importantes nos três encontros, I Congresso de Habitação, realizado em São Paulo em 1931, I Congresso Pan-Americano de Habitação, ocorrido em Buenos Aires em 1939, Jornada de Habitação Econômica, promovido pelo IDORT na cidade de São Paulo em 1941, foi a defesa da casa isolada como propriedade privada, conforme demonstram os excertos a seguir:

"A classe média, entre nós, possue companhias immobiliarias (...) que facilitam a construção de casas residênciaes - de orçamentos sempre superiores às possibilidades das classes inferiores - situadas em pontos de terrenos caros(...); entretanto, a classe pobre dos operários, ainda não encontrou em São Paulo - o centro econômico mais próspero do paiz quem the proporcionasse a propriedade de casas econômicas." (DÓRIA, 1931). 
"A opção pela casa própria: considera que o problema da vivenda deva ser resolvido, de preferência, pela construção de casas individuais, cuja propriedade possa ser adquirida pelos trabalhadores e constituída como bem de família.

A manutenção da unidade familiar: Nos casos que por motivos econômicos não possa ser adotada essa solução, poderá optar-se pela vivenda coletiva; mas em tais casos deverá ser garantida a independência de cada família". (COMISSÃO DE ASPECTO SOCIAL, 1939).

Concluindo, Francisco de Paula Ferreira, assistente social, requeria que "Que um dos votos dessa jornada seja, outrossim, uma campanha inteligente e duradoura em prol da casa própria para o operário(...)" (FEIRREIRA, 1941),

A habitação coletiva seria aceita apenas em situações em que não fosse viável a construção de casas isoladas e deveria ser construída prevendo um amplo programa para educação dos futuros moradores, de modo a prepará-los para a convivência respeitosa com os demais moradores, conforme a tese de Jacy Coutinho Vianna na Jornada de Habitação Econômica, em 1941.

"É preciso, portanto, educar solidamente os moradores em habitações coletivas, para que, preservando e salvaguardando a independência da vida familiar, lembrem-se dos que residem ao lado apenas como pessoas humanas dignas de respeito constante, e também merecedoras de apoio em casos de necessidade. Esse trabalho poderá ser feito pelos agentes de educações em geral, como sejam, professores, os dirigentes das associações existentes, e os encarregados dos serviços de assistência. Passando à construção moral: podemos 
fazer distinção de dois aspectos diferentes: legislativo e educativo; O primeiro, com um extenso programa que resumimos pela observância dos seguintes princípios básicos: incentivar a construção de casas populares, isoladas ou em bloco; obrigar o seguro de vida; limitar os aluguéis; facilitar a aquisição da casa própria às classes populares. Pelo aspecto educativo, parece-nos que o mais importante seria uma campanha preparatória, visando diretamente cada unidade familiar, a fim de preparála a receber uma situação melhor; bem como um serviço permanente de assistência que a leve, sem sentir, a perseverar no zelo de sua propriedade. Neste poderá influir favoravelmente o regulamento interno de cada prédio. Ao lado dessa educação, é necessário o esclarecimento em questões de ordem familiar, visando à formação de hábitos moralmente sadios" (VIANNA, 1941).

Mas, essa preocupação não era apenas brasileira. No Primer Congreso Panamericano de la Vivenda Popular, sua Comisión Tercera, Aspectos Sociales, alertava sobre a "conveniencia, em el caso de que deban hacerse casas colectivas, de que el uso de patios e jardines para niños está sujeto a la vigilancia de persona de sexo femenino de calificada moral e idoneidad." (COMISIÓN TERCERA, 1939).

Naquele contexto, a propriedade assume a posição de "símbolo material mais importante de que a valorização do trabalhador e a política de amparo ao homem brasileiro estavam efetivamente dando resultados" (Bonduki, 1998, p.86), isto porque, segundo Porto, "a propriedade familiar educa o trabalhador que a constitui pela própria economia e conserva pela própria administração. (Porto, 1937)"

Vista também como uma forma de dar estabilidade ao regime, a pequena propriedade e o progresso material que representava se contraporiam às ideias 
socialistas e comunistas, introduzidas no Brasil a partir da década de 1920. Por isso, Dodsworth, para justificar suas posições e as do Estado brasileira daquele momento, foi se amparar nas palavras do Diretor do Instituto Nacional de Estudos Econômicos e Sociais de Londres, em seu pronunciamento na Sociedade das Nações, em 1938:

"Existe, pois um problema de lar, feição das mais salientes desse outro problema muito sério: o levantamento do padrão de vida, econômica e social, do homem do povo. Problema mundial, que preocupa os diretores do pensamento em todos os países e que se tornou um dos campos de ação, a muitos dos setenta e tantos governos que se espalham pela superfície do globo. É que os economistas e sociólogos demonstraram que a "manutenção da segurança econômica e política das nações prósperas e dos indivíduos afortunados depende hoje, em grande parte, da aplicação de medidas apropriadas e assegurar pelo menos um nível mínimo de existência fisiológica à massa da população". São essas as palavras do diretor do Instituto Nacional de Estudos Econômicos e Sociais de Londres, Sr. N. F. Hall - (estudo apresentado à Sociedade das Nações em 1938, p.1.). O ideal social da "incorporação do proletariado à sociedade moderna" confundiu-se assim com 0 do soerguimento econômico da massa das populações." (DODSWORTH, 1942, p. 130).

Essas também eram as conclusões do Primeiro Congresso de Vivenda Popular que, por meio de sua Oitava Comissão tornava pública a seguinte deliberação:

\footnotetext{
"La conferência recomienda el fomento de estas construcciones como medio indispensable para
} 
conservar el orden social en las naciones y como mejor elemento para levantar el nivel cultural $y$ moral de los favorecidos." (Comisión Octava, Aspecto Jurídico y Legislativo, 1939)

Os trabalhadores deixariam de ser as classes perigosas e veriam na obtenção da casa própria individual e salubre o resultado do seu trabalho, uma dádiva que compensaria seus sacrifícios; já o morador do cortiço ou da moradia insalubre seria um revoltado, um alvo fácil para embarcar em aventuras políticas esquerdistas para desestabilizar a ordem.

O combate às moradias coletivas, principalmente aos cortiços e outras formas de habitação não higiênicas físicas e moralmente, que promoviam a delinquência e degeneração social, no que concerne principalmente à mulher, representaria uma defesa da família, da célula básica da formação do homem novo que o Estado Novo queria forjar:

"Realmente, as habitações econômicas, como quaesquer outras, precisam ser salubres, sólidas, relativamente confortáveis, e convenientemente orientadas de modo a constituir o ambiente propicio á conservação da saúde physica e mental de seus moradores." (MAGRO, 1931, p. 56)

"O problema da habitação afeta direta ou indiretamente todos os membros da comunidade. Afeta diretamente aqueles que estão a sofrer os efeitos da má habitação, no seu habitar. Indiretamente, aqueles que, não vivendo nelas, sofrem em virtude das desvantagens decorrentes das habitações indesejáveis como lugares de maior delinquência, de controle social deficiente, de promiscuidade perigosa para os bons cânones da moral, de desorganização da família, de focos de moléstias e de endemias que representam; das 
práticas de má ordem a que induzem." (RUDOLF, 1942, p. 30)

De modo geral, podemos observar que alguns objetivos foram claramente colocados pelos diversos saberes científicos que se debruçaram sobre a solução do problema, como a manutenção da reprodução da força de trabalho, sem que isso representasse necessariamente um aumento de salário, o aumento da produtividade para o desenvolvimento nacional, a separação das classes sociais, com o pobre bem instalado na periferia da cidade, e a garantia da estabilidade política:

"O caráter do homem sofre, por outro lado, grandes perversões em face das dificuldades da vida de que a casa anti-higiênica e sem conforto é um constante lembrete. Após um dia de trabalho extenuante exercido sem a necessária e compensatória alimentação e uma caminhada longa ou uma vigem em circunstâncias pouco cômodas, o operário que não encontra em casa um ambiente que Ihe propicie o necessário descanso físico e mental, torna-se um revoltado contra uma ordem de coisas que o escraviza a um trabalho mal remunerado." (FERREIRA, 1941, p. 174).

Quanto às orientações projetuais para a construção da moradia popular, essas não estão no cerne da discussão que se estabeleceu nos meios debatedores analisados, mas como ponta Manoel (2004), o discurso moralista em torno do problema habitacional, a defesa da propriedade e da casa isolada, as preocupações higienistas e de salubridade foram, ao lado do fator dominante em torno do problema, qual seja, a economia e o financiamento da construção, determinantes na tipologia habitacional adotada como expressão do combate ao problema da moradia. A casinha isolada, com varanda, telhado de duas águas, jardim e quintal seria, de uma forma geral, a solução ideal para o problema, da maneira como foi abordado no período citado. 
No campo do urbanismo, isso implicava o crescimento periférico ilimitado das cidades sem que os municípios tivessem qualquer planejamento para arcar com as consequências dessa forma de urbanização: transporte adequado e suficiente; infraestrutura urbana; áreas para lazer e trabalho para as famílias, entre outros. Como vimos no primeiro capítulo, essa discussão estava no coração da questão dos principais exemplos de produção de habitação internacional que inspiraram muitos técnicos no Brasil.

\subsubsection{A intervenção Estatal}

Os meios para se resolver o problema habitacional, debatidos e defendidos de maneira geral no período por diferentes profissionais, foram os financiamentos estatais para a solução do problema da moradia, uma vez que a iniciativa privada não poderia oferecer os juros baixos que a moradia popular exigia; o ideal de assistencialismo, educação e moralização do trabalhador para que este entendesse e almejasse as vantagens de uma casinha na periferia ao invés da moradia coletiva e promíscua no centro da cidade.

Segundo Bonduki (1998), os setores ligados à produção rentista, na República Velha, sempre tiveram força para impedir ações que prejudicassem o mercado de locação da habitação.

O Estado, a despeito do discurso higienista contra a precariedade das habitações, limitava-se a medidas legislativas para tentar sanar situações indesejadas. Mesmo a polícia sanitária agia apenas em situações mais calamitosas. As medidas estatais para intervir no problema, como isenções de impostos para estimular a produção, quase sempre acabavam sendo favoráveis ao setor rentista.

A situação da moradia da classe trabalhadora nos grandes centros urbanos, à partir da década de 1930, tornava-se cada vez mais grave, o que resultaria já no Primeiro Governo Vargas, no consenso de técnicos, políticos e outros debatedores do assunto de que a iniciativa privada era incapaz de resolver o problema, tornando inevitável a intervenção estatal.

Por outro lado, o predomínio da concepção keynesiana e a ascensão de fascismo e do socialismo criaram um clima ideológico que favorecia a intervenção estatal na economia e no provimento aos trabalhadores das condições básicas de sobrevivência, entre elas a habitação. Como evidencia 
Bonduki (1998), a produção estatal de habitação social por alguns países europeus, como Alemanha, Holanda e Bélgica, reforçou a tese da intervenção estatal no Brasil. No contexto americano, as orientações formuladas no I Congresso Panamericano de Vivenda Popular, realizado em Buenos Aires em 1939, fora importantes para reforçar uma mentalidade estatizante, que ia de encontro ao modelo de desenvolvimento então adotado.

\section{"Para desarrollar este programa se recomienda la constitución de organismos centrales dotados de capital suficiente por el Estado que dirijan los labores en todo el país y que reciban la contribuición de los municipios y de los gobiernos seccionales." (COMISIÓN OCTAVA, 1939)}

A partir dos anos 1930, discursos originários de diversos setores - dos técnicos da FIESP, aos comunistas, passando pelos ministros de Vargas mostram a aceitação de que a produção e a locação de moradias "revestiam-se de características especiais que a diferiam de outros bens e que, portanto, requeriam a intervenção governamental“ (Bonduki, 1998, p. 78), posicionamento de que são exemplo os excertos a seguir, de Bruno Simões Magro, Dodsworth, Roberto Simonsen, dentre outros:

"O Governo Provisório, por seu ministério do Trabalho, estuda no momento a coordenação de esforços individuaes, pretendendo estabelecer normas de projeto e construcção uniformes para todo o Paiz." (MAGRO, 1931, p. 87)

"O chefe brasileiro que nos deu o direito ao repouso diário e às férias anuais, a nacionalização do trabalho, o regulamento do serviço feminino e dos menores, o contrato coletivo do trabalho, o salário mínimo e a justiça do trabalho, não poderá deixar de fundar e organizar a política brasileira de habitação, 
degrau a subir, neste momento, da escada necessária que conduz ao levantamento do padrão nacional de vida." (DODSWORTH, 1942, p.30).

"Para o custeio das casas baratas, reconheceu-se a necessidade da ação conjunta do Estado e dos capitais particulares, a colaboração das instituições de crédito e a atenção especial de todos os países da América, dado que o fomento dessas construções é um meio indispensável para conservar a ordem social nos Estados e o melhor elemento para levantar o nível cultural e moral dos que são por elas beneficiados." (SIMONSEN, 1942, p. 13).

Em relação à postura dos engenheiros e engenheiros-arquitetos, já nos anos 1920 vemos que a escassez de habitação, principalmente a operária, torna-se uma das preocupações do urbanismo no Brasil. Podemos observar a inserção da questão da moradia no Plano de Avenidas elaborado para a cidade de São Paulo por Francisco Prestes Maia, no final dos anos 1920, e no Plano de Remodelação, Extensão e Embelezamento para o Rio de Janeiro (1926), elaborado pelo arquiteto francês Alfred Agache - a pedido do prefeito Antônio Prado Júnior.

Esse contexto, marcado pela omissão do Estado nos períodos anteriores e a proposta de criação de um novo Estado, explicam tantas manifestações a favor da intervenção estatal vindas de segmentos diversos da sociedade. Por isso, em 1937, o Deputado Salgado Filho, ex-ministro do Governo Provisório dizia que...

"senhor presidente, a construção de casas para operários deve ser obras obrigatória do Estado, tal a magnitude do problema, tais os encargos financeiros que exige, indispensáveis para sua realização. É certo que, até 1930, nada se havia feito nesse setor." (Discurso do Deputado Salgado Filho, apud Boletim 
do Ministério do Trabalho, Indústria e Comércio, 1937).

Na mesma linha de raciocínio, Roberto Simonsen, Presidente da FIESP, na abertura das Jornadas de Habitação Econômica, dizia que se tratava de um

"Problema de difícil solução por simples iniciativa privada, porque num país o capital é escasso e caro e o poder aquisitivo meio tão baixo, não podemos esperar que a iniciativa privada venha em escala suficiente ao encontro das necessidades da grande massa proporcionando-Ihe habitações econômicas. O problema das moradias das grandes massas nas cidades populosas passa a ser questão de urbanismo. Para sua integral solução torna-se indispensável a intervenção decisiva do Estado." (Apud Nabil, 1998, p. 79).

O jornal, Hoje, ligado aos comunistas, em sua edição de 18 de outubro de 1945, se manifesta exatamente na linha dos dois autores já citados, mas avança na discussão da ineficiência do Estado liberal:

"Proporcionar meio para que o povo habite de forma decente e agradável ou pelo menos humana é um dos problemas de governo. Ora, diante da premência de uma solução é necessário que se firme definitivamente o seguinte: o problema da habitação deve ser resolvido pelo governo. É claro que dentro do regime de liberalismo econômico em que vivemos até há alguns anos atrás, o Estado não devia nem podia intervir na solução do problema. Dentro do 'laissez-faire' cada um que se arrumasse como pudesse. Isto porém é coisa que passou..." (Hoje. 18 10 1945). 
Significativo observar que mesmo ativistas cristãos defenderam essas mesmas teses, não importando se faziam coro com o intervencionismo de direita ou com as teses da esquerda, desde que a proposta fosse antiliberal e visasse à melhoria de vida da classe trabalhadora. $\mathrm{Na}$ inauguração de um conjunto habitacional para operários, Waldemar Falcão se manifestava dizendo que...

\begin{abstract}
"dentre essas funções hodiernas do Estado, nenhuma outra é mais simpática ao ponto de vista humano e cristão da civilização brasileira que a de (...) assistir e defender os trabalhadores fracos economicamente. (...) A realização que nesta hora se consagra na inauguração deste conjunto de habitações proletárias é uma eloqüente demonstração desse acerto." (Falcão. Apud Boletim do Ministério do Trabalho, Indústria e Comércio, 1938)
\end{abstract}

Segundo Carpintéro (1997), os dois planos elaborados nos anos 20 na cidade de São Paulo, embora tivessem uma proximidade maior no campo do discurso, isto é, na presença do mesmo campo conceitual, apresentam a questão da habitação no planejamento urbano como um fator primordial para o desenvolvimento da cidade, ao lado da circulação, saneamento e zoneamento.

No Plano de Avenidas de Prestes Maia, algumas questões importantes são apontadas no capítulo "Habitações Populares". Embora não tenha traçado nenhuma proposta definitiva para o problema habitacional, aponta alguns caminhos que indicam a importância do Estado nos programas habitacionais e a ineficiência dos incentivos privados. Prestes Maia também introduz na discussão a possibilidade de compra da casa pelo trabalhador como uma forma de libertálos das péssimas condições de vida e das desordens causadas pela sublocação.

No I Congresso de Habitação, embora as teses se voltassem mais para a discussão concernente à construção propriamente dita de habitação para as populações carentes, outros temas mereceram destaque no decorrer do congresso como os debates em torno dos códigos municipais de obras e os 
problemas relacionados à presença de loteamentos clandestinos ${ }^{5}$. Na verdade, esses técnicos desejavam a possibilidade do controle do poder público sobre o crescimento da cidade e, além disso, reivindicavam do governo a necessidade de uma política nacional de habitação.

Por isso, dizia Américo Pereira Silva, naquele Congresso, que:

"A expansão das cidades e dos povoados devem obedecer a um plano de conjunto previamente estudado, e organizado de accordo com a topografia e com as sugestões de engenharia sanitária. As leis de desapropriação por utilidade pública devem ser modeladas para que os casos de desapropriação por insalubridade ou para salubridade pública sejam devidamente attendidos". (SILVA, 1931, p. 59)

Como exposto na tese de Silva, existia a preocupação à época em relação aos loteamentos clandestinos e habitações impróprias que brotavam nas capitais devido à impossibilidade da iniciativa privada de prover habitações dignas a custo acessível para as camadas mais pobres da população. Contudo, as leis necessárias para intervenção no solo urbano nunca se efetivaram como um mecanismo legítimo de atuação do Estado na regulamentação da ação privada e intervenção nas áreas clandestinas existentes tanto durante a República Velha, pela política do laisse-farie, como no período populista, devido ao ônus político e administrativo que representava tais posturas. Em relação ao planejamento urbano que nortearia essa produção, como ocorria nos exemplos europeus, essa prática nunca chegou a se efetivar, impossibilitando assim, qualquer ação do governo da união associada a planejamentos municipais.

O consenso sobre a intervenção estatal na questão habitacional resultou, já no primeiro Governo Vargas, na criação ou fortalecimento dos órgãos governamentais encarregados de produzir ou financiar a produção de habitação, como é o caso da criação das Carteiras Prediais dos Institutos de Aposentadoria e Pensão. Outra forma de intervenção estatal direta no setor habitacional foi o

5 Ver: Defesa da Municipalidade contra o arruamento clandestino para a especulação em terrenos. Tese apresentada por Lysandro Pereira Silva. Anais do I Congresso de Habitação, 1931, p. 87. 
congelamento dos alugueis através da Lei do Inquilinato, em 1942. Segundo Bonduki (1998) e como apontado no primeiro capítulo, essa prática vinha sendo adotada na América Latina e em alguns países europeus desde a Primeira Guerra Mundial e foi um duro golpe contra a produção rentista de habitação. As críticas contra a Lei do Inquilinato dos aluguéis só tiveram maior peso depois de terminada a Segunda Guerra, pois a sua renovação indicava que ela viera para ficar, e o Governo não tinha mais a justificativa para sua promulgação de que o país vivia numa situação de emergência devido à guerra.

Embora defendida pela quase totalidade dos técnicos, políticos e empresários voltados para o problema da produção de habitação para os trabalhadores, a maneira e o grau que essa intervenção deveria atingir foram pontos bastante discutidos. Um exemplo dessa discussão é a passagem abaixo, de Plínio Cantanhede que afirmava que

"A intervenção do Estado se impõe, quer pela intervenção direta, como se verifica em muitos países, quer pela segurança que o Estado dá aos capitais que são investidos nesses empreendimentos e que pela sua própria natureza social não podem ter a remuneração normal de aplicação de capitais, ou no caso das instituições de seguro, seja de seguro privado ou social, a remuneração mínima que as suas reservas assim o exijam" (CANTANHEDE, 1942, p. 135).

A utilização das reservas da previdência para o financiamento da produção de moradia, embora fosse necessária para alavancar a construção no país, causava polêmica entre os técnicos que debatiam a questão. Pois, além de comprometer as reservas dos Institutos, uma vez que o capital não era investido a juros compensadores, essa atuação não configurava uma política habitacional. Os Institutos agiam isoladamente e sem um plano de atuação que pudesse atingir todo o território nacional, para além do fato da produção ser destinada somente aos seus associados, excluindo assim, toda a parcela de trabalhadores informais do período. 
No entanto, apesar da ausência de uma real política habitacional na produção dos IAP's, essa produção não foi irrisória, e teve um grande valor arquitetônico, urbanístico e social nos conjuntos edificados.

\subsection{Principais órgãos e medidas estatais destinadas ao enfrentamento da questão}

\subsubsection{As operações imobiliárias dos IAP's}

Embora tenham sido os grandes agentes promotores de moradia de baixa renda nos anos de 1937 á 1964, os IAP's sempre relegaram essa atividade a um segundo plano em relação às suas finalidades precípuas, isto é, aposentadoria, pensão e assistência médica.

A habitação sempre apareceu como uma questão ambígua dentro dos IAP's, ora como um benefício ligado à seguridade plena, ora como uma modalidade de capitalização de recursos. Essa diversidade de posturas e dificuldade de se modificar a estrutura previdenciária foi um dos principais fatores que impediu a implementação de uma política habitacional sólida no período populista.

A regulamentação da previdência no Brasil teve início com a Lei Eloy Chaves - Decreto Federal n. 4.682, de 24/01/1923, que criou as Caixas de Aposentadoria e Pensão, aprovada para atender as empresas ferroviárias e posteriormente, através do decreto Federal n. 5.109, de 20/12/1926, as empresas portuárias e de navegação marítima e fluvial. O modelo corporativista de previdência na República Velha era dividido por empresas. A criação dos IAP's se dá entre 1933 e 1938, rompendo o vínculo entre empresas e previdência existente nas CAP's e estabelece o benefício por categoria.

Nesse período foram criados seis Institutos: IAPM (marítimos), IAPB (bancários), IAPC (comerciários), IAPI (industriários), IAPETEC (condutores de veículos e empregados de empresas de petróleo) e IAPE (estivadores).

As CAP's ofereciam garantia de aposentadoria e pensão, assistência médica e auxílio funeral para os funcionários da empresa. O Decreto Federal $\mathrm{n}$. 19.469, de 17/12/1930, estabeleceu a possibilidade de investimento das suas reservas em construção de casas para seus associados. No caso dos IAP's, que seguia o mesmo padrão das CAP's no investimento de suas reservas, a 
regulamentação de fato para a atuação na produção habitacional se deu com o Decreto Federal n. 1.749, de 28/06/1937, que cria suas Carteiras Prediais, permitindo a utilização de $50 \%$ das reservas acumuladas para a produção de habitação. Além disso, o decreto também estabelecia redução da taxa de juros para $6 \%$ ao ano (não mais $8 \%$ ), dilatação dos prazos de pagamento de 10 para até 25 anos, medidas que implicariam na ampliação da demanda para esse benefício (FARAH, 1983, p. 46).

Segundo a bibliografia especializada, não é fácil determinar quais a preocupações que de fato levaram a tais medidas na área habitacional dentro dos Institutos. Farah (1983), atribui a promulgação do decreto a pressão, ainda que embrionária, por parte dos associados para maiores investimentos na área habitacional; Melo (1987), destaca que parte dessas modificações deveu-se a pressões por parte da Igreja católica, preocupada em facilitar o acesso do povo à casa própria. No entanto, segundo Bonduki (1998), é possível detectar na promulgação desse decreto tanto a preocupação em aumentar o benefício da habitação entre os associados, como o de ampliar a rentabilidade das reservas dos IAP's.

Embora cada Instituto tivesse uma atuação diferente na área habitacional, devido ao funcionamento de suas carteiras prediais baseadas em normas e instrumentações específicas, as operações imobiliárias do IAPI, baseadas em três planos - A, B e C, foram gradativamente sendo adotadas pelos outros Institutos, conforme a explanação de Bonduki:

"Plano A: locação ou venda de unidades habitacionais em conjuntos residências adquiridos ou construídos pelos institutos, com o objetivo de proporcionar aos associados moradia digna, sem prejuízo da remuneração mínima do capital investido. Plano B: financiamento aos associados para aquisição da moradia ou construção em terreno próprio.

Plano C: empréstimos hipotecários, feitos a qualquer pessoas física ou jurídica, bem como outras operações imobiliárias que o Instituto julgasse conveniente, no sentido de obter uma constante e 
mais elevada remuneração de suas reservas."

(BONDUKI, 1998, p. 104).

Os imóveis residenciais construídos pelos IAP's através do Plano A, em sua grande maioria, não eram vendidos aos usuários, mas permaneciam propriedades dos institutos e eram alugados a quem tivesse direito de fazê-lo. Os outros planos habitacionais dos Institutos, Planos B e C, baseavam-se na propriedade, mas não tinham o alcance social do primeiro. O Plano $\mathrm{B}$, destinado ao financiamento para a construção ou aquisição de habitação por iniciativa dos associados, foi pouco utilizado; já o Plano $C$ era destinado aos empréstimos hipotecários feitos a qualquer pessoa física ou jurídica. Vacum caracteriza o Plano C como uma tendência empresarial, cuja

"principal preocupação era a manutenção da
estabilidade econômico-financeira das instituições
previdenciárias, o que limitava as aplicações
imobiliárias destinadas a possibilitar o acesso à
classe trabalhadora ao montante de verba que não
comprometesse o equilíbrio financeiro dos IAP's"
(Varon ,1988, p. 237).

Embora os IAP's financiassem todo tipo de construção através desse plano, "de asilos a indústrias", os edifícios para as classes média e alta foram a principal inversão do capital, representando $80 \%$ das aplicações do IAPI, por exemplo (Farah, 1983).

A adoção do aluguel como forma de acesso aos conjuntos é outro ponto que demonstra a dificuldade do enquadramento da questão habitacional nos Institutos. Como visto anteriormente, o debate sobre habitação, a partir dos anos 30, aponta claramente a preferência pela casa própria por diversos setores formadores de opinião. Contudo, a adoção do aluguel por parte dos Institutos revela a perspectiva que defendia a preservação do patrimônio e dos recursos previdenciários, sem levar em conta aspectos sociais ou ideológicos. Os Institutos, principalmente, o IAPI, adquiriam grande quantidade de terras em várias cidades do país, constituindo um patrimônio que ultrapassava em muito sua capacidade de edificação (Farah, 1983). 
O aluguel pode ser entendido nesse contexto como uma das formas de capitalização de recursos e de manutenção do patrimônio dos IAP's, principalmente se levar em conta a alta valorização imobiliária no período, e a tradição herdada do período da República Velha de investimento em moradia de aluguel. É preciso ressaltar que não existia nenhuma instrução na regulamentação da locação das habitações produzidas pelos IAP's através do Plano A quanto ao aluguel a ser cobrado, como por exemplo, um valor abaixo do mercado. Como demonstra Bonduki (1998), foi a Lei do Inquilinato, a partir de 1942, que transformou o Plano A num programa de alcance social, pois, ao contrário do que acontecia com a iniciativa privado, os institutos eram obrigados a manter os aluguéis congelados.

A atuação dos Institutos na área habitacional, como demonstra Farah (1983), Melo (1987), Varon (1988) e Bonduki (1998), sempre foi marcada por conflitos e dificuldades. O que nos interessa ressaltar aqui, é que se por um lado os recursos da previdência eram indispensáveis para uma produção em larga escala de habitação popular, visto que não existia no país outra forma de captação de recursos dessa envergadura à cargo do Estado, a aplicação massiva desses recursos em programas socais, como o da habitação de baixa renda, significaria uma importante perda de capital por parte dos Institutos, o que comprometeria suas principais finalidades.

Assim sendo, a quem caberia o financiamento de moradia de baixa renda no período? Como deveria ser o acesso do trabalhador às unidades habitacionais, através do aluguel ou da venda? Embora os recursos previdenciários fossem indispensáveis na produção estatal de habitação, a forma de atuação dos Institutos, e mesmo a sua possibilidade real de atuação, não correspondia às diretrizes traçadas por técnicos, políticos e empresários na questão habitacional no Primeiro Governo Vargas. Nesse período de formulação de uma política habitacional no país, o que se assiste é um grande descompasso entre discurso técnico/ político e ações governamentais concretas no campo habitacional.

\subsubsection{Fundação da Casa Popular e a política da propriedade unifamiliar}

O projeto inicial da FCP, divulgado nos principais jornais em março de 1946 para sugestões, trazia a proposta de uma produção habitacional em larga 
escala, 100.000 unidades inicialmente. O projeto se baseava somente na construção e financiamento da casa própria, não trazendo a proposta da moradia de aluguel, nem projetos urbanísticos, confirmando a fragilidade social e política da discussão entre produção de habitação e urbanismo no período.

Nesse anteprojeto, ficava estabelecido que os recursos de que disporia a Fundação seria constituído por doações, empréstimos e principalmente por parte das reservas dos Institutos e Caixas de Aposentadoria e Pensão. As atividades dos Institutos referentes à produção habitacional seriam transferidas para a nova Instituição, a qual caberia a resolução do problema de moradia brasileiro.

Este anteprojeto da Fundação foi alvo de críticas provenientes de diversos setores da sociedade, pois, uma vez instituída, a FCP desarticularia toda a estrutura habitacional montada com os Institutos. O contexto político em torno da implementação do projeto também são reveladores para os rumos que a FCP tomou, que contudo não serão abordados com profundidade no presente trabalho.

Mesmo sem apoio político, e tendo sido alvo de várias críticas, o projeto da FCP foi implementado em $1^{\circ}$ de maio de 1946, com o Decreto-lei 9.218, trazendo algumas modificações importantes, no que dizia respeito principalmente ao seu capital inicial, mas com a política da casa própria, no campo ou na cidade, como a única atribuição do novo órgão.

Em 06 de setembro de 1946, foi anunciado o Decreto-lei 9.777, o qual discorria sobre as novas atribuições, objetivos e fontes de recursos da FCP, ampliando ainda mais seu campo de atuação, como para o financiamento de materiais de construção, financiamento e construção de equipamentos urbanos, execução e financiamento de projetos de urbanização, construção de núcleos rurais, habitações para aluguel ou moradia, pesquisas sócio-econômicas, etc.

Com este novo decreto a FCP tinha um projeto de atuação que the permitia atacar o problema da moradia em quase todos os aspectos, tendo para isso incorporado várias teses que se lançaram em torno da provisão habitacional no país naquele período.

Assim, embora com um projeto ambicioso, que contemplava não só a construção da moradia, mas a de equipamentos e serviços para os conjuntos, núcleos rurais, projetos urbanos e de urbanização e financiamentos para a produção de materiais de construção, a FCP mais uma vez não obteve o apoio político e financeiro necessário para que se tornasse de fato a expressão 
acabada de uma política habitacional inédita no país. Seu projeto não contemplava muitos aspectos da arena política do contexto em que foi implementada.

Apesar de muitos segmentos sociais defenderem a criação de uma agência estatal destinada à produção habitacional e da Fundação ter incorporado em seu projeto grande parte das teses defendidas sobre o problema da moradia e seu enfrentamento nos anos 30 e $40^{6}$, ela não obteve o apoio político e financeiro para que se sobressaísse em relação aos IAP's e pudesse ter enfrentado de maneira eficaz a crise habitacional no país, o que refletiu numa produção escassa, com poucos núcleos habitacionais desprovidos de equipamentos coletivos, construídos sem grandes inovações, ou mesmo sem nenhuma inovação arquitetônica e urbanística (MANOEL, 2004).

Durante o Segundo Governo Vargas (1951-1954), num período em que a crise habitacional se agravava, provocada principalmente pelo êxodo rural e o inchaço das grandes cidades, foram tomadas várias medidas para que a Fundação da Casa Popular pudesse agir de forma decisiva no enfrentamento desta crise de moradia.

Dentre os diversos projetos elaborados para o revigoramento da FCP, podemos citar uma significativa injeção de capital na forma de Dotações Orçamentárias, previstas para um período de 10 anos, com início em 1.952.

Além dessa injeção de capital, ocorreram modificações importantes tanto na estrutura interna de administração da FCP, como nas suas atribuições, o que resultou numa produção mais intensa nesse período, ainda que igualmente pouco expressiva.

Segundo Manoel (2004), quanto à forma de atuação e o corpo técnico da Casa Popular, foi realizada uma reestruturação interna no início de 1.952, na qual os seus Conselhos Central e Técnico, órgãos máximos de sua administração, foram reformulados, com a nomeação de um novo Superintendente, um novo Presidente e novos Conselheiros. Dentre os novos Conselheiros do Conselho Central podemos destacar os arquitetos Affonso Eduardo Reidy, Henrique Mindlin e a engenheira Carmen Portinho, profissionais

${ }^{6}$ Como as defendidas no I Congresso de Habitação em São Paulo, promovido em 1931 pelo Instituto de Engenharia e pela Prefeitura Municipal, no I Congresso Panamericano de Habitação em Buenos Aires, no ano de 1939, e na Jornada de Habitação Econômica promovida em 1942 pelo IDORT. 
envolvidos com a produção habitacional da baixa renda e o Movimento Moderno de Arquitetura.

Estes profissionais possuíam uma visão de política habitacional muito distinta daquela adotada pela Fundação e defendida pela maioria dos profissionais envolvidos com o tema no período.

Atuando com uma política habitacional pautada na construção de núcleos habitacionais constituídos de casas térreas, isoladas ou geminadas, segundo uma concepção tradicional, destinadas à venda aos futuros moradores, a Fundação sempre construiu pequenos conjuntos habitacionais, que dificilmente ultrapassavam 100 unidades.

A posse e a propriedade da moradia pelo operariado era vista como um meio de prevenção contra as "desordens" e "subversões" porque o povo morando em locais insalubres e coletivos, estaria exposto às incitações às revoltas e também exposto a criminalidade. Seria necessário, entretanto, reeducar o trabalhador, acostumado à vida coletivas e promíscuas de outros tipos de moradia.

Concebida sob esse contexto, a Fundação da Casa Popular, segundo Manoel (2004), incorporou em seu programa muitas das diretrizes que se propunha na época como solução para o problema da moradia. Analisando alguns teóricos do período, como Rubens Porto e Francisco Batista de Oliveira, verificamos que existia a preocupação em se preservar a família que, vista como célula da sociedade, poderia ser corrompida em habitações coletivas.

"Renegar para o plano do salário a proteção à família é desconhecer a realidade das coisas, vista como, em todos os terrenos, o princípio a ser atacado. Proteger a família, célula máter da nacionalidade, 0 poderemos fazer sobre várias modalidades. $E$ sinceramente não creio que possa haver melhor oportunidade do que aquela que se trata de construção do lar, local onde se educam os filhos, os homens da nação de amanhã." (Rubens Porto, 1937). 
"A vida da família requer uma casa sã e adequada, porque ela é o fator que a consolida e protege, e bem sabemos que da família, base da sociedade, dependem a seguridade e a grandeza da nação." (F. Batista de Oliveira, 1941)

A habitação coletiva, tão combatida na época e no período anterior pelos higienistas, por representar um meio de insalubridade e de subversão dos trabalhadores, raramente foi promovida pelo FCP, com exceção de conjuntos construídos em Brasília, no Rio de Janeiro (RJ) e em Santo André.

Enquanto a FCP se voltava para a construção destes pequenos núcleos, para os quais não eram previstos equipamentos coletivos, alguns dos novos conselheiros da FCP em 1952 se posicionavam a favor de grandes conjuntos habitacionais, verdadeiras cidades, providos de vários equipamentos, vistos tão essenciais como a própria moradia. Colocava ainda a moradia de aluguel como a opção mais coerente para o trabalhador de renda mínima, pois entendiam que provisão habitacional deveria ser um serviço prestado à comunidade pelo Estado, já que estes trabalhadores não teriam como adquirir uma casa própria sem que grande parte da construção fosse subsidiada.

O breve período de reestruturação da FCP de 1951-1954 resultou na experiência habitacional mais interessante da agência, vinculada à linha de projetos de Pedregulho e Gávea, o Conjunto Residencial Presidente Getúlio Vargas, mais conhecido como Deodoro (Manoel, 2004).

À exceção do conjunto habitacional de Deodoro, a grande maioria dos conjuntos promovidos pela FCP é constituída de unidades unifamiliares - casas isoladas ou geminadas, solução que foi defendida no momento da implementação do órgão, que trabalhou sempre com grande escassez de recursos e adotou projetos mais tradicionais. Mesmo o Núcleo Residencial Carmela Dutra, que foi campo experimental de novas técnicas construtivas, como a casa de zinco, de casca de concreto e de aglomerado de concreto e papelão, teve a grande maioria das unidades construídas como unidade unifamiliares com o sistema tradicional de construção. 
CAPÍTULO 02 
CAPÍTULO 03

PARALELOS E DISTANCIAMENTOS 
CAPÍTULO 03 
"Proporcionar meios para que o povo habite de forma decente e agradável ou pelo menos humana é um dos problemas de governo. Se é fora de dúvida que a principal obrigação de um governo é cuidar do bem-estar público, não há como negar sua responsabilidade pelas condições calamitosas em que habita a imensa maioria da população do Brasil. O que resta apurar é qual dos três poderes municipal, estadual ou federal - é que deve assumir a responsabilidade pela solução do problema." 1

Jornal Hoje, 18/10/1945

1 Jornal Hoje, 18/10/1945, in: BONDUKI, N. (1998), p. 79. 
CAPÍTULO 03

222 
O que certamente podemos afirmar sobre a formação da política brasileira de habitação pré-BNH, é que no campo técnico a discussão quanto à produção habitacional internacional era bastante conhecida e difundida.

A bibliografia especializada demonstra que os técnicos brasileiros tinham acesso a essa produção seja através das publicações especializadas; das visitas dos mestres do modernismo ao Brasil; da indicação de uma delegação brasileira para o CIAM, ou mesmo através da formação de arquitetos brasileiro no exterior, como o caso de Attílio Correia Lima, de Carmem Portinho, e uma série de arquitetos do Mackenzie que estudaram na Pensilvânia (ATIQUE, 2007). Como nos demonstra Bonduki (1998), os alunos da Escola Nacional de Belas Artes, depois da tentativa de reforma de ensino proposta por Lúcio Costa, tiveram contato com as propostas dos CIAM, especialmente o tema do II CIAM Wohnung für das existenz-minimum, passando a estudar, assim, as funções dos espaços antes de propor as formas e distribuição do espaço construído. Essa nova postura projetual, totalmente diversa do classicismo e do ecletismo reinante, modificou profundamente uma geração inteira de arquitetos, propiciando o pleno desenvolvimento da arquitetura moderna a partir dos anos 1930 no Brasil, como demonstrado por outros estudos.

A questão que nos interessou nesta investigação, foi entender de que forma as experiências pioneiras de produção habitacional na Europa foram apropriadas na produção e política de habitação de interesse social no Brasil, já que vemos claramente os reflexos dessa discussão nos nossos conjuntos. Fazia parte das propostas dos CIAM's a difusão do ideário moderno entre os países, pelas razões já analisadas. Assim, não seria estranho que se formassem adeptos desses princípios no Brasil, inclusive na questão de produção em massa de habitação proletária, apesar do pouco entusiasmo de alguns profissionais importantes para com o tema, como explicitou Oscar Niemayer e Villanova Artigas em diversas ocasiões.

Apesar da abertura no âmbito técnico para essa nova área de atuação do arquiteto, o formato da política habitacional no Brasil no período estudado não propiciou o desenvolvimento desses princípios da mesma forma que nas cidades europeias no enfrentamento da questão. O populismo controverso de Vargas e dos presidentes que o seguiram; a pouca maturidade das organizações sociais no sentido de reivindicar melhores condições de vida, associadas a um empresariado ainda com visões oligárquicas e quase escravocratas, não 
permitiam uma reforma habitacional coerente e inegavelmente eficaz, a exemplo das estudadas no primeiro capítulo. As primeiras reformas e intervenções na questão habitacional acontecem de forma superficial com as vilas operárias e ações filantrópicas ainda na Primeira República, que acontecem ao lado de legislações parciais e pouco propícias a intervenção do Estado na gestão do solo urbano. Durante o período populista, a questão foi tratada de maneira fragmentada e desconectada, e no período da ditadura militar como uma questão financeira, através do $\mathrm{BNH}$. A maturidade sobre as questões habitacionais no meio político parecer ter acontecido somente recentemente, com o Estatuto da Cidade.

Apesar das dificuldades impostas pelo contexto social, político e econômico, a arquitetura moderna se desenvolveu no Brasil também no campo da habitação social, de forma fragmentada, em alguns casos até pouco lógica pela falta de alinhamento com uma política coerente, principalmente no campo do planejamento urbano municipal. Enfim, de forma surpreendente, como Le Corbusier mesmo atestou ao visitar Pedregulho em 1961, os arquitetos modernos brasileiros se apropriaram do ideário moderno de forma brilhante; mas também se apropriaram das diversas referências internacionais concomitantes, como a cidade-jardim e outros debates, tentando assim imprimir uma cultura de reforma habitacional no país no período pré-BNH, embora com pouco sucesso.

Destacamos para demonstrar as contradições e acertos dessa produção alguns conjuntos que claramente interpretam, adaptam ou simplesmente reproduzem de forma fragmentária o repertório de produção habitacional na Europa. As referências mais perceptíveis dizem respeito à produção teórica e prática de Le Corbusier, seja no campo da arquitetura, como no planejamento urbano; as imagens amplamente divulgadas da arquitetura alemã racionalista do entre - guerras, e o material gráfico e teórico publicado pelos CIAM's. Além, é claro, de toda uma interpretação simplificada da cidade-jardim, já existente no Brasil à partir principalmente da vinda de Barry Parker para São Paulo para a construção dos bairros "Jardins".

\subsubsection{Legados de Le Corbusier}

Mesmo com um cenário politicamente controverso e uma industrialização tardia e lenta, vemos a tentativa de se construir conjuntos habitacionais 
modernos pelas atuações de algumas figuras chaves inseridas no contexto estatal de provisão habitacional. Carmen Portinho, Reidy, Carlos Frederico Ferreira, Rubens Porto e Attílio Correa Lima foram personagens dessa luta quase que pessoal pela reforma habitacional e uma nova concepção de cidade.

Um dos legados dos ensinamentos de Le Corbusier e dos CIAM é a obraprima do arquiteto A. E. Reidy, Pedregulho, que deu início ao programa do Departamento de Habitação Popular da Prefeitura do Distrito Federal (criado em 1946 e dirigido pela engenheira Carmen Portinho até 1961). O programa proposto do DHP era o de implantar conjuntos residenciais em dez bairros do Rio de Janeiro, atendendo funcionários de baixos salários da Prefeitura do Distrito Federal.

O DHP concebia a habitação como um serviço público, incluindo uma gama variada de equipamentos coletivos para atender todas as necessidades cotidianas do morador, fora o trabalho. $O$ aluguel das moradias foi estabelecido em dez por cento do salário do funcionário, descontado na folha de pagamento. Pedregulho foi o carro-chefe da produção do DHP e o conjunto residencial que teve maior repercussão em todo o período.

Num terreno de alta declividade, com um desnível de 52 metros, localizado em São Cristóvão, Reidy desenvolveu um plano urbanístico influenciado pela unidade de vizinhança e pela proposta utópica. A proposta de Pedregulho para ocupação de áreas íngremes foi preconizada por Le Corbusier quando da sua visita ao Brasil e América do Sul em 1929. O arquiteto francosuíço realizou diversos croquis para remodelação do Rio com edifícios contornando os morros, dispostos sobre pilotis, com um pavimento intermediário diferenciado para circulação, como se pode observar pelos croquis. A ideia de edifícios contornando encostas não era nova, mas nunca havia sido aplicada antes de Pedregulho. Reidy tirou partido da topografia e da paisagem, respeitando a condição original do terreno com a implantação de um grande bloco serpenteante sobre pilotis, de sete pavimentos, com 250 metros de extensão, que contorna o terreno acidentado. Composto por 522 unidades, o projeto original previa ainda dois blocos de quatro pavimentos, um edifício de doze pavimentos e uma gama completa de equipamentos coletivos. 


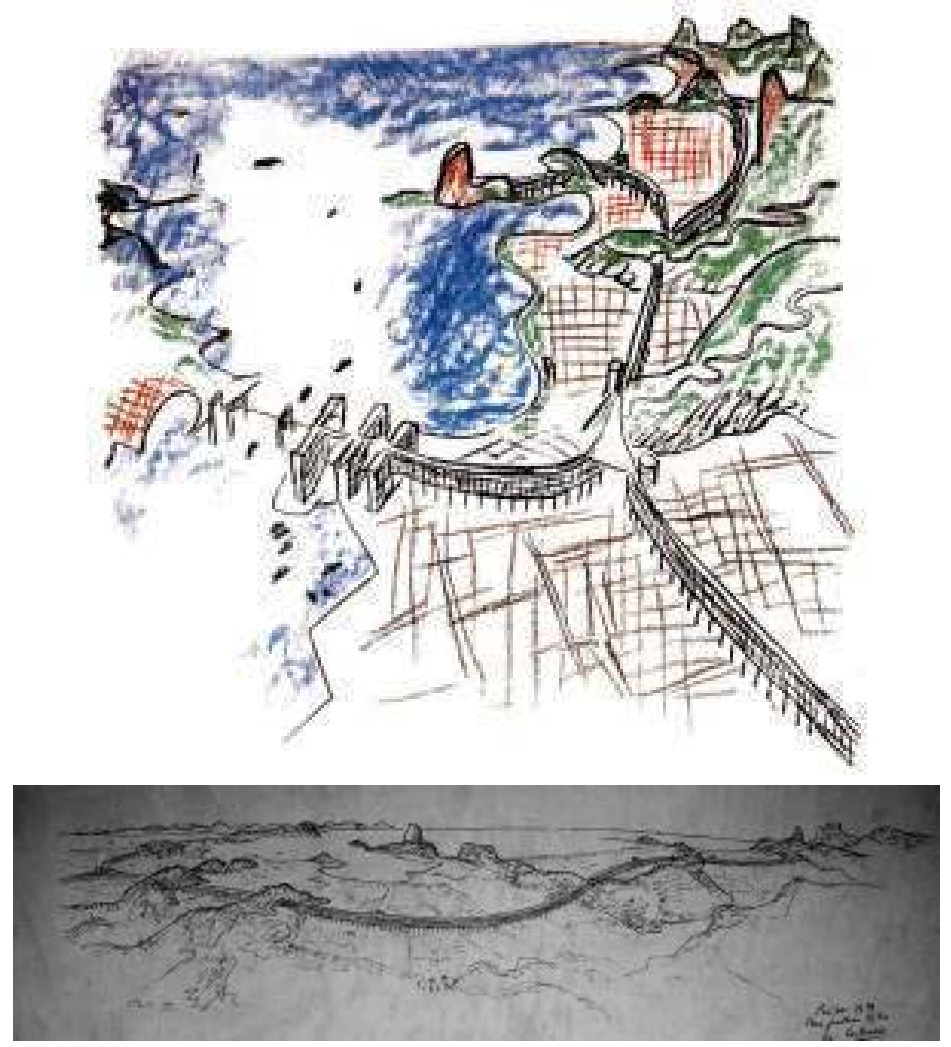

Figuras 260-1. Estudos de Le Corbusier para Rio de Janeiro, 1929. Fonte: http://www.fondationlecorbusier.fr
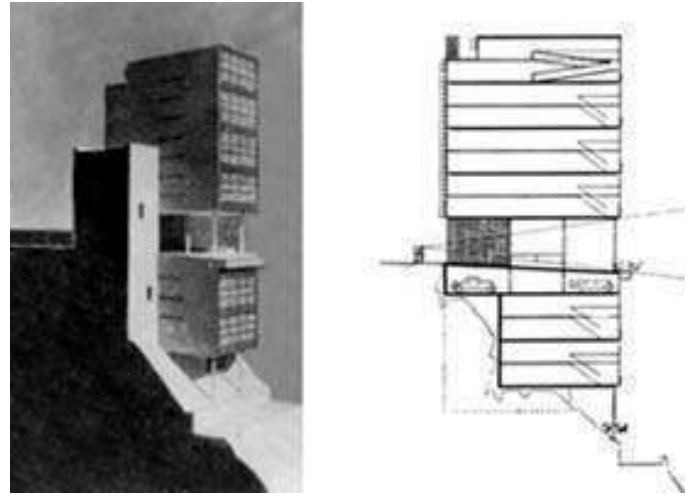

Figuras 262-3. Edificio de Le Corbusier para Argel, 1933. Fonte: http://www.fondationlecorbusier.fr

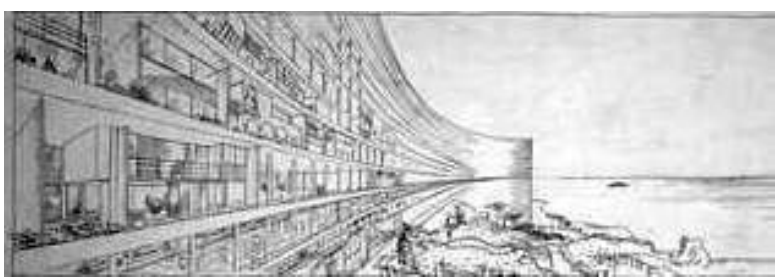

Figuras 264-5. Estudo de Le Corbusier para Argel, 1930. Fonte: http://www.fondationlecorbusier.fr 
O edifício serpenteante é o elemento principal do conjunto. $O$ acesso pelo terceiro pavimento viabiliza a circulação sem elevador para os sete andares, criando uma verdadeira rua suspensa, varanda aberta para a paisagem deslumbrante da cidade. Nesse nível foram localizados o serviço social, creche, áreas comerciais e de recreação. No primeiro e segundo pavimentos, localizamse quitinetes de 26 metros quadrados para casais sem filhos; nos andares superiores, com acesso pelo quarto e sexto pavimentos, estão os duplex, com dois, três e quatro dormitórios. Corredores serpenteantes, fechados por cobogós, criam um ambiente excepcional, onde o conforto térmico se combina com uma plasticidade belíssima.

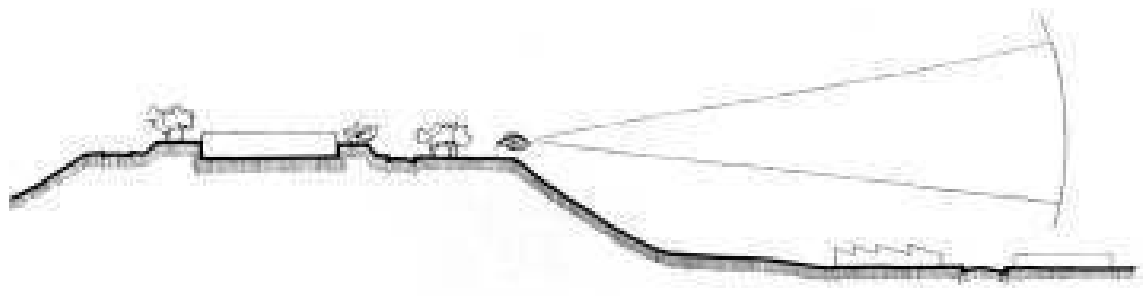

Figura 266. Declividade do terreno. Fonte: Acervo Grupo Pioneiros.

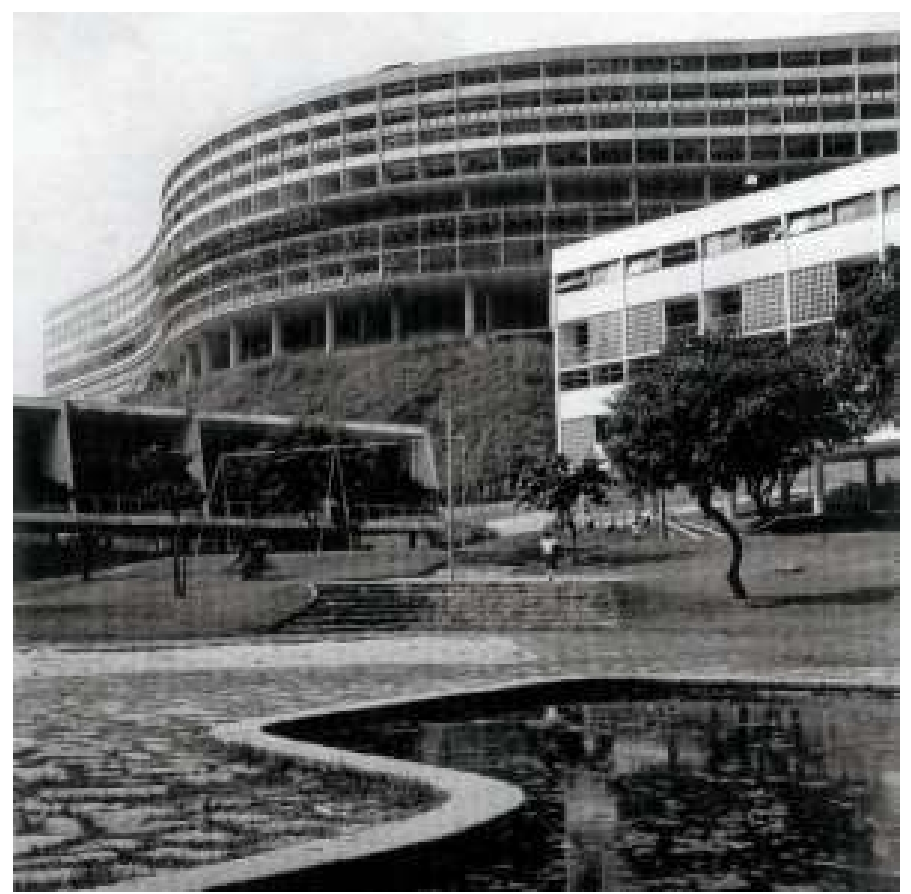

Figura 267. Vista, em primeiro plano da área livre do conjunto, com a escola à esquerda, e os blocos laminares em segundo plano e o serpenteante ao fundo. Em primeiro plano, detalhe do paisagismo de Burle Marx. Fonte: Acervo Grupo Pioneiros. 


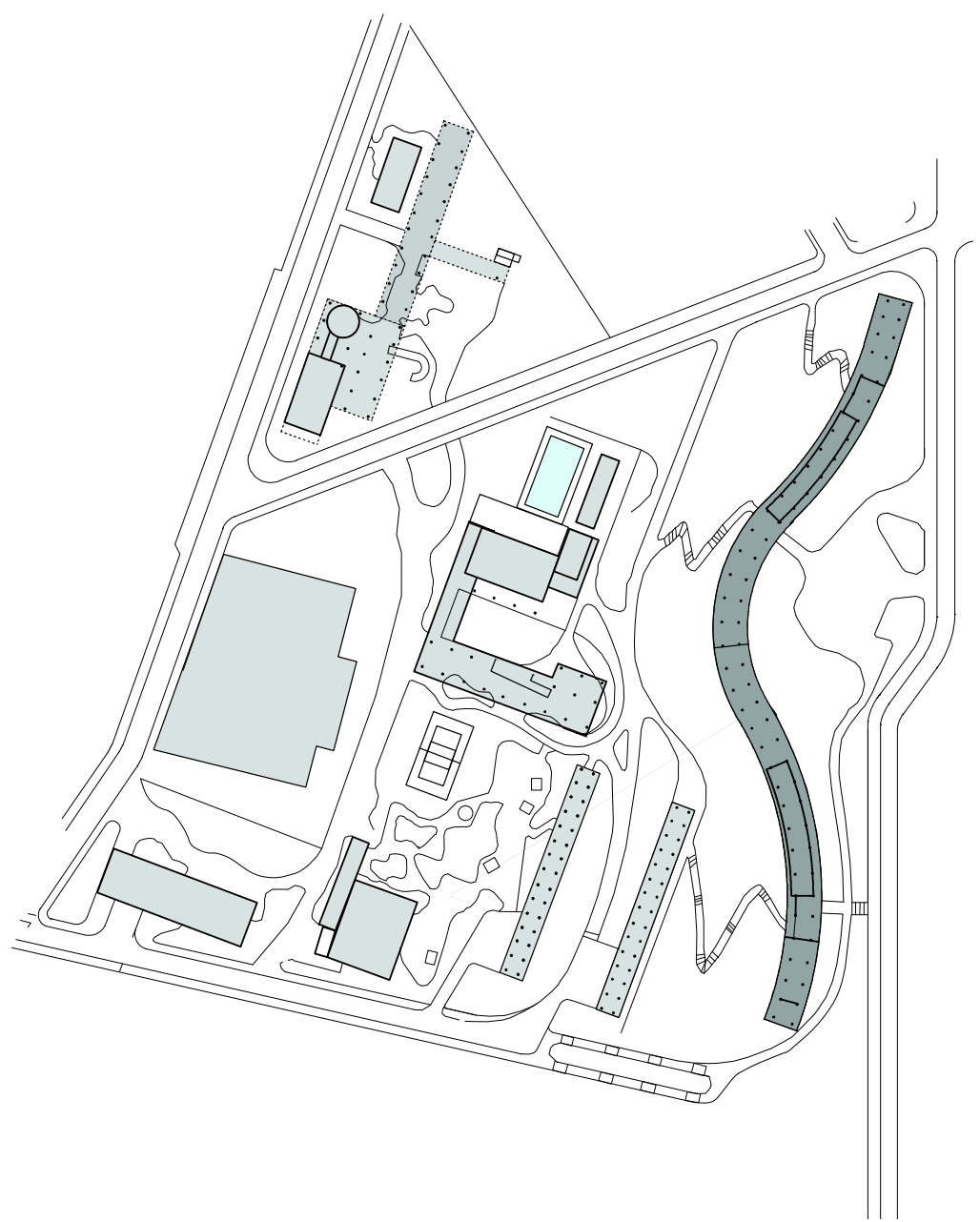

Figura 268. Implantação geral. Fonte: FRENCH, 2009, CD-ROM.

$\mathrm{Na}$ parte baixa do terreno, localizam-se os equipamentos e os blocos residenciais de quatro pavimentos sobre pilotis, com apartamentos duplex e uma expressiva composição de cobogós nas duas fachadas. A circulação vertical foi organizada num volume separado do corpo principal do edifício, que se articula com corredores no segundo e no quarto pavimento. Esses blocos são magistralmente modelados, destacando-se dos demais projetos de blocos laminares realizados no período.

O empenho de Carmen Portinho foi decisivo para a viabilização quase integral do projeto; só não foram construídos o clube e o edifício de doze andares. Concretizou-se, assim, uma unidade de vizinhança com escola, ginásio, piscina, centro comercial, posto de saúde, lavanderia mecanizada e 
creche, todos com grande qualidade arquitetônica. Portinho e Reidy defendiam a integração entre as artes, incluindo no empreendimento obras de artistas como Cândido Portinari (painel de azulejos no ginásio), Burle Marx (mosaicos na escola e projeto paisagístico) e Anísio Medeiros (azulejos no Centro de Saúde).
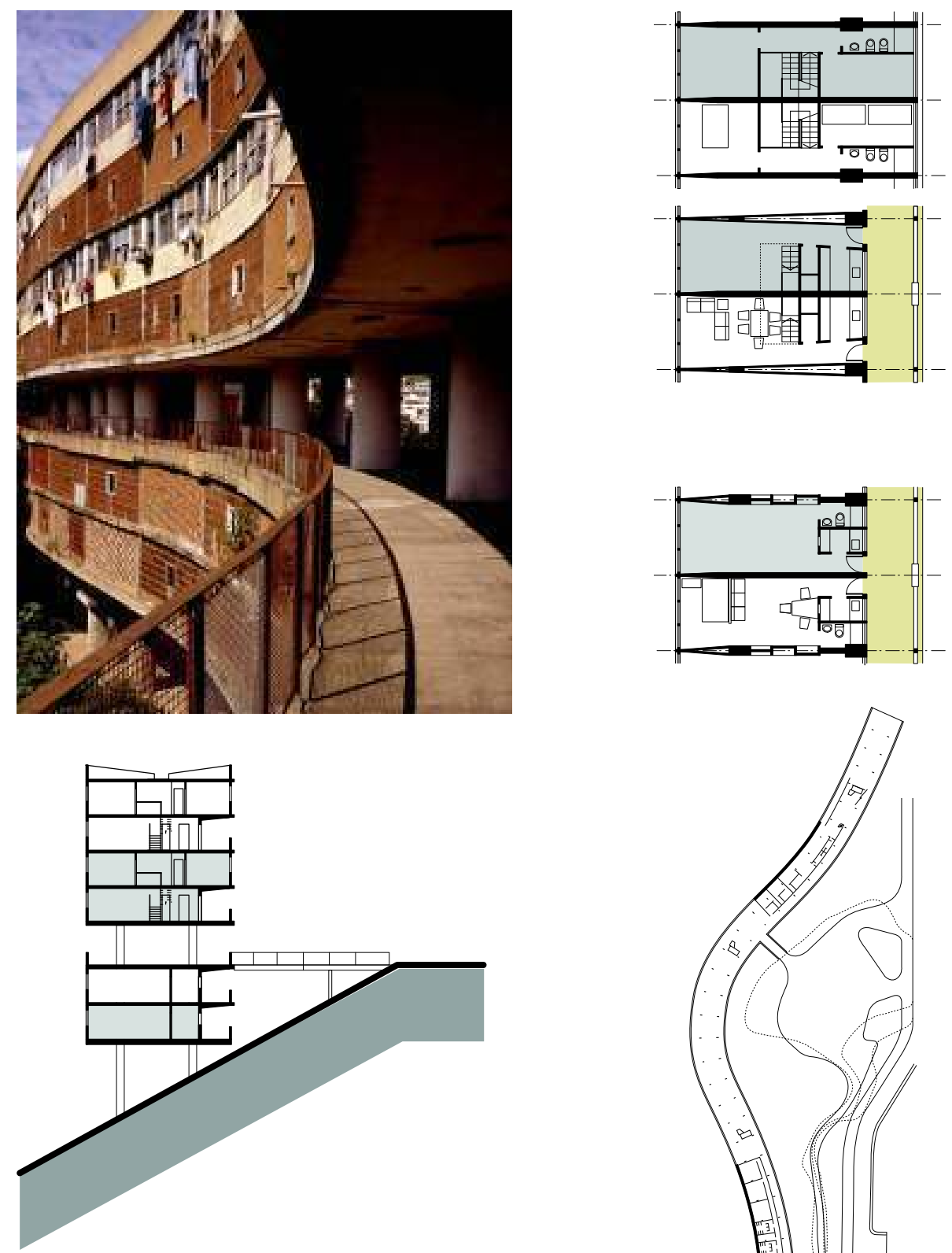

Figura 269. Foto bloco principal. Fonte: Acervo Pioneiros.

Figuras 270-73. Corte apartamentos tipos e pavimento de acesso. Fonte: FRENCH, 2009, CDROM.

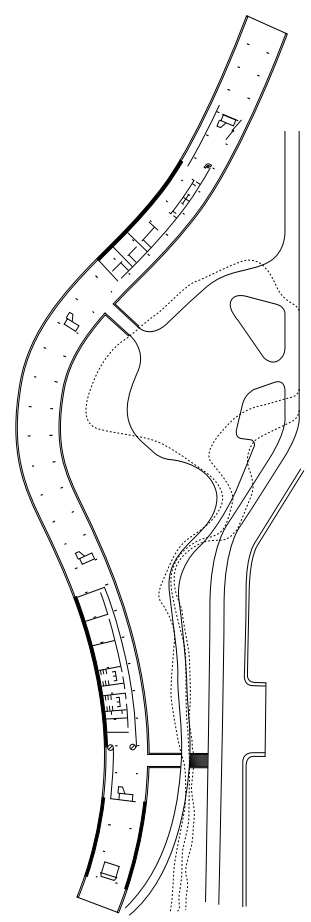


Pedregulho tornou-se uma referência indispensável da arquitetura brasileira. Mas não é uma obra isolada, integrando um ciclo de projetos habitacionais produzidos no Brasil no período. Sua concepção foi regida pelos mesmos princípios que, desde Realengo, orientaram muitos outros projetos: implantação urbanística moderna, autarquização, implantação de equipamentos comunitários, valorização do espaço público, racionalidade e renovação do modo de morar, tratando a habitação como um serviço público. Pedregulho se destaca porque esses princípios foram implementados num projeto original, com a plasticidade que caracterizou a arquitetura moderna brasileira. A preocupação com a economia, entretanto, não orientou sua concepção. Isso só foi possível porque o DHP recebia recursos a fundo perdido do orçamento do Distrito Federal. Obra monumental e dispendiosa, Pedregulho teve suas obras finalizadas em 1961, sem, contudo o projeto ter sido inteiramente executado. Sem restrições econômicas, Pedregulho incorporou, num projeto de habitação social, a linguagem que destacou a produção brasileira no cenário do movimento moderno.

Apesar de sua orientação pouco econômica para os padrões brasileiros, o Departamento de Habitação Popular do Rio de Janeiro foi uma iniciativa louvável no sentido de se incorporar a questão habitacional no agenda do município de forma associada ao planejamento urbano. Principal exemplo disso, como já vimos, foi Pedregulho, cuja localização e seleção dos moradores foram primorosamente estudadas em função de uma demanda local. A implantação inusitada para o cenário brasileiro proposto por Reidy, apoiando e realizando uma solução para ocupação de áreas de encosta, revelam a maturidade do arquiteto no conhecimento dos pressupostos modernos de arquitetura difundidos pelo CIAM e pela figura de Le Corbusier, e na sensibilidade para as questões locais da expressão dessa linguagem moderna.

A partir dessa solução, foi possível construir outro conjunto habitacional pelo próprio DHP em área relativamente nobre, na Gávea, incorporando também a noção de edifício ponte, já utilizada em conjuntos europeus. Gávea não tem a mesma maestria do primeiro conjunto, mas resolve a situação de implantação do complexo de forma pertinente com a expansão urbana do Rio. 


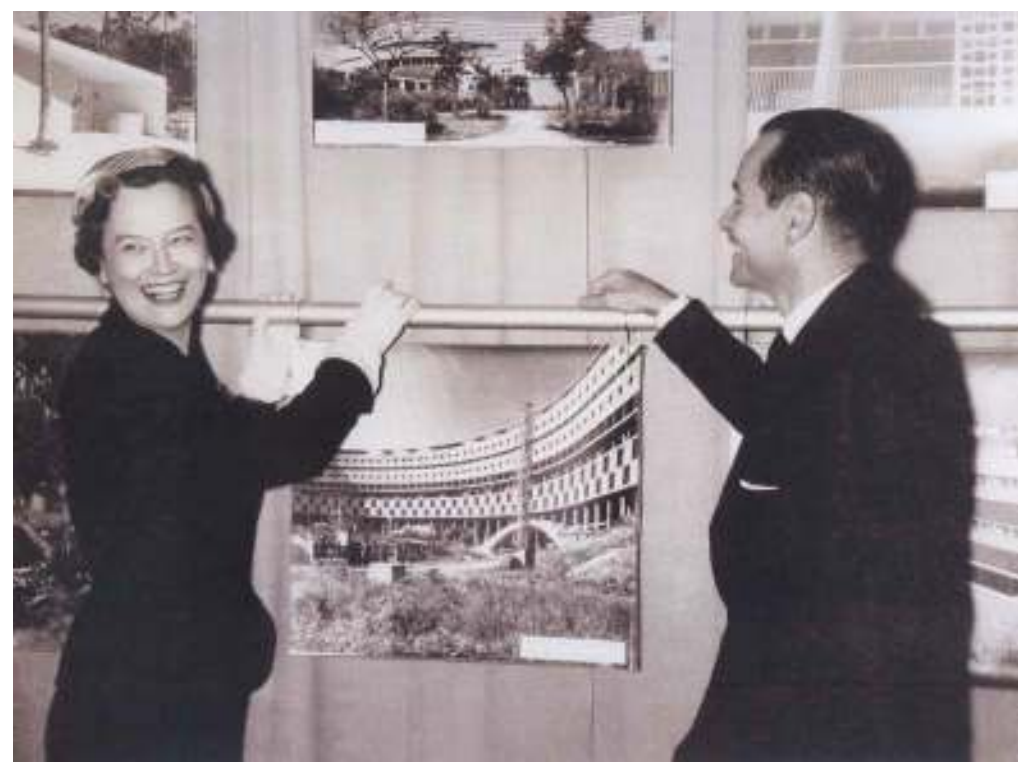

Figura 274. Reidy na exposição de Arquitetura Brasileira em Nova York. Ao fundo, os conjuntos residenciais do DHP. Fonte: Acervo Pioneiros.

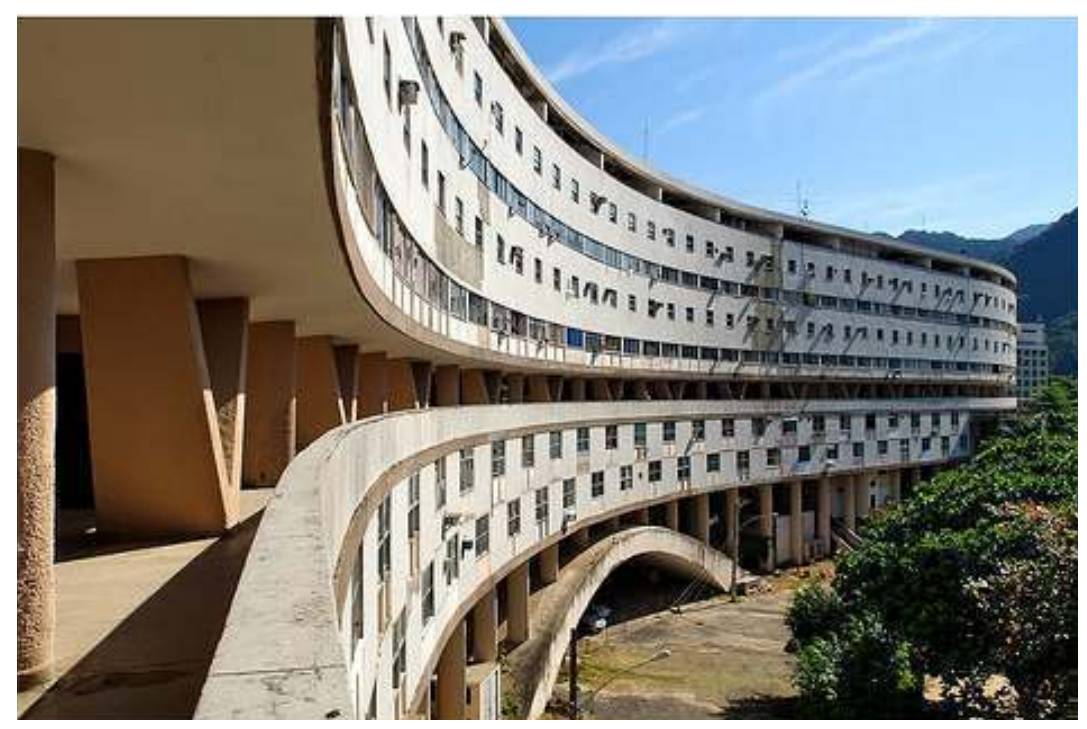

Figura 275. Conjunto da Gávea. Fonte: Acervo Pioneiros.

O terceiro conjunto da linhagem dos edifícios serpenteantes é o mais controverso de todos. Construído pela Fundação da Casa Popular entre os anos de 1952-1956, o conjunto apresenta a maior extensão de bloco serpenteantes, 460 metros, contornando parcialmente um aclive do terreno, se articulando com um segundo bloco menor, também serpenteante; no intervalo entre esses blocos o arquiteto Flávio Marinho Rego, pertencente a equipe de Reidy na Prefeitura, preservou uma área repleta de mangueiras maduras. Apesar de mais simples e 
menos conhecido, o conjunto de Deodoro tem a característica de propor uma arquitetura menos elaborada nos detalhes, e, portanto mais barata. Talvez seja o edifício mais apropriado para a aplicação em larga escala para habitação de baixa renda, pois propõe uma implantação pertinente ao sítio acidentado da cidade, como os demais, mas com a possibilidade de seriação de vários elementos construtivos desenvolvidos para o conjunto, de forma a baratear bastante a construção. Esses elementos foram empregados também nos blocos laminares, como exposto pelo arquiteto aos Conselhos da FCP (MANOEL, 2004). É preciso ter em vista que nem toda a produção seriada permite o barateamento da obra, pois depende muito do design do elemento, da disponibilidade do material, do estado da técnica no local da proposta, e da possibilidade de aplicação em larga escala, e não apenas em casos específicos, como no caso do Pedregulho e da Gávea².

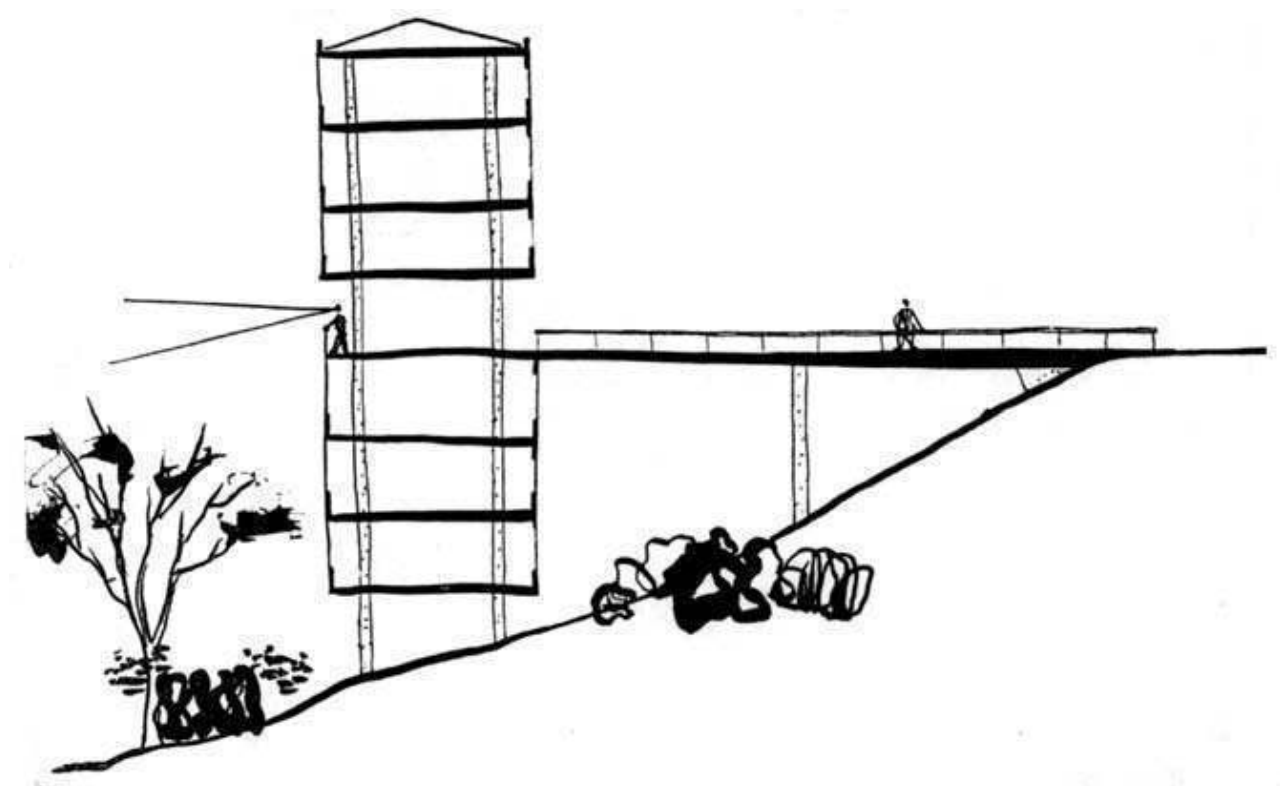

Figura 276. Corte esquemático do sítio de Deodoro. Fonte: MANOEL, 2004.

2 Como exemplo, podemos citar as esquadrias e elementos vazados que diferem de um edifício para outro na tentativa de conseguir efeitos plásticos próprios. 

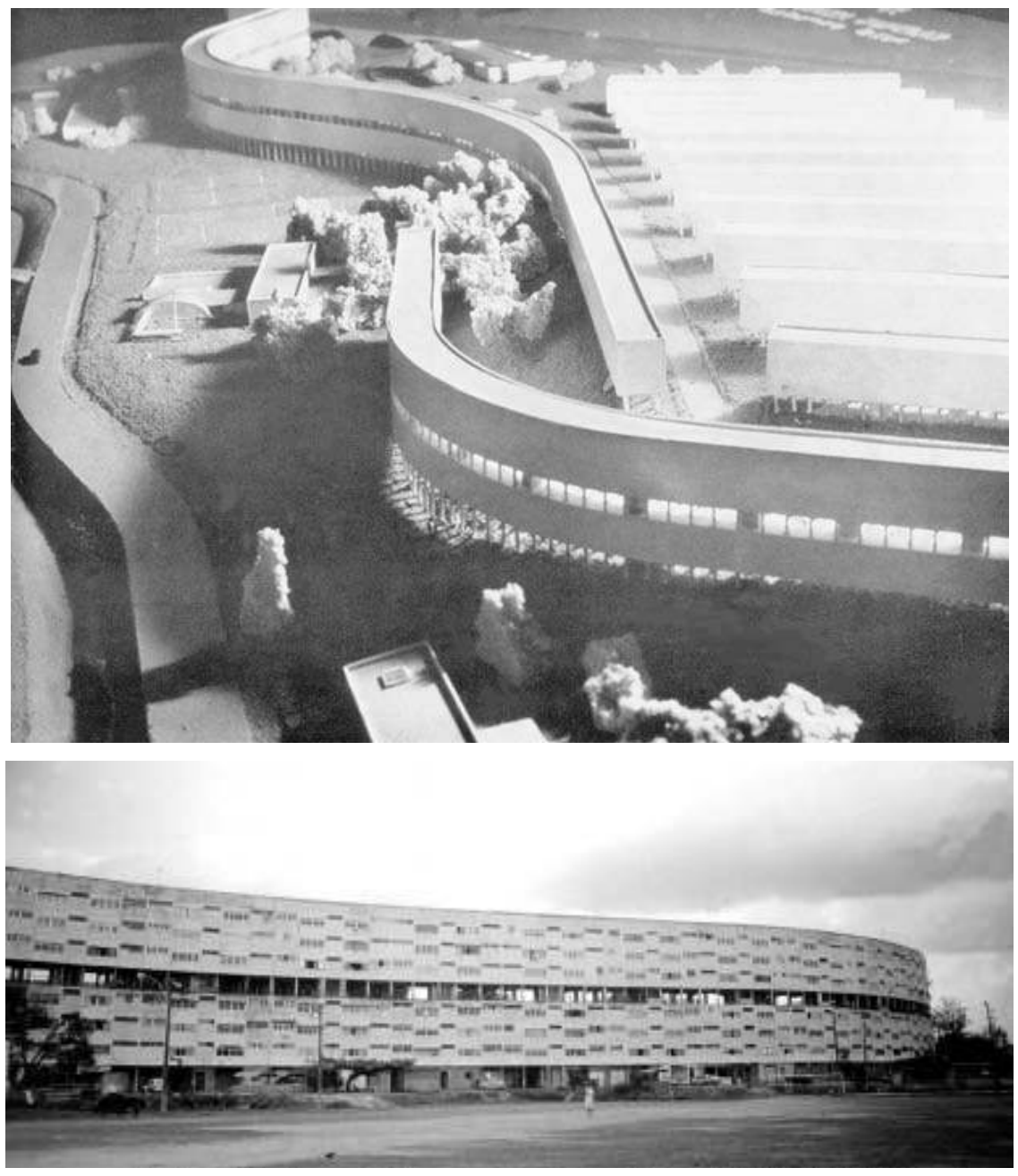

Figuras 277-78. Maquete do conjunto. Vista do bloco serpenteante. Foto da autora (2003).
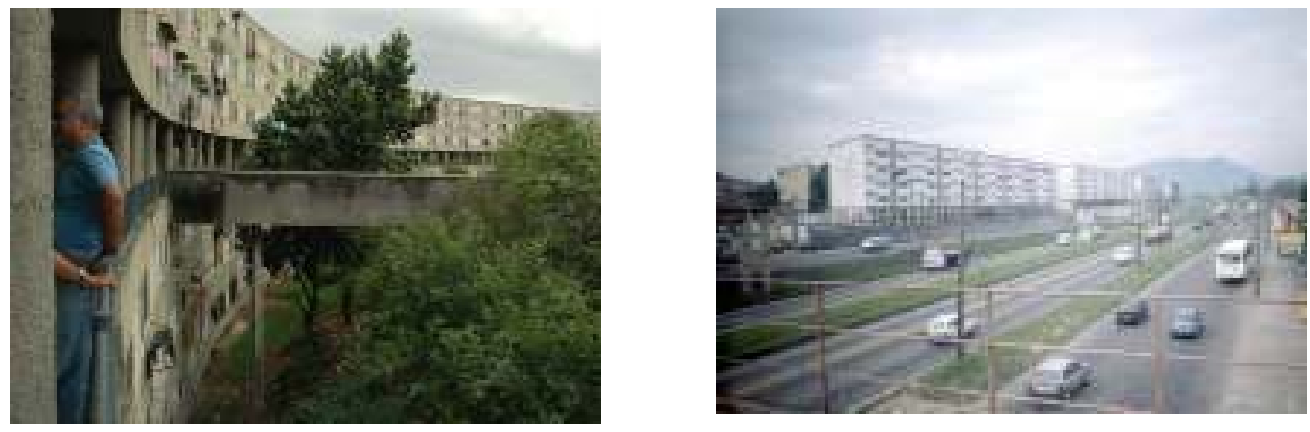

Figura 279. Passarela para pavimento intermediário. Fonte: Acervo Pioneiros.

Figura 280. Blocos próximos à Av. Brasil, com disposição final determinada pelo Ministério da Guerra (MANOEL, 2004). Foto da autora (2003) 
Um dos projetos que despertam a discussão sobre a influência dos ensinamentos de Le Corbusier sobre o urbanismo e a arquitetura moderna no Brasil é o edifício Japurá, projetado pelo arquiteto paulista Eduardo Kneese de Mello, primeiro presidente do IAB-SP, localizado no entorno da área central da capital paulista, no bairro do Bexiga (Bela Vista), no local onde exista um grande cortiço. Na produção do IAPI, esse edifício se destaca por buscar enfrentar a questão da habitação social em áreas centrais, tema de grande atualidade, com um edifício verticalizado voltado majoritariamente para o uso residencial.

Nesse projeto, Kneese de Melo manipula uma série de conceitos modernos para produzir habitação em série, colocando a economia e a funcionalidade em primeiro plano. Nesse empreendimento, está presente a concepção de Le Corbusier de unidade de habitação, ressaltando-se que a proposta de Kneese antecede o famoso projeto do arquiteto francês para Marselha. Embora tenha alguns pontos em comum com Pedregulho, também posterior, o Japurá apresenta elementos que permitem sua reprodutibilidade, ao contrário do projeto de Reidy.

O edifício localiza-se na depressão do vale do córrego Bexiga, junto ao Viaduto Jacareí, obra de arte viária que integra o Anel de Irradiação que o Prefeito Prestes Maia implantava em São Paulo na mesma época. No local onde o edifício foi construído, havia um dos mais famosos complexos de cortiços da cidade, Vila Barros, onde se destacava um bloco de habitação coletiva chamado de Navio Parado, que se tornou para a elite paulistana, no início da década de 1940, sinônimo das formas mais condenáveis de moradia. Todo o complexo foi adquirido e demolido pelo IAPI, em atitude saneadora.

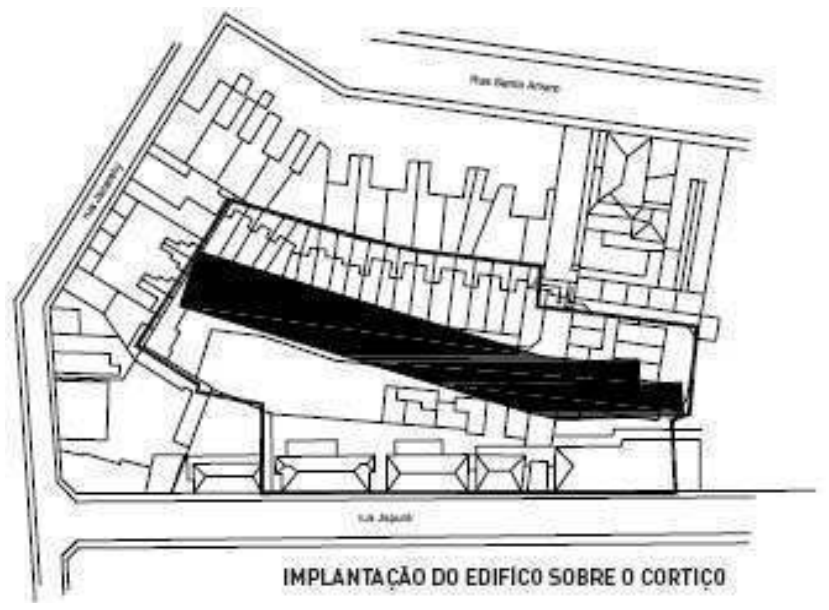

Figura 281. Implantação. Fonte: Acervo Pioneiros. 
Kneese inspirou-se no Navio Parado, de autoria desconhecida, para definir a posição do edifício-lâmina: o fundo do vale, recuado em relação à rua, acompanhando, tal como Pedregulho, as curvas de nível. Ainda que a topografia seja menos acidentada do que no projeto carioca, é um terreno de difícil ocupação e a solução é excelente para contemplar o meio físico.

Viabilizando a construção de 288 unidades habitacionais em um único edifício de catorze pavimentos, num terreno de difícil equacionamento, Kneese utilizou várias propostas do repertório moderno, buscando economia com qualidade. Como o edifício está implantado com um recuo significativo e em nível mais baixo do que a Rua Japurá, o acesso é feito por pontes fechadas, como galerias envidraçadas.

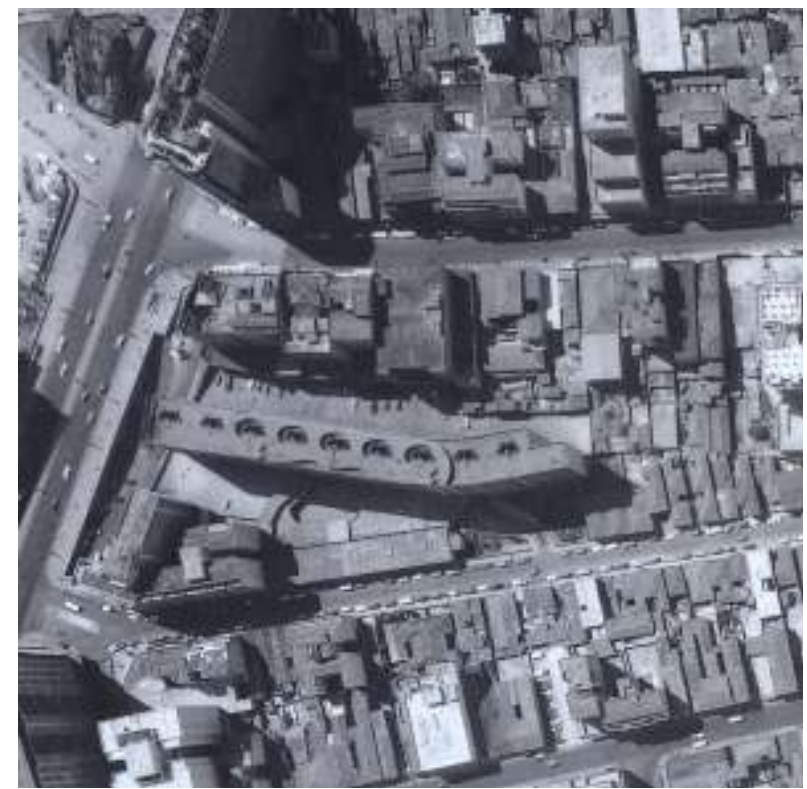

Figura 282. Foto aérea. Fonte: Acervo Pioneiros.

Para racionalizar o projeto e implantar o maior número possível de unidades, respeitando a legislação municipal, Kneese optou por utilizar unidades duplex. Assim, conseguiu reduzir o número de paradas do elevador, a área de circulação e o pé-direito dos andares ímpares, pois a legislação permitia altura mínima de 2,5 metros somente para a sala e a cozinha, enquanto que os dormitórios eram obrigados a ter pé-direito de três metros no mínimo. Por meio desse artifício conseguiu, com a mesma volumetria, ampliar em quinze por cento o número de unidades e, ainda, racionalizar as plantas dos apartamentos. Com o 
uso de pilotis, o arquiteto destacou o edifício do solo e, aproveitando o espaço aberto pelos pilotis e o desnível do terreno, implantou, além da garagem, restaurante popular e cozinha, concebidos como equipamentos coletivos. Na laje de cobertura do subsolo foi instalada uma área de recreação infantil.
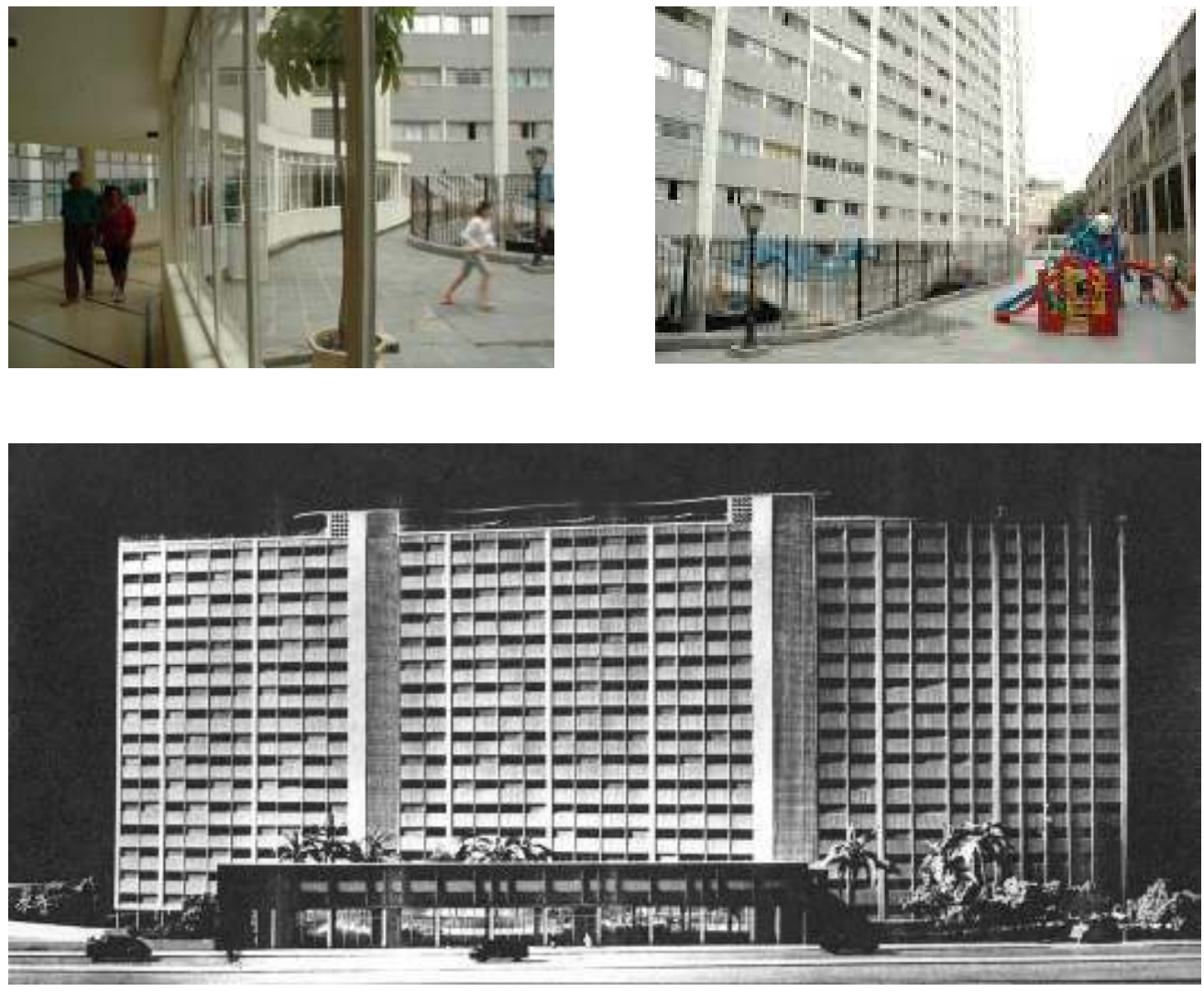

Figura 283-84. Fotos das passarelas cobertas. Fonte: Acervo Pioneiros.

Figura 285. Maquete. Fonte: Acervo Pioneiros.

No alinhamento da rua, numa implantação tradicional, localiza-se o bloco secundário, de dois pavimentos, que lembra uma fileira de sobrados de uso misto, tão presente em bairros antigos da cidade, como o próprio bairro do Bexiga. Na primeira versão do projeto, esse bloco tinha seis pavimentos. No térreo, no nível da rua, foram instaladas lojas e, no segundo pavimento, 22 apartamentos de uso residencial destinados a operários solteiros, verdadeiras quitinetes de área mínima, com sala-quarto, banheiro e uma pequena área para preparo e conservação de alimentos. Trata-se de um projeto pioneiro de quitinete, muito criticado na época por ser considerado semelhante a um cortiço. 
Em São Paulo, o Japurá foi o primeiro edifício com uma concepção próxima à ideia de edifício-cidade, na linguagem de Lamas (2002), precursor de um ciclo de empreendimentos privados de grande dimensão que, na década de 1950, desenvolveram essa proposta. No entanto, ocupando um lote encravado no tecido urbano do centro da cidade, cercado por um processo de verticalização intenso, o projeto de Kneese acabou por perder expressão, ficando oculto na paisagem urbana.
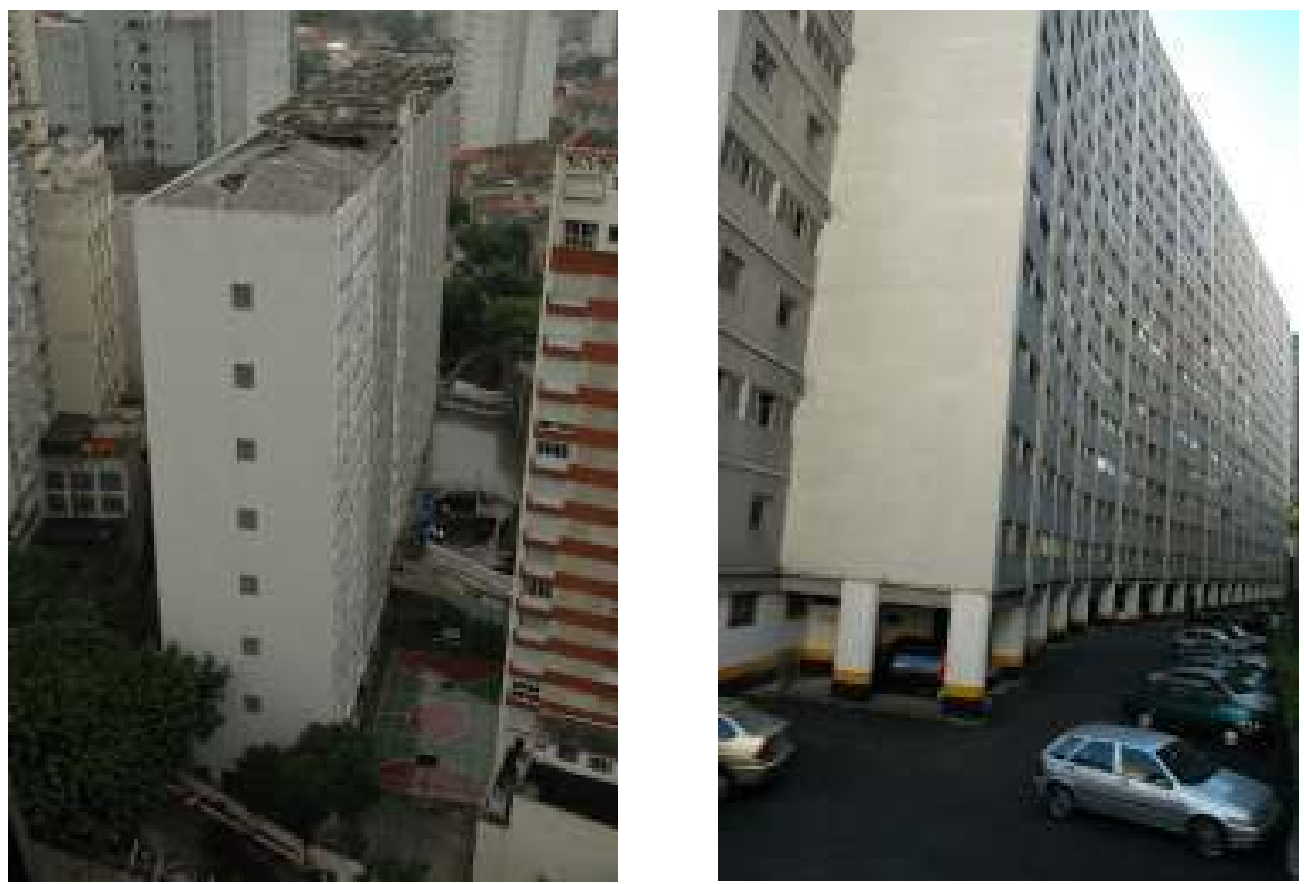

Figura 286-87. Fotos gerais do edifício mostrando a cobertura com telhado instalado posteriormente e estacionamento no subsolo. Fonte: Acervo Pioneiros.

Podemos observar que a proposta do edifício Japurá, além das possíveis aproximações com a unidade de habitação, guarda relações com as ideias do grupo OSA na União Soviética, pela proposta de um edifício principal, predominantemente residencial, com unidades mínimas, inclusive para solteiros, conectado a outro edifício com equipamentos coletivos, notadamente um restaurante popular. Kneese de Mello utilizou unidades duplex para otimizar a circulação horizontal e vertical, como nos edifícios soviéticos, nas propostas de verticalização de Gropius e no projeto da Várzea do Carmo, de Attílio Correia 
Lima. O fato de Japurá representar uma condensação de vários experimentos habitacionais da vanguarda moderna revela que a arquitetura moderna dos CIAM's de fato se difundiu no mundo ocidental, e foi apreendida e reformulada de várias formas no Brasil na produção habitacional, podendo inclusive ter antecipado propostas dos mestres europeus.

Outra forma bastante difundida nos estudos teóricos de Le Corbusier que foram apropriadas de diversas formas pelos arquitetos modernos é o redan. Utilizada como uma forma racional, a partir de uma modulação que pode ser replicada infinitamente, o redan foi utilizado por Le Corbusier no projeto para a Ville Radieuse. A primeira edificação construída com essa tipologia a experiência da Casa Bloc, em Barcelona, do grupo GATEPAC, como protótipo para expansão das áreas residenciais da cidade proposta pelo Plan Maciá.
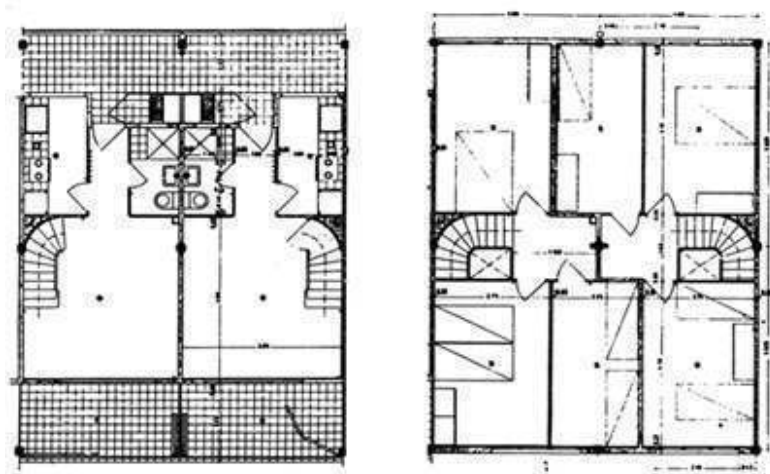

Figura 286. Planta do apartamento tipo "duplex".
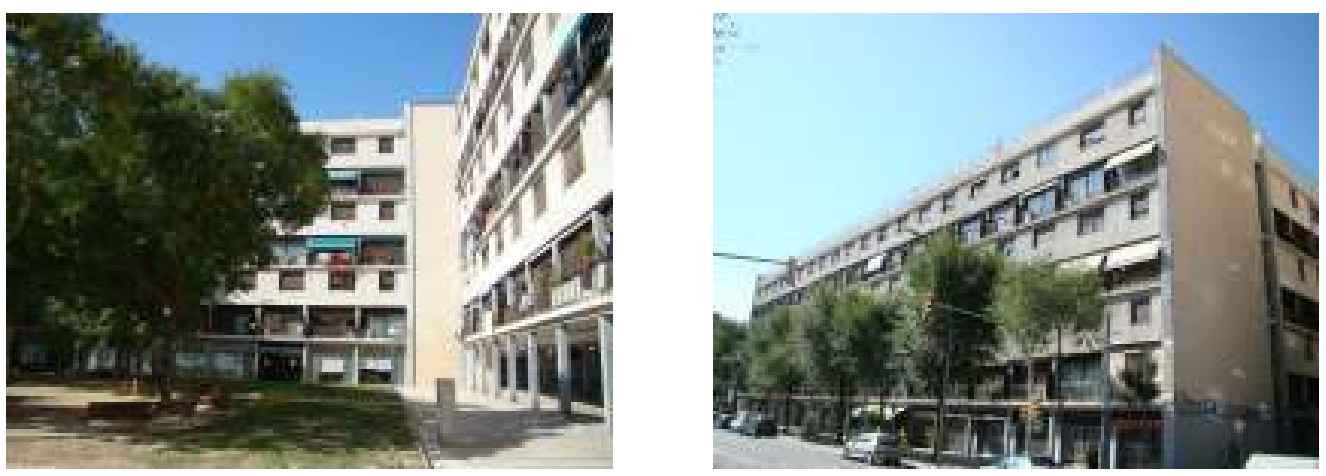

Figuras 287-88. Pátio interno e rua principal de acesso ao conjunto. Fotos da autora (2008). 

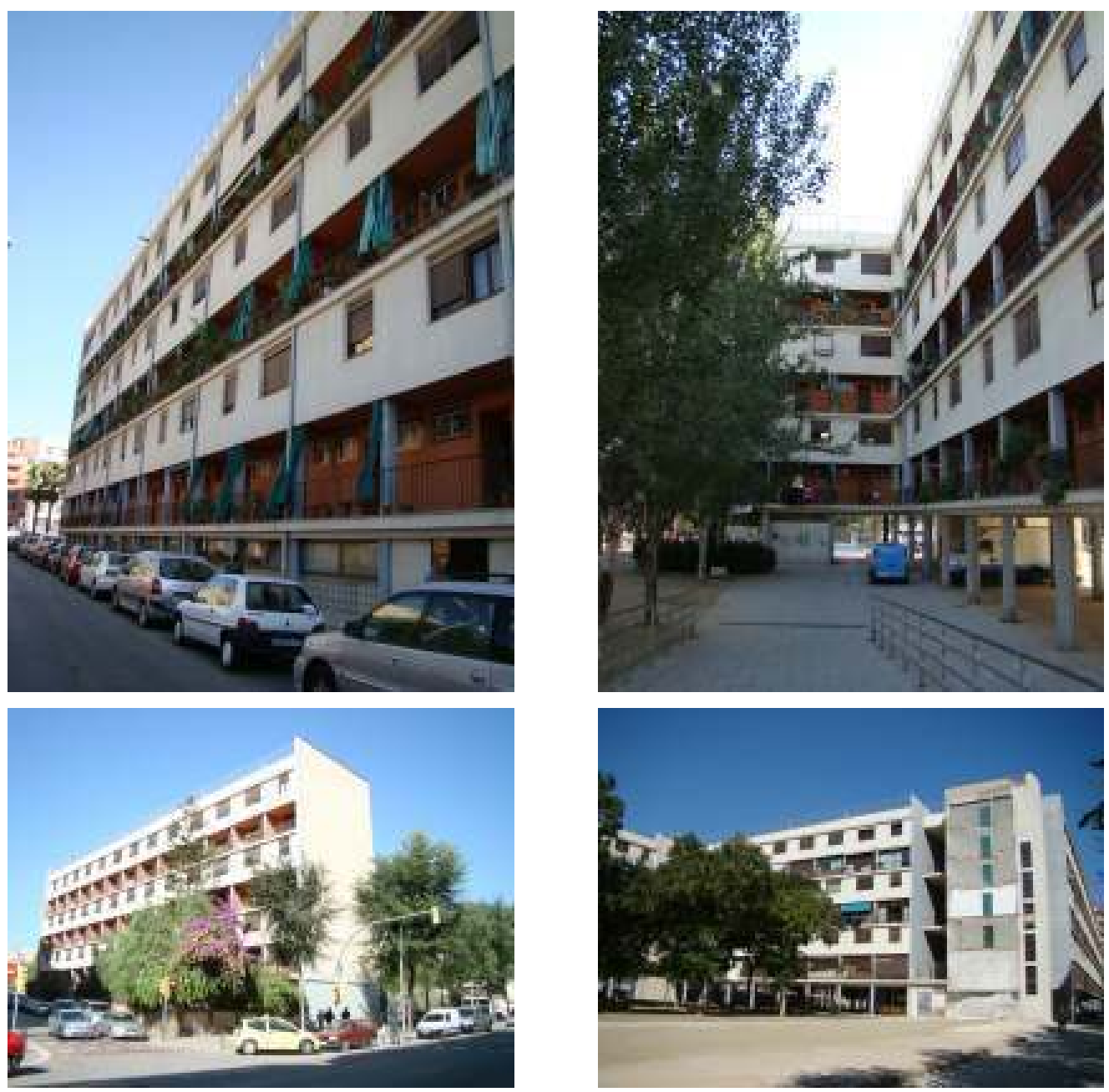

Figuras 289-92. Fotos gerais do edifício mostrando os pilotis, a área comercial voltada para a avenida principal, as caixas de escada e a composição de cheios e vazios das fachadas com as galerias de circulação e abertura sequenciadas nos panos lisos. Fotos da autora.

No Brasil observamos essa tipologia no conjunto Vila Isabel, último a ser iniciado pelo DHP e o mais incompleto das obras municipais. Implantado em meio a um parque na área do antigo jardim zoológico da cidade, o projeto pretendia criar um grande redan, inspirado na concepção de Le Corbusier, que já havia sido proposta por Reidy no seu frustrado Plano de Urbanização da área resultante do desmonte do morro de Santo Antônio, em 1948. Embora o autor do projeto seja o arquiteto Francisco Bolonha, é visível a influência de Reidy e Portinho na concepção geral do empreendimento.

Como nas demais glebas utilizadas pelo DHP, o conjunto de Vila Isabel ocupa uma encosta de morro, com um trecho plano na parte baixa. A proposta 
de um redan nessa topografia revela uma variação na produção do DHP que, naquele momento, estava construindo com grande sucesso o bloco de Pedregulho.
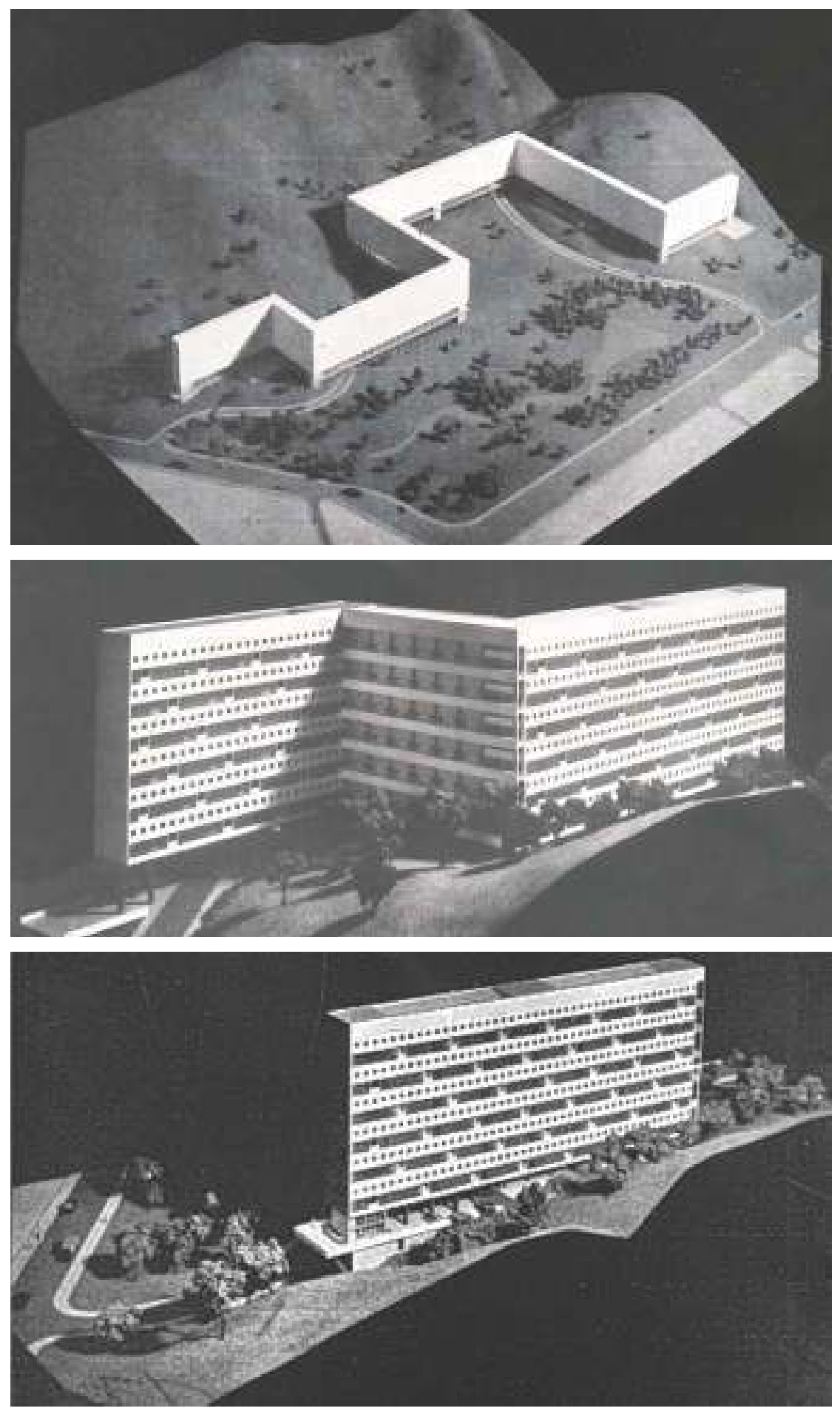

Figuras 293-95. Modificações nos projetos de Vila Isabel até restar apenas um dos blocos da proposta original. 
O projeto original, publicado em várias revistas a partir de 1954, propunha uma unidade de vizinhança formada pelo edifício em forma de um redan, medindo aproximadamente 660 metros lineares de comprimento, com sete segmentos de retas e doze pavimentos residenciais. Na parte baixa da gleba, foi proposta a implantação de uma gama diversificada de equipamentos sociais, incluindo creche, escola maternal, escola primária, ginásio esportivo, quadras esportivas, piscina, playground, ambulatório, lavanderia, mercado, capela, teatro, cinema, anfiteatro e clube social. Trata-se de um dos mais completos programas de equipamentos previstos em conjuntos residenciais no período, o qual, no entanto, ficou no papel. A documentação técnica existente resume-se ao que foi publicado nas revistas, dificultando o entendimento global da proposta. Os projetos dos equipamentos são desconhecidos, pois nem mesmo a maquete apresenta sua volumetria.

O histórico do empreendimento revela um processo continuo de redução da dimensão do redan: os sete edifícios, correspondentes a igual número de segmentos de reta, transformaram-se em três, com uma redução significativa de seu comprimento, até que, finalmente, apenas um foi construído, com apenas oitenta metros de comprimento. O edifício é uma lâmina de oito pavimentos sobre pilotis, com apartamentos duplex, incluindo unidades que variam de um a quatro dormitórios.

A circulação estrutura-se a partir de colunas de escadas e galerias de circulação na parte posterior do bloco, nos andares ímpares, que são parcialmente fechados por cobogós. A frente do edifício é composta de maneira a romper a monotonia arquitetônica dos conjuntos residenciais; assim, os andares ímpares apresentam janelas horizontais, que correspondem às salas dos apartamentos e que se alternam com as aberturas quadradas dos quartos, localizados nos andares pares, proposta semelhante à adotada na Gávea, mostrando a vinculação entre os projetos desenvolvidos no DHP.

Além da evidente referência aos projetos de Le Corbusier, como uma releitura do grande edifício ondulante sobre a malha urbana do Rio de Janeiro, podemos relacionar esse complexo habitacional e sua ideia de repetição no tecido urbano ao consagrado projeto Casa-Bloc, do grupo barcelonês GATEPAC. Além da forma em redan, a composição das fachadas, que também alternam pisos com "vazios" horizontais na composição, e pisos com panos cegos com aberturas quadradas, são elementos semelhantes entre os projetos. 
É imprescindível ter em vista que a maquete deste conjunto em Barcelona foi capa da publicação de Rubens Porto "O problema das Casas Operárias e os Institutos e Caixas de Pensão" (1937), de grande circulação entre os agentes de habitação social no Brasil. A possibilidade de segmentação em várias partes da proposta original, e também sua possível ampliação por adição de novos blocos, aproxima a concepção do planejamento urbano e forma arquitetônica desses edifícios.

Outro conjunto no Brasil que remete a solução original do redan é o Edifício do Ipase em Pelotas, construído em 1956. O conjunto mantém a forma externa do redan, criando pequenos pátios com os segmentos de retas, mas na verdade é composto de dois blocos "H" deslocados, com caixas de escada independentes para cada quatro unidades por andar. Embora o complexo esteja implantado num terreno pequeno, o deslocamento dos blocos e a adoção do térreo livre pelo uso dos pilotis proporcionam ao conjunto um aspecto dinâmico e aberto, pois a principal área livre se encontra na esquina do conjunto, criando um afastamento parcial em relação à rua. Embora a concepção desse conjunto seja em Bloco $\mathrm{H}$, a disposição conformando pátios e a articulação criada permite a combinação de vários blocos, numa sequencia infinita, como na proposta do Casa-Bloc, em Barcelona.

Ainda na sequência dos redan, outro conjunto, na verdade um edifício isolado, pode ser analisado por esse prisma. O Edifício Inconfidência (IAPI) de Carlos Frederico Ferreira, em Recife, é formado por dois prismas retangulares disposto de forma perpendicular, conformando um "L", conectados pela circulação vertical. A galeria externa de circulação possibilita a agregação de vários prismas, em qualquer direção, permitindo vários agenciamentos e a repetição infinita do modelo. O edifício traz ainda a solução duplex de apartamentos com varandas e uma composição das fachadas bastante rica, com jogo de cheios e vazios pelos acabamentos dos balcões e os vazios da galeria de circulação.

Além das referências às tipologias arquitetônicas do mestre franco-suíço, apropriadas de diversas formas no cenário nacional, a utilização dos pilotis foi outro aspecto do seu repertório formal usado pelos arquitetos brasileiros, assim como ocorreu na produção privada. 

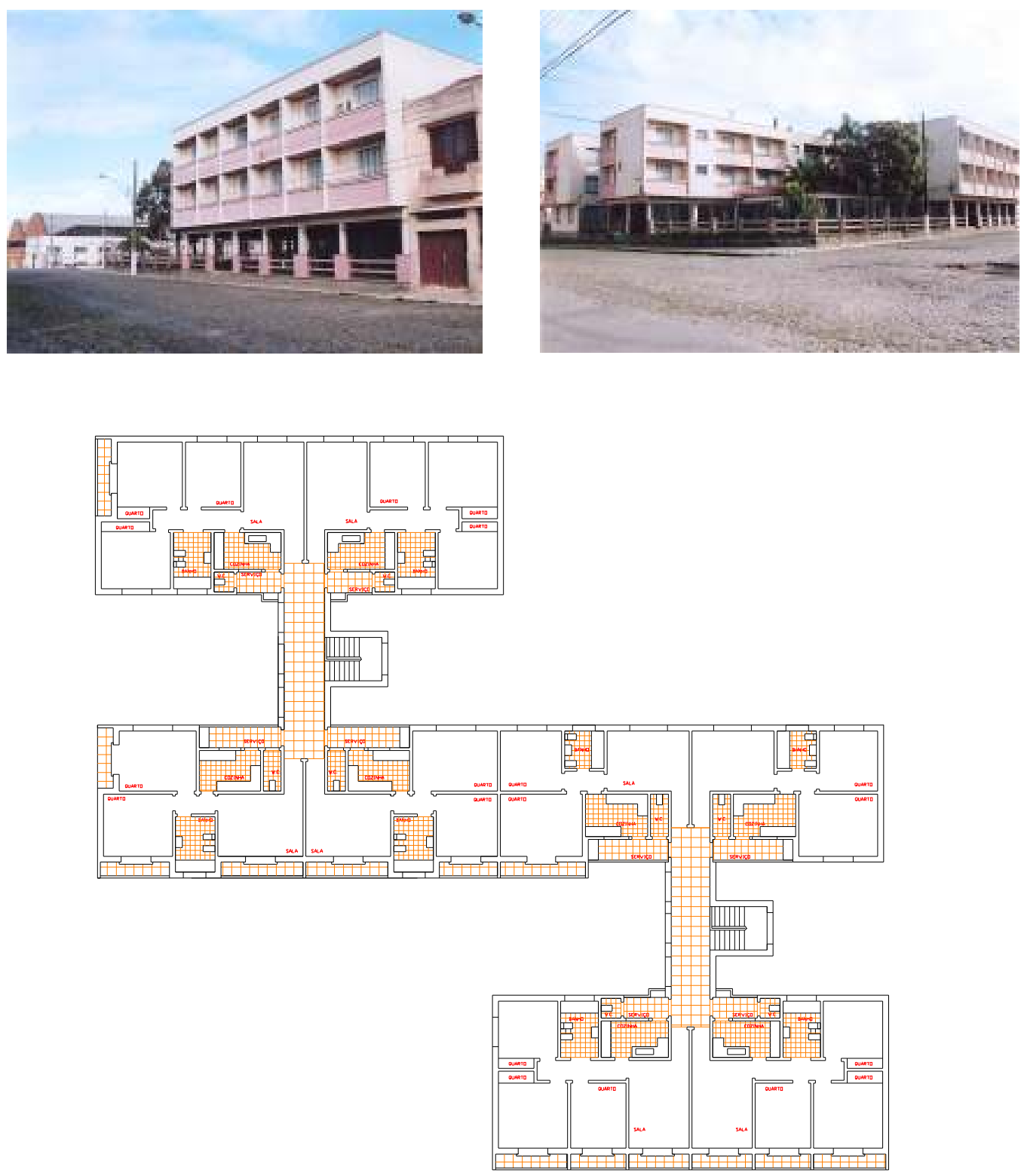

PLANTA
RSOZO - I.P.A.S.E. - PELLTAS
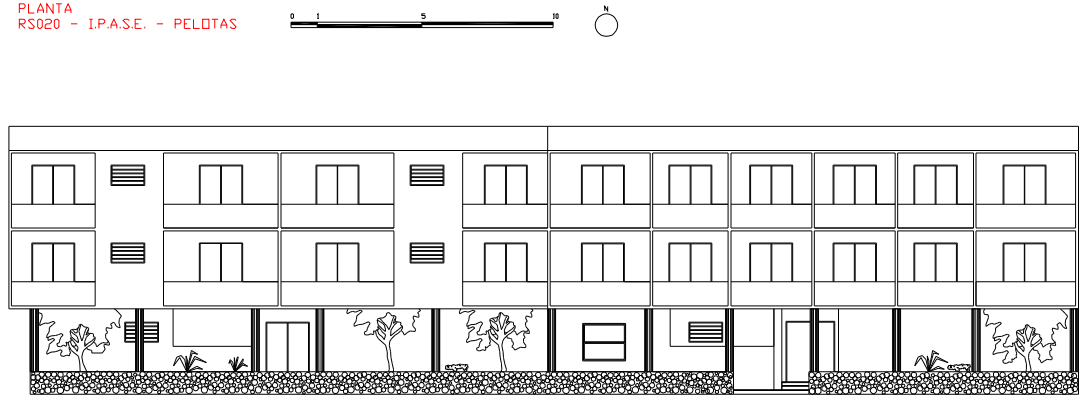

FACHADA RUA 15 DE NGVEMBRD
RSOEO - I.P.A.S.E. - PELDTAS

Figuras 296-99. Vistas gerais do conjunto. Implantação e fachada principal do edifício do IAPSE em Pelotas. Fotos da autora (2008). Fonte: Acervo Pioneiros. 

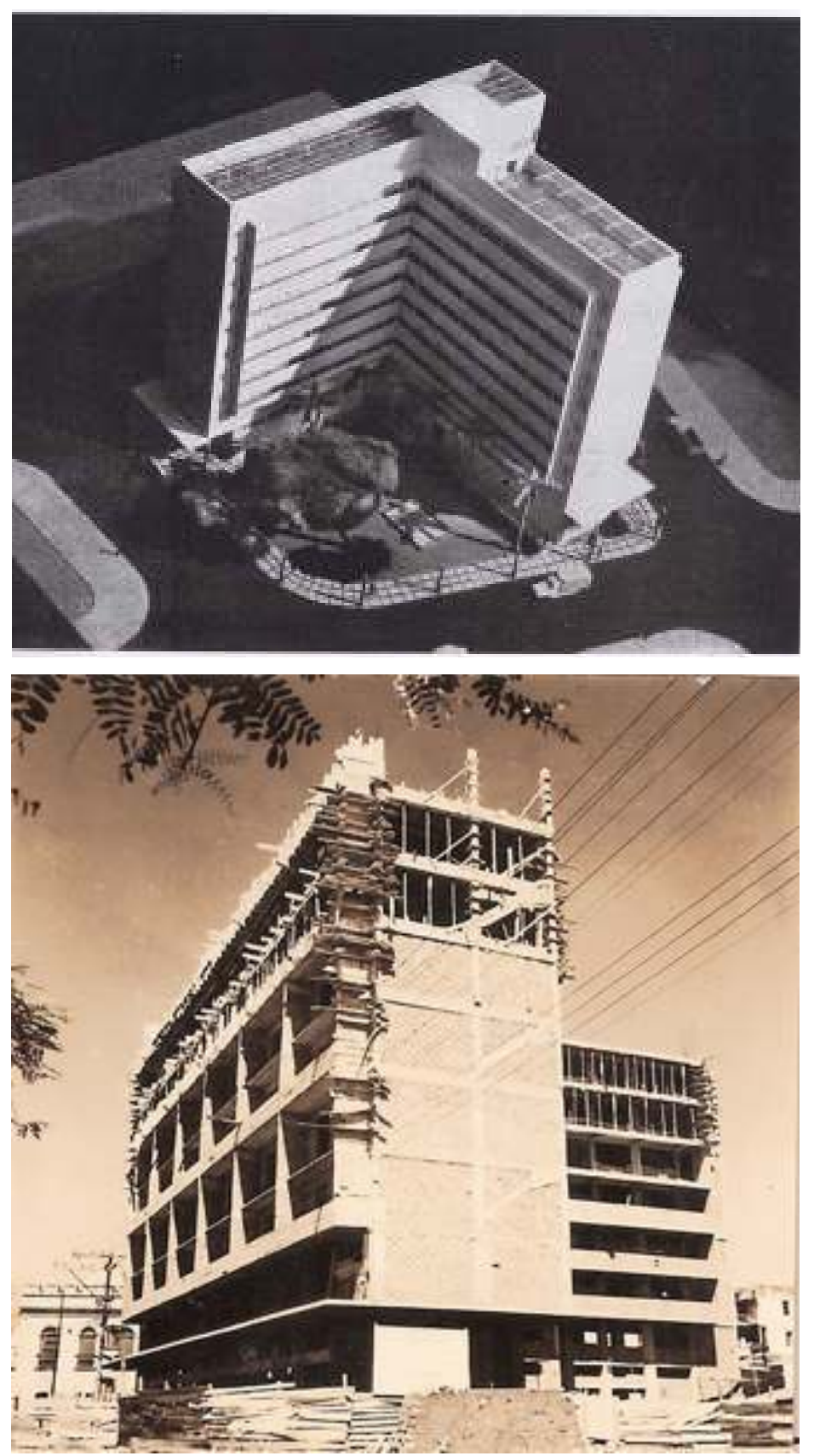

Figuras 300-01. Maquete e foto do período das obras do edifício. Fonte: Acervo Pioneiros. 

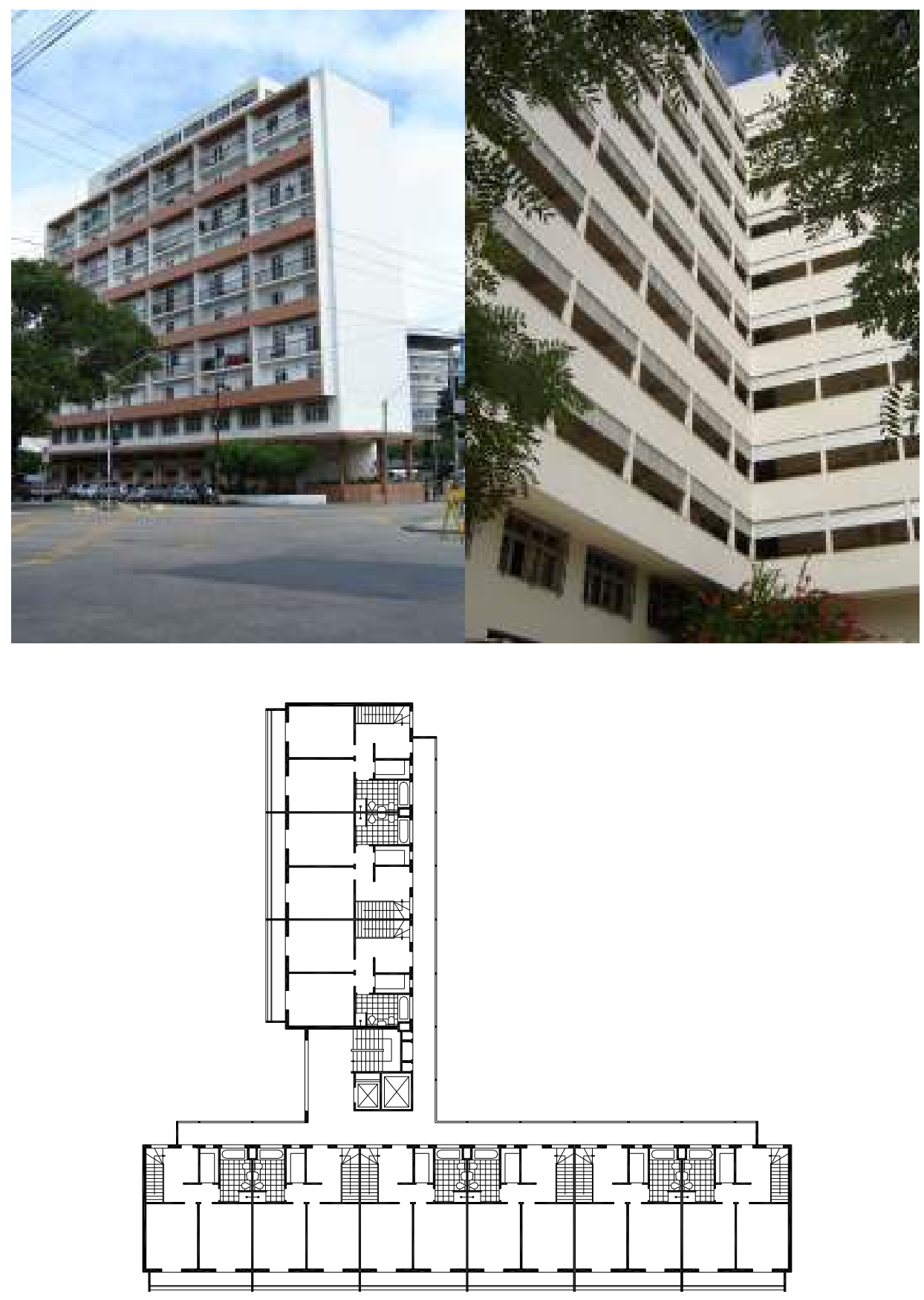

Figuras 302-04. Foto da fachada principal e vista interna do conjunto, com detalhe para as galerias de circulação marcando a fachada horizontalmente. Planta do pavimento tipo. Fonte: Acervo Pioneiros.

Rubens Porto foi um dos principais defensores das possibilidades espaciais do uso dos pilotis na produção de habitação econômica e esse artifício foi utilizado em diversos conjuntos, de diversos órgãos: Vila Guiomar, Mooca 
IAPI, Pedregulho, Vila Isabel, Deodoro, Santos IAPI, Edifício Anchieta, Japurá, IAPI Salvador, edifícios altos da Várzea do Carmo e outros. Contudo, a solução mais corriqueira eram os blocos laminares assentados diretamente no solo; em alguns casos foi empregada da solução do uso do térreo para comércio ou serviços dos próprios Instituo.
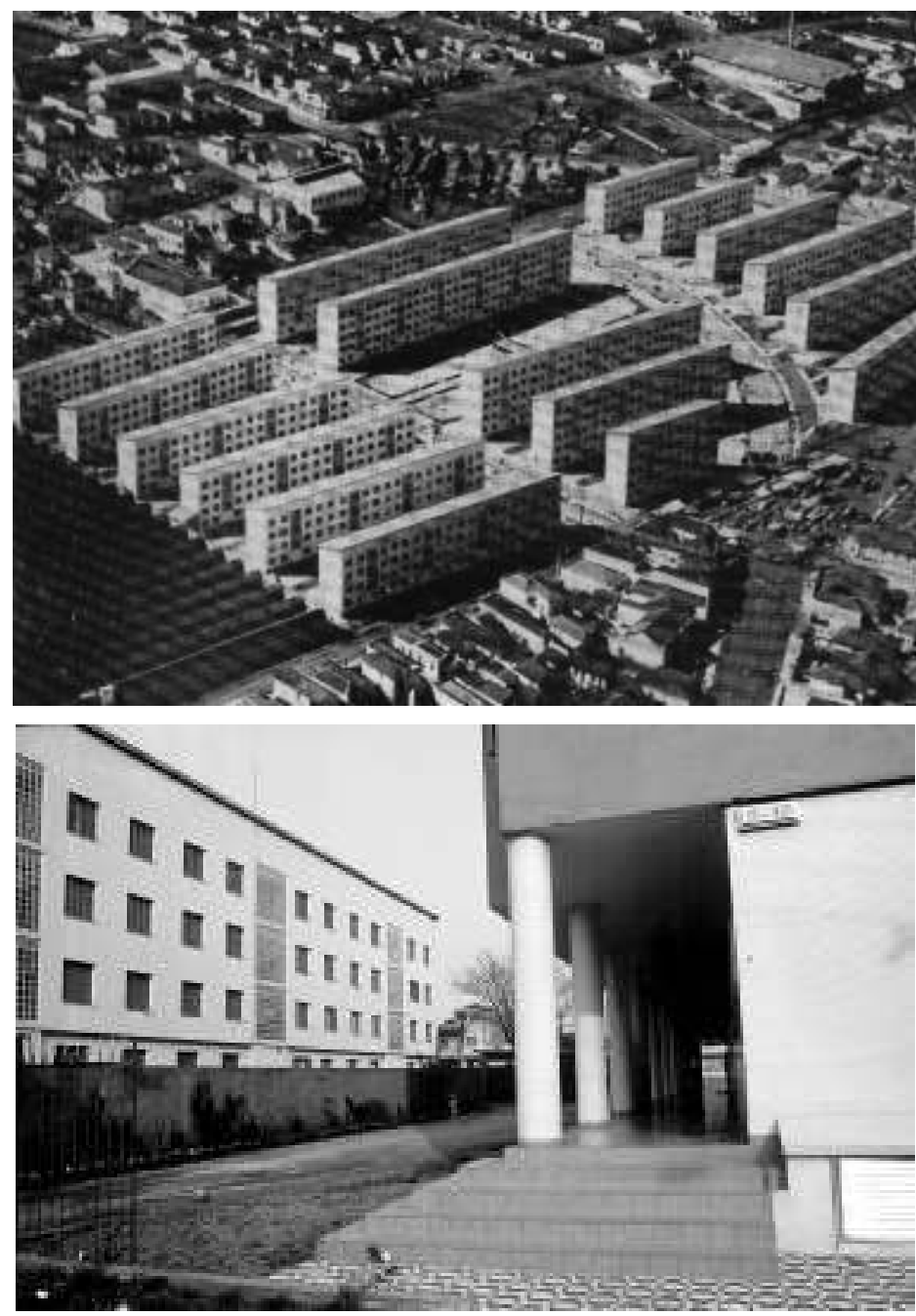

Figuras 305-06. Mooca IAPI - São Paulo, de autoria do Arq. Paulo Antunes Ribeiro. O conjunto conta 576 apartamentos de 01, 02 e 04 quartos. O térreo parcialmente ocupado por pilotis é uma contribuição original do arquiteto no cenário do IAPI. Fonte: Acervo Pioneiros. 


\subsection{As diversas referências dos CIAM's}

Outro aspecto bastante significativo no conjunto dessa produção é o amplo emprego de filas de blocos médios de habitação descolados do alinhamento das ruas e com amplas áreas verdes entre eles.

Embora essa solução tenha sido condenada por Le Corbusier e Gropius nos CIAM's, como econômica e socialmente inviável, ela foi amplamente utilizada como solução habitacional no período entre guerras na Europa, o mesmo acontecendo no Brasil no período de 1946-1955. A paisagem de uma sequência de blocos laminares, disposto de forma paralela, invariavlemente remete às fotos de divulgação do WeisseStadt, ou aos desenhos de Ludwig Hilberseimer para seu livro "A Arquitetura da Grande Cidade".

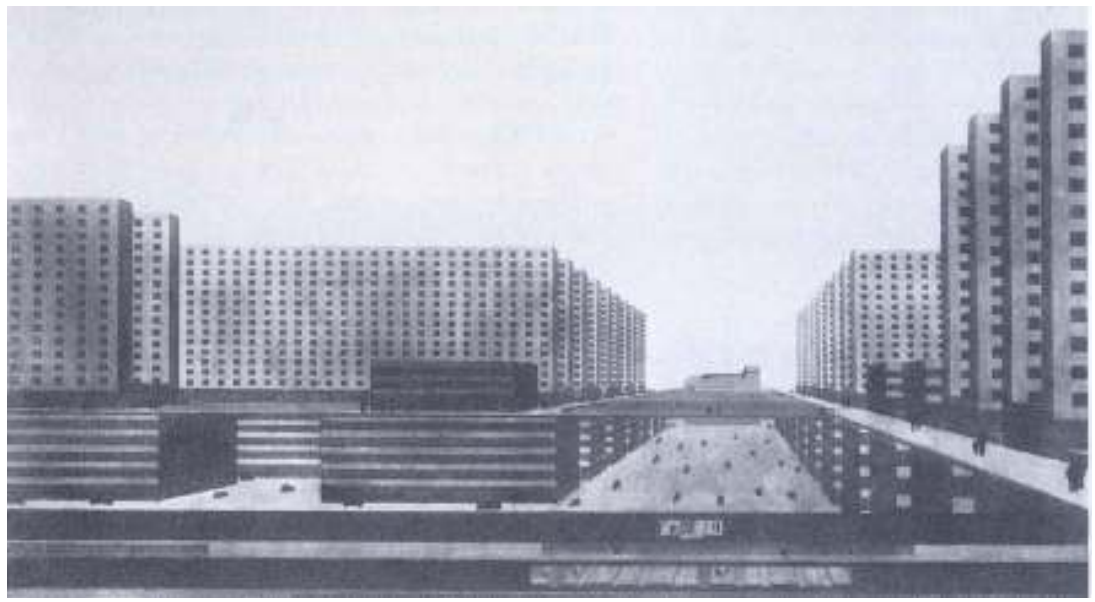

Figura 307. Imagem utilizada pelo arquiteto alemão Ludwig Hilberseimer em seu livro "A Arquitetura da grande cidade" (1927). Fonte: HILBERSEIMER, 1927.

A apropriação brasileira desse arranjo habitacional levou a soluções diversificadas e algumas aparentemente inusitadas no cenário da habitação, como o emprego do térreo parcialmente ocupado por pilotis, no Mooca IAPI; o arranjo dos blocos "H" conformando lâminas, sem paralelo na historiografia internacional de habitação nos anos de 1920 a 1930, ou mesmo a situação impar do conjunto do IPASE em Pelotas.

O bloco laminar agenciado por uma galeria de circulação horizontal e uma caixa de escada, como acontecia nas propostas soviéticas (1925-1930), no Lawn Road inglês (1934) ou no modelo da Unidade de Habitação de Marselha (1946-1952), não foi uma tipologia difundida na produção dos IAP's. Este 
repertório fez parte principalmente das primeiras experiências brasileiras, momento em que o nível de experimentação arquitetônica, urbanística e de produção eram maiores, assim como a oportunidade destes arquitetos para, a partir dos modelos internacionais, elaborarem novas soluções urbanísticas e arquitetônicas.

\section{DEL CASTILHO}

IAPC 1950

Rio de Janeiro, RJ.

1077 unidades

Casas e blocos.

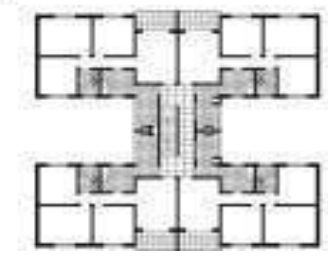

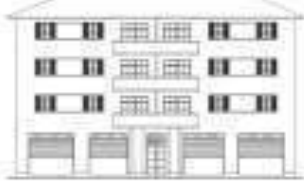

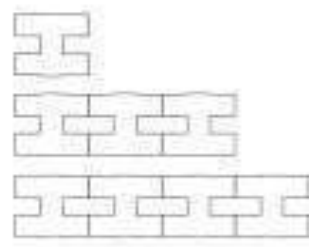

\section{DARCY VARGAS}

LAPETC Década de 1950. Rio de Janeiro, $R$. 342 unidades. Blocos.
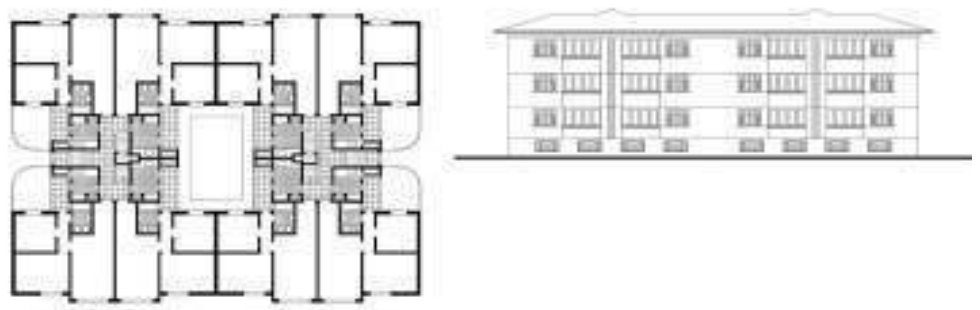

1950 CR CACHAMBI

IAPC Década de 1950.

Rio de Janeiro, RJ. 1054 unidades Blocos.
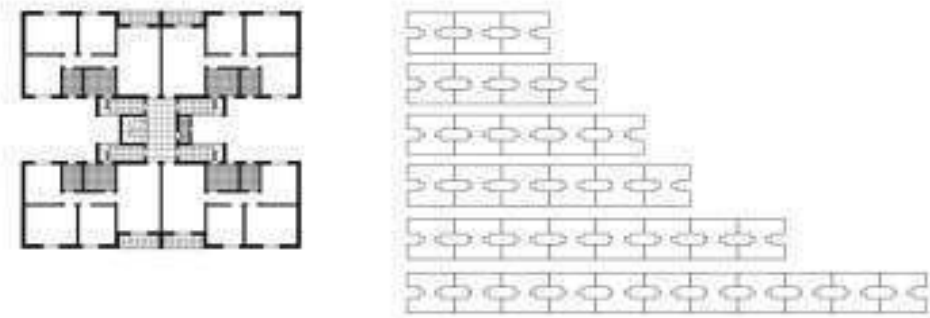

1953 JORGE RUDGE

(API 1953

Rio de Janeiro, R.J.

96 unidades.

Blocos.
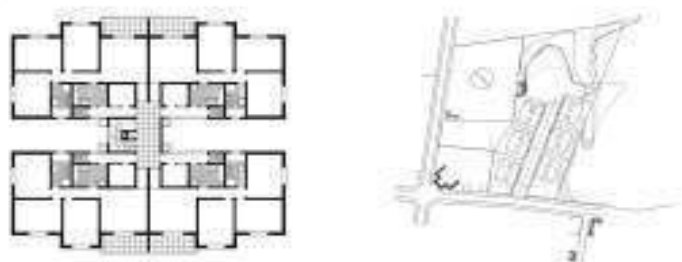

Figura 308. Exemplos de conjuntos com diversos agenciamentos do bloco "H". Fonte: BONDUKI, N. G., KOURY, A. P.; MANOEL, S.K. (2003)

O primeiro bloco de caráter modernista no Brasil foi proposto para Conjunto Residencial Operário em Realengo, como um experimento para 
propostas futuras, como ocorreu no próprio empreendimento, segundo o arquiteto Carlos Frederico Ferreira, autor do projeto (BONDUKI, 1998).

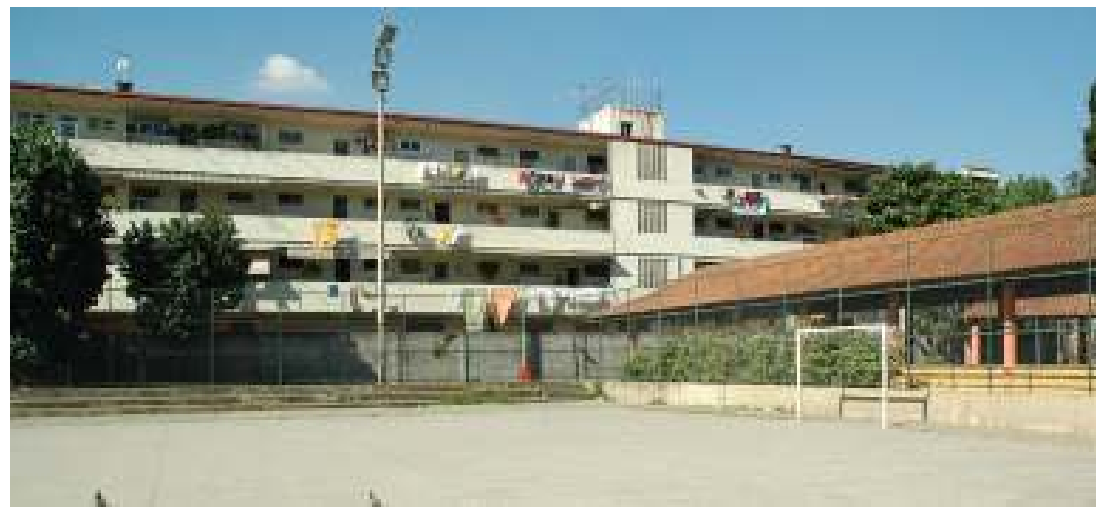

Figura 309. Foto do edifício de habitações coletivas com a fachada composta pelas varandas de acesso aos apartamentos. Fonte: Acervo Pioneiros.

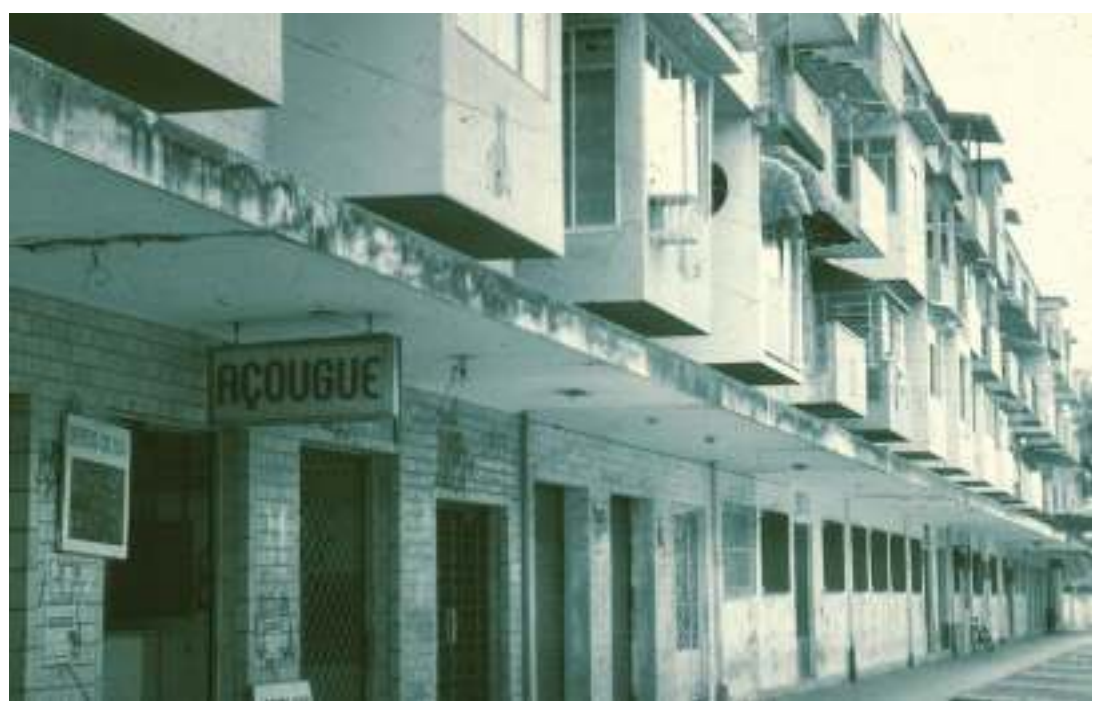

Figura 310. Foto do edifício de habitações coletivas com a fachada dos pequenos balcões, tirada nos anos 1990. Fonte: Acervo Pioneiros.

Primeiro empreendimento habitacional de grandes dimensões construído no país e medalha de ouro no IV Congresso Pan-Americano de Arquitetos (1940), o Conjunto Residencial Operário em Realengo, com 2.344 unidades, foi idealizado e construído entre 1938 e 1943, como marco fundador das atividades do Instituto de Aposentadoria e Pensões dos Industriários - IAPI - na área da habitação. 


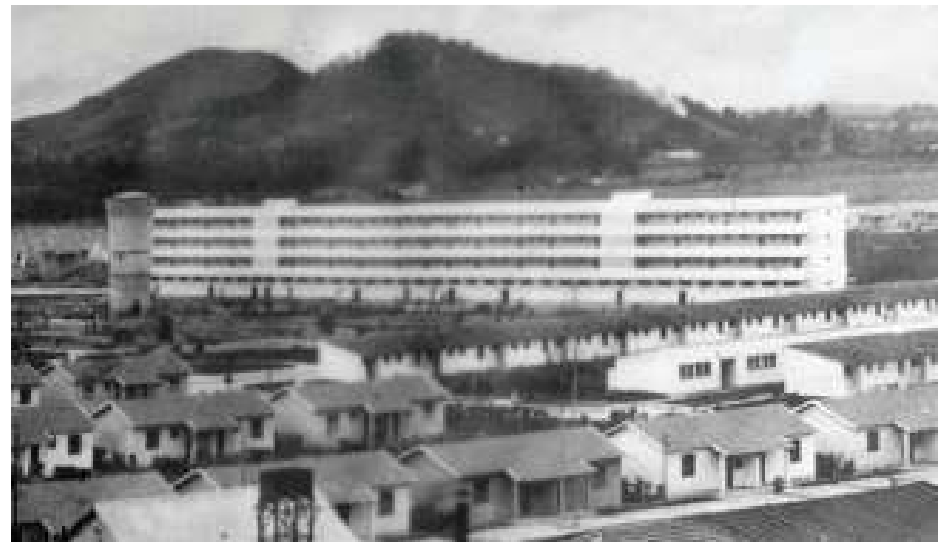

Figura 311. Foto de época do conjunto Realengo, anos de 1940. Fonte: Acervo Pioneiros.

Projetado pelo arquiteto chefe do Setor de Arquitetura e Desenho do IAPI, o conjunto localiza-se junto à estação de trem de Realengo, subúrbio do Rio de Janeiro. Vasto campo de experimentação projetual, sua concepção estabeleceu uma linhagem de tipos - unidades unifamiliares e blocos de apartamentos - que pudessem ser utilizados, conforme as necessidades, em distintas localidades. A preocupação com a inovação tecnológica, seriação e barateamento do produto final manifesta-se de forma inédita nesse empreendimento vultoso do IAPI, um projeto racional que visava à qualidade, economia e produção seriada, aproximando-se no plano teórico dos preceitos do II e III CIAM's, mas mantinha um ar pitoresco pelo telhados das unidades e áreas verdes.

O empreendimento colocou em prática a concepção definida pelo governo Vargas para a construção de núcleos habitacionais para os trabalhadores, com infraestrutura completa (redes de água, luz e esgoto, galerias de águas pluviais, pavimentação e estação de tratamento de esgoto) e vários serviços de caráter coletivo, efetivamente implantados, como áreas comerciais, escola primária para 1.500 alunos, creche para cem crianças, ambulatório médico, gabinete dentário, quadras para a prática de esportes, templo católico e horto florestal, concretizando a proposta de uma unidade de vizinhança onde o trabalhador pudesse encontrar tudo aquilo de que necessitasse além do trabalho. 


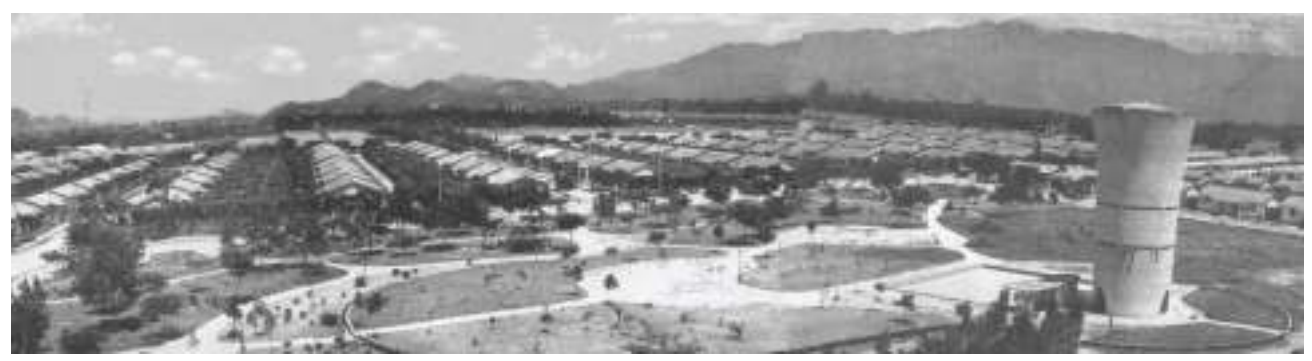

Figura 312. Foto de época do conjunto Realengo, anos de 1940.Fonte: Acervo Pioneiros.

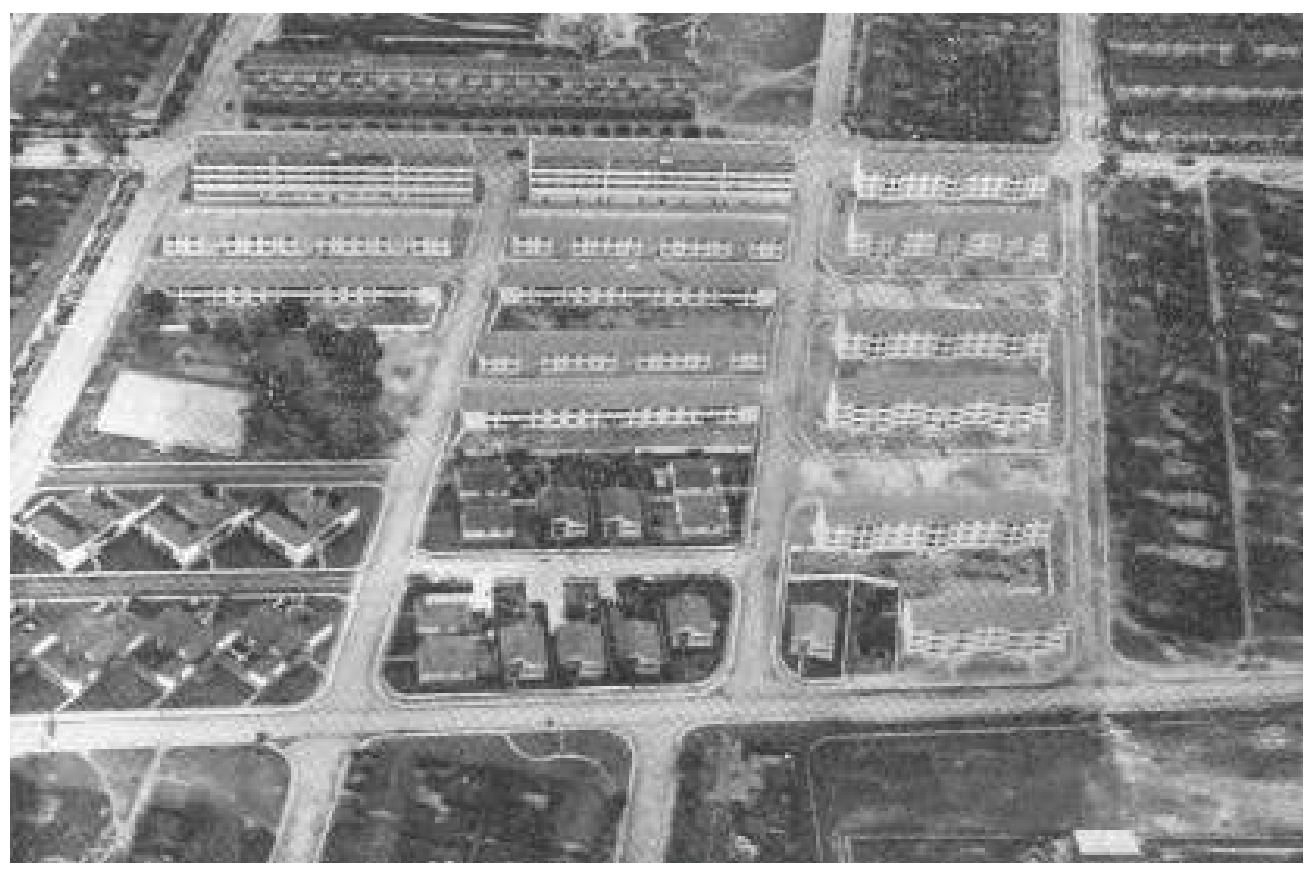

Figura 313. Foto de época do conjunto Realengo, final dos anos 1940. Fonte: Acervo Pioneiros.

Embora o conjunto tenha sido implantado sobre um arruamento preexistente, o parcelamento foi substituído por uma configuração mais moderna, eliminando parcialmente a divisão em lotes. Os edifícios foram implantados no espaço público e as casas geminadas, embora unifamiliares, não foram cercadas, possibilitando uma continuidade entre o quintal e o espaço público. Com a venda das unidades aos moradores, após a extinção do IAPI em 1964 , os lotes foram cercados, fato esse bastante comum entre os empreendimentos dos Institutos.

Modernizar o processo construtivo, objetivando a produção massiva e a economia, foi uma das intenções do projeto. Nele foi utilizada, pela primeira vez no Brasil, uma máquina para fabricar blocos de concreto. A alvenaria de blocos de concreto permitiu a aplicação da pintura sem reboco, com grande economia. 
Outra inovação foram os painéis pré-fabricados de madeira nas paredes internas, o que dispensava fundações e tornava as divisões da habitação mais flexíveis. Esses painéis apresentaram grande durabilidade e até hoje existem exemplares originais em perfeito estado.

Outro destaque é o bloco principal com sua fachada frontal formada por balcões intercalados, criando um rico jogo de volumes, fortemente influenciado pelo edifício para residência estudantil da Bauhaus, em Dessau, de Walter Gropius (1926). Galerias lineares no fundo do edifício possibilitam o acesso aos sessenta apartamentos, células habitacionais mínimas de 37,5 metros quadrados, incluindo quarto, sala, cozinha e banheiro. No térreo, foram instaladas áreas comerciais e de serviços do IAPI, criando uma forte referência urbana, reforçada pela implantação, numa segunda etapa, de outro prédio paralelo no lado oposto da avenida. As galerias externas de circulação em blocos médios como elemento escultórico da fachada, assim como a utilização de balcões pequenos e mais leves projetados para além do plano da fachada com a mesma finalidade, pode ser observada em outros exemplos importantes da historia da arquitetura moderna, como no caso de bloco de apartamentos na Lawn Road, em Londres (1930).
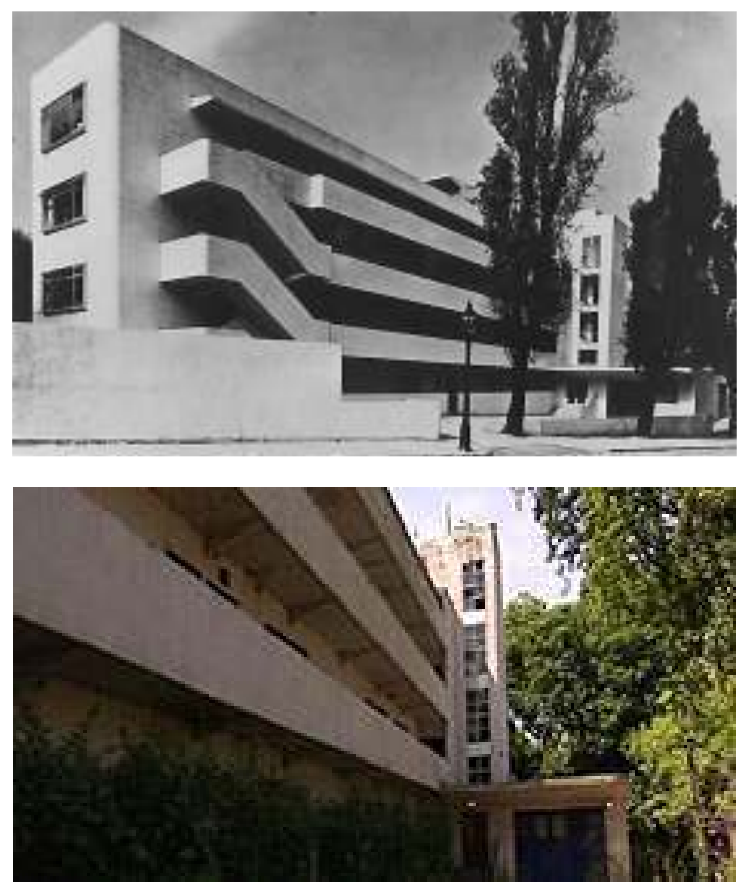

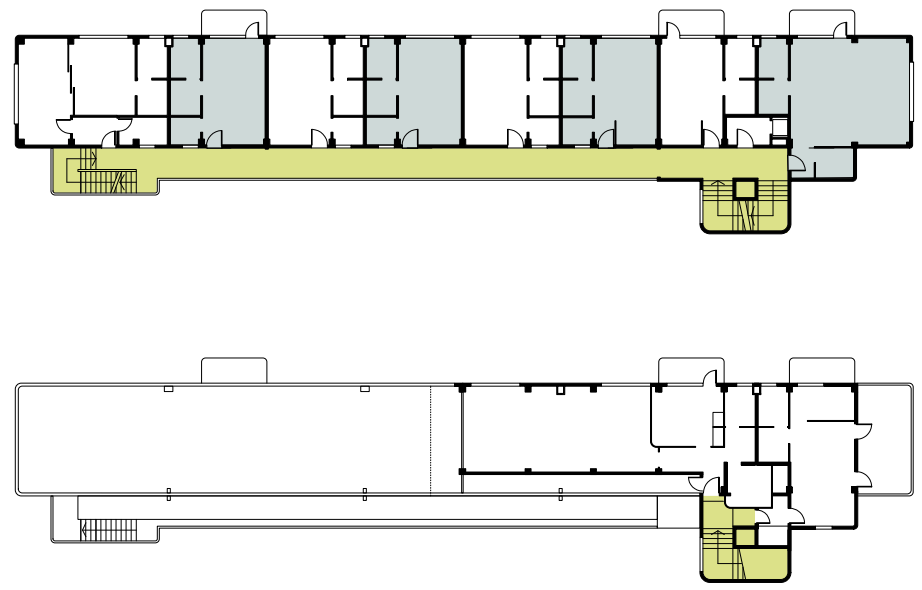

Figuras 314-17. Edifício Lawn Road (hoje Isokon), em Londres (1934). O projeto do arquiteto WellCarters, membro do MARS - que se dedicava a promoção da arquitetura moderna na Inglaterra. O edifício conta com quitinetes e apartamentos de 01 quarto; conta com serviço de lavanderia e cozinha. Foi Publicado no livro The Modern Flat, em 1937.

Fotos. Fonte: http://modernarchitecturelondon.com/pages/kensal-house.php Plantas baixas. Fonte: FRENCH, 2009, CD-ROM.

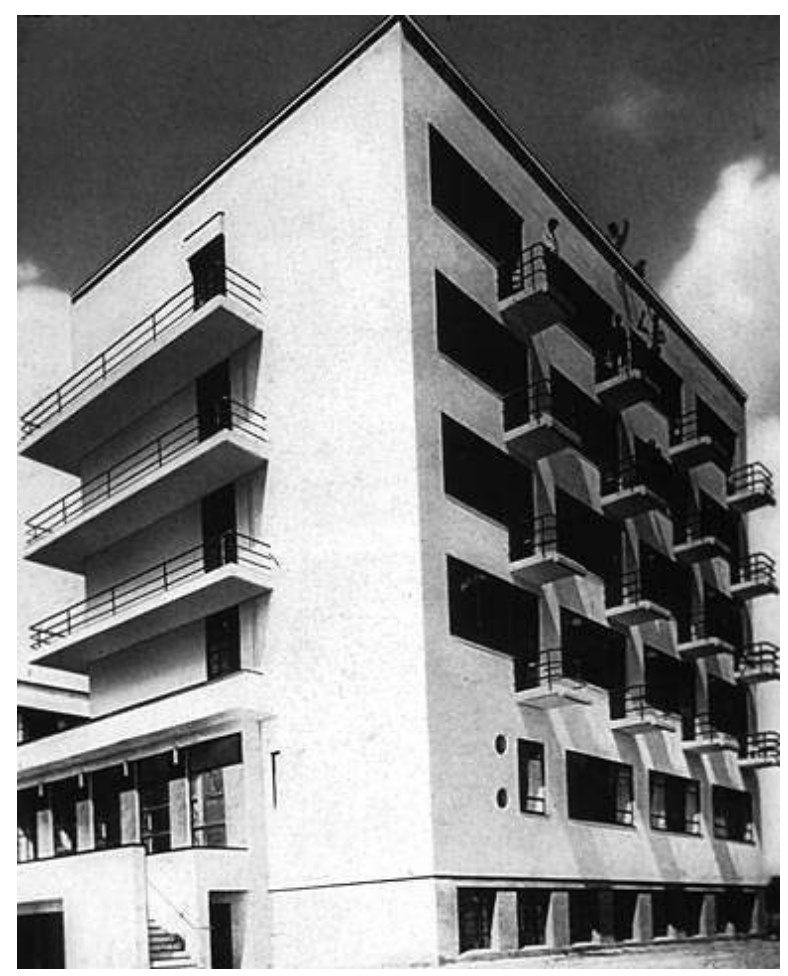

Figura 318. Walter Gropius, Bauhaus, 1926, Dessau, Alemanha.

Uma das tipologias projetadas para a produção em série (Bloco 03), tratase de um volume coberto por duas águas que dialoga diretamente com as casas 
geminadas duas a duas. As varandas e a caixa de escadas, que articula duas unidades, avançam para além dos telhados e do volume do edifício, configurando uma saliência translúcida, vedada apenas por cobogós.

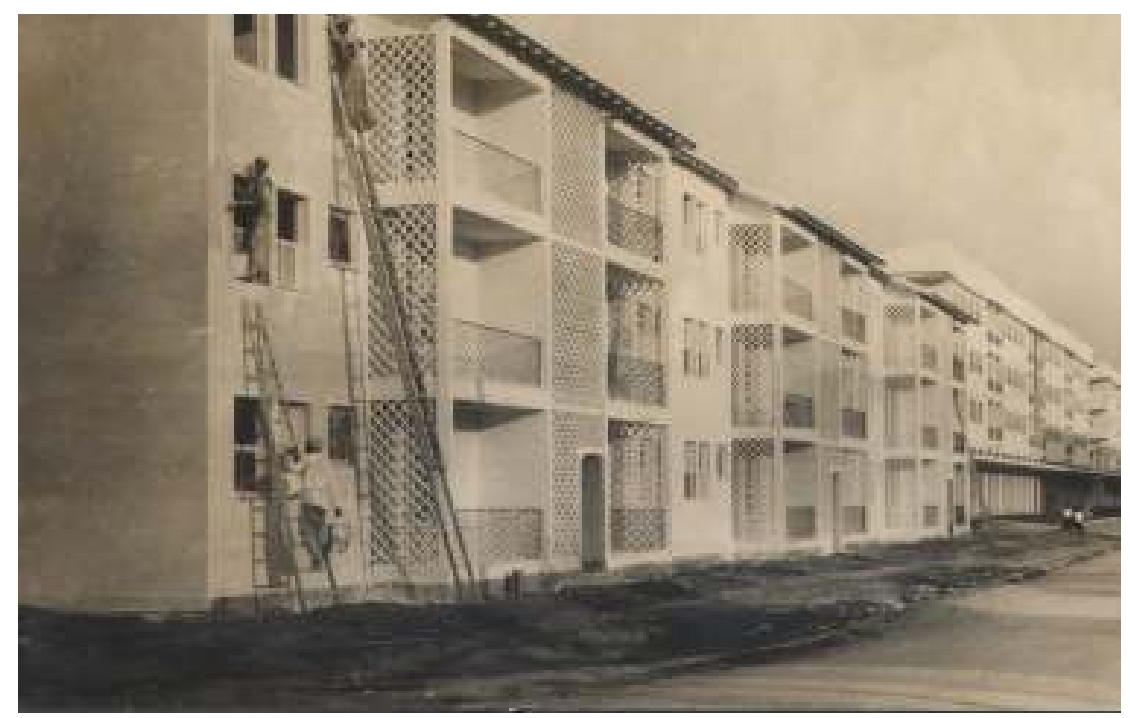

Figura 319. Bloco residencial de três pavimentos. Fotos da época da construção. Fonte: Acervo Pioneiros.

Os sobrados em fileira diferenciam-se das soluções tradicionais. Organizados em grupos de oito a doze unidades, têm térreo livre, onde se situa apenas a área de serviço. Uma escada dá acesso ao piso superior, onde se localizam as demais dependências: sala, cozinha, banheiro e dois quartos. Esse tipo era considerado pelo arquiteto como um modelo vantajoso, pois, segundo ele, "apresentava as mesmas qualidades de construções em pilotis", em razão dos espaços livres do térreo.

A grande maioria das unidades, no entanto, é constituída por casas geminadas duas a duas que, salvo o inovador processo construtivo de blocos de concreto, são tradicionais quanto ao agenciamento espacial. 


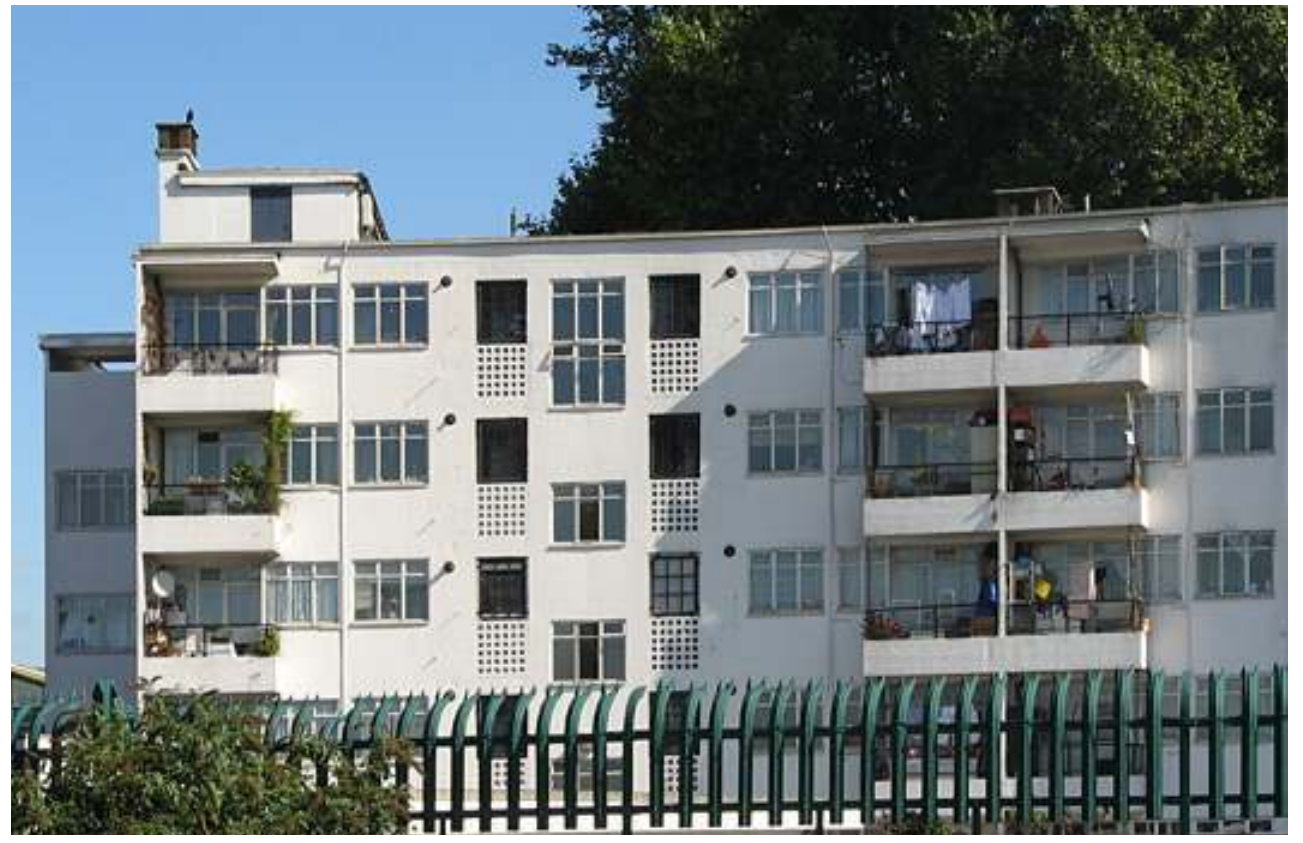

Figura 320. O uso de elementos vazados em habitação social, amplamente utilizado no Brasil, pode ser visto de forma tímida em outras localidades, como no conjunto Kensall House, projeto por Edwin Maxwell Fry e equipe em 1936, e concluído em1938. A área de serviço nesse conjunto destinado a baixa renda é aberta, protegida apenas por um guarda-corpo de elemento vazado. Ao lado de Highpoint One e Lawn Road Flats, esse conjunto fez parte das experiências modernistas no Inglaterra à partir de 1930. Fonte:

O uso massivo de blocos laminares agenciados de forma radicalmente racinalista e funcionalista apareceram primeiramente na proposta de Attílio Correia Lima para a Várzea do Carmo. A proposta desse conjunto como um todo é bastante avançada, principalmente ser elaborada no âmbito de um órgão previdência social, com todas as implicações que isso tinha na produção habitacional de baixa renda: numa gleba de custo elevado, propunha habitação para operários de baixo salário. A intervenção era um grande desafio projetual e urbano, pois o IAPI buscava garantir uma remuneração adequada para os investimentos realizados com os fundos previdenciários: "A renda a se obter com a locação das habitações dos conjuntos residenciais, em que se procura realizar a finalidade de habitação sadia, higiênica e confortável, dentro das possibilidades dos salários, implica, simultaneamente, a contingência de obtenção de um mínimo de porcentagem sobre o capital aplicado, sem o qual não é possível ao Instituto o pagamento dos benefícios" (Lima, 1942). A equipe envolvida nesse projeto colocou a questão da viabilidade econômica do empreendimento em primeiro plano: "o alto valorado terreno adquirido pelo IAPI 
em 1938, junto à Avenida do Estado, entre 05 e 15 minutos, de bonde, do Largo da Sé", obviamente tinha "pesado sobremaneira nas diretrizes básicas do plano a empreender". Só adensamento populacional tornaria o empreendimento vantajoso.

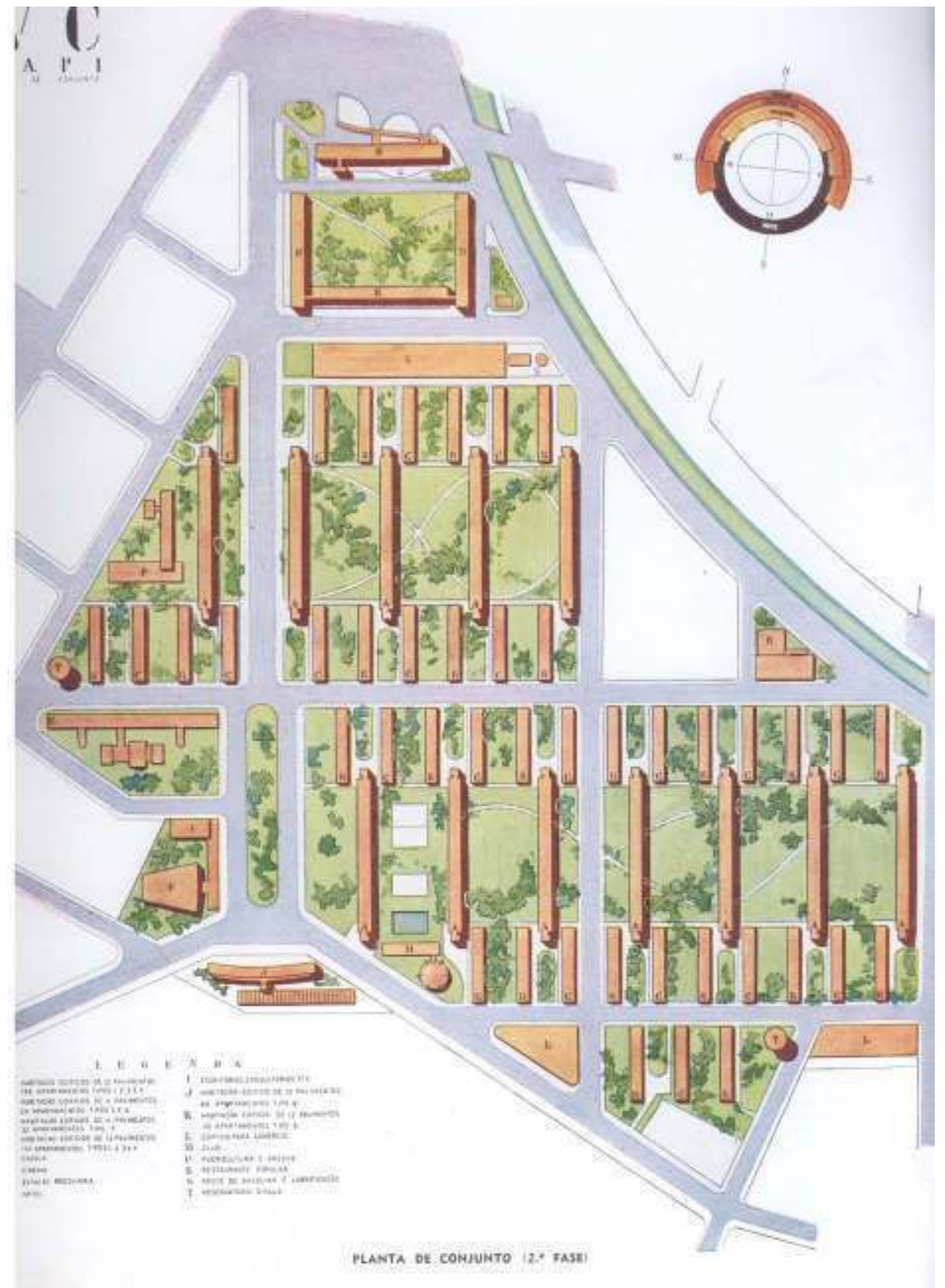

Figura 320. Implantação completa do conjunto. Fonte: LIMA, 1943. 

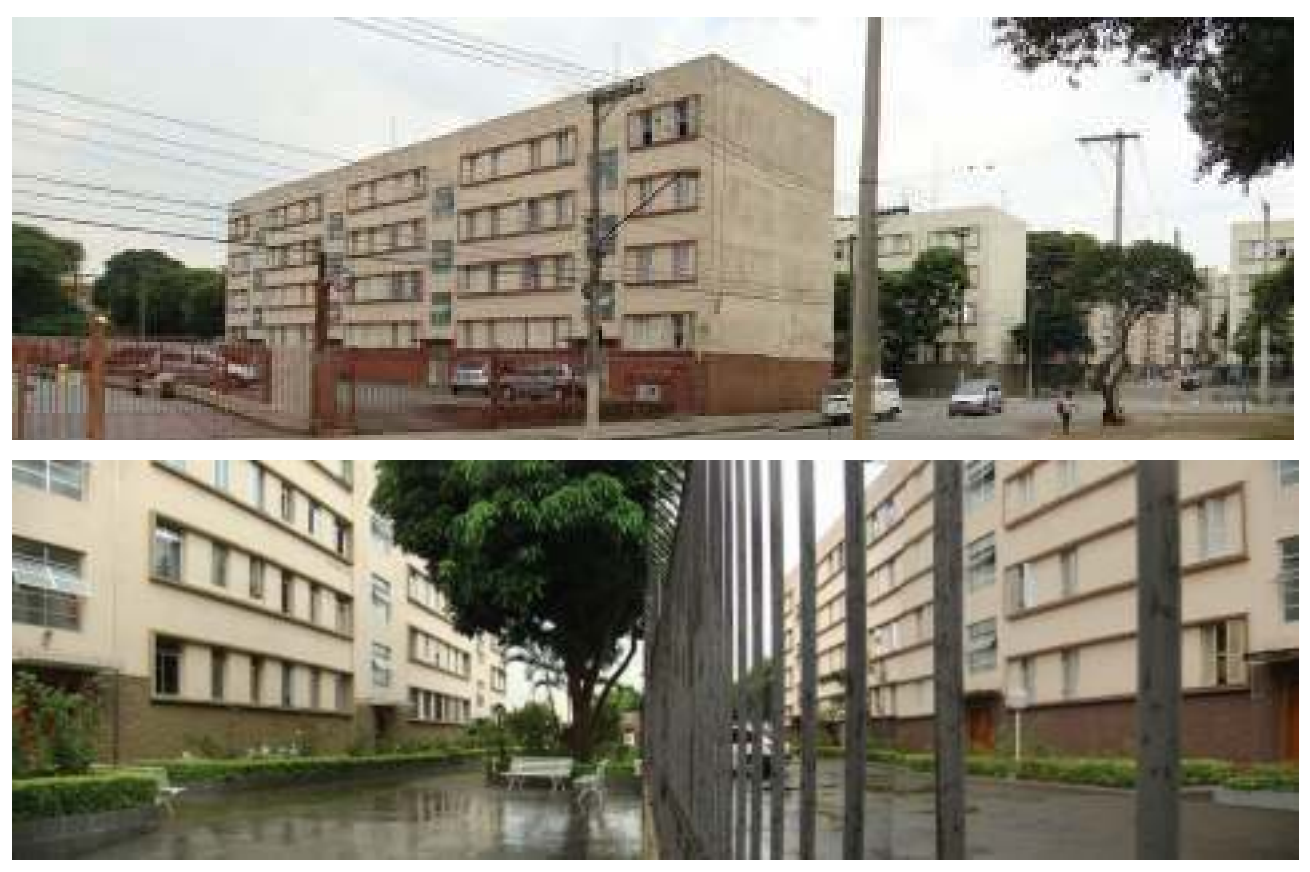

Figuras 321-22. Várzea do Carmo. Vista atual do conjunto. Fonte: Acervo Pioneiros.

O programa do empreendimento tirou partido da localização e propôs espaços lucrativos, como uma estação rodoviária, proposta visionária a para época, acoplada a um hotel, que criaria um elemento de modernização e centralidade numa região ainda pouco valorizada. A proposta rompia os limites de um programa 'clássico' do conjunto residencial moderno "que previa equipamentos sociais ligados ao morar, mas não edifícios voltados ao trabalho, tornando a proposta única para a época".

O plano foi estruturado com base em alguns elementos urbanísticos principais: reestruturação viária com a criação de superquadras; organização racional do setor residencial, numa trama que combina edifícios altos e médios; criação de uma centralidade urbana, formada por uma praça fechada por quatro edifícios, junto à estação rodoviária; organização de um centro de caráter local, agrupando os equipamentos sociais no setor sudoeste, nas sobras de formato irregular da gleba.

A orientação longitudinal norte-sul de todos os blocos foi estipulada por um detalhado estudo das condições climáticas de São Paulo. O artigo publicado na Revista Municipal de Engenharia, da Prefeitura do Distrito Federal, o memorial de justificativa do projeto, apresentava o levantamento mensal da temperatura, insolação, chuvas, vento e nebulosidade em um período de 20 a 35 anos, segundo os pontos cardeais, analisando as vantagens e desvantagens de 
cada orientação da fachada, para demonstrar que cada decisão foi resultado de um apurado rigor técnico.

A solução integral do plano previa 43 blocos e 16edifícios-lâmina (incluindo quatro de padrão mais elevado), totalizando 4.038 unidades para 22 mil moradores, com uma densidade bruta de 1.250 habitantes por hectare, "sem um impacto significativo no custo final e sem a ocupação massiva do terreno", pois a taxa de ocupação ficaria em 18,5\% (Lima, 1942). Na primeira etapa, enquanto não pudesse ser implantada parte da superquadra prevista para o terreno da indústria, o conjunto teria 2.880 unidade sem 37 blocos e 12 edifícios.

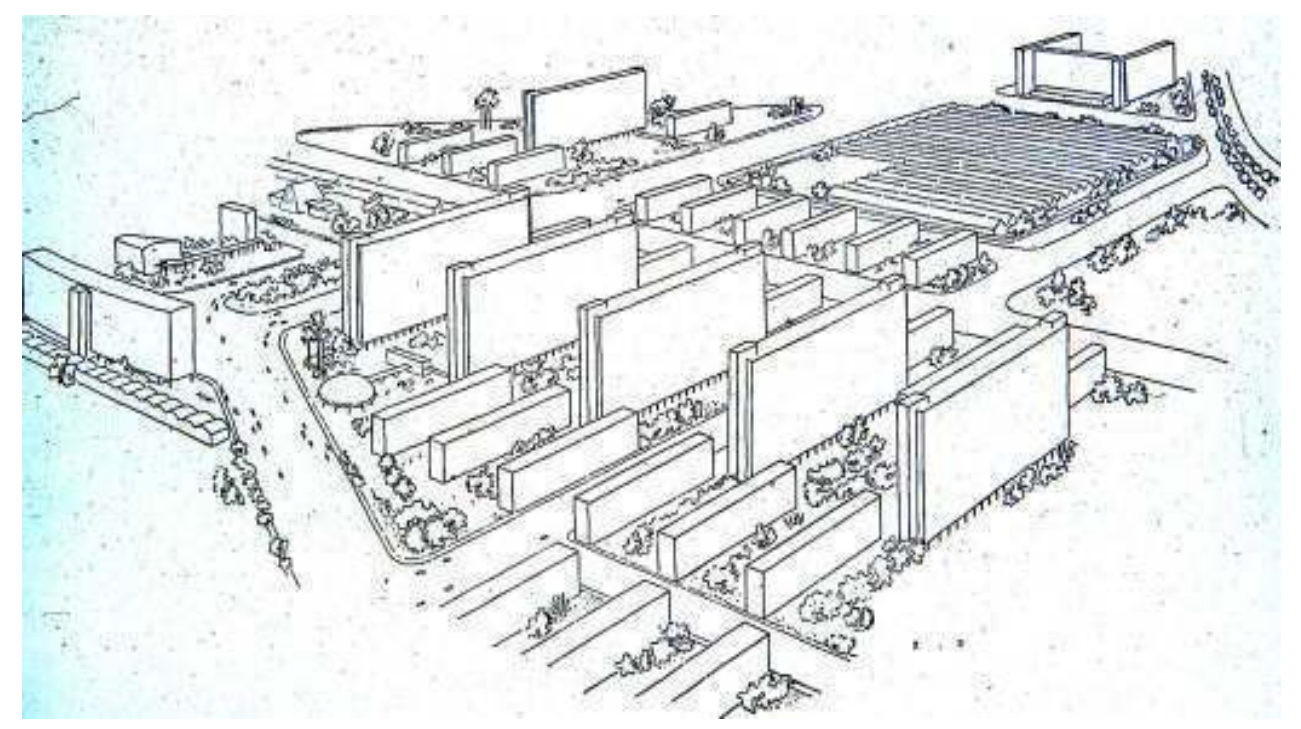

Figura 323. Várzea do Carmo. Perspectiva geral do conjunto. Fonte: LIMA, 1942.

O enfrentamento do alto custo de elevadores e de sua manutenção nos edifícios altos demonstra a familiaridade de Attílio Correia Lima sobre as questões de produção em massa de habitação debatidas no II e III CIAM, os quais discutiram as vantagens e desvantagens do uso de cada tipologia habitacional. A solução encontrada por Attílio e sua equipe, de utilização de galerias horizontais de circulação a cada três pavimentos, conectadas aos elevadores e a escadas que levariam os moradores aos pavimentos não servidos pelos elevadores, mostrava-se eficiente. Embora possamos citar exemplos europeus que trataram da questão dos elevadores e da otimização das circulações horizontais e verticais, que certamente Attílio conhecia, como o artigo apresentado por Herbert Boehm e Eugen Kaufmann no III CIAM, ou 


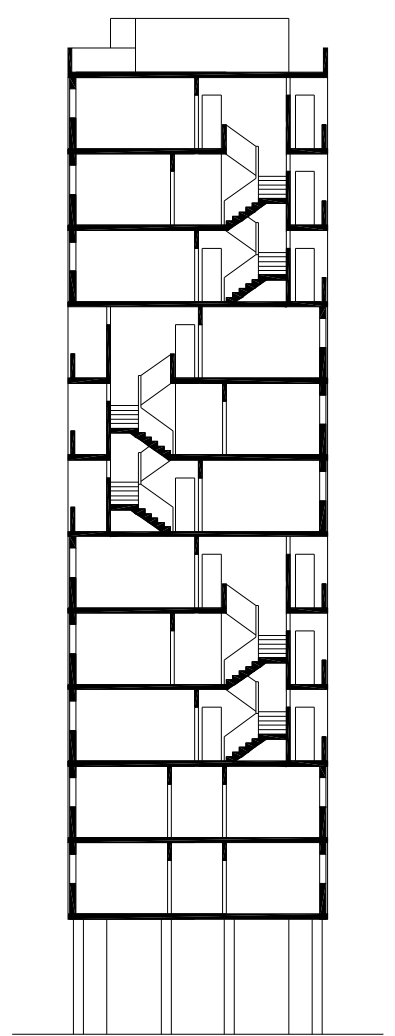

Figura 323. Corte transversal.

Fonte: Acervo Pioneiros. mesmo o famoso artigo de Gropius apresentado no mesmo congresso, a solução da equipe de arquitetos brasileiros foi original e sem precedentes.

Por tratar-se de habitação de baixa renda, todo e qualquer adorno e sofisticação de acabamentos foi eliminada da concepção projetual, conferindo ao conjunto projetado e edificado um caráter austero, abrandado pelas grandes áreas verdes ao redor do conjunto. Para racionalizar a construção e baratear a obra, os autores previram o uso de estrutura de concreto e lajes planas, além de esquadrias padronizadas.

Os blocos de 04 pavimentos, os únicos construídos do projeto, tinham a caixa de escada marcada apenas por uma pequena marquise e uma sequência de esquadrias diferentes na fachada. Essa linguagem era muito comum nas soluções alemãs de blocos médios ou nas casas em fita de Ernst May.

Além de conjuntos memoráveis, como Realengo, Passo d'Areia, Japurá e Várzea do Carmo, o Instituto dos Industriários construiu uma série de conjuntos residências no interior do Estado de São Paulo, como Campinas, Jundiaí, Taubaté e São José dos Campos, utilizando uma tipologia de sobrados em fileiras, com diferentes implantações, reproduzidas do livro organizado pelo IAPI, em 1950. Em Sorocaba, embora planejado, o conjunto não chegou a ser construído devido a dificuldades com a desapropriação dos terrenos. 


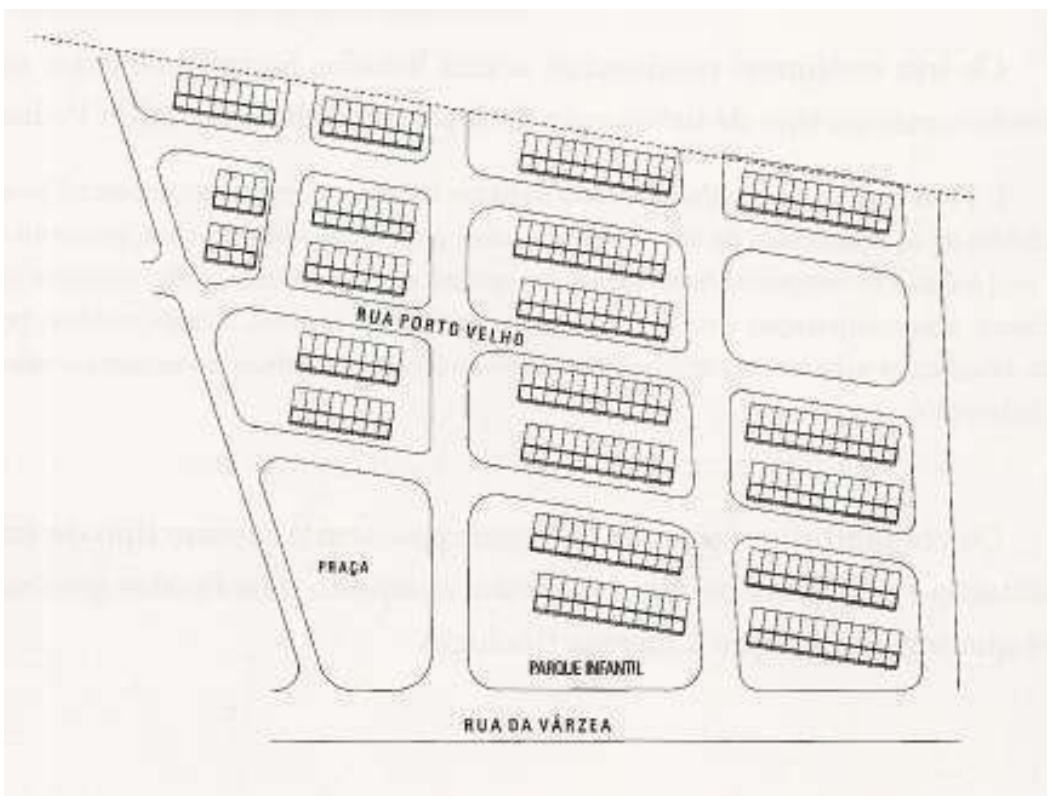

Figura 324. Implantação do conjunto. Fonte: IAPI, 1950.

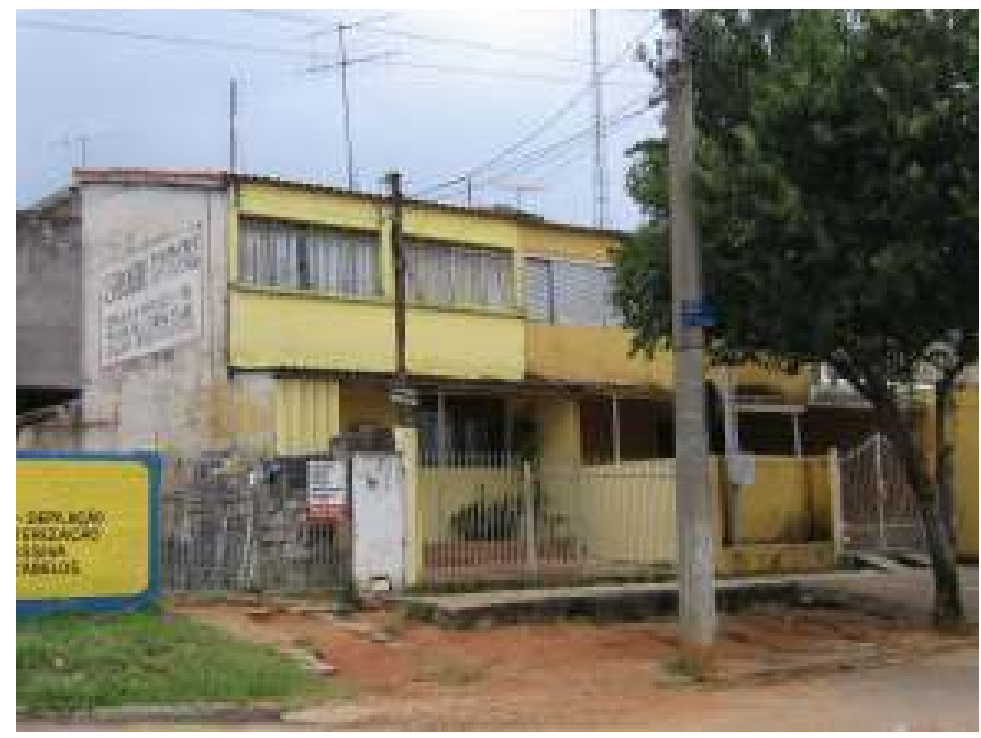

Figura 325. IAPI de Jundiaí - Vila Agapeama (1946-1950). Sobrados com características originais, como as janelas de vidro ocupando a fachada toda do segundo pavimento, a varanda na entrada e a porta protegida por elemento vazado de concreto de dois tipos, em réguas ou circulares. Foto da autora (2005). 


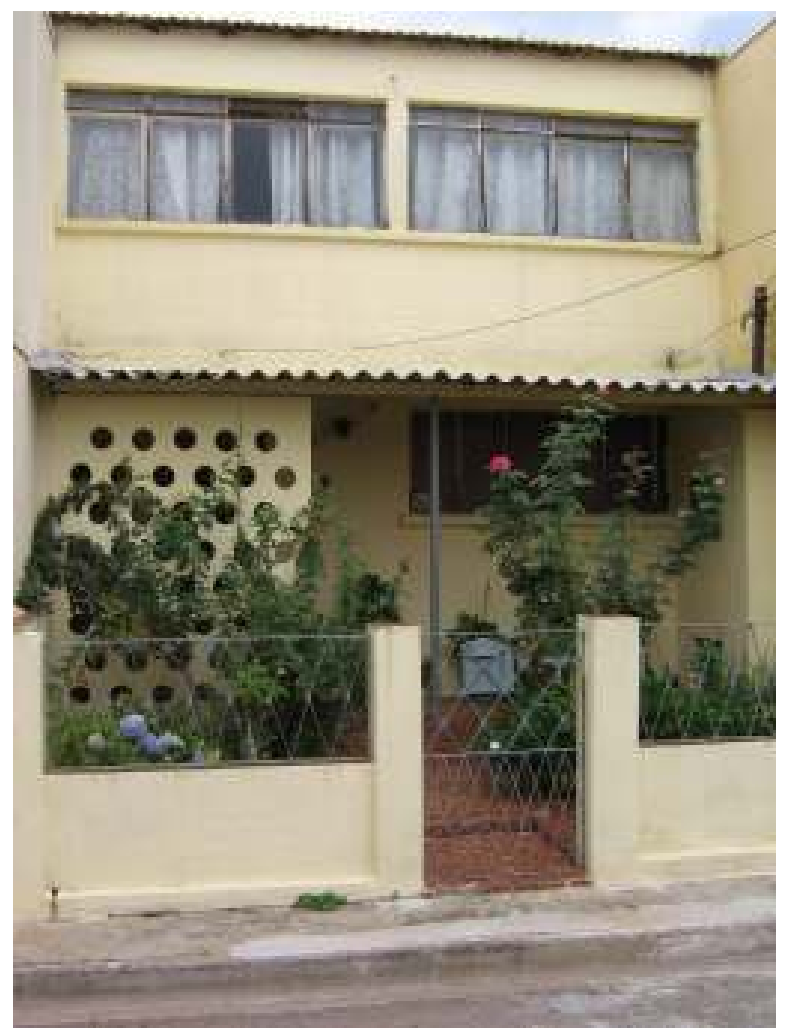

Figura 326. IAPI de Jundiaí - Vila Agapeama (1946-1950). Foto da autora (2005).

Visivelmente influenciados pelas Siedlungen alemães de Frankfurt e no Conjunto Kiefhoek, de J.P. Oud, - a equipe do IAPI, que tinha a presença do engenheiro calculista Joaquim de Almeida Santos, projetou fileiras de sobrados como blocos soltos em meio à área verde, em áreas de diferentes formatos, descoladas da trama urbana. Embora os lotes sejam bem delimitados e as moradias unifamiliares, com uma varanda na frente e um quintal-pátio no fundo, o conjunto não foi proposto como um loteamento tradicional, pois deixava entre os renques de lotes uma grande quantidade de espaços públicos. $O$ acesso às moradias era feito através de vielas de pedestres e é clara a intenção do IAPI de reduzir os custos com urbanização pela concentração das unidades segundo o conceito moderno de edificação de moradias dentro de um parque. 


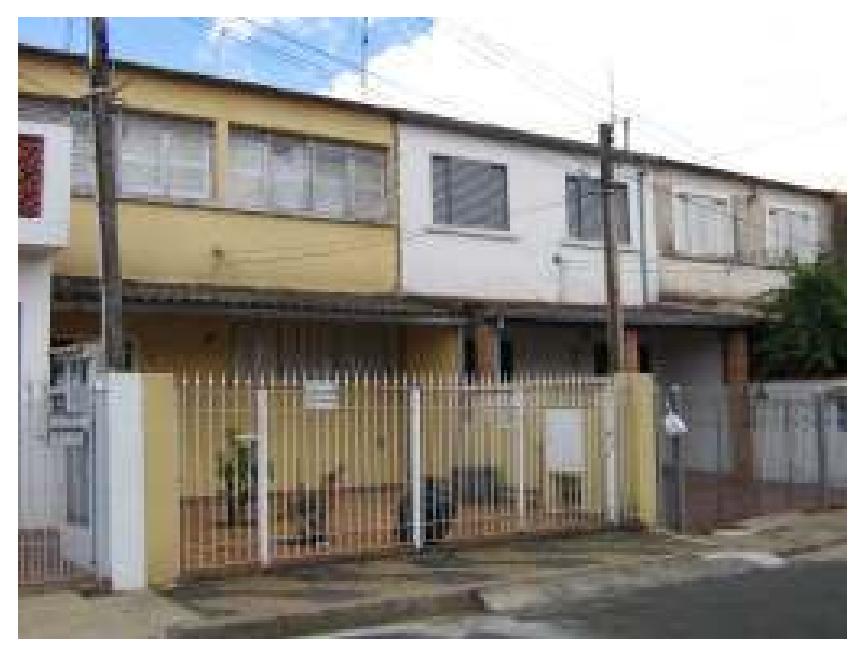

Figura 327. Vila Teixeira, antiga Vila Bonfim. Fotos da autora (2005).

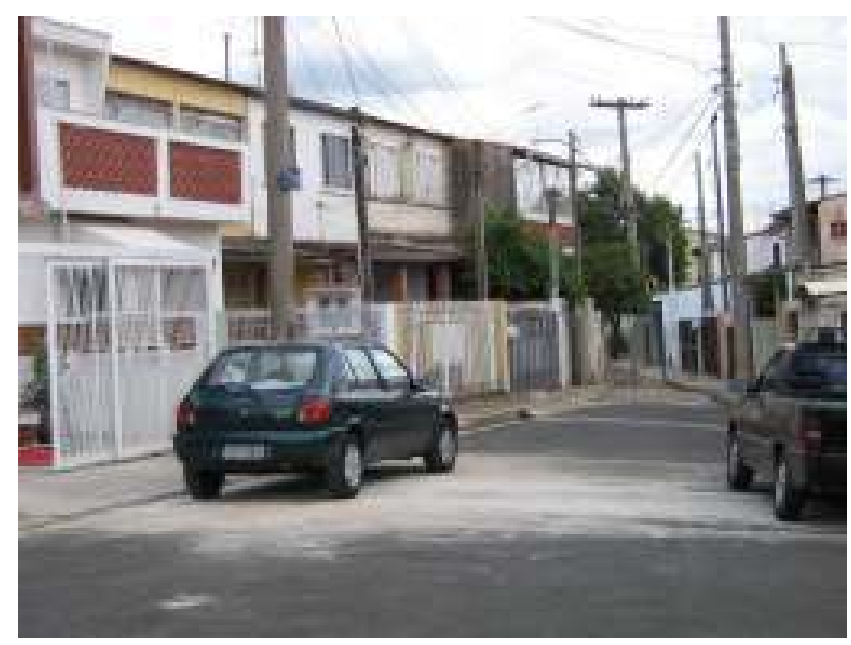

Figura 328. Vila Teixeira. Fotos da autora (2005).

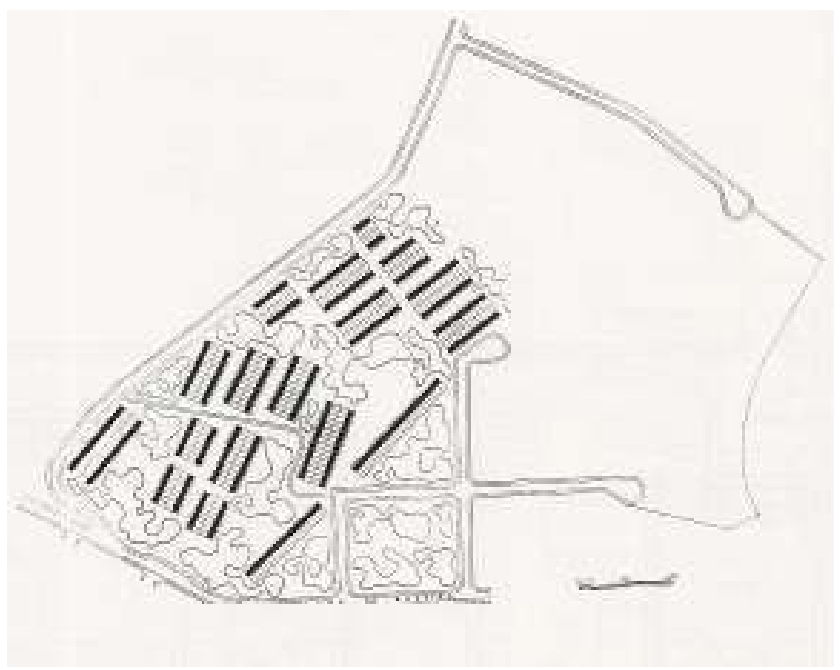

Figura 329. Implantação do conjunto. Fonte: IAPI, 1950. 
De acordo com relato dos primeiros moradores, a Vila Teixeira foi inaugurada em 1953, com água encanada, luz e telefonia, sem pavimentação, mas as casas foram sendo ocupadas ao longo de vários anos. As indústrias da região tinham uma cota de unidades para seus funcionários, mas muitos operários resistiram a morar nas casas, por serem pequenas e geminadas de ambos os lados.

A execução das casas foi concluída, mas, as áreas livres previstas ao redor do conjunto ficaram abandonadas, sem paisagismo, e os passeios de pedestres não foram implantados conforme a proposta. Muitas casas avançaram na área pública do conjunto na frente do lote e, finalmente, em meados dos anos de 1980, nos lugar de passeios de pedestres foram abertas ruas, não previstas no projeto original.

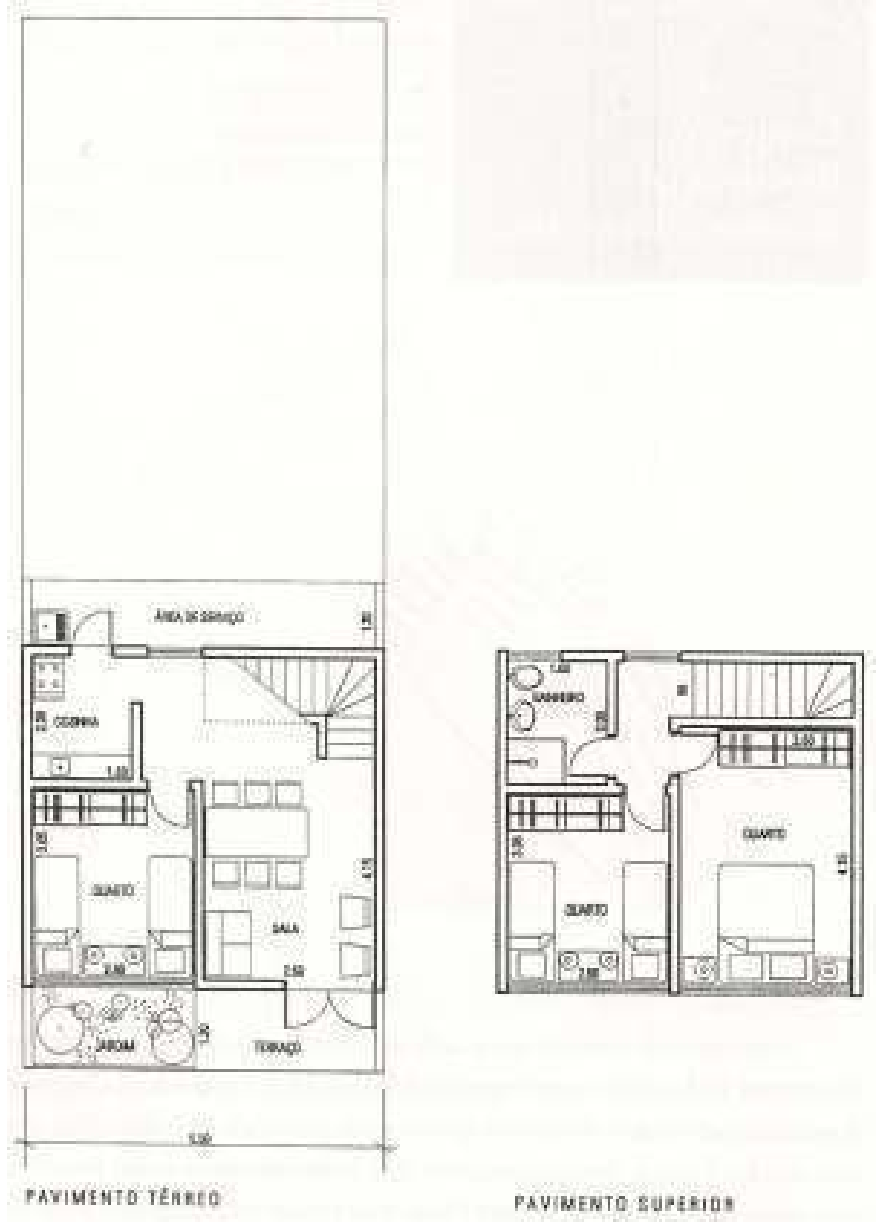

Figura 330. Planta baixa do sobrado tipo. Fonte: BRUNA, 2010, p.215. 
Em Jundiaí, o IAPI a mesma tipologia adotada em Campinas. Os renques de sobrados em fileira são paralelos entre si e perpendiculares à rua, de onde saem as passagens de pedestres que dão acesso às unidades. Ao contrário das vilas convencionais, busca-se superar a tradicional "rua-corredor", contida entre os panos de fachadas, e as casas dão os fundos para frente das outras.

A unidade tem uma pequena varanda frontal, coberta com telha de amianto e projetada como uma transição entre o espaço público e o privado. Elementos vazados em concreto, com aberturas circulares ou brise-soleil verticais, resguardam a entrada e a intimidade da residência. A cozinha tem área bastante reduzida, o terceiro quarto fica no térreo e o banheiro, no segundo pavimento. Com o tempo, muitos moradores suprimiram o quarto no térreo e ampliaram a cozinha, construindo um dormitório nos fundos.

Segundo relatos, as fábricas receberam do IAPI uma cota de casas para distribuir entre seus operários, sendo o critério de seleção o número de filhos. Mas as moradias levaram quatro anos para serem ocupadas porque os associados achavam as casas pequenas e o conjunto muito afastado das fábricas e do centro da cidade. O lugar ficou conhecido como "pulgueiro" ou "pombal".

$\mathrm{Na}$ antiga Vila Magnesita, hoje bairro Madre Gertrudes, em Belo Horizonte, o IAPI implantou uma tipologia habitacional baseada nos sobrados geminados semelhante à utilizada em alguns conjuntos construídos no interior do Estado de São Paulo. O modelo foi repetido, com pequenas variações, em empreendimentos do Instituto em cidades do interior de Minas Gerais, como Diamantina, São João Del Rey, Itabirito e Sete Lagoas.

Os sobrados são organizados em fileiras de seis unidades, solução econômica também utilizada com frequência na produção rentista privada, mas também pelos racionalistas holandeses e alemães. O conjunto foi construído em duas quadras de um loteamento tradicional. Devido ao forte declive, parte das unidades fica abaixo do nível da rua, semienterradas, enquanto que outras ficam acima, requerendo uma escada de acesso. 


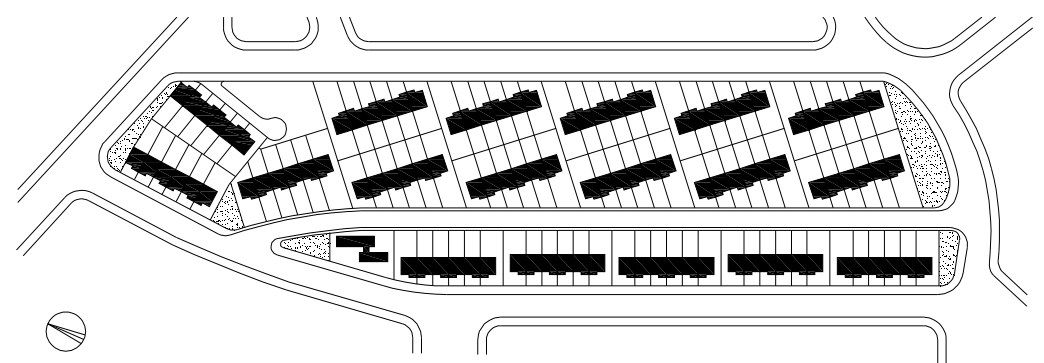

Figura 331. Implantação da Vila Magnezita, Belo Horizonte. Projeto de1947. Fonte: Acervo Pioneiros.

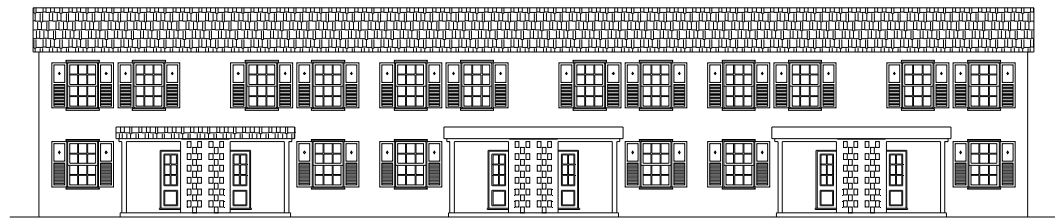

ELEVAÇÃo

Figura 332. Fachada principal. Vila Magnezita, Belo Horizonte. Projeto de1947. Acervo Pioneiros.

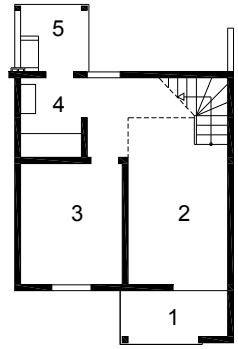

PLANTA TÉRREO

$\begin{array}{lll}0 & 1 & 2\end{array}$

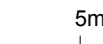

1 VARANDA

2 SALA

3 QUARTO

4 COZINHA

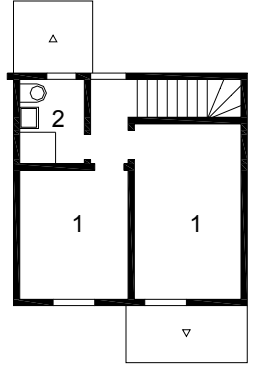

PLANTA PRIMEIRO PAVIMENTO

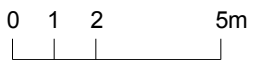

1 QUARTO

2 BANHEIRO

Figura 333. Planta Baixa do térreo e primeiro pavimento. Vila Magnezita, Belo Horizonte. Projeto de1947. Fonte: Acervo Pioneiros. 


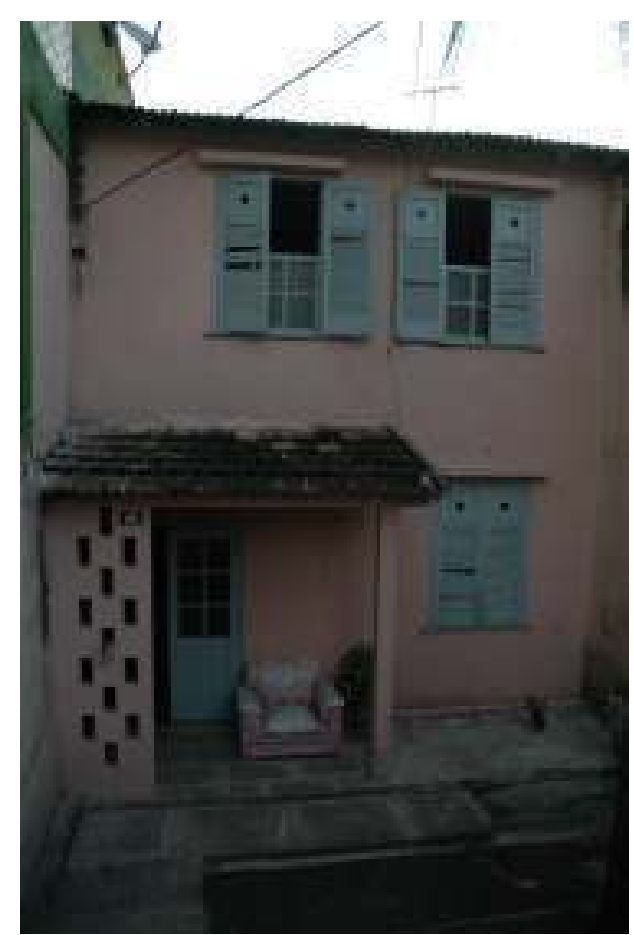

Figura 334. Foto de uma unidade com os materiais originais. Fonte: Acervo Pioneiros.

Cada unidade possui três dormitórios, sendo que o terceiro se localiza no térreo, ao contrário do que ocorre no sobrado geminado convencional, em que a área íntima se localiza no pavimento superior e as áreas sociais e de serviço, no térreo. Essa opção prejudica a cozinha, que fica com uma área de apenas 3,10 metros quadrados, em conformidade com a diretriz funcionalista do IAPI de reduzir ao mínimo esse compartimento tradicional da casa brasileira.

Outra variação da tipologia de casas em fileira pode ser vista no Núcleo Residencial de Santo André, da FCP, que apresenta algumas características distintas da produção geral da Fundação, ao invés de casas isoladas no lote, temos um conjunto de sobrados em fileira divididos em grupos de seis a oito unidades.

Foram projetadas 442 unidades habitacionais pela Fundação numa gleba não urbanizada, ao lado do bairro de Santa Terezinha, nas margens do Córrego Comprido. A construção desse núcleo se iniciou no dia 20 de setembro de 1948, segundo o jornal local "Borda do Campo", de 25 de janeiro de 1949 (data da inauguração do conjunto). 


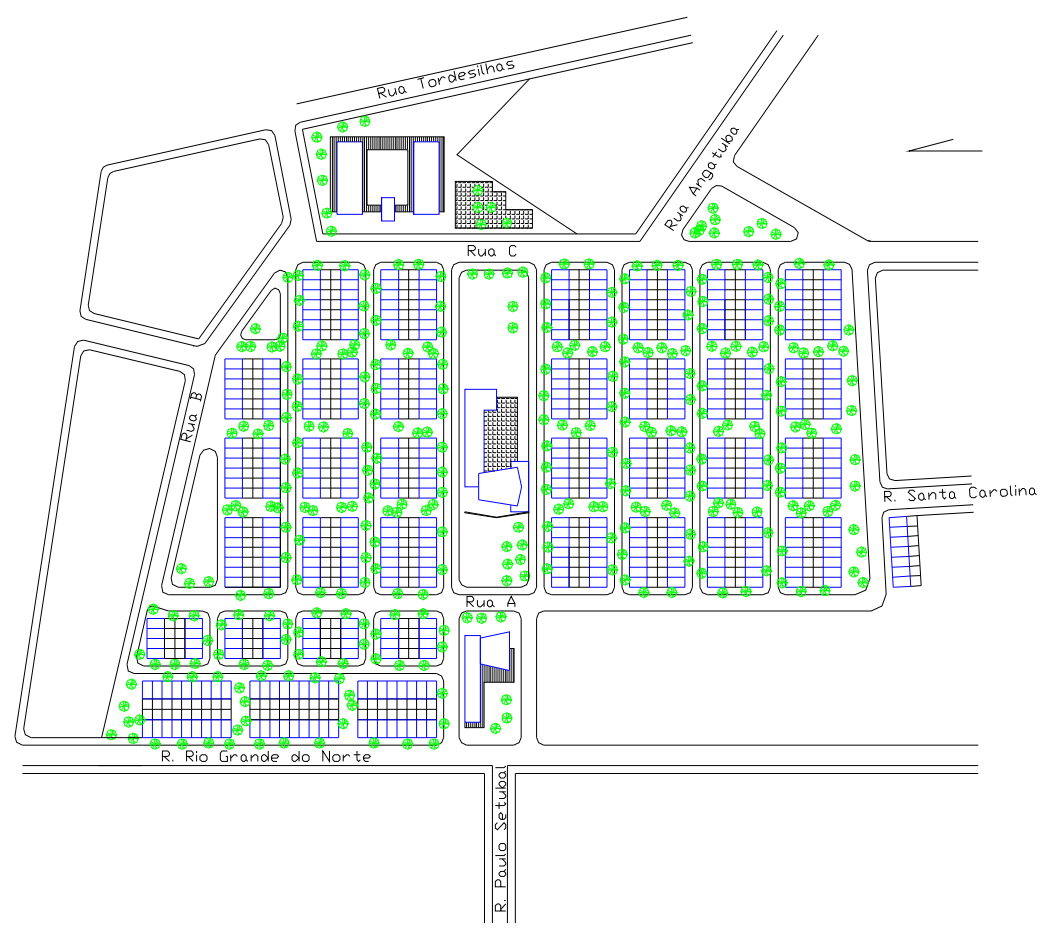

Figura 335. Implantação Núcleo Residencial de Santo André. Fonte: MANOEL, 2004.

Além dos sobrados em fileira, foram projetados alguns equipamentos coletivos: uma cooperativa, um grupo escolar e um centro de atendimento do serviço social, todos localizados na área central do conjunto e implantados ao longo de três praças. Com a divisão geométrica e ortogonal da gleba sobraram algumas franjas do terreno, nos quais foram projetadas pequenas praças.

Os sobrados em fileira estão dispostos de forma ortogonal, paralelos ou perpendiculares à Rua Rio Grande do Norte. A maioria das casas se encontra na orientação Norte-Sul, com a frente voltada para as ruas internas ou principais do conjunto, e os fundos do lote fazendo divisa com o quintal de outro grupo de sobrados em fileira. As ruas internas desse conjunto, com as quais as fachadas dos sobrados estão alinhados, são bastante estreitas, com aproximadamente 3,00 metros de leito, mais 2.9 metros de calçada em frente aos sobrados, que foram implantados no alinhamento do terreno, totalizando 8,80 metros entre as fachadas. Essas cotas do projeto foram alteradas, e as ruas internas foram construídas com aproximadamente 7,00 metros entre as fachadas. No projeto, essas ruas eram bastante arborizadas, assim como as passagens de pedestres. 

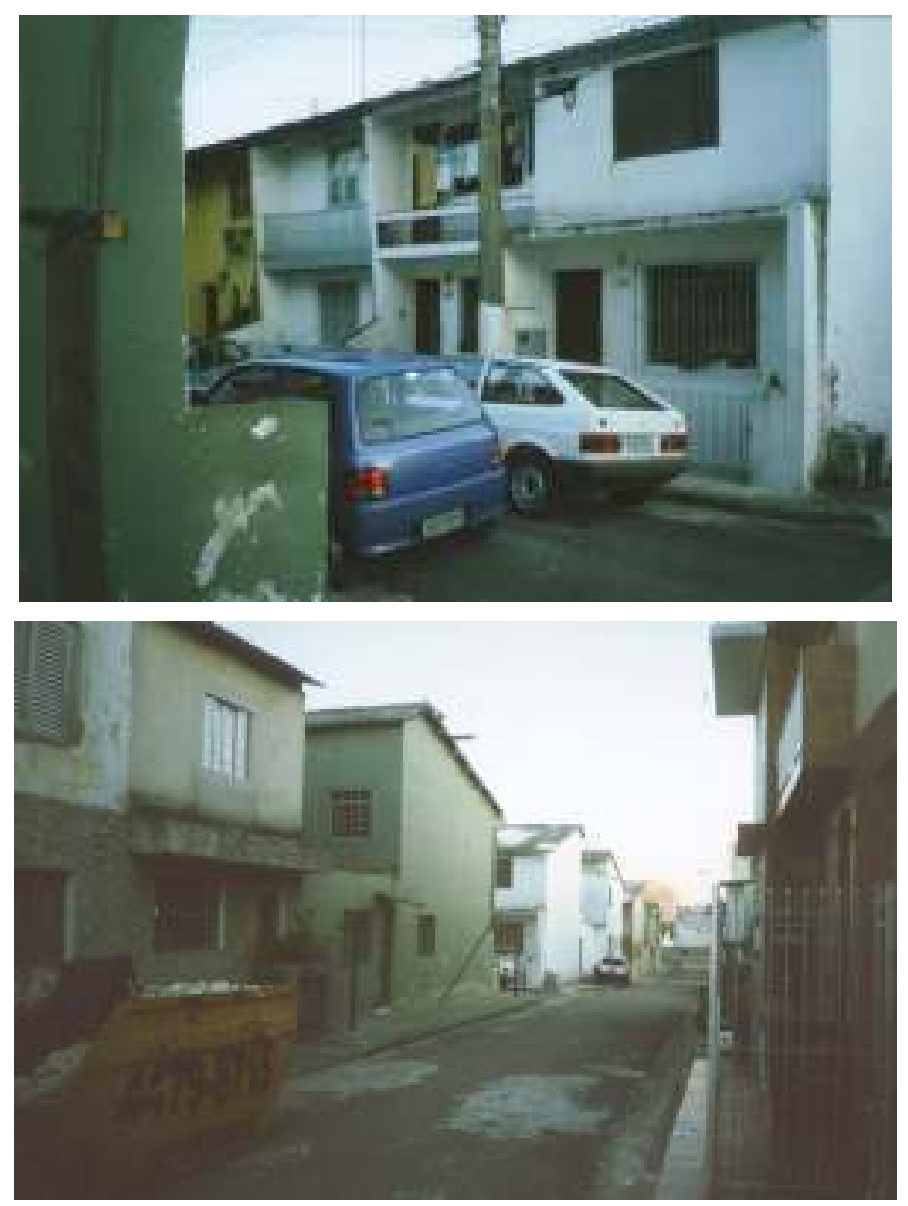

Figuras 336-37. Núcleo Residencial de Santo André. Fonte: MANOEL, 2004.

As unidades habitacionais possuíam $52,00 \mathrm{~m}^{2}$ de área, e o lote $41,77 \mathrm{~m}^{2}$, com $3,85 \mathrm{~m}$ de frente e $10,85 \mathrm{~m}$ de fundo. O lote foi ocupado em quase sua totalidade, com área mínima para quintal e sem área para jardins, coletiva ou individual. As unidades possuíam um banheiro e dois quartos no primeiro andar, sendo um dotado de uma varanda voltada para a rua; e sala, cozinha e um quartinho no térreo; o tanque ficava no quintal, que media $4,00 \mathrm{~m} \times 3,85 \mathrm{~m}$.

Devido à ocupação quase total do lote e a pouca largura das ruas e passagens de pedestres o conjunto tem uma caráter bastante conciso, quase sufocante, intensificado pela aridez da paisagem (os caminhos e canteiros deram lugar a ruas com o passar do tempo). A tentativa de conseguir o melhor aproveitamento da gleba através do estreitamento do espaço público, dos lotes e uso de unidades mínimas, apesar das grandes áreas coletivas centrais, resultou num espaço sem vida e desconfortável para os moradores, que foi bastante 
modificado ao longo do tempo. Contribuiu para essas modificações e apropriações das áreas públicas pelos habitantes o fato delas não terem sido construídas.

Embora existam exemplos felizes de apropriação do repertório moderno de construção de casas e blocos modernistas, a aplicação desses ideais não foi plena no caso brasileiro, especialmente em relação às áreas coletivas, tão importantes quanto as próprias habitações em si no caso europeu pelo seu entendimento como base da construção das cidades. Segundo a pesquisa temática, parece que houve uma maior negligência em relação à essas áreas no casos de conjuntos com unidades unifamiliares, embora a não execução integral dos projetos seja uma constante. No caso do IAPI, talvez essa negligência se explique pela relação do custo da infraestrutura em relação ao número de pessoas beneficiadas, pois os conjuntos eram pequenos se comparados aos blocos, e com uma densidade baixa. 


\subsection{Outros grupos de referências e tipologia especiais}

Além das relações diretas com as propostas dos CIAM's, que se fizeram presentes principalmente na construção de blocos laminares e sobrados em fileira, a produção brasileira tem a característica de ter absorvido outras propostas para a produção habitacional, como os preceitos da cidade-jardim, comumente na forma de subúrbios-jardins ou simplesmente casas em meio a traçado orgânico e bastantes áreas verdes. Embora o IAPC seja o órgão mais associado a esse tipo de produção, a ideia também foi empregada por arquitetos de outros órgãos. Até mesmo a FCP, logo no início da sua atuação fez menção a utilização desses pressupostos por dialogarem com a política que pretendia promover - a da casa isolada; mas não se tem notícia de nenhum conjunto com essas características no seu quadro de produção.

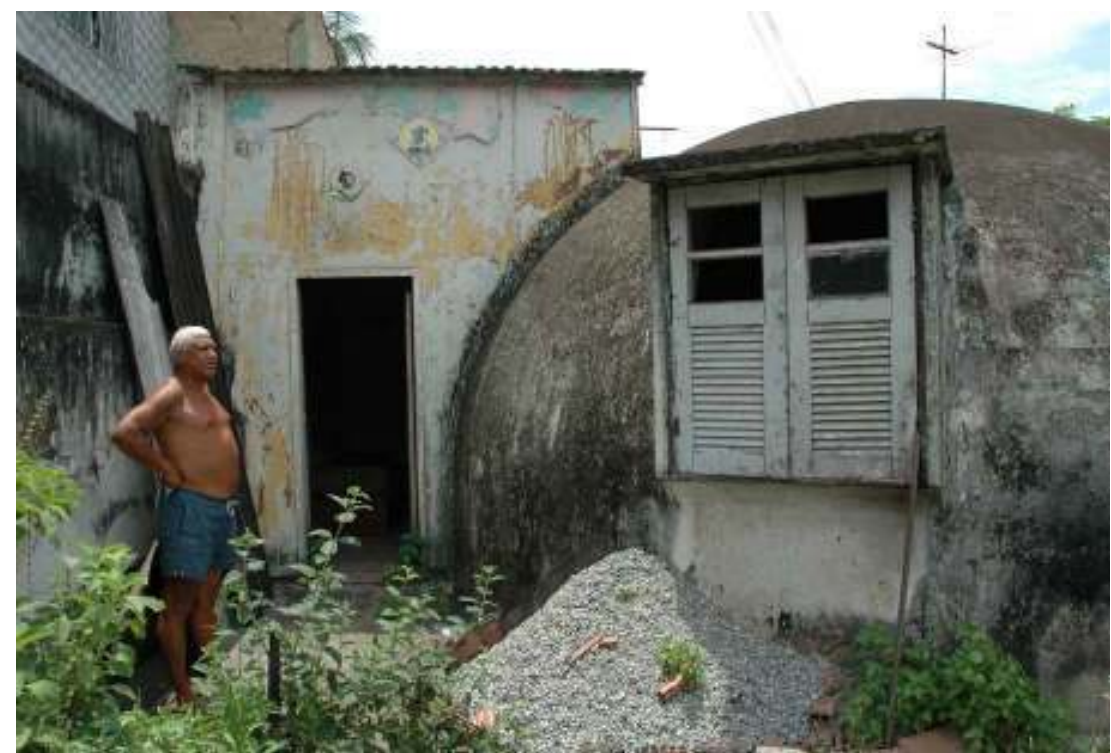

Figura 338. Casa Tipo Balão, de casca de concreto - Núcleo Residencial Carmela Dutra, Rio de Janeiro. FCP Modelo importado dos EUA (MANOEL, 2004). Fonte: Acervo Pioneiros.

O conjunto Vila Guiomar, em Santo André, bastante conhecido por seus blocos de habitações racionalistas, com galerias de circulação externas, pilotis, unidade mínima e grande área verde, também incorpora o caráter orgânico da composição urbanística, especialmente nas quadras das casas geminadas ou isoladas, as primeiras a serem construídas, em 1941-1942. Em terreno bastante acidentado, Carlos Frederico Ferreira e equipe se apropriaram do traçado 
orgânico já existente das ruas da gleba conhecida como Chácara Guiomar (PESSOLATO, 2007), moldada à topografia acidentada, e traçaram lotes e áreas verdes nas quadras já definidas. As quadras foram permeadas por áreas verdes coletivas, acessadas apenas por estreitas passagens de pedestres. Os blocos de quatro pavimentos estão dispostos livremente nas áreas periféricas a esse conjunto de casas, seguindo a mesma orientação solar. A construção foi realizada em suas etapas e conta com poucos tipos de habitações: casas geminadas de dois quartos e casas isoladas de três quartos; e apartamentos de 01, 02 e 03 dormitórios, na primeira fase, Na segunda fase, 1948-1951-foram construídos apartamentos de 03 dormitórios. No total, foram edificadas 1411 unidades.

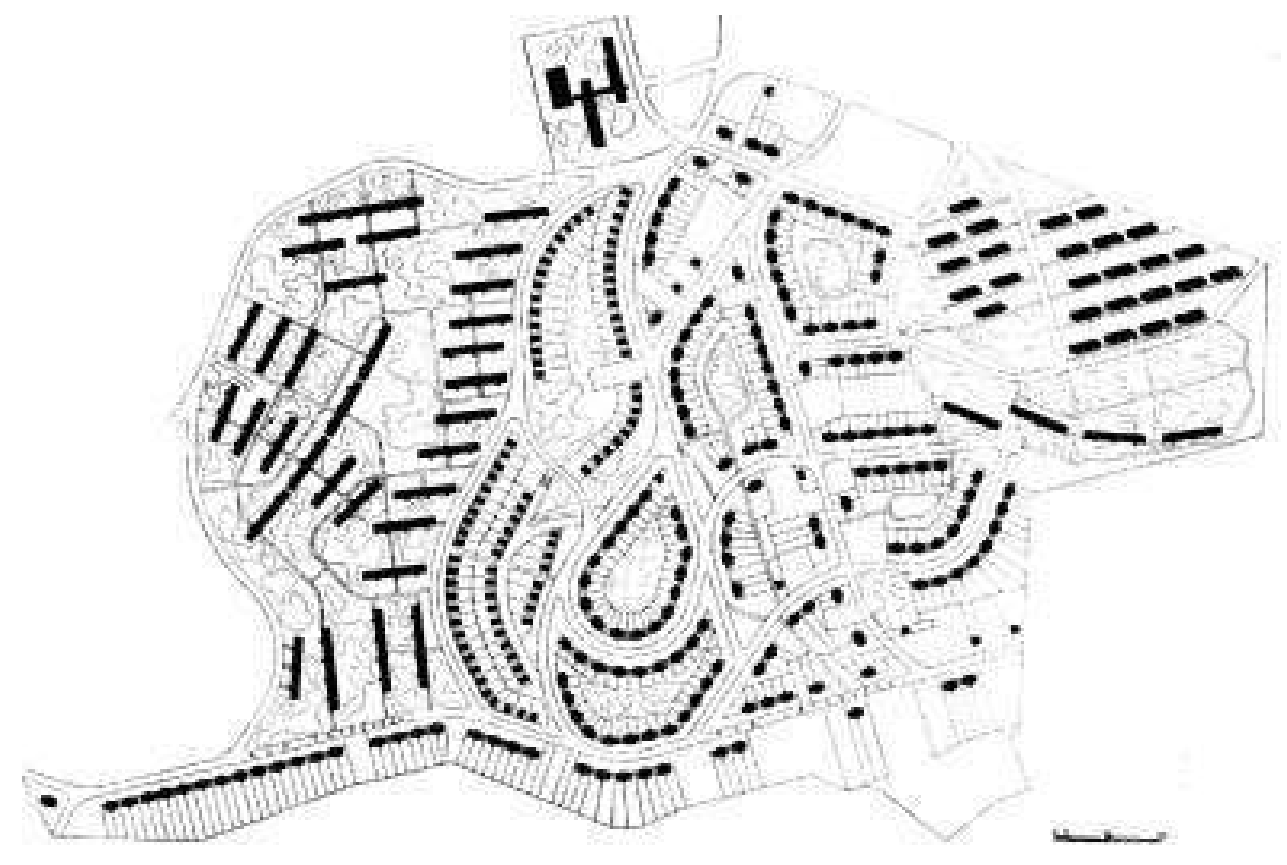

Figura 339. Implantação Vila Guiomar. IAPI, 1950.

Esse conjunto pode ser considerado um híbrido e faz parte do período de maior experimentação dos órgãos envolvidos com a promoção habitacional no país, pois conjuga princípios da cidade-jardim, inclusive com as baixas densidades que o movimento propunha, com o urbanismo e propostas de arquitetura racionalistas presente no projeto e disposição dos blocos de apartamento. A liberdade de composição desse empreendimento, e do conjunto Piratininga, em Osasco, contrastam com as propostas inteiramente racionalistas 
do IAPI que se seguiram em São Paulo, em Santos, e mesmo em Realengo, que seguia um traçado geometrizado bastante rígido. Contudo a racionalização está presente tanto no número reduzido de tipologias habitacionais, tendendo a padronização das construções, como no largo emprego de concreto armado nos blocos.
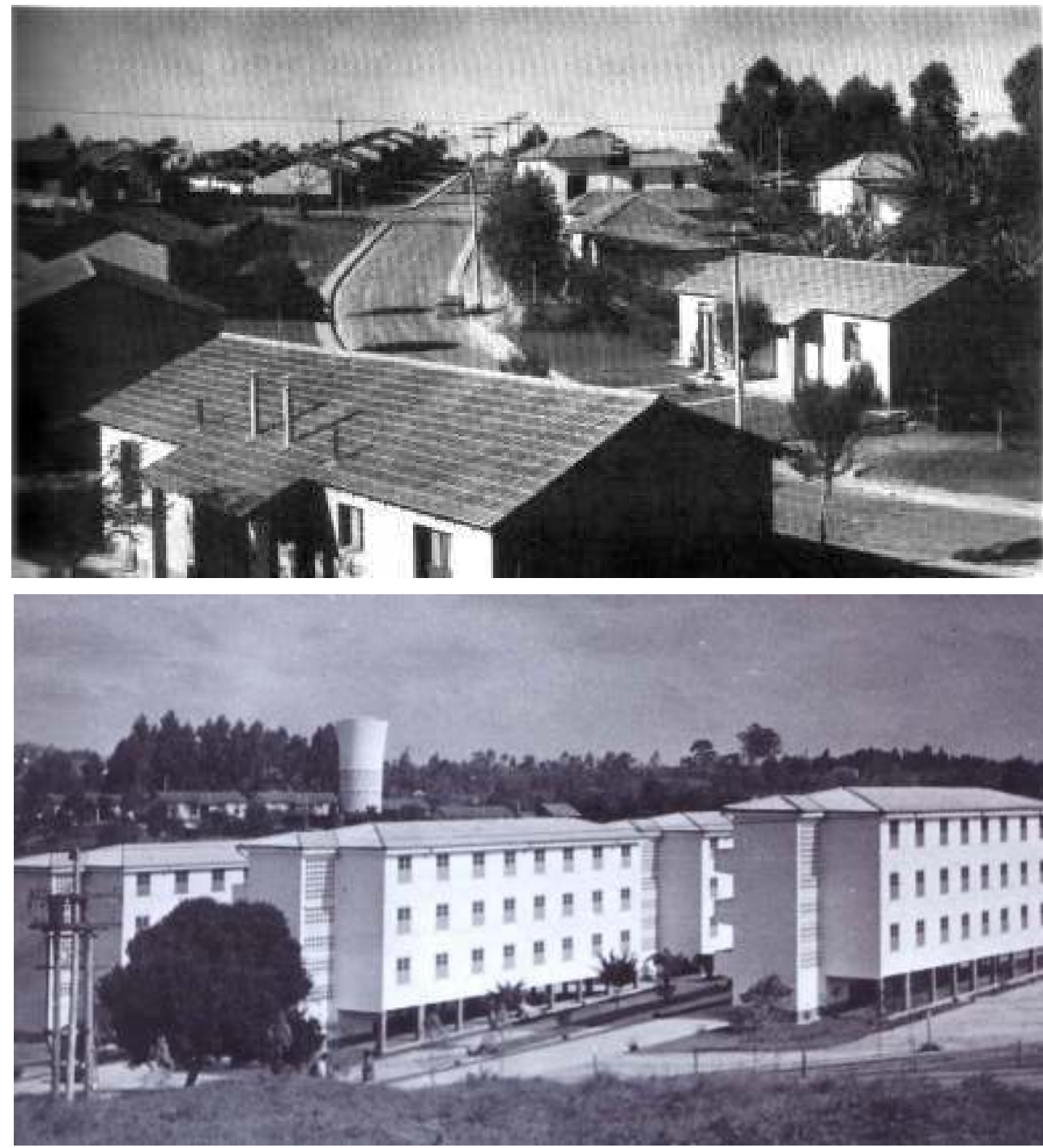

Figuras 340-41. Vila Guiomar, Santo André - Primeira fase. Foto de época. Fonte: Acervo Pioneiros.

A variação urbanística e arquitetônica da proposta da Vila Guiomar, que implementou unidades isoladas com áreas verdes coletivas nas quadras prédefinidas e blocos soltos no terreno sem arruamento prévio revela a capacidade de adaptação dos profissionais do IAPI e seu alto grau de conhecimento técnico 
sobre produção em massa de habitação para fazer escolhas coerentes com o sítio, sempre primando pelo fator economia nas obras.

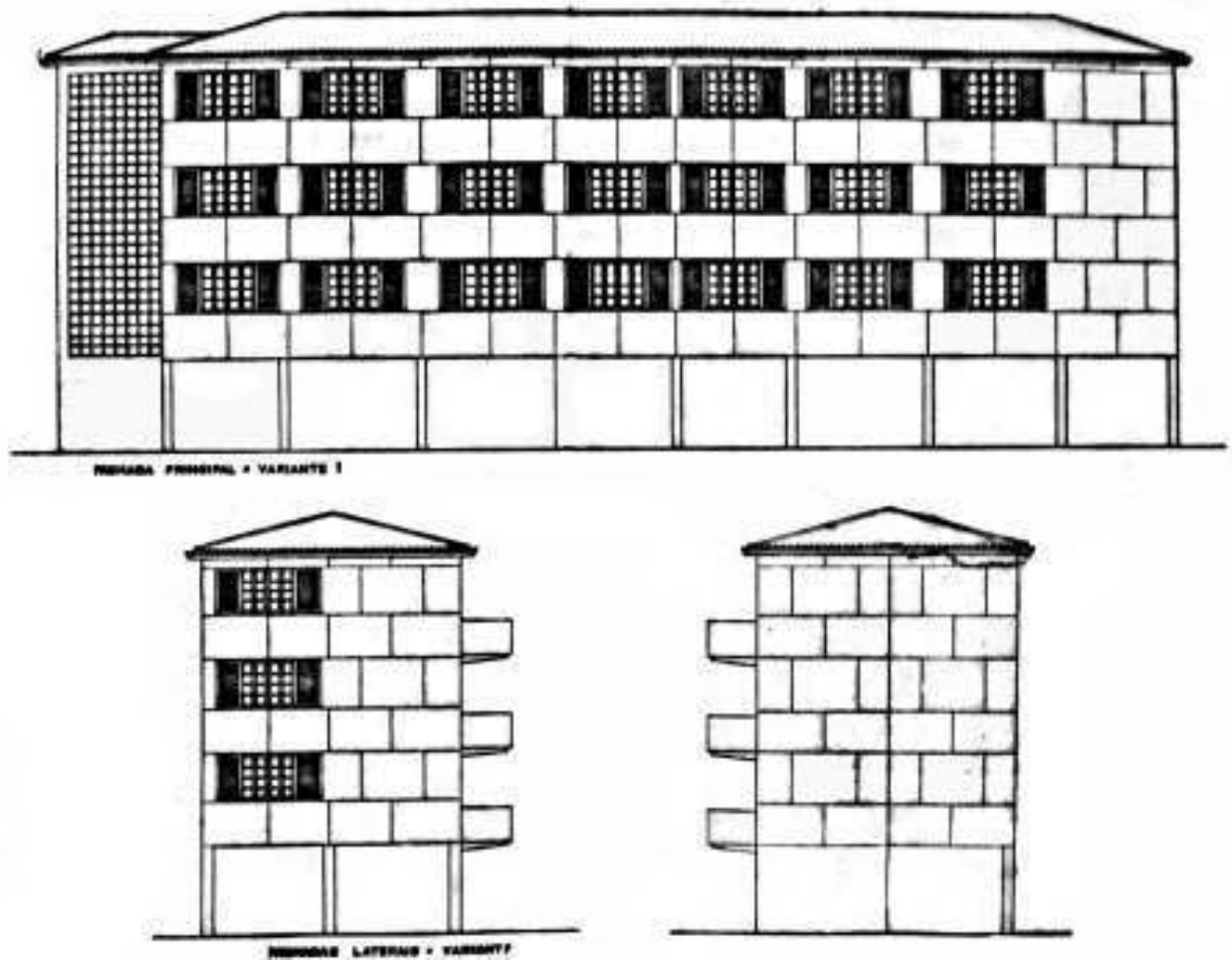

Figuras 342-43. Fachadas blocos da primeira fase - J1/J2. Fonte: PESSOLATO, 2007, p.120.

Quanto ao caráter arquitetônico, os blocos construídos na segunda etapa revelam uma depuração da forma, com estudos de fachadas com composições geometrizantes e abstratas, diferentes das esquadrias mais convencionais da primeira etapa. O uso dos elementos vazados associados ao telhado de uma água, deixando a fachada principal com aspecto de um volume puro destoam dos edifícios da primeira etapa, que tinham telhados de quatro águas, conferindo a esse conjunto um caráter mais pitoresco. 

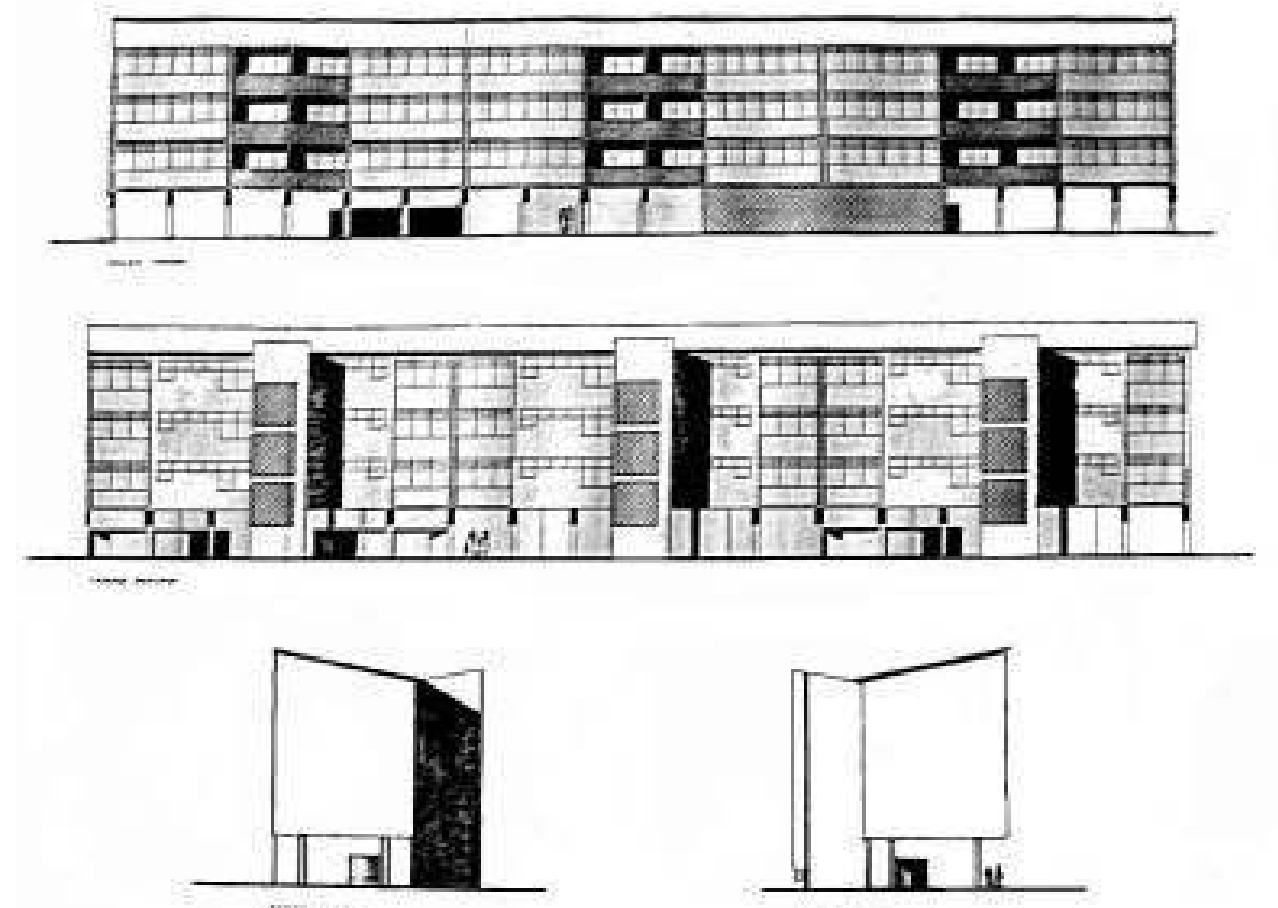

Figuras 344-45. Fachadas blocos da segunda fase. Fonte: PESSOLATO, 2007, p.124.

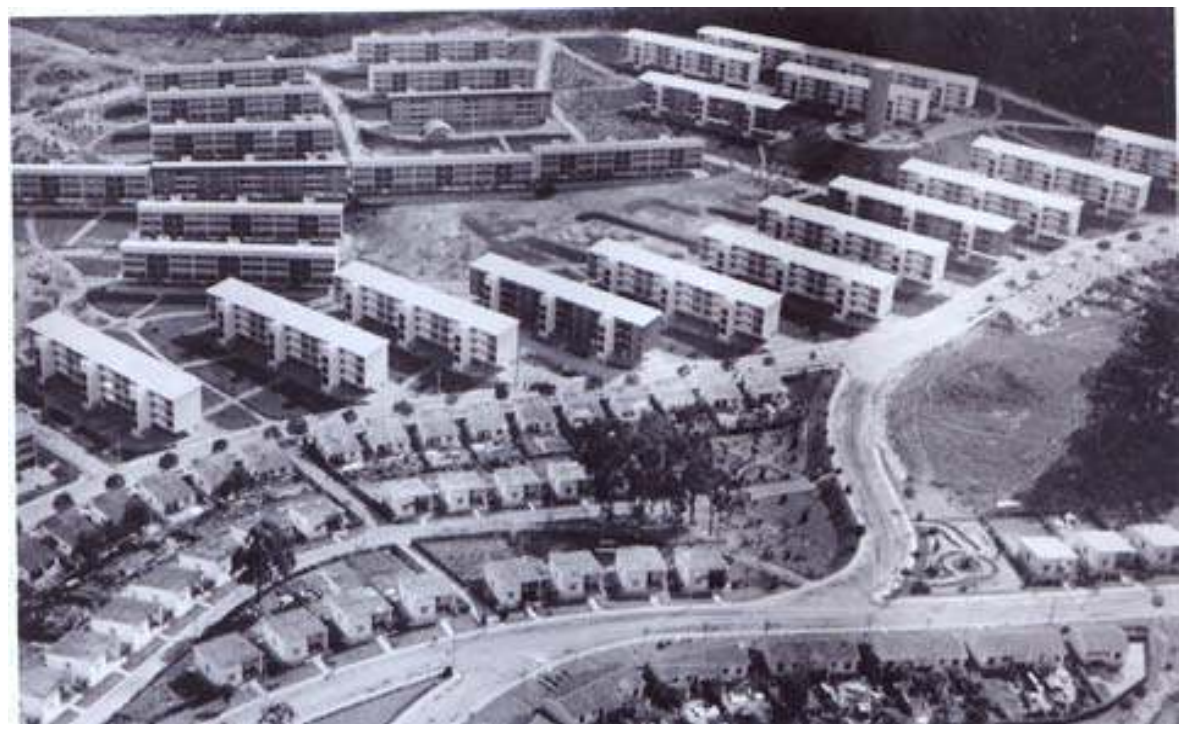

Figura 346. Vila Guiomar, Santo André - Segunda fase Foto de época. Fonte: Acervo Pioneiros.

Outro exemplo que associa agenciamentos urbanos diferentes, mas com traçado orgânico e grandes áreas verdes como mote, é a Vila Passo d'Areia, 
construída em Porto Alegre pelo IAPI, entre os anos de 1942 e meados dos anos de 1950.

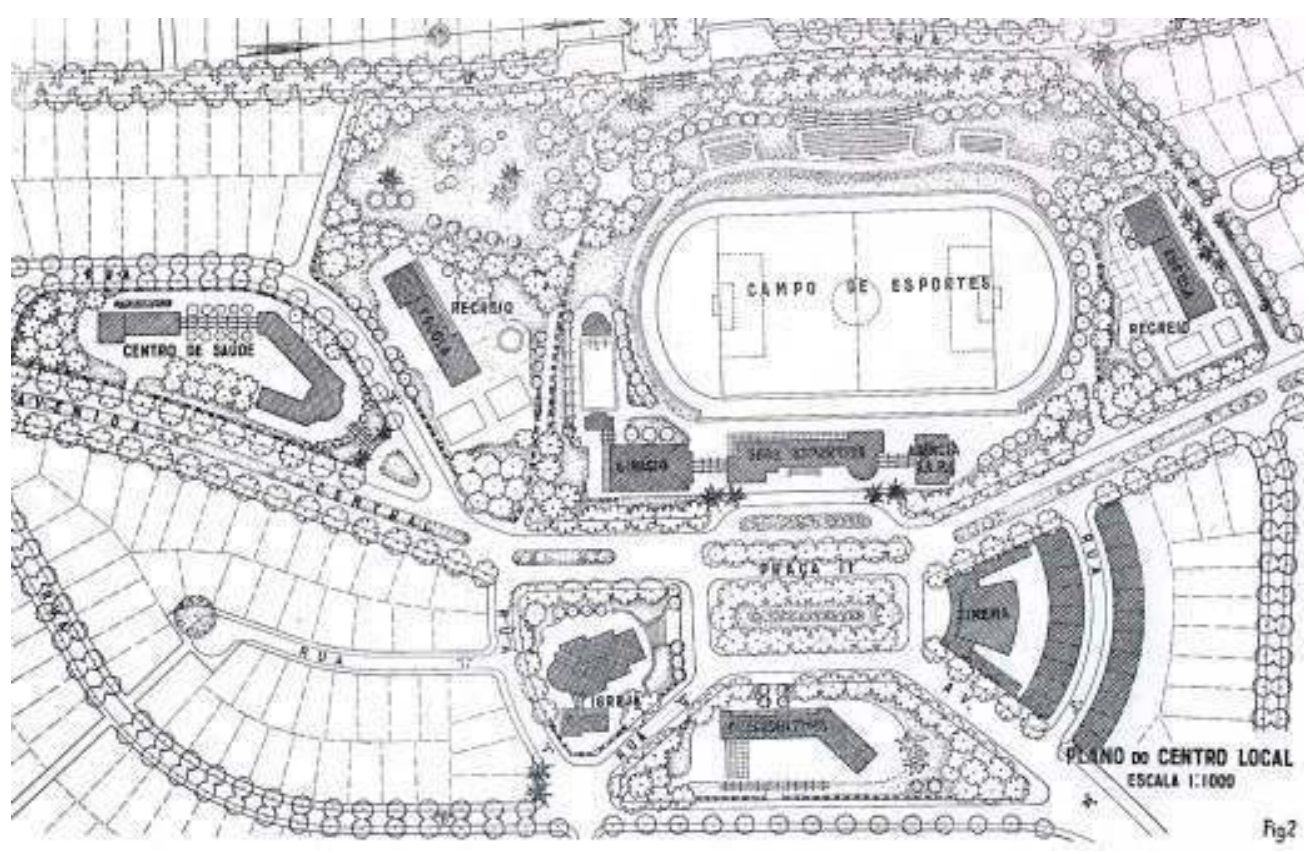

Figura 347. Proposta de Sabóia Ribeiro. SABÓIA RIBEIRO, 1943.

O conjunto pode ser considerado um dos melhores exemplos entre os Institutos em aproveitar o investimento dos órgãos da previdência para ordenar coerentemente o processo de expansão urbana. O destaque desse conjunto é o seu plano urbanístico, implantado no limite da área urbanizada, que mostra como as cidades brasileiras poderiam crescer, de forma ordenada, a partir de planos de extensão associados a projetos habitacionais, promovidos pelo poder público, como pudemos observar nos exemplos europeus. Implantado de modo compatível com o Plano Diretor de Porto Alegre, apresenta uma correta inserção urbana, respeito ao meio físico e uma qualidade de desenho urbano e de implantação urbanística que raras vezes ocorreu em cidades brasileiras $A$ execução primorosa do projeto, mesmo com as adaptações que levaram a proposta inicial de 1.600 unidades ao gigantesco complexo de 2.500 moradias, é uma das marcas que tornam a Vila IAPI tão especial e diferenciada no cenário dos demais conjuntos.

A Vila Passo d'Areia começou a ser idealizada em 1942 e só foi concluída em setembro de 1954, embora tenha sido inaugurada pelo presidente Getúlio Vargas em 1952. Com 2496 unidades, foi um dos maiores 
empreendimentos habitacionais implantados no país, no período estudado, que se diferencia pelo seu plano urbanístico, pelo tratamento paisagístico das áreas públicas e privadas, e pela diversidade de tipologias arquitetônicas, que refletiram características regionais, em geral pouco valorizada na produção dos IAP's.

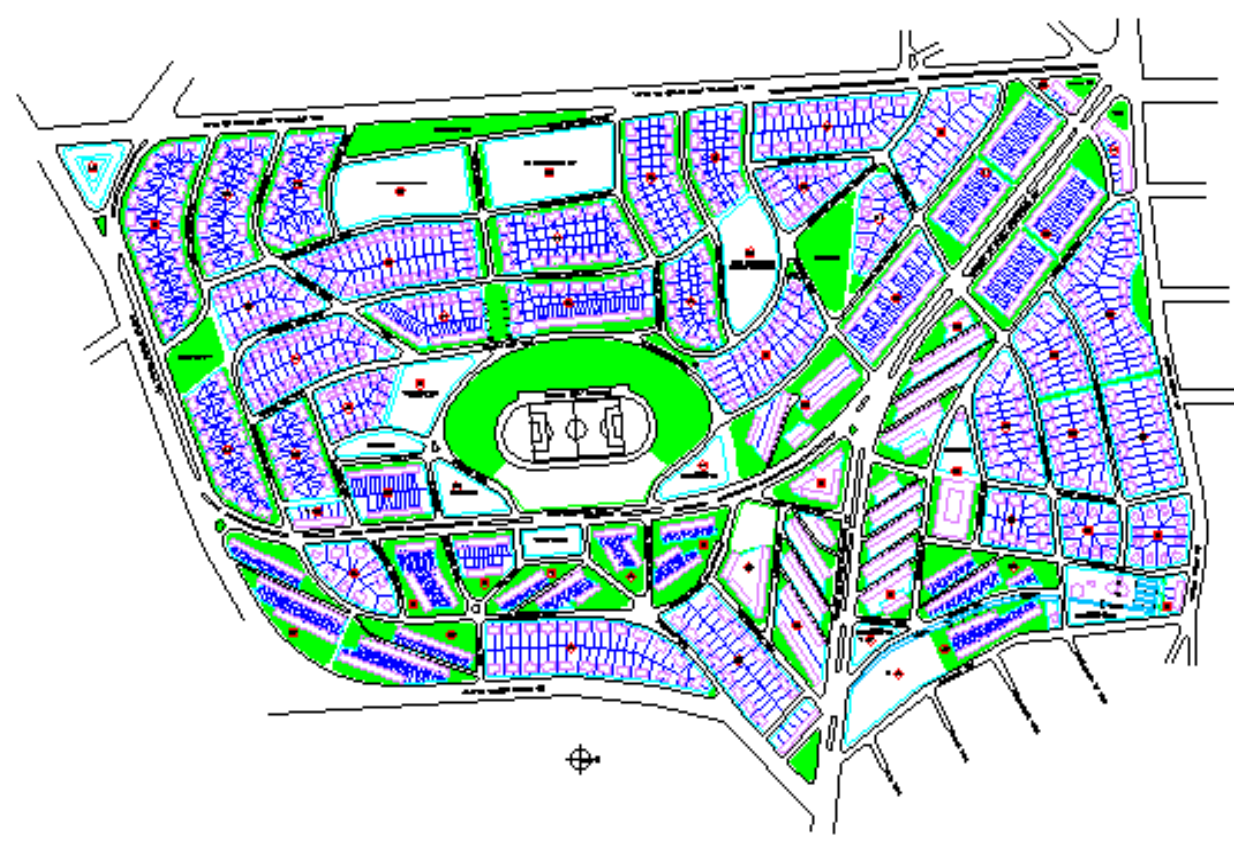

Figura 348. Implantação Marcus Krutter. Fonte: FAYET, 1995.

De forma ou pouco diferenciada da Vila Guiomar, o conjunto combina o traçado orgânico e generosas áreas verdes ao racionalismo da produção de blocos do IAPI. 


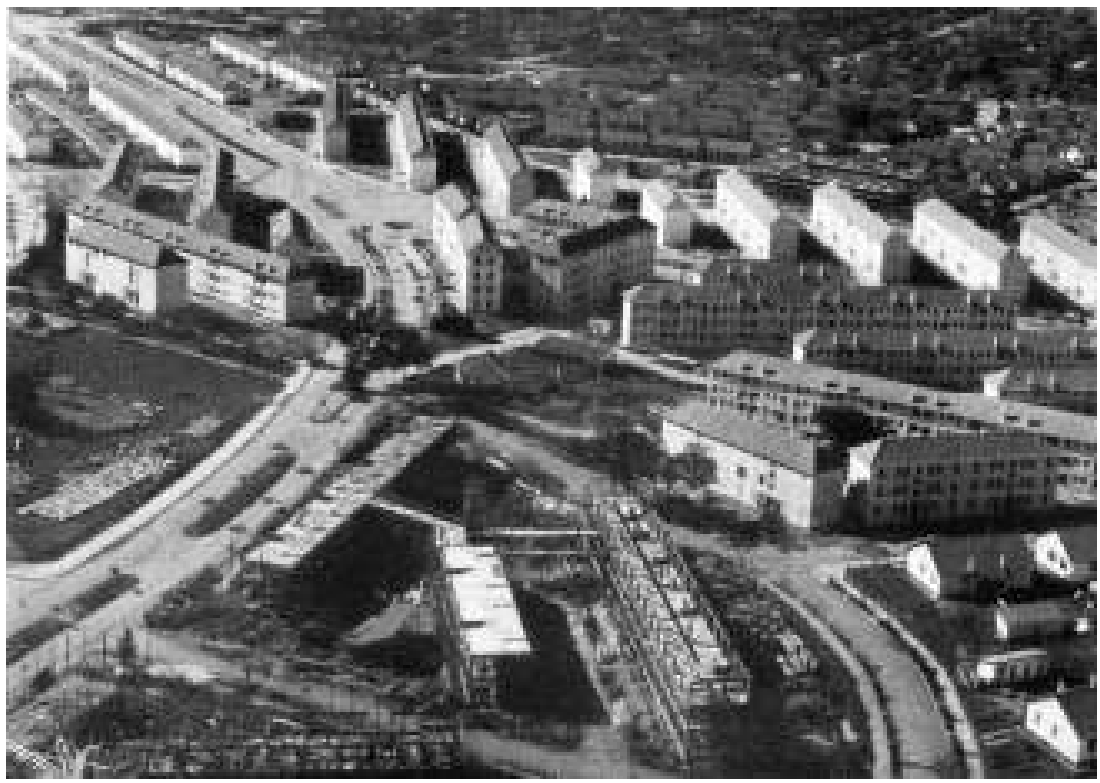

Figura 349. Vista Geral da parte que concentra os blocos de 04 pavimentos. Nota-se a articulação um pouco confusa em relação ao traçado, em decorrência da adaptação do plano para quase 2.500 unidades. Fonte: Acervo Pioneiros.

A concepção original do plano urbanístico foi de autoria de José Otacílio de Saboya Ribeiro e foi publicado no artigo "Bairro Residencial Autônomo da Chácara do Pires", publicado na Revista Municipal de Engenharia (Saboya, 1943). Embora alguns estudos, como o realizado por Fayet e equipe (1995), tenham ressaltado o papel do engenheiro gaúcho Marcos Kruter na elaboração deste plano, minimizando ou ignorando o papel do engenheiro carioca, todos os aspectos urbanísticos mais importantes da Vila do IAPI, inclusive a opção por um traçado orgânico e pitoresco, influenciado pelos princípios da cidade-jardim, já estavam presentes no estudo de Saboya.

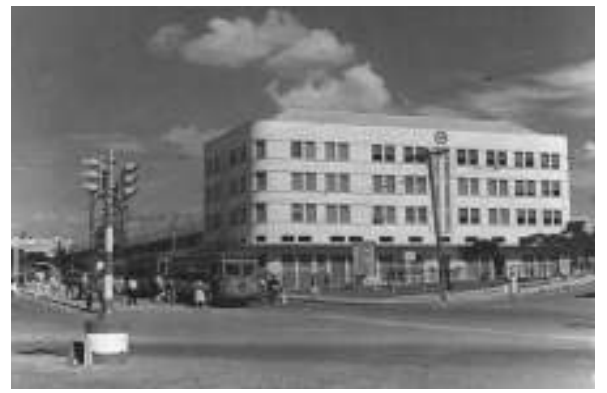

Figura 349. Edifício de uso misto marcando a entrada do conjunto. Fonte: Acervo INSS-RS. 
O engenheiro Edmundo Gardolinski, Coordenador do Departamento de Obras da Delegacia do IAPI em Porto Alegre, havia rejeitado essa proposta e outra promovida por um concurso em Porto Alegre (LAPOLLI, 2006). Contudo, o projeto desenvolvido e detalhado por Marcus Krutter, engenheiro contratado por Gardolinsk para desenvolver o plano urbanístico, manteve as principais características do projeto de Saboya e o coração do complexo, que era a grande área de lazer com um campo de futebol num grande anfiteatro natural do terreno do acidentado. As principais características do projeto foram: como a implantação de uma neighborhood unit; traçado viário orgânico e pitoresco; intensa arborização, edificações rodeadas de jardins; parque e equipamentos públicos, com destaque para o estádio, no coração do núcleo; avenida estruturadora marcada com edifícios representativos, e praças comerciais nas entradas do conjunto.
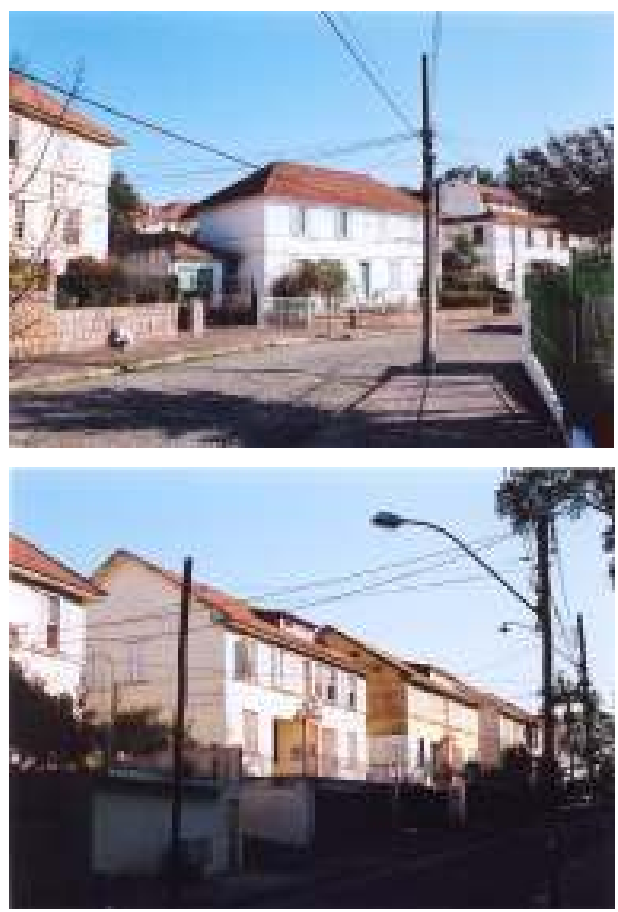

Figuras 350-53. Diversas tipologias habitacionais foram edificadas no conjunto, todas com primorosos detalhes regionalistas nas fachadas, telhados e matérias de acabamentos. Fotos da autora (2007)
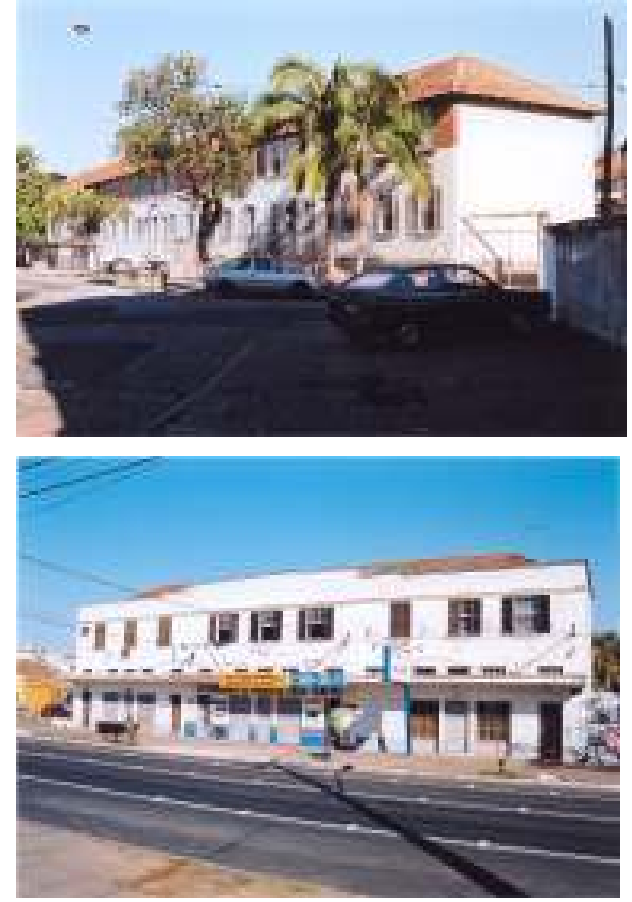

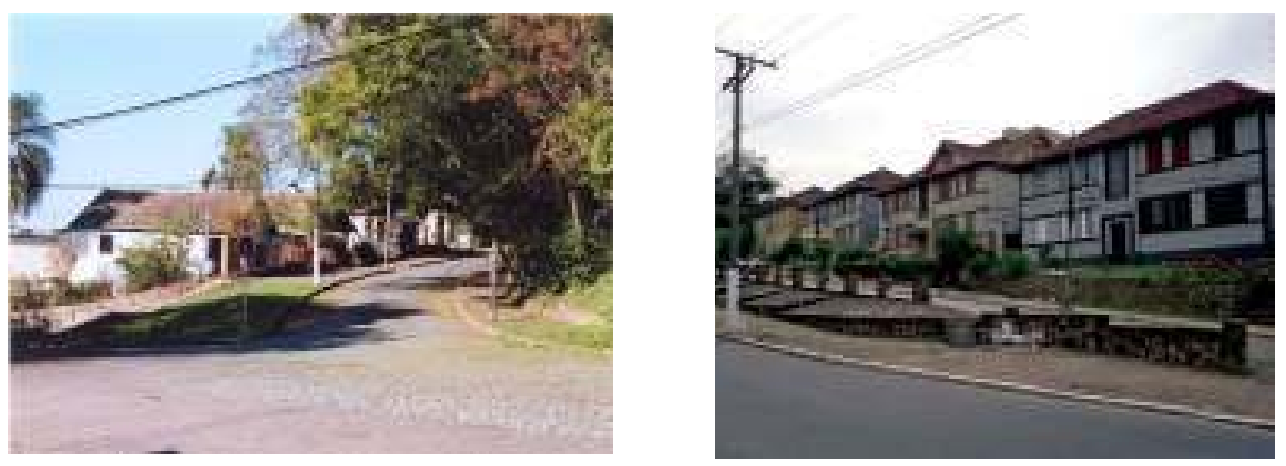

Figuras 354-55. Casas isoladas e blocos de pavimentos. Detalhe para arruamento adaptado a topografia. Fotos da autora (2007).

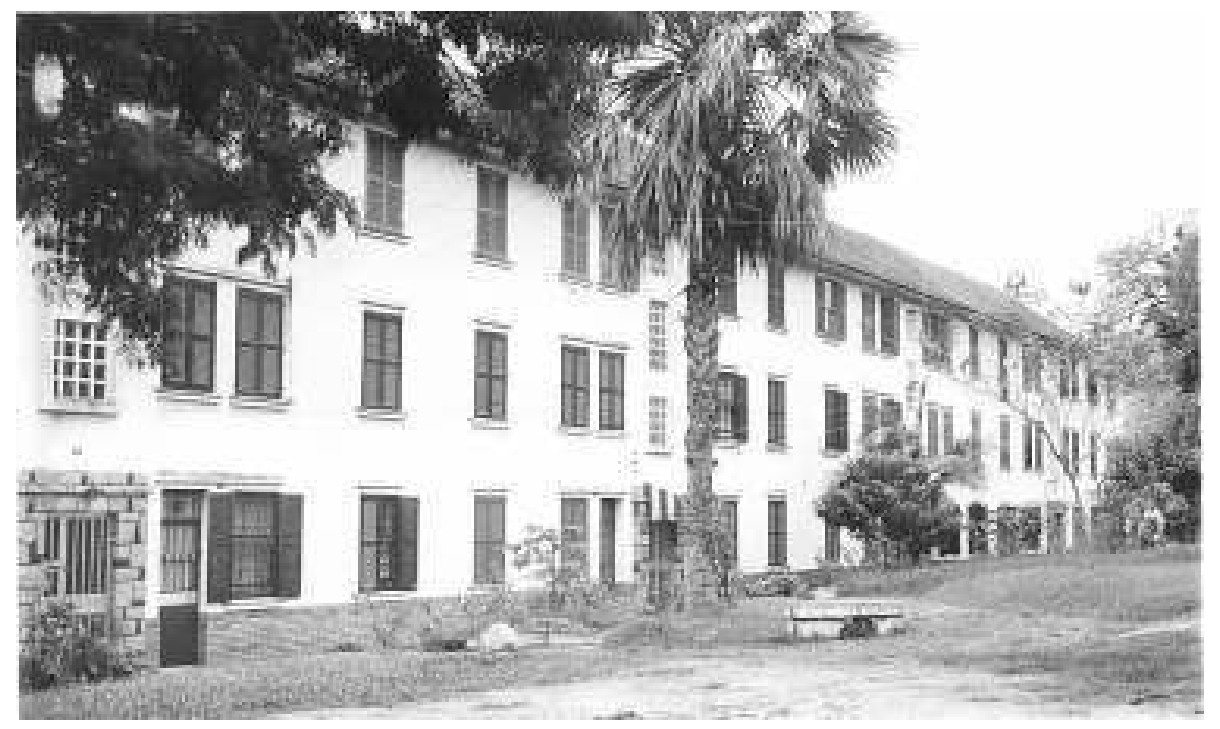

Figura 356. A execução dos equipamentos coletivos, pavimentação, calçamento e paisagismo também foram importantes fatores que conferem qualidade urbana ao conjunto. Fonte: Acervo Pioneiros.

Embora sem citar o estudo de Saboya em depoimento ao arquiteto Carlos Fayet em 1994, é notável que Kruter seguisse as orientações de Saboya e buscou "tratar o sítio como uma escultura", adequando-o às curvas de nível: "procuramos os efeitos belos, explorando no máximo os recursos naturais e intentamos criar, com as concordâncias harmoniosas do traçado, o ponto alto da solução paisagística" (Kruter, 1944).

A vegetação foi utilizada como um recurso estético e paisagístico: "Sempre juízo do aproveitamento racional do terreno no sentido de obter um máximo rendimento, decidimos disseminar (...) os espaços verdes, para que esse benéfico elemento, além de sua função decorativa, bizarra e alegre, possa 
ser usufruído de uma maneira equitativa por todos os futuros moradores do novo bairro" (Kruter, 1944).

Em uma longa explanação sobre as decisões técnicas para implantação do empreendimento, Saboya (1943) justifica suas decisões a partir do estudo dos planos das cidades-jardins e defende um variado número de tipologias habitacionais, primando pelas unidades unifamiliares. Mas, para atingir densidades que justificassem o empreendimento de baixa renda, propõe o uso de blocos de 02 e 03 pavimentos. Após o detalhamento de Krutter, e já durante a execução das obras, foram instalados 43 blocos laminares de habitação, com características bastante regionais, assim como os projetos das unidades unifamiliares.

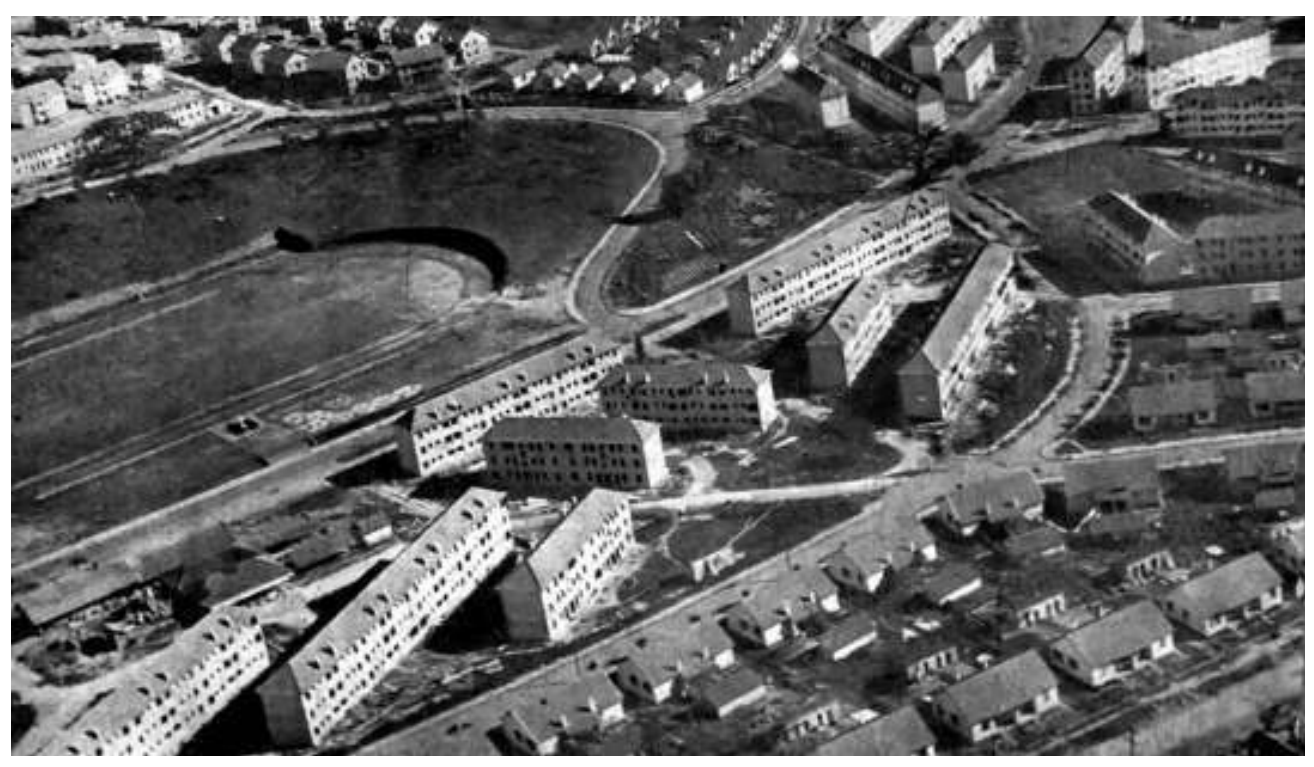

Figura 357. Foto aérea das obras bastante adiantadas. Fonte: Acervo pioneiros.

Além de uma gama de equipamentos coletivos e áreas de comércio, em grande parte concluída, o conjunto contava com 23 tipos habitacionais diferentes (Fayet, 1995), agenciados em casas isolada, geminadas, sobrados geminados, blocos laminares de 02, 03 e 04 pavimentos e blocos mistos. Para cada tipologia foram estudados diferentes alternativas (opções para terrenos em aclive e em declive; variações no desenho da varanda e na ornamentação etc.), gerando uma multiplicidade de soluções que garantiu uma heterogeneidade rara em conjuntos habitacionais de grande porte. Mas, o que garantiu um resultado surpreendente no Passo d'Areia não foi apenas a diversidade de soluções arquitetônicas (bastante tradicionais, nas suas formas variadas): foi sua 
combinação com um traçado orgânico, que valorizou o espaço físico acidentado, em meio a um ambiente arborizado e extraordinariamente bem urbanizado.

A combinação de traçado orgânico e pitoresco com a solução dos blocos laminares regionalizados destoam do movimento das cidades-jardins como proposto inicialmente, promovendo outra vertente desse ideário, assim como o projeto de Taut para Britz.

Ainda em terras gaúchas, outros conjuntos demonstram claramente a influência das cidades-jardins e traçados pitorescos no Brasil: Vila Teresópolis, do IAPC - Porto Alegre; IAPI de Novo Hamburgo, construído pela mesma equipe do Passo D'Areia; e o pequeno Conjunto Residencial Getúlio Vargas, do IAPTEC - Porto Alegre, construído ao lado do Passo d'Areia antes do início das obras daquele conjunto.

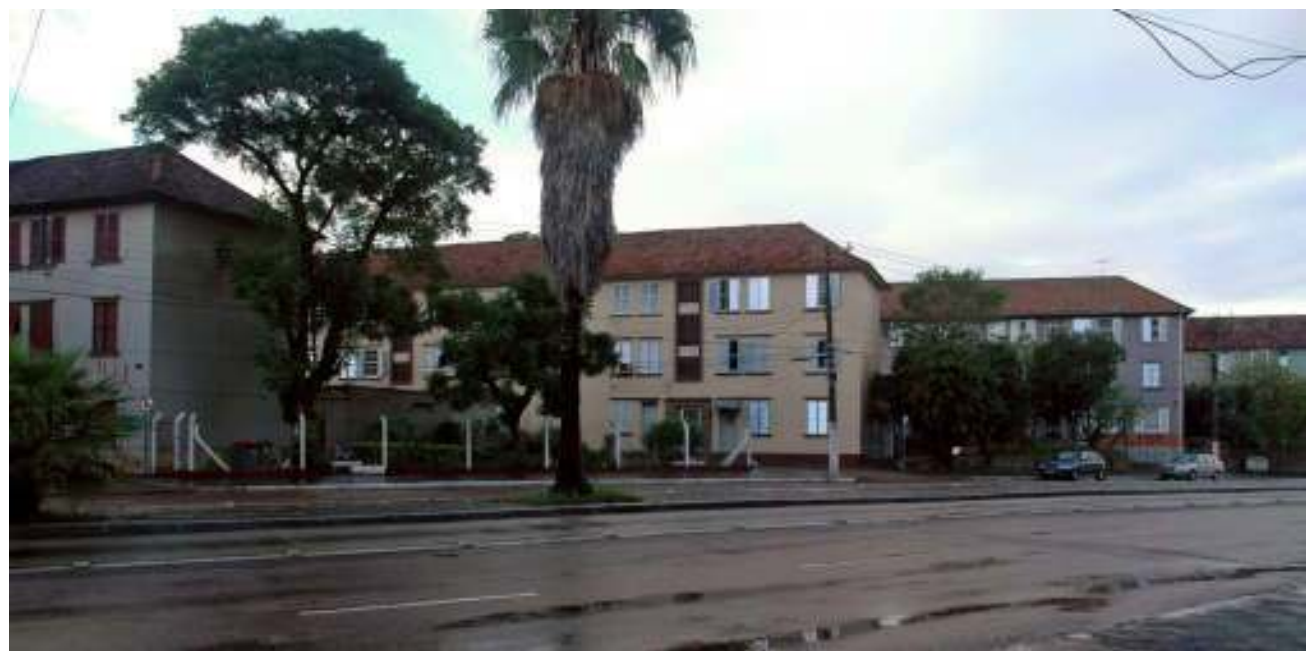

Figura 358. Blocos de três pavimentos ao longo da Av. Brasiliano Índio de Moraes. Fonte: Acervo pioneiros. 


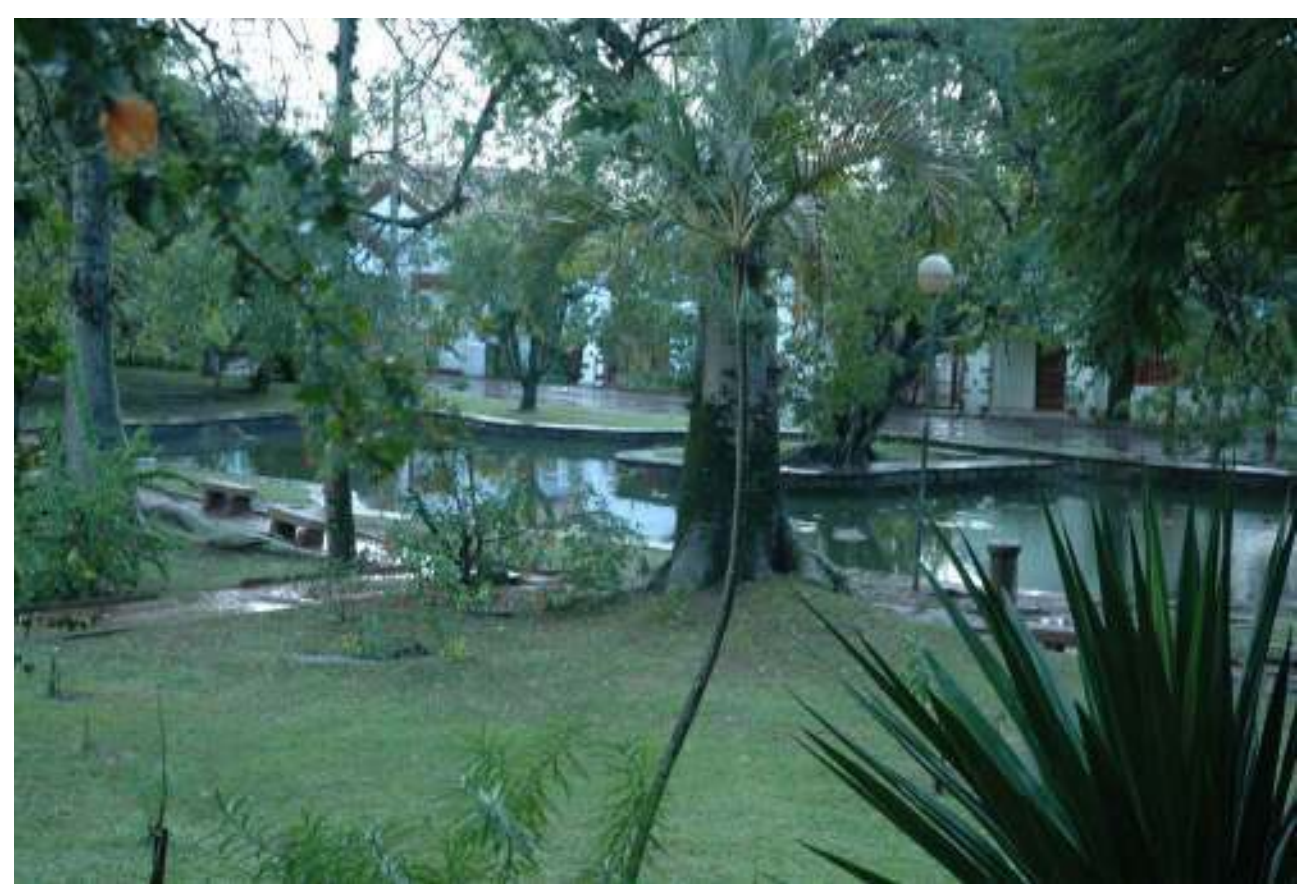

Figura 359. Paisagismo nas áreas públicas Fonte: Acervo Pioneiros. 
Outro aspecto interessante na produção dos IAP's são as tipologias especiais de arranjos habitacionais, que não se replicaram muitas vezes em outros conjuntos, seja por razões econômicas ou de falência da proposta. Podemos ver essas tipologias em três casos específicos: Olaria, no Rio de Janeiro, e Cidade-Jardim do Recife, do IAPC; Lagoinha, em Belo Horizonte, e Areal, no Rio de Janeiro, ambos do IAPI. Essas tipologias reforçam o caráter de experimentação dos órgãos na busca da melhor relação custo/benefício aliadas à qualidade de vida para os moradores, com especial atenção para os espaços públicos dos conjuntos.

O primeiro grande conjunto, implantado pelo IAPC em 1942, parte da proposta de Hellmeister, denominada cidade-jardim dos comerciários, foi implantado no bairro de Tamarineira, na época Casa Amarela, Recife, com 486 unidades. O empreendimento deu início a uma série de três projetos, baseado em uma inovadora tipologia de unidades sobrepostas.

Estas "cidades-jardim" podem ser consideradas a principal referência projetual desenvolvida pelo IAPC (Hellmeister 1944). Apesar do nome, a proposta tinha pouco a ver com a concepção urbanística das cidades jardins de Howard e, mesmo, com os bairros-jardins desenvolvidos por Barry Park e implantado em várias cidades brasileiras. Estas se caracterizam por um traçado orgânico acompanhando a topografia, ruas curvas, intensa arborização e baixa densidade, e foi utilizada em vários projetos habitacionais, como Passo d' Areia e Vila Guiomar do IAPI.

A proposta de Hellmeister seria um tipo de unidade de vizinhança, que apresenta características urbanísticas bem diversas do modelo clássico de bairro-jardim. Composta por uma combinação de unidades habitacionais padrão, sobrepostas e escalonadas, o modelo foi aplicado apenas nos conjuntos implantados nos bairros de Tamarineira (Recife, 1942), Olaria (Rio de Janeiro, 1944) e Perdizes (São Paulo, s/d).

A proposta, baseada em princípios como economia e racionalidade, pressupunha uma unidade padrão, com área entre 39 a 44 metros quadrados articulada vertical e horizontalmente, dispostas em renques com diferentes composições na área a ser ocupada, sem definição lotes e com acesso exclusivamente por vias de pedestre. A proposta criava pequenos blocos de grande dinamismo na composição arquitetônica, mas com unidades autônomas, implantados em composições que poderiam assumir, de acordo com o projeto 
urbanístico, diferentes configurações de maior ou menor densidade, criando áreas públicas de diferentes formatos e dimensões, pavimentadas ou com canteiros.

Ao criar uma unidade-padrão que pode se combinar com outras, vertical e horizontalmente, a proposta de Hellmeister possibilita várias alternativas de composição arquitetônica e projeto urbanístico, de modo a dar variação e diversidade a pequenas "vizinhanças" que se utilizam de apenas uma unidade habitacional econômica e padronizada, que poderia ser pré-fabricada, e aplicada sem gerar monotonia.

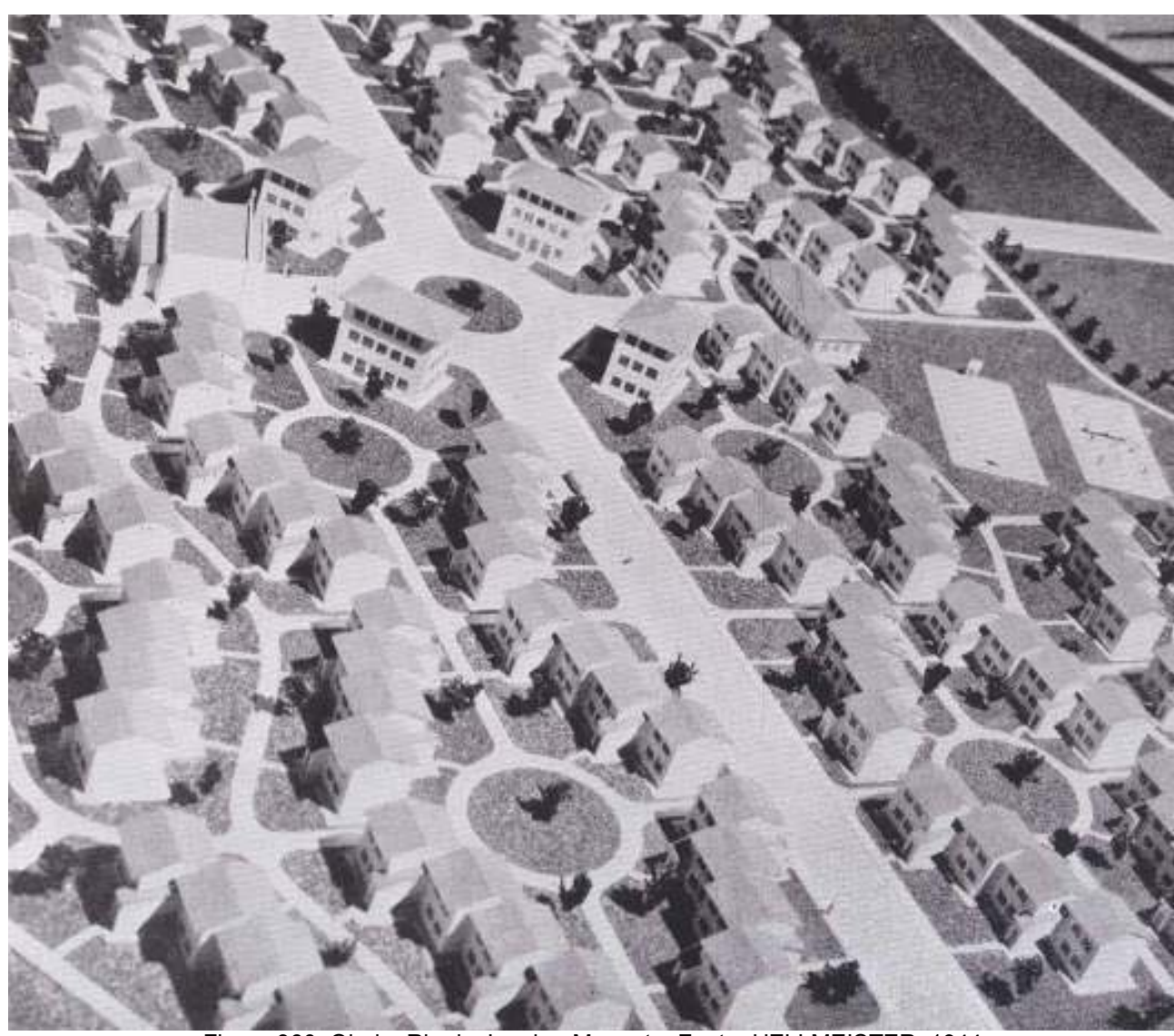

Figura 360. Olaria, Rio de Janeiro. Maquete. Fonte: HELLMEISTER, 1944.

A proposta tinha ainda outras vantagens significativas e muito interessantes do ponto de vista da criação de uma alternativa de baixo custo. Embora se pudesse alcançar adensamentos médios e até altos, como acontece na Tamarineira, a área de circulação é mínima, inexistindo espaços coletivos de acesso à unidades, o que elimina o eventual custo de condomínio. Adotando 
ruas de pedestres, a infraestrutura viária também é diminuta, com a vantagem de se criar espaços urbanos de grande qualidade.

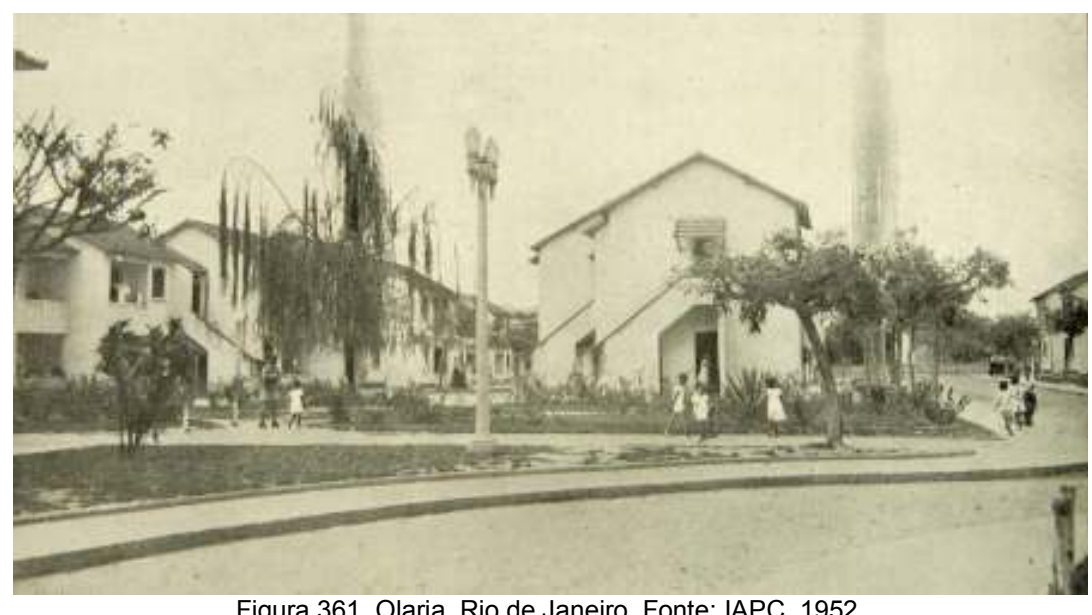

Figura 361. Olaria, Rio de Janeiro. Fonte: IAPC, 1952.

Apesar do uso de uma unidade muito parecida, considerando as três "cidades-jardim" implantadas pelo IAPC, verifica-se que o desenho urbano, densidade e relação entre volumetria construída e espaço livre são totalmente diferentes. Em Recife, a vila é bastante densa, com renques paralelos de blocos escalonados definindo vias de pedestres estreitas. A vila de São Paulo, o único empreendimento do período que foi integralmente demolido, é muito menos densa, com as unidades no perímetro externo do terreno de apenas cinco mil metros quadrados configurando uma praça que foi proposta como um espaço público, com acesso livre para a cidade.

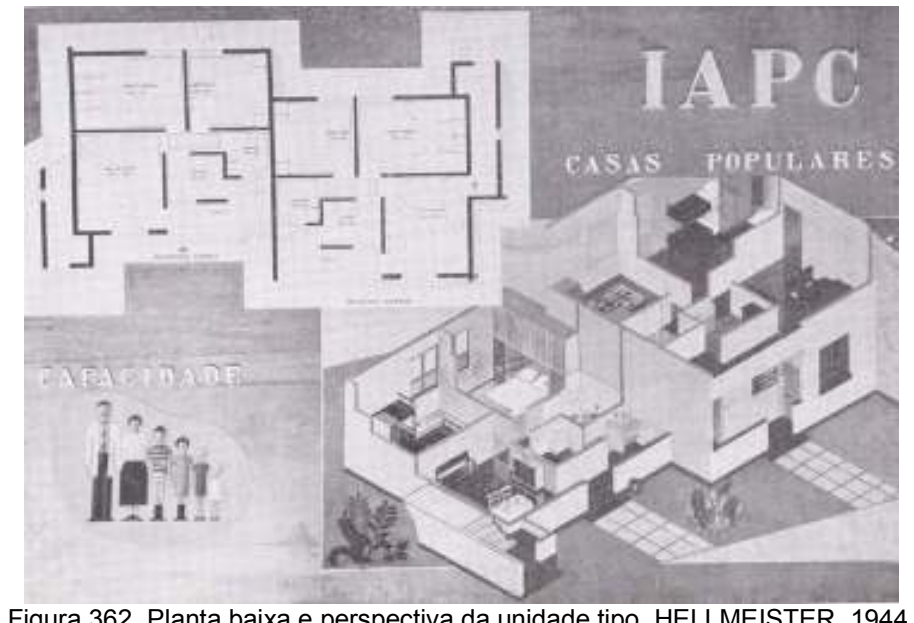




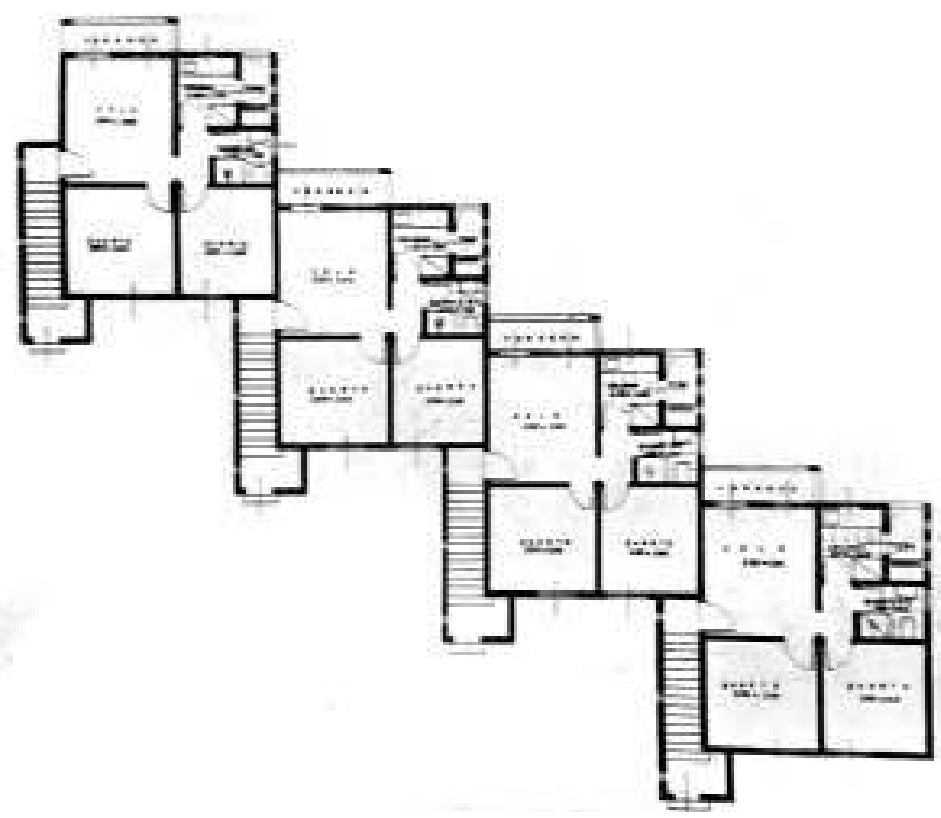

Figura 363. IAPC-Recife. Pavimento térreo de um renque de sobrados. Fonte: Acervo Pioneiros.

Em Olaria, o conjunto foi pensado como um modelo exemplar da política de projeto do IAPC (Hellmeister, 1944). Os equipamentos sociais formam um conjunto harmônico em redor de uma praça, de modo a gerar um efeito de monumentalidade. As unidades sobrepostas organizam-se em renques de oito apartamentos, como blocos, implantados em torno de pequenos largos em formato de losangos. A circulação de acesso às unidades ocorre por vias de pedestres, em meio a áreas verdes que ocupam todo o espaço livre que envolve as construções.

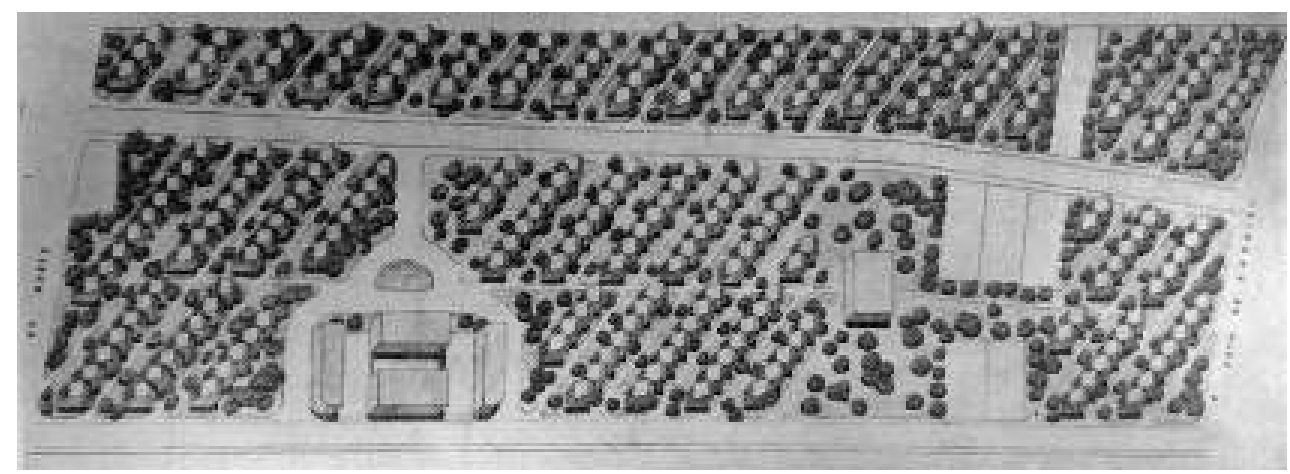

Figura 364. IAPC-Recife. Fonte: Acervo Pioneiros. 
Outra grande inovação tipológica foi conjunto residencial realizado em Minas Gerais, o Bairro Industriário, um dos marcos da produção do IAPI. Sua realização foi uma iniciativa do prefeito de Belo Horizonte, Juscelino Kubitschek de Oliveira que, em 1940, firmou um contrato com o IAPI e com a CASA objetivando a construção de um bairro popular. A CASA, entidade responsável pela elaboração do projeto, foi formalmente incluída no contrato por ter sido responsável pela articulação dos entes públicos para a promoção do empreendimento.

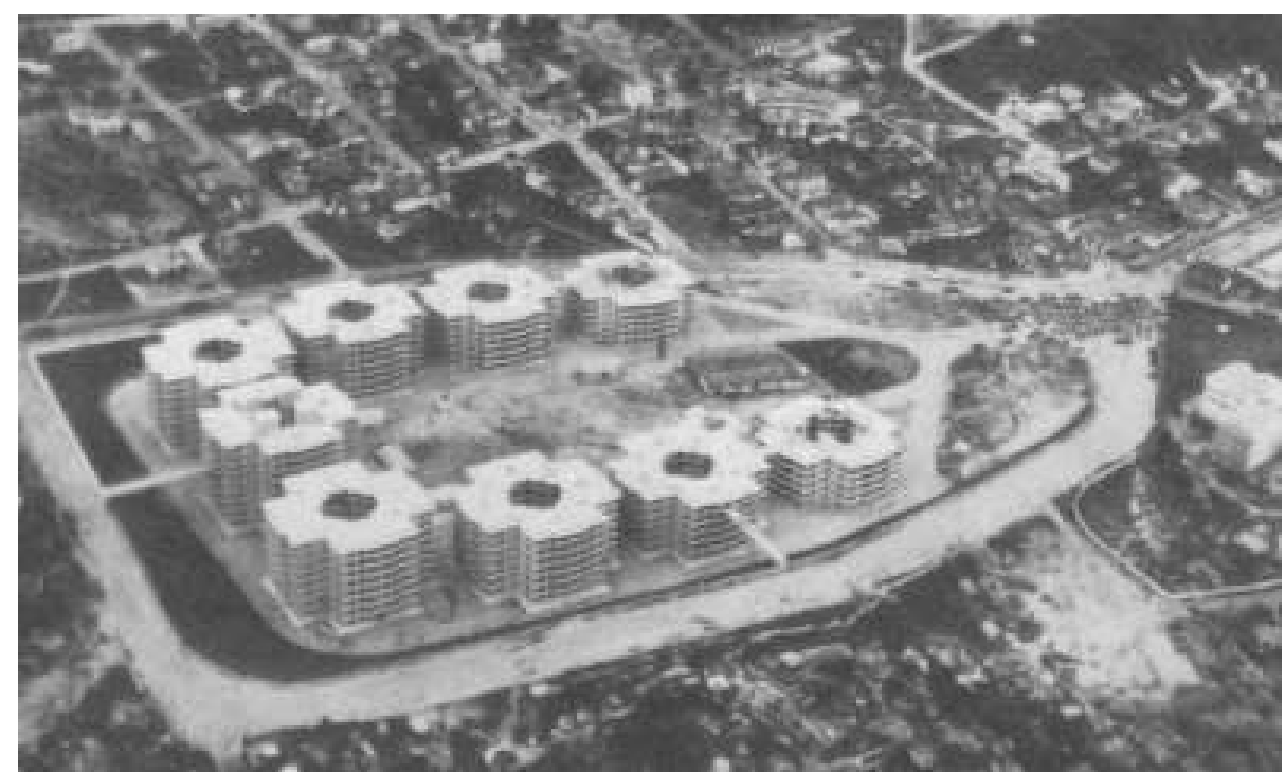

Figura 365. Lagoinha, foto de época. Fonte: Acervo Pioneiros.

O conjunto, que consiste de torres de edifícios com pequenos pátios internos, organizados ao redor de uma grande praça pode ser considerado uma excepcionalidade em termos de referências de projetos e construção de uma tipologia de habitação no Brasil dos anos 50.

Conforme acordado, a Prefeitura se obrigava a aforar ao IAPI um terreno localizado junto ao eixo viário de ligação com a Pampulha, a dois quilômetros do centro, no bairro da Lagoinha, onde havia uma favela, e a executar - ou viabilizar junto às concessionárias - os serviços de terraplanagem e infraestrutura. Em contrapartida, o IAPI custearia a construção, incluindo os equipamentos coletivos, e se comprometia a garantir aos funcionários da Prefeitura as mesmas condições dos industriários para a locação das moradias. 
A preocupação do futuro presidente em substituir uma favela por um conjunto de habitação social no caminho da Pampulha - bairro de alto padrão, onde se localizava o aeroporto, e que vinha recebendo da Prefeitura inúmeras benfeitorias, como o famoso conjunto arquitetônico projetado por Oscar Niemeyer - revela seu interesse em fazer dessa iniciativa social uma referência para seu mandato.

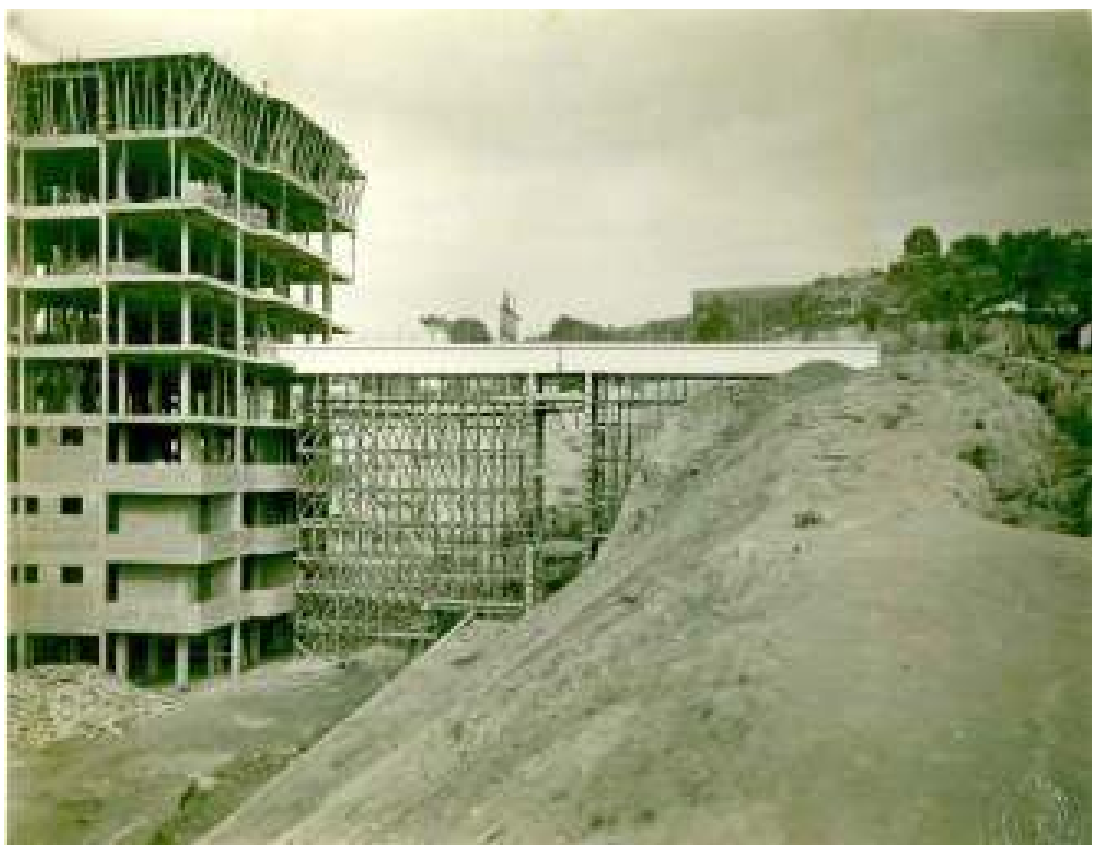

Figura 366. Lagoinha, foto da construção. Fonte: Acervo Pioneiros.

O conjunto tem feições monumentais e, ao contrário da maioria dos conjuntos do IAPI, não utiliza o bloco laminar, mas um edifício fechado em torno de um pátio, como edifício Nirvana, em Adia. Em volta desse pátio público, localiza-se a circulação vertical e horizontal, escadas e corredores de acesso aos apartamentos. Os nove blocos (onze no anteprojeto) têm gabaritos variando de cinco a nove pavimentos, sem elevador.

Além da entrada pelo térreo, foi proposta uma circulação geral, que interliga todos os blocos no nível do sexto pavimento por meio de passarelas, que possibilitam o acesso de pedestres pelas ruas que circundam o conjunto em nível mais elevado. Essa solução, que no Bairro Industriário garantiu a implantação de edifícios de até nove pavimentos sem elevador, foi utilizada por Reidy, posteriormente, no Pedregulho, com uma solução arquitetônica totalmente diferente. 
Embora o edifício em torno de um pátio seja um tipo tradicional, o projeto urbanístico é moderno, com os blocos dispostos numa grande área pública, implantados na face externa do terreno em forma de "U", criando uma grande praça destinada a equipamentos e quadras esportivas, e estando também prevista uma piscina. Oito lojas comerciais localizadas no térreo dos blocos estão voltadas para esse verdadeiro pátio central. No lado aberto da praça, em posição privilegiada, foi implantada uma igreja.

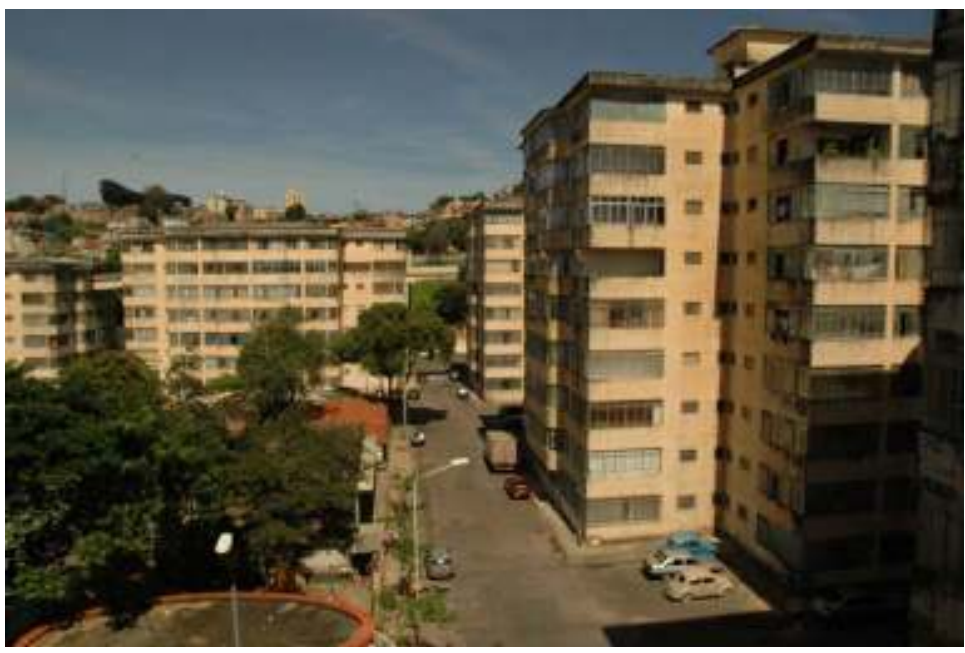

Figura 367. Foto atual do conjunto. Fonte: Acervo Pioneiros.

Assim como no caso do edifício Nirvana, que inicialmente foi projetado para ser um complexo de cinco edifícios idênticos e interligados com passadiços, os edifícios isolados, observados pelo lado externo, têm um aspecto pesado, como se fossem uma fortaleza. No entanto, ao entrar no interior do conjunto, surge uma trama labiríntica de circulação, numa sucessão de pátios e espaços públicos ou semi-públicos que surpreendem. As circulações suspensas, verdadeiras pontes que integram o sistema de circulação de cada bloco, permitem passear pelo interior de todo o conjunto, circulando pelo entorno dos pátios, numa experiência urbana poucas vezes vivida em cidades brasileiras. Nos blocos de cinco pavimentos, situados na frente do conjunto, as coberturas são tetos-jardins, áreas de uso coletivo interligadas ao sistema de circulação suspenso. Outra possível relação com o edifício Nirvana está na utilização de ganchos para içar móveis e outros objetos pesados em Lagoinha, bastante comuns nas construções holandesas. As hastes e ganchos chegaram a ser instaladas, mas foram tiradas com o tempo. 
A procedência dos autores desta obra é nebulosa. O contrato previa que a CASA elaborasse o projeto completo e fiscalizasse a implantação, mas não foi possível obter outras informações além de sua denominação completa (Companhia Auxiliar de Serviços de Administração - Engenheiros e Administradores) e da localização de sua sede, Rio de Janeiro. A empresa é desconhecida e não desenvolveu nenhum outro projeto habitacional que tenha sido identificado. Não se conhecem os autores desse trabalho, nem o histórico do envolvimento que possibilitou a contratação. Mas o anteprojeto apresentado pela CASA é um dos mais completos realizados no período, com um grau de sofisticação inédito. Por outro lado, consta que o engenheiro White Lírio da Silva, funcionário do IAPI em Minas Gerais, teve participação na execução do conjunto, não ficando clara qual foi exatamente sua contribuição.

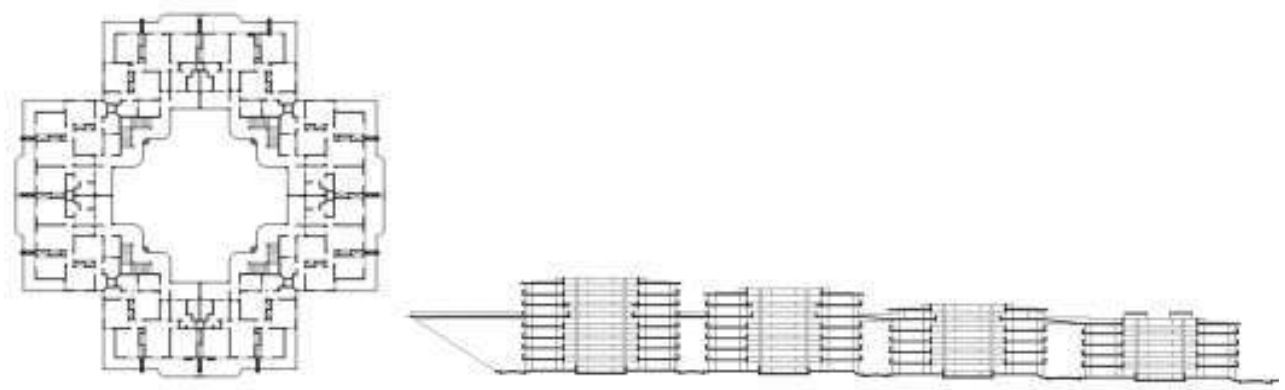

Figura 368. Pavimento tipo e corte esquemático. Fonte: Acervo Pioneiros.

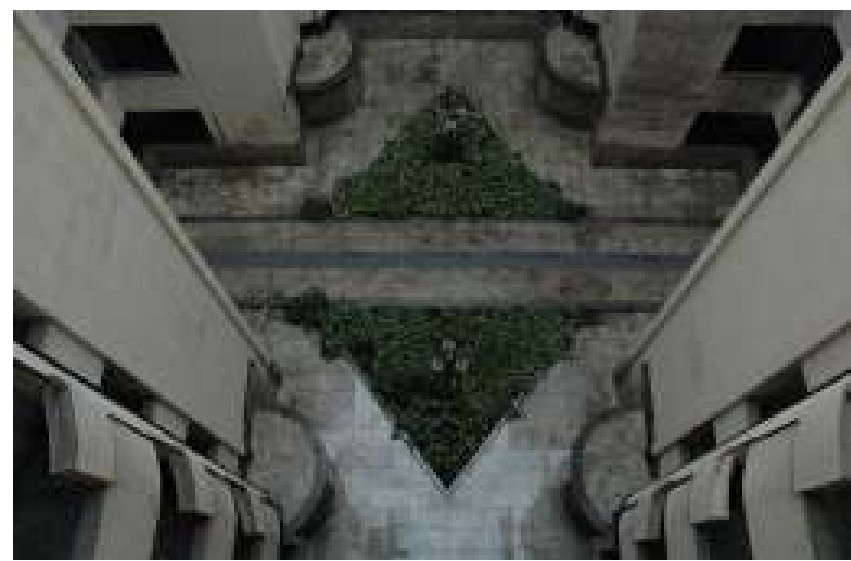

Figura 369. Vista do pátio interno. Ao contrário do edifício Nirvana, no conjunto Lagoinha vê-se um pequeno pátio interno, aproximando a ideia das Hofes vienenses. Fonte: Acervo Pioneiros. 
Até onde foi possível averiguar, a equipe do Setor de Engenharia do IAPI não se envolveu diretamente na concepção do empreendimento - que não guarda relação com a política de projeto do órgão. Esse suposto distanciamento talvez ajude a explicar a adoção de soluções arquitetônicas que não estão orientadas pela racionalidade e economia, embora tais preocupações estejam presentes no memorial justificativo do anteprojeto.

A organização dos espaços das unidades é sensivelmente penalizada pelo formato do bloco. A planta do pavimento-tipo gera espaços desperdiçados e área de circulação excessiva. Situação observada no conjunto de Spangen, em Roterdã, no qual as circulações se confundem realmente com ruas suspensas devido à sua dimensão, e Nirvana, em Haia, cujas passarelas foram eliminadas na construção do edifício, e os balcões externos fechados nas unidades menores para aproveitamento no espaço interno. Os compartimentos das unidades são prejudicados em seu conforto acústico e térmico, porque elas estão circundadas por corredores e localizadas em torno do pátio, orientadas para todas as direções, o que prejudica a ventilação cruzada e insolação de forma regular nas unidades. Outro dado que se deve levar em conta, é dada as dificuldades de execução da obra, a economia certamente não foi uma preocupação prioritária nesse conjunto, ao contrário da Postura do IAPI.

O conjunto residencial de Areal, construído na periferia do Rio de Janeiro, em Irajá, nos inícios dos anos de 1950, é constituído de 600 unidades habitacionais iguais agenciadas em blocos tipo " $\mathrm{Y}$ ", tipologia proposta pela primeira vez pela vanguarda soviética e posteriormente por Le Corbusier, em Argel e Barcelona.
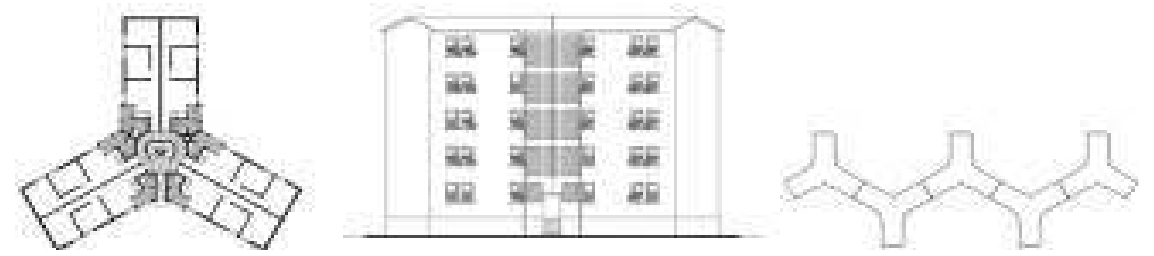

Figura 370-72. Planta do pavimento tipo; fachada e esquema da implantação. Fonte: Acervo Pioneiros.

Segundo relato de José Durval Cordeiro Sobrinho, arquiteto do IAPI, nenhum técnico do órgão assumia a autoria deste projeto. Talvez isto se deva ao fato dele se caracterizar por um padrão construtivo e habitacional abaixo do que se aceitava como admissível. No Areal, a busca pela redução de custos tornou- 
se radical, objetivando uma produção massiva para os industriários de mais baixa renda. Não por acaso, é o único dos conjuntos incluídos no livro publicado pelo IAPI em1950 com um subtítulo: "solução para o problema das favelas".

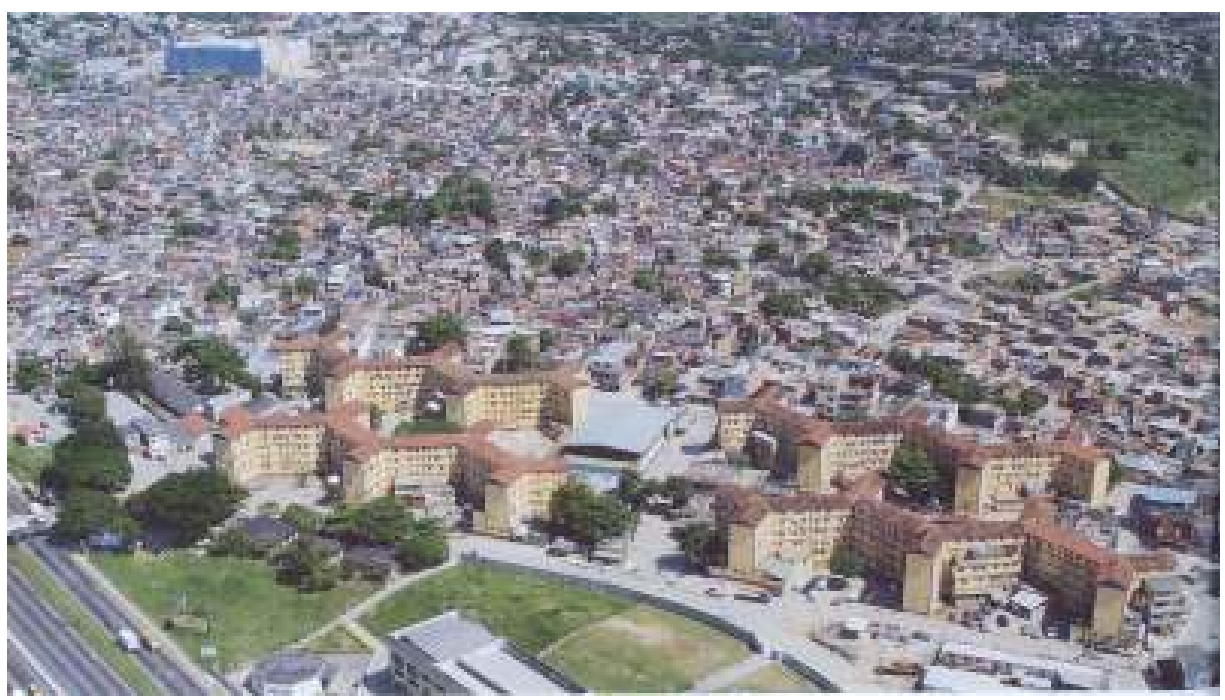

Figura 373. Foto geral do conjunto de Areal, Rio de Janeiro. Fonte: Acervo Pioneiros.

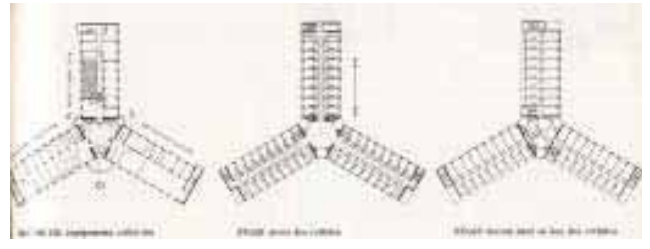

Figura 374. Proposta de moradia barata desenvolvida em Moscou nos anos 1920. Fonte: MONICA, 2004.

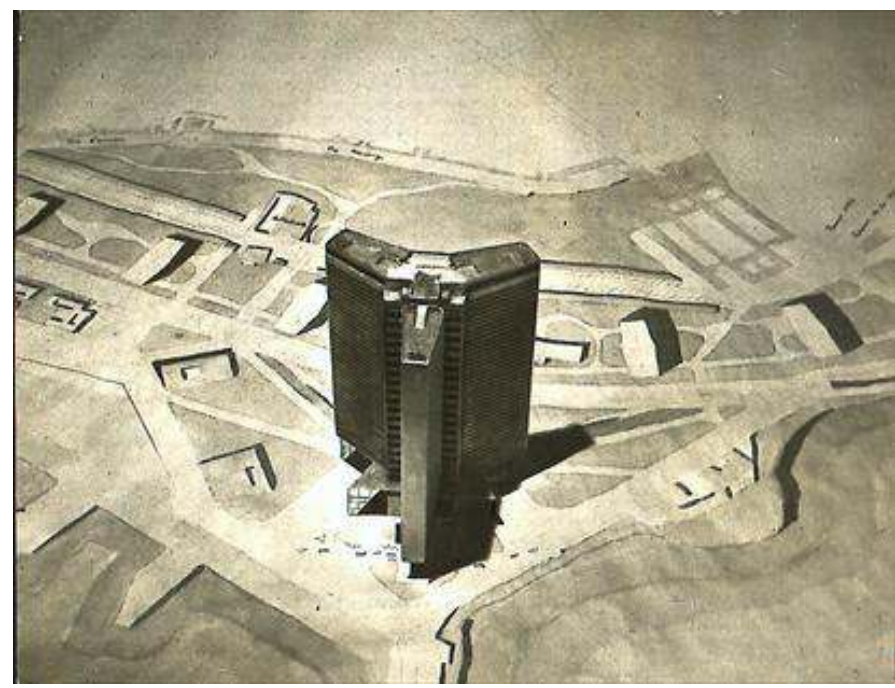

Figura 375. Arranha-céu Cartésien proposto por Le Corbusier nos anos 1930. Fonte: http://www.fondationlecorbusier.fr 
Ao contrário dos seus arquitetos, institucionalmente o IAPI defendia a proposta: "esse núcleo foi projetado com o objetivo de possibilitar moradia ao operário de salário mínimo e de família média (casal com dois filhos menores), representando empreendimento dos mais significativos no que concerne à construção de habitações satisfatórias de baixo custo". As opções de projeto e de acabamento são econômicas: área de $25 \mathrm{~m}^{2}$, cozinha acoplada à sala; alvenaria sem revestimento externo, instalações hidráulicas concentradas; pé direito de 2,40m; portas de $65 \mathrm{~cm}$; corredor de 0,70 m; piso cimentado (todos os demais projetos são de taco); paredes caiadas; esquadrias apenas envernizadas. Como afirma o órgão, embora "as especificações sejam simples e modestas, mantém-se o padrão construtivo permanente do ponto de vista técnico: estrutura de concreto armado, instalações de água e luz completas, recolhimento de lixo e tratamento dos esgotos domiciliares".

O tipo de bloco utilizado neste projeto, com circulação central circular dando acesso a seis unidades por pavimento, foi singular, não tendo sido utilizado em nenhum outro empreendimento. Sua adoção, talvez inspirada em conjuntos habitacionais contemporâneos edificados nos Estados Unidos, França e Itália, buscavam economia, reduzindo ao máximo as áreas de circulação. Enquanto na maioria dos conjuntos do IAPI cada escada dava acesso a oito unidades no total, no máximo 16 , no caso do Bloco "H", em Areal ela servia a trinta.

\subsection{Considerações gerais sobre a produção nacional}

A produção habitacional promovida pelo poder público em nível federal foi marcada pela diversidade arquitetônica e urbanística, adotando inclusive diferentes referências desenvolvidas primeiramente nas cidades europeias. Ao lado dos conhecidos blocos laminares característicos da produção alemã, assim como foi publicada e difundida pelos CIAM's e periódicos dos grupos de vanguarda de arquitetura, verificamos no terceiro capítulo a presença dos princípios de urbanismo funcionalista; subúrbio-jardim, tais como foram difundidos por Unwin e apropriados de maneira bastante simplificada em diversas localidades, ou mesmo o emprego dos mesmos subúrbios-jardins com uma caracterização mais funcionalista, na concepção de Ernst May. Contudo, os números indicam que o urbanismo tradicional, de malha quadriculada com o 
arranjo lote/quadra/rua, foi a opção mais empregada somando-se os órgãos regionais a esses números, como a Liga Social Contra os Mocambos. Essa produção pluralista brasileira também tem a especificidade de misturar diversas referências num mesmo projeto, criando por vezes situações inusitadas e coerentes.

Como foi demonstrada no primeiro capítulo, a produção habitacional no período pré I Guerra Mundial e entre guerras é marcada pela pluralidade de soluções arquitetônicas e urbanísticas, pois estavam intrinsecamente ligadas a um projeto social específico em cada país e cidade, definido em linhas gerais pelo "welfare".

No caso de Amsterdam, as questões regionais e históricas têm um peso muito grande na preferência por baixas densidades, áreas verdes e quintais privativos nas áreas habitacionais, além de um apelo estético declarado pela municipalidade como elemento de qualidade urbana. Tanto em Roterdã como Amsterdam, foram realizadas pesquisas de modo a criar espaços urbanos diferenciados nos conjuntos habitacionais, com áreas coletivas privadas ou jardim públicos; nova relação entre edificação e rua, e abertura dos quarteirões. Todas essas ações são o resultado da leitura das tendências econômicas, sociais e culturais modernas holandesas, ao lado de uma reação da própria sociedade, na forma de sindicatos e partidos de esquerda, para melhoria das condições de vida nas cidades. A Lei de Habitação de 1901 foi um feito histórico no urbanismo do século $X X$, e foi o resultado de um longo processo de intervenção municipal na questão habitacional. Além do planejamento urbano obrigatório para incluir as questões de habitação de baixa renda na agenda do município, as ações para qualificar as habitações impróprias e remover as favelas foram fundamentais para garantir a qualidade de vida urbana e rural para todos.

Tanto em Frankfurt como em Berlim, podemos ver o papel do estado como articulador fundamental no fomento à produção habitacional, sempre aliando a legislação federal às iniciativas locais para a execução do programa habitacional. As discussões das vanguardas modernas alemãs, artísticas e políticas, fizeram coro à iniciativa federal no sentido de se enfrentar a questão habitacional segundo as possibilidades técnicas e estéticas pesquisadas então. É preciso salientar, contudo, que não apenas a arquitetura de Ersnt May, Gropius ou mesmo Bruto Taut foram as eleitas para esse grande programa 
habitacional da República de Weimar. Arquiteturas mais tradicionalistas e princípios de subúrbios-jardim foram amplamente utilizados em outras cidades ${ }^{1}$, de acordo com a tendência do arquiteto escolhido pelos municípios para dirigir o departamento de construção e planejamento municipal. Mas, sem dúvida, a experiência de Frankfurt e Berlim foram as mais expressivas em números (LANE, 1968). A mesma pluralidade de manifestações pode ser observada em território holandês, pois estavam visceralmente conectadas a planejamentos locais regidos por uma legislação federal.

Em Viena, as particularidades do regime político, da legislação municipal vigente, associada à ideia de metrópole moderna que procurava se imprimir na cidade, e a ideia de uma modelo habitacional como meio e fim de uma revolução social, levaram à solução das famosas Hofës vienenses. A escolha do modelo de blocos residências que preenchiam os espaços vazios da cidade resultou que cada projeto tinha uma escala e características diferenciadas pelas condições do sítio.

A literatura internacional sobre a produção habitacional moderna procura demonstrar como essas experiências participaram da "evolução" do pensamento arquitetônico e urbanístico que resultaram no urbanismo funcionalista. Esse, por sua vez, mal interpretado e equivocadamente aplicado na reconstrução do segundo pós-guerra, produziu projetos habitacionais monótonos e repetitivos, fruto da busca cega pelo barateamento da unidade através da racionalização da construção. Não nos interessa, contudo, entender essa produção como parte de um processo evolutivo do pensamento urbanístico funcionalista, e sim, abordar os fatores locais que permitiram uma produção em larga escala, com qualidade, num curto período de tempo. Os princípios que introduziram as reformas habitacionais nas cidades europeias acabaram sendo também modeladores das suas características físicas, como demonstrado no primeiro capítulo. Bastante evidente disso é o exemplo de Amsterdam até os anos de 1920, e Viena.

À luz dessa leitura da produção internacional, e tendo como base teórica os diversos trabalhos sobre a formação da política habitacional no Brasil, podemos interpretar a variação tipológica de moradia de baixa renda produzida pelo Estado brasileiro como o resultado da contraditória política populista de Vargas, que se formatou através da controversa atuação dos IAP's e pela

${ }^{1}$ Que seria largamente difundido no período nazista. 
frustrada tentativa de implementação de uma verdadeira política federal com a Fundação da Casa Popular. Tudo ficou pelo meio do caminho, tanto a tão aclamada formação do homem novo, como a do Estado Novo em si. Avanços foram implementados na política e economia nacional, isso é certo, mas seria muito otimismo acreditar que a reforma habitacional, mesmo estando no discurso oficial do ditador e dos presidentes que se seguiram, faria parte do projeto de desenvolvimento nacional, como de fato não o fez. Vargas foi um hábil estadista, conseguindo apoio nos meios políticos mais diversos através da incorporação de políticos e intelectuais de esquerda e de direita em seus ministérios. O ditador promoveu uma repressão violenta aos comunistas, ao mesmo tempo em que incorporou intelectuais e artistas de vanguarda, com claras tendências de esquerda, em seu governo, apaziguando com ações dessa natureza os ânimos do controverso cenário político e social do Brasil em processo de industrialização.

Com a tabulação dos projetos pesquisados, pudemos avaliar que os primeiros conjuntos produzidos pelos IAP's, entre o final dos anos 30 e início dos anos 40, possuíam uma enorme variação tipológica, conjugando vários modelos de blocos, casas e edifícios (BONDUKI, KOURY e MANOEL, 2003). Mesmo a Fundação da Casa Popular, no início da sua produção, realizou pesquisas com novos materiais e trabalhou com diversas tipologias experimentais, como é o caso do Núcleo Residencial Carmela Dutra, com mais de 2.000 unidades habitacionais, construído no Rio de Janeiro entre os anos de 1947 e 1956 (MANOEL, 2004).

Tratava-se de uma fase de experimentação, de apropriação do ideário moderno e de outros modelos de produção em massa divulgados no Brasil por vários meios, já citados. Neste período, foi desenvolvida uma verdadeira pesquisa de soluções arquitetônicas, urbanísticas e construtivas, cujo exemplo pioneiro é o conjunto Realengo, de Carlos Frederico Ferreira. Como o próprio arquiteto afirmou, nunca se tinha de enfrentado o desafio de produzir um grande conjunto habitacional no Brasil quando o presidente do IAPI, Plínio Cantanhede, Ihe pediu um projeto com mais de 2.000 unidades em 1938 (Bonduki 1998).

O projeto do Realengo, que ganhou medalha de ouro no IV Congresso Pan-americano de Arquitetos em 1940, teve o início de sua construção no mesmo ano e, em 1943, eram entregues as primeiras habitações aos moradores. O projeto, como vimos, é marcado por uma enorme diversidade 
tipológica, abrangendo várias soluções de unidades térreas, assobradadas e ainda um bloco de apartamentos, com área de comércio no térreo. Foi o primeiro conjunto de grandes proporções construído no país e essa experiência permitiu que outros grandes empreendimentos fossem realizados.

A questão colocada naquele momento de início da produção habitacional custeada pelos cofres públicos era a de estabelecer parâmetros para uma produção que conjugasse a qualidade urbanística e arquitetônica das unidades a um bom aproveitamento dos terrenos e a um custo relativamente baixo de construção, com a perspectiva de possibilitar uma produção massiva de moradia, no âmbito das intenções de Vargas, que pretendia fazer da produção de habitação com recursos da previdência mais uma marca de sua atuação como protetor dos trabalhadores.

Este conjunto de experiências, apesar de toda dificuldade em relação a um modelo de intervenção, foi um momento importante de consolidação da experiência moderna para a arquitetura brasileira onde os arquitetos se depararam com o desafio das propostas dos primeiros Congressos Internacionais de Arquitetura Moderna - CIAM, La Sarraz (1928), Frankfurt (1929) e Bruxelas (1930), que constituíram o espaço mínimo da moradia e a racionalidade construtiva como o centro das preocupações da arquitetura moderna a partir do final dos anos vinte. A riqueza tipológica e urbanística conseguida por estes conjuntos e levantada no escopo da pesquisa temática permite realizar tal afirmação (BONDUKI, KOURY e MANOEL, 2003).

Entretanto, esta fase experimental e precursora da produção dos IAP's, que ocorreu entre o final dos anos 1930 e meados dos anos 1940, com destaque para o trabalho de Ferreira, foi, à partir dos anos de 1950, perdendo força criativa e se tornando referencia "morta". As propostas inovadoras de projeto arquitetônico cederam espaço a projetos cada vez mais padronizados, uniformes e empobrecidos do ponto de vista da arquitetura, o que caracteriza os empreendimentos dos anos 50 e 60, prenunciando o que viria a ser a tônica da produção do BNH depois de sua criação em 1964. A solução do bloco "H", com caixa de escada servindo a quatro apartamentos por andar, isolado ou conjugado foi a mais adotada à partir de meados de 1950, por realmente ser a 
solução que mais otimiza a área de circulação comum². Não é por acaso que essa tipologia é largamente utilizada até hoje, especialmente pelas COHAB's.

$\mathrm{Na}$ fase de consolidação da produção habitacional dessas instituições, nota-se que alguns institutos fizeram opções próprias quanto à tipologia a ser adotada, que estavam vinculadas ao amadurecimento do setor de projeto do órgão e às condições socioeconômicas dos associados.

O IAPI e o IAPB foram os que mais adotaram a solução de blocos médios com modelo de arranjo habitacional; cerca de $70 \%$ da produção de unidades desses institutos foi agenciada em blocos de até 04 pavimentos. Muitos dos empreendimentos do IAPB se caracterizaram pela implantação de edifícios altos ou blocos únicos de quatro pavimentos em pequenos terrenos, inseridos na malha urbana e próximos aos centros das cidades, próximo ao local de trabalho dos bancários. Conhecidos como "edifícios dos bancários", este tipo acabou por se constituir, ao lado dos "conjuntos dos bancários", formados por blocos, em fator identidade da categoria, que organizada em seu combativo sindicato, foi o que mais se empenhou pela implementação de um programa de produção habitacional para os associados. As casas em fileira, geminadas ou isoladas também foram utilizadas, mas em escala menor, e com uma vertente bastante tradicionalista, com uma linguagem próxima do mission style americano ${ }^{3}$ ou de um neocolonial ou ecletismo bastante simplificado. A variação tipológica e de arquitetura talvez seja a mais evidente dentre os institutos, inclusive pelo número de arquitetos que passaram pelas instituições.

A concepção de projeto do Instituto de Aposentadoria e Pensões dos Industriários (IAPI), cujo setor de arquitetura estava a cargo do já citado Carlos Frederico Ferreira, situa-se na preocupação de gerar tipologias que pudessem ser implantadas numa produção massiva. Este órgão foi o que mais se preocupou em estabelecer uma política de projeto, relacionando as soluções

2 O trabalho de BONDUKI, KOURY e MANOEL apresentado no DOCOMOMO 05, em 2003, faz a análise dos blocos de apartamentos construídos até aquele momento, focalizando 0 agenciamento das circulações verticais e horizontais. A solução com galeria de circulação comum representa uma área construída muito grande em relação às áreas de cada unidade de habitação, ao passo que o bloco "H" é o que representa menor área comum de circulação por unidade.

${ }^{3}$ A tese de doutorado de Fernando Atique (2007) revela a difusão desse estilo de construção no Brasil a partir dos anos de 1920 e sua adoção em várias modelos de casas econômicas publicadas nas revistas de arquitetura à época. 
habitacionais com as categorias de cidades onde eles seriam edificados, buscando fazer da economia uma diretriz básica de sua atuação: o custo da terra passou a ser um elemento determinante para a opção adotada, pois os empreendimentos imobiliários deveriam ser rentáveis. Assim, nas cidades como São Paulo, Rio de Janeiro, Porto Alegre, Salvador e Belo Horizonte, os conjuntos do IAPI foram, em sua grande maioria, blocos de altura média, entre três e sete pavimentos, em alguns casos chegando a edifícios altos e, em outros mesclando diferentes tipologias, como no caso de Porto Alegre. Já nos empreendimentos implantados no interior do estado de São Paulo, onde o custo da terra era menor, optou-se pelas casas unifamiliares preferencialmente implantadas em fileiras, apesar de ter também adotado o modelo de casas econômicas tradicionais difundidos à época. O custo da terra foi uma discussão que perpassou todos os órgãos e acarretou diversas soluções de implantação de tipologias habitacionais, procurando o melhor aproveitamento das glebas e/ou redução do custo da construção da unidade habitacional.

O Instituto de Aposentadoria dos Comerciários (IAPC), em geral, adota a solução da casa unifamiliar, tendo o mote da cidade-jardim como norteador dos projetos nas zonas suburbanas (sem efetivamente sê-lo) ${ }^{4}$. Ulysses Hellmeister realizou projetos característicos de casas sobrepostas para as "cidades-jardins dos comerciários", mas poucos exemplos foram construídos: Olaria, no Rio de Janeiro; Cidade-Jardim, em Recife e um conjunto em São Paulo inteiramente demolido. No período do pós-guerra, quando se intensificou a crise e a produção habitacional, foram realizadas experiências para a utilização de novos materiais e processos construtivos, mas de forma limitada. No Conjunto Residencial Coelho Neto, implantou-se uma usina de pré-fabricação de um bloco de solocimento, cujos resultados não foram suficientemente avaliados, nem se deu noticias sobre a sua eventual reprodução em outros empreendimentos. De certa forma, as posturas projetuais do IAPC não eram tão claras como as do IAPI.

Já o Departamento de Habitação Popular, foi sem dúvida, o que alcançou mais destaque na qualidade arquitetônica dos projetos - se observado pela ótica da historiografia da arquitetura moderna brasileira, tendo contado com dois

${ }^{4}$ A partir do Decreto 1749/1937, que abriu a possibilidade de inversões imobiliárias dos institutos, o IAPC adquiriu grande quantidade de terras, sobretudo no Rio de Janeiro. Eram grandes glebas em diversos bairros da zona norte e subúrbio, como Méier, Del Castilho, Ramos, Olaria e terrenos menores em locais mais valorizados no centro e bairros da zona sul. 
expoentes deste movimento como Reidy e Bolonha - mas que esteve distante de formular um equacionamento consistente ao problema habitacional. Dos quatro conjuntos construídos pelos órgãos, três foram projetos que se inspiraram em propostas de Le Corbusier e foram desenvolvidas magistralmente, em soluções de grande plasticidade, com destaque para Pedregulho.

Os conjuntos habitacionais da FCP, a agência que de fato deveria ser uma resposta ao problema da moradia, são bastante característicos por causa do modelo habitacional implícito no próprio projeto de Lei que a instituiu. Dependendo basicamente de terrenos doados para a construção de conjuntos habitacionais, e com baixíssimo capital para investir, a FCP adotou a tipologia de unidades unifamiliares por se tratar do meio mais barato de construção no Brasil. Por depender de doações e infraestrutura provida pela prefeitura, a FCP implantou seus modelos de casas tradicionais em situações bastante diversas: edificando os modelos em áreas já loteadas e doadas pela prefeitura (como nos conjuntos de Campinas, Itu, e parte do conjunto de Marechal Hermes), propondo o parcelamento do solo em vazios urbanos (como em Araraquara, SantosMacuco e Santo André), ou propondo o reparcelamento do solo e abertura de vias em quadras existentes (Vilas em Santos e São Carlos).

Quanto agenciamento urbano da FCP em glebas doadas sem parcelamento previamente estabelecido, podemos verificar uma tendência à redução das vias de automóveis no interior dos conjuntos; à utilização de passagens de pedestres entre grupos de casas, e à concentração de equipamentos coletivos em praças. Tais escolhas, em nossa leitura, estão mais relacionadas à tentativa de se obter maior número de lotes no parcelamento do solo, do que propriamente a questões relacionadas ao urbanismo funcionalista ou do subúrbio-jardim, pois não existem áreas verdes entre as edificações e nenhuma diferenciação formal ou tipológica quanto às unidades que faceiam as ruas.

Observando o conjunto da produção como um todo, os conjuntos habitacionais com características arquitetônicas e urbanísticas diferenciadas, que podem ser classificados como exemplos pertinentes ao cenário brasileiro, são sobretudo trabalhos autorais, fruto da interpretação e esforço pessoal de um arquiteto ou equipe, e não o fruto de uma política consciente. Nas cidades europeias observadas, os conjuntos também poderiam ser considerados autorais, mas de outra forma, pois são o fruto de uma política federal que 
obrigava a formação de toda uma estrutura associada à administração local para a sua implementação. Assim, sem dúvida, esses conjuntos teriam características semelhantes numa mesma cidade, pois todas as iniciativas eram analisadas ou produzidas por uma equipe municipal, e fariam parte de um conjunto de intervenções para uma reforma habitacional completa, associada a um planejamento urbano de longo prazo. Basta recordar que os planos de Expansão de Berlage e Van Eesterem para Amsterdam, que orientaram quase a totalidade da produção em massa de habitação na cidade, perduram durante décadas (vinte anos o primeiro e mais de trinta anos o segundo), e só foram revistos quando concluídos. Como isso não aconteceu no caso brasileiro, é comum vermos soluções tão distintas e desarticuladas numa mesma cidade, como o Rio de Janeiro - podemos citar os conjuntos de Pedregulho, Deodoro, Areal, Marechal Hermes, Carmela Dutra, Olaria, Coelho Neto e Casa da Bancária. A diversidade em si não é um problema na produção habitacional, pelo contrário, estimula a criação de novos projetos e cria uma identidade com o local; o que nos interessa ressaltar aqui é a desarticulação das propostas, até de um mesmo Instituto, na sua produção numa cidade específica, contribuindo para o processo de periferização e desarticulação das estruturas urbanas e serviços básicos.

Outro fator que nos interessa abordar aqui diz respeito à execução da política proposta para as cidades europeias. Como pudemos observar na literatura específica e em visita aos conjuntos edificados, na qual tivemos a possibilidade de entrevistar moradores antigos e atuais, os conjuntos foram projetados e implantados em sua totalidade, com a infraestrutura urbana concluída, paisagismo executado e, em muitos casos, as casas eram equipadas com facilidades como cozinha completa e mobiliada. Ou seja, o espaço privado, coletivo ou não, e o espaço público eram claramente delimitados e construídos ${ }^{5}$, possibilitando que o conjunto fosse apropriado pelos moradores da maneira como planejado pelos arquitetos. Tal situação foi rara nos conjuntos brasileiros, como pudemos averiguar com as visitas in loco e nas entrevistas com moradores antigos.

Com exceção do conjunto Passo d'Areia, em Porto Alegre, era de praxe a entrega dos conjuntos habitacionais sem a infraestrutura urbana concluída, como

5 Podemos citar Spangen; Hoek van Holland; Kiefhoek; Papaverhof; Transvaalt; Vreewijk; Eigen Haard; Betondorp; Niedrrad; Römerstadt, Prauhein; etc. 
por exemplo, pavimentação, galeria de água pluvial ou energia elétrica; embora presentes nos projetos, os equipamentos coletivos previstos raramente eram construídos em sua totalidade; as áreas de lazer e áreas verdes invariavelmente não eram delimitadas e construídas, permanecendo durante anos como terra de ninguém, e muitas vezes invadidas pelos moradores.

Outro fator a ser abordado aqui, diz respeito a dicotomia entre grandes obras públicas e sua implementação. Apesar das dificuldades enfrentadas pela FCP, podemos observar que os pequenos conjuntos edificados nas cidades brasileiras acabaram sendo plenamente incorporados pela malha urbana ao longo do tempo. Esse fato pode ser entendido tanto pela ausência de avanços no planejamento urbano e pelo crescimento das cidades impulsionado pela iniciativa privada através de loteamentos "tradicionais", no qual o projeto da FCP se encaixava muito bem, mas também pela falta de integração entre conjuntos ditos modernistas e a cidade existente, reforçada pela não implementação dos equipamentos públicos e facilidades para a vida dos moradores, que seriam a ligação entre o novo e o velho.

Além das dificuldades dessa falta de infraestrutura, na maioria esmagadora das vezes os conjuntos não eram servidos por transporte público eficiente, e os moradores ficavam ilhados na periferia das cidades. Essa postura frente à execução das conjuntos também reforça a face populista da iniciativa; era necessário fazer uma inauguração, geralmente no $1^{\circ}$ de maio, entregar as unidades e agradar a população, sem levar em consideração os problemas que seriam enfrentados pela falta de infraestrutura. A própria política pública de habitação perpetuava uma condição precária de habitabilidade, legitimando os loteamentos sem infraestrutura tão comuns nos anos 1940 e presentes até hoje nas nossas cidades. 
CONCLUSÃO 
A produção brasileira de habitação no período estudado, como demonstrado anteriormente, tem um caráter bastante conflitante. Ao mesmo tempo em que se coloca na posição de vanguarda em casos brilhantes de implementação de moradia econômica, como em Realengo, Penha, Pedregulho, Passo d'Areia, Lagoinha, Japurá e outros, também produz uma arquitetura e urbanismo desprovidos de qualquer qualidade técnica ou estética, como em diversos conjuntos da FCP e IAP's espalhados pelo Brasil. $\mathrm{Na}$ verdade, as razões para essa contradição tem raízes muito mais profundas do que o debate técnico simplesmente, pois refletem a constituição da sociedade brasileira no período populista, e a Fundação da Casa Popular é o retrato mais acabado da construção da "política" do Estado do Bem-Estar Social no Brasil.

A FCP foi, em sua breve duração de dezoito anos (1946 - 1964), uma tentativa do Estado Brasileiro de atuar de modo firme e eficaz para resolver o problema crucial, até aflitivo, do déficit habitacional para as classes trabalhadoras, seja na cidade, seja no campo.

Com o lento, mas contínuo e progressivo processo de urbanização do país $^{1}$, o déficit habitacional nas cidades passou a se constituir em um problema com desdobramentos na esfera social e política, com implicações sanitárias e policiais; mas também a população remanescente no campo sofria com a falta de moradias que atendessem suas necessidades de habitação condigna.

Ficava evidente, à época, que o problema não deveria ser deixado a cargo dos particulares, conforme a pura doutrina liberal norte-americana, por exemplo, mas exigiria, para seu equacionamento e resolução, a intervenção de uma política de Estado, conforme, mais apropriadamente aas diretrizes do Estado de Bem Estar Social, nos rumos da social democracia europeia.

Mesmo que o Gal. Eurico Gaspar Dutra, Presidente eleito após a queda da ditadura de Getúlio Vargas, ao fim da $2^{\mathrm{a}}$ Guerra Mundial e a vitória dos Aliados e sua política liberal democrata, não fosse o maior defensor do Welfare State, ele se viu obrigado pelas circunstâncias e pelos compromissos assumidos, a intervir no problema do déficit habitacional criando a Fundação da Casa Popular pelo Decreto Lei 9218, de $1^{\circ}$ de maio de 1946 - data singularmente significativa a simbolizar que a FCP viria a resolver o problema

\footnotetext{
${ }^{1}$ Com exceção de São Paulo, Rio de Janeiro e outras poucas cidades, cujo crescimento urbano se deu de forma muito acelerada.
} 
habitacional das classes trabalhadoras, a simbolizar que a habitação social passaria a ser uma política prioritária do Estado Brasileiro.

Até então, o problema habitacional fora equacionado parcialmente pelos Institutos de Aposentadoria e Pensão (IAP's). Entretanto, os Institutos não se dedicavam à resolução do problema de falta de habitação social para as classes trabalhadoras, mas consideravam a construção de habitações como atividade de terceiro plano, com a finalidade de aplicação de suas reservas financeiras visando à sua ampliação.

Essa concepção explica porque os IAP's se dedicavam à construção de edifícios de luxo para as classes mais abastadas, ou então conjuntos habitacionais destinados exclusivamente para seus afiliados, em particular destinados ao aluguel. Essas eram formas de inversão de capital financeiro que possibilitaria seu retorno ampliado.

Em outros termos, os IAP's não faziam parte de uma política de Estado que tivesse por objetivo resolver o problema da habitação social no Brasil. Para os IAP's, a construção de moradias, particularmente aquelas destinadas à locação, se restringia ao plano financeiro e atuarial.

Essa política deveria, em tese, ser equacionada pela Fundação da Casa Popular, cujo objetivo era, conforme seu projeto, construir 100.000 unidades de habitações populares em sua fase inicial. Conforme o Decreto Lei 9218, a FCP..."destinar-se-á a proporcionar a brasileiros ou estrangeiros com mais de dez anos de residência no país ou com filhos brasileiros, a aquisição ou construção de moradia própria, em zona rural ou urbana."

No entanto, de 1946 a 1960, a FCP construiu apenas 17.780 unidades habitacionais e 171 conjuntos, sendo que, de 1961 a 1964, ano de sua extinção, não construiu nenhum metro quadrado.

Somente esses números já demonstram que a Fundação da Casa Popular não atingiu nem a meta de construções inicialmente proposta, revelando não só a falência do projeto, quanto a própria ineficácia do Estado Brasileiro nessa questão.

Para se ter uma clara percepção dessa falência, compare-se com os E.U.A e com a Inglaterra.

Nos Estados Unidos que, por sua tradição ultra liberal, o Estado não intervém na questão habitacional, a não ser como regulador e fiscalizador dos cumprimentos das regras estabelecidas, no ano de 1917, dentro de um período 
de economia de guerra, construiu as warvillages, residências para trabalhadores, beneficiando 360.000 trabalhadores e suas famílias.

$\mathrm{Na}$ Inglaterra, finda a $1^{\text {a }}$ Guerra Mundial, o Estado Britânico promulgou leis de Habitação e leis de Planejamento Urbano, incumbindo as administrações municipais de equacionarem e resolverem o problema de déficit de habitações sociais e, para tanto, criou também os fundos de recursos necessários.

De 1919 a 1934, quinze anos, portanto, as administrações locais foram encarregadas de produzirem 763.000 moradias na Grã-Bretanha (SILVA, 2007).

Diante desses dados cabe perguntar, a guisa de conclusão, sobre as razões que podem explicar o fracasso do processo de implantação de uma política habitacional no país.

Fosse o Estado Brasileiro ultraliberal, cabendo-lhe apenas a tarefa reguladora e fiscalizadora, poder-se-ia atribuir à iniciativa privada a incapacidade de equacionar e resolver o problema do déficit de habitação social.

Ora, o Estado Brasileiro nunca se definiu claramente pela liberal democracia, desde o século XIX. Toda literatura existente sobre o assunto demonstra que os políticos brasileiros, desde aquela época, construíram um entendimento muito estreito sobre os limites do liberalismo e da democracia, repudiando-os exatamente naqueles tópicos que significassem avanços sociais.

É bastante conhecida na literatura e sempre relembrada a posição do Senador do Império, Bernardo de Vasconcelos, para quem as ideias liberais não poderiam ser confundidas com abertura de espaços e concessão de direitos para o "poviléu", a "escumalha social", conforme as palavras de Emilia Viotti da Costa (2007).

A título de exemplo pode-se consultar os argumentos dos industriais e políticos brasileiros que se posicionaram contra os projetos de leis que visassem à concessão de direitos trabalhistas, por exemplo, leis de férias e do salário mínimo. Seus posicionamentos, conforme a demonstração do livro, $\mathbf{0}$ pensamento industrialista no Brasil (1889 - 1930), de Edgar Carone (1977), revelam terem os industriais e políticos brasileiros, já adentrando o século $X X$, uma mentalidade ainda escravocrata, para quem os trabalhadores, em particular os operários, não deveriam ter direitos considerados "abusivos" e "luxuosos".

Mas, o Estado Brasileiro também não era organizado conforme os preceitos da esquerda, de modo que se pudesse atribuir à crise habitacional a crise do sistema comunista. Ao contrário, os IAP's, que se dedicaram às tarefas 
já referidas, foram criados no primeiro período Vargas (1930 - 1945), em que o Estado Brasileiro era mesclado de tintas fascistas permeadas do romantismo conservador católico. Tanto assim que muitos da equipe varguista de governo estavam ligados à Ação Católica, como o próprio Rubens Porto.

Mas, o problema também não era técnico. Paulo Bruna, no seu livro Os Pioneiros da Arquitetura Moderna, demonstra que existiam condições técnicas e ciência das experiências quantitativa e qualitativamente importantes para a implementação de uma arquitetura moderna voltada para o problema habitacional popular dado o nível de especialização e dos debates dos arquitetos brasileiros. Do ponto de vista técnico, existiam condições para a intervenção do Estado Brasileiro visando à resolução do problema da habitação social e mesmo dos problemas do planejamento urbano inerentes a ele.

Rigorosamente falando, desde o século XIX o poder público no Brasil, em particular em São Paulo, se preocupava sim com o urbanismo e com as edificações. Em um primeiro momento, as preocupações se voltam para o saneamento da cidade, sempre sujeita a surtos de doenças epidêmicas e contagiosas. Depois, para o embelezamento da cidade e também para disciplinar o uso do espaço público e descongestionamento do trânsito que se intensificava.

Raquel Rolnik, em seu livro, $\boldsymbol{A}$ cidade e a lei, explana de modo claro e lúcido esse processo, revelando também que as intervenções do poder público em São Paulo, dos fins do século XIX em diante, se preocupou mais em disciplinar a residência do pobre, de tal maneira que ele não conseguia mais residir no centro da cidade e iniciou o processo de "periferização" da capital paulista. Como demonstra Bonduki (1998), a crise habitacional dos anos 1940, e a ineficiência do Estado em executar uma política habitacional coerente fez com que o processo de periferização, com loteamento precários e a autoconstrução, se incentivasse e fosse legitimada socialmente como solução para o problema da falta de moradia.

Desse modo, se se quiser um entendimento sobre as razões da falência do projeto da Fundação da Casa Popular, como de resto da crise constante no setor habitacional e do urbanismo no Brasil, há que se entender suas raízes populistas, clientelistas e autoritárias, que impregnam o Estado Brasileiro desde a Proclamação da República, mas cujas raízes estão firmadas na própria organização do Estado imperial e escravocrata do século XIX. 
Existe uma extensa literatura que estuda esse aspecto do Brasil, essas raízes. Essa literatura não foi discutida na presente tese, por fugir de seus objetivos, mas de que alguns exemplos podem ser lembrados, como Os donos do poder, de Raymundo Faoro (2001); A consciência conservadora no Brasil, de Paulo Mercadante (2003); Brasil: o fracasso do conservadorismo, de Paulo do Couto e Antônio Houais (1989); Coronelismo enxada e voto, de Victor Nunes Leal (1976), e tantos outros.

Essa literatura mostra que, desde a segunda metade do século XIX, no Brasil, se firmaram algumas ideias e práticas do exercício do poder e de administração da Res Publica.

A primeira dessas ideias e práticas é exatamente a negação da ideia de res publica, da concepção de coisa pública. A ideia de coisa pública, que está nos fundamentos da liberal democracia, preceitua que o Estado detém um poder que emana do povo e que o governo, na qualidade de gerenciador da coisa pública, deve agir para garantir os direitos e as liberdades individuais e para realizar o bem público, o bem de todos.

No Brasil, no entanto, desde Pedro II se firmou a noção de Estado patrimônio, Estado como propriedade de seu governante e, como tal, sujeito apenas aos seus interesses, que às vezes pode até coincidir com o interesse público, mas não necessariamente.

A segunda dessas ideias e práticas é a concepção de governante como "pai do povo". Não por acaso, Getúlio Vargas, durante o período em que foi ditador, era cognominado de "pai dos pobres". Essa é uma ideia de tintas e fortes raízes firmadas no terreno do romantismo católico conforme o livro o Pêndulo da História, de Ivan Manoel (2004).

Nessas condições, o interesse público passa a ser considerado um benefício que o governante pode, ou não, conceder, dependendo de seu critério estritamente particular de avaliação.

Em outros termos, conforme as duas ideias consolidadas no Brasil, não existe o bem público, como também não o princípio de cidadania. O que existe é o "povo" que deve ser tutelado e recebe benefícios conforme os interesses políticos do governante, aí incluído o próprio Legislativo.

Esse modo de conceber o Estado, o governo e o exercício do poder aparece claramente nos atos legislativos da criação e funcionamento da 
Fundação da Casa Popular, particularmente no que dizia respeito às suas fontes de recursos e forma de financiamento.

O Decreto Lei 9218, que instituiu a Fundação da Casa Popular, determinava que seu capital fosse de 2.000.000.000 de cruzeiros (art. $9^{\circ}$ ), dos quais 3.000.000 de cruzeiros proviriam da doação do Governo Federal (art. $8^{\circ}$ ), e os outros 1.997.000.000 seriam integralizados por doações dos Estados e Municípios na forma de terrenos, e por um empréstimo compulsório sobre as operações imobiliárias.

Portanto, o empréstimo compulsório era a única fonte garantida de recursos para a Fundação da Casa Popular.

Porém, pressionado pelos interesses políticos, o Governo Federal alterou o Decreto Lei 9.218, de maio de 1946, por meio do Decreto Lei 9.777, de 06 de setembro de 1946, eliminando justamente o empréstimo compulsório, isto é, eliminando a única fonte garantida de recursos para a Fundação da Casa Popular.

Em seu lugar foi criada uma taxa sobre a transmissão de imóveis, taxa que, a bem da verdade muito pouco foi recolhida, porque a tarefa de cobrá-la e repassá-la à Fundação da Casa Popular cabia aos Estados, e esses a rejeitaram alegando que ela traria fortes "desgastes" políticos. Como visto nos exemplos notórios de promoção pública de habitação, a criação de um fundo de reserva era uma das primeiras atitudes do Estado para solução do problema, ao lado de leis para expropriação de terras.

A concepção paternalista, no entanto, não se restringiu apenas a desprover a Fundação da Casa Popular dos fundos necessários ao seu funcionamento, a pretexto de proteção ao mutuário, ou de se evitar o "desgaste político". Na própria organização e funcionamento do sistema para financiar o mutuário reapareceu a ideia de se baratear o custo financeiro em benefício dos que adquiriram suas casas por meio da Fundação da Casa Popular.

Segundo as regras do financiamento, o mutuário somente poderia comprometer até $25 \%$ de sua renda no pagamento das parcelas do empréstimo contraído. Entretanto, como se admitia a somatória dos ganhos de todos os membros da família para se compor a renda familiar, não raro o comprometimento ultrapassava os $25 \%$, chegando mesmo até $40 \%$ da renda auferida pelo contraente do financiamento (MANOEL, 2004). 
Portanto, já estava aí posto o risco da inadimplência. Mas, além disso, como a Fundação da Casa Popular fora desprovida de fontes de recursos financeiros, ela, para ter fundos para custear as construções previstas, tomava empréstimos junto aos IAP's ou no mercado financeiro à taxa de $5 \%$ anuais, e os repassava aos usuários a $3 \%$ anuais, e isso em um momento histórico em que a inflação sempre esteve acima de $6 \%$ ao ano.

O resultado evidente dessa prática de defesa hipotética do mutuário de baixa renda foi o seu inverso.

Com a Fundação da Casa Popular sofrendo um prejuízo aritmético de, ao mesmo, $8 \%$ ao ano, considerando que as inadimplências ocorreram, e que não existia um capitação constante de recursos, logo os empréstimos concedidos se converteram em "fundos perdidos" gerando, evidentemente, sua descapitalização impedindo, assim, que continuasse a sua tarefa: construir habitações de interesse social para as classes sociais mais carentes da sociedade brasileira.

Em outros termos, só por esses dois fatos arrolados tem-se a impressão de que a Fundação da Casa Popular foi criada para não funcionar e não perdurar.

A pesquisa temática demonstrou que o IAPI foi 0 instituto mais aparelhado e capacitado tecnicamente para enfrentar o problema da moradia e propor inovações no projeto e na construção. Contudo, a produção destinada ao Plano $\mathrm{A}$, para os associados de baixa renda, não foi superior em números à produção da FCP - cerca de 20.000 unidades em ambos os casos ${ }^{2}$; a FCP distribui esses números em cerca de 170 conjuntos espalhados pelos estados da união, enquanto que o IAPI concentrou sua produção, 66 conjuntos, nos centros industriais, locais com maior número de associados. Se por um lado o IAPI conseguiu criar uma estrutura de produção e projetos consistentes do ponto de vista da arquitetura e do urbanismo, produzindo iniciativas de vanguarda, a FCP universalizou o benefício da habitação. Esse dado bastante revelador, pois coloca em pé de igualdade a capacidade produtiva do IAPI e da FCP, reforça a leitura da falência da produção nesse período pelo próprio formato das políticas implementadas, e não pela proposta técnica de arquitetura e do urbanismo.

2 Idem. 
O IAPI desenvolveu, na verdade, todo um aparato para investimento e retorno de capital, de forma a ter rentabilidade com seus empreendimentos imobiliários; sua política de atuação, com pesquisas e tentativas de industrialização do processo, adotando e adaptando preceitos da arquitetura racionalista para economia na construção, não reflete na verdade uma política de habitação social, pois inexiste a associação entre os interesses dos poderes municipais, estaduais e federais (pressuposto para uma política coerente). A lei que implementava a Fundação da Casa Popular tentou estabelecer esse vínculo, além de tentar sanar as deficiências da indústria da construção civil e da infraestrutura urbana, mas existia uma dicotomia muito grande entre discursar sobre a questão habitacional e promover habitação social, entendendo-a como um direito e como parte imprescindível do planejamento urbano.

Reidy, em discurso sobre as vantagens da construção de blocos para a gleba de Deodoro perante o Conselho Central da Fundação da Casa Popular, em 1952, expôs com clareza os vários revezes da política e produção habitacional naquele momento:

"A residência individual e a coletiva, seja a casa térrea isolada, com jardim e quintal e o apartamento em edifícios de diversos pavimentos: velho tema de discussões que parecia já ser assunto superado, mas que precisa ser retomado nesta oportunidade". A primeira questão que se apresenta é a seguinte: qual o tipo de habitação mais indicado para as classes menos favorecidas: o individual ou o coletivo? A favor da habitação individual podemos alinhar os argumentos de permitir maior tranquilidade e isolamento, amplitude de movimentação ao jardim e facilidade de vigiar as crianças. Em compensação sua conservação é cara e trabalhosa, obriga a percorrer grandes distâncias para utilizar-se dos serviços externos e absorve grande área de terrenos, cabendo a cada habitação uma cota muito elevada do mesmo. Se o custo da construção da casa térrea é mais barato que o do apartamento em edifício de vários pisos, o encarecimento resultante da soma das despesas necessárias à urbanização externas de áqua, luz e esgotos, pavimentações, etc., adicionadas à elevada cota correspondente 
ao terreno, torna, em condições normais, a casa isolada mais onerosa do que o apartamento.

A habitação coletiva, isto é, em apartamentos, em edifícios de vários andares embora tenha o custo de construção, por unidade, majorado pelas áreas destinadas aos acessos comuns e às escadas e pela despesa com estrutura, permite uma grande redução na cota de terreno, admite uma maior densidade demográfica, em condições satisfatória, proporciona maiores áreas livres para recreação, melhores condições de arejamento, economia nas despesas de urbanização e encurtamento das distâncias, facilitando a utilização dos serviços comuns externos. São essas, as principais características dos dois tipos de habitação. Não me parece, entretanto, que se deva, de plano, eliminar qualquer das duas modalidades. 0 exame de cada caso concreto indicará a solução adequada. O que não poderá ser nunca esquecido é que a habitação é a célula mater da cidade e que, como elemento fundamental de sua estrutura, deve estar sempre selecionada com os demais elementos que constituem o complexo urbano. O que não é admissível, é que a própria Administração Pública, continue a contribuir para agravar os problemas, adequado que, devido à falta de previsão e deficiência de instalações assistências, transforma-se, em pouco tempo, nas piores favelas.

Aos órgãos da Administração Pública compete planejar para 0 bem-estar social. A função habitar não se resume na vida de dentro de casa. Ela se estende também em atividades externas, compreendendo serviços e instalações complementares que proporcionam ao habitante as facilidades necessárias à vida de todo o dia. Casa isolada ou habitação coletiva, casa térrea ou edifício de vários pisos, qualquer das duas modalidades exige a presença de serviços comuns, externos, facilmente acessíveis aos seus moradores. Da mesma maneira que deverão ser previstos o abastecimento d'água e a iluminação pública, terão que ser considerados o abastecimento de gêneros, os estabelecimentos de ensino, a assistência médica, as áreas para 
a recearão e a prática dos esportes; enfim, todas as instalações, locais e edifícios cuja frequência é imposta pelas necessidades da vida cotidiana.

Algumas dessas instalações poderão ser custeadas pela municipalidade local, outras por organizações especializadas ou associações de iniciativa particular. De qualquer forma o que importa é que, por este ou por aquele sistema, seja assegurada a existência daqueles serviços por ocasião da ocupação das habitações. A ausência das facilidades acima mencionadas, assim como de um serviço organizado de assistência social, contribui de forma decisiva para a transformação dos núcleos residenciais em favelas." ${ }^{3}$ (grifos nossos)

A falência da Fundação da Casa Popular reflete a própria falência das políticas habitacionais de interesse social e do próprio planejamento urbano, mas revela, sobretudo esse desentrosamento do Estado Brasileiro em seus três níveis - o municipal, o estadual e o federal.

Nesse quadro de desentrosamento entre eles, em que cada um se entende como soberano em sua esfera de competência, o nível municipal é o que mais se julga independente. Não por acaso é clássico o livro de Maria Isaura Pereira de Queiroz (1956), O mandonismo local na vida política brasileira.

No município, o mandonismo local tem um efeito perverso, talvez mais do que nos outros dois níveis, dada a proximidade entre os poderes municipais (a prefeitura e a câmara municipal) e a população, propiciando mais diretamente a prática do clientelismo, do paternalismo e seu correlato, o filhotismo.

No período abordado por esta tese, o prefeito e o presidente da Câmara Municipal ainda conservavam o status de chefes políticos (hoje cognominados, "caciques políticos"), o que Ihes dava a pretensão de seguir, ou não, as políticas públicas projetadas pelo governo estadual ou federal, além de reterem em suas mãos e distribuírem como favor aquilo que se estatuía como direito do cidadão. Mas, isso não significava que também os governos estaduais e o próprio governo federal não praticassem de igual maneira.

${ }^{3}$ Fonte: FUNDAÇÃO DA CASA POPULAR (1953). Anais do Conselho Técnico, p. 154-157. 
Veja-se, como exemplo, a atitude do Estado de São Paulo em relação às taxas que deveria recolher junto à Fundação da Casa Popular. Segundo o Decreto Lei 9777, o Estado deveria recolher a taxa de transmissão de imóveis e fazer o repasse do montante para a Fundação da Casa Popular.

O Estado de São Paulo se comprometeu com o recolhimento e o repasse, mas decretou que somente entregaria à Fundação da Casa Popular $30 \%$ do total arrecadado em cada exercício fiscal, e reteria $70 \%$ em seus cofres, agindo acima e além de um decreto da União. Essa situação perdurou até 1961, durante o governo de Jânio Quadros.

Quanto às prefeituras, os Estatutos da Fundação da Casa Popular a partir da tentativa de reforma do órgão em 1951, exigiam um comprometimento no nível municipal em um ponto básico para que seu projeto fosse eficiente, qual seja, caberia às municipalidades providenciar o terreno e implantar a infraestrutura necessária para a construção projetada e sua posterior habitação.

Segundo o livro "Habitação e Poder" (Andrade e Azevedo, 1982), os conjuntos poderiam ser solicitados pelas prefeituras de cada cidade, que deveriam doar o terreno para o projeto e arcar com a infraestrutura necessária do local.

Mediante várias solicitações, a Fundação deveria ter como prioridade a necessidade do local, o apoio técnico da prefeitura (que preferivelmente deveriam ser responsabilizadas pelo empreendimento) e por último a ordem de solicitação. No entanto, segundo Andrade e Azevedo (1982), na maioria das vezes as localidades eram escolhidas por relações clientelísticas e de interesse político.

Como se lê em normas internas da FCP para a elaboração dos projetos, seus técnicos deveriam examinar os terreno doáveis em companhia do prefeito, caracterizá-los pelas condições topográficas, melhoramentos públicos (água, luz, esgoto, pavimentação, etc.), possibilidade de enchentes; selecionar o terreno com melhores condições e obter documento no qual a prefeitura se responsabilize pelas obras de infraestrutura. Com o terreno selecionado, deveriam relacionar os preços dos materiais de construção no local e da mão de - obra da região; examinar as peculiaridades locais construtivas e a possibilidade de obtenção de materiais vernaculares (MANOEL, 2004).

Com o terreno selecionado e essas informações recolhidas, o Departamento de Engenharia da FCP faria o projeto do conjunto. 
Invariavelmente, esse tipo de participação dos municípios não ocorreu no caso da FCP, mas podemos citar exemplos dos IAP's e DHP em que essa associação teve resultados interessantes: Passo d'Areia, em Porto Alegre, funcionando como um subúrbio-jardim na área de expansão da cidade; Japurá e Várzea do Carmo, em São Paulo, esse último com a intenção de ocupar um vazio urbano e propiciar habitação barata perto das indústrias; Pedregulho, Gávea, Paquetá e Vila Isabel, no Rio de Janeiro, nesses casos, por se tratar de uma iniciativa local para suprir uma demanda específica, a dos funcionários públicos.

Uma das dificuldades para essa coerência de projetos políticos era (e é) que no Brasil as terras (glebas) urbanas passaram a se constituir em um estoque de capital imobilizado a longo prazo, à espera de sua valorização, muitas vezes forçada. Como também sempre houve as coincidências entre a posse das terras urbanas e a posse do poder político municipal, ou a subserviência da segunda à primeira, nunca se conseguiu estabelecer uma legislação apropriada e ágil para as desapropriações em caráter social visando à construção de habitações para as classes mais pobres.

Nessas condições, as prefeituras ficavam sem instrumentos legais para estabelecerem um planejamento para a construção de habitações populares, e sem instrumentos para planejar o próprio crescimento urbano, de maneira ordenada e atendendo os interesses comuns. Por isso, quando a prefeitura conseguia a desapropriação pretendida, em geral a área desapropriada, ou recebida em doação, era aquela de interesse, não social, mas de seu proprietário.

Mas, convém ressaltar que essa situação não afligia apenas a Fundação da Casa Popular, mas também os IAP's. Embora os IAP's tenham se tornado os maiores proprietários de terras no Brasil, eles geralmente adquiriam áreas distantes das áreas já urbanizadas, desprovidas, portanto, de toda infraestrutura, incluindo-se o transporte urbano. Essa constatação valida a afirmação de Karl Polanyi, em seu livro publicado em 2000, quando afirma que o grande problema é que o capitalismo transformou a terra, no caso, a terra urbana, em capital, em estoque de capital, satisfazendo, assim, interesses exclusivamente de seus proprietários e não aos da coletividade.

Mais uma vez as comparações se tornam imperiosas. 
$\mathrm{Na}$ Holanda, de 1888 a 1895, diversos estudos e ações do Estado holandês, que até hoje é monárquico, delegou e exigiu das municipalidades que se responsabilizassem pela infraestrutura, incluindo o abastecimento de água, luz, gás, transporte coletivo (bondes) e telefonia.

Decorrente daí, em 1894, foi elaborado um relatório sobre a questão da habitação social, com o objetivo de alicerçar uma legislação que permitisse às municipalidades desapropriarem terras e edifícios urbanos visando à erradicação de cortiços, gerando, a partir desse Relatório, a Leis de Habitação, decretada em 1902.

Em consonância com essas leis de 1902 e, mais importante ainda, com suas necessidades, a cidade de Amsterdam planejou sua expansão em direção ao sul da cidade, em 1915, projetando a construção de 12.000 moradias, com o planejamento urbano de Berlage. Em 1928, iniciou-se, na cidade o projeto de Van Eesteren, cuja implantação teve início em 1934 e foi concluído nos anos de 1960, estipulando a construção de 45.000 moradias. Digno de nota é o fato de que toda a área de expansão foi ocupada como previsto no plano geral, com variações mínimas. Para os conjuntos projetados nessas áreas, a execução foi primorosa, da infraestrutura, incluindo os transportes, passando pelo paisagismo projetado, e pelas habitações em si, por vezes equipadas com mobiliário e outras facilidades.

Essa situação também era prática comum na Alemanha, do final da $1^{\text {a }}$ Guerra Mundial até a ascensão do nazismo, a começar pela posse da terra urbana. Naquele período, as prefeituras desapropriavam terras e faziam um estoque de áreas públicas para a execução de projetos de habitações de interesse local. Frankfurt, por exemplo, no período estudado, formou um estoque abrangendo um total de $45 \%$ de todas as terras urbanas do município, terras que formaram a base das construções de interesse social e planejamento do crescimento urbano.

$\mathrm{Na}$ Alemanha, também as prefeituras eram encarregadas de projetar, por seus próprios arquitetos, ou supervisionar o trabalho das cooperativas $\mathrm{e}$ associações no projeto das habitações, construí-las ou supervisionar a construção integralmente como foram planejadas, além de determinar o financiamento. 
Tanto na Holanda, quanto na Alemanha, com o objetivo de minimizar ou impedir a inadimplência, o financiamento para a casa jamais era concedido diretamente ao mutuário, como pessoa física, mas para cooperativas municipais.

Considerado em seu conjunto, o problema habitacional e de planejamento urbano, entendido como integração com os planejamentos de expansões das cidades, indica que o Estado brasileiro sempre seguiu na contra mão da história por continuar em pleno regime republicano, cujo próprio nome indica ser o governo da coisa pública, do interesse comum, a praticar o clientelismo característico do império luso e continuado pelo império brasileiro, a partir de 1822. A continuidade da concepção patrimonialista do Estado e a prática do clientelismo relegaram o cuidado com a moradia para as classes mais despossuídas e o cuidado com o próprio planejamento da expansão das cidades e os necessários implementos urbanísticos a um segundo plano, quando não, como um favor, uma benesse do Poder em prol do "poviléu" e, logicamente, em troca de votos.

Essa prática se confirma até na própria qualidade dos conjuntos e moradias construídas, em particular pela Fundação da Casa Popular. Muitas foram as reclamações quanto à qualidade do material empregado, problemas de estruturas e falta de término nos conjuntos realizados. Uma política sem começo, sem meio(s), e fatalmente com um fim trágico.

Nesse cenário tão controverso, é realmente notável que tenha existido uma produção de qualidade, em consonância com as realidades locais, atuando como vanguarda no campo habitacional, as quais ainda nos inspiram, nos comovem e nos fazem agir. 


\section{REFERÊNCIAS BIBLIOGRÁFICAS}


ACKEL, L. G. M (2007). Attilio Corrêa Lima uma trajetória para a modernidade. São Paulo, Tese de Doutorado, FAUUSP.

ALENCAR, José M. (1943) Casa própria, aspiração popular. in Cultura Política n. ${ }^{\circ} 28$, jun.

ALVIM, Agostinho (1951) Comentário à Lei do Inquilinato. Ed. Saraiva SP.

ANDRADE, C. R. M (1992). Peste e o plano: o urbanismo sanitarista do engenheiro Saturnino de Brito. Dissertação de Mestrado, FAU USP, São Paulo, 1992.

ANDRADE, L. A. G.; AZEVEdo, S. (1982). Habitação e Poder. Da Fundação da Casa Popular ao Banco Nacional de Habitação Zahar, Rio de Janeiro

ARAUJO, M.C. Soares d', O Segundo Governo Vargas. Ed. Ática, São Paulo, 1992 (2 edição)

ARAUJO, O. Egidio (s.d.) O papel da habitação no nível de vida da família operária, in Revista do Arquivo Municipal, n. ${ }^{\circ} 82, \mathrm{SP}, 1942$.

ARAVECHHIA, N. (2000) Habitação social no Rio de Janeiro e as contribuições e influências de Carlos Frederico Ferreira e Rubens Porto. Relatório de Iniciação Científica FAPESP. Departamento de Arquitetura e Urbanismo, Escola de Engenharia de São Carlos da Universidade de São Paulo, São Carlos.

ARQUITETURA E ENGENHARIA. (1957). Conjuntos residenciais operários em Belo Horizonte. n. 49, Belo Horizonte.

ASSEMBLÉIA NACIONAL CONSTITUINTE (1946) Diário da Assembleia Constituinte. Imprensa Nacional, Rio de Janeiro, abril. (1946) Diário da Assembleia Constituinte. Imprensa Nacional, Rio de Janeiro, maio. (1946) Diário da Assembleia Constituinte. Imprensa Nacional, Rio de Janeiro, junho. (1946) Diário da Assembleia Constituinte. Imprensa Nacional, Rio de Janeiro, julho. (1948) Anais da Assembleia Nacional Constituinte. Imprensa Nacional, Rio de Janeiro, março de 1946, vol.3 (1948) Anais da Assembleia Nacional Constituinte. Imprensa Nacional, Rio de Janeiro, abril de 1946, vol.6 (1948) Anais da Assembleia Nacional Constituinte. Imprensa Nacional, Rio de Janeiro, abril-maio de 1946, vol.7

(1948) Anais da Assembleia Nacional Constituinte. Imprensa Nacional, Rio de Janeiro, maio de 1946, vol.8

(1948) Anais da Assembleia Nacional Constituinte. Imprensa Nacional, Rio de Janeiro, agosto de 1946, vol.12

AYMONINO, C. (1975) La vivienda racional, G. Gili, Barcelona

AZEVEDO, Aldo M (1958) A quem favorece a lei do inquilinato? In: Digesto Econômico, n. 142, ano XIV, julho/agosto p.p. 14-20.

AZEVEdO, Luiz A. (1996). A crise da Política Habitacional, in RIBEIRO, L. C.; AZEVEDO, L. A.(org.) (1996) A crise da moradia nas grandes cidades. Ed. UFRJ, Rio de Janeiro.

BANCO NACIONAL DE HABITAÇÃO (1974). Documenta. Rio de Janeiro. (1974). BNH: 1974. Rio de Janeiro. 
(s/d). Ação da área de programas de natureza social. Rio de Janeiro

BATISTA, H. (1945) Locação de Imóveis. Rio de Janeiro.

BELO HORIZONTE. (1949). Relatório de 1949; apresentado à Câmara Municipal por Octacílio Negrão de Lima. Prefeitura Municipal de Belo Horizonte.

BENÉVOLO, Leonardo (1989). História da Arquitetura Moderna. Ed. Perspectiva. São Paulo.

BLAU, Eve (1999). The architecture of Red Vienna, 1919-1934.Cambridge, Mass: MIT Press.

BOLETIM DO DEPARTAMENTO ESTADUAL DE ESTATístICA (1946). Padrão de vida do Operário Paulista n. 3, $3^{\circ}$ trimestre, São Paulo.

BOLETIM MENSAL DO DEPTO. DE CULTURA (1953) Pesquisa sobre a casa própria, in BMDC, $n^{0} 48$, nov/dez.

BOLETIM DO MINISTÉRIO DO TRABALHO, INDÚSTRIA E COMÉRCIO. (1936). As construções nas caixas de aposentadoria e pensões, $n .^{\circ} 26$, out. (1936). Casas para empregados e operários sindicalizados em S. Paulo, n. ${ }^{\circ} 27$, nov.

(1936). A aquisição da propriedade coletiva, n. ${ }^{\circ} 28$, dez.

(1937). Carteiras Hypothecárias e predial do Instituto Nacional de Previdência, n. ${ }^{\circ}$ 30, fev. (1937). Criação da carteira predial do Instituto de Aposentadoria e Pensões dos Comerciários, n. ${ }^{\circ}$ 36,ago.

(1937). Casas para operários, $\mathrm{n}^{0} 37$, set.

(1937). A semana da Ação Social Católica, n. 40, dez.

(1937). Instruções para o funcionamento da Carteira Predial do Instituto de Aposentadoria e Pensões dos bancários, n. ${ }^{\circ} 40$, dez.

(1946). Imprensa Nacional, Rio de Janeiro. n. 136-144, jan-dez.

BOLONHA, F. Conjunto Residencial Paquetá. Departamento de Habitação Popular, secretaria geral de viação e obras da Prefeitura do Distrito Federal. Revista Municipal de Engenharia, vol. XX, n. 1, pp.3-6jan. -mar, 1953.

Conjunto Residencial Paquetá. Departamento de Habitação Popular, secretaria geral de viação e obras da Prefeitura do Distrito Federal. Revista Municipal de Engenharia, vol. XXI, n. 1, jan.- mar. 1954a.

Conjunto Residencial Paquetá. Departamento de Habitação Popular, secretaria geral de viação e obras da Prefeitura do Distrito Federal. Revista Municipal de Engenharia, vol. XXI, n. 4 out. -dez, $1954 b$.

Conjunto Residencial Vila Izabel. Departamento de Habitação Popular, secretaria geral de viação e obras da Prefeitura do Distrito Federal. Revista Municipal de Engenharia , vol. XXI, n. 1, pp.11-18, jan.- mar. 1954d.

Conjunto Residencial Paquetá. Departamento de Habitação Popular, secretaria geral de viação e obras da Prefeitura do Distrito Federal. Revista Municipal de Engenharia, vol. XXII, n. 1, jan.- mar. 1955.

Conjunto Residencial Vila Isabel. Brasil Arquitetura Contemporânea, $n^{0}$ 7, 1956.

Reinhaus-siedlung Paquetá. Brasil Arquitetura Contemporânea, nº 10, 1957. 
BONDUKI, N. G. (1982) Origens do problema de habitação popular em São Paulo, in Espaço e Debates n. 5 ano 2, abril pp. 81-112.

(1987) Habitação e família: porque casa própria. Relatório de pesquisa. "Modo e condições de vida em São Paulo", coord. Lúcio Kowarick, CEDEC/DIEESE (mimeo) (1998) Origens da Habitação Social no Brasil. Estação Liberdade, São Paulo, SP. (2000) Affonso Eduardo Reidy. São Paulo/ Lisboa: Lina \& P. M. Bo Bardi/Blau.

BONDUKI, N. G., KOURY, A. P.; MANOEL, S.K. Análise Tipológica da Produção de Habitação Econômica no Brasil (1930-1964). In Anais 5 Seminário DOCOMOMO Brasil, São Carlos, SAP/EESC/USP, 2003.

BOURGEOIS, Victor (1929) La Organizacion de la Vivienda Minima, in AYMONINO, Carlo (1975)

BRANDÃO, Armando B. ( 1983) "Habitação Popular no Brasil: uma visão histórica 1900/1980 " UNB (mimeo)

BRENNE, Winfried (2008) Bruno Taut - Master of colourful architecture in Berlin. DeutscherWerkbunde.V., Berlin.

BRUAND, Yves (1981) Arquitetura Contemporânea no Brasil, Perspectiva, São Paulo.

BRUNA, P. J. V. (1976) Arquitetura, Industrialização e Desenvolvimento. São Paulo: Perspectiva. (2010) Os Primeiros Arquitetos Modernos. Habitação Social no Brasil: 1930-1950. Edusp, São Paulo

BULLOCK, Nicholas (1978). Housing in Frankfurt 1925 to 1931 and the new Wohnkultur. In: The Architectural Review, vol. CLXIII, n.976, jun.

CALDEIRAS, N. Mendes (1945) A crise de habitação em São Paulo, in Boletim do Departamento Estadual de Estatísticas, $n .^{\circ} 3,3^{\circ}$ trimestre (1939) Construções no Rio e em São Paulo, in O Observador Econômico e Financeiro, ano IV, n. ${ }^{0}$ $47, \mathrm{RJ}$.

CAPOMOLA, R; VITTORINI, R. (org.) l'Architettura INA-Casa (1949-1963). Aspetti e problemidiconservazione e recupero. Roma: Ed. Gangemi, 2003.

CARPINTÉRO, Marisa Varanda T. (1997). A construção de um sonho: os engenheiros-arquitetos e a formulação da política habitacional no Brasil. Ed. da UNICAMP, Campinas, SP.

CARVALHO, A. M. (1936) Comentários de Viagem. In: ARQUITETURA E URBANISMO, n.3, setembro/outubro de 1936.

CARONE, E. (1944) O Movimento Operário no Brasil 1877-1944. Difel - SP. (1980) A Quarta República (1945-1964). Difel - SP

CANTANHADE, Plínio de (1942) O problema da habitação sob o aspecto econômico-financeiro, in Revista de Organização Científica. Vol XI, n. 126.

CARONE, Edgar (org.) O pensamento industrialista no Brasil (1880-1945). São Paulo: Difel, 1977.

CAVALCANTI, Hélio Uchôa; FLÔRES, Alberto de Mello; LIMA, Attílio Correia; SILVA, José Theoduloda.(1943) Conjunto Residencial Várzea do Carmo - IAPI (parte 2) Revista Municipal de Engenharia, vol X, n. 4, out.

COHN, A. - Previdência Social e Processo Político no Brasil. Ed. Moderna, SP, 1981 
CORBUSIER, Le; JEANNERET, Pierre (1929) - Analise de los Elementos Fundamentales en el Problema de la Vivienda Minima, in AYMONINO, Carlo (1975)

CORÇÃO, Gustavo (1946) Três alqueires e uma vaca. Editora Agir, Rio de Janeiro.

COSTA, Emilia V. da C. (2007) Da monarquia República: Momentos decisivos. São Paulo: Editora Unesp.

COSTA F.‥, J. Mendes (1953) Propriedade, desapropriação, inquilinato, Ed. Freitas Bastos, RJ.

COSTA, João Pedro (2005) Bairro de Avalade - Um paradigma do urbanismo português. Livros Horizonte, Lisboa; $2^{\circ}$ edição.

COSTA, L. (1995) Lúcio Costa: Registro de uma vivência. São Paulo: Empresa das Artes

COUTTO, P; HOUAISS, A. (1989) Brasil: o fracasso do conservadorismo. São Paulo: Ed. Ática.

CULTURA POLÍTICA (1943) O Estado Nacional e o problema das casas operárias, n. ${ }^{33}$, ano III, out., pp.73-82

CUNHA, Tristão de (1949) A defesa da propriedade. In: Digesto Econômico, n. ${ }^{\circ}$ 51, ano V, fev.

D'AURIA, F (1942) Jornada de Habitação econômica, in Revista do Arquivo Municipal, n. ${ }^{\circ}$ 82, SP

DA A.C. 17 (1935) Urbanismo e arquitetura na Rússia. In: Revista de Arquitetura, n.13, junho de 1935.

DE FEO, Vittorio (1979). La arquitectura en la U.R.S.S., 1917-1936. Madri: Alianza Editorial.

DEGANO, J. L. (2003)Tradição e Modernidade no Ciclo dos IAP's - O Conjunto Residencial do Passo d' Areia e os projetos modernistas no contexto da habitação popular dos anos 40 e 50 no Brasil. Dissertação de Mestrado. Programa de Pós-Graduação em Planejamento Urbano e Regional da Universidade Federal do Rio Grande (PROPURUFRGS),Porto Alegre.

DODSWORTH, E. (1931) Descrição de um novo elemento construtivo - Bloco Duplex. In: Anais do I Congresso de Habitação, 1931.

DUVIVIER, Eduardo (1948) O problema do inquilinato. In: Digesto Econômico, n. ${ }^{\circ}$ 54, ano V, jul.

DUPRAT, Augusto L (1948) Política habitacional. Inédito

ENSAIOS DE OPINIÃO (1975) Getúlio Vargas, Ed. Inúbia, Rio de Janeiro.

ENGELS, F. (1988) A questão da habitação. (Coleção clássicos das ciências sociais). São Paulo: Acadêmica.

ENGENHARIA (1946) A casa popular, n. ${ }^{\circ} 45$, ano IV, maio (1946)Fundação da Casa popular , n. ${ }^{\circ} 46$, ano IV, jun. , pp. 349-50 (1946) Muitas casa no papel. $n^{\circ} 47$, ano IV, jul.

ESTELITA, J. (1934) A visão da Guerra e a sua influência na estrutura das novas cidades europeias. In: REVISTA DA DIRECTORIA DE ENGENHARIA, n. 8/ Ano II, janeiro de 1934.

FARAH. M. (1983)Estado, Previdência Social e Habitação, Dissertação de Mestrado apresen6tado à FFCHLUSP, mimeo (1985) Estado e habitação no Brasil: o caso dos Institutos da Previdência . In: Espaço e Debates n. 16, ano V, pp.73-82

FAORO, Raymundo. (2001) Os donos do poder. Rio de Janeiro: Editora Globo. $3^{\circ} \mathrm{ed}$.

FAYET, Carlos M. Vila do IAPI: Patrimônio Cultural da Cidade, Porto Alegre: Prefeitura Municipal de Porto Alegre, 1994. 
FAUSTO, B (1972) A Revolução de 1930. Ed. Brasiliense, SP

(1981) O Brasil Republicano: Estrutura de poder e economia (1889-1930). vol. 1 Difel, Difusão Editorial SA, São Paulo.

(1981) O Brasil Republicano: sociedade e política (1930-1964). vol. 3, Difel/Difusão Editorial SA, São Paulo

FAVELAS E HABITAÇÃO POPULAR (1954) Uma nova política para enfrentar o problema da habitação popular. Rio de Janeiro.

FERRAZ, Geraldo (1966). Warchavchik e a implantação da Arquitetura Moderna no Brasil: 1925-1949. São Paulo: MASP.

FERREIRA, C. F.(1935). Pavilhão de Estudantes numa Cidade Universitária. Revista da Diretoria de Engenharia do Estado da Guanabara. n.15, ano IV, Mar.

(1940) Conjunto Residencial Operário em Realengo. Revista Municipal de Engenharia, v. VII, n.2, Jan.

FINEP-GAP (1985) Habitação Popular - Inventário da ação governamental. FINEP, Rio de Janeiro.

FICHER, S. (2005) Os Arquitetos da Poli: Ensino e Profissão em São Paulo. São Paulo: FAPESP e EDUSP.

FRAMPTON, K. (1997) História Crítica da Arquitetura Moderna. São Paulo: Martins Fontes.

FRASSON, Alexandra de Souza. Habitação Social e Arquitetura Moderna: a apropriação dos Conjuntos

Residenciais dos IAP's (1940-2000). Dissertação de mestrado apresentada à Escola de Engenharia de São Carlos. 2000. São Carlos, 2000.

FREITAS, M. L.(2005) . O Lar conveniente: os engenheiros e as inovações espaciais e tecnológicas nas habitações populares de São Paulo (1916-1931). Dissertação de mestrado. São Carlos, EESCUSP.

FUNDAÇÃO DA CASA POPULAR (1951) O Núcleo, Rio de Janeiro, ano I, maio, n. 1.

(1951) O Núcleo, Rio de Janeiro, ano I, maio, n. 1.

(1951) O Núcleo, Rio de Janeiro, ano I, junho, n. 2.

(1951) O Núcleo, Rio de Janeiro, ano I, julho, n. 3.

(1951) O Núcleo, Rio de Janeiro, ano I, agosto, n. 4.

(1951) O Núcleo, Rio de Janeiro, ano I, set-out-nov-dez., n. 5.

(1952) Estatutos; aprovado pela portaria n. 69, de 23 de maio de 1952, do Ministério do Trabalho, Indústria e Comércio, Rio de Janeiro, 25 pp.

(1952) Norma de seleção e classificação de candidatos à Casa Popular, aprovada pela resolução n.

244, de 16 de maio de 1952, do Conselho Central. Rio de Janeiro.

(1952) Plano de Aconselhamento, Rio de Janeiro.

(1952) Anais do Conselho Central, Rio de Janeiro.

(1952) Anais do Conselho Técnico, Rio de Janeiro.

(1953) Anais do Conselho Central, Rio de Janeiro.

(1953) Anais do Conselho Técnico, Rio de Janeiro.

(1954) Anais do Conselho Central, Rio de Janeiro.

(1956) Normas para obras, modificações e acréscimos . Rio de Janeiro. 
(1958) Normas para modificações e acréscimos. Rio de Janeiro.

(1961) Fundamentos e bases de um plano de assistência habitacional. Rio de Janeiro.

(1961). Quadro demonstrativo das obras executadas e em execução pela Fundação da Casa Popular até 31 de dezembro de 1960, Rio de Janeiro.

(s/d) Escritura particular de promessa de compra e venda de imóvel. Rio de Janeiro.

(s/d) Normas gerais para execução dos trabalhos de topografia. Rio de Janeiro.

(s/d) Normas gerais para organização e funcionamento dos Escritórios Locais de Obras. Rio de Janeiro.

GAIARSA, Octaviano A. (1991) Santo André: ontem, hoje e amanhã. Coleção Memórias da Cidade, Prefeitura Municipal de Santo André, SP

GIEDEON, S. (1929) Los Congresos Internacionales de Arquitetura Moderna. In: AYMONINO, Carlo (1975) (1952) Pedregulho. L'Architeture D'Aujour'Hui, ano 23, n. 42-43, ago., 1952. (2004) Espaço, tempo e arquitetura. O desenvolvimento de uma nova tradição. Martins Fontes, São Paulo.

GITAHY, M. L. C.; PEREIRA, P. C. X. (Org.) (2002) O Complexo Industrial da Construção e a Habitação Econômica Moderna 1930-1964. São Carlos: RiMa.

GOLDMAN, Simão (1963) Diretrizes para uma política nacional de habitação. Caixa Econômica Federal do RGS.

GOMES, A. C. (1988) A invenção do Trabalhismo, Ed. Vértice, SP, Ed. Revista dos Tribunais, RJ.

GOMES, M.A; LIMA, F. (1999)Pensamento e Prática Urbanístico em Belo Horizonte. In: LEME, M.C. (org.) (1999)Urbanismo no Brasil. Ed. Studio Nobel, São Paulo

GOODWIN, Philip L. (1943) Construção brasileira. Arquitetura moderna e antiga 1652 - 1942. Museu de Arte Moderna, Nova York.

GREENHALGH F. ${ }^{\circ}$, Richard (1950) A Casa Popular no Brasil. In: revista do Serviço Público, n. ${ }^{\circ}$ 2, ano XIII, fev., pp. 71-81

GRINBERG, Donald I. (1982) Housing in the Netherlands 1900-1940. Delft Student Press. Pg. 33-86.

GROPIUS, Walter (1929) Los Fundamentos Sociológicos de la Vivienda Minima. In: AYMONINO, Carlo (1975)

(1972) Novarquitetura. São Paulo, Perspectiva.

GODOY F.', Armando de G (1947) A habitação popular, diante da realidade brasileira. in Revista Engenharia, n. 63, nov., pp.117-119.

GUCCIONE, Margherita; SEGARRA, Lagunes M. Margarita; VITTORINI, Rosalia. Guida ai quartieriromanilna Casa. Roma: Ed. Gangemi, 2002.

GUIMARÃES, B. M. (1991). Cafuas, barracos e barracões: Belo Horizonte. tese de doutoramento apresentada no IPERJ, Rio de Janeiro.

GUSMíES, Alberto A. C. (1948) - Crise de habitação. In: O observador Econômico e Financeiro, n. ${ }^{\circ}$ 148, anoXIII, maio

HASPEL, J; JAEGGI, A. (2007).Housing Estates in the Berlin Modern Style.DeutscherKunstverlag, Munique.

HABITAT (1956) Uma divergência na solução da Casa Popular, n. ${ }^{\circ} 30$, maio 
HELLER, Frederico (1944) Aspectos da crise de habitação. In: O Observador Econômico e Financeiro, $n^{\circ}$ 07, ano IX, dez.

HELLMEISTER, Ulysses (abr. 1944). "Cidade Jardim do Comerciário - Olaria - Distrito Federal". Revista Municipal de Engenharia - PDF, n.2, vol. XI. Rio de Janeiro: p. 56-58.

(jan. 1945). "A influência dos conjuntos residenciais no problema de habitação econômica". Revista Municipal de Engenharia - PDF, n.1, vol. XII. Rio de Janeiro: p. 19-22.

(jul. 1947). "Habitações Populares". Revista Municipal de Engenharia - PDF, n.3, vol. XIV. Rio de Janeiro: p. 136-143.

HENKET, Hubert-jan;HEYNEM, Hilden. (2002). Back from utopia - The chalenge of the Modern Moviment.010Publishers, Rotterdam

HOLANDA, Sérgio Buarque de (1963). Raízes do Brasil. Livraria José Olympio Editora, São Paulo.

HOWARD, E. Cidades Jardins de Amanhã. São Paulo: Annablume, 2002. Introdução de Dácio A. B. Ottoni.

I CONGRESSO PANAMERICANO DE VIVIENDA POPULAR (1939). In:. Arquitetura e Urbanismo, São Paulo, nov/dez .

INSTITUTO DE APOSENTADORIA E PENSÕES DOS COMERCIÁRIOS (IAPC). Departamento de Aplicação de Fundos. Revista do IAPC, Rio de Janeiro, ano III, n. 33, p.101 - 105, fev. 1941a.

INSTITUTO DE APOSENTADORIA E PENSÕES DOS COMERCIÁRIOS (IAPC). Quarenta mil contos em casas baratas para os comerciários. Revista do IAPC, Rio de Janeiro, ano III, n.34/35, p.68 e 161, mai. -jun. $1941 \mathrm{~b}$.

INSTITUTO DE APOSENTADORIA E PENSÕES DOS INDUSTRIÁRIOS (IAPI). Inapiários. Revista do IAPI. Rio de Janeiro, 1938-1944.

INSTITUTO DE APOSENTADORIA E PENSÕES DOS INDUSTRIÁRIOS (IAPI). Conjunto Residencial da Penha. Rio de Janeiro: Instituto de Aposentadoria e Pensões dos Industriários, 1949.

INSTITUTO DE APOSENTADORIA E PENSÕES DOS INDUSTRIÁRIOS (IAPI). O seguro social, a indústria brasileira, o Instituto dos Industriários. Relatório-estudo do Engenheiro Alim Pedro, Presidente do IAPI no período de 26-2-1946 a 29-1-1951. Rio de Janeiro: IAPI, 1950.

INSTITUTO DE APOSENTADORIA E PENSÕES DOS COMERCIÁRIOS (IAPC). VI aniversário do Conjunto Residencial de Olaria. Sociedade dos moradores nos Conjuntos Residenciais do IAPC. Revista do IAPC, Rio de Janeiro, ano IV, n. 35, p.12, abr. 1952a

INSTITUTO DE APOSENTADORIA E PENSÕES DOS INDUSTRIÁRIOS (IAPI). Cálculo para determinação dos valores locativos: Conjunto Residencial Várzea do Carmo. Revista dos Industriários. São Paulo: out.-nov., 1952 b.

INSTITUTO DE APOSENTADORIA E PENSÕES DOS COMERCIÁRIOS (IAPC). Relatório das atividades em 1952. Revista do IAPC, Rio de Janeiro, ano V, n. 44, p. 21, jan. 1953a.

INSTITUTO DE APOSENTADORIA E PENSÕES DOS INDUSTRIÁRIOS (IAPI). Ata de vistoria e recebimento do edifício B-20 das obras do Conjunto Residencial da Várzea do Carmo. Revista dos Industriários. São Paulo: mar., 1953b.

INSTITUTO DE ENGENHARIA. (1931). Annaes do / Congresso de Habitação, São Paulo, 1931

INSTITUTO DE PESQUISA TECNOLÓGICA (1979) - Diretrizes habitacionais. IPT/CNPq, SP, inédito.

IORIO, Oswaldo (1972). O novo sistema de amortização dos planos habitacionais. BNH, Rio de Janeiro, 48 pp.

IV CIAM. A carta de Atenas. Tradutor: Eduardo Kneese de Mello. Acrópole, São Paulo, n. 109, pp.1-4, 1947 [1933].

JORNADA DE HABITAÇÃo ECONÔMICA. In: Revista do Arquivo Municipal, Dep. de Cultura, São Paulo, $\mathrm{n}^{\circ} 82$, p. 174.

KOPP, Anatole (1990) Quando o moderno não era um estilo e sim uma causa. Nobel Edusp, São Paulo. 
KRUTER, M. (1944) Memorial descritivo do projeto do conjunto residencial Passo d'Areia apresentado ao IAPI, por intermédio do ministro Regional de Obras. Porto Alegre.

LAMAS, J.M.R.G (2004) Morfologia Urbana e desenho da cidade. Fundação Calouste Gulbenkian e Fundação para a Ciência e Tecnologia, Porto, Portugal.

LANE, B. M. (1968). Architecture and Politics in Germany: 1918-1945.Harvard University Press: Cambridge, Massachusetts.

LAPOLLI, A. (2006) Como destruir um patrimônio cultural urbano: a Vila do IAPI, crônica de uma morte anunciada! Dissertação de Mestrado. Programa de Pós-Graduação em Planejamento Urbano e Regional da Universidade Federal do Rio Grande do Sul (PROPUR-UFRGS), Porto Alegre.

L'ARCHITECTURE D'AUJOURD’HUI (1952). Brésil (Edição especial sobre arquitetura brasileira), n 42/43, ag0.

LE CORBUSIER(1976) Os três estabelecimentos humanos. Editora Perspectiva, São Paulo. (1994) Por Uma Arquitetura. Editora Perspectiva, São Paulo.

(2004). Precisões sobre um estado presente da arquitetura e do urbanismo. Cosac Naify: São Paulo.

LEAL, Victor Nunes (1976). Coronelismo Enxada e Voto: o município e o regime representativo no Brasil. São Paulo: Editora Alfa-Ômega.

LEITE, L. da Costa (1942) - Casa econômica para o funcionário público. In: IDORT, nº 130, 1942

LEITE, Mauro Renault (1983). Marechal Eurico Gaspar Dutra: O dever da verdade. Editora Nova Fronteira, Rio de Janeiro, RJ.

LEME, M. C. (org.).Urbanismo no Brasil1895-1965. São Paulo, Studio Nobel, 1999.

- (coord.) Banco Documental Urbanismo no Brasil. Disponível em http://www.urbanismobr.org/bd/autores, consultado em 30 out. 2009.

LEMOS, Carlos A. C. (1999.)A República ensina a morar (melhor). São Paulo: Hucitec.

LIMA, A. C. Conjunto Residencial Várzea do Carmo IAPI. Revista Municipal de Engenharia, nov. 1942. Conjunto Residencial Várzea do Carmo IAPI (continuação do artigo anterior) Revista Municipal de Engenharia, out. 1943.

Artigo sobre o conjunto Várzea do Carmo. Architectural Forum, vol. 87, n. 5, nov., 1947

LIRA, J. T. C. de(1996). Mocambo e Cidade: regionalismo na arquitetura e ordenação do espaço habitado.

Tese de doutorado. Faculdade de Arquitetura e Urbanismo da Universidade de São Paulo, São

Paulo.

MAIA. F. P.(1930) Estudo de um Plano de Avenidas para a cidade de São Paulo. São Paulo:

Melhoramentos.

(1952-53). Casas Populares (de I a III),†Digesto Econômico nº 28, 29 e 30, ano III, mar/abr/mai, 1947

MALHEIROS, V. C. (1942.Trabalho e Habitação. In: Revista do Arquivo Municipal n 82 , SP

MANOEL, I.A. (2004). O Pêndulo da História. Tempo e eternidade no pensamento católico (1800-1960). Eduem, Maringá. 
MANOEL, S. K. (2001).A Produção Habitacional da Fundação da Casa Popular (1946-1964). Relatório final de Iniciação Científica - FAPESP, São Carlos. (2004) Fundação da casa popular (1946-1964): projeto frustrado de construção de uma política habitacional no Brasil. Dissertação de mestrado apresentada ao Departamento de Arquitetura e Urbanismo SAP/ EESC/ USP. São Carlos, São Paulo.

MARICATO, Ermínia (1987). Política Habitacional no Regime Militar. Ed. Vozes, Petrópolis, R.J.

MARTINS, C. A. F (1988) Arquitetura e Estado no Brasil. Elementos para uma análise da constituição do discurso moderno no Brasil. A obra de Lucio Costa 1924-52. Dissertação de mestrado apresentada ao Programa de Pós-Graduação em História Social/ FFLCH/ USPC. A. F

(2010). Identidade nacional e Estado no projeto modernista. Modernidade, Estado e tradição. In GUERRA, A. (org.). Textos fundamentais sobre história da arquitetura moderna brasileira. Parte 1. São Paulo: Editora Romano Guerra, 2010, pp.279-297.

MAY, Ernst (1929) La Vivienda para el Minimo Nivel de Vida. In: AYMONINO, Carlo (1975)

MÉDICl, Ademir (1992) Migração, Urbanismo e Cidadania: a história de Santo André contada por seus personagens. Prefeitura Municipal de Santo André, Santo André, SP

MELO, Marcus A. B. C. (1991) A não política da casa popular, 1946-1947. in Revista Brasileira de Ciências Sociais n. 15, ano 6, ANPOCS. (1991) Estado e mercado: a construção social da agenda do Estado na esfera da habitação 19301990. in Anais do IV Encontro Nacional da CNPUR, Salvador 28-31 de maio. (1987) The state, the housing question and policy formation in Brazil (1937-1975). Tese de doutoramento, Graduate School in Art and Social Studies, Londres.

(sd) $O$ Estado, o boom do século e a crise da habitação: Rio de Janeiro e Recife (1937-1946).in Fernandes, Ana e Gomes, Marco A. F (org.) Cidade e História UFBA, Salvador.

MELLO, L. de A. (1950) - O problema da habitação. In: Digesto Econômico nº, ano VI, novembro

MENDONÇA, M. T. C. (1931) Casas Populares Cidades Jardins. In: ARCHITECTURA E CONSTRUCÇÕES, n. 22, outubro.

MERCADANTE, Paulo (2003). A consciência conservadora no Brasil. São Paulo: Topbooks.

MESQUITA, Rodrigo, O. (1951) Construções e crise da habitação em São Paulo in Revista Engenharia janeiro pp. 217-220

MINISTÉRIO DE RELACIONES Y CULTO DE LA REPUBLICA ARGENTINA - Primero Congresso Panamericano de la Vivienda Popular. Talleres Graficos del M. Obras Publicas, Buenos Aires, 1940

MINDLIN, H. (1956), Modern Architecture in Brazil, Amsterdam/N. York, Reinhold.

MONTE-MÓR, R. L. M (1994). Belo Horizonte: Espaço e tempos em construção. CEDEPLAR/PBH, belo Horizonte, $94 \mathrm{pp}$.

MOREIRA, F. Batista de (1943) O acesso do povo à casa própria. In: O Observador Econômico e Financeiro, $n^{0}$ 92, ano VIII, set.

MONICA, H. R. M. (2004) As dimensões da arquitectura construtivista. Tese (doutorado). Faculdade de Ciências e Tecnologia de Coimbra. 2004. 
MOTA, J. C. (2000). Planejamento urbano e habitação em Goiânia - Os projetos de Attílio Correia Lima e Armando de Godoy. Relatório final de Iniciação Científica - FAPESP, São Carlos.

MUNFORD, E (2000). The CIAM discourse on urbanism (1928-1960).MIT Press, Cambridge, Massachusetts.

MUMFORD, Lewis (1991). Cidade na historia: suas origens, transformações e perspectivas. São Paulo : Martins Fontes, 1991

NASCIMENTO,F.,B (2007). Habitação como patrimônio; a preservação dos conjuntos habitacionais. In: Revista CPC, São Paulo, n.4, p.23-39, maio/out. 200737

Entre a estética e o hábito: o Departamento de Habitação Popular (Rio de Janeiro, 19461960). Dissertação (Mestrado) - EESC-USP, São Carlos, 2004.

NEDERLANDS INSTITUUT VOOR VOLKSHUISVESTING (1920?). Dutch Housing Legislation. Printed by Drukkerij en Uitgevérij J. H. de BUSSY, AMSTERDAM.

OLIVEIRA, Francisco. (1988). A Economia Brasileira: Crítica à Razão Dualista. Ed. Vozes, Petrópolis, RJ, (6 edição).

(s/d). O Estado e o Urbano no Brasil. São Paulo.

OLIVEIRA, Francisco B. de (1940) A casa proletária brasileira. In: Acrópole, n. ${ }^{\circ} 27$, ano III, jul., pp.105 (1941) Instituto Brasileiro da Casa Popular. In: BMTIC, nº 86, out., pp.247-258

(1943) $O$ acesso do povo à Casa própria. In: Observador Econômico e Financeiro n. 92 set. 1943 pp. 124 - 129.

OLIVEIRA, M. Cardoso de - As atividades imobiliárias dos Institutos de Previdência Social. In: IDORT, $\mathrm{n}^{0}$ 132, 1942.

OSBORN, M. (1935) A Nova Arquitetura Alemã. In: Revista de Arquitetura, n. 15, agosto.

PASSARELI, Silvia (1994) O Diálogo entre o trem e a cidade: O caso de Santo André. Dissertação de Mestrado, Universidade de São Paulo (USP), Faculdade de Arquitetura e Urbanismo (FAU), São Paulo, SP.

PANERAI, P. (2004) Urban forms : the death and life of the urban block / Philippe Panerai, Jean Castex\& Jean-Charles De Paule; English edition and additional material by Ivor Samuels; translated by Olga Vitale Samuels. Oxford [England]: Architectural Press, Boston.

PESSOLATO, Cintia (2007) Conjunto IAPI Vila Guiomar - Santo André - SP: projeto e história. Dissertação (Mestrado - Área de Concentração: História e Fundamentos da Arquitetura e Urbanismo) FAUUSP.

POMMER, RICHARD (1991). Weissenhof 1927 and the modern movement in architecture. Chicago : University of Chicago Press, 1991.

POLANYI, Karl (2000). A grande transformação: As origens da nossa época. São Paulo: Ed.Campus.

PORETTI, Sergio (org) (2002). L'INA Casa: II cantiere e la costruzione. Roma: Departamiento De Ingegnaria Civile - Universitá di Roma Tor Vergata.

PORTINHO, C. (1932) A arquitetura moderna na Holanda. In: REVISTA DA DIRECTORIA DE ENGENHARIA, v. 1, n. 1, julho de 1932. 
PORTO, Rubens (1937) O problema da habitação operária. In: BMTIC, n. 30, fev/37, pp.169-78 (1937) $O$ problema da habitação operária. In: BMTIC, n. 35, jul/37 , pp.245-70 (1937) O problema das Casas Operárias e os Institutos e Caixas de Pensão, Rio de Janeiro

PRADO JR, Caio. (1966) A revolução brasileira. São Paulo: Brasiliense.

PROVOOST, Michelle; VANSTIPHOUT, Wouter. The New Town. Rotterdam: The New Town, Thursday 16 November 2006. Disponível em: <http://www.thenewtown.nl/article.php?id_article=101> Acesso em 13 mai. $2007,13: 15: 30$

PROVOOST, Michelle. The Happy Hoogvlite. Rotterdam: The New Town, Wednesday 23 June 2004. Disponível em: <http://www.thenewtown.nl/article.php?id_article=15> Acesso em 13 mai. 2007, $14: 15: 30$

QUEIROZ, Maria Isaura Pereira de. (1956) O mandonismo local na vida política brasileira. São Paulo: Anhembi.

RADFORD, Gail (1996) Modern Housing for America. Policy Struggles in the New Deal Era. The University of Chicago Press, Chicago.

REGO, Flávio Marinho. (1953). Conjunto residencial em Deodoro. In: Revista Municipal de Engenharia, n. ${ }^{2}$, abr-jul, pp.73-84.

REIDY, A. E.(1948a). Conjunto Residencial Pedregulho. Revista Municipal de Engenharia, vol. XV, n. 1, pp. 2-13 jan.-mar.

(1948b) Conjunto Residencial Pedregulho. Revista Municipal de Engenharia,, vol. XV, n. 3, jul.- set. (1948c) Escola Primária do Conjunto Residencial Pedregulho Revista Municipal de Engenharia, vol. XV, n. 3, pp.95-100, jul.- set.,. (1950) New Neighborhood at Pedregulho. The Architectural Review, vol. 108, n. 646, out. (1952a) Unité d'habitation de Pedregulho à Rio de Janeiro. L'Architeture D'Aujour'Hui, ano 23, n. 42-3, ago. (1952b) Pedregulho Neighborhood, Rio: Gymnasium and Primary School The Architectural Review, vol. 112, n. 667, jul.

(1954) Conjunto Residencial Marquês de São Vicente. Departamento de Habitação Popular, Secretaria geral de viação e obras da Prefeitura do Distrito Federal. Revista Municipal de Engenharia, vol. XXI, jan.- mar.

(1955) Conjunto Residencial Arquitetura e Engenharia, ano VI, n. 37, nov. -dez.

(1956)Conjunto Residencial Marquês de S. Vicente. Brasil Arquitetura Contemporânea, $n^{0} 7$.

REVISTA BRASíLIA (1957) n.22, outubro. Novacap, Rio de Janeiro.

(1958) n. 14, fevereiro. Novacap, Rio de Janeiro.

(1959) n. 29, maio. Novacap, Rio de Janeiro.

(1959) n. 31, julho. Novacap, Rio de Janeiro.

(1959) n. 33, setembro. Novacap, Rio de Janeiro.

(1960) n. 38, fevereiro. Novacap, Rio de Janeiro.

RIBEIRO, Luís C. Q. (1991) A formação do capital de incorporação: trajetória histórica da habitação no Rio de Janeiro. in Anais de IV encontro Nacional da ANPUR, Salvador 28-31 maio. 
ROLNIK, R. (2003) A cidade e a lei: legislação, política urbana e territórios na cidade de São Paulo. São Paulo: Studio Nobel/ FAPESP.

RUDOLFER, Bruno (1942) O problema social da habitação. In: Revista do Arquivo Municipal, $n^{0} 82$, SP

SABÓIA RIBEIRO, J. O. de. (1943). Bairro Residencial Autônomo da Chácara do Pires. Revista Municipal de Engenharia, Rio de Janeiro, Prefeitura do Distrito Federal, vol. X, n. 1, Jan. 1943.

SAMPAIO, M Ruth A. De (1993) Habitação Popular no período Getulista. O caso de São Paulo. Trabalho, apresentado ao Congresso Habitação na Cidade Industrial 1870-1950, Instituto de Ciências Sociais de Lisboa (mimeo)

(1994) Habitações e Cidade. FAU-USP - FAPESP, São Paulo.

(1994) O papel da Iniciativa Privada na Formação da Periferia Paulista. In: Espaço e Debates, São Paulo, n.37, ano XVI

SAMPAIO, Maria Ruth e BONDUKI, Nabil (1995) Habitação Econômica e Arquitetura Moderna no Brasil (1930-1964), Projeto de pesquisa temática, FAPESP

SCHIMIDT, Hans. (1929)Ordenanzas Edificatórias y Vivienda Minima. In: AYMONINO, Carlo (1975)

SEGAWA, H. (1999) Arquiteturas no Brasil: 1900-1990. São Paulo: EDUSP.

SERT, José Luis. Can our cities survive? An ABC of urban problems, their analysis, their solutions José Luis Sert; based on the proposals formulated by the C.I.A.M., International Congresses for Modern Architecture, Congrès internationaux d'architecture moderne. Cambridge; London: Harvard University Press: H. Milford, Oxford University Press, 1942.

SILVA, Luís Octávio da (2008). Primórdios da habitação social: as experiências do entre guerras na Europa e Estados Unidos. Arquitextos, São Paulo, 09.097, Vitruvius, jun 2008.<http://www.vitruvius.com.br/revistas/read/arquitextos/09.097/136>.

SINGER, P. (1968) Desenvolvimento econômico e Evolução Urbana. São Paulo: EDUSP.

SKIDMORE, T. (2000). Brasil: de Getúlio a Castelo, Ed. Paz e Terra, São Paulo, (12 edição).

SOMBRA, Severino (1941) Trabalho e propriedade: horizontes sociais no Estado Novo. In. Cultura Política, $\mathrm{n}^{0} 4$, junho, São Paulo.

SOBELMAN, C (1978) A casa imprópria: um estudo do BNH e SFH. Tese apresentada a FFLCHUSP.

STIEBER, Nancy (1998) Housing design and society in Amsterdam. Reconfiguring urban order and identity (1900-1920). The University of Chicago Press, Chicago.

TAFURI, M. e DAL CO, F. Architettura Contemporânea. Milão: Electa, 1976.

TAFURI, M. (1981) Teoria e História da Arquitetura, Lisboa: Presença/Martins Fontes. (1986) Projeto e Utopia. Lisboa: Editorial Presença.

TELLES, V. da S. (1999) Direitos sociais: Afinal do que se trata. Belo Horizonte: Ed. UFMG. (2001) Pobreza e Cidadania. São Paulo: Editora 34.

THANE, P. (2004) Histories of the Welfare State. University of London. URL:www.stm.unip.it/clioh/tabs/libri/4/03-thane_27-40.pdf (19/10/2004)

TOPALOV, Christian (1987). Le Logement en France. Presses de la Fondation Nationale des Sciences Politiques. Paris.

VAITSMAN, M. (1984) Quanto custou Brasília. Novacap, D.F. 
VARON, Conceição de M. F de (1988) E a história se repete... As vilas operárias e os conjuntos residenciais dos IAP's no Rio de Janeiro. Dissertação de Mestrado FAU-USP, São Paulo

VIANAS, J. C (1941) - O ideal em habitação coletiva. In: Revista do Arquivo Municipal, nº 82, SP

VIEITAS, Raul (1943) "A planificação da casa econômica”, Revista do Arquivo Municipal, São Paulo, n. 89, p. $130-136$

XAVIER, Alberto (org.) 1987 "Arquitetura Moderna Brasileira. Depoimento de uma geração". ABEA/FVA/PINI São Paulo. 


\section{Revistas e periódicos}

Anais da Assembleia Constituinte

Anais do Conselho Central da Fundação da Casa Popular

Anais do Conselho Técnico da Fundação da Casa Popular

Arquitetura

Arquitetura e Construção, São Paulo

Arquitetura e Engenharia

Boletim do Departamento Estadual de Estatística, São Paulo

Boletim do Ministério do Trabalho, Indústria e Comércio

Diário Oficial (federal)

Digesto Econômico

Engenharia, São Paulo

Espaço e Debates

Habitat

Módulo

O Núcleo - FCP

O Observador Econômico e Financeiro, Rio de Janeiro

Projeto, São Paulo

Revista Brasília, NOVACAP,

Revista de Engenharia

Revista do Arquivo Municipal

Revista do IDORT

Revista Polytecnica, São Paulo

Jornais

A Noite, Rio de Janeiro.

Correio da Manhã, Rio de Janeiro.

Diário de Notícias, Rio de Janeiro.

O Globo, Rio de Janeiro.

Jornal de Santo André da Borda do Campo, Santo André, SP. 


\section{Leis, Decretos e Portarias}

\section{Federais}

- Decreto - Lei n. 9.218 , de $1^{\circ}$ de maio de 1946. Autoriza a instituição da "Fundação da Casa Popular".

- Portaria Ministerial n. 108 - A, de 12 de julho de 1946, do Ministério do Trabalho, Indústria e Comércio. Aprova os Estatutos da Fundação da Casa Popular.

- Decreto - Lei n. 9.621, de 21 de agosto de 1946. Dispõe sobre a execução de serviços da Fundação da Casa Popular e dá outras providências.

- Decreto - Lei n. 9.777, de 6 de setembro de 1946. Estabelece bases financeiras para a Fundação da Casa Popular e dá outras providências.

- Lei n. 1.473, de 24 de novembro de 1951. Dispõe sobre recursos financeiros para a fundação de Casa Popular, altera a lei do Selo e dá outras providências;

- Lei n. 1.569, de 8 de março de 1952. Autoriza o Poder Executivo a doar imóveis sitos nos Municípios de Lavras e São João Del Rei, estado de Minas Gerias, provenientes de heranças vacantes, a Fundação da Casa Popular de São João Del Rei e à Instituições do mesmo Estado.

- Portaria Ministerial n. 69, de 23 de maio de 1952, do Ministério do Trabalho, Indústria e Comércio. Altera os Estatutos da Fundação da Casa Popular.

- Decreto n. 40.872, de 7 de fevereiro de 1957. Autoriza o Instituto de Aposentadoria e Pensão dos Industriários a ceder à Fundação da Casa Popular, em Juiz de Fora, Estado de Minas Gerais, uma gleba não urbanizada.

- Decreto n. 50.316, de 6 de março de 1961. Dispõe sobre as operações de créditos nas Caixas Econômicas Federais e dá outras providências.

- Decreto n. 50.349, de 16 de março de 1961. Dá nova redação aos artigos $4^{\circ}$ e $6^{\circ}$ e parágrafo único do artigo 14 do Decreto n. 50.316, de 6 de março de 1961.

- Decreto n. 50.488, de 2(?) de abril de 1961. Cria o Conselho Nacional de Planejamento de Habitação Popular, e dá outras providências.

- Decreto n. 50.869, de 27 de junho de 1961. Dispõe sobre a política habitacional do Governo e dá outras providências.

\section{Municipais}

- Lei n. 43, de 4 de agosto de 1948. Prefeitura Municipal de Belo Horizonte, MG. Autoriza o prefeito do Município de Belo Horizonte a construir casas de moradia para servidores do matadouro municipal.

- Lei n. 113, de 22 de novembro de 1949. Prefeitura Municipal de Belo Horizonte, MG. Autoriza a doação de terrenos à Fundação da Casa Popular.

- Lei n. 145, de 30 de junho de 1950. Prefeitura Municipal de Belo Horizonte, MG. Autoriza a doação de terrenos à Fundação da Casa Popular.

- Lei n. 209, de 30 de maio de 1951. Prefeitura Municipal de Belo Horizonte, MG. Muda para "Salgado Filho" a denominação da Vila de Mato da Lenha. 
- Lei n. 263, de 3 de janeiro de 1952. Prefeitura Municipal de Belo Horizonte, MG. Denomina "Bairro São Paulo" a atual Vila do Matadouro.

- Lei n. 0833, de 8 de julho de 1960. Prefeitura Municipal de Belo Horizonte, MG. Concede isenção de impostos e taxas não remuneratórias de serviços à Fundação da Casa Popular.

- Lei n. 13 , de $1^{\circ}$ de outubro de 1948. Prefeitura Municipal de Araraquara, SP. Dispõe sobre doação de terrenos de propriedade do município e dá outras providências.

- Lei n. 114, de 4 de dezembro de 1948. Prefeitura Municipal de Campinas, SP. Autoriza doação de terrenos municipais.

- Lei n. 3, de 5 de abril de 1948. Prefeitura Municipal de Itú, SP. Dispõe sobre doação de terrenos.

- Lei n. 12, de 7 de junho de 1948. Prefeitura Municipal de Itú, SP. Dispõe sobre doação de terrenos.

- Decreto n. 293, de 4 de fevereiro de 1948. Prefeitura Municipal de Santos, SP. Decreta de utilidade pública áreas de terreno.

- Lei n. 1.212, de 30 de dezembro de 1949. Prefeitura Municipal de São Carlos, SP. Doação de terrenos para a Fundação da Casa Popular. 


\section{Bibliotecas e arquivos pesquisados}

- Arquivo do Instituto Nacional de Seguridade Social, Rio de Janeiro, RJ

- Arquivo do Senado Federal, DF

- Arquivo Histórico Municipal "José Chiachiri", Franca, SP

- Arquivo morto de Irajá, Rio de Janeiro, RJ

- Arquivo morto do Ministério do Trabalho, Rio de Janeiro, RJ

- Arquivo Municipal, Rio de Janeiro, RJ

- Arquivo Municipal, Araraquara, SP

- Arquivo Público de Belo Horizonte, MG

- Arquivo Público do Distrito Federal, NOVACAP, DF

- Biblioteca Central da UFRJ

- Biblioteca Central da UNB

- Biblioteca da Caixa Econômica Federal, Rio de Janeiro

- Biblioteca da Câmara do Deputados, DF

- Biblioteca da FAU-USP

- Biblioteca do Departamento Jurídico da Prefeitura Municipal de Recife, PE

- Biblioteca do Instituto Nacional de Seguridade, Rio de Janeiro

- Biblioteca do Ministério do Trabalho, DF

- Biblioteca do Ministério do Trabalho, Rio de Janeiro, RJ

- Biblioteca do Palácio da Justiça, DF

- Biblioteca da Secretaria de Planejamento da Prefeitura Municipal de Recife, PE

- Biblioteca Estadual do Recife, PE

- Biblioteca Jurídica da Prefeitura Municipal de Campinas, SP

- Biblioteca Municipal Mário de Andrade, Araraquara, SP

- Biblioteca Nacional, Rio de Janeiro, RJ

- Departamento de Engenharia da Prefeitura Municipal do Rio de Janeiro, RJ

- Departamento de Habitação Social da Prefeitura Municipal de Santo André, SP

- Departamento de Planejamento da Prefeitura Municipal de Itú, SP

- Departamento de Planejamento Urbano da Prefeitura Municipal de Campinas, SP

- Departamento de Planejamento Urbano da Prefeitura Municipal de Franca, SP

- Departamento de Planejamento Urbano da Prefeitura Municipal de Santo André, SP

- Empresa Urbanizadora de Recife, PE

- Instituto de Planejamento do Distrito Federal, DF

- Museu D. João Sexto, UFRJ

- Museu da Cidade, CONDEPHAAT, Campinas, SP

- Museu da Cidade, Santo André, SP 
- Museu da Cidade, Santos, SP

- Museu da Cidade do Recife, PE

- Núcleo de Apoio a Pesquisa, UfRJ

- Regional 4 da Prefeitura Municipal de Recife, PE

- Seção de Engenharia do INSS, Rio de Janeiro, RJ

- Seção de Cadastro da Prefeitura Municipal de São Carlos, SP

- Seção de Cadastro e Microfilmes da sede do Governo do Distrito Federal (GDF), DF

- Seção de Cadastro Fiscal da Prefeitura Municipal de Itú, SP

- Seção de Cadastro Fiscal da Prefeitura Municipal de Santo André, SP

- Seção de Cadastro Imobiliário da Prefeitura Municipal de Santos, SP

- Seção de Expediente da Prefeitura Municipal de Itú, SP

- Seção de Expediente da Prefeitura Municipal de São Carlos, SP

- Seção de Geo - Processamento da Prefeitura Municipal de Recife, PE

- Seção de Planejamento Urbano da Prefeitura Municipal de São Carlos, SP

- Seção de Taquigrafia da Câmara dos Deputados, DF

- Secretaria de Obras da Prefeitura Municipal de Araraquara, SP

- Secretaria de Planejamento Urbano da Prefeitura Municipal de Santos, SP

- Secretaria de Planejamento da Prefeitura Municipal de Recife, PE

- Secretaria Municipal de Habitação da Prefeitura Municipal de Belo Horizonte, MG

- Secretaria Municipal de Regulação Urbana da Prefeitura Municipal de Belo Horizonte, MG

- GEDURB- Gabinete de Estudos e Documentação Urbana- Departamento de Urbanismo da Faculdade de Arquitetura da Universidade Federal do Rio Grande do Sul (Porto Alegre);

- Laboratório de História e Teoria da Arquitetura- UniRitter- Centro Universitário Ritter dos Reis;

- INSS - Porto Alegre;

- Secretaria Municipal de Planejamento da Prefeitura de Porto Alegre;

- Secretaria de Habitação de Prefeitura Municipal de Porto Alegre;

- Arquivo Municipal da Prefeitura de Porto Alegre;

- Secretaria Municipal de Urbanismo da Prefeitura Municipal de Pelotas;

- Faculdade de Arquitetura e Urbanismo da Universidade Federal de Pelotas;

- Biblioteca da Universidade Federal de Pelotas;

- Secretaria Municipal de Planejamento Urbano da Prefeitura Municipal de Novo Hamburgo;

- Museu da Cidade de Novo Hamburgo;

- Secretaria Municipal de Planejamento da Prefeitura Municipal de Santa Maria;

- Departamento de Arquitetura e Urbanismo da Universidade Federal de Santa Maria;

- Biblioteca Central da Universidade Federal de Santa Maria;

- Arquivos do jornal local A Razão, da cidade de Santa Maria/RS;

- Prefeitura Municipal de Itatiba; 
- Prefeitura Municipal de Jundiaí.

- NAI: Instituto dos Arquitetos Holandeses - Rotterdam - Arquivo e Biblioteca.

- Bauhaus ArchivMuseum

- Faculdade de Arquitetura do Instituto Politécnico de Madri 